Submitted to the Faculty of Educational Sciences at Linköping University in partial fulfilment of the requirements for the degree of Doctorate of Philosophy

Studies in Science and Technology Education No 81

Studies published by the Swedish Institute for Children's Books No 128

\title{
Barnlitteraturens tekniklandskap
}

\section{En didaktisk vandring från Nils Holgersson}

\section{till}

\section{Pettson och Findus}

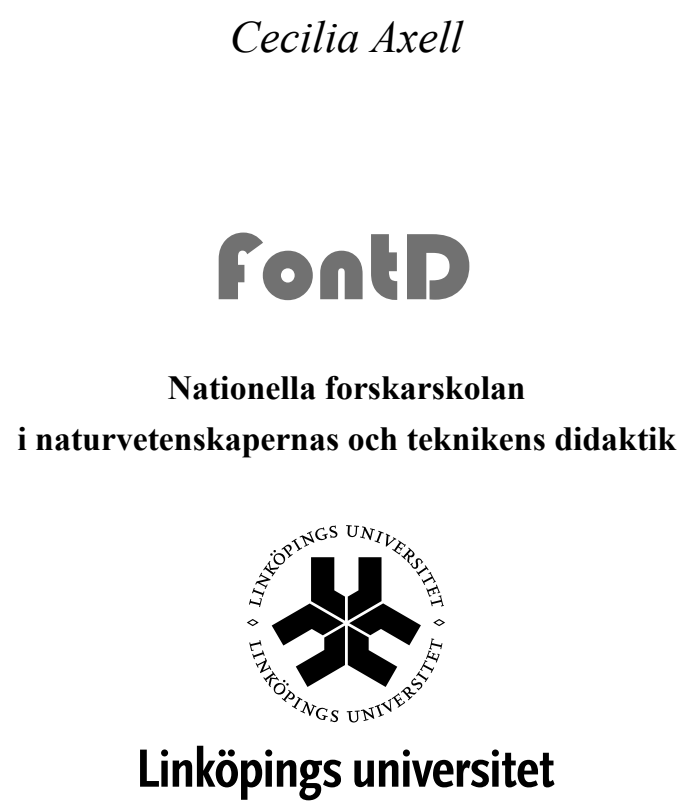

Linköpings universitet, Institutionen för samhälls- och välfärdsstudier, Norrköping, 2015 
Studies in Science and Technology Education No 81

ISSN 1652-5051

ISBN 978-91-7519-227-7

Skrifter utgivna av Svenska barnboksinstitutet nr 128/Studies published by the Swedish Institute for Children's Books No 128

ISSN 0347-5387.

Nationella forskarskolan i Naturvetenskapernas, Matematikens och Teknikens didaktik, FontD, http://www.isv.liu.se/fontd, tillhör Institutionen för samhällsoch välfärdsstudier (ISV) och Styrelsen för utbildningsvetenskap (SUV) vid Linköpings universitet. FontD är ett nätverk av följande medverkande lärosäten: Luleå tekniska universitet, Mälardalens högskola, Mittuniversitetet, Linnéuniversitetet och universiteten i Umeå, Karlstad, Linköping (värd), Göteborg och Lund samt högskolorna i Malmö, Kristianstad, Halmstad och Gävle. FontD publicerar skriftserien Studies in Science and Technology Education, ISSN 1652-5051.

Distribuerad av:

Nationella forskarskolan i Naturvetenskapernas, Matematikens och Teknikens didaktik, (FontD), Institutionen för samhälls- och välfärdsstudier, (ISV).

Linköpings universitet

60174 Norrköping

Sverige

Cecilia Axell (2015)

Barnlitteraturens tekniklandskap.

En didaktisk vandring från Nils Holgersson till Pettson och Findus.

Technology Landscapes in Children's Literature.

A Didactic Journey from Nils Holgersson to Pettson and Findus.

Copyright (C) Cecilia Axell, 2015

Andra upplagan

Tryck: LiU-Tryck, Linköping, 2015

Omslagsbild: Olav Lunde

Omslagslayout: Christian Larsson 


\begin{abstract}
\\ Tag tänkte mig enbart möjligheten af att en skald skulle kunna se att telefonen är en underbar saga, att synålen är ett poem, att tåghjulet har Hugins, korpens, vingar fast osynliga eller höra att turbinens sång är Näckens gamla harpa och känna, att Skogrån ej är död, att den flyttat in i papperet, som är den söndermalda skogen [...]."
\end{abstract}

Otto Witt, 14 januari $1916^{1}$

1 O. Witt, Privat brev till Verner von Heidenstam, daterat 16 januari 1916, Övralidsarkivet (E005/1984:5). Brevskrivarregistret, Linköpings stiftsbibliotek, Linköping. 



\section{Förord}

Klockan är strax efter elva på förmiddagen och vid fågelbordet utanför köksfönstret trängs talgoxar, pilfinkar, nötväckor, blåmesar, gulsparvar och en och annan domherre. Med en känsla av lättnad och vemod, men även tillförsikt, konstaterar jag att den sista julen med Avhandlingen just har passerat. Känslan av lättnad och möjligen även tillförsikt delar jag förmodligen med flera i min omgivning. Däremot är jag nog rätt ensam om att känna vemod inför det faktum att min avhandlingsskrivande går mot sitt slut. Jag betraktar den stora högen med papper bredvid mig på köksbordet och böckerna som ligger i höga staplar på kökssoffan. Under det senaste halvåret är det vid det här köksbordet och köksfönstret som många av mina tankar formulerats till ord, genomgått ett antal metamorfoser innan de till sist nått sin slutliga utformning. "Slutliga”, förresten? Känner man sig någonsin riktigt färdig med en avhandling? Sannolikheten att texten plötsligt kliver fram, slår näven i bordet och bestämt deklarerar att nu är den minsann klar, är i det närmaste obefintlig. Sanningen är snarare att en dag får den som skriver sätta ned foten och bestämt tala om att nu, kära text, så är du faktiskt klar! Och det är något jag nu har gjort. Det pockande behovet att vilja omformulera, flytta om, revidera eller stryka är borta. Inget mer uppvaknande mitt $i$ natten för att sedan smyga upp och sätta på datorn - bara för att få ned den där formuleringen som plötsligt dykt upp i huvudet. Nej, nu är texten klar, punkt slut! En sak kvarstår dock: att skriva de tackord som ska inleda avhandlingen. Men att kort och koncist försöka sammanfatta åren som doktorand samt få med alla som förtjänar ett stort tack, är en utmaning. I själva verket skulle även detta avsnitt behöva ett eget kapitel.

När Alice i Alice $i$ Underlandet för första gången träffar på Cheshirekatten undrar hon om katten kan vara så snäll och tala om vilken väg hon ska ta. När katten säger att det beror på vart hon vill komma., svarar Alice att det inte spelar så stor roll. "Då spelar det heller ingen roll vilken väg du tar”, konstaterar katten. På samma sätt som Alice behövde fundera över vart hon i själva verket ville komma, behöver man som doktorand ha ett tydligt mål med sitt avhandlingsskrivande. Vad jag ville skriva om hade jag klart för mig relativt tidigt. Jag förstod att för att kunna ägna mig hängivet åt något $\mathrm{i}$ så många år, måste det vara något jag brinner för. Därför blev det teknik och barnlitteratur. Viktiga under arbetet med avhandlingen har mina handledare varit. Det är de som fått mig att återkommande reflektera över hur mitt slutmål ska se ut samt gett kloka råd om hur jag kunna nå dit. Utan dem hade det varit svårt att hittat rätt. Jag vill därför rikta ett stort och varmt tack till mina båda handledare, Jonas Hallström och Jan-Erik Hagberg. Tack för alla inspirerande och kreativa samtal samt att ni bistått mig med att finna framkomliga vägar när jag gått vilse i avhandlingsskrivandets eget snåriga "Underland”. 
Ett stort tack också till alla doktorandkollegor och seniora forskare inom FontD och TekNaD för givande seminarier, tankar och tips som hjälpt mig att komma vidare i mitt arbete. Ni har alla bidragit. Ett särskilt tack vill jag rikta till vår administratör Anna Ericson. Är det något man undrar eller inte förstår - då kan man vara säker på att Anna vet. CETIS och de personer som ingår där har också varit viktiga för mig, så tack Classe Klasander och CETIS tidigare föreståndare Thomas Ginner samt alla övriga som på ett eller annat sätt ingår eller har ingått i CETIS under de här åren. Likaså vill jag sända ett tack till alla tekniklärarutbildare i det nationella nätverk som CETIS driver. Denna trevliga och kunniga samling människor har gett mig både energi och inspiration under arbetet med avhandlingen. Andra som har varit viktiga under de här åren är alla de kollegor vid andra universitet, såväl i Sverige som utomlands, som jag lärt känna genom kurser, resor och seminarier. Här ingår ni i "Rockelstadgruppen”. Stort tack till er allihop för ert engagemang, kreativa feedback och stöttande av mitt avhandlingsprojekt. Jag vill också tacka Olav Lunde för den fina bilden som du gjort till avhandlingens framsida och Christian Larsson för all hjälp med omslagslayout samt övrig support när min dator börjat leva sitt eget liv. Och tack mamma och pappa för att ni ställt upp och hjälpt till med både djur och hem när jag varit iväg på konferenser.

Avslutningsvis vill jag sända en stor tackkram till min familj. Tack Johan för att du stöttat mig när det varit motigt, skött all logistik och på något mirakulöst sätt lyckats upprätthålla någon slags struktur när det varit som körigast och rörigast. Tack Jacob och Gabriel för att ni har haft tålamod med en mamma som tidvis suttit som klistrad vid datorn, att huset förvandlats till en filial till universitetsbiblioteket samt att jag stundtals glömt bort både tid och rum. Under åren med avhandlingen har jag i alla fall haft något att skylla på ...

Lämmetorp, januari 2015

\section{Cecilia Axell}




\section{INNEHÅLL}

KAPITEL 1.

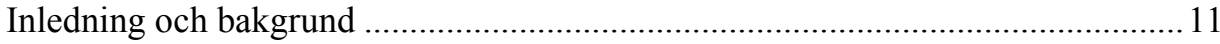

Studiens syfte och övergripande frågeställning ............................................ 18

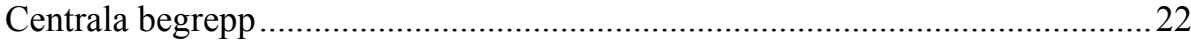

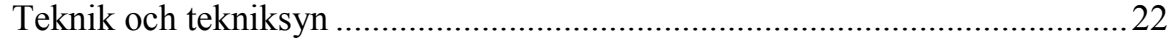

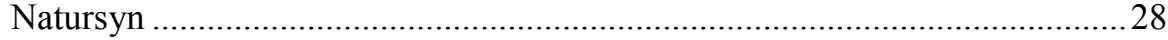

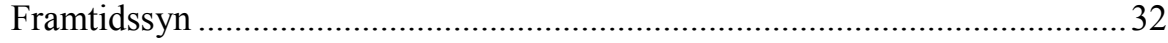

Sammanfattning av centrala begrepp .................................................... 34

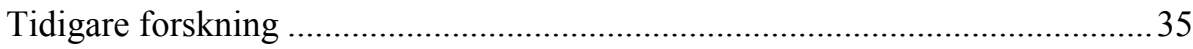

Studier av tekniken som fenomen i vuxenlitteraturen ................................. 35

Studier av tekniken som fenomen i barnlitteraturen .................................... 38

Sammanfattning av tidigare forskning ................................................... 44

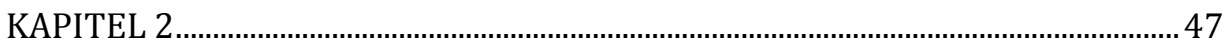

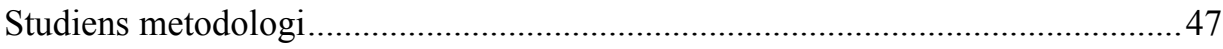

Analys och tolkning utifrån ett hermeneutiskt perspektiv ............................. 47

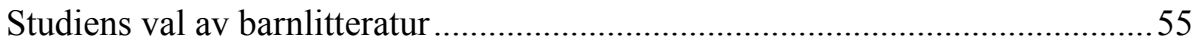

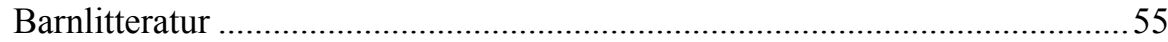

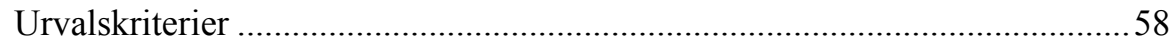

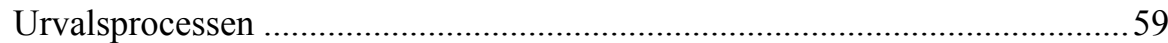

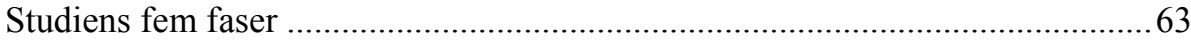

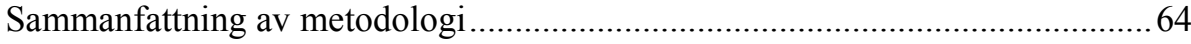

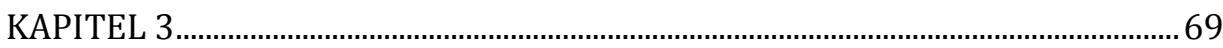

Tekniklandskapet i Selma Lagerlöfs barnbok Nils Holgerssons underbara resa .. 69

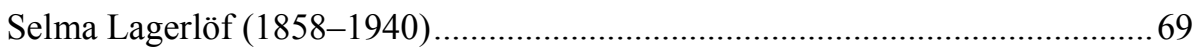

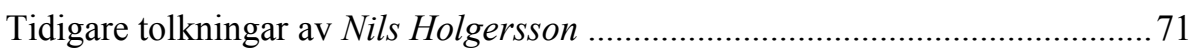

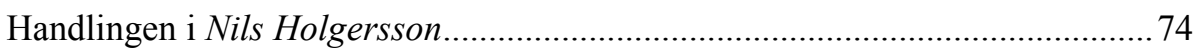

Tekniksynen i Nils Holgersson ..................................................................... 75

Natursynen i Nils Holgersson ........................................................................ 90

Framtidssynen i Nils Holgersson................................................................... 97 


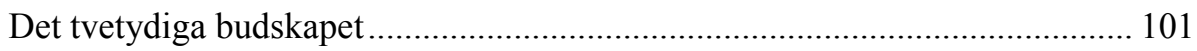

Sammanfattande analys av Nils Holgersson ..................................................... 104

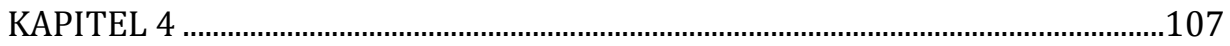

Tekniklandskapet i Otto Witts tekniska sagor....................................................... 107

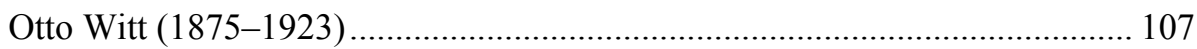

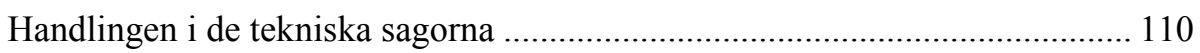

Tekniksynen i Otto Witts tekniska sagor ........................................................ 112

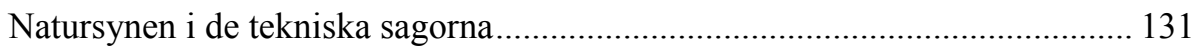

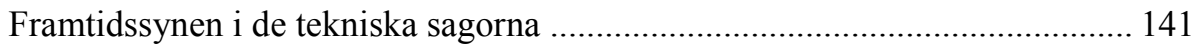

Sammanfattande analys av Otto Witts tekniska sagor ....................................... 142

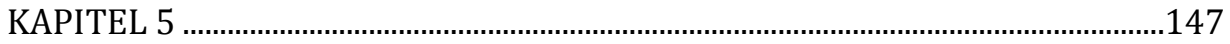

Tekniklandskapet i Elsa Beskows sagor............................................................ 147

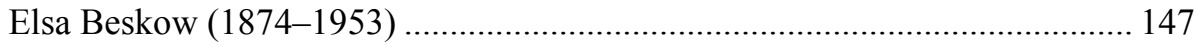

Tekniksynen i "Herr Klumpedump från Klumpedonien”................................... 150

Teknik- och framtidssynen i "Doktor Klokamundus' uppfinning" .................... 158

Teknik- och natursynen i "När stora blåbärsberget kom till stan"..................... 167

Teknik- och natursynen i "Den gröna bilen" ................................................... 172

Sammanfattande analys av Elsa Beskows sagor............................................... 178

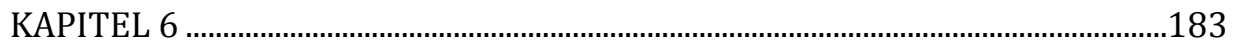

Tekniklandskapet i Karl-Aage Schwartzkopfs barnböcker.................................. 183

Karl-Aage Schwartzkopf (1920-2009) ...................................................... 183

Handlingen i böckerna om familjen Tuff-Tuff ............................................... 185

Tekniksynen i böckerna om familjen Tuff-Tuff ............................................... 188

Natursynen i böckerna om familjen Tuff-Tuff ................................................. 201

Framtidssynen i böckerna om familjen Tuff-Tuff ............................................ 201

Handlingen i böckerna om höghuset Talleborg ………................................... 202

Tekniksynen i böckerna om höghuset Talleborg ……….................................. 204

Natursynen i böckerna om höghuset Talleborg ................................................ 214

Framtidssynen i böckerna om höghuset Talleborg .......................................... 220

Sammanfattande analys av Karl-Aage Schwartzkopfs barnböcker ................... 221 
Tekniklandskapet i Sven Wernströms barnbok Den underbara resan .................227

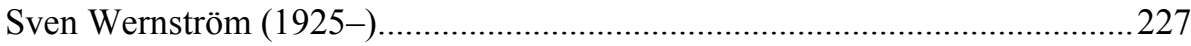

Handlingen i Den underbara resan ............................................................2229

Tekniksynen i Den underbara resan .........................................................2230

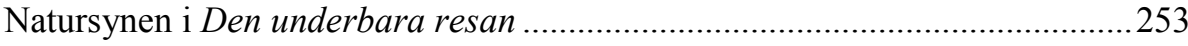

Framtidssynen i Den underbara resan ......................................................258

Sammanfattande analys av Den underbara resan .......................................25

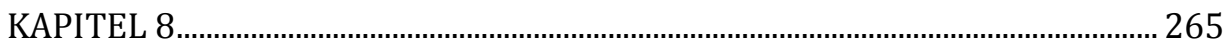

Tekniklandskapet i Sven Nordqvists böcker om Pettson och Findus .................265

Sven Nordqvist (1946-).................................................................................2. 265

Handlingen i böckerna om Pettson och Findus ..............................................267

Tekniksynen i böckerna om Pettson och Findus ............................................268

Natursynen i böckerna om Pettson och Findus .............................................297

Framtidssynen i böckerna om Pettson och Findus .....................................299

Sammanfattande analys av böckerna om Pettson och Findus .........................299

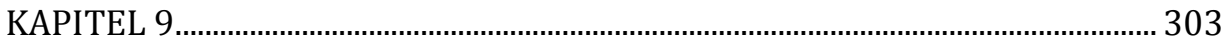

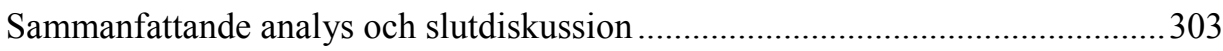

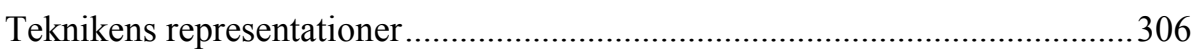

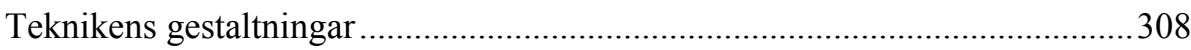

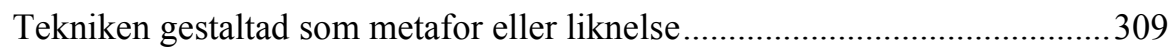

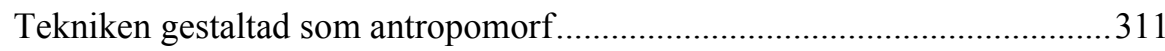

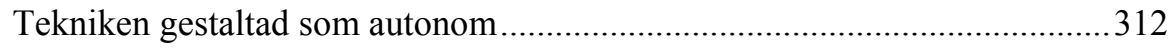

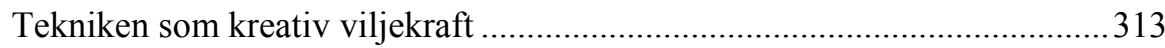

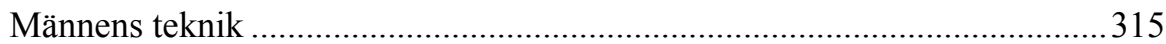

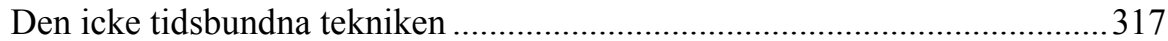

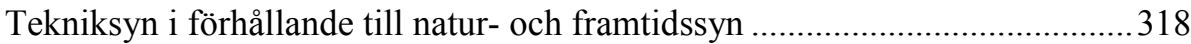

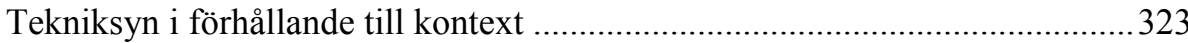

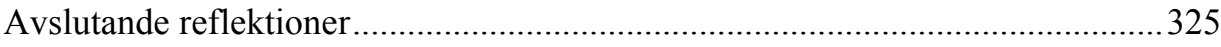

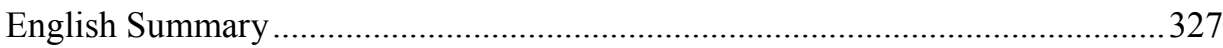

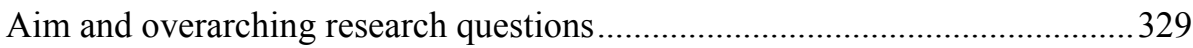




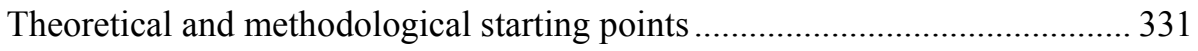

Representations of technology and technology as system ................................ 333

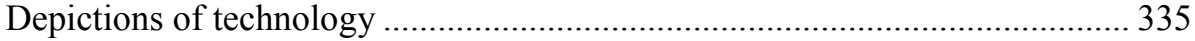

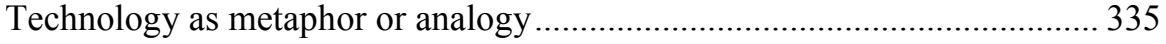

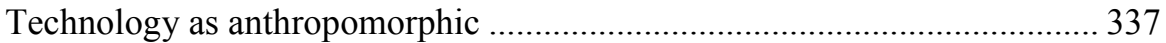

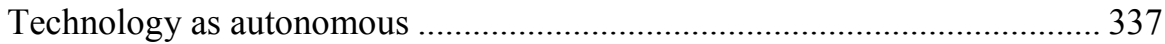

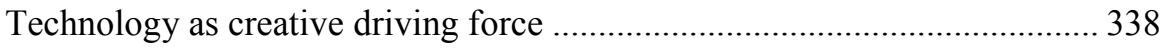

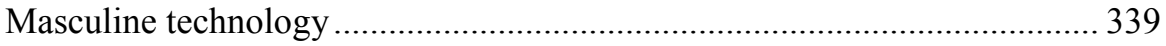

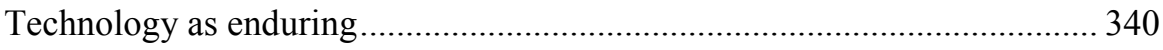

Views of technology and its relationship to the views of

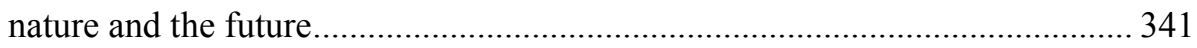

Views of technology in relation to contexts..................................................... 343

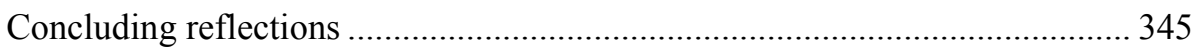

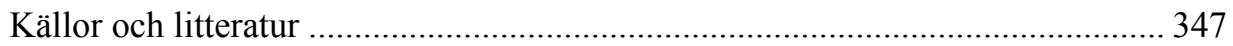




\title{
KAPITEL 1
}

\section{Inledning och bakgrund}

\begin{abstract}
Örnen rörde vingarna och for över till Alnön, som låg mittemot Sundsvall. Här råkade pojken i största förvåning över alla de sågverk, som klädde stränderna. De lågo på Alnön det ena bredvid det andra, och de lågo på fasta landet mittemot, verk vid verk, brädgård vid brädgård. Han räknade åtminstone till fyrtio, men han trodde nog, att de voro ändå fler. «Det är då underbart, att det kan se så ut häroppe«, sade han. «Ett sådant liv och en sådan rörelse har jag inte sett på något annat ställe under resan. Det är ett märkvärdigt land, som vi har. Vart jag kommer, alltid finns det något för människor att leva av. $\ll^{2}$
\end{abstract}

r 1906 flög Selma Lagerlöfs barnbokskaraktär Nils Holgersson över
Sverige och de svenska folkskolebarnen fick följa hans äventyr genom
läseboken Nils Holgerssons underbara resa genom Sverige. Det var ett Sverige statt i förändring, då landet genomgick en radikal förvandling från agrarland till industrination. Industrialiseringen grundade sig på utnyttjandet av järnmalm, skog och vattenkraft och under sin färd genom Sverige får Nils se tekniska innovationer som masugnar, sågverk, ångmaskiner, slåttermaskiner och krigsskepp. Tekniken väcker Nils förundran över vad "snillrika män" kan åstadkomma. Trots att Sverige var ett av de länder i Europa som industrialiserades relativt sent, gick det desto snabbare när strukturomvandlingen väl kom igång. ${ }^{3}$ Cirka åttio år senare, i Sven Wernströms bok Den underbara resan, företar en pojke en resa i Nils Holgerssons spår. I den berättelsen ska Selma Lagerlöfs bok bli tv-film och tolvårige Nicke Svensson från Norrköping har blivit uttagen att spela huvudrollen.

\footnotetext{
${ }^{2}$ S. Lagerlöf, Nils Holgerssons underbara resa genom Sverige, Bd 2, Stockholm: Bonnier, 1908, s. 528 .

${ }^{3}$ T. Frängsmyr, Svensk idéhistoria: Bildning och vetenskap under tusen år. D. 2, 1809-2000, Stockholm: Natur och Kultur, 2000, s. 102.
} 
Tillsammans med filmteamet ger han sig av i transportbil och helikopter för att filma Nils äventyr genom Sverige. Nicke läser Lagerlöfs bok under filminspelningen och han inser att det Sverige han upplever skiljer sig från landet som Nils kom i kontakt med under sin färd på gåsryggen. Nickes tekniklandskap är fyllt av tidens modernare teknik som bilar, rymdraketer, industrirobotar, skogsmaskiner, högeffektiva jordbruksmaskiner, kärnkraftverk, kemiska industrier och vattenkraftverk. Nicke inser att tekniksamhället har en baksida och att tekniken har utvecklats till ett hot mot såväl människa som natur. Boken har ett budskap om att nationen befinner sig i ett kritiskt tillstånd eftersom samhällsutvecklingen enbart sker på grundval av ekonomiska intressen och utan hänsyn till individ och miljö. ${ }^{4}$

Nils Holgersson underbara resa genom Sverige, liksom Sven Wernströms parafras på densamma, är exempel på barnböcker där tekniken gestaltas i en skönlitterär kontext. Berättelserna är skildringar av samhällsutvecklingen i Sverige vid två olika tidpunkter under 1900-talet. Den fiktiva värld som böckernas huvudpersoner förflyttar sig genom kan beskrivas som ett tekniklandskap som över tid och rum skiftar karaktär. ${ }^{5}$ Men trots att tekniklandskapet med dess ingående artefakter och system har genomgått en förändring finns också likheter. I berättelserna förs ett samtal om teknikens inverkan på individ, samhälle och natur, liksom mot vilken framtid samhället är på väg. De båda barnböckerna visar att diskussionen om teknisk utveckling och det moraliska ansvaret för densamma inte enbart pågår i debattböcker, statliga utredningar och filosofiska skrifter, utan även inom skönlitteraturen. ${ }^{6}$ Det som skönlitteraturen gör är att öppna för identifikation. Vi kan föreställa oss det tänkta händelseförloppet samtidigt som vi laborerar med alternativa bilder av den verklighet som berättelserna presenterar. ${ }^{7}$ Eftersom skönlitteraturen många gånger skildrar konkreta bilder av hur människor upplever olika sam-

\footnotetext{
${ }^{4}$ S. Wernström, Den underbara resan: En läsebok om Sverige, D1-3, Stockholm: Gidlund, 198587.

${ }^{5}$ J.-E. Hagberg, Livet genom tekniklandskapet: Livslopp, åldrande och vardagsteknikens förändring, Institutet för forskning om äldre och åldrande, Linköpings universitet, Norrköping, 2008; J.-E. Hagberg, "Att lära i teknikens rum och landskap. En metadidaktisk betraktelse" i Världens gång - teknikens utveckling: Om samspelet mellan teknik, människa och samhälle, P. Gyberg \& J. Hallström (red.), Lund: Studentlitteratur, 2009, s. 41-75.

${ }^{6}$ J. Anshelm, Förnuftets brytpunkt: Om teknikkritiken i P. C. Jersilds författarskap, diss., Linköpings universitet, Stockholm: Bonnier, 1990, s. 21.

${ }^{7}$ Ibid., s. 17.
} 


\section{Inledning och bakgrund}

hällsföreteelser, lyfter den också bättre fram människan i hennes komplexitet och motsägelsefullhet jämfört med andra texter. ${ }^{8}$

En viktig utgångspunkt för denna avhandling är min övertygelse om att skönlitterära barnböcker kan betraktas som bärare av värderingar och förhållningssätt till teknik och att de därför är intressanta att studera utifrån ett teknikdidaktiskt perspektiv. Teknikdidaktisk forskning handlar såväl om kunskaper $i$ som om teknik och hur dessa är invävda i olika sociala, kulturella och historiska kontexter. Den teknikdidaktiska forskningen har följt den allmänna strömningen inom didaktisk forskning och har som primärt fokus att studera undervisning $i$ teknik men också elevers lärande och förståelse. Forskningen tar dessutom upp andra innehållsliga frågor som vilken kunskap som är central i undervisningen i teknik, vilken inverkan kontextuella förhållanden har för lärande och undervisning i teknik samt hur kreativa lärandemiljöer kan skapas. ${ }^{9}$ Denna studie behandlar huvudsakligen perspektivet kunskaper om teknik och jag kopplar detta till de tekniksyner som har förmedlats och förmedlas till barn via skönlitterära barnböcker, från 1900talets början fram till i dag. Det empiriska materialet motiveras av att jag ser det historiska liksom det samhälleliga perspektivet som en naturlig del i tänkande kring teknik. Historien är viktig för att vi ska förstå nuet och kunna tänka om framtiden. Teknik kan därutöver kopplas till tid genom att den som begrepp är associerad med sådant som uppfinningar, utveckling och förändring. ${ }^{10}$ Därtill, och som Jonas Hallström konstaterar, kan det historiska perspektivet hjälpa till att belysa tekniken i sig och hur människans förhållande till den förändras. Perspektivet kan också frilägga återkommande teman som bidrar till att vi kan tolka vår egen tid, vilket i sin tur kan hjälpa oss att inför framtiden göra genomtänkta val avseende

\footnotetext{
${ }^{8}$ E. Tengström, Bilen \& människan i svensk prosa och poesi, Stockholm: Stockholmia, 2009, s. 17.

${ }^{9}$ J.-E. Hagberg \& M. Hultén, Skolans undervisning och elevers lärande i teknik: Svensk forskning $i$ internationell kontext, Stockholm: Vetenskapsrådet, 2005, s. 19; S. Selander, "Didaktik - undervisning och lärande" i Lärande, skola, bildning: [grundbok för lärare], U. P. Lundgren, R. Säljö och C. Liberg (red.), Stockholm: Natur och Kultur, 2010, s. 197-215.

${ }^{10}$ D. Edgerton, The shock of the old: Technology and global history since 1900, London: Profile Books, 2006, s. ix-xviii, 28-51.
} 


\section{Inledning och bakgrund}

teknik. ${ }^{11}$ Eftersom skönlitteratur dessutom skildrar tekniken utifrån människors upplevelser och tankar om den, ökar den möjligheten att undersöka budskap om tekniken i sig.

Teknikfilosofi är ett relativt ungt ämnesfält vars syfte är att systematiskt reflektera över olika aspekter av teknik och teknologi. ${ }^{12}$ Som Carl Mitcham konstaterar är skapande och användande av teknik till stor del en praktisk aktivitet, men på grund av den moderna teknikens effekter och inneboende komplexitet, behöver vi också reflektera och tänka om teknik. ${ }^{13}$ Ett återkommande tema inom teknikfilosofin handlar därför om huruvida tekniken kan betraktas som ett värdeneutralt redskap eller ej. Inkorporerar tekniken i sig värderingar eller är det enbart hur människan använder sig av tekniken som kan bedömas vara "gott" eller "ont"? Vissa teknikfilosofer, exempelvis Joseph C. Pitt, menar att tekniken värdemässigt är neutral eftersom den ett är redskap i människans tjänst. Den kan därför inte ha någon moralisk agens. ${ }^{14}$ Andra filosofer är av motsatt åsikt och anser att eftersom den tekniska utvecklingen är en målinriktad process, har tekniska artefakter per definition vissa funktioner. Denna begreppsmässiga koppling mellan tekniska artefakter, funktioner och mål gör att det är svårt att påstå att tekniken skulle vara neutral, hävdar företrädarna för detta synsätt. ${ }^{15}$ Langdon Winner anser exempelvis att om man endast ser tekniken som ett neutralt redskap som kan användas på ett ont eller gott sätt, så missar man att ta ställning till huruvida den vid konstruktionstillfället och genom sin design fick vissa oavsedda konsekvenser. Genom att se tekni-

\footnotetext{
${ }^{11}$ J. Hallström, "Teknikhistoria öppnar upp vidare perspektiv på tekniken” i Ginners teknikdidaktiska handbok: Några teser om teknik, skola och samhälle, J. Hallström \& C. Klasander (red.), Linköping: Linköping University Press, 2013, s. 62-65.

${ }^{12}$ Se exempelvis V. Dusek, Philosophy of technology. An introduction, Malden, Mass.: Blackwell, 2006; M. de Vries, Teaching about technology: An introduction to the philosophy of technology for non-philosophers, Dordrecht: Springer, 2005, s. 1-12.

${ }^{13}$ C. Mitcham, Thinking through technology: The path between engineering and philosophy, Chicago: University of Chicago Press, 1994, s. 1.

${ }^{14}$ J. C. Pitt, “'Guns don't kill, people kill'; Values in and/or around technologies” i The moral status of technical artefacts [Elektronisk resurs], P. Kroes \& P. Verbeek (red.), Dortrecht: Springer, 2014, s. 89-102.

${ }^{15}$ Se exempelvis M. Franssen, G. Lokhorst \& I. van de Poel, "Philosophy of technology" i The Stanford Encyclopedia of Philosophy[Elektronisk resurs], E. N. Zalta (red.), Metaphysics Research Lab, Center for the Study of Language and Information, Stanford California: Stanford University, 1995, http://plato.stanford.edu/2013 (läst 2014-02-15).
} 
ken som neutral och endast värdera den som ett redskap som har vissa användningsområden, finns en risk att vi kommer att vara blinda för mycket som är av praktisk betydelse, skriver Winner. Som exempel på detta visar han hur handikapporganisationer i USA under 1970-talet lyfte fram problemen med hur designen av bussar, byggnader, trottoarer, VVS-artiklar och dylikt gjorde det omöjligt för handikappade personer att röra sig fritt. Dessa artefakters design gynnade vissa men fick samtidigt den oavsiktliga konsekvensen att en grupp människor exkluderades från den offentliga miljön. ${ }^{16}$

I sina "Laws of technology" väljer Melvin Kranzberg vad man kan kalla en medelväg. Som första lag slår han fast att "Technology is neither good nor bad; nor is it neutral". Med det menar han att teknikens interaktion med omgivningen är av sådan art att den ofta får miljömässiga och sociala konsekvenser som går långt utöver den omedelbart tänkta tillämpningen av den. En teknisk lösning som först verkar vara en välsignelse för mänskligheten, kan utvecklas till ett hot när användningen av den blir utbredd. Kranzbergs poäng är att, beroende på sammanhanget, kan samma teknik ses på olika sätt. Vid en värdering av teknik bör man därför ställa "vad-skulle-ha-varit" mot "vad-som-faktiskt hände" samt att ta i beaktande de avvägningar man gör mellan vad som är positivt respektive negativt med en viss teknik. Allt detta kan bara göras genom att man undersöker hur teknik samverkar med hela den sociokulturella miljön, menar Kranzberg. ${ }^{17}$

John R. Dakers ansluter sig till åsikten att tekniken inte är neutral. Diskussioner om tekniken som sådan och hur den påverkar vår kulturella utveckling bör följaktligen betraktas som en viktig del av det tekniska kunskapsområdet, anser Dakers. Lärande sker inte i ett vakuum eller isolerat från den kulturella, historiska och sociala miljö som vi föds in i. Som människor bör vi därför förstå teknikens relevans utifrån en meningsfull kontext och inte enbart utifrån hur den fungerar

\footnotetext{
${ }^{16} \mathrm{~L}$. Winner, The whale and the reactor: A search of limits in an age of high technology, 5. uppl., Chicago: University of Chicago Press, 1989, s. 25-26.

${ }^{17}$ M. Kranzberg, "Technology and history: 'Kranzberg's Laws', Technology and Culture, vol. 27(3), 1986, s. 544-560.
} 
eller hur den har tillverkats. Vi behöver lära oss att tolka den tekniska världen, vilket vi enligt Dakers endast kan göra genom samtal (discourse) om teknik. ${ }^{18}$

I denna studie knyter jag det didaktiska samtalet om teknik till barnlitteraturen och dess didaktiska funktion. Lennart Hellsing skriver att socialt sett har barnlitteraturen, liksom annan konst, flera uppgifter. Förutom att lära barnet att behärska språket ska den orientera barnet socialt $\mathrm{i}$ tid och rum, så att det kan bygga upp önskvärda föreställningar om omgivningen. ${ }^{19}$ Om en av barnbokens uppgifter är att orientera barnet i tid och rum, så menar jag att tekniken blir ett naturligt inslag i böckernas innehåll, eftersom teknik är något som har genomsyrat hela den mänskliga historien. Eller som H. Joseph Schwarcz uttrycker det:

Children's literature is one of the means by which children are socialized and are acquainted with important aspects and features of their civilization. It is, therefore, only natural that gadgets and machines should loom prominently in children's books in an era and a society that is, in fact, based on technological development. ${ }^{20}$

Barnlitteraturen har dessutom en historisk anknytning till fostran, skola och utbildning. Historiskt sett har barnböckernas underhållningsvärde varit underordnat dess fostrande syfte och länge betraktades barnlitteraturen i första hand som något som skulle bistå föräldrar och pedagoger vid inpräntandet av värderingar hos tidens barn. ${ }^{21}$ Barnlitteraturens nära anknytning till skolan och didaktiken speglas genom

\footnotetext{
${ }^{18}$ J. R. Dakers, "Towards a philosophy for technology education" i Defining technological literacy: Towards an epistemological framework, J. R. Dakers (red.), New York: Palgrave Macmillan, 2006b, s. 145-158.

${ }^{19}$ L. Hellsing, Tankar om barnlitteraturen, Ny utg., Stockholm: Rabén \& Sjögren, 1963/1999, s. 26.

${ }^{20}$ H. J. Schwarcz, "Machine animism in modern children's literature”, The Library Quarterly, vol. 37(1), 1967, s. 82.

${ }^{21}$ L. Furuland, Ö. Lindberger, M. Örvig, Barnlitteratur i Sverige: Läsning för barn och barnboksprogram, Stockholm: Wahlström \& Widstrand, 1970, s. 15-116; E. S. Hintz, "Heroes of the laboratory and the workshop: Inventions and technology in books for children, 1850-1950" i Enterprising youth: Social values and acculturation in nineteenth-century American children's literature, M. M. Elbert (red.), New York: Routledge, 2008, s. 197-211; G. Klingberg, Svensk barnoch ungdomslitteratur 1591-1839: En pedagogikhistorisk och bibliografisk översikt, diss., Uppsala universitet, Stockholm: Natur och Kultur, 1964, s. 13-160; L. Kåreland, Barnboken i samhället, Lund: Studentlitteratur, 2013, s. 110; J.D. Zipes, Saga och samhälle: Den klassiska genren för barn och civilisationsprocessen, Bromma: Mannerheim \& Mannerheim, 1984, s. 19-20; E. von Zweigbergk, Barnboken i Sverige 1750-1950, Stockholm: Rabén \& Sjögren, 1965, s. 11-51.
} 
olika tiders läroplaner och pedagogiska debatter. Skolan har haft och har fortfarande till uppgift att lära barnen läsa, uppmuntra till läsning samt att ge dem möjlighet att komma i kontakt med "den goda litteraturen". ${ }^{22}$ Som en konsekvens av barnbokens didaktiska funktion är budskap och värderingar ofta mer explicit uttryckta i barnböcker jämfört med i vuxenlitteraturen. Kimberley Reynolds konstaterar att många av de barnböcker som skrevs för länge sedan fortfarande läses. På så vis fortsätter den äldre litteraturen att påverka över tid och forma hur vi uppfattar, organiserar och hanterar våra liv. ${ }^{23}$ Maria Nikolajeva menar å andra sidan att om den äldre barnlitteraturen var ett medium som hade som syfte att överföra tidens etablerade normer, moral och attityder, kan den didaktiska ambitionen i den modernare barnlitteraturen snarare beskrivas som att den ifrågasätter etablerade maktstrukturer. I en del av den moderna barnlitteraturen framställs exempelvis skolan som en förtryckarmekanism. ${ }^{24}$ Men trots att barnlitteraturen har utvecklats till att $i$ allt högre grad presentera världen utifrån barnets perspektiv, liksom att uppmuntra till ifrågasättande av rådande normer och värderingar, anser jag att ifrågasättande likväl kan betraktas som ett uppfostringsideal. Därmed kvarstår den didaktiska intentionen även i de moderna barnböckerna.

\footnotetext{
${ }^{22}$ N.O. Bruce, Svenska folkskolans historia. D. 4. Det svenska folkundervisningsväsendet 19001920, utg., Stockholm, 1940, s. 413-414; G. Klingberg, Sekelskiftets barnbokssyn och Barnbiblioteket Saga, Stockholm, 1966, s. 21; L. Kåreland, Gurli Linders barnbokskritik: Med en inledning om den svenska barnbokskritikens framväxt, diss., Stockholms universitet, Stockholm: Bonnier, 1977, s. 68-73; G. Linder, Våra barns fria läsning, Stockholm: Norstedt, 1916; Motion 2008/09:Ub236, Litterär kanon, http://www.riksdagen.se/sv/Dokument-Lagar/Forslag/Motioner /Litterar-khanon_GW02Ub236/?text=true, (läst 2013-12-13); H. Schmidl, Från vildmark till grön ängel: Receptionsanalyser av läsning $i$ åttonde klass, diss., Uppsala universitet, Göteborg: Makadam, 2008; SFS 2010:860 Lag om ändring i bibliotekslagen (1996:1596), http://www.lagboken.se/dokument/andrings-sfs/638660/sfs-2010_860-lag-om-andringbibibliotekslagen-1996_1596?id=59924 (läst 2012-03-14); Skolverket, Läroplan för grundskolan, förskoleklassen och fritidshemmet, Stockholm: Fritzes, 2011.

${ }^{23}$ K. Reynolds, “Introduction” i Children's literature studies: A research handbook, K. Reynolds \& M. O. Grenby (red.), Basingstoke: Palgrave Macmillan, 2011, s. 1-2.

${ }^{24}$ M. Nikolajeva, Barnbokens byggklossar, Lund: Studentlitteratur, 2004, s. 17.
} 


\section{Inledning och bakgrund}

\section{Studiens syfte och övergripande frågeställning}

Syftet med denna avhandling är att utifrån ett didaktiskt perspektiv undersöka budskap om teknik i ett urval svenska skönlitterära barnböcker samt undersöka hur berättelsernas tekniksyner förhåller sig till deras natur- respektive framtidssyn. Med min studie önskar jag därmed visa hur man med teknikdidaktiska glasögon kan läsa och tolka skönlitterära barnböcker. Min förhoppning är att mina resultat ska väcka intresse för en didaktiskt grundad diskussion om teknik och barnböcker, där både ett historiskt perspektiv och reflektioner kring tekniken som sådan ingår. Studiens övergripande frågeställning är:

Vilka olika slags tekniksyner kommer till uttryck i skönlitterära barnböcker med ett teknikdidaktiskt innehåll och hur förhåller sig tekniksynerna till natur-respektive framtidssyn?

Studien har en hermeneutisk ansats till vilken jag hämtat inspiration från Paul Ricoeurs (1913-2005) idé om misstankens hermeneutik. Att jag finner den användbar har sin grund i att den lyfter fram betydelsen av att i tolkningsprocessen gå under ytan och söka efter det "dolda" och inte tydligt uttalade i texterna. ${ }^{25}$ Genom att rikta "en misstanke" mot det som förefaller uppenbart, har jag i tolkningsprocessen sökt nå en djupare tolkning av berättelsernas budskap om teknik - en tolkning som går bortom det explicit uttalade. Liksom Ricoeur ser jag tolkningsprocessen som en syntes mellan förklaring och förståelse av texternas innehåll. ${ }^{26}$ Samtidigt be-

\footnotetext{
${ }^{25}$ S. Claesson m.fl., "Ricoeurs kritiska hermeneutik vid empiriska studier", Pedagogisk forskning i Sverige, vol. 16(1), 2011, s. 18-20; B. Gustavsson, "Bildning i vår tid", Högskoleverket, s. 6, www.hsv.se/bildning (läst 2014-09-20); B. Kristensson Uggla, Kommunikation på bristningsgränsen: En studie i Paul Ricoeurs projekt, diss., Lunds universitet, Stockholm: B. Östlings bokförl. Symposion, 1994, s. 251-284; P. Ricoeur, "The model of the text: Meaningful action considered as a text", New Literary History, vol. 5(1), 1973, s. 91-117; P. Ricoeur, "Förklara och förstå. Text - handling - historia" i Från text till handling: En antologi om hermeneutik, 4. uppl., Stockholm: B. Östlings bokförl. Symposion, 1993a, s. 77-78.

${ }^{26}$ M. Alvesson \& K. Sköldberg, Tolkning och reflektion: Vetenskapsfilosofi och kvalitativ metod, 2. [uppdaterade] uppl., Lund: Studentlitteratur, 2008, s. 242-247; J. From \& C. Holmgren, "Hermeneutik och pedagogik", Nordisk Pedagogik, vol. 20(4), s. 221-223; P. Ricoeur,"Vad är en text?" i Från Text till handling: En antologi om hermeneutik, 4. uppl., Stockholm: B. Östlings bokförl. Symposion, 1993c, s. 39-43; P.-J. Ödman, Tolkning, förståelse, vetande: Hermeneutik $i$ teori och praktik, Stockholm: ePan/Norstedt, 1979/2001, s. 81-85; P.-J. Ödman, "Hermeneutik
} 


\section{Inledning och bakgrund}

traktar jag förförståelsen som förutsättning för att en tolkningsprocess överhuvudtaget ska komma igång. ${ }^{27}$ I min förförståelse ingår bland annat den historiska kontext de analyserade barnböckerna kommit till i. Kontexten gör det möjligt att tolka berättelserna som en del av ett meningssammanhang samtidigt som mina tolkningar här och nu berikas av kontakten med det förflutnas erfarenheter. ${ }^{28}$ Däremot är jag försiktig med att dra slutsatser om författarnas eventuella intentioner; det är texten som talar till mig - inte författaren. ${ }^{29}$

Mitt teknikdidaktiska perspektiv gör att jag finner det senaste århundradet som en särskilt intressant tidsperiod att undersöka. Det var då Sverige gick från att vara ett jordbruksland till att bli en modern industrination. Landets tekniklandskap kom därmed att genomgå stora strukturella förändringar. Det analyserade materialet består därför av ett urval svenska skönlitterära barnböcker skrivna vid olika tidpunkter under det senaste århundradet. Några av dem tillhör än i dag de mest utlånade på biblioteken. Att just dessa barnböcker går att betrakta som teknikdidaktiska motiverar jag med att de innehåller frågeställningar och problematiker som är betydelsefulla och relevanta inom teknikens didaktik i dag. Det kan exempelvis handla om reflektioner kring tekniken som sådan, diskussioner om dess föroch nackdelar och att tekniken diskuteras utifrån en samhällelig eller historisk kontext. $^{30}$

Jag använder begreppet tekniklandskap som ett sätt att betrakta en viss miljö med glasögon som gör att jag avtäcker förekomsten av tekniska objekt och sambanden dem emellan. De fungerar med andra ord som en slags kartografering av en viss (empirisk) "verklighet". Tekniklandskapen ser olika ut och de har också skif-

och forskningspraktik" i Kunskapande metoder inom samhällsvetenskapen, B. Gustavsson (red.), 3. rev. uppl., 2004, Lund: Studentlitteratur, s. 74-77.

${ }^{27}$ S. Selander \& P.-J. Ödman, "Inledning" i Text och existens. Hermeneutik möter samhällsvetenskapen, S. Selander \& P.-J. Ödman (red.), Göteborg: Daidalos, 2005, s. 11; P.-J. Ödman, Tolkning, förståelse, vetande: Hermeneutik i teori och praktik, s. 45, 81-82.

${ }^{28}$ B. Gustavsson, "Bildning i vår tid", s. 6.

${ }^{29}$ P. Ricoeur, "Vad är en text?", 1993c, s. 34-35.

${ }^{30}$ V. Bjurulf, Teknikdidaktik, Stockholm: Norstedt, 2011, s. 209; J.R. Dakers, "Towards a philosophy for technology education”, 2006b, s. 145-158; J.-E. Hagberg \& M. Hultén, Skolans undervisning och elevers lärande i teknik: Svensk forskning i internationell kontext, 2005, s. 12-19. 
tat karaktär över tid. ${ }^{31}$ I denna studie handlar denna "empiriska verklighet" om barnböckernas fiktiva tekniklandskap. ${ }^{32}$ I tekniklandskapen ingår tekniska artefakter och system och med dessa följer olika slags syn på teknik. Med tekniksyn avser jag här sådant som kan tolkas som en uppfattning om, eller inställning till, teknik samt dess inverkan på individ, natur och samhälle. Till grund för en viss syn på teknik ligger olika värderingar och föreställningar. Dessa är kulturbundna och präglade av den sociala miljö vi befinner oss i. Värderingar är därför inte stabila utan kan skifta när vår livssituation förändras, exempelvis genom samhällsförändringar. ${ }^{33}$

Ett ställningstagande till teknik handlar sällan enbart om tekniken i sig, utan ställningstagandet är många gånger knutet till olika föreställningar om natur (natursyn), samtid och framtid (framtidssyn). ${ }^{34}$ När människan utvecklar teknik har det ofta någon slags inverkan på naturen och det är många gånger i naturen människan finner de resurser som krävs för att utveckla tekniken. Därtill har människan genom historien hämtat inspiration och idéer till tekniska konstruktioner från naturen. Att teknik går att koppla till en specifik framtidssyn motiveras av att tekniken frekvent ses som en lösning på inte enbart nutida utan också framtida problem.

${ }^{31}$ J.-E. Hagberg, Livet genom tekniklandskapet: Livslopp, åldrande och vardagsteknikens förändring, 2008, s. 19-20; J.-E. Hagberg, "Att lära i teknikens rum och landskap. En metadidaktisk betraktelse", 2009, s. 45-46.

32 Begreppen "tekniklandskap" respektive "technological landscape" används också i exempelvis L. Ingelstam, Teknikpolitik: En bok om tekniken, människan och socialismen, Stockholm: Tiden, 1978; A. Kaijser, "Snärjda i systemen?" i Spänningsfält: Tekniken - politiken - framtiden, L. Sturesson (red.), Stockholm: Carlsson, 2002, s. 87-102; S. Lindqvist, "Change in the technological landscape: The temporal dimension in the growth and decline of large technological systems" i Economics of Technology, O. Granstrand (red.), Amsterdam: Elsevier, 1994, s. 271-288. I studien utgår jag från J.-E. Hagbergs definition av begreppet (se tidigare fotnot).

${ }^{33}$ G. Hammarström, "Att studera värden och värdeförändringar: Ett konkret exempel från en tregenerationsundersökning" i I tider av uppbrott, J. Anshelm (red.), Stockholm: B. Östlings bokförl. Symposion, 1995, s. 37-65.

${ }^{34}$ N. Applebaum, "The myth of the innocent child: Interplay between nature, humanity and technology in contemporary children's science fiction", The Journal of Children's Literature Studies, vol. 3(2), 2006, s. 1-17; N. Applebaum, Representations of technology in science fiction for young people, New York: Routledge, 2010; T. Frängsmyr, Framsteg eller förfall: Framtidsbilder och utopier $i$ västerländsk tanketradition, 2. uppl., Stockholm: Allmänna förl., 1990, s. 234-243; M. Kylhammar, Maskin och idyll: Teknik och pastorala ideal hos Strindberg och Heidenstam, diss., Linköpings universitet, Malmö: Liber Förlag, 1985, s. 11-12. 
Den har därutöver många gånger en giltighet under lång tid. I tekniksyn, natursyn och framtidssyn ingår ett ställningstagande till vilken roll människan har i denna växelverkan mellan människa/samhälle, natur och framtid. Då dessa nyckelbegrepp saknar enhetliga och entydiga beskrivningar, kommer jag i nästa avsnitt ge utrymme för att dels problematisera, dels presentera hur de är avsedda att förstås i min fortsatta framställning.

I analyserna identifierar jag vad för slags teknik som finns representerad i barnböckernas tekniklandskap och hur den gestaltas. Förutom tekniken som konkret representation (olika slags teknik), ingår språkliga symboler som utnyttjas i gestaltningen som exempelvis metaforer och liknelser. ${ }^{35}$ Varför-frågan belyser jag genom att undersöka berättelsernas budskap om teknikens mål och syften (tekniksyn) i förhållande till deras syn på natur och framtid. Studien har utifrån ovanstående tre analytiska perspektiv:

1. Att identifiera den teknik som finns representerad i barnböckerna samt undersöka hur den gestaltas.

2. Att undersöka barnböckernas tekniksyner och hur dessa förhåller sig till böckernas syn på natur och framtid.

3. Att göra en jämförande analys och på så vis identifiera gemensamma teman barnböckerna emellan.

35 För vidare läsning om den underliggande psykologin bakom metaforer, filosofiska implikationer och språklig analys av litteratur, se exempelvis G. Lakoff \& M. Johnson, Philosophy in the flesh: The embodied mind and its challenge to Western thought, New York: Basic Books, 1999; G. Lakoff \& M. Johnson, Metaphors we live by, Chicago: University of Chicago Press, 2003. Barry S. Brummet delar in i fyra huvudtroper: metafor, metonymi, synekdoke och ironi. Jag har valt att i studien enbart använda mig av begreppen liknelse och metafor. När jag använder begreppen inkluderar jag vad som brukar kallas analogi respektive allegori. En liknelse kan beskrivas som en "kusin" till metaforen men med den skillnaden att en liknelse är när man säger att en sak är som något annat, exempelvis "han kan springa som vinden". En liknelse eller analogi är när en parallell dras eller en jämförelse görs mellan företeelser explicit, det vill säga att det framgår tydligt vad man jämför. Metaforen är att se något $i$ termer av något annat. Den består av en bild utan jämförelseord ("som"), exempelvis "Livet är en resa". En allegori är ett konsekvent utbyte av ett egentligt budskap mot en metafor och fabler är ett exempel på allegorier. För vidare läsning se exempelvis B. S. Brummett, Techniques of close reading, Los Angeles: SAGE, 2010, s. 73-96 och L. Elleström, Lyrikanalys: En introduktion, Lund: Studentlitteratur, 1999, s. 80-94. 


\section{Inledning och bakgrund}

Det är berättelsen respektive kontexten som är föremål för analys och tolkning i de valda barnböckerna. Med berättelse avser jag här vad texten handlar om, vad som händer, de platser, personer och den teknik huvudpersonerna möter, med mera. Kontexten handlar dels om berättelsen i sin helhet, dels om det kulturella och historiska sammanhang berättelsen kommit till i. ${ }^{36}$

Givet den mängd barnlitteratur som publicerats sedan 1900-talets början, har en selektering varit nödvändig. Efter genomläsning av ett större antal noggrant utvalda titlar, utkristalliserade sig vissa författares verk. Jag valde till sist att låta sex författares barnböcker ligga till grund för min studie: Selma Lagerlöf, Otto Witt, Elsa Beskow, Karl-Aage Schwartzkopf, Sven Wernström och Sven Nordqvist. Att just dessa författare valdes ut handlar dels om att jag tolkar deras böckers innehåll som teknikdidaktiskt, dels att titlarna finns upptagna i olika tiders dominerande bibliotekstekniska hjälpmedel. De är författare vars böcker är skrivna från mitten av 1900-talet och framåt har dessutom legat högt i den nationella utlåningsstatistiken, vilket talar för att de har varit flitigt lästa och därmed nått en stor läsekrets. I studiens metodologiska avsnitt återkommer jag med en mer utförlig redogörelse för själva urvalsprocessen.

\section{Centrala begrepp}

\section{Teknik och tekniksyn}

Trots att "teknik" är något som vi kommer i kontakt med dagligen, är begreppet inte lätt att beskriva. Många definitionsförsök har gjorts, inte minst inom teknikfilosofin. Eftersom det inte är möjligt att skapa en komplett översikt av alla de diskussioner som har förts (och förs), kommer jag här endast att lyfta fram några exempel och då i syfte att påvisa begreppets komplexitet. Earl G. Ingersoll tar upp definitionsproblematiken när han slår fast att:

\footnotetext{
${ }^{36}$ R. Ross Johnston, "Reader response" i Children's literature studies: A research handbook, K. Reynolds \& M. O. Grenby (red.), Basingstoke: Palgrave Macmillan, 2011, s. 137-139.
} 


\section{Inledning och bakgrund}

Since technology is frequently misconceived as merely "applied science", we ought to begin with an attempt at definition, with one obvious proviso: full definitions of science and technology would entail an effort as large as this study. ${ }^{37}$

Som Ingersoll konstaterar handlar ett av definitionsproblemen om att tekniken reduceras till att beskrivas i termer av tillämpad naturvetenskap och mycket av dagens moderna teknik bygger också ofta på naturvetenskapliga teorier och landvinningar. Människan utvecklade dock tekniska lösningar långt innan naturen hade börjat studeras vetenskapligt. ${ }^{38}$ En tänkbar distinktion mellan naturvetenskap och teknik är deras mål. Inom naturvetenskapen är kunskapen om världen målet, medan teknikutvecklingens mål snarare är att skapa användbara och fungerande lösningar. Med andra ord utgår tekniken från andra premisser och ställer andra frågor än naturvetenskapen. ${ }^{39}$ Ett annat definitionsproblem handlar om att tekniken ofta decimeras till att enbart inbegripa fysiska artefakter. Konsekvensen blir då att man förbiser de kunskaper och de processer som ligger bakom att en viss teknik har skapats. ${ }^{40}$ Svante Lindqvist tar upp några av de vanligast förekommande definitionerna av teknik och problematiserar dem, bland annat utifrån ett motsatt problem: att det finns en risk att definitionen är så bred att den inkluderar alltför

\footnotetext{
${ }^{37}$ E.G. Ingersoll, Representations of science and technology in British literature since 1880, New York: P. Lang, 1992, s. 7.

${ }^{38}$ D. Herschbach, "From industrial arts to technology education: The search for direction", Journal of Technology Studies, vol. 23(1), 1997, s. 24-32; D. Layton, "A school subject in the making? The search for fundamentals" i Innovations in science and technology education, vol. 5, D. Layton (red.), UNESCO, Paris, 1994, s. 11-28; P. Norström, Technology education and nonscientific technological knowledge, lic.-avh., Architecture and the built environment, Kungliga Tekniska Högskolan, Stockholm, 2011, s. 4-5.

${ }^{39}$ J.-E. Hagberg \& M. Hultén, Skolans undervisning och elevers lärande i teknik: Svensk forskning $i$ internationell kontext, 2005, s. 25; L. Ingelstam, System: Att tänka över samhälle och teknik, 2. uppl., Eskilstuna: Statens energimyndighet, 2012, s. 247; P. Norström, Technology education and non-scientific technological knowledge, 2011, s. 22.

${ }^{40}$ J. R. Dakers, "Introduction" i Defining technological literacy: Towards an epistemological framework, J. R. Dakers (red.), New York: Palgrave Macmillan, 2006a, s. 1-2; M. de Vries, "Technological knowledge and artifacts: An analytical view" i Defining technological literacy: Towards an epistemological framework, J. R. Dakers (red.), New York: Palgrave Macmillan, 2006, s. 17-30; P. Gyberg \& J. Hallström, "Inledning" i Världens gång - teknikens utveckling: Om samspelet mellan teknik, människa och samhälle, P. Gyberg \& J. Hallström (red.), Lund: Studentlitteratur, 2009, s. 15-24.
} 


\section{Inledning och bakgrund}

fundamentalt skilda fenomen. Hans slutsats är att teknik skulle kunna beskrivas som att det är:

[‥] människans metoder att tillfredsställa sina önskningar genom att använda sig av fysiska föremål, eller alla handlingar som har ett syfte och vilka förändrar den materiella världen. ${ }^{.41}$

När vi i svenska språket använder oss av begreppet "teknik" menar vi ofta tekniska artefakter samt tekniska metoder och processer, medan vi med "teknologi" avser "läran om" eller "kunskaper om" tekniken. Att dra en skarp gräns mellan användningen av de båda termerna kan dock vara svårt. Förutom de rent språkliga skillnaderna har definitionerna genomgått stora förändringar över tid. ${ }^{42}$ Det innebär att om man undersöker budskap om, eller inställning till, teknik i texter som är skrivna vid olika tidpunkter i historien, utgår man i själva verket från en term som för de historiska aktörerna kan ha inneburit och inkluderat olika saker. Utifrån ett svenskt teknikhistoriskt perspektiv var det exempelvis ett hantverks- och industribetonat teknikbegrepp som dominerade från sekelskiftet 1900 och fram till seklets mitt, något som tidens uppslagsböcker bekräftar. ${ }^{43}$

Mitcham identifierar fyra olika sätt att beskriva teknik: som objekt (object), aktivitet (activity), kunskap (knowledge), och viljekraft/viljeyttring (volition). ${ }^{44}$ Med teknik som objekt menar Mitcham att vi kan se teknik som en uppsättning

${ }^{41}$ S. Lindqvist, "Vad är teknik?" i I teknikens backspegel: Antologi i teknikhistoria, B. Sundin (red.), Stockholm: Carlsson, 1987, s. 33.

${ }^{42}$ T.P. Hughes, Human-built world: How to think about technology and culture, Chicago: University of Chicago Press, 2004, s. 4; L. Marx, "The idea of "technology' and postmodern pessimism" i Does technology drive history? The dilemma of technological determinism, M. R. Smith \& L. Marx (red.), Cambridge, Mass.: MIT Press, 1994, s. 237-257; E. Schatzberg, "Technik comes to America. Changing meaning of technology before 1930", Technology and Culture, vol. 47(3), 2006, s. 486-512.

${ }^{43}$ Jämför exempelvis "Teknologi", Nordisk familjebok, 1891, http://www.runeberg.org (läst 201109-26); "Teknologi”, Nordisk familjebok. Uggleupplagan, 1919, http://www.runeberg.org, (läst 2011-09-26) och "Teknik", Nordisk familjebok, 1891, http://www.runeberg.org (läst 2011-09-26); "Teknik", Nordisk familjebok. Uggleupplagan, 1919, http://www.runeberg.org (läst 2011-09-26). När det gäller svårigheterna att utgå från ordböckers och uppslagsverks definitioner, se exempelvis R. Oldenziel, "Introduction. Signifying semantics for a history of technology", Technology and Culture, vol. 47(3), 2006, s. 477.

${ }^{44}$ C. Mitcham, Thinking through technology: The path between engineering and philosophy, 1994, s. 160. 


\section{Inledning och bakgrund}

artefakter som alla är resultat av design och tillverkning. Teknik som aktivitet refererar till den domän som sysslar med design, tillverkning och användandet av en viss produkt eller process. Det handlar om hantverk, att uppfinna, konstruera, arbeta, driva och bevara. Teknik som kunskap beskriver Mitcham som sensomotoriska färdigheter, tekniska maximer, deskriptiva lagar (äldre) samt tekniska regler och teorier (moderna). Teknik som viljekraft refererar till uppfattningen att teknik är en del av vår mänskliga strävan att vilja överleva, kontrollera, känna frihet, nå effektivitet och att förverkliga oss själva. ${ }^{45}$ Med hjälp av följande figur illustrerar Mitcham hur människan använder sina tekniska kunskaper, sin vilja att skapa teknik för att sedan genomföra en teknisk aktivitet som resulterar i ett tekniskt objekt (min översättning):

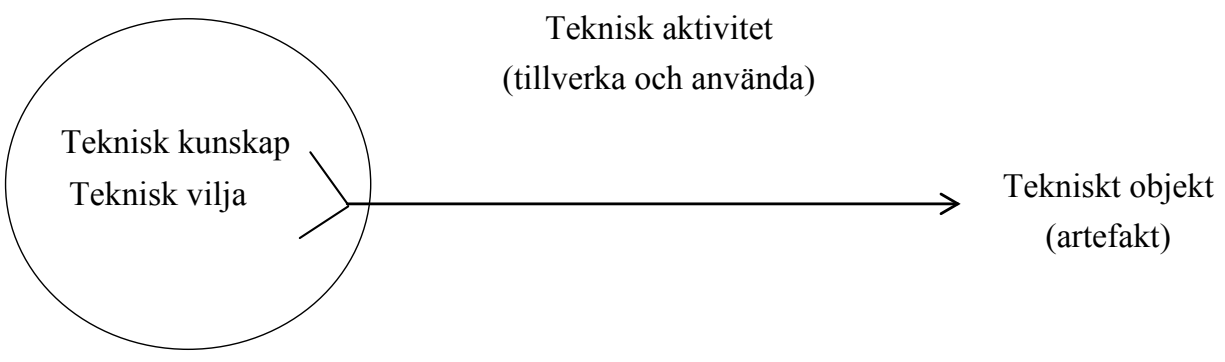

Figur 1: "Modes of the manifestations of technology" (Mitcham, 1994, s. 160).

Eftersom tekniken är en del av människans kultur, kan den också kopplas till värderingar. ${ }^{46}$ Jürgen Habermas konstaterar exempelvis att samtidigt som tekniken fungerar i enlighet med vissa tekniska regler, eftersom den är ett objekt (föremål), är den alltid bärare av betydelser, värderingar och normer. Därför, skriver Habermas, fungerar tekniken alltid som en sorts motspelare. ${ }^{47}$

Mitchams beskrivningar av teknik har fått stort genomslag och en av dess fördelar är att de lyfter fram teknikens olika dimensioner. Samtidigt saknas system-

\footnotetext{
${ }^{45}$ Ibid., s. 247- 248.

${ }^{46}$ M. de Vries, "Technological knowledge and artifacts: an analytical view”, 2006, s. 19.

${ }^{47}$ J. Habermas, "Teknik och vetenskap som ideologi" i Den rationella övertygelsen: en antologi om legitimitet, kris och politik, Stockholm: Akademilitteratur, 1984, s. 63-103.
} 


\section{Inledning och bakgrund}

perspektivet. ${ }^{48}$ Tekniken som socialt och politiskt system är något som har studerats av teknikhistoriker och tekniksociologer sedan 1970-talet. Tekniken kan bestå av enskilda artefakter men ofta är tekniken delar (komponenter) i större sammankopplade system och helheter, det vill säga tekniska system. ${ }^{49}$ Bruno Latour anser exempelvis att samhälle och teknik inte går att separera från varandra, eftersom samhället inte är en enhet som är skild från allt det som ingår i det. Teknik och samhälle är ömsesidigt konstitutiva, är helt beroende av varandra och bokstavligen skapar varandra. Utan teknik skulle det inte finnas något mänskligt samhälle, och utan samhället skulle det inte finnas någon teknik, skriver Latour. ${ }^{50}$

Thomas P. Hughes använder metaforen seamless web för att beskriva relationen mellan teknik och samhälle. Med det menar Hughes att tekniken och samhället är så sammanvävda att det kan vara svårt att urskilja var gränserna går mellan såväl delkomponenter som andra tekniska system. Han konstaterar vidare att utifrån ett systemperspektiv är även gränserna mellan teknik, naturvetenskap och sociologi många gånger "sömlösa" eller diffusa: ${ }^{51}$ "Technological systems contain messy, problem-solving components. They are both socially constructed and society shaping. ${ }^{, 52}$ Hughes beskriver det tekniska systemet som något som består av två delar: dels komponenterna, dels den sociala dimensionen. Med det sistnämnda avser han samhälleliga delar som lagstiftning, institutioner, ingenjörsfirmor, banker, forskning, intressegrupper, sociala klasser samt politiska och ekonomiska krafter. Människor, som exempelvis ingenjörerna som konstruerar och bygger, ingår i systemet - liksom miljön i form av naturresurser. ${ }^{53}$ Hughes för också fram politikens

${ }^{48}$ J. Hallström, m.fl., "Inledning" i Teknik som kunskapsinnehåll i svensk skola 1842-2010, J. Hallström, M. Hultén \& D. Lövheim (red.), Möklinta: Gidlund, 2013, s. 13.

${ }^{49}$ T. P. Hughes, "The evolution of large technological systems" i The social construction of technological systems: New directions in the sociology and history of technology, W. E. Bijker, T. P. Hughes \& T. J. Pinch (red.), Cambridge, Mass.: MIT Press, 1987, s. 51-82.

${ }^{50}$ B. Latour, Reassembling the social: An introduction to actor-network-theory, Oxford: Oxford University Press, 2005.

${ }^{51}$ T. P. Hughes, "The seamless web: Technology, science, etcetera, etcetera”, Social Studies of Science, vol. 16(2), 1986, s. 281-292.

52 T.P. Hughes, "The evolution of large technological systems", 1987, s. 52.

${ }^{53}$ Ibid..; T. P. Hughes, "Technological momentum" i Does technology drive history? The dilemma of technological determinism, M. R. Smith \& L. Marx (red.), Cambridge, Mass.: MIT Press, 1994, s. 101-113. 
betydelse för större tekniska system och hur politiska förändringar i en del av systemets komponenter kan få effekter för övriga delar och därmed systemet som helhet. ${ }^{54}$ Stora tekniska system möjliggör försörjning eller transport av information, varor, naturresurser, energi och människor. Eftersom de gör dessa funktioner åtkomliga för ett stort antal människor fyller de en samhällsfunktion och har därmed en demokratisk betydelse. ${ }^{55}$ Var gränsen går för vad som ingår i ett system kan dock vara svårt att avgöra utifrån Hughes beskrivning. Bland annat framgår inte huruvida han inkluderar den omgivning som inte står under det tekniska systemets kontroll men som ändå påverkar det. ${ }^{56}$

Vad gäller olika syn på teknik och dess inverkan på samhällsutvecklingen går dessa i grova drag att dela in i två synsätt: att tekniken lever sitt eget liv oberoende av sociala krafter i samhället (determinism) eller att tekniken är ett resultat av människans sociala och kulturellt konstruerade värld. Tanken om tekniken som autonom betyder att tekniken följer sin egen väg oberoende av människans inverkan. Langdon Winner anser att idén om den autonoma tekniken är missvisande men att den ändå har påverkat det moderna tänkandet under de senaste århundradena. ${ }^{57}$ Även Lewis Mumford konstaterar att trots att tekniken kan uppfattas som okontrollerbar, är den i själva verket något som påverkas av de sociala grupper som utnyttjar den. Människans tekniska val och handlingar kan dock få oanade konsekvenser, skriver Mumford. ${ }^{58}$ Mumford och Winner är sålunda överens om att det är människan som styr tekniken och inte tvärtom. Jacques Ellul utmanar denna uppfattning när han hävdar att den teknikutveckling som sker i det nutida samhället är för snabb för att kunna integrera äldre traditioner, något som teknikutvecklingen längre tillbaka i tiden gjorde. Därför, framhåller Ellul, följer tekniken

\footnotetext{
${ }^{54}$ T.P. Hughes, "The evolution of large technological systems", 1987, s. 51-82.

${ }^{55}$ J. Hallström, "Technology, social space and environmental justice in Swedish cities: Water distribution to suburban Norrköping and Linköping, 1860-90", Urban History, vol. 32(3), 2005, s. 413-433; J. Hallström,"Systemteori och teknik. En introduktion till stora tekniska system" i Världens gång - teknikens utveckling: Om samspelet mellan teknik, människa och samhälle, P. Gyberg \& J. Hallström (red.), Lund: Studentlitteratur, 2009, s. 99-117.

${ }^{56}$ Ibid., s. 101.

${ }^{57}$ L. Winner, Autonomous technology: Technics-out-of-control as a theme in political thought, Cambridge, Mass.: MIT Press, 1977, s. 13.

${ }^{58}$ L. Mumford, Technics and civilization, 1. Harbinger books ed., New York: Harcourt, Brace \& World, 1934/1963, s. 6.
} 


\section{Inledning och bakgrund}

nu sina egna lagar, regler och principer. Dessa bygger på rationalitet och effektivitet, vilket har lett till att människan har förlorat kontrollen över den. ${ }^{59}$ Elluls beskrivning kan tolkas som att det är tekniken som skapar samhällsförändringarna och inte tvärtom, medan Winner och Mumford anser att trots att vi inte kan förutse vilka konsekvenser teknikutveckling får, är det ändå människan som sitter vid rodret. En sådan tekniksyn går att koppla till den tidigare nämnda diskussionen om huruvida tekniken är värdeneutral eller ej. Utifrån exempelvis Pitts synsätt (att tekniken i sig är neutral vilket inte människans användning av den är), blir tekniken något som människan styr och inte tvärtom. ${ }^{60}$

Mumford tar upp ytterligare en aspekt på relationen mellan människa och teknik. Han menar att två slags tekniker har existerat sida vid sida: en auktoritär och en demokratisk. I den förstnämnda är det tekniska systemet i centrum (oerhört kraftfullt, men i sig instabilt) medan i den demokratiska tekniken så är människan i centrum (ett relativt svagt system, men resursstarkt och hållbart). Den demokratiska tekniken har sina rötter långt tillbaka i tiden, ända tillbaka till när människan skapade sina första redskap, skriver Mumford. ${ }^{61}$

\section{Natursyn}

Enligt Sverker Sörlin innefattar begreppet natursyn "de synsätt, attityder, estetiska och moraliska föreställningar om naturen som människor hyser". ${ }^{62}$ Begreppet kan i en något bredare bemärkelse sägas handla om idéer om hur människor upplever naturen som väsen, dess innersta struktur och villkor. På ett djupare plan handlar natursyn om relationen mellan kunskap om naturens förutsättningar och samhällets idéer om relationen mellan människa och natur. ${ }^{63}$

\footnotetext{
${ }^{59}$ J. Ellul, The technological society, New York: Vintage Books, 1964, s. 14; J. Ellul, “The autonomy of technology" i Technology and values: Essential readings, C. Hanks (red.), Malden, MA: Wiley-Blackwell, 2010, s. 67-75.

${ }^{60}$ J.C. Pitt, “'Guns don’t kill, people kill’; Values in and/or around technologies”, 2014, s. 89-102.

${ }^{61}$ L. Mumford, "Authoritarian and democratic technics", Technology and Culture, vol. 5(1), 1963, s. 1-8.

${ }^{62}$ S. Sörlin, "Natursyner" i Humanekologi, K. V. Abrahamsson m.fl. (red.), Stockholm: Carlsson, 1999, s. 332.

${ }^{63}$ I. Hjorth, "Natursyn i förändring: Från natur med själ till ekosystem" i Vetenskapens ansikten, H. A. Larson (red.), Jönköping: Jönköping University Press, 1997, s. 79.
} 
Biocentrisk respektive antropocentrisk är två begrepp som används för att beskriva olika slags natursyn. Den antropocentriska natursynen betecknar ett förhållningssätt där människan sätts i centrum och naturen är till för människan, vilket betyder att naturen i sig inte har något egenvärde. Inom den västerländska idéhistorien är det främst Francis Bacon (1561-1626) och René Descartes (1596-1650) som mer än andra ligger till grund för befästandet av en antropocentrisk etik. Bacon kan betraktas som en banbrytare för den moderna naturvetenskapens framväxt och han anlade ett framstegsperspektiv på teknikutvecklingen. Bacon betraktade naturen som något som skulle tuktas och tyglas till en lydig slav. ${ }^{64}$ Bacons utopi, Det nya Atlantis (postumt publicerad 1627), är strängt hierarkisk och patriarkalisk och vetenskapsmännen utför experiment i syfte att öka människans kontroll över naturen. ${ }^{65}$ Det är intressant att notera att Bacon beskriver den kaotiska naturen som att den är av kvinnligt kön. ${ }^{66}$ Till följd därav sker Bacons beskrivning av exploateringen av naturen med hjälp av kvinnliga metaforer:

[Nature] is either free, and follows her ordinary course of development $[\ldots]$ or she is driven out of her ordinary course by the perverseness, insolence, and forwardness of matter and violence of impediments [...] or, lastly, she is put in constraint, moulded, and made as it were new by art and the hand of man; as in things artificial." ${ }^{, 67}$

Bacons Det nya Atlantis agerade förebild för the Royal Society, den mest ansedda vetenskapsakademin i världen och såväl Bacons texter som Royal Societys program genomsyras av sexuell symbolik. Naturen är kvinnan som ska betvingas av vetenskapsmannen. ${ }^{68}$ Georg Henrik von Wright kallar Bacon för "teknologiens mästerfilosof”, eftersom Bacon mer vältaligt än någon annan profeterat om veten-

\footnotetext{
${ }^{64} \mathrm{C}$. Merchant, The death of nature. Women, ecology and the scientific revolution, Ny utg., San Francisco: Harper \& Row, 1989, s. 164-190; B. Skovdahl, Förlorad kontroll: Den ifrågasatta framstegstanken, Stockholm: Dialogos, 2010, s. 56; S. Sörlin, Naturkontraktet: Om naturumgängets idéhistoria, Stockholm: Carlsson, 1991, s .72-81; G. H. von Wright, Vetenskapen och förnuftet: Ett försök till orientering, Stockholm: Bonnier, 1987/2010, s. 55-65.

${ }^{65}$ C. Merchant, The death of nature. Women, ecology and the scientific revolution, 1989, s. 172177; S. Sörlin, Naturkontraktet: Om naturumgängets idéhistoria, 1991, s. 79-80.

${ }^{66}$ Ibid., s. 79.

${ }^{67}$ F. Bacon, "De Augmentis", Works, vol. 4., s. 320, 325. Citerad i C. Merchant, The death of nature. Women, ecology and the scientific revolution, 1989, s. 170.

${ }^{68}$ G. H. von Wright, Vetenskapen och förnuftet: Ett försök till orientering, 1987/2010, s. 65.
} 
skapens frukter och välsignelser i form av tekniska uppfinningar och hur dessa skulle upprätta människans herravälde över universum. Genom tillämpningen av teknik blev vetenskapen ett redskap att utöva makt, skriver von Wright. ${ }^{69}$

När det västerländska samhället mekaniserades alltmer under 1600-talet, var det med hjälp av tekniken och maskinen som "Moder Jord" skulle kuvas och bli människans slav. ${ }^{70}$ Descartes använde den mekanistiska synen på naturen och menade att djuren inte var något annat än komplexa maskiner. Det som skiljer människa och djur åt, enligt Descartes, är människans själ, vilken berättigar hennes herravälde över djur och natur. ${ }^{71}$ Genom filosofer som Bacon och Descartes fick den antropocentriska uppfattningen därmed ett slags vetenskaplig legitimitet.

En mer sentida definition av den antropocentriska utgångspunkten är att den företräder ett synsätt där varje påverkan på naturen bör värderas utifrån den effekt som den har på människan. Nu levande människor får därför inte handla så att framtida generationers liv och välbefinnande hotas. ${ }^{72}$ Grunden för detta synsätt är normen att alla människors liv är lika värdefulla. Argumentet för att inte tömma jorden på dess resurser är att människan då kan förstöra för sina efterkommande. Vi har sålunda samma förpliktelser mot alla av samma art som oss själva (inklusive de ofödda), men däremot är det inte självklart att vi har förpliktelser mot andra levande arter. Om denna natursyn gynnar andra arter, beror det endast på rena tillfälligheter. ${ }^{73}$ En slutsats av ovanstående är att en antropocentrisk natursyn nödvän-

\footnotetext{
${ }^{69}$ Ibid., s. 55.
}

${ }^{70}$ C. Merchant, The death of nature. Women, ecology and the scientific revolution, 1989, s. 2; C. Merchant, Radical ecology: The search for a livable world, New York: Routledge, 1992, s. 45.

${ }^{71}$ P. J. Bowler, The earth encompassed: A history of the environmental sciences, Ny utg., New York: Norton, 2000, s. 93; S. Sörlin, Naturkontraktet: Om naturumgängets idéhistoria, 1991, s. 72-77; D. Worster, De ekologiska idéernas historia, Stockholm: SNS (Studieförb. Näringsliv och samhälle), 1996, s. 62; G. H. von Wright, Vetenskapen och förnuftet: Ett försök till orientering, 1987/2010, s. 62.

72 Jämför Agenda 21: Programme of action for sustainable development: Rio declaration on environment and development; Statement of forest principles: the final text of agreements negotiated by governments at the United Nations Conference on Environment and Development (UNCED), 3-14 June 1992, Rio de Janeiro, Brazil, United Nations Department of Public Information, New York, 1993.

${ }^{73}$ E. Erlandson-Hammargren, Från alpromantik till hembygdsromantik: Natursynen $i$ Sverige från 1885 till 1915, speglad i Svenska turistföreningens årsskrifter och Nils Holgerssons under- 
digtvis inte innebär ett hänsynslöst utnyttjande av naturen. Däremot rättfärdigar synsättet att människan utnyttjar naturen för sina egna syften.

Företrädare för den biocentriska natursynen hävdar det motsatta, det vill säga att naturen har ett egenvärde. Människan intar inte någon hierarkiskt högre position gentemot andra arter utan bör se sig som en del av naturen. Det råder därmed ingen rangordning arter emellan. På så vis skapas en skiljelinje mellan miljöetik och den etik som gäller människor emellan. Ett biocentriskt förhållningssätt betyder att en art, ett ekosystem eller ett naturfenomen har ett egenvärde, oavsett dess betydelse och värde för oss människor. ${ }^{74}$

Enligt Donald Worster är Charles Darwin (1809-1882) den mest övertygande kraften bakom den biocentriska rörelsen. Trots att Darwin fann att naturen inte var en helt angenäm värld, var det ändå inte skäl för honom att tycka att människan var överlägsen övriga levande varelser. Istället såg han jorden som en gemensam plats där allt på den är knutet till varandra och bildar en helhet och han kunde bli djupt gripen av lidande och orättvisor i världen. Han rättfärdigade inte att människan behandlade andra intellektuellt underlägsna arter illa och han beskrevs av sina vänner som en människa som var enastående fäst vid djur och som aldrig medvetet vållat någon levande varelse smärta. Darwin gav därmed den biocentriska natursynen sitt personliga godkännande och en vetenskaplig grund. Han menade att evolutionen visar att människan inte skapats med särskild omsorg till Guds avbild, utan människan är en av alla andra arter. ${ }^{75}$ Darwin kom att påverka inflytelserika företrädare för det biocentriska synsättet, exempelvis Henry David Thoreau (18171862) och Ernst Haeckel (1834-1919). ${ }^{76}$ Thoreau läste Darwins tidiga skrifter och fann Darwins tankar både revolutionerande och intressanta. ${ }^{77}$ Samtidigt tolkades

bara resa genom Sverige, diss., Lunds universitet, Hedemora: Gidlund, 2006, s. 19; S. Sörlin, Naturkontraktet: Om naturumgängets idéhistoria, 1991, s. 157-159.

${ }^{74}$ E. Erlandson-Hammargren, Från alpromantik till hembygdsromantik: Natursynen i Sverige från 1885 till 1915, speglad i Svenska turistföreningens årsskrifter och Nils Holgerssons underbara resa genom Sverige, 2006, s. 19; S. Sörlin, Naturkontraktet: Om naturumgängets idéhistoria, 1991, s. 157-159.

${ }^{75}$ D. Worster, De ekologiska idéernas historia, 1996, s.140.

${ }^{76}$ P. J. Bowler, The earth encompassed: A history of the environmental sciences, 2000, s. $327-$ 328; S. Sörlin, Naturkontraktet: Om naturumgängets idéhistoria, 1991, s. 132-137; D. Worster, De ekologiska idéernas historia, 1996, s. 149-150.

${ }^{77}$ S. Sörlin, Naturkontraktet: Om naturumgängets idéhistoria, 1991, s. 109. 
Darwin på olika sätt av sin samtid och paradoxalt nog kom hans teorier att utnyttjas som argument för att även bekräfta den antropocentriska utgångpunkten. ${ }^{78}$ Peter J. Bowler konstaterar att utifrån Darwins beskrivning av hur olika arter interagerar och påverkar varandra, hade en filosofi kunnat utvecklas som utgår från att människan har ansvar för andra arter på jorden. I den viktorianska era som Darwin verkade i var dock utvecklingstanken överordnad den ekologiska dimensionen i hans teori. ${ }^{79}$ Istället användes Darwins evolutionsteori som ett argument hos de darwinister som företrädde en antropocentrisk natursyn.

Som Sörlin noterar erbjuder såväl det antropocentriska som det biocentriska perspektivet vissa problem. Eftersom naturen inte helt kan fredas från människans påverkan, behöver biocentriker ta ställning till vad som är tillåtet att utnyttja i naturen och under vilka betingelser detta får ske. Det problem som antropocentrikerna å andra sidan har att hantera är att människor inte är ense om vilka intressen som kommer att finnas hos framtida generationer. ${ }^{80}$

\section{Framtidssyn}

Framtidssyn förknippas ofta med olika former av utopier. Ordet "utopi" är en konstruktion sammansatt av den grekiska negationen ou (inte) och topos (plats) och betyder följaktligen "ingenstans". Den utopiska litteraturen är en form av imaginär realism eftersom den gestaltar en fiktiv värld samtidigt som den framställer den som en verklighet. Genren är uppkallad efter engelsmannen Thomas Mores skrift Utopia (1516) som handlar om ett imaginärt land i Amerika, en kontinent som i början av 1500-talet ännu var outforskad av européerna. De utopiska samhällena är uttänkta och inrymmer en föreställning om hur det goda samhället ska se ut. Ronny Ambjörnsson konstaterar att 1800-talet är utopiernas klassiska tid med företrädare

\footnotetext{
${ }^{78}$ P. J. Bowler, The earth encompassed: A history of the environmental sciences, 2000, s. 324; T. Frängsmyr, Framsteg eller förfall: Framtidsbilder och utopier $i$ västerländsk tanketradition, 1990, s. 188; M. Hård \& A. Jamison, Hubris and hybrids: A cultural history of technology and science, New York: Routledge, 2005, s. 65-66; D. Worster, De ekologiska idéernas historia, 1996, s. 130-139.

${ }^{79}$ P. J. Bowler, The earth encompassed: A history of the environmental sciences, 2000, s. 324.

${ }^{80}$ S. Sörlin, Naturkontraktet: Om naturumgängets idéhistoria, 1991, s. 157-159; E. ErlandsonHammargren, Från alpromantik till hembygdsromantik: Natursynen i Sverige från 1885 till 1915, speglad i Svenska turistföreningens årsskrifter och Nils Holgerssons underbara resa genom Sverige, 2006, s. 19.
} 
som exempelvis Robert Owen och William Morris, medan 1900-talet är dystopiernas. Dystopier är utopiernas motsats med föreställningar om ett ont samhälle som hotar mänskligheten. Exempel på dystopiska framtidsvisioner är George Orwells 1984 (1949), Aldous Huxleys Du sköna nya värld (1932) och Karin Boyes Kallocain (1940). Det har skrivits en hel del science fiction-litteratur med både utopiska och dystopiska inslag som handlar om imaginära världar bortom vår egen. ${ }^{81}$

Tore Frängsmyr kopplar samman framtidssyn med natursyn när han beskriver hur olika framtidsbilder och utopier i västvärlden vuxit fram ur politiska, ekonomiska, religiösa och vetenskapliga föreställningar. En positiv syn på den tekniska utvecklingen knyter Frängsmyr till framtidssynen det effektiva samhället. Det effektiva samhället är tekniskt och administrativt välorganiserat och företräder en natursyn där människan härskar över naturen. Det effektiva samhället står i motsatsförhållande till det goda livet, vilket är ett synsätt där den personliga utvecklingen är viktig, liksom människans anpassning till naturen. Samtidigt, konstaterar Frängsmyr, finns en förhoppning om ett effektivt samhälle även i den utopiska tanken om det goda livet. Så trots att tron på teknisk utveckling och en anpassning till naturen kan tyckas vara varandras motsatser, blir framtidssynen förvånansvärt likartad. Frängsmyrs förklaring till detta är att de flesta utopister som drömt om ett alternativt samhälle, samtidigt varit fast i det västerländska rationella idealet. Därför har de stannat för en effektivitetsmodell. Enligt Frängsmyr handlar skillnaden

\footnotetext{
Ekocentrism är ytterligare ett begrepp som används för att beskriva relationen mellan människa och natur. Inom det ekocentriska synsättet går det inte att separera människorna från de oorganiska/organiska delarna av naturen som omsluter dem och på så vis är synsättet ett slags vidareutveckling av det biocentriska perspektivet. Ekocentrismen innefattar sålunda även den ickelevande naturen och landskapet i form av floder, berg etcetera. I denna studie har jag valt att enbart använda mig av begreppen antropocentrism respektive biocentrism. För vidare läsning om ekocentrism, se exempelvis: S. J. Rowe, "Ecocentrism: The responsive chord", The Trumpeter, vol.11(2), 1994, http://trumpeter.athabascau.ca/index.php/trumpet/article/view/330/508 (läst 2013-11-12); M. Stenmark, Miljöetik och miljövård: Miljöfrågornas värderingsmässiga dimension, Lund: Studentlitteratur, 2000; S. Sörlin, Naturkontraktet: Om naturumgängets idéhistoria, 1991, s. 123-152.

${ }^{81}$ R. Ambjörnsson, Fantasin till makten! Utopiska idéer $i$ västerlandet under fem hundra år, Stockholm: Ordfront, 2004, s. 17-19, 28. Angående dystopier inom science fiction, se exempelvis N. Applebaum, "The myth of the innocent child: Interplay between nature, humanity and technology in contemporary children's science fiction", 2006, s. 1-17; N. Applebaum, Representations of technology in science fiction for young people, 2010;
} 
mellan de båda framtidsbilderna istället om att endast den ena, det effektiva samhället, har prövats i verkligheten. ${ }^{82}$

Von Wright skriver att begreppen framsteg och dess motsats förfall brukar definieras som att framsteg handlar om en förändring till det bättre, medan förfall är en förändring till det sämre. Han definierar tre olika slag av framsteg: framsteg i vetande/kunnande som är garanterad av vetenskapens och teknikens ackumulativa växt, framsteget genom människans förbättrade materiella villkor samt framsteget som höjd civilisatorisk nivå. ${ }^{83}$ Skovdahl använder begreppet framtidsoptimism som en allmän beteckning för alla optimistiska förebilder och attityder till framtiden. Revolutionära förhoppningar och politisk utopism kan också leda till optimistiska framtidsbilder. En kris av något slag kan leda till en bruten framtidsoptimism. Framstegsoptimism, eller framstegstro, handlar däremot om den framtidsinriktade delen av en övergripande framstegstanke och skulle också kunna beskrivas som en utvecklingsoptimism, skriver Skovdahl. ${ }^{84}$

I studien utgår jag från Frängsmyrs framtidssyner och jag gör dessutom en distinktion mellan en positiv syn på framtiden och framstegstro. Min tolkning av begreppen är att en positiv syn på framtiden (framtidsoptimism) inte per automatik innebär en positiv framstegstro. Framstegstro kopplar jag till teknisk utveckling, det vill säga en tilltro till tekniska framsteg. Framtidsoptimism ser jag (liksom Skovdahl) som ett vidare begrepp. Att vara framtidsoptimist skulle exempelvis kunna innebära en tro att samhället kan utvecklas i en positiv riktning men som inte inkluderar eller är ekvivalent med framsteg på det tekniska området.

\section{Sammanfattning av centrala begrepp}

Sammanfattningsvis kan teknik beskrivas i termer av artefakter, metoder och aktiviteter som människan skapat för ett specifikt ändamål eller för att lösa ett eller flera problem. Samtidigt är teknik ofta en del av en större helhet som inte går inte att separera från den samhälleliga kontext den ingår i, det vill säga en delkompo-

\footnotetext{
${ }^{82}$ T. Frängsmyr, Framsteg eller förfall: Framtidsbilder och utopier $i$ västerländsk tanketradition, 1990, s. 227-236.

${ }^{83}$ G. H. von Wright, ’Den stora tanken om framsteget. Om framstegstänkande, tvivel och humanism" i Handla! Om förändring, välfärd, arbete, lärande, konsumtion, arkitektur, design, kultur, framtid, G. H. von Wright (red.), Stockholm: Nerenius \& Santérus, 1997, s. 23-38.

${ }^{84}$ B. Skovdahl, Förlorad kontroll: Den ifrågasatta framstegstanken, 2010, s. 8.
} 


\section{Inledning och bakgrund}

nent $\mathrm{i}$ ett system. I studien använder jag mig därför av Carl Mitchams fyrdelade beskrivning av teknik i kombination med Thomas P. Hughes beskrivning av tekniska system när jag undersöker tekniken i barnböckerna. En tekniksyn förknippas dessutom ofta med en specifik syn på naturen eftersom tekniken så gott som alltid har någon form av inverkan på naturen. När jag tolkar vilka syner på naturen som berättelserna förmedlar, använder jag mig av begreppen antropocentrisk respektive biocentrisk natursyn. Teknik betraktas dessutom ofta som en lösning på såväl nutida som framtida problem, vilket gör att jag i min läsning av texterna även undersöker budskap om framtiden. Jag utgår då från framtidsbeskrivningarna av det effektiva samhället respektive det goda livet.

\section{Tidigare forskning}

Det finns forskning som undersöker tekniken i skönlitterära vuxen- eller barnböcker och jag har gått igenom studierna inom båda forskningsfälten. Det de har gemensamt är att de ser på tekniken som ett kulturellt fenomen. Forskningsgenomgången har som syfte att ge en översikt av inriktningar, metoder och teoretiska utgångspunkter samt identifiera kunskapsluckor. Utifrån denna genomgång önskar jag sedan positionera min studie och synliggöra på vilket sätt den kan betraktas som ett kunskapsbidrag.

\section{Studier av tekniken som fenomen i vuxenlitteraturen}

En genomgång av forskningen som undersöker tekniken i vuxenlitteratur visar att dessa studier till stor del handlar om reaktionen och kritiken mot teknikens inverkan på samhället och hur detta kommer till uttryck i skönlitteraturen. Forskarna menar att litteraturen vittnar om en ambivalens när det gäller inställningen till teknik och naturvetenskap. En majoritet av studierna undersöker litteratur från tiden kring den västerländska industriella revolutionens genombrott i västvärlden. Leo Marx böcker The machine in the garden: Technology and the pastoral ideal in America (1964) respektive The pilot and the passenger: Essays on literature, technology, and culture in the United States (1988) är exempel på sådana studier. Marx identifierar spänningen mellan tidens pastorala idéer i Amerika och den snabba utvecklingen inom vetenskap, teknik och industri. Marx utgår bland annat från Mark Twains Adventures of Huckleberry Finn (1884) för att undersöka hur människan försöker hitta en balans mellan lantlig lycka och produktivitet, välstånd och makt. Marx undersöker även det mer sentida samspelet mellan litteratur, teknik 
och politisk ideologi i USA och i en essä i The pilot and the passenger beskriver han att den misstro mot tekniken som växte fram bland intellektuella i USA efter atombomben i Hiroshima 1945. ${ }^{85}$

Martin Kylhammars avhandling Maskin och idyll. Teknik och pastorala ideal hos Strindberg och Heidenstam (1985) är ett exempel på en svensk studie som utifrån skönlitteraturen analyserar spänningen mellan pastorala ideal och industrialisering. Kylhammars slutsats är att såväl August Strindberg som Verner von Heidenstam var på kollisionskurs med den moderna tiden och den industriella civilisationen, innan de till sist lyckades försona sig med den industriella kulturen och dess viktiga kraftcentrum: Strindberg med arbetarrörelsen och Heidenstam med tekniken och vetenskapen. ${ }^{86}$

I avhandlingen Förnuftets brytpunkt. Om teknikkritiken i P C Jersilds författarskap (1990) undersöker Jonas Anshelm diskussionen om teknisk utveckling och moraliskt ansvar inom P. C. Jersilds författarskap. Anshelms slutsats är att Jersild sällar sig till den upplysningstradition som lierade sig med vetenskapen och den tekniska utvecklingen i kampen mot fördomar och traditionalism. Anshelm menar att liksom upplysningsfilosofen Kant, sätter Jersild i sina skrifter sin tilltro till det kritiska förnuftet. Men samtidigt identifierar Anshelm en dialektik mellan Jersilds tilltro till förnuftet och tvivel på detsamma. Därför, menar Anshelm, kan Jersilds arbeten ses som ett bidrag till de viktiga diskussionerna om teknisk utveckling och mänskligt ansvar i det moderna samhället. ${ }^{87}$

Exempel på en studie som fokuserar på ett specifikt teknikområde är uppsatsen Ljus över landet. Elektrifieringen och litteraturen (1991), i vilken Lars Furuland undersöker vad ljuset och elektrifieringen betydde för människorna utifrån författare som August Strindberg, Vilhelm Moberg och Harry Martinsson. Furulands slutsats är att elektriciteten ledde till att boken nådde fler människor än tidigare eftersom den förändrade människors livsmönster, bland annat i form av belysning $\mathrm{i}$ hemmen vilket i sin tur ledde till ökad läsning. På så vis, menar Furuland, bidrog

\footnotetext{
${ }^{85}$ L. Marx, The machine in the garden: Technology and the pastoral ideal in America, New York: Oxford University Press, 1964; L. Marx, The pilot and the passenger: Essays on literature, technology, and culture in the United States, New York: Oxford University Press, 1988.

${ }^{86}$ M. Kylhammar, Maskin och idyll: Teknik och pastorala ideal hos Strindberg och Heidenstam, 1985, s. 201.

${ }^{87}$ J. Anshelm, Förnuftets brytpunkt: Om teknikkritiken i P. C. Jersilds författarskap, 1990.
} 
elektrifieringen även till folkbildningen. Teknikskiftet med dess tillhandahållande av tekniska artefakter påverkade också tidens författares språk i form att nya metaforer. $^{88}$

I boken Bilen \& människan i svensk prosa och poesi (2009) undersöker Emin Tengström, utifrån svensk skönlitteratur, relationen mellan människan och bilen från tidiga erfarenheter av bilåkning i början av förra seklet till den sentida diskussionen om hur vi ska hantera bilismen i dagens och framtidens globala samhälle. I sin studie visar Tengström hur både bilentusiaster och kritiker bland de svenska författarna formulerade sina upplevelser av bilen. Harry Martinsson var exempelvis en av de första att fästa uppmärksamheten vid det i längden ohållbara i förhållandet mellan människa och bil. Tengströms slutsats är att om framtidens människor till sist inser att relationen mellan människa och bil har ett alltför högt pris, såväl socialt som miljömässigt, kommer de kanske att hänvisa till Harry Martinssons bilkritiska texter från 1900-talets mitt. ${ }^{89}$

I Representations of science and technology in British literature since 1900 (1992) analyserar Earl G. Ingersoll tekniken i sexton "representativa skönlitterära verk", skrivna mellan åren 1880 och 1980. Ingersoll konstaterar bland annat att maskinteknik som ångbåtar och tåg användes som symboler eller metaforer för hur ny teknik gjorde sitt intåg och påverkade människor, samhälle och natur. ${ }^{90}$

Science fiction är en genre som använder tidens vetenskapliga och tekniska framsteg för att beskriva visioner om framtiden. Den svenska forskningen om tekniken i science fiction-litteraturen är dock än så länge begränsad i sin omfattning, men ett exempel är Michael Godhes avhandling Morgondagens experter. Tekniken, ungdomen och framsteget $i$ populärvetenskap och science fiction i Sverige under det långa 1950-talet (2003). I studien undersöker Godhe vilka förhoppningar och förväntningar på ungdomen som uttrycktes i den populärvetenskapliga litteraturen och vilken roll science fiction spelade för dessa visioner. Godhes slutsats är att science fiction-litteraturen bidrog till att normalisera den nya atomtekniken med

\footnotetext{
${ }^{88}$ L. Furuland, "Ljus över landet. Elektrifieringen och litteraturen" i Ljus över landet och andra litteratursociologiska uppsatser, Hedemora: Gidlund, 1991, s. 33-62.

${ }^{89}$ E. Tengström, Bilen \& människan i svensk prosa och poesi, 2009, s. 18.

${ }^{90}$ E. G. Ingersoll, Representations of science and technology in British literature since 1880, 1992.
} 
närvaron av atombombshot och omforma den till en sorts "vardag". ${ }^{91}$ En annan svensk avhandling i ämnet är Jerry Määttäs avhandling Raketsommar: Science fiction i Sverige 1950-1968 i vilken Määttä beskriver science fiction-genrens framväxt i Sverige samt hur den togs emot av läsare och kritiker. Han beskriver även hur en läsarrörelse växte upp kring litteraturgenren. ${ }^{92}$

\section{Studier av tekniken som fenomen i barnlitteraturen}

Den befintliga forskningen som undersöker tekniken i barnlitteraturen har ett annat fokus än studierna av vuxenlitteraturen. Som konstaterades i inledningen har barnlitteraturen historiskt sett framför allt bedömts utifrån dess fostrande och pedagogiska funktion, vilket också är utgångspunkten för en majoritet av studierna.

J.H. Schwarcz beskriver i artikeln "Machine animism in modern children's literature" (1967) hur litteraturen levandegör artefakter i syfte att skapa en relation mellan de unga läsarna och den nya teknik som de möter i sin vardag. Schwarcz identifierar ett antal mer eller mindre distinkta gestaltningar av maskinen. Skillnaderna dem emellan handlar dels om graden av personifiering, dels om vilken roll maskinen får i berättelsen. Schwarcz slutsats är att ju betydelsefullare maskinen är för historien, desto mer kommer den att förses med biologiska och psykiska egenskaper. ${ }^{93}$

Eric Hintz går i antologin Enterprising youth: Social values and acculturation in nineteenth-century American children's literature (2008) tillbaka till industrialiseringens genombrott när han undersöker ett antal biografier skrivna mellan 1850 och 1900. Ett av hans syften är att ta reda på vad författarna kan ha velat att deras läsare skulle lära sig om teknik när de valde uppfinnare som huvudpersoner i böckerna. Hintz konstaterar att uppfinnare som Edison kom att bli populära i biografier skrivna för den yngre publiken kring förra sekelskiftet och deras primära uppgift var att inympa moral i sina unga läsare. Hintz studie visar att uppfinnarna

\footnotetext{
${ }^{91}$ M. Godhe, Morgondagens experter: Tekniken, ungdomen och framsteget i populärvetenskap och science fiction i Sverige under det långa 1950-talet, diss., Linköpings universitet, Stockholm: Carlsson, 2003, s. 204-207.

92 J. Määttä, Raketsommar: Science fiction i Sverige 1950-1968, diss., Uppsala universitet, Lund: Ellerström, 2006.

${ }^{93}$ H. J. Schwarcz, "Machine animism in modern children's literature", The Library Quarterly, vol. 37(1), 1967, s. 82-83.
} 
inte enbart fick statuera exempel för sin professions värden, utan också sociala värden som kristen asketism, måttlighet och patriotism. ${ }^{94}$ Hintz slutsats är att samtidigt som uppfinnarna var med och skapade ett nytt tekniskt samhälle, fick de också agera förebilder för traditionella värderingar och moral. ${ }^{95}$ En liknande studie finns i antologin National identity. The role of science and technology (2009). I ett kapitel undersöker Katherine Pandora sambanden mellan barndomens natur och ett vetenskapligt medborgarskap. Hon gör det genom att analysera några nyckeltexter om natur, vetenskap och teknik skrivna av två av de mest populära barnboksförfattarna vid tiden före amerikanska inbördeskriget: Samuel Griswold Goodrich och Jacob Abbott. De båda författarna var av åsikten att de genom sin litteratur kunde bidra till att forma Amerikas framtida medborgare och påverka republikens framtida öde. De betraktade sina arbeten som användbara i såväl skolans klassrum som hemundervisningen, skriver Pandora. Målet var inte att skapa vetenskapsmän utan att de unga skulle kunna uppnå en känsla av vetenskapligt medborgarskap för att på så sätt få tillgång till de rättigheter och privilegier som följde en sådan status. Abbotts tydliga pedagogiska och didaktiska synsätt handlade om att lärarna och föräldrarna skulle söka kunskap tillsammans med barnen och att de vuxna inte alltid skulle sitta inne med svaren på barnens frågor. Abbott menade att det var själva sökandet efter kunskap som var det viktiga ${ }^{96}$ Huruvida dessa pedagogiskt progres-

${ }^{94}$ Det Hintz beskriver går även att applicera på en svensk historisk kontext. I de så kallade Grundkatalogernas förteckningar över litteratur som ansågs lämplig för folk- och skolbibliotek finns ett antal biografier om olika uppfinnare upptagna. Exempelvis finns böcker om John Ericsson, Alfred Nobel, Emanuel Swedenborg, Christopher Polhem, Johan Gutenberg och Thomas Edison med i förteckningarna över lämplig barn- och ungdomslitteratur. Att dessa inte finns med i min studies analys beror på att de inte kan kallas skönlitterära, utan snarare är en slags faktalitteratur. Hintz resultat är dessutom intressant utifrån det faktum att beskrivningarna av uppfinnarnas liv användes för att överbrygga spänningarna mellan det nya och gamla i samhället, liksom för att moraliskt fostra det uppväxande släktet. Detta är något som man kan anta att också skolbibliotekens skönlitterära barnböcker skulle bidra till. Se Katalog över Böcker som folk- och skobibliotek samt riksförbund som bedriva biblioteksverksamhet kunna erhålla i statsbidrag: På uppdrag av Kungl. Ecklesiastikdepartementet, Grundkatalog 1 för åren 1915-16, 2 för åren 1924-31 samt Grundkatalog 2 med Tillägg för åren 1932-1964, Stockholm: Haeggströms Boktryckeri.

${ }^{95}$ E. S. Hintz, "Heroes of the laboratory and the workshop: Inventions and technology in books for children, 1850-1950", 2008, s. 209.

${ }^{96}$ K. Pandora, "The children's republic of science in the Antebellum literature of Samuel Griswold Goodrich and Jacob Abbot" i National identity: The role of science and technology, C. E. Harrison \& A. Johnson (red.), Chicago: University of Chicago Press, 2009, s. 75-98. 
siva författare i realiteten kom att påverka didaktiken i skolorna på det sätt som författarna själva önskade visar inte Pandoras studie. Böckerna är dock exempel på berättelser med explicita budskap och hur författare skriver fram syftet med sina böcker.

Den enda studie jag funnit som inte undersöker barnlitteratur i en västerländsk kontext är en artikel skriven av John McCannon. Han har studerat teknik, naturvetenskap och utopier i sovjetisk barnlitteratur åren 1921-1932 (2001). McCannon konstaterar att auktoriteterna inom utbildning och kultur under Lenins och Stalins regimer var övertygade om att barnlitteraturen var ett effektivt redskap i formandet av unga sovjetiska medborgare och den utvecklades därför till att bli tydligt didaktisk under den kommunistiska regimen. I Samuil Marshaks barnbok War with the Dnieper (1931) skildras exempelvis bygget av en kraftverksdamm som ett krig mot floden. Målet med kraftverksdammen är att tämja flodens vatten och ge elektricitet åt regionen. Floden är mäktig men de riktiga hjältarna är maskinerna, ånggrävmaskinen och lyftkranen. McCannon menar att den sovjetiska regimen använde barnlitteraturen som redskap för att förmedla att de nått målet att skapa en socialistisk utopi. Likaså finns ett budskap om att tekniken är mänsklighetens starkaste vapen mot naturen. ${ }^{97}$

Schwarcz, Hintz, Pandoras respektive McCannons studier är alla exempel på forskning som undersöker barnlitteraturen utifrån dess fostrande och didaktiska funktion. Det finns emellertid ett par studier som tydligare lyfter fram kopplingar mellan den tekniska samhällsutvecklingen och barnlitteraturens innehåll. I boken Children's literature and social change (2010) presenterar Dennis Butts tolv fallstudier där han undersöker sambanden mellan barnlitteratur och dess sociala, kulturella och politiska sammanhang under de senaste två hundra åren, från tiden för den industriella revolutionens genombrott och framåt. När samhället förändrades började vissa författare successivt att artikulera sin religiösa och moraliska undervisning i ett mindre idylliskt socialt sammanhang jämfört med tidigare, skriver Butts. Under vissa tidsperioder framstår barnlitteraturens innehåll som allvarligt och tydligt didaktiskt, medan den under andra är mer lättsam och underhållande. Hans sammantagna slutsats är dock att barnböckerna har ett didaktiskt innehåll

\footnotetext{
${ }^{97}$ J. McCannon, "Technological and scientific utopias in Soviet children's literature, 1921-1932", Journal of Popular Culture, vol. 34(4), 2001, s. 153-169.
} 
oavsett vilken tid de härrör från, även om budskapen i mer sentida böcker är mer subtila. $^{98}$

I kapitlet "Barbara Hofland: The moral tale and the Industrial Revolution" konstaterar Butts att författarinnan Barbara Hofland (1770-1844) gav uttryck för en filosofi där det finns en förbindelse mellan religiös övertygelse, strävsamhet och framgång. Hennes berättelser handlar ofta om barn och unga som kämpar under ogynnsamma förhållanden för att upprätthålla integritet och kristen dygd, samtidigt som de utövar olika slags affärsmannaskap kopplade till industrin för att försörja sig själva och sina familjer. Denna kombination är något som alltid belönas i berättelserna. De utspelar sig dessutom i ett industrialiserat urbant samhälle och inte den lantliga miljö som tidigare moraliska berättelser utspelade sig i, skriver Butts. ${ }^{99}$ I ett annat kapitel i boken, "Imperialists of the air: Flying Stories 1900 1950", hävdar Butts att framväxten av flygberättelser i 1900-talets början inte enbart kan ses som en förlängning av den traditionella äventyrsromanen utan också måste betraktas som en respons på tidens tekniska utveckling inom flyget. W.E. Johns (1893-1968) Bigglesböcker är ett exempel på böcker inom denna genre. Butts slutsats är att böckerna har ett tydligt nationalistiskt budskap, samtidigt som tekniken skildras som om den vore levande och agerar som pilotens mänskliga följeslagare. ${ }^{100}$ Även Stefan Mählqvist har studerat Bigglesböckerna. I sin studie Biggles i Sverige: En litteratursociologisk studie av W. E. Johns Bigglesböcker (1983) tecknas böckernas historia men också hur bokserien utvecklades i förhållande till samhällsförändringarna. En skillnad mellan forskarnas analyser är att Butts menar att flygplanet ofta ges en mänsklig skepnad i flygböckerna, medan Mählqvists konklusion är att Johns rör sig i en modern tid, där flygmaskinen står i handlingens centrum och långt ifrån gestaltas som besjälad. ${ }^{101}$ Något som Butts

\footnotetext{
${ }^{98}$ D. Butts, "Introduction" i Children's literature and social change: Some case studies from Barbara Hofland to Philip Pullman, Cambridge: Lutterworth Press, 2010, s. ix-x.

${ }^{99}$ D. Butts, "Barbara Hofland: The moral tale and the industrial revolution" i Children's literature and social change: Some case studies from Barbara Hofland to Philip Pullman, Cambridge: Lutterworth Press, 2010, s. 8-9.

${ }^{100}$ D. Butts, "Imperialists of the air: Flying stories 1900-1950" i Children's literature and social change: Some case studies from Barbara Hofland to Philip Pullman, Cambridge: Lutterworth Press, 2010, s. 110-115.

${ }^{101}$ S. Mählqvist, Biggles i Sverige: En litteratursociologisk studie av W. E. Johns Bigglesböcker, Stockholm: Gidlund, 1983, s. 19.
} 
och Mählqvist dock är överens om är att flygberättelserna kretsar kring vita äventyrshjältar som modigt slår sig fram i allehanda exotiska miljöer, vilket går att förena med ett nationalistiskt och imperialistiskt intresseperspektiv. ${ }^{102}$

I sin avhandling Representations of technology in science fiction for young people (2010) liksom i en artikel från 2006 undersöker Noga Applebaum vilka attityder till teknik som förmedlas via science fiction-litteratur som vänder sig till yngre läsare. Applebaum utgår från frågeställningen om vår ökade vana och vårt ökade beroende av teknik som datorer, internet och mobiltelefoner är något som reflekteras i texterna, i form av en mer positiv attityd till teknik och dess relation till naturen. Hon använder sig av begreppen mechanism, naturalism respektive equilibrium för att beskriva attityderna till teknik i böckernas framtidssamhällen. Applebaums slutsats är att i fjorton av de sexton romanerna utmålas det framtida livet i samhällen som mechanism, det vill säga ett fiktivt samhälle i vilken tekniken används för att exploatera och dominera naturen och där människor som har teknologisk makt är placerade högst upp i hierarkin. I dessa böcker är författarna fast beslutna att varna sina läsare för teknikutvecklingen. Applebaum finner det märkligt att trots att miljöexperter i dag erbjuder utvecklingsbeskrivningar som försöker balansera användandet av modern teknik med bevarande av naturen, är det enbart ett fåtal böcker som skildrar en sådan lösning (equilibrium). Att en majoritet av författarna tycks föredra att barn lever i en icke-teknisk, primitiv värld (naturalism) visar att myten om "the innocent child" lever vidare, menar Applebaum. Hon är av åsikten att om böcker för unga istället kunde presentera olika kreativa och alternativa scenarion om framtiden där tekniken inkluderas istället för förkastas, skulle denna destruktiva världsbild kunna suddas bort. På så sätt skulle författarna nå sitt ursprungliga syfte: att varna unga människor för farliga vägval i framtiden och göra dem medvetna om mer önskvärda alternativ. ${ }^{103}$

När det gäller den svenska forskningen som undersöker teknik i böcker som vänder sig till lite yngre barn, är den ännu begränsad till sin omfattning. ${ }^{104}$ Boel

\footnotetext{
${ }^{102}$ Ibid., s. 29.

${ }^{103}$ N. Applebaum, "The myth of the innocent child: Interplay between nature, humanity and technology in contemporary children's science fiction”, 2006, s. 1-17; N. Applebaum, Representations of technology in science fiction for young people, 2010.

${ }^{104}$ B. Westin, "Karlsson som technobody", Tidskrift för litteraturvetenskap, vol. 32(4), 2003a, s. 128; B. Westin, "Världens bästa Karlsson: Barnlitteratur och teknologi", Nordisk tidskrift för
} 


\section{Inledning och bakgrund}

Westin anser att teknologi, sedd som vetenskapen om teknik, kan fungera som markör av tid eller rum på ett synkront och/eller diakront plan, eftersom den kan verka som en narrativ utkikspunkt. Exempelvis ser hon den motoriserade Karlsson på taket i Astrid Lindgrens böcker som kompatibel med samtidens svenska flygplansteknologi. Karlsson företräder dessutom en okomplicerad syn på förhållandet mellan kropp och maskin, en symbios mellan kropp och maskin, där tekniken kan ses som en förlängning av kroppen, skriver Westin och hänvisar till Donna Haraways beskrivning av cyborgen. ${ }^{105}$ Samtidigt finner Westin benämningen technobody som en mer passande beskrivning av Karlsson, det vill säga "den teknologiserade kroppen som ingenjörsprodukt". ${ }^{106}$

En studie som tangerar teknik i barnlitteratur är Martin Hellströms avhandling Förpackningens förvandlingar. Konsumtion och karneval i barnboken (2011). Hellström undersöker vad de massproducerade förpackningarna representerar i barnböcker och i studien ingår barnböcker skrivna av bland annat Roald Dahl, Tove Jansson, Astrid Lindgren, Barbro Lindgren och Maurice Sendak. Hellströms slutsats är att förpackningarna representerar ett alternativ till konsumtionssamhället; ett levnadssätt som handlar om att istället för att drivas av en önskan efter nya produkter se värdet $\mathrm{i}$ det man redan har och att vi måste börja leva ett liv som stämmer mer överens med de materiella resurser som finns. Ur den aspekten, skriver Hellström, är barnen inte de främsta mottagarna av budskapet $\mathrm{i}$ barnlitteraturen. Barnlitteraturen öppnar ögon och kräver en förändring, och då i första hand av de vuxna. ${ }^{107}$

vetenskap, konst och industri, vol. 79(4), 2003b, s. 294. Mailkontakt med L. Kåreland, Uppsala universitet 2009-11-23 och B. Westin, Stockholms universitet 2010-08-18.

${ }^{105}$ D. J. Haraway, "A cyborg manifesto: Science, technology, and socialist-feminism in the late twentieth century" i Simians, cyborgs and women: The reinvention of nature, London: Free Association Books, 1991, s. 149.

${ }^{106}$ B. Westin, "Karlsson som technobody", 2003a, s. 128-142; B. Westin, "Världens bästa Karlsson: Barnlitteratur och teknologi", 2003b, s. 293-300. För ytterligare läsning om Haraways cyborg, se D. J. Haraway, "A cyborg manifesto: Science, technology, and socialist-feminism in the late twentieth century”, 1991, s. 149-181.

${ }^{107}$ M. Hellström, Förpackningens förvandlingar: Konsumtion och karneval i barnboken, diss., Linköpings universitet, Stockholm: Carlsson, 2011. 


\section{Sammanfattning av tidigare forskning}

I den existerande forskningen om relationen mellan teknik, samhälle och litteratur är barnlitteratur som vänder sig till yngre barn generellt inte införlivad. ${ }^{108}$ Den begränsade forskning som trots allt finns härrör företrädesvis från Storbritannien och USA. Den undersöker i huvudsak litteratur som skrevs före år 1900. Ett sannolikt skäl till detta är att många forskare finner den tid då det västerländska samhället industrialiserades som särskilt intressant när man vill undersöka hur den tekniska samhällsutvecklingen skildras i litteraturen. När det gäller svenska studier som undersöker det tekniska innehållet i barnlitteratur som vänder sig till yngre barn, har jag funnit Westins två artiklar om Karlsson på taket. Som ett exempel på forskning om tekniken i ungdomslitteraturen finns Mählqvists studie om Biggles samt en växande svensk forskning inom science fiction-genren. ${ }^{109}$

En stor del av den befintliga forskningen visar hur uppfinnare och flygare fătt agera hjältar och förebilder för att ingjuta moral, patriotism och traditionella värderingar hos barn samt hur författare genom sina böcker velat bidra till barns utvecklande av ett vetenskapligt medborgarskap. Tekniken i barnböckerna har historiskt sett samtidigt fungerat som ett medel för att upptäcka det okända, exempelvis genom luftfärder.

I animerad form får tekniken agera metafor för samhällsutvecklingen och därmed vara ett medium för att skola in tidens barn i ett modernt industrialiserat samhälle där teknik och människa ska samexistera. Angående relationen mellan teknik och framtidssyn finns en tendens inom sentida anglosaxisk science fiction att beskriva det framtida samhället som en teknikdeterministisk dystopi, där tekniken tagit herraväldet på bekostnad av människor och natur.

Sett till den forskning som finns har min studie gemensamma beröringspunkter med forskningen om tekniken i såväl vuxenlitteraturen som barnlitteraturen, framför allt genom att en majoritet av denna har en historisk utgångspunkt. Men jag har

\footnotetext{
${ }^{108}$ B. Westin, "Karlsson som technobody", 2003a, s. 128; B. Westin, "Världens bästa Karlsson: Barnlitteratur och teknologi”, 2003b, s. 294. Mailkontakt med L. Kåreland, Uppsala universitet 2009-11-23 och B. Westin, Stockholms universitet 2010-08-18.

${ }^{109}$ M. Godhe, Morgondagens experter: Tekniken, ungdomen och framsteget i populärvetenskap och science fiction i Sverige under det långa 1950-talet, 2003; S. Mählqvist, Biggles i Sverige: En litteratursociologisk studie av W. E. Johns Bigglesböcker; 1983; J. Määttä, Raketsommar: Science fiction i Sverige 1950-1968, 2006.
} 
inte funnit någon forskning som undersöker barnlitteraturen utifrån ett teknikdidaktiskt perspektiv. Tidigare forskning har haft som huvudsakligt mål att placera och undersöka det tekniska innehållet $\mathrm{i}$ barnböckerna i ett historiskt och kulturellt sammanhang. Detta är något även denna studie gör, men när jag i nästa steg i tolkningsprocessen identifierar olika teman $i$ berättelserna, bortser jag från den kontext böckerna kommit till i. På så vis önskar jag synliggöra barnböckernas teknikdidaktiska innehåll utifrån flera av de perspektiv som i dag anses betydelsefulla inom teknikens didaktik. ${ }^{110}$

\footnotetext{
${ }^{110}$ V. Bjurulf, Teknikdidaktik, Stockholm: Norstedt, 2011, s. 209; J.R. Dakers, "Towards a philosophy for technology education”, 2006b, s. 145-158; J.-E. Hagberg \& M. Hultén, Skolans undervisning och elevers lärande i teknik: Svensk forskning i internationell kontext, 2005, s. 12-19.
} 



\section{KAPITEL 2}

\section{Studiens metodologi}

\section{Analys och tolkning utifrån ett hermeneutiskt perspektiv}

Min studie vilar på en hermeneutisk grund. Hermeneutik handlar om att tolka och att tolka är att tyda tecken. Den som tolkar berättar att han/hon ser något som något, det vill säga ger det en betydelse. ${ }^{111}$ Litteraturvetare som M.O. Grenby och Lars Elleström gör en åtskillnad mellan att analysera och tolka. Grenby menar att vid analysen av primärmaterialet bryts texten ned för att göra det möjligt att undersöka hur dess olika beståndsdelar skapar den samlade effekten. När man sedan tolkar texten söker man efter betydelser, det vill säga vad texten säger mig som läsare. ${ }^{112}$ Elleström skriver att när man analyserar strävar man efter att vara så objektiv och tydlig som möjligt, medan när man tolkar en text så tillskriver man texten en sorts subjektiv mening. Liksom Elleström finner jag det dock vara svårt att i praktiken skilja mellan analys och tolkning. Som människor tolkar vi hela tiden omedvetet allting i vår omgivning för att göra den begriplig, vilket vi då gör utifrån de kunskaper och fördomar vi har. Det viktiga är därför inte att argumentera för att den egna tolkningen är "rätt" utan att den är värd att ta i beaktande. ${ }^{113}$ En hermeneutisk forskares tolkningar är därmed av förklarliga skäl svåra att upprepa med exakt samma resultat av en annan forskare. Den förståelse som tolkas fram kan

\footnotetext{
${ }^{111}$ P.-J. Ödman, Tolkning förståelse vetande. Hermeneutik i teori och praktik, 2005, s. 44.

${ }^{112}$ M. O. Grenby, "Basic children's literature research skills" i Children's literature studies: A research handbook, K. Reynolds \& M. O. Grenby (red.), Basingstoke: Palgrave Macmillan, 2011, s. 24.

${ }^{113}$ L. Elleström, Lyrikanalys: En introduktion, 1999, s. 96.
} 


\section{Studiens metodologi}

däremot ibland även sägas gälla i andra sammanhang. ${ }^{114}$ Som Ödman konstaterar innebär detta att det inte kan finnas en generaliserbarhet i egentlig mening. Genom argumentation får man som forskare istället visa hur man har tänkt och på så sätt ge läsaren en möjlighet att ta ställning till tolkningarna. ${ }^{115}$ På så vis används inom hermeneutiken ett slags argumentationslogik istället för en valideringslogik. ${ }^{116}$ Ödman skriver vidare att det mest grundläggande "validitetskriteriet" $i$ en hermeneutisk undersökning är att bli varse hur delar och helheter i tolkningarna hänger ihop och att vi som forskare självkritiskt granskar hur vi närmar oss det som ska tolkas. På så sätt kan vi urskilja vår egen roll i tolkningssituationen samt nå en insikt om hur vår egen förförståelse påverkar tolkningarna. Därför, hävdar Ödman, behöver vi som forskare få grepp om de diskursiva praktiker vi själva är inbegripna i och hur de påverkar vårt tänkande. ${ }^{117}$

Wilhelm Dilthey (1833-1911), en av hermeneutikens förgrundsgestalter, är av åsikten att det som utmärker humanvetenskaperna är möjligheten till en förståelse inifrån, något som står i kontrast till de förklaringsinriktade naturvetenskapernas målsättning. ${ }^{118}$ Exempelvis kan naturvetenskapliga förklaringsmodeller utnyttjas för att fastslå orsaker till människans beteende, medan exempelvis historievetenskaperna, litteraturteorin och existensfilosofin istället söker förstå motiven bakom människans upplevelser och handlande. ${ }^{119}$

Ett alternativ till detta synsätt har formulerats av en av den så kallade kritiska hermeneutikens företrädare, Paul Ricoeur. Han företräder ett slags "både-ochperspektiv", vilket gör att jag finner delar av hans synsätt som användbara ut-

\footnotetext{
${ }^{114}$ B. Gustavsson, "Kunskapandets mångfald - från enhet till fragment" i Kunskapande metoder inom samhällsvetenskapen, B. Gustavsson (red.), Lund: Studentlitteratur, 2004, s. 13-14.

${ }^{115}$ P.-J. Ödman, "Hermeneutik och forskningspraktik", 2004, s. 84.

${ }^{116}$ M. Alvesson \& K. Sköldberg, Tolkning och reflektion: Vetenskapsfilosofi och kvalitativ metod.2., 2008, s. 207.

${ }^{117}$ P.-J. Ödman, "Den hermeneutiska cirkelns gränser. Till validitetsfrågan inom hermeneutiken" i Text och existens. Hermeneutik möter samhällsvetenskap, S. Selander \& P.-J. Ödman (red.), Göteborg: Daidalos, 2005, s. 101, 110-111.

${ }^{118}$ Se exempelvis P. Ricoeur, "Vad är en text?", 1993c, s. 31, 39; P.-J. Ödman, Tolkning, förståelse, vetande: Hermeneutik i teori och praktik, 1979/2001, s. 27-30.

${ }^{119}$ P. Kemp \& B. Kristensson, "Inledning" i Från text till handling: En antologi om hermeneutik, 4. uppl., Stockholm: B. Östlings bokförl. Symposion, 1993, s. 13-14; P.-J. Ödman, Tolkning, förståelse, vetande: Hermeneutik i teori och praktik, 1979/2001, s. 59.
} 
gångspunkter för min studie. Ett huvudtema $\mathrm{i}$ hans texter är hans dialektiska förhållningssätt till den vetenskapliga kampen mellan naturvetenskapliga förklaringar och humanvetenskapernas sökande efter förståelse samt hans strävan att bygga en bro mellan dessa två kulturer. Ricoeur menar att en uppdelning mellan förklaring och förståelse inte är möjlig, eftersom de i själva verket är två på varandra följande moment i tolkningsprocessen. Istället bör man, enligt Ricoeur, sträva efter att upprätta en mer komplementär och ömsesidig relation mellan dessa båda attityder. ${ }^{120}$ Ricoeur anser att vetenskapliga förklaringar utifrån orsaker och lagbundenhet exempelvis inte kan påvisa att människan har någon egen vilja. Denna vilja handlar först och främst om hans/hennes möjlighet att säga nej och själv kunna påverka sina egna möjligheter. Människan som helhet är skapad genom en "pakt" mellan natur och frihet och därför måste förklaring och förståelse komplettera varandra: ${ }^{121}$ "Människan är just sådan att hon samtidigt tillhör orsakmässighetens rike och motivationens rike, alltså både förklaringens och förståelsens domäner." ${ }^{122}$

Den kritiska hermeneutiken saknar på förhand bestämda metoder för hur det empiriska materialet ska behandlas. Hos Ricoeur finns en grundtanke om en öppenhet för vad texten säger läsaren, en öppenhet som har som mål att leda till en förståelse av det studerade. ${ }^{123}$ Samtidigt som han tar avstånd från traditionellt positivistiska vetenskapsideal, kräver han en distans till såväl det studerade som textens upphovsman. Detta krav på distans motiverar Ricoeur med att författarens intention aldrig sammanfaller med textens innebörd, eftersom texten alltid säger läsaren något mer än vad författaren ursprungligen avsett att säga: ${ }^{124}$

\footnotetext{
${ }^{120}$ P. Ricoeur, "Förklara och förstå. Text - handling - historia", 1993a, s. 68; P. Ricoeur, "Vad är en text?", 1993c, s. 53.

${ }^{121}$ P. Kemp \& B. Kristensson, ’Inledning” i Från text till handling: En antologi om hermeneutik, 1993, s. 14. Kemp \& Kristensson hänvisar till Ricoeurs Det frivilliga och det ofrivilliga (Le volontaire et l'involontaire, Paris, 1950).

${ }^{122}$ P. Ricoeur, "Förklara och förstå. Text - handling - historia", 1993a, s. 83.

${ }^{123}$ S. Claesson m.fl., "Ricoeurs kritiska hermeneutik vid empiriska studier", 2011, s. 18-35.

${ }^{124}$ B. Engdahl, "Hungern efter entydighet. Om Ricoeurs både-och och samhällsvetenskapens andra" i Text och existens. Hermeneutik möter samhällsvetenskapen, Staffan Selander \& PerJohan Ödman (red.), Göteborg: Daidalos, 2005, s. 119; P. Ricoeur, "Vad är en text?", 1993c, s. 59.
} 


\section{Studiens metodologi}

To begin with, writing renders the text autonomous with respect to the intention of the author. What the text signifies no longer coincides with what the author meant; henceforth, textual meaning and psychological meaning have different destinies. ${ }^{125}$

Med Ricoeurs synsätt är inte läsande av en text detsamma som ett samtal mellan författare och läsare. Genom texten har dialogsituationen försvunnit och författaren har förlorat kontrollen över textens mening. Författarens intention finns inte längre med som ett kriterium för hur den ska tolkas, utan den har blivit en del av texten. ${ }^{126}$ I en text finns en vilja att säga något, men till skillnad mot samtalet är den direkta kommunikationen mellan den som talar och den som lyssnar bruten. Det är texten som "svarar" läsaren och inte författaren. Därför är det texten som ska tolkas och inte författarens avsikter med den, enligt Ricoeur. ${ }^{127}$ Även Butts tar upp relationen mellan författare och text. Hans åsikt är att litteraturen inte kan ses som en passiv konstruktion som enbart reflekterar samhället. Litteraturen kan till exempel tolkas som att den reagerar emot, protesterar eller har som mål att förändra samhället. ${ }^{128}$ För att illustrera sin ståndpunkt citerar Butts författaren D.H. Lawrence: "Never trust the artist; trust the tale". ${ }^{129}$

För att finna möjliga förklaringar inom texten rekommenderar Ricoeur en strukturell analys, i vilken det sker en avkronologisering av texten. Den strukturella analysen handlar om att textens olika delar (ord, satser, tecken) registreras och organiseras. En avkronologisering innebär att tidsföljden inom berättelsen demonteras och rekonstrueras i syfte att synliggöra mönster och frilägga meningsbärande delar. Därmed förändras den ursprungliga berättelsens kronologi. Den strukturella analysens syfte är att beskriva texten utifrån olika perspektiv för att skapa en så allsidig bild av den som möjligt. Ricoeurs åsikt är att även om målet är att nå en

${ }^{125}$ P. Ricoeur, "The hermeneutical function of distanciation" i Hermeneutics and the human sciences: Essays on language, action and interpretation, John B. Thompson (red.), Cambridge: Cambridge University Press, 1981, s. 139.

${ }^{126}$ B. Kristensson Uggla, Kommunikation på bristningsgränsen: En studie i Paul Ricoeurs projekt, 1994, s. 302-303.

${ }^{127}$ P. Ricoeur, "Vad är en text?", 1993c, s. 34-36.

${ }^{128}$ D. Butts, "Introduction" i Children's literature and social change: Some case studies from Barbara Hofland to Philip Pullman, 2010, s. xii.

${ }^{129}$ D.H. Lawrence, Studies in classic American literature, London: Heineman, 1924 /1971, s. 2. 
förståelse av vad texten säger, är förklaringen av textens struktur en förutsättning för att en djupare förståelse ska kunna nås. ${ }^{130}$

Då denna studie inte har en lingvistisk ambition, utan en teknikdidaktisk utgångspunkt, har jag med inspiration från Ricoeurs synsätt låtit registrera, analysera samt tolka de ord och satser i texten som handlar om teknik. För att få textens innebörd att framstå tydligare, har jag i analyserna strukturerat om så att de delar som verkar ha liknande meningsinnehåll förts samman i teman. Här utgår jag från hur Leo Marx definierar begreppet tema. Marx anser att det är viktigt att särskilja det litterära verkets handling från dess tema, eftersom: "A poem set in a factory need be no more about industrialism than Hamlet about living in castles [...]" ${ }^{131}$ Enligt Marx är en forskares skyldighet i första hand att förstå vad texten egentligen handlar om och det är först därefter han/hon kan fortsätta att söka förklaringar till de teman som finns i texten. Med detta menar han inte att den historiska betydelsen ska förnekas. Däremot bör texttolkaren söka efter specifika teman och uppfattningar i texterna som finns där trots att de har sitt ursprung i en specifik historisk kontext. ${ }^{132}$ Min uppfattning är att Marx definition av tema sammanfaller med Ricoeurs syn på tolkningsprocessen, det vill säga att förståelsen för vad texten säger bör sökas inom texten samtidigt som förförståelsen är viktig för att jag ska kunna göra rimliga tolkningar.

Enligt Ricoeur bör den som tolkar dessutom eftersträva att nå en förståelse som innefattar både det medvetna och det omedvetna som uttrycks i det empiriska materialet. Genom vad han kallar misstankens hermeneutik kan dessa dolda sidor av det studerade friläggas. En hermeneutisk tolkning måste därför vara både lyssnande och "misstänksam", eftersom tolkning handlar om att avslöja sådant som inte framträder tydligt $\mathrm{i}$ texten. Med "dolt" avser inte Ricoeur vad som gömmer sig bakom texten, det vill säga vad man skulle kunna kalla "författarens hemliga agenda", utan vad som avslöjas framför den. Misstankens hermeneutik handlar om en strävan att förstå den värld som öppnas genom texten samt att synliggöra tysta och

\footnotetext{
${ }^{130}$ P. Ricoeur, "Vad är en text?", 1993c, s. 50-52.

${ }^{131}$ L. Marx, The pilot and the passenger: Essays on literature, technology, and culture in the United States, 1988, s. 114.

${ }^{132}$ Ibid.
} 
dolda motsägelser i det empiriska materialet. ${ }^{133}$ Bengt Kristensson Uggla beskriver tolkningsakten som: "[A]tt tolka är att lyssna och att misstänka. Man måste vara misstänksam för att bevaras i sanningen, men det måste också finnas ett lyssnande i varje misstanke om inte kommunikationen skall upphöra." ${ }^{134}$

Som redan klargjorts i avhandlingens syftesavsnitt, betraktar jag en förståelse av den historiska kontexten som betydelsefull för mina tolkningar av barnböckerna. Det vi ser och upplever tolkar vi så gott som alltid utifrån de förkunskaper vi har, det vill säga vår förförståelse. Om vi inte förstår en text, får vi sätta textens struktur i relation till de villkor och föreställningar den vilar på för att på så vis finna förklaringar. ${ }^{135}$ Som Ödman skriver är vår förförståelse "[...] unik i så måtto att den sammanhänger med vår historikalitet, vår bakgrund och våra erfarenheter som individer". ${ }^{136}$ Därmed betraktar jag sådant som lärdomar, erfarenheter och upplevelser som förutsättningar för att en tolkningsprocess överhuvudtaget ska komma igång. För att förstå måste vi förklara, liksom det omvända: för att kunna förklara något måste vi ha förstått det vi ämnar förklara. Eller som Ödman sammanfattar det: "[V]i kan inte förstå utan att redan ha förstått." 137

Med stöd i ovanstående menar jag att en förutsättning för att primärtexternas (barnböckernas) budskap om teknik ska kunna tolkas begripligt, bör studiet av böckerna grunda sig på en syntes av tolkningar av de enskilda texternas olika delar i relation till sekundärkällor (historiska källor) respektive texterna som helhet. ${ }^{138}$ Med detta avser jag inte att det i texterna finns entydiga, objektiva budskap om teknik, utan genom ett kritiskt och "misstänksamt" läsande, ämnar jag argumentera för möjliga tolkningar. Därutöver följer jag Göran B. Nilssons råd att försöka

\footnotetext{
${ }^{133}$ S. Claesson m.fl., "Ricoeurs kritiska hermeneutik vid empiriska studier", 2011, s. 18-20; B. Kristensson Uggla, Kommunikation på bristningsgränsen: En studie i Paul Ricoeurs projekt, 1994, s. 310-311; P. Ricoeur, "The model of the text: Meaningful action considered as a text", 1973, s. 91-117; P. Ricoeur, "Förklara och förstå. Text - handling - historia", 1993a, s. 77-78.

${ }^{134}$ B. Kristensson Uggla, Kommunikation på bristningsgränsen: En studie i Paul Ricoeurs projekt, 1994, s. 256.

${ }^{135}$ S. Selander \& P.-J. Ödman, "Inledning" i Text och existens. Hermeneutik möter samhällsvetenskapen, 2005, s. 11; P.-J. Ödman, Tolkning, förståelse, vetande: Hermeneutik i teori och praktik, 1979/2001, s. 45, 81-82.

${ }^{136}$ Ibid., s. 186.

${ }^{137}$ Ibid., s. 81.

${ }^{138}$ P.-J. Ödman, "Hermeneutik och forskningspraktik", 2004, s. 83.
} 
skriva historia framlänges istället för baklänges, det vill säga försöka förstå det vi undersöker utifrån den kunskap och det vetande som fanns när det vi tolkar ägde rum. När man undersöker historiskt material är det lätt att glömma aktörsperspektivet eftersom man sitter med facit $\mathrm{i}$ hand, skriver Nilsson. Nilsson varnar för vad han kallar "kronologisk imperialism" där man som forskare sätter sig på människor i det förflutna som inte har en chans att försvara sig. Utgår man däremot från ett perspektiv där de historiska aktörernas framtidsbedömning tas på allvar, fördjupas förståelsen. ${ }^{139}$ Lars J. Lundgren är inne på samma linje som Nilsson när han framhåller att man inte bör se det som skett som en rätlinjig utveckling utan som en väv av händelser som samverkar eller kolliderar med varandra. Människor agerar för att förändra, reagerar på förändringar, gammal teknik slås ut av ny och nya tekniker kopplas samman. Inget av detta går att förutsäga, menar Lundgren. Hans slutsats är att även om man har som ambition att beskriva det historiska förloppet framlänges, får man acceptera det dialektiska förhållandet mellan det förflutna och nuet, ett dubbelt perspektiv. ${ }^{140}$

Med stöd i Ödman, Nilsson och Lundgren betraktar jag kunskaper om den historiska kontext i vilken berättelserna kommit till som betydelsefulla för mina tolkningar. Genom information om det förflutna kan jag bygga upp den förförståelse som krävs för att göra rättvisa tolkningar. Likaså kan, som Håkan Arvidsson poängterar, ingen forskare undgå att påverkas av sin samtid. Den fastställer forskarens perspektiv och påverkar hans eller hennes synfält. På grund av nuet tvingas vi ständigt skriva om historien. ${ }^{141}$

Mitt fokus i studien är att undersöka, förstå och tolka den föreliggande texten samt söka efter likheter respektive skillnader berättelserna emellan avseende deras teknikdidaktiska innehåll. Med inspiration från Ricoeurs kritiska hermeneutik analyserar jag och tolkar berättelserna var för sig, i kronologisk ordning samt i relation deras historiska kontext. I den påföljande fasen i tolkningsprocessen identifierar jag respektive berättelses tekniksyn i förhållande till natur- respektive framtidssyn

${ }^{139}$ G. B. Nilsson, "Historia som humaniora" i Den lycklige humanisten: Tio offensiva essäer, Stockholm: Carlsson, 1990, s. 47-66.

${ }^{140}$ L. J. Lundgren, Staten och naturen: Naturskyddspolitik $i$ Sverige 1869-1935. D. 1, 1869-1919, Brottby: Kassandra, 2009, s. 21.

${ }^{141}$ H. Arvidsson, "Dåtiden - tur och retur", Historisk Tidskrift, Stockholm, vol. 122(3), 2002, s. 409. 


\section{Studiens metodologi}

samt strukturerar om så att de delar som verkar ha gemensamma beröringspunkter förs samman till sammanhängande enheter. ${ }^{142}$

I avhandlingens avslutande och sammanfattande diskussion avkronologiserar jag berättelserna och utifrån en jämförande analys för jag samman textavsnitt med liknande innehåll. Med avkronologisering avser jag här att tidsföljden (såväl inom de enskilda berättelserna som berättelserna emellan), struktureras om i analysarbetet. Syftet är att identifiera teman som inte är explicit tidsbundna. I analyser och tolkningar inkluderar jag också språkliga symboler som används för att gestalta tekniken, såsom metaforer och liknelser.

Vid tolkningen av texterna utnyttjar jag närläsning som metod för att finna väsentliga idéer och budskap i varje enskild text, vilket är den metod som Grenby rekommenderar vid studiet av innehållet i barnlitteratur. ${ }^{143}$ Barry S. Brummet definierar närläsning (close reading) som "[...] the mindful, disciplined reading of an object with a view to deeper understanding of its meaning". ${ }^{144}$ Närläsning handlar därmed (och i samstämmighet med Ricoeur) om att tolka en text utöver det som uttryckligen står skrivet. Min läsning av sekundärmaterialet sker i huvudsak genom vad Grenby kallar en värdering av texterna. I detta ingår att undersöka huruvida mina tolkningar överensstämmer med andra forskares tolkningar och ställningstaganden samt om det finns något som saknas i tidigare analyser och som jag kan tillägga. ${ }^{145}$

Eftersom det empiriska materialet till vissa delar består av böcker med illustrationer föreligger ytterligare en metodologisk aspekt. Nikolajeva menar att samspelet mellan text och bild har en avgörande betydelse för tolkningarna av en bilderbok. Om ord och bild uttrycker samma sak öppnas dock inte berättelsen för så många alternativa tolkningar som när ord och bild står i kontrast till varandra eller

\footnotetext{
${ }^{142}$ Ricoeur använder begreppet "avkronologisering" när han beskriver hur texterna i den strukturella analysen demonteras och rekonstrueras (P. Ricoeur, "Vad är en text?", 1993c, s. 50-52). I den första delen av analysarbetet, det vill säga i analyser och tolkningar av varje enskild berättelse, sker därmed också en form av avkronologisering. Detta med hänvisning till att när jag identifierar tekniksyn i förhållande till natur- respektive framtidssyn, sker detta genom att avsnitt som har liknande budskap förs samman.

${ }^{143}$ M. O. Grenby, "Basic children's literature research skills", 2011, s. 14, 32.

${ }^{144}$ B. S. Brummett, Techniques of close reading, 2010, s. 25.

${ }^{145}$ M. O. Grenby, "Basic children's literature research skills”, 2011, s. 24.
} 
förmedlar alternativ information. ${ }^{146}$ Mina tolkningar av bilderböckerna bygger därför på vad Kristin Hallberg kallar en ikonotextuell tolkning. Med ikonotext avser Hallberg den berättelse som skapas genom interaktionen mellan bilderbokens båda berättande medier, med andra ord en holistisk tolkning av bild och text. ${ }^{147}$

I Bilderboken: På väg mot en teori (2001), gör Ulla Rhedin en analys av bilderbokens uppbyggnad och historia och hon finner att böckerna med illustrationer kan kategoriseras på tre sätt utifrån hur bild och text är utformade i förhållande till varandra. Under den första kategorin hamnar illustrerade texter och där placerar hon böcker där texten är det bärande för historien. Bilderna kan tas bort eller läggas till utan att berättelsen förändras. Den andra kategorin, expanderande texter, handlar om bilderböcker där texten och illustrationerna kompletterar varandra för att bilda en komplett berättelse. Med den tredje kategorin, genuina bilderböcker, avser Rhedin böcker där bild och text är helt beroende av varandra och inte fungerar var för sig. ${ }^{148} \mathrm{I}$ denna studie ingår böcker från Rhedins alla tre kategorier. Jag har låtit bilder ingå i de analysavsnitt där jag finner dem vara av betydelse för tolkningar och analyser, alternativt fungerar som ett stöd för mina tolkningar.

\section{Studiens val av barnlitteratur}

\section{Barnlitteratur}

För att kunna göra ett urval bland barnböckerna krävs ett klargörande av vad jag $\mathrm{i}$ denna studie avser med barnlitteratur. Att strikt dela in litteraturen i läroböcker respektive skönlitteratur kan vara svårt, det vill säga att särskilja den litteratur som varit ämnad att ingå i skolans undervisning, från den som inte har haft detta som

\footnotetext{
${ }^{146}$ M. Nikolajeva, Bilderbokens pusselbitar, Lund: Studentlitteratur, 2000, s. 27.

${ }^{147}$ K. Hallberg, "Litteraturvetenskapen och bilderboksforskningen", Tidskrift för litteraturvetenskap, vol. 3-4, 1982, s. 163-168; K. Hallberg, "Kom an, Alfons Åberg! En studie av Gunilla Bergströms bilderbokssvit", i Barnlitteraturanalyser, M. Andersson \& E. Druker (red.), Lund: Studentlitteratur, 2008, s. 9.

${ }^{148}$ U. Rhedin, Bilderboken: På väg mot en teori, 2. rev. uppl., Stockholm: Alfabeta, 2001, s. 81, $89,96$.
} 


\section{Studiens metodologi}

primärt syfte. ${ }^{149}$ Ett exempel på detta är Nils Holgerssons underbara resa genom Sverige, som var tänkt som en geografibok för nioåringar, men kom att räknas till klassikerna inom svensk litteratur. Dessutom är den en av våra mest internationellt kända böcker. ${ }^{150}$ Noriko Thunman berättar exempelvis att hon under sin uppväxt $\mathrm{i}$ Japan läste den som en fantastisk äventyrshistoria och att det var först när hon kom till Sverige som hon fick veta att den skrevs för barn i undervisningssyfte. ${ }^{151}$

Även gränsdragningen mellan barn- och vuxenlitteratur är oklar och hur de skiljer sig åt är en återkommande diskussion bland barnboksforskare. ${ }^{152}$ En del litteratur kan ha förlorat sin ställning som vuxenlitteratur över tid och istället kommit att räknas till barnlitteraturen. Folksagorna, de antika fablerna men också äventyrslitteratur som De tre musketörerna (Alexander Dumas), Gullivers resor (Jonathan Swift) och Robinson Crusoe (Daniel Defoe) är exempel på detta. ${ }^{153}$ Andra författare har från början inte haft intentionen att skriva för barn, men böckerna har senare ändå kommit att kategoriseras som barnlitteratur. Det motsatta förhållandet existerar också, det vill säga att böcker som från början skrivits för barn senare har blivit populära bland vuxna. ${ }^{154}$ Böckerna om Harry Potter är i England och övriga världen utgivna som barnböcker, samtidigt som de nått en stor publik av vuxna läsare. ${ }^{155}$ Den alltmer frekvent använda kategoriseringen av litteratur som crossover- eller allålderslitteratur, belyser definitionsproblematiken ytterliga-

\footnotetext{
${ }^{149}$ G. Klingberg, Svensk barn- och ungdomslitteratur 1591-1839: En pedagogikhistorisk och bibliografisk översikt, 1964, s. 10.

${ }^{150}$ V. Edström, S. X. Erixson, Uppdrag läsebok: Nils Holgersson, Stockholm: Rabén \& Sjögren, 1996, s. 7.

${ }^{151}$ N. Thunman, "Selma Lagerlöf i Japan” i Selma Lagerlöf seen from abroad: Ett symposium $i$ Vitterhetsakademien den 11 och 12 september 1997, Stockholm: Kungl. Vitterhets-, historie- och antikvitetsakademien, 1998, s. 41.

${ }^{152}$ L. Kåreland, Barnboken i samhället, 2013, s. 13.

${ }^{153}$ G. Klingberg, Svensk barn- och ungdomslitteratur 1591-1839: En pedagogikhistorisk och bibliografisk översikt, 1964, s. 7.

${ }^{154}$ D. C. Thacker \& J. Webb, Introducing children's literature: From romanticism to postmodernism, London: Routledge, 2002, s. 12-14.

${ }^{155}$ L. Kåreland, Barnboken i samhället, 2013, s. 14.
} 
re. ${ }^{156}$ "Barnlitteratur" kan således definieras på flera olika sätt. När man pratar om barnböcker kan man dessutom dels avse den för barn producerade litteraturen, dels den som barn konsumerar. ${ }^{157}$ För att särskilja dessa brukar man när man menar det senare istället tala om barns läsning. ${ }^{158}$

I sin avhandling om svensk barnlitteratur (1964) utgår Göte Klingberg från "[...] sådana verk som uteslutande eller företrädesvis utgivits för barn och ungdom”. ${ }^{159}$ Med detta avser han litteratur där det på titelblad eller på annat sätt framgår att författaren eller utgivaren avsett en läsning för unga människor. Med andra ord avser Klingberg i princip alla böcker som avsiktligt skrivits för barn oberoende av deras innehåll. Klingberg menar att en sådan avgränsning är motiverad i ett arbete med pedagogikhistorisk orientering eftersom han då kan inkludera fler viktiga litteraturgrupper. ${ }^{160}$

Enligt Reynolds är det mest universellt accepterade kriteriet för att en bok ska klassificeras som barnbok föreslaget av John Rowe Townsend. ${ }^{161}$ Townsend hävdar att skiljelinjen mellan litteratur för vuxna och litteratur för barn är godtycklig och till stor del skapad av administrativa eller ekonomiska skäl. Hans slutsats är att den enda praktiska definitionen av en barnbok är: "[A] book which appears on the children's list of a publisher." ${ }^{162}$ Kåreland föreslår något liknande när hon skriver

\footnotetext{
${ }^{156}$ När det gäller så kallad crossover-litteratur, se exempelvis D. Galef, "Crossing over: Authors who write both children's and adults' fiction", Children's Literature Association Quarterly, vol. 20(1), 1995, s. 29.

${ }^{157}$ R.G. Kelly, Mother was a lady: Self and society in selected American children's periodical, 1865-1890, Westport, Conn., 1974, s. xiii; G. Klingberg, Svensk barn- och ungdomslitteratur 1591-1839: En pedagogikhistorisk och bibliografisk översikt, 1964, s. 5; L. Kåreland, Gurli Linders barnbokskritik: Med en inledning om den svenska barnbokskritikens framväxt, 1977, s. 9.

${ }^{158}$ Ibid.

${ }^{159}$ G. Klingberg, Svensk barn- och ungdomslitteratur 1591-1839: En pedagogikhistorisk och bibliografisk översikt, 1964, s. 5.

${ }^{160}$ Ibid., s. 4-10. Med "pedagogisk viktig litteraturgrupp" avser Klingberg bland annat den höviska litteraturen som annars inte hade kunnat inkluderas $i$ hans studie.

${ }^{161}$ K. Reynolds, "Introduction" i Children's literature studies: A research handbook, 2011, s. 6.

162 J.R. Townsend, A sense of story: Essays on contemporary writers for children, London: Longman, 1971, s. 10.
} 


\section{Studiens metodologi}

att en hanterbar definition kan vara: "[D]e böcker som av förlagen lanserats och marknadsförts som barn- och ungdomsböcker". ${ }^{163}$

Med hänvisning till avhandlingens syfte och övergripande frågeställning ser jag det som viktigt att utgå från en beskrivning som tar hänsyn till studiens didaktiska intention. Här handlar det om att inkludera barnböcker som vänder sig till barn mellan sex och tolv år och som dessutom har ett innehåll som i dag anses relevant inom teknikens didaktik. ${ }^{164} \mathrm{Jag}$ utgår därför från Townsends respektive Kårelands definitionsförslag och de analyserade böckerna har valts inom den litteratur som kan definieras som: Den litteratur som de bibliotekstekniska hjälpmedlen kategoriserar som böcker för barn mellan sex och tolv år.

\section{Urvalskriterier}

Den analyserade litteraturen består av svenska skönlitterära barnböcker som är skrivna från början av 1900-talet fram till början av 2000-talet. Det teknikdidaktiska perspektivet har varit utgångspunkten för urvalet. Som tidigare nämnts, innebär detta att utöver att texterna innehåller skildringar av teknik, inkluderar deras innehåll också frågeställningar och problematiker som i dag betraktas som betydelsefulla och relevanta inom teknikens didaktik. ${ }^{165}$ Urvalet har skett utifrån följande kriterier:

1. Böckerna/berättelserna innehåller teknik som går att identifiera utifrån Carl Mitchams fyrdelade beskrivning av teknik och/eller Hughes beskrivning av tekniska system. ${ }^{166}$

\footnotetext{
${ }^{163}$ L. Kåreland, Barnboken i samhället, 2013, s. 13.

${ }^{164}$ V. Bjurulf, Teknikdidaktik, 2011, s. 209; J. R. Dakers, "Towards a philosophy for technology education", 2006b, s. 145-158; J.-E. Hagberg \& M. Hultén, Skolans undervisning och elevers lärande i teknik: svensk forskning i internationell kontext, 2005, s. 12-19.

${ }^{165}$ V. Bjurulf, Teknikdidaktik, 2011, s. 209; John R. Dakers, "Towards a philosophy for technology education”, 2006b, s. 145-158; J.-E. Hagberg \& M. Hultén, Skolans undervisning och elevers lärande i teknik: svensk forskning i internationell kontext, 2005, s. 12-19.

${ }^{166}$ T.P. Hughes, "The seamless web: Technology, science, etcetera, etcetera", 1986, s. 281-292; T.P. Hughes, "The evolution of large technological systems", 1987, s. 51-82; T.P. Hughes, “Technological momentum", 1994, s. 101-113; C. Mitcham, Thinking through technology: The path between engineering and philosophy, 1994, s. 160.
} 
2. Böckerna/berättelserna förmedlar ett budskap om teknik (tekniksyn), samtidigt som de förmedlar en syn på teknikens inverkan på människa, natur eller framtid. I detta ingår ett ställningstagande till människans roll genom den växelverkan som finns mellan människa/samhälle, teknik, natur och framtid.

3. Böckerna/berättelserna vänder sig till barn i åldern sex till tolv år.

4. Författarna och deras böcker finns upptagna i den aktuella tidsperiodens dominerande bibliotekstekniska hjälpmedel (grundkataloger respektive Bibliotekstjänsts sambindningskataloger). I den senare delen av den undersökta tidsperiodens barnböcker ska författaren finnas med i författarfondens utlåningsstatistik.

Ett medvetet val är att inte inkludera sådan litteratur som genremässigt räknas till science fiction-litteraturen. Min motivering till detta är att jag vill studera hur tekniken skildras och gestaltas i en samtida kontext.

\section{Urvalsprocessen}

Att jag vid urvalet av barnböcker utgått från tidens bibliotekstekniska hjälpmedel, och inte det bokbestånd som verkligen stod i bibliotekens hyllor, beror på att några sådana förteckningar inte finns att tillgå. Enligt skolbiblioteksföreningarna är skoloch folkbibliotek sammanslagna i den existerande statistiken. Skolbiblioteken har aldrig varit en homogen grupp. För många skolor, såväl förr som nu, är verkligheten att de varken har ett skolbibliotek eller tillgång till en skolbibliotekarie. De är istället hänvisade till allmänna folkbibliotek. ${ }^{167}$ De bibliotekstekniska hjälpmedel jag använt mig av är de så kallade grundkatalogerna samt Bibliotekstjänsts sambindningskataloger. Sveriges författarfonds statistik från 1960-talet och framåt har också utnyttjats som urvalsinstrument.

Grundkatalogerna började ges ut 1915 på initiativ av Ecklesiastikdepartementet och deras uppgift var att främja folk- och skolbiblioteken. De består av bokförteckningar och korta recensioner. Eftersom biblioteken kunde få statsbidrag om de valde böcker ur dessa förteckningar, kom grundkatalogerna att i hög grad styra

\footnotetext{
${ }^{167}$ Personlig kommunikation via mail 2010-10-22 med Fredrik Ernerot, Ordförande i Skolbibliotek Väst.
} 


\section{Studiens metodologi}

bibliotekens bokinköp. ${ }^{168}$ Med tiden kom grundkatalogerna dock att förlora sitt inflytande och den sista gavs ut 1964. Kritikerna menade att den inte var anpassad som hjälpmedel vid inköp av böcker till folkskolans bibliotek samt att de inte uppdaterades i samma takt som den nya litteraturen gavs ut. ${ }^{169}$

1952 började Bibliotekstjänst att, två gånger per månad, ge ut listor över nyutkommen litteratur. Sedan 1970-talet är dessa kompletterade med lektörsrecensioner. Sambindningskatalogerna tog successivt över inflytandet när det gäller bibliotekens inköp och används än i dag. ${ }^{170}$ Vid urvalet av litteratur till den senare delen av 1900-talet har jag därför utgått från sambindningskatalogens förteckningar i kombination med Sveriges författarfonds statistik. Statistiken har jag använt mig av för att säkerställa att urvalet består av böcker som nått en stor läsekrets. Författarfondens förteckningar är samordnade undersökningar av författarnas utlåningsstatistik där både folk- och skolbibliotekens utlåning ingår. Deras undersökningar går tillbaka till 1954 och det finns listor av skiftande kvalitet från början av 1960-talet. ${ }^{171}$

${ }^{168}$ N.O. Bruce, Svenska folkskolans historia. D. 4. Det svenska folkundervisningsväsendet 19001920, 1940, s. 491-493; Katalog över böcker som folk- och skolbibliotek samt riksförbund, som bedriva skolbiblioteksverksamhet kunna erhålla i statsbidrag: på uppdrag av Kungl. Ecklesiastikdepartementet. Grundkatalog 1, Stockholm: Haeggströms Boktryckeri, 1915-1922; Katalog över böcker som folk- och skolbibliotek samt riksförbund, som bedriva skolbiblioteksverksamhet kunna erhålla i statsbidrag: på uppdrag av Kungl. Ecklesiastikdepartementet. Grundkatalog 2, Stockholm: Haeggströms Boktryckeri, 1924-1931; Katalog över böcker som folk- och skolbibliotek samt riksförbund, som bedriva skolbiblioteksverksamhet kunna erhålla i statsbidrag: På uppdrag av Kungl. Ecklesiastikdepartementet, Grundkatalog 2 med Tillägg för åren 1932-1964, Stockholm: Haeggströms Boktryckeri, 1932-1964.

${ }^{169}$ D. Andersson, Folkbibliotek, makt och disciplinering: En genealogisk studie av folkbiblioteksområdet under den organiserade moderniteten, diss., Stockholms universitet, Stockholm, 2009, s. 91; R. Arnling, "De moderna pionjärerna", Ikoner, vision och tradition, nr. 2, 2006, s. 6-9, http://www.btj.se/ikoner/arkiv/2006/pdf/06_2.pdf. (läst 2010-03-17); K. Regfors, ”Hjälpmedel vid valet av böcker för barn och ungdom”, Biblioteksbladet, vol. 17, 1932, http://runeberg.org/biblblad/1932/0190.html (läst 2010-05-14).

${ }^{170}$ Telefonsamtal och mailkontakt med Gunvor Assergård, redaktör, Bibliotekstjänst, 2012-03-26; Bibliotekstjänst, Btj, "Historik", Bibliotekstjänst, http://corp.btj.se/?id=96 (läst 2011-09-20).

${ }^{171}$ Författarfonden förmedlar den statliga biblioteksersättningen som utgår till upphovsmän till litterära verk för användningen av deras verk genom de svenska folk- och skolbiblioteken och innehar därför statistik över vilka författare som är mest utlånade. Enligt författarfonden gjorde de tidigare separata undersökningar för folk- och skolbibliotek (grund-, gymnasie- samt folkhögskolor), men listorna omfattar alltid både och. Att i efterhand separera utlåningstalen är därför inte 
Första steget i studiens urvalsprocess var att gå igenom grundkatalogerna för åren 1915 och till och med 1964, inklusive tillägg. En förteckning upprättades över alla de böcker som uppfyllde urvalskriterierna samt hade ett innehåll som motsvarade studiens syfte och frågeställning (se avsnittet Urvalskriterier). De korta recensionerna i grundkatalogerna gav mig information om huruvida böckerna kunde vara intressanta för ett närmare studium eller ej. Då grundkatalogerna innehåller rekommenderad barnlitteratur skriven före 1915, kunde jag även finna böcker från 1900-talets början som var intressanta för studien. 51 titlar valdes ut för en noggrannare genomgång.

När det gäller urvalet av barnlitteratur från sambindningskatalogerna för tiden från 1950 och framåt tedde sig mängden boklistor alltför omfattande för att gås igenom i sin helhet. ${ }^{172}$ Enbart antalet kataloger för åren 1950 till 1986 översteg 900 stycken (med 35-100 titlar per katalog). Därför valde jag slumpmässigt ut i genomsnitt fyra kataloger per år, cirka 80 stycken titlar. 79 av dem uppfyllde mina kriterier och jag undersökte därefter hur böckernas författare låg till i författarfondens utlåningsstatistik från 1961 och framåt. Förutom att böckerna skulle uppfylla kriterierna, ville jag att urvalet skulle bestå av böcker/berättelser av så varierande karaktär och bredd som möjligt avseende teknikdidaktiskt innehåll, målgruppens ålder (sex till tolv år) samt tidpunkt för tillkomst (från sekelskiftet 1900 till 2000talets början). Läsningen visade att det var åtta författare vars barnböcker återkommande hade ett tydligt teknikdidaktiskt innehåll. Deras produktion genomgick därför en noggrannare analys. ${ }^{173}$ Sex författare och femton verk kom slutligen att bli föremål för djupare analyser och tolkningar:

möjligt. Numera skiljer man inte på skol- och folkbibliotek utan gör en samordnad undersökning av utlåningen. Bakgrunden är den integrering av folk- och skolbibliotek som blivit alltmera vanlig. Källa: Personlig kontakt via mail 2010-10-22 med Johan Lammassaari, Sveriges författarfond.

${ }^{172}$ Angående den svenska barnboksutgivningen, se exempelvis Å. Warnqvist, "Dragonball, LasseMaja och Twilight: Utgivningen av barn- och ungdomslitteratur i Sverige 2001-2010" i Läsarnas marknad, marknadens läsare: En forskningsantologi utarbetad för Litteraturutredningen (SOU 2012:10), s. 329-361, http://www.riksdagen.se/sv/Dokument-Lagar/Utredningar/Statensoffentliga-utredningar/Lasarnas-marknad-marknadens-1_H0B310d4/?html=true (läst 2013-12-12).

${ }^{173}$ Förutom djupare analyser av böcker skrivna av Selma Lagerlöf, Otto Witt, Elsa Beskow, KarlAage Schwartzkopf, Sven Wernström och Sven Nordqvist, gjordes även analyser av Inger och Lasse Sandbergs och Jan Lööfs böcker. Av Sandbergs böcker: Lena berättar (1963), Tomtens stadsresa (1966), Pojken med de många husen (1968), Filurstjärnan (1969), Vad är det som ryker? (1971). Jan Lööfs böcker: Pelles ficklampa (1978), Pelle hjälper en riddare (2004), Pelle träffar en lokförare (2004), Pelle i djungeln (2005), Pelle och farbror Ottos uppfinning (2006). 


\section{Studiens metodologi}

Selma Lagerlöf (1858-1940):

Otto Witt (1875-1923):

Elsa Beskow (1874-1953):

Karl-Aage Schwartzkopf: (1920-2009)

Sven Wernström (1925-):
Nils Holgerssons underbara resa genom Sverige (1906-07/1908)

Tekniska sagor för stora och små (1914)

Krigets tekniska sagor för stora och små (1915)

Sagobok (1915/1955)

Muntergök (1919/1996)

Röda bussen och gröna bilen (1952)

Familjen Tuff-Tuff(1949/1966)

Hemma hos Familjen Tuff-Tuff (1950/1966)

Höghuset vid myren (1965)

Höghuset flyttar norrut (1969)

Den underbara resan D. 1 (1985)

Den underbara resan D. 2 (1986)

Den underbara resan D. 3 (1987)

Rävjakten (1986)

Tomtemaskinen (1994) $)^{174}$

Övriga berättelser/barnböcker som analyserats men som inte finns redogjorda för i avhandlingens analysdel, eller endast omnämns, är: Slåtterkarlarna från Ekolsund (Selma Lagerlöf, 1912), Den sönderslagna flaskan (Elsa Beskow, 1954), Äventyret bor $i$ en vattenledning (Karl-Aage Schwartzkopf, 1968), Revolutionen i Soldalen (Karl-Aage Schwarzkopf, 1972), Rymdskeppets gåta (Sven Wernström, 1968), Destination Mars (Sven Wernström, 1969), Olle och fabriken (Sven Wernström, 1970), Pannkakstårtan (Sven Nordqvist, 1984), Pettson tältar (1992), När Findus var liten och försvann (2001). Därtill har sagosamlingarna Bland tomtar och troll för åren 1951-1977 genomgått en övergripande analys.

${ }^{174}$ Samtliga Nordqvists böcker i serien om Pettson och Findus skrivna mellan åren 1984 och 2012 har analyserats men kapitlet om tekniksynen i böckernas tekniklandskap bygger i huvudsak på dessa två titlar. 


\section{Studiens metodologi}

\section{Studiens fem faser}

Avhandlingsarbetet kan sammanfattningsvis beskrivas som en arbetsprocess som bestått av fem olika delar eller faser:

Fas I: Inläsning av kontext gällande svensk allmänhistoria, idéhistoria, teknikhistoria, utbildningshistoria och barnlitteraturhistoria. Likaså ingick läsning av viss teknikfilosofisk litteratur. Texter som exempelvis pedagogiska tidskrifter som speglar tidens diskussioner kring pedagogik och barnlitteratur var också inkluderade i litteraturläsningen. Syftet med denna inläsning var att grundlägga den förförståelse som skulle krävas för att senare kunna förstå och förklara texterna, det vill säga att tolka.

Fas II: En genomgång av de för tiden dominerande litteraturförteckningar som styrde urvalet av böcker till folk- och skolbibliotek. Ett antal titlar valdes ut för noggrannare genomgång, 51 titlar från grundkatalogerna och 79 titlar från sambindningskatalogerna. Urvalet från sambindningskatalogen kontrollerades i förhållande till Sveriges författarfonds statistik för att säkerställa att böckerna nått många läsare. Med utgångspunkt i studiens syfte och övergripande forskningsfråga, identifierades de barnböcker som hade ett teknikdidaktiskt innehåll, det vill säga ett budskap om eller inställning till teknik (tekniksyn).

Fas III: Sex författares böcker valdes ut för att fungera som primärmaterial och därmed genomgå djupare analyser och tolkningar: Selma Lagerlöf, Otto Witt, Elsa Beskow, Karl-Aage Schwartzkopf, Sven Wernström och Sven Nordqvist. Anledningen till att valet föll på just dessa författare var att innehållet i deras böcker har ett återkommande teknikdidaktiskt tema samt att de troligtvis var/är frekvent utlånade på biblioteken.

Fas IV: Inläsning av biografiska fakta om aktuella författare för att ytterligare fördjupa min förförståelse. Därefter följde en hermeneutisk tolkningsprocess, där teknikinnehållet $i$ texterna undersöktes. Jag närmade mig texterna genom närläsning, där jag försökte lyfta fram det (utifrån min 


\section{Studiens metodologi}

studies syfte) mest väsentliga i varje enskild text. Själva tolkningsprocessen går att beskriva enligt följande:

a) En identifiering av olika representationer av (olika slags) teknik i berättelserna samt en analys av hur tekniken gestaltas.

b) En tolkning av berättelserna i relation till den historiska kontext de tillkommit i.

c) En hermeneutisk process där jag med inspiration från Ricoeurs så kallade misstankens hermeneutik sökte efter "dolda" budskap om teknik. Här handlade det om vilken slags tekniksyn texterna förmedlar i förhållande till deras natursyn respektive framtidssyn. Varje kapitel avslutas med en sammanfattande analys av författarens böcker.

Fas V: Avslutningsvis avkronologiserades texterna $\mathrm{i}$ en jämförande analys $\mathrm{i}$ syfte att identifiera övergripande och gemensamma teman. Här sökte jag efter såväl likheter som skillnader texterna emellan avseende budskapen om teknik (tekniksyn) i förhållande till böckernas olika naturrespektive framtidssyn. Slutsatserna presenteras i en sammanfattande analys och slutdiskussion.

\section{Sammanfattning av metodologi}

Denna avhandling är en undersökning av ett urval svenska skönlitterära barnböckers tekniklandskap. Med tekniklandskap avser jag här den "empiriska verklighet" med dess ingående tekniska artefakter och system som berättelserna utspelar sig i. ${ }^{175}$ Syftet med studien är att utifrån ett didaktiskt perspektiv undersöka budskap om teknik i ett urval svenska skönlitterära barnböcker samt undersöka hur berättelsernas tekniksyner förhåller sig till deras natur- respektive framtidssyn. Genom att knyta det didaktiska samtalet om teknik till den syn på teknik som förmedlas via skönlitterära barnböcker, önskar jag visa hur man med teknikdidaktiska glasögon kan läsa och tolka barnlitteratur. Då jag betraktar det historiska perspektivet som

\footnotetext{
175 J.-E. Hagberg, Livet genom tekniklandskapet: Livslopp, åldrande och vardagsteknikens förändring, 2008, s. 19-20; J.-E. Hagberg, "Att lära i teknikens rum och landskap. En metadidaktisk betraktelse", 2009, s. 45-46.
} 


\section{Studiens metodologi}

en naturlig del i tänkandet kring teknik, är det barnböcker som är skrivna under det senaste århundradet som är föremål för analys. Urvalet grundar sig på en kvalitativ bedömning av böckernas innehåll i relation till studiens syfte och övergripande frågeställning. Att det skulle komma att bestå av berättelser skrivna av sex författare var något som utkristalliserades under urvalsprocessen. Förutom att författarnas produktion uppfyllde de fastställda kriterierna, innehåller deras berättelser både gestaltningar av teknik och budskap om teknik, exempelvis vilken inverkan teknik har på natur, människa, och samhälle och framtid. Därmed har de ett innehåll som inkluderar sådant som betraktas som betydelsefullt inom teknikens didaktik. Tilläggas kan att då de skönlitterära texterna är så pass olika till sin karaktär, varierar analysernas uppläggning, då de anpassats efter vilken text det handlar om.

Jag har hämtat inspiration till de teoretiska och metodologiska utgångspunkterna samt angreppssätten från en rad olika forskningsdiscipliner, men framför allt teknikdidaktik, teknikhistoria, teknikfilosofi, litteraturvetenskap och idéhistoria. Studien har tre analytiska perspektiv: att identifiera tekniken i barnböckerna och undersöka hur den gestaltas, att undersöka de tekniksyner som förmedlas och hur dessa förhåller sig till böckernas natur- respektive framtidssyn samt att göra en jämförande analys för att på så sätt identifiera gemensamma teman berättelserna emellan. När det gäller budskapen om teknik (tekniksyn) betraktar jag dessa som intimt förknippade med de argument i texten som framförs för eller emot (explicit eller implicit) ett tekniskt "fenomen" eller en teknisk samhällsutveckling.

Teknik som fenomen och begrepp i samhället är svårfångat men ytterst handlar teknik om att förändra världen och att lösa problem med hjälp av människoskapade objekt (artefakter), metoder, aktiviteter och processer. För att fånga centrala aspekter av tekniken använder jag Carl Mitchams fyrdelade teknikbeskrivning (objekt, kunskap, aktivitet och viljekraft) kombinerat med ett systemperspektiv som utgår från Thomas P. Hughes beskrivningar. ${ }^{176}$ Detta ringar in de delar av tekniken som är väsentliga för analyser av de barnböcker jag valt att studera. För att beskriva synen på naturen och framtiden i berättelserna använder jag mig av begreppen an-

\footnotetext{
${ }^{176}$ T.P. Hughes, “The seamless web: Technology, science, etcetera, etcetera”, 1986, s. 281-292; T.P. Hughes, "The evolution of large technological systems", 1987, s. 51-82; T.P. Hughes, "Technological momentum", 1994, s. 101-113; C. Mitcham, Thinking through technology: The path between engineering and philosophy, 1994, s. 160.
} 


\section{Studiens metodologi}

tropocentrisk respektive biocentrisk natursyn samt det effektiva samhället respektive det goda livet då det gäller framtidssynerna. ${ }^{177}$

Trots att jag finner den historiska och kulturella kontexten som viktig förförståelse för att förstå texterna, betraktar jag inte berättelserna som direkta speglingar av vare sig en viss tids allmänna tankegångar och värderingar eller som uttryck för enskilda författares synsätt. Eftersom författaren inte är närvarande i "samtalet" med mig som läsare, är det texten som för fram budskapet. ${ }^{178} \mathrm{I}$ tolkningarna av texternas budskap har jag hämtat inspiration från den kritiska hermeneutiken och Ricoeurs idé om misstankens hermeneutik då jag i en kritisk läsning av texterna inte bara sökt efter tydliga budskap om teknik, utan också efter dolda. ${ }^{179}$ Det "kritiska" handlar sammantaget om dels betydelsen av att hålla en kritisk distans till det studerade, dels att synliggöra den konflikt som uppstår mellan olika alternativa tolkningar. På så vis öppnar den kritiska hermeneutiken för en kritisk diskussion. ${ }^{180}$ Närläsning är den metod jag använt mig av i analyser och tolkningar av texterna. ${ }^{181}$ Med stöd i Ricoeurs kritiska hermeneutik betraktar jag tolkningsprocessen som en syntes mellan förklaring och förståelse av texterna, samtidigt som jag ser förförståelsen som den grund på vilken processen vilar. ${ }^{182}$ Förklaringar har jag sökt i teorier hämtade från olika vetenskapsfält liksom tidigare forskning. I samstämmighet med misstankens hermeneutik har jag dock inte låtit detta slag av förklaringar ta överhanden när det gäller att förstå texternas innebörd.

\footnotetext{
${ }^{177}$ T. Frängsmyr, Framsteg eller förfall: Framtidsbilder och utopier $i$ västerländsk tanketradition, 1990, s. 227-236.

${ }^{178}$ P. Ricoeur, "Vad är en text?”, 1993c, s. 34-35.

${ }^{179}$ S. Claesson m.fl.,"Ricoeurs kritiska hermeneutik vid empiriska studier”, 2011, s. 18-35; P. Ricoeur, "The model of the text: Meaningful action considered as a text", 1973, s. 91-117; P. Ricoeur, "The hermeneutical function of distanciation", 1981, 131-144; P. Ricoeur, "Förklara och förstå. Text - handling - historia", 1993a, s. 65-98.
}

${ }^{180}$ S. Claesson m.fl., "Ricoeurs kritiska hermeneutik vid empiriska studier", 2011 s. 18-35; P. Ricoeur, "Hermeneutik och ideologikritik" i Från Text till handling: En antologi om hermeneutik, 4 uppl., Stockholm: B. Östlings bokförl. Symposion, 1993b, s.144-156.

${ }^{181}$ B. S. Brummett, Techniques of close reading, 2010, s. 25.

${ }^{182}$ M. Alvesson, K. Sköldberg, Tolkning och reflektion: Vetenskapsfilosofi och kvalitativ metod, 2008, s. 242-247; J. From \& C. Holmgren, "Hermeneutik och pedagogik", 2000, s. 221-223. P. Ricoeur,"Vad är en text?", 1993c, s. 39-43; Ödman, Tolkning, förståelse, vetande: Hermeneutik $i$ teori och praktik, Stockholm: ePan/Norstedt, 1979 /2001, s. 81-85; P.-J. Ödman, ”Hermeneutik och forskningspraktik", 2004, s. 74-77. 
När mina tolkningar har tyckts stämma överens med en specifik teoretisk förklaring, har jag istället låtit detta väcka min misstänksamhet, då den annars skulle kunna vara ett hinder för mig att nå en djupare förståelse av textens budskap. Det är texten jag tolkar, samtidigt som min förståelse för kontexten berättelsen kommit till i ger mig stöd i att göra rimliga tolkningar. Genom att tolkningarna av barnböckernas budskap om teknik (tekniksyn) bygger på en process där förförståelse, förståelse och förklaring interagerar, har jag i de olika kapitlen låtit kontext och tolkningar vävas samman till en sammanhängande och berättande text. Analyserna och tolkningarna av texterna bygger på en omstrukturering av textinnehållet. ${ }^{183}$ Med utgångspunkt i Leo Marx definition har sedan olika teman identifierats, vilket i denna studie handlar om hur tekniken i sig gestaltas, liksom hur relationen mellan människa, natur och teknik skildras. ${ }^{184}$

Analyserna av de undersökta barnböckerna presenteras, med ett undantag, i kronologisk ordning. Skälet till undantaget är att en av författarnas produktion (Elsa Beskow) sträcker sig över en längre tidsperiod än övrigas. Några av de i studien ingående författarna är, liksom deras berättelser, relativt okända i dag, andra är välkända. Varje analysavsnitt inleds därför med en kort presentation av var och en av författarna, liksom en sammanfattning av berättelsernas handling. Tillsammans med avhandlingens bakgrundsavsnitt syftar dessa inledningar till att synliggöra den teoretiska förförståelse som jag bär med mig in i tolkningsprocessen.

\footnotetext{
${ }^{183}$ P. Ricoeur, "Vad är en text?", 1993c, s. 50-51.

${ }^{184}$ L. Marx, The pilot and the passenger: Essays on literature, technology, and culture in the United States, 1988, s. 114.
} 



\section{KAPITEL 3}

\section{Tekniklandskapet i Selma Lagerlöfs barnbok Nils Holgerssons underbara resa}

\section{Selma Lagerlöf (1858-1940)}

Selma Lagerlöf föddes på herrgården Mårbacka i Värmland. Hon utbildade sig till lärarinna vid Högre lärarinneseminariet i Stockholm och fick 1885 arbete vid flickskolan i Landskrona. Lagerlöfs stora passion var att skriva men hon hade samtidigt en pedagogisk ådra. Vivi Edström skriver att hennes förmåga att levandegöra svensk historia och trollbinda sina elever var legendarisk. ${ }^{185}$ Som 33-åring debuterade Lagerlöf med romanen Gösta Berlings saga. Hösten 1897 bröt hon upp från Landskrona och läraryrket för att slå sig ned som författarinna i Falun och med tiden kom hon att bli en av Sveriges mest framgångsrika sådana. 1909 blev Lagerlöf den första kvinnan att få Nobelpriset i litteratur och 1914 valdes hon som första kvinna in i Svenska Akademien. Lagerlöf blev under sin livstid känd över hela världen och hennes böcker översattes till otaliga språk. Verken dramatiserades och blev film och hennes liv har beskrivits i ett antal biografier. ${ }^{186}$

Kring sekelskiftet 1900 var sagan var en hyllad genre och Lagerlöf framstod som den stora sagoberättaren. Tack vare att hon och andra berömda vuxenförfattare skrev berättelser för barn, höjdes sagans renommé. ${ }^{187}$ Denna tid kom också att utgöra en vändpunkt för svensk barnlitteratur och brukar beskrivas som

\footnotetext{
${ }^{185}$ V. Edström, S. X. Erixson, Uppdrag läsebok: Nils Holgersson, 1996, s. 9.

${ }^{186}$ L. Vinge, "Selma Lagerlöf”, Litteraturbanken, http://litteraturbanken.se/\#!/forfattare/LagerlofS (läst 2010-09-10).

${ }^{187}$ L. Kåreland, Gurli Linders barnbokskritik: Med en inledning om den svenska barnbokskritikens framväxt, 1977, s. 72-73.
} 
dess första "guldålder" ${ }^{188}$ Landets folkskollärare spelade en viktig roll i denna process när de lanserade olika projekt för att främja barnlitteratur och barns läsning. ${ }^{189}$ Som en följd av att barnet och barndomen (bland annat genom Ellen Key) tillskrevs en ny och upphöjd status, gjorde barnlitteraturen sitt intåg inom finkulturen. Utifrån mottot "konsten i skolan" kom barnlitteratur och barns läsning i skolan att betraktas som viktiga delar i tidens allmänna folkbildningssträvanden. ${ }^{190}$ Teknikutvecklingen bidrog till den ökade spridningen av böcker. Upplagorna ökade och priset på böckerna sjönk, vilket ledde till att tillgången ökade. I skolan fick barnen i och med utvecklingen ta del av de böcker som tagits fram för att intressera dem på ett helt annat sätt än tidigare. ${ }^{191}$

I januari 1901 tillsatte Sveriges allmänna folkskollärarförening en kommitté för att ta fram en modern läsebok. ${ }^{192}$ Initiativtagarna var folkskolläraren Fridtjuv Berg (senare ecklesiastikminister) och överläraren Alfred Dalin i Huskvarna. ${ }^{193}$ I ett brev till väninnan Sophie skrev Selma Lagerlöf att det inte enbart var för "det ekonomiska" utan även av "människokärlek" som hon ville åta sig uppgiften att skriva boken. Hon ville att folkskolebarnen skulle få ”[...] en präktig bok att fröjda sig åt". Vidare konstaterade hon att hon själv är "[...] av hederlig prästsläkt kom-

\footnotetext{
${ }^{188}$ M. Andersson, "Borta bra, men hemma bäst? Elsa Beskows och Astrid Lindgrens idyller" i Barnlitteraturanalyser, M. Andersson \& E. Druker (red.), Lund: Studentlitteratur, 2008, s. 57; L. Kåreland, "Barnlitteraturens utveckling i Sverige", Litteraturbanken, 2008, http://litteraturbanken.se/\#!/presentationer/specialomraden/BarnlitteraturensUtvecklingISverige.ht $\mathrm{ml}$ (läst 2010-10-10).

${ }^{189}$ B. Westin, Children's literature in Sweden, 2., rev. ed., Stockholm: Svenska institutet, 1996, s. 16-17.

${ }^{190}$ L. Kåreland, Gurli Linders barnbokskritik: Med en inledning om den svenska barnbokskritikens framväxt, 1977, s. 75-76.

${ }^{191}$ D. Butts, "Introduction" i Children's literature and social change: Some case studies from Barbara Hofland to Philip Pullman, 2010, s. x-xi; M. Ekholm, ”Den hållbaraste läroplanen 1919 års undervisningsplan för rikets folkskolor", Vägval i skolans historia: Tidskrift från föreningen för svensk utbildningshistoria, vol. 6 (3-4), 2006, s. 3-5.

${ }^{192}$ I ovan citerade artikel står det år 1902 men eftersom S. Lagerlöfs brev till Dalin är daterat till november 1901, utgår jag från att von Zweigbergks datering stämmer.

${ }^{193}$ V. Edström \& S. X. Erixson, Uppdrag läsebok: Nils Holgersson, 1996, s. 9; S. Lagerlöf, Brev $i$ urval / 1, 1871-1902, Lund, 1967, s. 250.
} 
men, och det skulle roa mig att predika för hela mitt folk”. Barnen skulle få hennes idéer och tankar, vilket tilltalade henne. ${ }^{194}$

Trots att Selma Lagerlöf skrev Nils Holgerssons underbara resa genom Sverige utifrån ett uppdrag att skapa en geografibok, är det intressant att notera att boken finns upptagen i grundkatalogerna under de skönlitterära kategorierna "Böcker för barn och ungdom" och "Berättelser och sagor". Utifrån bakgrunden till bokens uppkomst hade det varit mer logiskt att den hamnat under "Läseböcker". ${ }^{195}$ Detta vittnar om att den av många i första hand räknades som en skönlitterär barnbok, vilket sannolikt också var skälet till att den blev så framgångsrik utomlands. ${ }^{196}$ Selma Lagerlöf gav aldrig ut några fler barnböcker än Nils Holgersson. ${ }^{197}$ Däremot lämnade hon en hel del bidrag till barntidningar, både före och efter utgivandet av boken.

\section{Tidigare tolkningar av Nils Holgersson}

Selma Lagerlöfs natursyn har berörts av ett antal forskare och en majoritet av dem anser att hon är den av de större sekelskiftesförfattarna som var mest positivt inställd till den industriella utvecklingen i Sverige. Gunnar Ahlström skriver:

Vad pojken där får skåda och beundra av svenskt näringsliv är ingenting annat än just storindustrien som håller på att förvandla ödemarkerna till sjudande verksamhetsfält för nya företagareinitiativ. Därför blir dessa partier av boken till ett levande industriepos. Selma Lagerlöfs ord får desto större betydelse, som det är första gången en svensk diktare anlägger sådana synpunkter på företeelserna. En positiv inställning till industrialismen hörde länge till ovanligheterna i litteraturens värld. ${ }^{198}$

Vivi Edström gör en liknande tolkning när hon konstaterar att Lagerlöf låter "Tummetott" häpna över all ny teknik han ser under sin resa, som exempelvis

\footnotetext{
${ }^{194}$ V. Edström \& S. X. Erixson, Uppdrag läsebok: Nils Holgersson, 1996, s. 10.

${ }^{195}$ Se tillägg nr 3 till Grundkatalog 1915-16 omfattande arbeten utkomna åren 1919-1920.

${ }^{196}$ N. Thunman, "Selma Lagerlöf i Japan”, 1998, s. 41.

${ }^{197}$ I min fortsatta framställning samt i analyser och tolkningar av berättelsen, är titeln förkortad och benämns som Nils Holgersson. Analyser och tolkningar bygger på en upplaga som kallas "skolupplaga" och som publicerades i två band 1908.

${ }^{198}$ G. Ahlström, Den underbara resan: En bok om Selma Lagerlöfs Nils Holgersson, Lund: Gleerup, 1942, s. 207.
} 
järnvägar, fabriker, sågverk och järnverk. ${ }^{199}$ Erland Lagerroth bekräftar denna bild när han skriver att genom att lämna "[...] svärmeri för den växande säden i gammal romantisk och biblisk anda [...]" lyfter Lagerlöf fram Sverige mer som skogens än som sädens land. På så sätt är hon den första att ge ”[...] en inträngande litterär gestaltning av den hörnsten $i$ det moderna svenska näringslivet, som skogen utgör." ${ }^{200}$ Ahlströms slutsats är att bakgrunden till Lagerlöfs bejakande av den industriella samhällsutvecklingen går att finna $i$ att hennes egna framgångar var ett resultat av produktivt och träget arbete, det vill säga ett arbete i samklang med "den nya tidens vaknande tillförsikt". ${ }^{201}$ Lagerlöf var dessutom tidig med att omnämna bilen i svensk skönlitteratur, vilket hon gör i Gösta Berglings saga som gavs ut $1891 .^{202}$

Teknik och industrisamhälle var något som invaderade kulturen vid denna tid, samtidigt som konstnärer och diktare trodde sig hålla på med något annat, skriver Göran Hägg. Liksom Ahlström finner han Selma Lagerlöf vara den mest teknikvänliga av de så kallade "nittiotalisterna". ${ }^{203}$ Som exempel lyfter han fram att det $\mathrm{i}$ Nils Holgersson finns ett i svensk litteratur "nära unikt" kapitel om järnverket i Bergslagen, där Selma Lagerlöf skriver om allt det goda som järnet gör. ${ }^{204}$ Björn Sundmark gör en liknande tolkning och menar att Selma Lagerlöf i sin optimistiska syn på framtiden och på barnens inneboende potential företräder en utopisk diskurs. Samtidigt konstaterar han att hennes engagemang för naturen inte går att ta miste på. Han tolkar berättelsen om Nils Holgersson som delvis ekocentrisk eftersom den visar hur en pojke lär sig leva $\mathrm{i}$ interaktion med naturen och djurvärlden. Samtidigt anser Sundmark att Lagerlöf ger uttryck för en tydlig tro på

\footnotetext{
${ }^{199}$ V. Edström \& S. X. Erixson, Uppdrag läsebok: Nils Holgersson, 1996, s. 23.

${ }^{200}$ E. Lagerroth, Landskap och natur $i$ Gösta Berlings saga och Nils Holgersson, Stockholm:
} Bonnier, 1958, s. 285.

${ }^{201}$ G. Ahlström, Den underbara resan: En bok om Selma Lagerlöfs Nils Holgersson, 1942, s. 206.

${ }^{202}$ E. Tengström, Bilen \& människan i svensk prosa och poesi, 2009, s. 23.

${ }^{203}$ G. Hägg, "Det nygamla riket: det industriella genombrottets avspegling i svenskt kulturliv" i Den välsignade tillväxten: Tankelinjer kring ett århundrade av kapitalism, teknik, kultur och vetenskap, P. Elmlund \& K. Glans (red.), Stockholm: Natur och Kultur, 1998, s. 44. Hägg räknar August Strindberg, Oscar Levertin, Verner von Heidenstam, Per Hallström, Selma Lagerlöf, Gustaf Fröding och Erik Axel Karlfeldt till denna grupp, då han menar att det är den socialt sett mest framgångsrika författargruppen som Sverige ägt.

${ }^{204}$ Ibid., s. 53. 
tekniska, ekonomiska och sociala framsteg. Lagerlöf visar bland annat entusiasm för sågverk, gruvor och stålverk och en tro på att även de fattigaste delarna av landet ska komma att dra nytta av utvecklingen, skriver Sundmark. Saker och ting skulle bli bättre. ${ }^{205} \mathrm{Jag}$ ställer mig dock tveksam till Sundmarks användande av begreppet "ekocentrisk" i beskrivningen av budskapet i Nils Holgersson. Min tolkning av ekocentrism är att ekosystemen har ett egenvärde oberoende människans syften. ${ }^{206}$ I Sundmarks tolkning är det snarare för människan som naturens tillskrivs värden. En ekocentrisk hållning betraktar jag därmed som svårt att förena med hur Sundmark i övrigt tolkar Lagerlöfs inställning till industrialiseringen.

Av de studier som berörts ovan är det en forskare vars tolkningar skiljer sig något från övriga när det gäller budskapet i Nils Holgersson. I sin avhandling från 2006 lyfter Erik Erlandson-Hammargren fram Selma Lagerlöfs natursyn, samt inställning till den industriella samhällsutvecklingen, i ett alternativt ljus. ErlandsonHammargren hänvisar till forskare som Ahlström, Lagerroth och Edström, men drar slutsatsen att även om Lagerroth och Ahlström inte har undvikit att lyfta fram kritiken av den industriella processen, så är den ändå något knapphändig. Erlandson-Hammargren menar att om man läser bokens texter om järnverk, sänkta sjöar, döda sjöar med gult vatten, stenöknar och slagghögar utifrån ett biocentriskt perspektiv, blir resultatet ett budskap som sätter den ensidigt industrioptimistiska hållningen i ett nytt ljus. Erlandson-Hammargrens åsikt är att Nils Holgersson snarare innehåller en direkt kritik av de miljömässiga effekterna av industrialiseringen. Å ena sidan har Lagerlöf ett budskap till den nioårige skoleleven (som säkerligen tolkade historierna emotionellt). Å andra sidan finns ett budskap till den vuxne läsaren som genom berättelsen i första hand förväntas upptäcka Sveriges utveckling. På så vis har Selma Lagerlöf gett barnet sitt hjärta, samtidigt som uppdragsgivarna fått sitt framtidsland, skriver Erlandson-Hammargren. Med tanke på att Nils Holgersson var en läsebok för flera generationers skolelever, ser Erlandson-Hammargren boken som ett av tidens allra viktigaste verktyg för att

\footnotetext{
${ }^{205}$ B. Sundmark, "Citizenship and children's identity in The wonderful adventures of Nils and scouting for boys", Children's Literature in Education, vol. 40(2), 2009, s. 109-119.

${ }^{206}$ Se exempelvis S. J. Rowe, "Ecocentrism: The responsive chord”, 1994; M. Stenmark, Miljöetik och miljövård: Miljöfrågornas värderingsmässiga dimension, 2000; S. Sörlin, Naturkontraktet: Om naturumgängets idéhistoria, 1991, s. 123-152.
} 
sprida en natursyn som låg i linje med det moderna Sveriges utveckling. ${ }^{207}$ Här finner jag dock Erlandson-Hammargren något svårtolkad eftersom han samtidigt anser att boken förmedlar ett kritiskt budskap om industrialiseringens konsekvenser till de unga läsarna.

En tänkbar förklaring till varför Ahlström och Lagerroth har gjort så olika tolkningar av Lagerlöfs budskap jämfört med Erlandson-Hammargren kan vara att deras studier gjordes 1942 respektive 1958. Den offentliga miljödebatten var då ännu i sin linda, vilket kan ha påverkat med vilka "glasögon" de läste Lagerlöfs text. Erlandson-Hammargrens avhandling är däremot skriven i en tid där ekologiska frågor och hållbar utveckling är närvarande i samhällsdebatten och i diskussionerna om framtiden. När det gäller forskare som Edström, Hägg och Sundmark har deras primära syfte inte varit att studera natursyn eller inställningen till industrialiseringen i Nils Holgersson, vilket kan förklara varför de inte har problematiserat eller gjort en djupare analys av just denna aspekt.

\section{Handlingen i Nils Holgersson}

Berättelsens huvudkaraktär är den fjortonårige, skånske pojken Nils. Han är i bokens början en lat yngling som inte vill lära sig något i skolan. Han föredrar att sova och ställa till "odygd" och är dessutom elak mot djuren. När hans föräldrar ska åka till kyrkan, vägrar Nils följa med och blir därför ålagd att läsa Luthers postilla. Han finner uppgiften tråkig och det vackra vårvädret utanför gör honom sömnig. Då dyker plötsligt en liten tomte upp och Nils tar flughåven och fångar in tomten. Tomten bönar och ber att få bli fri. I gengäld erbjuder han Nils några värdefulla föremål. Nils tycker inte att det är mycket till erbjudande men då tomtegubben skrämmer honom, släpper han honom fri ändå. I samma ögonblick får Nils en örfil så han far in mot väggen och blir medvetslös. När han vaknar upp har han förvandlats till en liten pyssling som förstår djurens språk.

När en flock vildgäss flyger förbi lockas familjens gåskarl att följa med. Nils försöker hindra fågeln att ge sig av och kastar sig om halsen på honom. Konsekvensen blir att han får följa med gåskarlen och vildgässen på en resa genom

\footnotetext{
${ }^{207}$ E. Erlandson-Hammargren, Från alpromantik till hembygdsromantik: Natursynen i Sverige från 1885 till 1915, speglad i Svenska turistföreningens årsskrifter och Nils Holgerssons underbara resa genom Sverige, 2006, s. 300-440.
} 
Sverige. Boken kan ses som en slags bildningsroman i vilken Nils, vartefter resans gång, når insikten att hans tidigare beteende och inställning till omgivningen inte varit den rätta. ${ }^{208}$ Genom att han hjälper djur och människor genomgår han en moralisk metamorfos och med tiden utvecklas han till en snäll och omtänksam följeslagare till gässen. Under sin resa upptäcker Nils dessutom både sitt lands ljusa framtidsutsikter och människans kreativa skaparkraft. Det är därmed utifrån upplevelser och erfarenheter som Nils lär sig och mognar som individ, inte genom teoretiska kunskaper. Genom bokens beskrivningar av rika naturtillgångar, industrier och en befolkning med såväl arbetssträvan som stor innovationsförmåga, framställs Sverige som framtidslandet. Samtidigt är det inte säkert att det var så som läsarna tolkade berättelsen. Något som talar för alternativa tolkningar är att boken internationellt inte uppfattades som en lärobok utan som en skönlitterär berättelse. Utifrån ett teknikdidaktiskt perspektiv är det dessutom intressant att notera att Lagerlöf lät bokens centralgestalt upptäcka Sverige genom att flyga över landet. Valet av färdmedel för tankarna till den svenske ingenjören Salomon August Andrées (1854-1897) luftballongfärd till Nordpolen 1897. När Lagerlöf skrev boken hade ännu ingen svensk färdats i ett flygplan över Sverige. ${ }^{209}$

\section{Tekniksynen i Nils Holgersson}

Industrialiseringsprocessen inleddes i många fall på landsbygden genom att jordbruket effektiviserades och växte i storlek. Jordbruket, liksom gruvnäringen och sågverksindustrin, genererade kapital som sedan kunde investeras i industriell produktion. ${ }^{210}$ Även om inga framträdande tecken pekade mot en industriell nydaning vid 1800-talets mitt, hade inrättningar som främjade samhällomvandlingen redan etablerats. Bland annat hade flera banker bildats, villiga att låna ut till kapitalinvesteringar, och efterfrågan på framför allt svenska trävaror ökat. Industri-

\footnotetext{
208 "Bildningsroman" (efter tyskans Bildungsroman) är en romantyp som skildrar en ung hjältes eller hjältinnas utveckling till vuxen mogenhet, se exempelvis Nationalencyklopedin, http://www.ne.se/bildningsroman, (läst 2014-05-05).

${ }^{209}$ År 1910 brukar räknas som det svenska flygets födelseår. Se exempelvis Tekniska muséet, "Jubileumsflygningen på Stockholms flygfestival", http://www.tekniskamuseet.se/1/1808.html (läst 2014-03-10).

${ }^{210}$ J. Hult, "Järn, ånga och ingeniörer: 1815-1870" i Svensk teknikhistoria, J. Hult (red.), Hedemora: Gidlund, 1989b, s. 187-229.
} 
utvecklingen skedde snabbt under 1870- och 1890-talen, men under det mellanliggande decenniet var takten något lugnare. När jordbruken effektiviserades behövdes inte längre lika mycket arbetskraft och människor flyttade från landsbygden in till de alltmer industrialiserade städerna. Under 1800-talets tre sista decennier kom antalet industriarbetare att mer än fördubblas. ${ }^{211}$

Jämfört med många andra länder skedde industrialiseringsprocessen något senare i Sverige men när den väl kom igång gick den desto snabbare. ${ }^{212}$ Den tekniska utvecklingen bidrog till att landet genomgick stora strukturella förändringar när andelen människor som livnärde sig på jordbruk minskade samtidigt som övergången till andra näringar ökade. ${ }^{213}$ Mellan åren 1851 och 1920 emigrerade dessutom över en miljon svenskar till Amerika. ${ }^{214}$ Enligt SCB:s statistik var år 1860 närmare 90 procent av Sveriges befolkning bosatt på landsbygden. Femtio år senare hade denna siffra sjunkit till cirka 70 procent. ${ }^{215}$ Förflyttningen från landet till städerna ledde till bostadsbrist och många familjer levde trångt och primitivt. Barnens situation observerades av lärarna i skolan och diskuterades i de pedagogiska tidskrifterna. ${ }^{216}$

Industrialiseringen gav inte enbart nya arbeten, utan de nya kommunikationerna band också samman orter och därmed människor. Genom järnvägarna blev det lättare att resa och transportera varor, samtidigt som järnvägsbyggena gav många människor arbete. Järnvägarna anlades ofta i ödebygder och nya samhällen växte upp vid järnvägsknutar och stationer. ${ }^{217}$

\footnotetext{
${ }^{211}$ J. Hult, "Bondeland blir industriland: 1870-1914" i Svensk teknikhistoria, J. Hult (red.), Hedemora: Gidlund, 1989a, s. 231.

${ }^{212}$ T. Frängsmyr, Svensk idéhistoria: Bildning och vetenskap under tusen år. D. 2, 1809-2000, 2000, s. 102.

${ }^{213}$ M. Morell, "Jordbruket och industriomvandlingen" i Då förändras Sverige: 25 experter beskriver drivkrafter bakom utvecklingen, E. Giertz (red.), Lund: Studentlitteratur, 2008, s. 34.

${ }^{214}$ A. Åberg, Vår svenska historia, Stockholm: Natur och Kultur, 1993, s. 422.

${ }^{215}$ H. Ylander, "Urbanisering och tätortsutveckling i Sverige", Örebro: SCB (Statistiska centralbyrån), 2008, http://www.scb.se/statistik/MI/MI0803/2000I02/MI03SA9301_06.pdf (läst 201305-05).

${ }^{216}$ Se exempelvis "Orsakerna till 'sedlig förvildning' hos ungdomen", Svensk Läraretidning 14, nr 4 april 1900, http://runeberg.org/svlartid/1900/0227.html (läst 2010-02-14).

${ }^{217}$ T. Frängsmyr, Svensk idéhistoria: Bildning och vetenskap under tusen år. D. 2, 1809-2000, 2000, s. 102-103.
} 
Förutom den inverkan industrialisering och teknisk utveckling hade på samhällsstrukturen, kom tiden kring och strax efter sekelskiftet 1900 även att präglas av reformpedagogik, nationalromantik, folkbildning och en förändrad syn på barndomen. Industrialiseringen kom i grunden att omforma samhällslivet och att den äldre agrara epoken var på väg att ersättas av en ny, modern och på många sätt osäker tid, fick som konsekvens att nationalismen växte sig allt starkare. När samhället förändrades kulturellt, ekonomiskt och socialt skapades spänningar mellan olika samhällsgrupper och människor behövde nya identifikationer när betydelsen av de traditionella formerna för hembygdskänsla och regionalism minskade. Andra bidragande orsaker till den nationalistiska utvecklingen var försvarsdebatten och det ryska hotet, ökade politiska spänningar, reformkrav på allmän rösträtt samt unionsfrågan och parlamentarismens införande i Norge (Norges ensidiga upplösning av unionen med Sverige skedde sedan 1905). Fosterlandet var ett vanligt förekommande motiv i den politiska idédebatten och nationalismen blev en ideologisk kraft som skulle förena nationens folk och skapa en gemenskap inom landets gränser. ${ }^{218}$ Institutioner som skola, armé och medier fick till uppgift att fungera som nationella homogeniseringsapparater och den svenska naturen fick en särskilt upphöjd roll. ${ }^{219}$ Rörelsen var förbunden med en konservativ samhällssyn som innebar att landet hyllades liksom dess historia och konstarter. ${ }^{220}$ Men som Alf W. Johansson poängterar, bör den svenska nationalismen vid denna tid dock inte enbart förknippas med politisk konservatism. Med tiden blev den alltmer folkligt förankrad. Trots att nationalism och socialism från början sågs som varandras motsatser, skapade även socialdemokratin en nationell ideologi som utgick från industrialiseringens konsekvenser för nationen och arbetarklassen. Därmed kom den nationalistiska ideologin att omfatta såväl de konservativa som arbetar-

\footnotetext{
${ }^{218}$ C. Nordlund, "Naturen och det nationella i det tidiga 1900-talets Sverigelitteratur" i Sekelskiftets utmaningar, A-K. Hatje (red.), Stockholm: Carlsson, 2002, s. 74-100; C. Strahl, Nationalism \& socialism. Fosterlandet i den politiska idédebatten 1890-1914, diss. Lunds universitet, Lund: Liber Förlag/Gleerup, 1983, s. 8-9.

${ }^{219}$ C. Nordlund, "Naturen och det nationella i det tidiga 1900-talets Sverigelitteratur", 2002, s. 74.

${ }^{220}$ T. Frängsmyr, Svensk idéhistoria: Bildning och vetenskap under tusen år. D. 2, 1809-2000, 2000, s. 150 .
} 
rörelsen. ${ }^{221}$ Likaså kom tidens intellektuella, som författare och konstnärer, att delta i debatten och formandet av den nationella identiteten. ${ }^{222}$ Den nationella samlingsidén överskred därmed individuella politiska åsikter och vitt skilda ideologiska lager och på så vis fungerade den som en överideologi. ${ }^{223}$

I sin mest kända och inflytelserika bok, Barnets århundrade (1900), förutspådde Ellen Key att 1900-talet skulle bli barnets speciella sekel och betydande förändringar gällande barns sociala villkor inom till exempel utbildning, ekonomi och kultur kom också att ske i vårt land sedan boken kommit ut. Utifrån ett utbildningshistoriskt perspektiv kom perioden 1900-1920 att bli en viktig brytpunkt i den allmänna skolutbildningens historia, eftersom det var under denna tid kyrkans makt successivt minskade. ${ }^{224}$ Debatten kring förra sekelskiftet formade en syn på vad den goda barndomen skulle innebära. Ett slags sörgårdsidyll skulle skapas åt alla barn där inga klassmotsättningar eller sociala problem fanns. ${ }^{225}$ Denna föreställning spreds bland annat via läseböcker och tidskrifter för barn. ${ }^{226}$

Debatten om barnlitteraturen vittnar om en oro för att barns levnadsförhållanden kunde framkalla en ensidighet. För att motverka detta förespråkade man läsning av böcker. Stadsbarn skulle läsa skildringar från bondlandet, lantbarnet höra om den "stora världen" och rikemansbarn berättelser om fattiga barn och vice versa. ${ }^{227}$ Lagerlöfs uppdrag var att skriva en läsebok för "folkets barn" och den skulle

\footnotetext{
${ }^{221}$ A.W. Johansson (red.), Vad är Sverige? Röster om svensk nationell identitet, Stockholm: Prizma, 2001, s. 10.

${ }^{222}$ S. Edquist, "Blå som himlen och gul som solen: Om vänstern och den svenska nationalismen kring sekelskiftet 1900" i I nationens intresse, L. Petterson (red.), Historiska institutionen, Uppsala universitet, Uppsala, 1999, s. 79-80; K. Johannisson, "Det sköna i det vilda: En aspekt på naturen som mänsklig resurs" i Paradiset och vildmarken: Studier kring synen på naturen och naturresurserna, T. Frängsmyr (red.), Stockholm: Liber Förlag, 1984, s. 72-73

${ }^{223}$ N. Edling, Det fosterländska hemmet: Egnahemspolitik, småbruk och hemideologi kring sekelskiftet 1900, diss., Stockholms universitet, Stockholm: Carlsson, 1996, s. 369.

${ }^{224}$ M. Ekholm, "Den hållbaraste läroplanen - 1919 års undervisningsplan för rikets folkskolor", 2006, s. 3-4.

${ }^{225}$ B. Sandin, "Barndomens omvandling - från särart till likart” i Barnets bästa - En antologi om barndomens innebörder och välfärden organisation, B. Sandin \& G. Halldén (red.), Eslöv: B. Östlings bokförl. Symposion, 2003, s. 222.

${ }^{226}$ M. Sundkvist, De vanartade barnen: Mötet mellan barn, föräldrar och Norrköpings barnavårdsnämnd 1903-1925, diss., Linköpings universitet, Uppsala: Hjelm, 1994, s. 55.

${ }^{227}$ E. von Zweigbergk, Barnboken i Sverige 1750-1950, 1965, s. 221.
} 
därmed inte innehålla några "rundkindade barnkammarbarn" som identifikationsobjekt. Sådana fanns det redan gott om i tidens bilderböcker, skriver Vivi Edström. ${ }^{228}$ Som huvudperson valde Lagerlöf därför sonen till "fattigt husmansfolk" på en skånsk gård. ${ }^{229}$ Trots att Lagerlöfs uppdrag var att skriva för "folkets barn", var det sannolikt en stor andel av folkskolebarnen som hade svårt att identifiera sig med Nils och känna igen sig i beskrivningarna. Det är framför allt jordbrukslandet Sverige som barnen får uppleva genom berättelsen, samtidigt som närmare en tredjedel av befolkningen kring sekelskiftet 1900 arbetade inom industrin. Likaså ges statarbefolkningen och deras barn litet utrymme i boken. Dock får den stora emigrationen till Amerika sin gestaltning genom den tragiska berättelsen om en småländsk bondkvinna som dör ensam på grund av att hennes barn emigrerat. Städerna får en relativt framskjuten plats bland illustrationerna i den första utgåvan av Nils Holgersson. Fem städer (Karlskrona, Jönköping, Gränna, Stockholm och Göteborg) finns med bland bokens fotografier, men skildringar av industriarbetarnas liv i städerna är dock frånvarande.

Lars Elenius ser berättelsen om Nils Holgersson som en illustration av idealbilden av den svenska nationen kring sekelskiftet 1900, alternativt en sammanfogning av en rad idealbilder från olika delar av landet. Norrland fick dessutom en förhållandevis framskjutande plats i boken, då 21 av de 96 kapitlen rör sig i en norrländsk miljö. Den riktningen Nils färdas i är från söder till norr, vilket Elenius ser som en metafor för att det moderna och framåtriktade finns i norr, medan traditionen och tillbakablickandet sker i söder: ${ }^{230}$

Bland allt detta, som rörde sig och vandrade söderut, såg han bara en sak, som stod stilla, och det var ett järnvägståg. Det stod alldeles under dem, och det var med tåget som med Gorgo, att det inte kunde komma ur fläcken. Lokomotivet sände ut rök och gnistor, det hördes ända upp till pojken hur hjulen rasslade mot skenorna, men tåget rörde sig inte. Skogarna gledo förbi det, banvaktarstugorna gledo förbi det. Grindar och telegrafstolpar gledo förbi det, men tåget stod stilla. En bred älv med en lång bro kom emot det, men älven och älvbron gledo fram under tåget utan minsta svårighet. Till sist kom en järnvägsstation farande. [...] På samma sätt som järnvägsstationen

\footnotetext{
${ }^{228}$ V. Edström \& S. X. Erixson, Uppdrag läsebok: Nils Holgersson, 1996, s. 42.

${ }^{229}$ E. Lagerroth, Landskap och natur i Gösta Berlings saga och Nils Holgersson, 1958, s. 286.

${ }^{230}$ L. Elenius, "Selma Lagerlöf och Norrland: Nationella idealbilder i Nils Holgerssons underbara resa" i Sekelskiftets utmaningar, A-K. Hatje (red.), 2002, s. 16-38.
} 
och allt det andra gled det bort mot södern. Pojken såg hur vagnsdörrarna slogos upp och de resande kommo ut ur tåget, allt under det att både detta och de resande flyttade sig söderut. Men då lyfte pojken blickarna från jorden och försökte se rätt framför sig. Han tyckte, att han blev yr i huvudet av att titta på det besynnerliga järnvägståget. $^{231}$

I ovanstående avsnitt upplever Nils att tåget under dem står alldeles stilla - det är landskapet som rör sig mot lokomotivet och inte tvärtom. Landets norra delar med sina naturresurser glider allt närmare de södra. Landet knyts samman och förloppet sker utan någon som helst svårighet eller motstånd. Tekniken (järnvägen) fungerar som en länk som binder samman landet och Nils färdas på fågeln åt samma håll som lokomotivet rör sig: i riktning mot Norrland där det finns viktiga naturtillgångar.

Kring sekelskiftet 1900 var Sverige i och med industrialiseringen indraget $i$ en ekonomisk kapplöpning om marknader och marknadsandelar. En nationell enhetssyn inom landet skulle därför gagna svenska intressen i denna kamp och intresset riktades mot de stora norrländska råvarutillgångarna. Norrland betraktades som ett slags "framtidsland" och intresset för det behandlades $i$ en mängd olika sammanhang: ekonomiska, politiska, vetenskapliga, journalistiska och konstnärliga. ${ }^{232}$ Som tidigare nämnts var ett utbyggt kommunikationsnät en förutsättning för att förbinda de olika landsdelarna och det var järnvägen som gjorde det möjligt att utnyttja naturtillgångarna. Norra stambanan till Storlien stod färdig 1884 och sträckan genom Lappland till Riksgränsen något senare. Samtidigt byggdes vägnät och ångbåtstrafik ut, vilket gjorde att Sveriges natur nu kunde inventeras med en helt annan effektivitet. Järnvägen erbjöd samtidigt förutsättningar för ett bredare resande och genom den inhemska turismen öppnades det möjligheter för andra grupper än enbart de mest privilegierade att upptäcka landet. ${ }^{233}$ När det gäller de lappländska malmfälten, gav de allmänt upphov till stor optimism och i tidens

\footnotetext{
${ }^{231}$ S. Lagerlöf, Nils Holgerssons underbara resa genom Sverige. Bd 2, 1908, s. 546.

${ }^{232}$ K. Johannisson, "Det sköna i det vilda: En aspekt på naturen som mänsklig resurs", 1984, s. 69-70; S. Sörlin, Framtidslandet: Debatten om Norrland och naturresurserna under det industriella genombrottet, diss., Umeå universitet, Stockholm: Carlsson, 1988, s. 60.

${ }^{233}$ S. Sörlin, "Norrlandsfrågan: Idéer och debatt i samband med det industriella genombrottet" i Paradiset och vildmarken: Studier kring synen på naturen och naturresurserna, T. Frängsmyr (red.), Stockholm: Liber Förlag, 1984, s. 265-319.
} 
patrioters föreställningsvärld blev Norrland något av en "skattkammare", konstaterar Sörlin. ${ }^{234}$ I Nils Holgersson är det med hjälp av järnvägen som människan intar vildmarken i norr. Därmed kan avsnittet om järnvägens intåg i Norrland likväl ses som en metafor för centralmaktens kolonisering. Textavsnittet nedan är ett av bokens exempel där en patriotisk eller nationalromantisk syn på naturresurserna uttrycks:

Se, det hade varit så, att fastän människor mycket länge hade vetat, att det fanns ett stort järnmalmsfält nära Gellivare, hade brytningen först kommit riktigt $\mathrm{i}$ gång för några år sedan, när järnvägen hade blivit färdig. Då hade flera tusen människor strömmat dit upp på en gång, och arbete hade det nog funnits för dem, men inte bostäder, utan sådana hade de fătt laga i ordning åt sig själva, så gott de hade kunnat. [...] Det fanns järnväg och elektriskt ljus och stora maskinhus, man kunde åka på spårväg djupt inåt berget genom en tunnel, som var upplyst av små glödlampor. Det var den väldigaste rörelse överallt, och det ena malmtåget efter det andra avsändes från stationen. Men runt omkring låg den stora vildmarken, där ingen åker plöjdes och inga hus timrades, där det inte fanns annat än lappar, som drevo omkring med sina renar. ${ }^{235}$

I berättelsens beskrivning av Gällivares malmindustri är det järnvägen som hade gjort det möjligt för människorna att utnyttja naturresurserna samt dra nytta av den tekniska utveckling i form av elektriskt ljus som följde i malmutvinningens spår. Naturen skildras som en resurs för människan, medan den orörda vildmarken och samerna som lever i naturen, är obetydliga i sammanhanget.

Den pågående industrialiseringen hade en stor inverkan på det svenska landskapet, vilket Nils observerar från fågelryggen. Förutom de förändringar som utvinningen av råvaror (malm och skog) eller uppdämning av sjöar medförde, växte det också upp fabriker som förändrade landskapsbilden. ${ }^{236}$ Det är framför allt det odlade och domesticerade landskapet som omformats av människan som framställs som intressant och som väcker Nils beundran, medan den vilda naturen är

\footnotetext{
${ }^{234}$ S. Sörlin, Framtidslandet: Debatten om Norrland och naturresurserna under det industriella genombrottet, 1988; S. Sörlin, "Norrlandsfrågan: Idéer och debatt i samband med det industriella genombrottet", 1984, s. 265-319.

${ }^{235}$ S. Lagerlöf, Nils Holgerssons underbara resa genom Sverige. Bd 2, 1908, s. 567-568.

${ }^{236}$ E. Erlandson-Hammargren, Från alpromantik till hembygdsromantik: Natursynen i Sverige från 1885 till 1915, speglad i Svenska turistföreningens årsskrifter och Nils Holgerssons underbara resa genom Sverige, 2006, s. 308.
} 
hotfull, mörk och till och med tråkig. Nils faller i sömn på fågelryggen när han flyger över ett landskap som enbart är skogsbeklätt:

Örnen bar honom nu med god fart bort över Gästrikland. I södra delen fanns inte mycket, som kunde fängsla blickarna. Där utbredde sig en slätt, som nästan överallt var täckt med granskog. Men längre mot norr sträckte sig tvärsöver landskapet, från Dalagränsen till Bottniska viken, en vacker trakt med lövträdsklädda kullar, blanka sjöar och forsande strömmar. Här lågo folkrika socknar omkring sina vita kyrkor, vägar och järnvägar korsade varandra, husen lågo vackert inbäddade i grönska, och blommande trädgårdar sände ljuvliga dofter upp i luften.

Utmed vattendragen funnos flera stora järnverk, sådana som pojken hade sett i Bergslagerna. De lågo med tämligen jämna mellanrum i en rad ända fram mot havet, där en stor stad utbredde sina vita husmassor. Norr om denna rika bygd vidtogo åter mörka skogar $[\ldots]^{237}$

Norra Värmland är en annan landsdel som skildras som att den endast består av "stora enformiga skogar". Den ödsliga bergsvidden beskrivs till och med som "ful". ${ }^{238}$ Ytterligare ett exempel på när Nils ger uttryck för sin beundran för människans tekniska framsteg sker när han vandrar runt i en kyrkby och får syn på en radsåningsmaskin. För ett kort ögonblick glömmer han bort att han är en liten pyssling och han kan inte låta bli att krypa upp på kuskens plats och låtsas att han kör. Han tänker på hur roligt det hade varit att ta sig fram över åkerfälten i en sådan grann maskin. Väl tillbaka i verkligheten, minns han sin situation och blir nedstämd. Nils slutsats är att den som alltid måste leva bland djuren, går miste om väldigt mycket. ${ }^{239}$

Tidens syn på tekniska framsteg går att koppla till Charles Darwin (18091882) och den i hans spår, så kallade darwinismen. Den gav ideologisk styrka åt dem som såg framsteget som en drivkraft och ofrånkomlig del av samhällsutvecklingen. ${ }^{240}$ Tiden innan darwinismen och framstegstanken slog igenom, fanns en föreställning om att det rådde en permanent ordning i naturen, skapad i tidernas

\footnotetext{
${ }^{237}$ S. Lagerlöf, Nils Holgerssons underbara resa genom Sverige. Bd 2, 1908, s. 499. ${ }^{238}$ Ibid., s. 622, 500.

${ }^{239}$ S. Lagerlöf, Nils Holgerssons underbara resa genom Sverige. Bd 1, 1908, s. 105.

${ }^{240}$ T. Frängsmyr, Svensk idéhistoria: Bildning och vetenskap under tusen år. D. 2, 1809-2000, 2000, s. 102.
} 
begynnelse. ${ }^{241}$ I och med evolutionsteorin och den industriella revolutionen kom synen att förändras. Genom naturvetenskapens och industrialismens genombrott utvecklades en stark tro på att samhället gick att utveckla i en viss riktning. Utopiska socialister, naturvetenskapliga filosofer och inflytelserika författare som Robert Owen, Edward Bellamy, William Morris, Karl Marx och Herbert Spencer med flera, tecknade alla sina egna bilder av det ideala framtidssamhället. Evolutionstänkandet blev en slags sammanfattning av tidens idéströmningar men, som Frängsmyr påpekar, kan man inte tillskriva darwinismen ensamt inflytande. Det var snarare så att idéströmningarna kring slutet av 1800-talet sammanföll med en livsåskådning som kunde bekräftas i Darwins evolutionsteori. ${ }^{242}$ Kamp och konkurrens kom att allmänt ses som naturligt och inte som något som borde stävjas. Utvecklingstänkandet betonade konkurrensens betydelse och att endast de mest lämpade individerna skulle överleva och sedan bli del i den fortgående förändringsprocessen. Herbert Spencer (1820-1903), som av vissa historiker betraktas som den förste av socialdarwinisterna, lade fram utvecklingsteorier som exempelvis innefattade att konkurrens och utslagning skulle betraktas som ett led i det mänskliga framsteget. Synsättet bidrog till att det bättre bemedlade samhällsskiktet accepterade den materiella nöden hos andra. Likaså gav tolkningarna av utvecklingsläran spelrum för imperialistiska strömningar och krig, liksom legitimerade västerländska intressen utanför Europa och Amerika samt utrotningen av urbefolkningar i de europeiska kolonierna. ${ }^{243}$

Hård och Jamison är av åsikten att Karl Marx (1818-1883) är den som mer än andra bidragit till skapandet av de centrala diskurserna om industrisamhället. En viktig källa till den marxistiska syntesen var just Darwins teori om evolutionen. Där Darwin härledde grundläggande lagar i naturen utifrån observationer av naturfenomen, framlade Marx sina teorier om den samhälleliga evolutionen. Båda bi-

\footnotetext{
${ }^{241}$ T. Frängsmyr, Framsteg eller förfall: Framtidsbilder och utopier $i$ västerländsk tanketradition, 1990, s. 78-93; D. Worster, De ekologiska idéernas historia, 1996, s. 99-102.

${ }^{242}$ T. Frängsmyr, Framsteg eller förfall: Framtidsbilder och utopier $i$ västerländsk tanketradition, 1990, s. 188.

${ }^{243}$ K. Berg, "Livingstone och Stanley. Synen på Afrikas natur" i Paradiset och vildmarken: Studier kring synen på naturen och naturresurserna, T. Frängsmyr (red.), Stockholm: Liber Förlag, 1984, s. 159-197; P. J. Bowler, The earth encompassed: A history of the environmental sciences, 2000, s. 310-314; B. Skovdahl, Förlorad kontroll: Den ifrågasatta framstegstanken, 2010, s. 61; D. Worster, De ekologiska idéernas historia, 1996, s. 130-137.
} 
drog till idén om att framsteg och förändringar är oundvikliga, ett synsätt som var centralt för den industriella omvandlingen och tidens tillämpning av teknik och vetenskap. Marx drevs av en stark tro på att vetenskap och teknik kunde transformera samhället och frigöra den mänskliga kreativiteten. Uppfinningsrikedom var ett av de utmärkande dragen för industrisamhället, menade han. ${ }^{244}$

Just människans uppfinningsrikedom är ett återkommande tema i Nils $\mathrm{Hol}$ gersson och något som hyllas, även om berättelsen inte företräder några marxistiska idéer. Under sin fortsatta promenad genom kyrkbyn får Nils se mer som bekräftar hans tankar om människans tekniska uppfinningsförmåga:

Han gick förbi postkontoret och tänkte då på alla tidningar, som var dag kommer med nyheter från alla världens fyra hörn. Han såg apoteket och doktorsbostaden, och han tänkte på att människors makt var så stor, att de kunde kämpa mot sjukdom och död. [...] Och ju längre han gick där, desto mer tyckte han om människorna. ${ }^{245}$

De uppfinningar och tekniska lösningar som Nils stöter på under sin resa, väcker inte bara hans beundran utan också en medvetenhet om människans innovationsförmåga, en insikt som visar sig ha en positiv inverkan på hans personlighetsutveckling. När han kommer till Karlskrona förundras han över att så stora och granna fartyg har byggts i Sverige. Han får höra hur "liv och blod" har vågats och hur "snillrika män" har ansträngt sig för att förbättra fartygen "som hade fädernelandets värn". Informationen får Nils att röras till tårar. ${ }^{246}$ Det är också fascinationen för människans (männens) tekniska förmåga som under ett ögonblick får Nils att glömma sin livsfarliga situation när han är fånge hos björnarna i Bergslagen. Björnen låter honom se in i järnverket:

Björnfar lät pojken se på det granna skådespelet, ända tills blåsningen var slut och det röda, flytande, skönt lysande stålet hälldes ur den runda kulan ner i ett par pytsar. Pojken tyckte, att det han såg var så ståtligt, att han blev rent betagen och nästan glömde bort, att han hölls fången mellan ett par björnramar. ${ }^{247}$

\footnotetext{
${ }^{244}$ M. Hård \& A. Jamison, Hubris and hybrids: A cultural history of technology and science, 2005, s. 65-66.

${ }^{245}$ S. Lagerlöf, Nils Holgerssons underbara resa genom Sverige. Bd 1, 1908, s. 105.

${ }^{246}$ Ibid., s. 135.

${ }^{247}$ S. Lagerlöf, Nils Holgerssons underbara resa genom Sverige. Bd 2, 1908, s. 366.
} 


\section{Tekniklandskapet i Selma Lagerlöfs barnbok ...}

Även järnverksarbetarna väcker Nils beundran och han konstaterar att "det är som en lek" för dem att hantera det fräsande järnet, det är ett "riktigt karlgöra": ${ }^{248}$

Björnen lät honom också se in i hyttan och i stångjärnssmedjan, och pojken blev allt mer och mer förundrad, när han såg hur smederna hanterade eld och järn. »De här människorna har ingen rädsla för värme och lågor», tänkte han. Sotiga och svarta voro de också. Han tyckte, att de voro som ett slags eldfolk. Det var därför, som de kunde böja och forma järnet, hur de behagade. Han kunde inte tro, att det var vanligt folk, som hade sådan makt. ${ }^{249}$

Här finns ett budskap om att människans övertag över naturen har sin grund $\mathrm{i}$ människans tekniska förmåga, vilket här knyts till elden och järnet. ${ }^{250}$ Fast samtidigt som en tydlig åtskillnad mellan människa och natur görs, vävs tekniken på många ställen i berättelsen samman med naturen. Den smygs in bland grönskande ängar och skogsbeklädda åsar:

Det stora järnverket reste sig med många höga och stora byggnader vid randen av ett vattenfall. Höga skorstenar sände ut svarta rökmoln, masugnarnas lågor flammade, och ur alla fönster och gluggar lyste ljus. Därinne voro hammare och valsverk igång, och de arbetade med en sådan kraft, att luften genljöd av rassel och dån. Runt omkring själva verkstadsbyggnaderna lågo ofantliga kolhus, stora slagghögar, packhus, brädstaplar och redskapsskjul. [...] Marken var svart omkring dem, himlen välvde sig skönt mörkblå över masugnslågorna, forsen strök förbi dem vitskummande, och själva stodo de och sände ut ljus och rök och eld och gnistor. Det var den väldigaste syn han sett. ${ }^{251}$

Bilden av gruvan och järnverket framträder på samma sätt genom en idyllisk landskapsbeskrivning:

Det löpte linbanor fram genom luften, på vilka korgar, lastade med malm, sakta färdades fram. I alla forsar snurrade hjul, elektriska ledningar ströko genom den tysta

\footnotetext{
${ }^{248}$ Ibid., s. 367.

${ }^{249}$ Ibid.

${ }^{250}$ Angående människans makt över naturen genom elden, se analysen av tekniklandskapet i Otto Witts tekniska sagor i avhandlingens fjärde kapitel.

${ }^{251}$ S. Lagerlöf, Nils Holgerssons underbara resa genom Sverige. Bd 2, 1908, s. 364.
} 
skogen, och ofantligt långa järnvägståg kommo rullande med sexti, sjutti vagnar, lastade än med malm och kol, än med järnstänger, plåtar och ståltråd. ${ }^{252}$

Som citatet ovan visar, vävs tekniken också här in i det pastorala landskapet genom måleriska beskrivningar. Vid tiden för industrialiseringens genombrott placerade många författare, poeter och konstnärer in den industriella omvandlingen $\mathrm{i}$ det välbekanta imaginära och konstnärliga formatet. ${ }^{253}$ David Nye konstaterar att maskinen, lokomotivet, ångbåten och telegrafen betraktades som en del av det sublima landskapet och de fick därför ingå i pastorala målningar som en harmonisk del. Denna sammanblandning av natur och teknik var något som ekonomiskt stöddes av järnvägens ägare, och förvaltare uppmuntrades beställa målningar av detta slag. ${ }^{254}$ Michael L. Smith använder välkända amerikanska litografier från 1860och 1950-talen som exempel på hur tåg fungerade som positiva metaforer för framsteg där teknikutvecklingen avbildas som ett tåg rusande mot en osynlig och icke skönjbar framtid bortom bilden. ${ }^{255}$ Samtidigt visar Earl G. Ingersoll och Leo Marx hur tågmetaforen användes i motsatt syfte, det vill säga som en reaktion mot industrialiseringen. Sådana illustrationer skildrar istället en stillsam landsbygdsidyll som brutalt invaderas av ett ånglok. ${ }^{256}$

I "Sagan om Småland" avbryter Åsa Lille Mats när han klagar över hur magert och kargt landskapet är. Hon håller inte med honom:

»Och minns du inte», fortfor Åsa, »att skollärarinnan sa, att en så livlig och vacker trakt som den biten av Småland, som ligger söder om Vättern, det finns inte i hela Sverige? Tänk på den vackra sjön och de gula strandbergen och på Gränna och Jönköping med tändsticksfabriken och Munksjö, och tänk på Huskvarna och de stora anläggningarna där!» - »Ja, det är nog sant, det», sa lille Mats än en gång. - »Och tänk på Visingsö, lille Mats, med de ruinerna och den ekskogen och de sagorna!

\footnotetext{
${ }^{252}$ Ibid., s. 356.

${ }^{253}$ M. Hård \& A. Jamison, Hubris and hybrids: A cultural history of technology and science, 2005, s. 149.

${ }^{254}$ D.E. Nye, American technological sublime, Cambridge, Mass.: MIT Press, 1994, s. 59.

${ }^{255}$ M. L. Smith, "Recourse of empire: Landscapes of progress in technological America" i Does technology drive history? The dilemma of technological determinism, M. R. Smith \& L. Marx (red.), Cambridge, Mass.; MIT Press, 1994, s. 37-52.

${ }^{256}$ E. G. Ingersoll, Representations of science and technology in British literature since 1880, 1992, s. 2; L. Marx, The machine in the garden: Technology and the pastoral ideal in America, 1964.
} 
Tänk på den dalen, där Emån går fram, med alla de byarna och kvarnarna och trämassefabrikerna och sågarna och snickerierna!»» ${ }^{257}$

Åsa knyter här samman naturen med den industriella utvecklingen. Naturen skildras som en förutsättning för industrin och när tekniken vävs in i landskapet går människa, natur och teknik inte att separera. Tillsammans bildar de en sammanhållen och odelbar helhet. Genom sin uppfinningsrikedom och framstegssträvan skapar människan något som är vackert och naturligt. Denna bild förstärks av att metaforer från naturen utnyttjas i beskrivningarna:

»Det här landet är klätt i granrisskjortel och gråstenströja,» tänkte pojken för sig själv. » Men kring midjan bar det ett bälte, som inte har sin like i kostbarhet, för det är utbroderat med blånande sjöar och blommande hagar, de stora järnverken pryder det som en rad av ädla stenar, och till spänne har det en hel stad med slott och kyrkor och stora klungor av hus.» ${ }^{258}$

Likaså liknas de blanka torpedbåtarna i flottan i Karlskrona vid "långa, smärta fiskar" och i järnverket fattar männen i valsverket de glödande "ormarna" med sina tänger och tvingar in dem under valsarna. ${ }^{259}$ Genom dessa liknelser och metaforiska fraser blir tekniken en del av naturen och inte något som stör den idylliska landskapsbilden. Det finns i berättelsen även det omvända: att fenomen i naturen beskrivs med hjälp av människans teknik. Ett sådant exempel är hur Småland beskrivs som "ett högt hus med granar på taket" och Blekinge är en "trappa". ${ }^{260}$ På samma sätt upplever Nils att Bergslagen är "lika randigt som mors förkläde". Det som pojken ser som ränder är åar, åsar, vägar och järnvägar. Genom att låta naturen och resultatet av människans teknik ingå som ränder på ett och samma förkläde, förstärks bilden av att dessa båda är två ej separerbara delar av landet. Ett ytterligare exempel på utnyttjandet av metaforer är Nils skildring av regnmolnen. Nere från marken upplevde han dem som "gråa och tråkiga" men från fågelryggen är hans upplevelse en annan:

\footnotetext{
${ }^{257}$ S. Lagerlöf, Nils Holgerssons underbara resa genom Sverige. Bd 1, 1908, s. 191.

${ }^{258}$ S. Lagerlöf, Nils Holgerssons underbara resa genom Sverige. Bd 2, 1908, s. 499.

${ }^{259}$ S. Lagerlöf, Nils Holgerssons underbara resa genom Sverige. Bd 1, 1908, s. 134; Ibid., Bd 2, s. 367.
}

${ }^{260}$ S. Lagerlöf, Nils Holgerssons underbara resa genom Sverige. Bd 1, 1908, s. 109. 
$\mathrm{Nu}$ såg han tydligt, att molnen voro ofantliga forvagnar, som körde fram på himlen med skyhöga lass: några av dem voro lastade med väldiga, gråa säckar, några med tunnor, som voro så stora, att de kunde rymma en hel sjö, och några med stora kar och flaskor, som voro uppstaplade till en förfärlig höjd. Och när så många av dem hade kört fram, att de fyllde hela rymden, var det, som om någon givit ett tecken, för på en gång började det att ur kar, tunnor, flaskor och säckar flöda ner vatten över jorden. $^{261}$

Budskapet i landskapsbeskrivningen är dock inte entydigt eftersom det parallellt med sammanvävningen av natur och människans teknik finns avsnitt där istället bilden av ett uppdelat land framträder. Pojken upplever exempelvis att han kan se tre olika världar från gåsryggen när han flyger över Ångermanland. Den första är dalen med sitt djup. Där älven far fram finns ångbåtar, timmerflottning, rasslande sågverk och där lastas stora fraktfartyg. I den andra världen ligger gårdarna, byarna, kyrkorna. Där sår bönderna sina tegar och där finns grönskande ängar, betande boskap, slingrande landsvägar och brusande järnvägståg. Den tredje världen är skogen med älgar, "lurande lodjur", "knaprande ekorrar" och "doftande barr". ${ }^{262}$

I berättelsen framställs människorna som märkvärdiga och duktiga, med hänvisning till deras förmåga att skapa teknik. Samtidigt är det i huvudsak djuren som berättar för Nils om tekniken och instruerar honom om hur den fungerar. I Bergslagen känner björnen till hur hela den tekniska processen i järnverket går till: ”Björnfar hade väl reda på järnbruket. Han hade gått omkring där många mörka nätter $[\ldots] " \cdot{ }^{263}$ Björnen tar med pojken till järnverket och lyfter upp honom så han kan se vad som sker därinne:

Inne i järnverket höllo de på med bessemerblåsning. I en stor, svart, rund kula, som satt uppe under taket och var fylld med smält järn, pressade de in en stark luftström. Och när luften med ett förfärligt dån trängde in i järnmassan sprutade stora svärmar av gnistor upp ur denna. ${ }^{264}$

\footnotetext{
${ }^{261}$ Ibid., s. 102.

${ }^{262}$ S. Lagerlöf, Nils Holgerssons underbara resa genom Sverige. Bd 2, 1908, s. 532.

${ }^{263}$ Ibid., s. 365.

${ }^{264}$ Ibid., s. 366.
} 


\section{Tekniklandskapet i Selma Lagerlöfs barnbok ...}

Björnfar låter därefter Nils se in i valsverket och från fönstret får han uppleva hur tjocka vidglödgade järnstycken pressas in i valsar tills de förvandlats till " [...] en många meter lång, rödglänsande tråd". ${ }^{265}$

När Nils passerar över en gruva och undrar varför så mycket gråsten hämtas upp ur jorden får han svaret:

»Hör på det nötet! Hör på det nötet!» kvittrade sparvarna som voro hemma på platsen och hade väl reda med sig. »Han kan inte skilja järnmalm från gråsten. Han kan inte skilja järnmalm från gråsten.» Då förstod pojken, att det, som han såg, var en gruva. $^{266}$

Strax därpå tror Nils att han bevittnar en eldsvåda, men får återigen svar på tal från fåglarna:

»Hör på den, som är rädd för elden»! kvittrade bofinkarna, som bodde i skogsbrynet och hade väl reda på vad som skedde i grannskapet. »Han vet inte hur järnet smältes ur malmen. Han kan inte skilja en masugnslåga från en eldsvåda.» ${ }^{267}$

Nils fortsätter sin färd genom tekniklandskapet och hör då ett oljud som han tolkar som att någon med starka slag försöker att försvara sig mot ett väsande vilddjur. En skata skrattar åt hans okunskap och informerar honom om att det inte är någon som blir sliten i stycken; det är järnet som sprakar och fräser när det läggs under hammaren. Nils undrar då varför det byggs så stora gårdar mitt i skogen där det inte finns någon åker. Av en tupp får han svaret: "Åkrarna ligger under jorden.,"268 Här används åkrar som metafor för järnmalmen, det vill säga att med hjälp av metaforer från en värld som Nils känner igen sig i, förklaras nya och för honom obekanta fenomen. Ytterligare en fågel, en gammal uv, ger avslutningsvis Nils svaret när han frågar vad landet där det "bara växer järn" heter: "Uhu, uhu, uhu. Det här landet kallas Bergslagerna. Om här inte hade vuxit järn, skulle det inte bo annat än uvar och björnar här än i dag." ${ }^{269}$ I berättelsen är det därmed framför allt fåglarna som är experter och förklarar för Nils vad det är han ser men i episoden vid järn-

\footnotetext{
${ }^{265}$ Ibid.

${ }^{266}$ Ibid., s. 352.

${ }^{267}$ Ibid.

${ }^{268}$ Ibid., s. 354.

${ }^{269}$ Ibid., s. 356.
} 
verket är det en björn. Sammantaget ges järnet och den teknik som är kopplad till den en framskjutande plats i Nils Holgerssons tekniklandskap.

\section{Natursynen i Nils Holgersson}

Samtidigt som berättelsen om Nils Holgersson kan tolkas som att den ger uttryck för en stark framstegstro och tilltro till teknisk utveckling, finns ett budskap om att det är viktigt att människan far varsamt fram med naturen. Detta budskap förstärks genom att naturen skildras som besjälad genom träd som "kryper", att solen "gömmer sig", landskap som "badar i havet" utan att känna köld, att hav och land möts "i glädje och endräkt", havet är "påträngande" och ljungväxter som troget "håller ihop". ${ }^{270}$ Den besjälade och antropomorfa naturen framträder särskilt tydligt i avsnittet om Dalälven som skildrar en tävling mellan vattendrag, bland annat Storån, Grövelån, Vångsjön och Sörälven. Vattendragen (liksom skogen) talar med varandra, ger uttryck för mänskliga tankar och känslor samt när de slutligen når havet känner sig både trötta och gamla. ${ }^{271}$

Geologen och upptäcktsresanden Adolf Erik Nordenskiöld uttalade redan 1880 en önskan om att skydda den svenska naturen. I argumenten i den artikel där han framför sitt budskap anför han dock inga vetenskapliga skäl. Inte heller framför han något argument om naturens betydelse för rekreation, vikten av biologisk mångfald eller att naturen har ett egenvärde. Nordenskiöld prisar istället de ekonomiska framstegen och uttrycker samtidigt en önskan om att en rikspark ska inrättas där skog, mark och sjö ska kunna förbli orörda. Nordenskiöld motiverar sitt förslag med att kommande generationer ska kunna göra sig en föreställning om hur deras fäders land en gång sett ut. ${ }^{272}$ Lars J. Lundgren menar att Nordenskiöld snarare såg bevarandet av naturen utifrån ett kulturellt perspektiv som påminner om viljan att bevara ett konstverk för kommande generationer. ${ }^{273}$ Nordenskiölds

\footnotetext{
${ }^{270}$ S. Lagerlöf, Nils Holgerssons underbara resa genom Sverige. Bd 1, 1908, s. 103, 110, 122 , 187, 193.

${ }^{271}$ S. Lagerlöf, Nils Holgerssons underbara resa genom Sverige. Bd 2, 1908, s. 373-382.

${ }^{272}$ C. Bernes \& L.J. Lundgren, Bruk och missbruk av naturens resurser: En svensk miljöhistoria, Stockholm: Naturvårdsverket, 2009, s. 40-41; L. J. Lundgren, Staten och naturen: Naturskyddspolitik $i$ Sverige 1869-1935. D. 1, 1869-1919, 2009, s. 38-45.

${ }^{273}$ Ibid., s. 42.
} 
önskan fick dock inget större gehör och först ett par årtionden senare fick naturskyddsrörelsen ett genomslag i Sverige. År 1909 infördes dels en lag om skydd av naturminnesmärken, dels en om inrättande av nationalparker i Sverige. Det största skälet till att lagarna gick att genomföra var att de områden som föreslogs till nationalparker var ekonomiskt ointressanta och saknade naturtillgångar. På så vis betraktades förslagen som "ofarliga" för både markägare och industri. ${ }^{274}$

Désirée Haraldsson konstaterar att i och med 1909 års naturskyddslagstiftning hade de grupper som drivit naturskyddsfrågan fått gehör för sina krav. De stora vinnarna var turistintressena och Svenska turistföreningen, STF. De vetenskapliga intressen som framfört ett mer långtgående och vetenskapligt baserat naturskydd fick inte gehör för sina krav. Haraldsson menar att trots de svagheter och inskränkningar som fanns i 1909 års naturskyddslagar skapades ändå en bas för ett fortsatt naturskyddsarbete. ${ }^{275}$ Samma år bildades Svenska Naturskyddsföreningen, SNF. Initiativet kom från väletablerade naturforskare, skogsvårdsföreträdare samt företrädare för bland annat frilufts- och turistområdet. ${ }^{276} \mathrm{SNF}$ lyckades dock inte samla mer än några få tusen medlemmar under sina första trettio år. ${ }^{277}$

Det Norrland som Nils upplever från fågelryggen skildras som ett grant och ståtligt land. Samtidigt konstaterar Nils när han lämnar Lappland, att Akka (ledargåsen) hade haft rätt när hon menade att denna del av landet skulle de svenska nybyggarna lika gärna kunna lämna i fred och överlåta åt björnarna, vargarna, renarna, vildgässen, fjällugglorna, lämlarna och lapparna, eftersom de " $[. .$.$] voro$ skapade för att leva där. ${ }^{, 278}$ Människa och natur kan leva sida vid sida utifrån en uppdelning där djuren (och samerna) tilldelas en fristad i de områden av landet som inte är ekonomiskt intressanta för samhällsutvecklingen. Med andra ord ett

\footnotetext{
${ }^{274}$ C. Bernes \& L. J. Lundgren, Bruk och missbruk av naturens resurser: En svensk miljöhistoria, 2009, s. 40-41; L. Gren, "Historiska tillbakablickar" i Samhällsförändringar och vården av natur och kultur: En debattskrift om natur- och kulturmiljövårdens utveckling under 100 år, [Elektronisk resurs], L. Gren (red.), Stockholm: Riksantikvarieämbetet, 2010, s. 15-16, http://www.raa.se/publicerat/9789172095717.pdf (läst 2011-01-08).

${ }^{275}$ D. Haraldsson, Skydda vår natur! Svenska Naturskyddsföreningens framväxt och tidiga utveckling, diss., Lunds universitet, Lund, 1987, s. 110-112.

${ }^{276}$ Ibid., s. 125.

${ }^{277}$ C. Bernes \& L. J. Lundgren, Bruk och missbruk av naturens resurser: En svensk miljöhistoria, 2009, s. 41.

${ }^{278}$ S. Lagerlöf, Nils Holgerssons underbara resa genom Sverige. Bd 2, 1908, s. 595-596.
} 
slags reservat där naturen och dess invånare är fredade från inverkan av den (nödvändiga) industrialiseringsprocessen.

I Nils Holgersson är det människorna som har herraväldet trots att djuren ofta agerar huvudkaraktärer. Det råder en hierarkisk skillnad mellan människa och djur samtidigt som de antropomorfa djuren beter sig och tänker som människor. Å ena sidan kan detta tolkas som att djuren i själva verket är människor i djurförklädnad och att berättelsen därmed är en fabel. Å andra sidan agerar djuren samtidigt språkrör för naturen i stort. När Nils blir tillfångatagen av björnfamiljen i Bergslagen diskuterar björnparet "bullerverket" (järnverket) som gjort att de inte längre trivs $i$ skogen där de bor. Björnfar har just återvänt från en utflykt till Värmland där han letat efter en ny boplats till sin familj och björnarna frågar sig vart de ska ta vägen för att få vara ifred för människorna. Björnfar får då en idé. Eftersom Nils har försökt skrämma björnarna genom att tända en svavelsticka förstår björnen vilken makt Nils har som kan hantera elden. Björnen ger Nils ett ultimatum: han får leva om han tänder eld på valsverket. Nils ber om betänketid:

»Nåja, det kan du få», sade björnfar, »men jag ska säga dig, att det är just järnet, som har gett människorna ett sådant övertag över oss björnar, att jag också fördenskull gärna vill få slut på arbetet här.» ${ }^{279}$

Nils funderar. Han tänker på vilken nytta järnet gjort för människorna och han inser att de behöver järnet till så gott som allting:

Järn var det i plogen, som redde upp åkern, i yxan, som byggde huset, i lien, som mejade säden, i kniven, som kunde brukas till allt möjligt. Järn var det $\mathrm{i}$ betslet som styrde hästen, i låset, som stängde dörren, i spikarna, som höllo ihop möblerna, i plåten, som täckte taket. Bössan, som hade utrotat vilddjuren, var av järn och likaså hackan, som hade brutit upp gruvan. Järn klädde krigsfartygen, som han hade sett $\mathrm{i}$ Karlskrona, på järnskenor rullade lokomotiven fram över landet, av järn var nålen, som sydde rocken, saxen, som klippte fåren, grytan, som kokade maten. Stort som smått, allt, som var nyttigt och oumbärligt, var av järn. Björnfar hade nog rätt $i$ att det var järnet, som hade gett människorna deras övermakt över björnarna. ${ }^{280}$

Nils förstärker järnets betydelse ytterligare när han når insikten att det nog är människans grubblande över järnet som har fått hennes förstånd att växa. Hans slutsats

\footnotetext{
${ }^{279}$ Ibid., s. 368.

${ }^{280}$ Ibid., s. 368-369.
} 
är att människorna har järnet att tacka för mer än vad de själva inser. Att järnet bidragit till att människan utvecklat ett förstånd som överträffar djurens, är något som även björnfar bekräftar. ${ }^{281}$ Järnet och björnen kan ses som metaforer för kampen mellan människans teknikutveckling (järnet) och naturen (björnen). Björnen hävdar sin rätt utifrån att han och hans förfäder har hållit till i trakterna, alltsedan det började växa skog i landet. ${ }^{282}$ Det är dock människan med sitt överlägsna förstånd och sin förmåga att utveckla teknik som är den starkare och därför går som segrare ur kampen.

Kamp mellan människa och natur är ett klassiskt motiv med rötter i upplysningstiden och som vid tiden kring förra sekelskiftet fick ny aktualitet genom darwinismen. ${ }^{283}$ Det är dock snarare en natursyn i linje med Darwins föregångare än Darwin själv som björnepisoden företräder. Föreställningen om kampen i naturen hade Darwin hämtat från sin mentor, geologen Charles Lyell (1797-1875). Lyell företrädde den viktorianska föreställningen att "makt ger rätt" och detta civilisationsideal var helt avhängigt av teknikens och vetenskapens erövring av naturen. Naturen måste besegras för att framåtskridande ska kunna genomföras. Människans tekniska dominans över naturen visar att den starkaste överlever och framåtskridandet ingår i denna ordning. ${ }^{284}$

Donald Worster lyfter fram Karl Marx respektive Friedrich Engels (18201895) som exempel på tidens inflytelserika tänkare som ansåg att kontrollen över naturen var ett grundvillkor för samhällsutvecklingen. Genom arbete och alltmer avancerad teknik skulle människan vinna herraväldet över naturen. Naturen är människornas tjänare och målet är ett tillstånd där naturen tvingats till fullständig lydnad. Hos Marx och Engels saknades därför intresse för att bevara någon känsla för naturen från äldre tider eller intresse för naturvård, konstaterar Worster. ${ }^{285} \mathrm{Att} i$

\footnotetext{
${ }^{281}$ Ibid., s. 369.

${ }^{282}$ Ibid., s. 365.

${ }^{283}$ K. Johannisson, ”Det sköna i det vilda: En aspekt på naturen som mänsklig resurs”, 1984, s. 70-71.

${ }^{284}$ D. Worster, De ekologiska idéernas historia, 1996, s. 132-134.

${ }^{285}$ Ibid., s. 337-338.
} 
första hand se naturen som en resurs för människan att utnyttja var ett synsätt som delades av många av 1800-talets utopister och naturvetenskapsfilosofer. ${ }^{286}$

I Nils Holgersson är människan genom sin teknik den starkare men djuren har också rätt att existera. Den tekniska utvecklingen är dock nödvändig och Nils kommer efter en stunds funderande fram till att han inte kan bränna upp valsverket, trots björnens ultimatum. Nils motiverar sitt beslut utifrån ett samhällsekonomiskt perspektiv: det är järnverket som har gett så många "bröd" och som gjort att människorna har fått det så mycket bättre, både fattig och rik. ${ }^{287}$ Det sammantagna motivet till varför Nils bestämmer sig för att offra sitt liv för utvecklingen kan å ena sidan tolkas som att järnet (industrialiseringen) är så viktig för utvecklingen (framstegstron) att vissa offer (naturen) är oundvikliga. Å andra sidan kan Nils slutsats ses som uttryck för en deterministisk tekniksyn: det finns inte någon återvändo eftersom den tekniska utvecklingen lever sitt eget "liv". Vare sig människa eller natur har makt att hindra den och Nils har därmed inget val. Däremot är människans makt över naturen otvetydig i episoden: naturen finns till för människorna. Björnhistoriens fortsättning talar emellertid för en alternativ tolkning. Just när björnen ska döda honom hör Nils ett knäppande ljud från en bössa. Utan att tänka sig för varnar han björnen som då hinner fly undan gevärskulorna. Som tack för varningen får Nils leva. Björnen viskar dessutom något i örat på Nils som ska hjälpa honom om han råkar ut för en björn någon mer gång. ${ }^{288}$ Varför varnar Nils björnen? Om Nils hade låtit jägaren döda den hade han med säkerhet fătt behålla livet. Ett möjligt budskap är att naturen (björnen) och människan kan leva sida vid sida, även om människan genom sin teknik (järnet) innehar herraväldet. Men samtidigt finns det episoder i Nils Holgersson där människan inte går som segrare ur kampen dem emellan.

Ytterligare ett exempel på kraftmätning mellan människa och natur utspelar sig vid sjön Tåkern där en liten pojke har försvunnit. Naturen står mot utvecklingen då det handlar om en sänkning av sjön, vilket har negativa konsekvenser för fågellivet. Pojkens mor inser att det skulle bli bekymmersamt för tusentals djur om

\footnotetext{
${ }^{286}$ S. Sörlin, Naturkontraktet: Om naturumgängets idéhistoria, 1991, s. 98; D. Worster, De ekologiska idéernas historia, 1996, s. 337-338.

${ }^{287}$ S. Lagerlöf, Nils Holgerssons underbara resa genom Sverige. Bd 2, 1908, s. 370.

${ }^{288}$ Ibid., s. 371.
} 


\section{Tekniklandskapet i Selma Lagerlöfs barnbok ...}

sjön förvandlades till en åker och hon undrar om det är den planerade sjösänkningen som ligger bakom sonens försvinnande:

Hon tänkte på att det var nästa dag, som beslutet om sjösänkningen skulle fattas, och hon undrade om det var fördenskull hennes lilla gosse hade kommit bort just $\mathrm{i}$ dag. Om det var Guds mening, att sorgen skulle komma och öppna hennes hjärta till barmhärtighet just i dag, innan det var för sent att avstyra den grymma handlingen ${ }^{289}$

Den "grymma handlingen" som åsyftas är sjösänkningen och dess konsekvenser för fåglarna. Modern beslutar sig för att stoppa genomförandet av sänkningen och snart återfinns pojken vid liv. Ett liknande budskap finns i avsnittet om Kolmården:

Och nu kom det, som bröt skogens makt. Människorna togo upp gruvor, de reste hytter och bruk på den gamla skogsmarken. Men detta hade inte behövt göra skogen allvarsam skada, om det inte hade varit så, att det gick åt en otrolig mängd ved och kol för bergshanteringen. [...] Även där skogen inte blevo alldeles bortröjd, blevo de gamla träden fällda och de täta snåren genomhuggna. Vägar drogos fram överallt och vilddjur och rövare jagades bort. När människorna äntligen hade fått makt med skogen, foro de förfärligt illa fram med den: högg och svedjade och kolade utan hejd. De hade inte glömt det gamla hatet till skogen, och nu tycktes de alldeles vilja förgöra den. $^{290}$

Det finns dock inte så mycket malm i skogen som människorna har hoppats på och Kolmårdsborna försöker sig på att försörja sig på jordbruk. Detta visar sig inte vara något framgångsrikt företag, då den "gamla skogsmarken" hellre vill "[...] bära jätteekar och storfuror än rovor och korn". ${ }^{291}$ Efter flera misslyckade försök att tämja skogen, inser människorna skogens värde:

De märkte snart, att om de bara fore förståndigt fram, kunde de få sitt levebröd av skogen likaväl som av åkern och av gruvan. Och då kommo de att betrakta den på ett

\footnotetext{
${ }^{289}$ S. Lagerlöf, Nils Holgerssons underbara resa genom Sverige. Bd 1, 1908, s. 251.

${ }^{290}$ S. Lagerlöf, Nils Holgerssons underbara resa genom Sverige. Bd 2, 1908, s. 267-268.

${ }^{291}$ Ibid., s. 268.
} 
annat sätt än förut. De lärde sig att vårda den och älska den. De glömde alldeles bort den gamla fiendskapen och ansågo skogen som sin bästa vän. ${ }^{292}$

Avsnitten om Tåkern och Kolmården visar att människan inte kan förgripa sig hur som helst på naturen utan att själv gå under. Utifrån en sådan natursyn kan den tidigare nämnda björnhistorien i Bergslagen tolkas som att Nils intuitivt visste att om han inte hade räddat björnen hade det inte slutat väl. Sensmoralen i berättelsen kan tolkas som att människan har rätt att utnyttja och förvalta naturen men det måste ske med hänsynsfullhet.

Lundgren anser att Nils Holgersson snarare företräder en naturskyddande än en miljöskyddande syn, vilket överensstämmer med mina tolkningar av berättelsens natursyn. ${ }^{293}$ Budskapet $\mathrm{i}$ berättelsen är att naturskyddet $\mathrm{i}$ första hand bör genomföras med hänsyn till människans behov och inte i första hand för att naturen i sig har ett värde. Att Nils Holgersson företräder en antropocentrisk natursyn förstärks ytterligare i avsnittet om "Djurens nyårsnatt". På nyårsnatten samlas tamboskapen på Blackåsen för att skogsrået ska bestämma vilka tamdjur som ska falla i rovdjurens våld under kommande år. En prost blir vittne till den dramatiska händelsen: "Han kände en stor ömkan med de arma kreaturen, som var under vild-

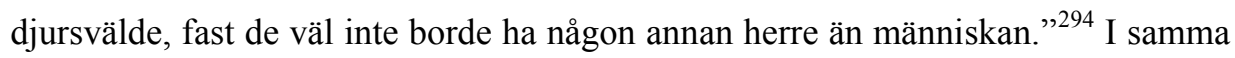
berättelse finns dock något som talar emot en explicit antropocentrisk natursyn, nämligen att människans makt $\mathrm{i}$ förhållande till naturen trots allt är begränsad. Prosten finner det "hjärtskärande" att se tamdjuren gå mot rovdjuren. Han skulle vilja ställa sig i vägen och hindra det som håller på att ske "[...] men han förstod nog, att det inte var någon människas makt att hejda boskapens vandring denna natt, och han höll sig stilla". ${ }^{295}$ Det omvända förhållandet, det vill säga att naturen räddas av människan, skildras när några barn planterar trädplantor på en plats där en skogsbrand härjat tio år tidigare:

Och de små plantorna, som de satte, skulle ju så småningom bli till höga träd. Det skulle kanske komma att byggas stora hus eller granna skepp av dem. Men om bar-

\footnotetext{
${ }^{292}$ Ibid., s. 269-270.

${ }^{293}$ L. J. Lundgren, Staten och naturen: Naturskyddspolitik i Sverige 1869-1935. D. 1, 1869-1919, 2009, s. 190-192.

${ }^{294}$ S. Lagerlöf, Nils Holgerssons underbara resa genom Sverige. Bd 2, 1908, s. 518.

${ }^{295}$ Ibid., s. 517.
} 


\section{Tekniklandskapet i Selma Lagerlöfs barnbok ...}

nen inte hade kommit hit och planterat, medan det ännu fanns litet jord kvar i skrevorna, då hade all myllan blivit bortförd av vind och vatten, och berget hade aldrig mer kunnat bli skogbeväxt. ${ }^{296}$

Här är det inte människan som är orsaken till förödelsen utan naturen själv. Människorna är däremot beredda att hjälpa naturen att återhämta sig och i gengäld får de material till hus och skepp av skogen. Den planterade skogen beskrivs som ett minnesmärke "inför kommande släkten". Istället för kal och naken höjd kommer framtida generationer kunna erbjudas "en stolt skog". ${ }^{297}$ Motiveringen till att rädda skogen utgår från människans behov av skogen och inte att naturen i sig har ett värde. Berättelsen om barnen som planterar skog går också att koppla till en pedagogisk tanke. När skogen "upptäcktes" som viktig råvara kring förra sekelskiftet, blev den en viktig del av den svenska moderniseringsprocessen. Förutom att lagstiftningen reformerades, växte det successivt fram en folklig upplysning om skogsvård. Under slutet av 1800-talet rådde dock, på grund av vanvård, en kris för de svenska skogarna och 1903 beslutade riksdagen att inrätta en skogsvårdslag. Några år senare mobiliserades folkskolebarnen i ett gigantiskt projekt som innefattade skolan, skogsägare och nationen Sverige. Barnen skulle lära sig plantera gran och tall samt så fröer på skogsytor som avverkats eller saknade skog. Dessa planteringsdagar fanns inskrivna i folkskolestadgan fram till och med $1954 .{ }^{298} \mathrm{Av}$ snittet om de planterande barnen andas positiv framtidstro och förmedlar ett budskap om att "det du sår i dag får du skörda i morgon". Det är framför allt barnen som företräder hoppet om en ljus framtid.

\section{Framtidssynen i Nils Holgersson}

Som tidigare nämnts betraktades framstegstron som mer eller mindre helig kring sekelskiftet 1900. Naturtillgångarna skulle kartläggas för att kunna lägga grunden för landets förvandling från ett efterblivet jordbrukssamhälle till ett modernt indu-

\footnotetext{
${ }^{296}$ Ibid., s. 503.

${ }^{297}$ Ibid., S. 505.

${ }^{298}$ M. Sjöberg, Barnen, skogen och skolan: Om skolelevers plantering av skog i Sverige ca 18801960, Stockholm: Kungl. Skogs- och lantbruksakademien, 2011.
} 
strisamhälle. ${ }^{299}$ Den starka tilltron till den tekniska utvecklingen bars upp av inflytelserika grupper i samhället, som exempelvis industriägare, entreprenörer och ingenjörer och det stundade också en gyllene tid för uppfinnarna. ${ }^{300}$ Den höga tilltron till teknisk utveckling var inte enbart något som det övre samhällsskiktet stod för, utan synsättet återfanns hos företrädare för arbetarklassen liksom hos dem som hade andra samhälleliga mål för ögonen. Karl Marx gav exempelvis den moderna kapitalismen äran för att ha skapat en ny inställning till samhällsförändringar. Den sociala samhörigheten människor emellan förändrades när samhällstrukturen övergick från gammal landsbygd till modern stad, vilket han såg som nödvändigt för att människor skulle frigöras från fördomar från det förflutna. ${ }^{301}$ Entusiasmen för teknikens betydelse för industrialiseringen blev också den dominerande ideologin inom de socialdemokratiska partierna och organisationerna som bildades för att representera arbetarklassen i Europa. Samtidigt fanns olika syn inom den marxistiska rörelsen. Anarkister som Mikhail Bakunin och Petr Kropotkin kritiserade exempelvis Marx för att vara alltför positivt inställd till den vetenskapliga och tekniska utveckling som kapitalismen skapade. ${ }^{302}$

Under inflytande av den snabba samhällsprocessen inträdde en sorts civilisationströtthet, framför allt bland samhällets intellektuella skikt. ${ }^{303}$ Exempel på kulturkritiker som hade ett inflytande kring sekelskiftet 1900 var Thomas Carlyle (1795-1881), John Ruskin (1819-1900) och William Morris (1834-1896) i England, men även Wilhelm Heinrich Riehl (1823-1897) i Tyskland. Denna samtidskritik spreds till Sverige och som språkrör agerade författare som August

${ }^{299}$ K. Johannisson, "Det sköna i det vilda: En aspekt på naturen som mänsklig resurs", 1984, s. 69; A. Lundgren, "Geologin och jordens tillgångar. Vetenskap och attityder vid 1800-talets slut" i Paradiset och vildmarken: Studier kring synen på naturen och naturresurserna, T. Frängsmyr (red.), Stockholm: Liber Förlag, 1984, s. 199-200.

${ }^{300}$ T. Frängsmyr, Svensk idéhistoria: Bildning och vetenskap under tusen år. D. 2, 1809-2000, 2000, s. 102.

${ }^{301}$ D. Worster, De ekologiska idéernas historia, 1996, s. 337-338.

${ }^{302}$ M. Hård \& A. Jamison, Hubris and hybrids: A cultural history of technology and science, 2005, s. 64-67.

${ }^{303}$ E. Erlandson-Hammargren, Från alpromantik till hembygdsromantik: Natursynen $i$ Sverige från 1885 till 1915, speglad i Svenska turistföreningens årsskrifter och Nils Holgerssons underbara resa genom Sverige, 2006, s. 182. 
Strindberg, Verner von Heidenstam och Viktor Rydberg. ${ }^{304}$ Med inspiration från bland annat Carlyle uppstod ett slags svärmeri för det folkliga, det förgångna och det provinsiella samt en motvilja till den moderna storstadscivilisationen. Många av nittiotalsförfattarna flyttade dessutom ut på landet; Selma Lagerlöf till Mårbacka, Verner von Heidenstam till Naddö och Övralid, Erik Axel Karlfeldt till Sjugare, Albert Engström till Grisslehamn och Ellen Key till Strand. ${ }^{305}$

Trots alla hyllningar av vad människan kan åstadkomma, löper också nostalgin till det förgångna som en röd tråd genom Nils Holgersson. När gässen passerar Taberg ser gruvarbetarna längtansfullt efter fågelflocken: "Vart ska ni fara? Vart ska ni fara?" Och Nils ropar till svar: "Dit, där varken finns hacka eller hammare." När gruvarbetarna tror att det var deras egen längtan som hade fått gåskacklet att låta som människotal, ropar de upp till gässen: "Låt oss följa med! Låt oss följa med!" Men de får till svar "Inte i år." När sedan gässen och Nils passerar Munksjö pappersbruk stannar arbetarna upp och ställer samma fråga som gruvarbetarna. De får svaret: "Dit, där varken finns maskiner eller ångpannor!" Även pappersarbetarna tror att det är deras längtan som svarar och de ber att få följa med gåsflocken. Vid tändsticksfabriken i Jönköping sker samma sak och en flicka som hänger sig ut genom ett av fönstren får av fåglarna svaret: "Till landet, där det varken behövs ljus eller tändstickor" och flickan ber att få följa med. Till och med barnen på skolgården i Huskvarna undrar om de inte kan få följa med vildgässen när de hör att fåglarna och Nils är på väg: "Dit, där varken finns böcker eller läxor." Men de får inte enbart svaret "inte i år" utan även "men till året!" 306 Trots att samhällsutvecklingen har lett till att människorna på många sätt har fått det bättre, är det ändå något som fattas dem. Det som gruvarbetare, pappersarbetare och skolbarn ger uttryck för kan tolkas som en slags längtan tillbaka till ett forna renodlat jordbrukssamhälle. Den nostalgiska känslan förstärks genom beskrivningarna av landskapet.

\footnotetext{
${ }^{304}$ N. Edling, Det fosterländska hemmet: Egnahemspolitik, småbruk och hemideologi kring sekelskiftet 1900, 1996, s. 103; M. Kylhammar, Maskin och idyll: Teknik och pastorala ideal hos Strindberg och Heidenstam, 1985.

${ }^{305}$ E.N. Tigerstedt, Svensk litteraturhistoria, Stockholm: Natur och Kultur, 1960, s. 457. Se exempelvis M. Stolares avhandling Kultur och natur: Moderniseringskritiska rörelser i Sverige 1900-1920, diss., Göteborgs universitet, Göteborg, 2003.

${ }^{306}$ S. Lagerlöf, Nils Holgerssons underbara resa genom Sverige. Bd 1, 1908, s. 230-234.
} 
Samtidigt som städer och industrier passerar under Nils på gåsryggen, är det i huvudsak jordbruks- och skogsbygd som skildras och böndernas särställning framhävs:

»[...] 'Jo, jag menar det så, kära fru,' sade bonden, 'att allt, vad kungar och klosterfolk och herremän och köpstadsbor bygger och upprättar, det har bara bestånd i ett par år. Men när ni säger mig, att i Östergötland alltid ska finnas bönder, som är ärekära och uthålliga, så vet jag också, att det ska få behålla sin gamla heder. För det är bara de, som går böjda under det eviga arbetet med jorden, som kan hålla det här landet oppe i välstånd och anseende från tid till tid.' ’> ${ }^{307}$

Ett annat exempel finns i avsnittet om "Spådomen" där bonden oroar sig för Östergötlands framtid. Ulvåsa-frun lugnar honom genom att först berätta om att hon ser liv och rörelse i Finspångsskogarna och hur det reses hyttor och smedjor och att hela landskapet blir hedrat för att järnet tillverkas. Sedan berättar hon om Göta kanalbygget: "Jag ser hur människor myllrar och arbetar från Motala till Mem. De gräver en farled tvärsigenom landet, och då kommer Östergötlands lov åter på allas läppar." ${ }^{308}$ När bondens oro kvarstår, säger Ulvåsa-frun att hon ser hur forsarna vid Motala ström "börjar dra hjul" och att hon hör hammare dåna i Motala och vävstolar slamra i Norrköping. Det är inte förrän Ulvåsa-frun berättar att det kommer att finnas högfärdiga och envisa bönder som bonden "ända till världens slut", som han blir nöjd och belåten med hennes svar.

Bönderna står i berättelsen för det stabila och varaktiga, en bild som förstärks genom att begrepp från jordbruket används som metaforer för att beskriva industrialiseringsprocessen. Skogen kallas för "skogsåker", skogsarbetarna är skogens "skördemän" eller "skördefolk", sågverken benämns som "timmerkvarnar" och gruvorna blir "åkrar under jorden". ${ }^{309}$ Genom liknelser och metaforer förvandlas industrialiseringen snarare till vidareutveckling av jordbruket än som en ersättning av densamma.

Framtidssynen i Nils Holgersson förmedlas genom budskapet att tekniken är något som är i ständig utveckling. Den sista meningen i följande citat öppnar

\footnotetext{
${ }^{307}$ Ibid., s. 260.

${ }^{308}$ Ibid., s. 259.

${ }^{309}$ S. Lagerlöf, Nils Holgerssons underbara resa genom Sverige. Bd 2, 1908, s. 522-527, 354.
} 
dessutom för läsaren att själv göra en bedömning av hur han eller hon ser på utvecklingen. Har det blivit bättre eller ej?

Till sist gick läraren åter ut på borggården, och där talade han om människosläktets långa arbete för att skaffa sig verktyg och vapen, kläder och hus, möbler och prydnader. Han sade, att en sådan gammal borg som Vittskövle var en milstolpe på vägen. Där kunde man se hur långt människorna var hunna för trehundrafemtio år sedan och själv bedöma om det sedan dess hade gått framåt eller tillbaka för dem. ${ }^{310}$

Sammantaget är det en framstegstro och positiv framtidssyn som förmedlas i Nils Holgersson. Nils häpnas och hänförs över allt fantastiskt människorna har lyckats åstadkomma och på så vis kan de unga nå insikten att de själva en dag kommer att vara med och påverka landets utveckling. Utvecklingen är nödvändig, trots att den sker på bekostnad av naturen.

\section{Det tvetydiga budskapet}

Sörlin beskriver 1900-talets början som en tid med rådande antropocentrisk optimism, något som var kännetecknande för upplysningshumanismen. Vad människan kunde klara av att uträtta på jorden fanns det inga gränser för. Sörlin kallar det möjligheternas diskurs. Sakta men säkert ersatte moderniteten religionen och samhället förvandlades till en "maskin" som skulle skapa välstånd. Naturen och icke-européer reducerades till natur- och arbetsresurser. ${ }^{311}$ Dissonanserna mot detta synsätt fanns framför allt inom det konstnärliga området och påverkade sällan framstegsoptimismen hos makthavare och vetenskapsmän. Samtidigt ökade under 1900-talets första decennium medvetenheten om resursernas ändlighet. Därför väcktes frågan om hur resurserna skulle utnyttjas för att mänskligheten skulle kunna dra största möjliga nytta av dem även i framtiden. ${ }^{312}$ Som flera av tidigare här nämnda exempel visar är budskapet om teknikens konsekvenser för samhällsutvecklingen inte alltid entydigt i Nils Holgersson. Förutom nostalgiska skrivningar om bönderna och jordbrukssamhället, framträder ett visst mått av ambivalens när

\footnotetext{
${ }^{310}$ S. Lagerlöf, Nils Holgerssons underbara resa genom Sverige. Bd 1, 1908, s. 62.

${ }^{311}$ S. Sörlin, Naturkontraktet: Om naturumgängets idéhistoria, 1991, s. 87-93.

312 A. Lundgren, "Geologin och jordens tillgångar. Vetenskap och attityder vid 1800-talets slut", 1984, s. 199, 236.
} 
teknikens negativa inverkan på naturen lyfts fram. På så vis företräder berättelsen både vad Sörlin kallar "antropocentrisk optimism" "313 och en kritik av hur naturresurserna utnyttjas.

Ett exempel som kan tolkas som explicit kritik handlar om sjön Tisken vid Falu koppargruva där gruvdriftens baksidor betraktas genom korpen Batakis ögon, Bataki som älskar allt som är "hemlighetsfullt":

\begin{abstract}
När det äntligen hade lyckats Bataki att få någorlunda god reda i allt detta, svävade han bort till den hemska stenöknen för att tänka efter varför det inte växte gräs mellan stenblocken, eller också begav han sig ner till Tisken. Denna sjö ansåg han för den underbaraste han någonsin hade råkat på. Hur kunde det komma sig, att den var alldeles utan fisk, och att dess vatten ibland, när det var upprört av storm, blev alldeles rött? Det var så mycket besynnerligare, som en stor gruvbäck, som föll ut i sjön, hade blänkande, klargult vatten. Han undrade på spillrorna efter förstörda byggnader, som låg kvar på stranden, och på det lilla stället Tisksågen, som kunde ligga där omgivet av gröna trädgårdsland och överskuggat av träd mellan den öde stenöknen och den besynnerliga sjön. ${ }^{314}$
\end{abstract}

Det ges ingen förklaring till vad Bataki egentligen ser, utan tolkningen lämnas till läsaren. Samtidigt framställs en korp, som annars brukar vara en symbol för klokhet, som naiv och en smula dum, medan uvar, bofinkar och sparvar får agera "teknikexperter". En möjlig tolkning är att berättelsen är en fabel som beskriver miljökonsekvenserna i Falun. Människan (korpen), är egentligen en klok varelse, men som ändå inte förstår konsekvenserna av gruvdriften, då människan förblindas av de ekonomiska fördelarna (det "vackra").

Effekterna av skogsavverkningen i Medelpad är ett annat exempel på tvetydigt budskap. När Nils ser marken som är "'...] täckt bara av stubbar och avhuggna riskvistar", konstaterar han för sig själv att "[...] detta var en bra ful och fattig plats". Örnen, som hör detta, ropar till honom att det är en "åker" som blev "avmejad förra vintern". ${ }^{315}$ Väl vid sågverket, kommenteras detta med orden: "Här arbetar de så, att de måtte hinna att såga opp all skog i Medelpad [...]". ${ }^{316}$ När det gäller

\footnotetext{
${ }^{313}$ S. Sörlin, Naturkontraktet: Om naturumgängets idéhistoria, 1991, s. 87-93.

${ }^{314}$ S. Lagerlöf, Nils Holgerssons underbara resa genom Sverige. Bd 2, 1908, s. 385-386.

${ }^{315}$ Ibid., s. 522.

${ }^{316}$ Ibid., s. 527.
} 
inställningen till Norrlands skogar som naturresurs är budskapet i Nils Holgersson sålunda tvetydigt.

Trots att tiden kring sekelskiftet 1900 beskrivs som präglad av stark framstegstro fanns samtidigt kritiska röster. Exempelvis ifrågasattes och debatterades Norrlands roll som "framtidslandet". Mot entusiasterna, som såg Norrlands naturresurser som en "skattkammare", stod kritikerna som menade att industrialiseringen ledde till att naturresurserna fördärvades, att skogarna skövlades och att skönhetsvärden gick till spillo när älvar och forsar dämdes upp. De sociala konsekvenserna (proletarisering, sedeslöshet och superi) av trävarubolagens skogsuppköp skapade den debatt som gick under benämningen "Norrlandsfrågan". Denna gav upphov till oro och ledde med tiden till en diskussion om huruvida en lagstiftning mot aktiebolags rätt till markförvärv behövde inrättas eller ej. Det handlade om bondeståndets framtid och om det var jordbruk eller industri som borde vara Norrlands huvudnäring. ${ }^{317}$

Ytterligare ett exempel på kritik av människans framfart återfinns i berättelsens avsnitt om råttorna vid Glimmingehus. Där fastslås att: "När ett djurfolk dör ut, bruka människorna oftast vara skuld till det, men så var inte fallet denna gång." 318 Förutom att människan framställs som skyldig till utrotningen av djur, används ordet "djurfolk" vilket kan tolkas som att det existerar ett släktskap mellan djur och människa.

Förhållandet mellan Nils och rovdjuren är däremot svårare att uttolka. Nils befriar örnen Gorgo och räven Smirre från fångenskapen på Skansen och han hjälper björnarna i Bergslagen att fly undan jägarnas kulor. När det gäller vargen, däremot, finns ingen försoning. De domesticerade djuren och övriga vilda djur gestaltas som genomgående "goda". Likaså framställs den natur som människan omvandlat till en resurs som "god", medan den av människan opåverkade och vilda naturen är hotfull och mörk.

\footnotetext{
${ }^{317}$ G. Sundbärg, Tankar om utvandringsfrågan, Stockholm: P.A. Nordstedts Förlag \& Söner, 1913, s. 82-99; S. Sörlin, Framtidslandet: Debatten om Norrland och naturresurserna under det industriella genombrottet, 1988, s. 157-158.

${ }^{318}$ S. Lagerlöf, Nils Holgerssons underbara resa genom Sverige. Bd 1, 1908, s. 76.
} 


\section{Sammanfattande analys av Nils Holgersson}

Genom att utgå från Mitchams fyra föreställningar om teknik som ett slags raster vid tolkningen av berättelsen ser jag att det är tekniken som process och viljekraft som dominerar tekniklandskapet i Nils Holgersson. ${ }^{319}$ Tekniska processer inom gruv-, järn- och trävaruindustrin och fiskerinäringen skildras relativt noggrant och budskapet är att teknikutveckling är något som skapar välstånd i samhället och socialiserar individen. ${ }^{320}$ De tekniska framstegen är något nödvändigt och naturen får därför underordna sig människans behov, även om människans utnyttjande av naturen bör ske med ett visst mått av hänsyn.

Det tekniklandskap som Nils Holgersson utspelar sig i är ett landskap som genomgår en snabb förändring. Den föråldrade och ineffektiva jordbruksnäringen är på väg att mönstras ut och ersättas av en ny och samtidigt osäker industriell näring. Nya samhällsklasser skapas i och med industrialiseringen, andra försvinner, vilket leder till motsättningar och oro. ${ }^{321}$ Nationalismen är därför en slags ideologisk kraft med målet att förena nation, politik och folk. ${ }^{322}$ Det nationalromantiska budskapet är också något som genomsyrar Nils skildringar av det land han upplever från gåsryggen. Det är ett äventyrsland som tack vare sitt uppfinningsrika och strävsamma folk går mot en ljus framtid. I historien samsas gammalt och nytt. Jordbruk, skogsbruk och industri utvecklas sida vid sida och vävs samman i måleriska och metaforiska beskrivningar. På så vis försöker berättelsen överbrygga spänningen mellan natur, jordbruk och teknikutveckling. Det är framför allt industrierna på landsbygden och i bruksorterna som skildras i berättelsen och inte de större industrierna i städerna.

Berättelsen om Nils Holgersson förmedlar till övervägande del en positiv inställning till industrialiseringen, samtidigt som kritiken mot skogsskövling, sänkning av sjöar och föroreningar av vattendrag är närvarande. Den kritik som

\footnotetext{
319 C. Mitcham, Thinking through technology: The path between engineering and philosophy, 1994, s. 209-246, 247-266.

${ }^{320}$ Ibid., s. 298

${ }^{321}$ E. Erlandson-Hammargren, Från alpromantik till hembygdsromantik: Natursynen i Sverige från 1885 till 1915, speglad i Svenska turistföreningens årsskrifter och Nils Holgerssons underbara resa genom Sverige, 2006, s. 282.

${ }^{322}$ C. Nordlund, "Naturen och det nationella i det tidiga 1900-talets Sverigelitteratur", 2002, s.74.
} 
finns är inte öppet utskriven utan gestaltad på ett sådant sätt att det öppnar för alternativa tolkningar. Människan är den "snillrika" som med hjälp av sin innovationsförmåga kan åstadkomma fantastiska ting. Människans intressen har alltid företräde framför naturens "behov" men människans utnyttjande av naturens resurser måste ske med hänsyn. Följaktligen är det en antropocentrisk natursyn som presenteras i Nils Holgersson, men med vissa naturskyddande inslag. Natursynen i berättelsen kan därför sägas företräda vad Andrew Dobson kallar svag antropcentrism. Han menar att denna benämning behövs eftersom den inrymmer ett brett spektrum av syner på relationen mellan människa och natur. Ett människocentrerat synsätt behöver inte betyda en helt instrumentell syn på naturen. ${ }^{323}$

Teknikutvecklingen skildras till stora delar utifrån djurens och naturens perspektiv, samtidigt som människan genom sin tekniska förmåga intar en hierarkiskt högre position gentemot djuren. När Nils blir en pyssling förvandlas djuren till antropomorfer och Nils och djuren förstår varandra, och eftersom djuren är teknikexperterna kan de lära Nils hur tekniken fungerar. En möjlig tolkning är att människan och tekniken kan leva sida vid sida med djuren. Det mest övertygande sättet att föra fram detta budskap blir då att låta naturen själv göra det. Djuren får agera naturens företrädare och informera Nils om teknikutvecklingens baksidor. I berättelsen är det inte enbart djuren som framställs med mänskliga tankar och känslor utan även naturen som helhet besjälas. Den beskrivs som både människans fiende och bästa vän. Om naturen har skadats av människan kan den återhämta sig med människans hjälp. Naturen framställs här som ett slags väsen som kan vara friskt eller sjukt. De metaforer som används i boken är av två slag: dels de explicita metaforerna som när landet beskrivs som klätt i granrisskjortel, gråstenströja och båtar som långa, smärta fiskar, dels de mer implicita som när naturen skildras som något som har känslor. Metaforer utnyttjas därutöver genom att sågverken benämns som "timmerkvarnar" och gruvorna som "åkrar under jorden". Gamla, och för läsarna sannolikt bekanta begrepp från jordbrukssamhället, varvas med de nya. Genom metaforerna knyts det gamla och nya samman och industrialiseringen gestaltas som en utveckling av jordbruket och inte som en hotfull konkurrent. Samtidigt löper en röd tråd av nostalgi till det förgångna genom berättelsen, som när gruvarbetarna vill följa med gässens färd mot en värld där varken hacka eller

\footnotetext{
${ }^{323}$ A. Dobson, Green political thought, 3. uppl., London: Routledge, 2000, s. 51-61.
} 
hammare finns. Människornas längtan kan tolkas som en önskan tillbaka till en pastoral idyll.

Det framtidsland som presenteras i Nils Holgersson går framför allt att koppla till såväl de fysiska råvarorna för industriellt bruk (järn och skog), som till jorden och jordbruket. I beskrivningen av det effektiva samhället är det bönderna som utgör basen, trots att det är mot ett industrisamhälle utvecklingen går. En möjlig tolkning är att det är till barnen hoppet att styra utvecklingen i positiv riktning står - bara de lär sig att fara varsamt fram och använda sitt förnuft.

Det budskap som berättelsen om Nils Holgersson förmedlar kan sammanfattas med vad Nils konstaterar från örnen Gorgos rygg: ”Det är ett märkvärdigt land, som vi har. Vart jag kommer, alltid finns det något för människor att leva av."

I Nils Holgersson kan tekniken sammantaget beskrivas som att den har en bildande, fostrande och nationalistisk uppgift. På så vis bekräftar mina analyser den tidigare forskningen som visar att teknik i barnlitteratur utnyttjats som didaktiskt redskap för att ingjuta moral i kombination med en känsla för nationen. ${ }^{325}$

Otto Witt var ungefär samtida med Selma Lagerlöf. Hans så kallade tekniska sagor har också vissa nationalromantiska inslag, men till skillnad mot i Nils Holgersson är diskussionen om tekniken och dess baksidor mer explicit närvarande i Witts sagor.

\footnotetext{
${ }^{324}$ S. Lagerlöf, Nils Holgerssons underbara resa genom Sverige. Bd 2, 1908, s. 528.

${ }^{325}$ D. Butts, "Barbara Hofland: The moral tale and the industrial revolution", 2010, s. 8-9; D. Butts, "Imperialists of the air: Flying stories 1900-1950", 2010, s. 110-115; J. McCannon, "Technological and scientific utopia's in Soviet children's literature, 1921-1932”, 2001, s. 153-169; K. Pandora, "The children's republic of science in the Antebellum literature of Samuel Griswold Goodrich and Jacob Abbot”, 2009, s. 75-98.
} 


\section{KAPITEL 4}

\section{Tekniklandskapet i Otto Witts tekniska sagor}

\section{Otto Witt $(1875-1923)^{326}$}

Författaren och tillika ingenjören Otto Witt levde mellan åren 1875 och 1923, och var verksam inom såväl flygplansutveckling som bergverksväsende. ${ }^{327}$ Witt föddes i Falun där hans far arbetade som ingenjör vid koppargruvan. ${ }^{328}$ Han kom att följa i sin fars fotspår och först läste han vid Norrköpings tekniska elementarskola för att sedan studera vidare till ingenjör vid Technische Universität Bergakademie i Freiberg, Tyskland. Han arbetade därefter som gruvingenjör och disponent vid olika verk i Finland och Norge. 1912 återkom Witt till Sverige för att på heltid ägna sig åt sitt skrivande och sin uppfinnarverksamhet. ${ }^{329}$ Förutom skönlitterära böcker publicerade han också ett antal vetenskapliga texter på tyska och norska. ${ }^{330}$

\footnotetext{
${ }^{326}$ Det empiriska material som detta kapitel bygger på har också delvis bildat underlag för ett kapitel i en antologi samt en vetenskaplig artikel. Se C. Axell, "Otto Witts tekniska sagor: Tekniksyn i det tidiga 1900-talets barnlitteratur" i Teknik som kunskapsinnehål i svensk skola 18422010, J. Hallström, M. Hultén \& D. Lövheim (red.), Möklinta: Gidlund, 2013, s. 55-102; C. Axell \& J. Hallström, "Representations of technology in the 'Technical stories' for children of Otto Witt, early $20^{\text {th }}$ century Swedish technology educator", International Journal of Technology and Design Education, vol. 23(4), 2013, s. 817-834.

${ }^{327}$ O. Witt, "Redaktören presenterar sig själv", Hugin, Presentationsnummer, 1 januari 1916, s. 12-13.

${ }^{328}$ A. Nyblom, "Giv åt släktet gosselynne, hoppfull håg och fantasi: Populärförfattaren Otto Witt ville med sina vetenskapliga romaner bereda plats åt fantasin i samtiden”, Tvärsnitt, 24(3), 2002a, s. $14-15$.

${ }^{329}$ O. Witt, "Redaktören presenterar sig själv", 1916; "Otto Witts elektriska bevattning. En nyhet som lofvar stort för trädgården", Svenska Dagbladet, 17 juni 1917; "Otto Witt vill ge oss socker
} 
Trots att Otto Witt var en produktiv författare under 1910-talet, finns inte mycket skrivet om honom och hans författarskap. Om han nämns är det framför allt som föregångsman inom science fiction, såväl i Sverige som internationellt. ${ }^{331}$ Han skrev sin första bok vid 35 års ålder och dog 48 år gammal, men hann under åren 1911-21 inte bara ge ut 85 nummer av sin tidskrift Hugin utan också ett trettiotal böcker, noveller och naturvetenskapliga arbeten. Under pseudonymen Sam King publicerade han dessutom ett antal kärleksberättelser och böcker i deckargenren. ${ }^{332}$ Andreas Nyblom anser att det ofta är en skev bild av författaren Otto Witt som målas upp. Det Nyblom syftar på är de sentida science fiction-kännare som avfärdat honom som litterärt undermålig och oläsbar. Vad som saknas i framställningarna, hävdar Nyblom, är den betydelse Witt spelade i sin samtid genom sitt engagemang för att popularisera vetenskapen och göra den tillgänglig för en större allmänhet. Nyblom ser Witt som en intressant tidsrepresentant eftersom han med sina berättelser ville få fler människor att förstå att de moderna industrierna och uppfinningarna var ett resultat av människans fantasi och tankeverksamhet. Utifrån den insikten ville Witt få människorna att delta i utformandet av det framtida Sverige och att landet på så sätt skulle bli en mer framgångsrik industrination. ${ }^{333}$

De nationalromantiska strömningar som karaktäriserade tiden kring förra sekelskiftet bidrog till tanken om att alla människor i samhället skulle ha samma kunskapsbas, vilket skulle öka sammanhållningen medborgarna emellan. Utifrån den gemensamma kunskapsbasen kunde sedan en mångfald av yrkesspecialiteter som var betydelsefulla för den pågående industrialiseringen grena ut sig. ${ }^{334}$ Som

gratis genom att utnyttja naturens egen sockerfabrikation", Karlshamns Allehanda, 7 augusti 1917.

330 "Dödsfall", Dalpilen, 16 oktober 1923, Kungliga bibliotekets digitaliserade svenska dagstidningar, http://magasin.kb.se/searchinterface/page.jsp?id=kb:132303\&recordNumber=1\&total RecordNumber=3 (läst 2012-08-12).

${ }^{331}$ M. Ashley, Out of this world: Science fiction, but not as you know it, London: British Library, 2011, s. 91.

332 A. Nyblom, Den tekniska sagan. samtidsförankring och framtidsvision i fyra svenska science fiction-romaner 1911-1932, Magisteruppsats, Uppsala universitet, Uppsala, 2001, s. 17.

333 A. Nyblom, "Svart på Witt. En svensk Jules Verne i glömska”, Dast Magazine, nr. 3, 2002b, http://www.dast.nu/artikel/svart-pa-witt-en-svensk-jules-verne-i-glomska (läst 2010-04-05).

${ }^{334}$ S. Liedman, I skuggan av framtiden: modernitetens idéhistoria, Stockholm: Bonnier, 1999, s. 222. 
en följd av detta diskuterades bildningsbegreppet livligt. Det fanns en ambition bland intellektuella att förmedla bildning till alla samhällsgrupper. Ellen Key var en av dem som engagerade sig i frågan och hon gav år 1897 ut en skrift med titeln Bildning. Tidens intresse för folkbildning kom även att utgöra grogrund för ett engagemang för barn och barnlitteratur. Intresset bidrog till att folkbiblioteksrörelsen tog fart och biblioteken fick en betydelsefull roll när det gällde att föra ut kunskap till de breda lagren. ${ }^{335}$ Under en stor del av 1900-talet förknippades bildningsbegreppet i Sverige med i första hand den organiserade folkbildningsrörelsen och olika alternativa utbildningsformer. Gränserna mellan vad som kan kallas bildning, utbildning respektive fostran har dock inte alltid varit så tydliga. Inom exempelvis den medborgerliga bildningen inom arbetarrörelsen knöt man an till den äldre upplysningstraditionen för att skapa kritiskt tänkande och aktiva medborgare, att bilda sig var att bli fri. ${ }^{336}$

I sin tidskrift Hugin. Tidskrift för naturvetande $i$ roande form klargör Otto Witt att kunskaper i och om teknik är något som hör till den medborgerliga bildningen. När han i den första utgåvan berättar om bakgrunden till sina sagor, skriver han att "Redaktören" hade, innan dessa gavs ut, ägnat fyra år åt att sprida denna form av sagor i olika tidningar. Julen 1913 samlade han berättelserna till en barnbok, Sagas julbok. Julen 1914 gav han ut ytterligare en sagosamling, Tekniska sagor för stora och små och våren året därpå Krigets tekniska sagor för stora och små. Den sistnämnda beskriver han som att den "[...] behandlade speciellt krigets vapen och krafter, avfattade neutralt och oblodigt". ${ }^{337}$ Höstterminen 1915 började sedan "Hugins redaktör" att med statsunderstöd hålla föreläsningar runt om i Sverige i "teknisk sagostil för gammal och ung". Witt konstaterar att han fick ett

\footnotetext{
${ }^{335}$ L. Kåreland, Gurli Linders barnbokskritik: Med en inledning om den svenska barnbokskritikens framväxt, 1977, s. 66-69.

${ }^{336}$ A. Burman \& P. Sundgren, "Inledning. Kampen om bildningen" i Bildning: Texter från Esaias Tegnér till Sven-Eric Liedman, A. Burman och P. Sundgren (red.), Göteborg: Daidalos, 2010, s. 11-12; T. Ginner, Den bildade arbetaren: Debatten om teknik, samhälle och bildning inom Arbetarnas bildningsförbund 1945-1970, diss., Linköpings universitet, Linköping, 1988.

${ }^{337}$ O. Witt, "Vad den 'tekniska sagan' är och dess korta historia", Hugin, Presentationsnummer, 1 januari 1916, s. 6.
} 
"ytterst välvilligt mottagande", vilket fick honom att ta ett nytt initiativ: "[D]en senaste fasen av »den tekniska sagans» utveckling - dess eget organ Hugin". 338

Otto Witt försökte väcka Verner von Heidenstams och Ellen Keys intresse för sin tidskrift Hugin, dock utan framgång. ${ }^{339}$ Ellen Keys engagemang i frågan, och hennes utgivning av skriften Bildning (1897), kan sannolikt ha påverkat Witts önskan om kontakt. Key, liksom Witt, kritiserade de sätt på vilket kunskaper förmedlades och båda betonade sagans betydelse för lärande.

\section{Handlingen i de tekniska sagorna}

Två böcker av Otto Witt har valts ut för analys: Tekniska sagor för stora och små (1914), respektive Krigets tekniska sagor för stora och små (1915). ${ }^{340}$ Till skillnad från Witts övriga skönlitterära böcker, vänder sig dessa till en yngre läsekrets. De är dessutom ingen science fiction-litteratur utan snarare en sorts populärvetenskaplig framställning av tidens teknik. I Grundkatalogerna klassificeras den förstnämnda boken som "uM. Teknologi", där u står för att den särskilt lämpar sig för folkskolebiblioteken, det vill säga böcker som riktar sig till barn och unga. ${ }^{341}$ Den andra boken är placerad i kategorin "O. Krigs- och sjöväsen. - Gymnastik och idrott". ${ }^{342}$ Trots att berättelserna är skrivna i sagostil, räknades de sålunda snarare som faktaböcker än som sagoböcker. I presentationsnumret av den första utgåvan

\footnotetext{
${ }^{338}$ Ibid.

${ }^{339}$ O. Witt, personligt brev till Verner von Heidenstam, 1 januari 1916; O. Witt, personligt brev till Verner von Heidenstam, 16 januari 1916, Övralidsarkivet (E005/1984:5) Brevskrivarregistret, Linköpings stiftsbibliotek, Linköping.

${ }^{340}$ I analyser och tolkningar av de båda böckerna förkortar jag den senare bokens titel och benämner den som Krigets tekniska sagor. När jag skriver om "de tekniska sagorna" avser jag båda böckerna.

${ }^{341}$ Katalog över böcker som folk- och skolbibliotek samt riksförbund, som bedriva skolbiblioteksverksamhet kunna erhålla i statsbidrag: på uppdrag av Kungl. Ecklesiastikdepartementet. Grundkatalog 1915-16, Tillägg 3 omfattande arbeten utkomna åren 1919 och 1920, s. 34. Böcker för barn och ungdom, UM. ("W. berättar i sagoform om en del rön från naturvetenskapens och teknikens områden, såsom om ångmaskinen, tändstickorna, världsrymdens oändlighet o.s.v.”).

${ }^{342}$ Ibid., Tillägg 1 till grundkatalogen 1915-16 omfattande arbeten utkomna 1916 och 1917, s. 49. ("Författaren berättar på ett kåserande sätt om det moderna krigets tekniska hjälpmedel. Så skildrar han såväl undervattensbåten, pansarbåten, flygmaskinen, torpeden och kanonen som användning av den trådlösa telegrafien och taggtrådsstängslet.”)
} 
av Hugin år 1916 definierar Otto Witt en teknisk saga som "[...] ett populärt sätt att beskriva de företeelser som dagligen omgiva oss". ${ }^{343}$

Tekniska sagor för stora och små (1914) består av sjutton olika sagor i vilka artefakterna kommer till liv och själva berättar hur de fungerar. I bokens tekniklandskap ingår bland annat det tekniska arbetets värde, elektricitet, färglära, blyertspennan, spiselsvärta, kolbrytning, erosion, diamantbrytning, solens betydelse för "allt", inklusive "den modärna tekniken", de första människorna, människan och elden, tändstickan, bläckpennan ("den gyllene plogen"), järnvägsbron, ångpannan, stenkrossen, hagelkornet, bössan, kaffetillverkningen, te-tillverkningen och hur en termos fungerar. Det är framför allt den teknik som tidens barn mötte i sin vardag som finns beskriven. Den kritik som finns invävd i ett par av sagorna tar upp att det svenska jordbruket ligger långt efter i den tekniska utvecklingen samt vilka ödesdigra konsekvenser det får om den som handhar teknik saknar tillräckliga kunskaper om den. Dessutom finns kritik av jakt och dödandet av djur.

När Krigets tekniska sagor för stora och små (1915) publicerades hade första världskriget brutit ut och berättelsernas tekniklandskap domineras av den militära tekniken. Exempel på sådan är: torpedbåten, undervattensbåten, taggtråden, telefonen, telefonnätet, telegrafen, kameran, aeroplanet, luftskeppet, kompassnålen, den elektriska kanonen, pistolen, geväret, järnvägstunneln, olika slags gevärskulor, granaten, det kemiska krutet, klockan, med mera. Kriget har fått som konsekvens att såväl människans som teknikens sämre sidor har blivit tydliga. Krigets tekniska sagor består även den av sjutton sagor, i vilka djuren intar en större plats än i den första boken. De förvånas och häpnar över människans i mångt och mycket destruktiva teknik. Djuren och naturen utnyttjas dessutom i hög grad som metaforer och för att beskriva hur tekniken fungerar. Något annat som skiljer de båda böckerna åt är att berättelserna i Krigets tekniska sagor tydligt lyfter fram relationen mellan människa, teknik och natur. Därutöver innehåller den senare i högre grad tankar om teknikens baksidor.

I båda böckerna utnyttjas antropomorfism för att beskriva den nya teknik som tidens människor mötte. Antingen är det tekniken (artefakterna) som kommer till liv och förklarar hur den fungerar alternativt hur en viss teknisk process går till, eller så är det (i likhet med Nils Holgersson) djur som berättar.

\footnotetext{
${ }^{343}$ O. Witt, "Vad den 'tekniska sagan' är och dess korta historia", 1916, s. 6.
} 
De tekniska sagorna är inte de första barnböckerna att skildra antropomorfa ting. Hans Christian Andersen (1805-1875) intresserade sig tidigt för teknik och förde in den i sina skönlitterära barnböcker. ${ }^{344}$ Andersen har bland annat skrivit en saga om en flaska och en annan om en stoppnål. I båda sagorna har tingen känslor och kan tala. ${ }^{345}$ Den engelska författarinnan A.L.O.E. (Charlotte Maria Tucker, 18211893) är ett annat tidigt exempel. I berättelsen "En synåls historia" kommer inte bara synålen till liv utan Tucker låter den redogöra för hela den tekniska processen, från järnmalm till färdig synål. ${ }^{346}$ Flera av hennes böcker blev översatta till svenska och de finns upptagna i grundkatalogerna. Den svenske barnboksförfattaren Richard Gustafsson (1840-1918) skrev även han berättelser om tekniska artefakter som är levande. Gustafssons sagor handlar framför allt om sådan teknik som ansågs intressera pojkar - som pråmar och lokomotiv. ${ }^{347}$

\section{Tekniksynen i Otto Witts tekniska sagor}

Tiden Otto Witt verkade i beskrevs av samtiden som präglad av ingenjörsvetenskap och nya tekniska uppfinningar. ${ }^{348}$ Den teknikutveckling som spelade en viktig roll för den industriella samhällsomvandlingen hade dels sin grund i exploateringen av landets naturresurser (vilket behandlades i kapitlet om Nils Holgersson), dels i exporten av svenska innovationer via flera stora ingenjörsföretag. ${ }^{349}$ Förutom

\footnotetext{
${ }^{344}$ B. Westin,"Karlsson som technobody", 2003a, s. 293.

${ }^{345}$ H. C. Andersen, "Stoppenaalen" i Nye eventyr, 2 saml., Kjøbenhavn: Reitzel, 1845; H. C. Andersen, "Flaskehalsen" i Nye Eventyr og Historier I:1 Bd 3, s. 25-33, Arkiv for Dansk Litteratur, 1845, http://adl.dk//adl_pub/vaerker/cv/e_vaerk/e_vaerk.xsql?ff_id=22\&id=9151\&hist= fmF\&nnoc=adl_pu, (läst 2013-09-09).

${ }^{346}$ A. L. O. E., En synåls historia: Berättelse för barn och ungdom, 4. uppl., Stockholm: Evangeliska forsterlandsstiftelsen, 1904.

${ }^{347}$ E. von Zweigbergk, Barnboken i Sverige 1750-1950, 1965, s. 209-211.

${ }^{348}$ H. Björck, Teknikens art och teknikernas grad: Föreställningar om teknik, vetenskap och kultur speglade i debatterna kring en teknisk doktorsgrad 1900-1927, diss., Kungliga Tekniska högskolan, Stockholm, 1992; T. Frängsmyr, Svensk idéhistoria: Bildning och vetenskap under tusen år. D. 2, 1809-2000, 2000, s. 102-103; B. Sundin, Ingenjörsvetenskapens tidevarv: Ingenjörsvetenskapsakademin, Pappersmassekontoret, Metallografiska Institutet och den teknologiska forskningen i början av 1900-talet, diss., Umeå universitet, Umeå, 1981.

${ }^{349}$ B. Berner, "Professional or wage worker? Engineers and economic transformation in Sweden" i Engineering labour: Technical workers in comparative perspective, P. Meiksins \& C. Smith
} 
utbyggnaden av järnvägar och spårvägar skedde också utveckling av andra tekniska system som vattenförsörjning och avlopp, telegraf- och telefonlinjer och Sverige kom tidigt att bli en av världens ledande telefonländer. ${ }^{350}$ Tekniken att maskintillverka papper och förbättringarna av den grafiska processen ledde dessutom till att dagspressen kom att få en växande betydelse för opinionsbildningen. ${ }^{351}$

Elektrifieringen var en viktig faktor för såväl den tekniska som sociala utvecklingen i landet. I Sverige började elektriskt ljus användas för första gången 1876. Runt 1880 började glödlampor användas, men det dröjde mer än 25 år innan de fanns över hela landet. Det elektriska ljuset förändrade på flera sätt industriarbetets villkor. Först och främst bidrog det till bättre arbetsbelysning och ljuset bidrog också till att olyckor kunde undvikas. Som Jan Garnert konstaterar gav det elektriska ljuset tillgång till ljus dygnet runt vilket var en förutsättning för att industrisamhällets teknik skulle kunna utnyttjas till fullo och det bidrog också till att förändra människornas uppfattning om tid. ${ }^{352}$ Den elektriska belysningens större genombrott ägde rum i städer och i större orter under 1910-talet och på drygt tio år växte andelen hushåll som hade elektrisk ström från knappt 30 procent till över 90 procent. Landsbygden tog längre tid att elektrifiera men där skedde en kraftig ökning under 1910-talet. 1920 hade mellan 40 och 50 procent av hushållen utanför tätorterna fått tillgång till elektrisk ström. ${ }^{353}$

I början av det förra seklet blev elektriciteten den dominerande drivkällan inom industrin och senare också inom järnvägsdriften. I hemmen byttes fotogen-

(red.), London \& New York: Verso, 1996, s. 173-174; J. Hult, "Bondeland blir industriland: 1870-1914", 1989a, s. 231-268; L. Magnusson, "Det nya riket: Industrialismens genombrott i Sverige" i Den välsignade tillväxten: Tankelinjer kring ett århundrade av kapitalism, teknik, kultur och vetenskap, P. Elmlund \& K. Glans (red.), Stockholm: Natur och Kultur, 1998, s. 27-40.

${ }^{350} \mathrm{~J}$. Hallström, Constructing a pipe-bound city: A history of water supply, sewerage, and excreta removal in Norrköping and Linköping, Sweden, 1860-1910, diss., Linköpings universitet, Linköping, 2002, s. 301-334; S. Hansson, Den skapande människan: Om människan och tekniken under 5000 ar , Lund: Studentlitteratur, 2002, s. 411-423, 430-433; J. Hult, "Bondeland blir industriland: 1870-1914", 1989a, s. 238-250.

${ }^{351}$ Ibid., s. 252.

352 J. Garnert, Anden i lampan: Etnologiska perspektiv på ljus och mörker, diss., Stockholms universitet, Stockholm: Carlsson, 1993, s. 131-132, 150, 161.

${ }^{353}$ J.-E. Hagberg, Tekniken i kvinnornas händer: Hushållsarbete och hushållsteknik under tjugooch trettiotalen, diss., Linköpings universitet, Malmö: Liber Förlag, 1986, s. 32-33. 
lampan ut mot den elektriska glödlampan. Tillsammans med folkbibliotekens genombrott fick detta som konsekvens att alltfler fick möjlighet att läsa böcker och elektrifieringens betydelse för folkbildningsarbetet har omvittnats av många samtida författare. Trots den allmänna folkskolans införande 1842, hade bristen på fri tid för läsning (under den ljusa tiden arbetade man), ont om läsmaterial och dålig belysning fått som konsekvens att ingen bred och folklig läskultur hade kunnat utvecklas. När det elektriska ljuset sedan slog igenom kring sekelskiftet 1900, väcktes optimismen bland folkbildare att om den elektriska belysningen tändes $i$ varje hem, skulle möjligheten av läsning och upplevelse "den goda boken" öppnas upp för alla. Det elektriska ljuset hade mer betydelse för landsbygden än städerna, eftersom belysningen där till största delen hade bestått av fotogenlampor, medan man i många städer hade gasljus som både gatu- och hembelysning. ${ }^{354}$

"Kamelen och de tusen hästarna" är en fabel i vilken två djur för första gången kommer i kontakt med den för tiden nya tekniken i form av elektricitet, ett möte som får en olycklig utgång. Sagan inleds med att en kamel och en dromedar sammanstrålar i öknen för att diskutera ett rykte de hört om att "[...] någon galning i västerlandet hittat på något knep, modärn teknik” som fått tusen hästar att gå genom ett rör som inte är tjockare än djurens halsar. ${ }^{355}$ Ryktet gör djuren så nyfikna att de bestämmer sig för att leta reda på den "konstiga tråden":

När de kommo närmare, sågo de, att på var stolpe var anbragt ett svart plakat, och på det plakatet hade tecknats en dödskalle av en människa med ett par korslagda ben inunder.

»Egendomlig smak», anmärkte kamelen, ty den visste inte alls, att ett sådant plakat överallt i hela välden betyder: »livsfarligt». Den hade ej reda på, att människan använder det tecknet på starka gifter likaså som på ett kruthus och på elektriska ledningsstolpar, där en högspänd elektrisk ström går fram. ${ }^{356}$

Djuren förstår inte varningsskyltens innebörd och förundrade betraktar de högspänningsledningen. För att förklara fenomenet elektricitet används i sagan en

\footnotetext{
${ }^{354}$ L. Furuland, "Ljus över landet. Elektrifieringen och litteraturen”, 1991, s. 33-62; J. Hult, "Tekniken mitt ibland oss: 1914-1970" i Svensk teknikhistoria, J. Hult (red.), Hedemora: Gidlund, 1989c, s. 288-289.

${ }^{355}$ O. Witt, "Kamelen och de tusen hästarna" i Tekniska sagor för stora och små, Stockholm: Hökerberg, 1914c, s. 13-14.

${ }^{356}$ Ibid., s. 19-20.
} 


\section{Tekniklandskapet i Otto Witts tekniska sagor}

hästhjord som metafor för elektricitet, där djur motsvarar elektronerna. Elektricitetens kapacitet i högspänningsledningen liknas vid 40000 hästar som rusar genom ett rör i en hastighet av 300000 kilometer i sekunden. De båda djuren tycker att det låter för märkvärdigt för att vara sant och i sin iver att ta reda på hur den "modärna tekniken" fungerar, ställer sig kamelen på dromedarens rygg. När kamelens nos nuddar kraftledningen, faller de båda döda till marken.

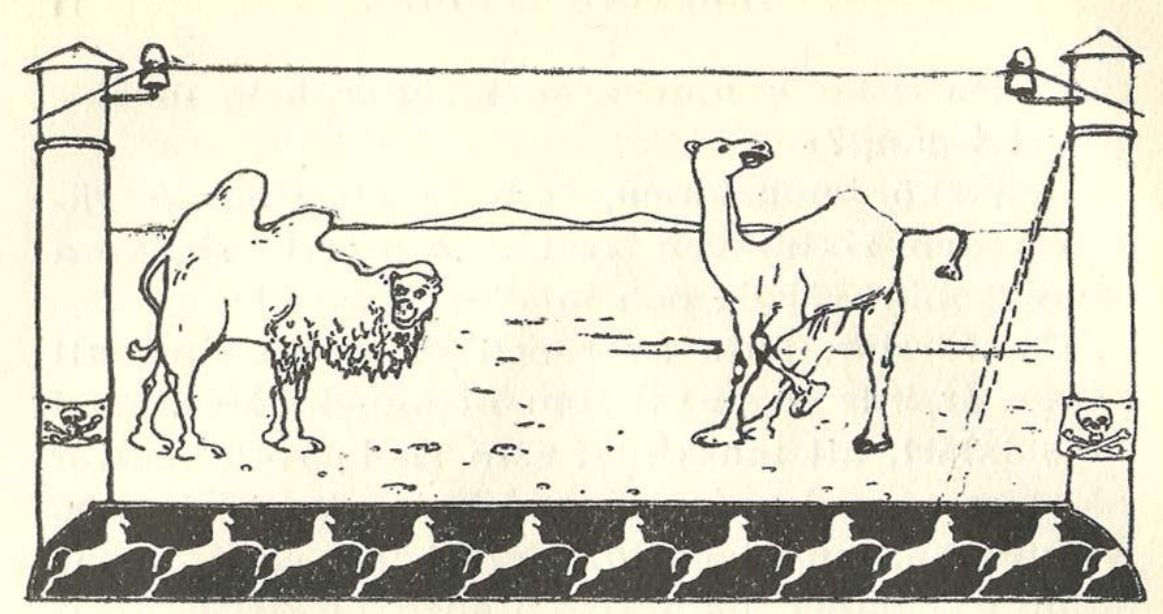

Bild 4.1: Illustration från "Kamelen och de tusen hästarna" (Edwin \& Ingeborg Lindborg, 1914)

Sekelskiftet 1900 blev genombrottet för vattendriven elproduktion. Inledningsvis drevs flertalet elverk av koleldade ångmaskiner och elpriset var mycket högt. Elverk drivna av rinnande vatten från avsides belägna vattenfall utgjorde ett problem, då den lågspända likströmmen inte kunde ledas mer än några kilometer utan stora energiförluster. Men kring sekelskiftet 1900 lanserades växelströmsgeneratorer och transformatorer som gjorde det möjligt att överföra elkraft över långa avstånd. Vid samma tid utvecklades också effektiva turbiner som kunde utvinna mycket mer energi ur vattenfallen jämfört med vattenhjulen. ${ }^{357}$

${ }^{357}$ C. Bernes \& L. J. Lundgren, Bruk och missbruk av naturens resurser: En svensk miljöhistoria, 2009, s. 135. 
Elektrifieringen ledde till en förändring när det gäller människornas teknikförståelse, skriver Garnert. De tidigare utnyttjade energiformerna (exempelvis muskelkraft och ångmaskiner) alstrade energi i nära anslutning till där den skulle användas. De nya elektriska distributionsnäten innebar att kraften nu producerades i kraftverk som låg långt bort från den plats där energin skulle användas. Det visuella sambandet mellan energiproduktion och användningen av energin försvann och därmed, menar Garnert, försvann också en viktig förutsättning för teknikförståelse. ${ }^{358}$

I "Kamelen och de tusen hästarna" beskrivs hur energin som skapas i vattenfallets dynamomaskiner kan ledas till en guldgruva som ligger långt därifrån, det vill säga ett tekniskt system. Samtidigt är elektriciteten farlig och kan döda människor och djur. I sagan skildras mötet med tidens nya teknik. Okunskap om hur den fungerar när den synliga (visuella) förståelsen är frånvarande kan få ödesdigra konsekvenser.

"Det förvånade spindelparet" är en annan saga i vilken djuren häpnas över människans uppfinningar, samtidigt som de förfasas över den mänskliga förstörelselustan och bristen på empati för den egna arten. Herr Spindel kommer hem till sin fru och berättar att han har "otäcka nyheter". Människan har blivit "högfärdsgalen" och börjat spinna nät trots att hon inte har "någon bakdel att tala om". 359 Fru Spindel skrattar och säger att det har människan gjort länge och hon hänvisar till fiskargubbens nät och den "stiliga frökens" hårnät. Herr Spindel menar att det är ett annat slags nät. Han har sett hundratals män slå ned pålar i marken för att sedan dra tråd mellan pålarna, kors och tvärs. Hans fru tycker att det låter ovanligt dumt: "Människan har ju hundratals andra sätt att fånga sin föda - varför behöver hon apa efter just oss." ${ }^{360}$

Herr Spindel berättar vidare att han hört att människan nu flyger omkring i luften buren av brummande "jätteinsekter" som ”[...] väsnas värre än den värsta bålgeting" ${ }^{361}$ Kanske är det för att fånga in dem som människan tagit fram nätet? Fru Spindel finner dock denna förklaring egendomlig. Varför skulle människan ställa i

\footnotetext{
${ }^{358}$ J. Garnert, Anden i lampan: Etnologiska perspektiv på ljus och mörker, 1993, s. 147.

${ }^{359}$ O. Witt, "Det förvånade spindelparet" i Krigets tekniska sagor för stora och små, Stockholm: Hökerberg, 1915b, s. 60.

${ }^{360}$ Ibid., s. 61.

${ }^{361}$ Ibid., s. 62.
} 
ordning nät för att fånga sina egna maskiner? För att utforska vad som sker beger sig de bägge spindlarna till fältet. De upptäcker ett taggtrådsstängsel och eftersom de båda djuren vet att törnesnåret har sina taggar som skydd mot skadliga fiender, förstår de nu vad taggtrådsstängslet är till för:

Ty vad vi lärt oss nu är ohyggligt. Människan är ond. Oändligt mycket ondare än djuren. Hon är icke överdjurisk - nej - hon är underdjurisk. Hon gör en sak, som aldrig vi djur skulle göra - hon lever i osämja inom sitt eget släkte. Människan ställer upp försåt för människan. Inte göra vi spindlar så mot varandra. ${ }^{362}$

Några män dyker upp och tänder en sprängladdning som spränger bort tråden. De båda spindlarna ilade inåt skogen, grubblandes över varför " [...] människan jämt ska förstöra vad hon själv har gjort". ${ }^{363}$

I "Arbetets värde" skildras tekniken utifrån ett ekonomiskt perspektiv och det är den enda av de tekniska sagorna i vilken tekniken inte enbart är skildrad som antropomorf i text, utan finns även avbildad som sådan (se bild 4:2). I övriga illustrationer är tekniken inte skildrad som levande. I berättelsen skryter ett guldur, en pennkniv, en glödlampa, ett leksakståg och ett stycke järnmalm om vem som är mest värdefull. Uret hävdar att eftersom det består av den dyraste metallen, borde det vara det mest värdefulla tinget. Metallen uret består av är dock inte guld, som pennkniven först tror, utan stål. Det "talträngda" uret berättar om hur stålet kommer till. Först existerar det som järnmalm, som med hjälp av dynamiten, bergborrning och uppforsling från gruvan fraktas till masugnen. Där, genom stenkolens och koksens kraft (skapad genom solen), utvinns råjärn, som har "ett värde av 4 à 5 öre per kilogram". ${ }^{364}$ Genom "kemiskt arbete" blir det sedan till stål. Efter att stålet bearbetats med "mekaniskt arbete" kan det bli bra stålpennor, värda hela 20 kronor. Klockan fortsätter berätta:

»Ännu tydligare märker man ändå det tekniska arbetets värde, då man ser, huru detta järn, som i malmen är värt 1 öre per kilogram, först arbetas om till stål och detta stål därefter till de allra finaste klockfjädrar - den lilla 'oron' som är mitt pulserande

\footnotetext{
${ }^{362}$ Ibid., s. 65.

${ }^{363}$ Ibid., s. 66.

${ }^{364}$ O. Witt, "Arbetets värde" i Tekniska sagor för stora och små, Stockholm: Hökerberg, 1914a, s. 6.
} 
hjärta. Ett kilogram sådana urfjärdrar kostar nämligen i det närmaste 10,000 kronor.» ${ }^{365}$

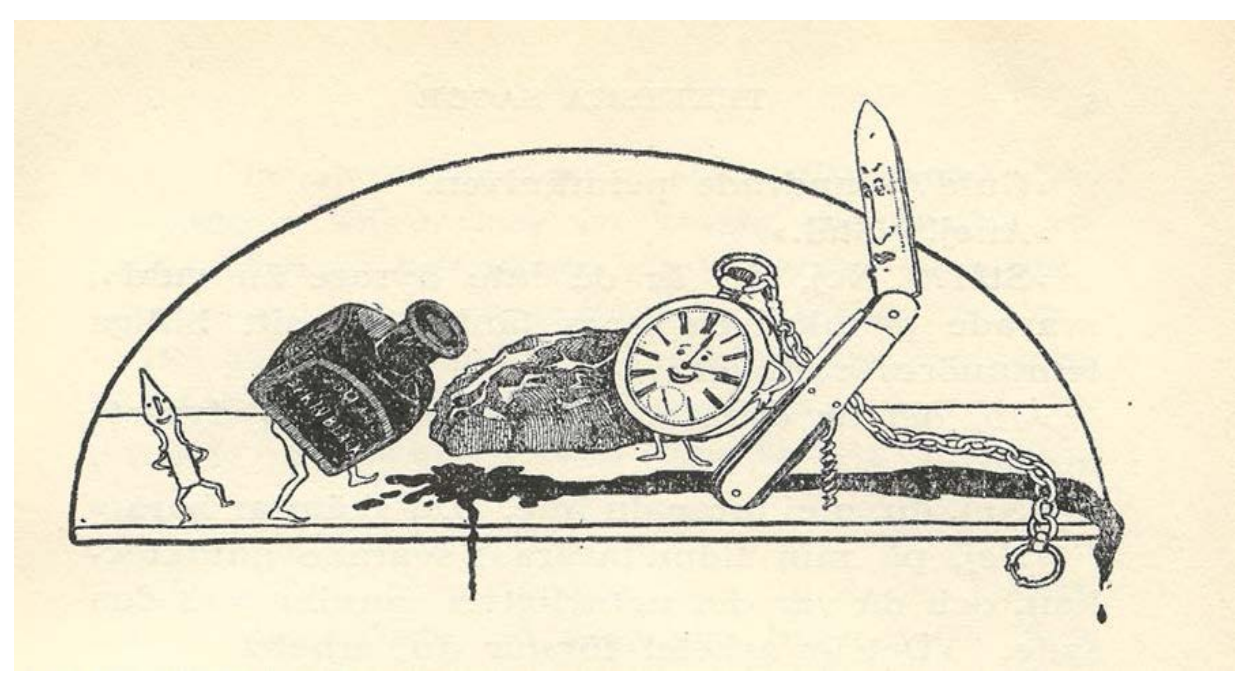

Bild 4.2: Illustration från ”Arbetet och dess värde" (Edwin \& Ingeborg Lundborg, 1914)

Sedan blandar sig andra ting i samtalet: "Alla tycktes de taga detta, om arbetets värde, som en solklar sak." ${ }^{366}$ Glödlampan vill också ha något att skryta över och ber de övriga att titta på hennes koltråd, som dock inte längre är "modärn". Hon berättar att vanligt stenkol bara är värt ett öre, men genom arbetet som förvandlat det till en glödtråd, höjs dess värde väsentligt. ${ }^{367}$

Det som glödlampan hänvisar till är att glödlamporna förbättrades avsevärt några år in på 1900-talet när glödtråden i lamporna började tillverkas av metaller som osmium, volfram och tantal. Glödlampor med metalltråd introducerades i Sverige 1907. Eftersom lampor med metalltråd bara förbrukade en tredjedel elekt-

\footnotetext{
${ }^{365}$ Ibid., s. 7.

${ }^{366}$ Ibid., s. 8.

${ }^{367}$ Ibid.
} 


\section{Tekniklandskapet i Otto Witts tekniska sagor}

ricitet jämfört med koltrådslamporna, blev de inte bara energisnålare utan också både billigare och mer hållbara. ${ }^{368}$

I sagan vänder leksakståget på perspektivet när det hävdar att dess låga pris (10 öre) likväl är ett bevis på arbetets värde:

»Att jag är så billig beror just på arbetets värde. Genom praktiska maskiner och genom uppfinningar, som gjort, att man lyckats spara in så mycket som möjligt på onödigt arbete, kunde man framställa mig så här otroligt billigt. Arbete är en sak, som man måste hushålla med. Det kostar pengar det; och det ger pengar. Därför bör det alltid åtminstone få komma det egna landets arbetare till godo.»» ${ }^{369}$

Konversationen mellan de olika tingen skildrar hur de alla är ett resultat av ett tekniskt arbete - från billig råvara till en betydelsefull artefakt med ett högt värde. Men det är inte enbart det arbete som maskiner utför som har ett värde. Bläcket menar att dess värde skapas genom arbetet när författaren "[...] binder mig till ord och satser, som förläggaren betalar med tusen kronor". ${ }^{370}$

När urets och pennknivens ägare sedan tar en promenad, får de båda tingen höra om det som sker utanför hemmets väggar. I industrialiseringens spår har maskinerna ersatt människor och djur och den samhällsekonomiska betydelsen av ånga, vatten och elektricitet tas upp:

De hörde, huru framstegen inom maskintekniken och elektrontekniken hade givit berg- och hyttverken medel i händerna till att utbyta det gamla arbetssättet med användande av människornas och djurens arbetskraft mot ett nytt arbetssätt, med ånga, vatten och elektricitet och hurusom detta hade medfört ett oanat uppsving. ${ }^{371}$

"Arbetets värde" är en av de tekniska sagorna i vilken Mitchams beskrivning av teknik som viljekraft (volition) får sin gestaltning genom antropomorfa ting. Tekniken är här associerad med olika motiv som strävan, intention och val, som exempelvis viljan att överleva, tillfredsställa behov, viljan att kontrollera, makt,

\footnotetext{
${ }^{368}$ J. Garnert, Anden i lampan: Etnologiska perspektiv på ljus och mörker, 1993, s. 165.

${ }^{369}$ O. Witt, "Arbetets värde", 1914a, s. 9.

${ }^{370}$ Ibid., s. 8 .

${ }^{371}$ Ibid., s. 10 .
} 
eller viljan att skapa effektivitet. ${ }^{372}$ Sagans budskap är att utan tanken och viljan som "kommenderar", liksom hjärnans planering, blir det inget kropps- eller maskinarbete:

»[...] Handens och pennans arbete är ej så stort; men tanken och viljan som kommendera dem har ett oerhört arbete att utföra. Och hur uppstår tanken och viljan hos författaren, tror ni. Genom arbete. Ty av arbete gives det en oändlighet av former, fast många kalla blott kroppsarbetet eller det maskinmässiga arbetet för arbete. De förstå ej, att utan hjärnans grundläggande och planerande arbete gåves det intet kropps- eller maskinarbete alls.») ${ }^{373}$

Krigets tekniska sagor, som publicerades 1915, har ett mer kritiskt budskap om teknik jämfört med den tekniksyn som förmedlas i Tekniska sagor för stora och små. I sagan "De röda soldaterna" skildras vilka följder det får när människan inte utnyttjar sin kreativitet och vilja att skapa teknik. "De röda soldaterna" (rödmyror) plundrar fiender och tar slavar - till och med småbarn: "De röda soldaternas krigskonst och krigslust är i den mest slående grad lika människornas." ${ }^{374}$ De bortrövade småbarnen växer upp och blir duktiga, trofasta slavar, medan de röda soldaterna inte gör något nyttigt arbete alls. Bristen på sysselsättning leder till att de blir slavarnas slavar. De röda soldaternas oförmåga att klara sig själva märks extra tydligt när slavarna blev bortförda av en stark och okänd makt kallad "Människans vilja”. De röda myrorna som blir kvar kan varken bygga hus eller laga sin mat, trots att alla förutsättningar finns runtomkring dem. De vill bara slåss och svälter hellre ihjäl än arbetar. Den som räddar kolonin är den enda slaven som finns kvar:

Denne ende slav utvecklade strax den livligaste verksamhet. Han sprang fram och tillbaka mellan maten och de döende, gav dem rikligt med föda, ägnade den ömmaste omsorg åt småbarnen - och denne ende slav räddade hela kolonien. ${ }^{375}$

I denna historia dras implicita paralleller mellan myror och människor och myrstacken blir en metafor för det pågående världskriget. När människorna (här gestal-

\footnotetext{
372 C. Mitcham, Thinking through technology: The path between engineering and philosophy, 1994, s. 247-266.

${ }^{373}$ O. Witt, "Arbetets värde", 1914a, s. 8.

${ }^{374}$ O. Witt, ”De röda soldaterna" i Krigets tekniska sagor för stora och små, 1915a, s. 172.

${ }^{375}$ Ibid., s. 171.
} 
tade av rödmyror) inte utnyttjar sin förmåga att utveckla och skapa saker, börjar de istället förgöra sig själva. Finns ingen viljekraft, sker inget (tekniskt) skapande. Sagans sensmoral är att om människans tekniska förmåga inte utnyttjas, dör människan ut. En alternativ tolkning är att om det pågående kriget ska få ett slut, är det avhängigt människans vilja. Hoppet står till människans empatiska förmåga och vilja att förändra.

I sin beskrivning av vad han kallar "megamaskinen" gör Mumford en jämförelse mellan myror och människor. Mumford menar att från att människan skapat redskap och vapen för att uppnå makt över naturkrafterna, har utvecklingen övergått i något annat. Megamaskinen är en hierarkisk samhällsorganisation där varje individ förvandlats till en del av en stor helhet, vars mål är att förverkliga stora projekt. Standardexempel på detta är stora arméer, byggandet av pyramiderna och den kinesiska muren. Megamaskinen skapar stora materiella fördelar på bekostnad av en avhumanisering. En stor armé kan erövra territorium och nå utökad makt, men bara om den lyckas upprätthålla en strikt disciplin. ${ }^{376}$ Mumford konstaterar att den främsta icke-mänskliga art som praktiserar krig med organiserade arméer är vissa slags myror. Redan för sextio miljoner år sedan "uppfann" dessa sociala insekter alla de stora institutioner som ingår i den mänskliga civilisationen. Som exempel ger Mumford militär erövring, arbetsdelning, separering av funktioner, indelning i kaster samt domesticering av andra arter. Myrorna har till och med en början till ett slags "jordbruk". Den civiliserade människans främsta bidrag till denna komplexa "myrstack" är, enligt Mumford, kraftfull stimulans av irrationell fantasi. ${ }^{377}$ I sagan om "De röda soldaterna" skildras, i likhet med Mumfords beskrivning av megamaskinen, ett hierarkiskt uppbyggt samhälle i vilket individerna glömt sina grundläggande behov. Följden blir att samhället brakar samman.

I berättelsen "Kriget och dess släktingar" känner huvudkaraktären, pojken Karl Axel, att han vill slippa höra de vuxna tala om den hemska "farsoten" som härjar över jorden. Karl Axel tänker att: "Där ingen tidning fanns och ingen telegraf, där märktes väl heller ingen dyning af kriget." ${ }^{378}$ Istället för att leka med sina tenn-

\footnotetext{
${ }^{376}$ L. Mumford, The myth of the machine. Vol. 1. Technics and human development, New York: Harcourt Brace Jovanovich, 1967, s. 188-194.

${ }^{377}$ Ibid., s. 216.

${ }^{378}$ O. Witt, "Kriget och dess släktingar" i Krigets tekniska sagor för stora och små, Stockholm: Hökerberg, 1915d, s. 7.
} 
soldater, sitt svärd och sin hjälm väljer Karl Axel att vandra långt ut i skogen för att söka efter freden. Plötsligt dånar det till. En väldig jätte, fem våningar hög och iförd stålutrustning, svärd och gevär, kommer klivande genom skogen. Jätten presenterar sig som "Kriget". Karl Axel undrar förvånat om han verkligen finns här ute i skogen. Jätten svarar att, jodå, han finns överallt där Livet finns:

»Se på mig. Jag är det modärna, mänskliga kriget. Jag är teknikens fulländning i vår tid. Jag är kulsprutornas, luftskeppens, den trådlösa telegrafens, undervattensbåtarnas och jättekanonernas krig. Jag är människornas krig.» ${ }^{379}$

En möjlig tolkning av varför jätten presenterar sig som "teknikens fulländning" är att tekniska uppfinningar ofta har en anknytning till det krigstekniska området. I många fall har teknik utvecklats som ett direkt svar på militära behov, för att sedan komma att utnyttjas i civila och fredliga tillämpningar. På samma sätt finns exempel på teknik som först utvecklats för civilt behov men som inte fått någon betydelse förrän man funnit en militär tillämpning för den. ${ }^{380}$ Konservburken, radion, penicillinet, kulsprutor, undervattensbåtar, jättekanoner och telegrafen är alla exempel på teknik som går att koppla till den militära teknikutvecklingen. ${ }^{381}$

Mumford ser första världskriget som en storskalig industriell operation, men konstaterar samtidigt att det omvända perspektivet också stämmer; att industrialismen likväl är en storskalig militär operation. Utvecklandet av olika skjutvapen inverkade på teknikutvecklingen på tre sätt, enligt Mumford: för det första att det uppkom ett ökat behov av järn, för det andra att geväret rent tekniskt sett kan ses som en encylindrig förbränningsmotor och därmed betraktas som en första form av de moderna bensinmotorerna och för det tredje att krigen genom sitt behov av vägbyggen, kanaler, pontoner och broar, skapade ingenjören. Den billigare och mer effektiva produktionen av järn var ett direkt resultat av militär efterfrågan.

\footnotetext{
${ }^{379}$ Ibid., s. 9.

${ }^{380}$ S. Hansson, Teknikhistoria: Om tekniskt kunnande och dess betydelse för individ och samhälle, Lund: Studentlitteratur, 1996, s. 383; J. Hult, "Tekniken mitt ibland oss: 1914-1970", 1989c, s. 269; M. Hård \& A. Jamison, Hubris and hybrids: A cultural history of technology and science", 2005, s. 57.

${ }^{381}$ S. Hansson, Teknikhistoria: Om tekniskt kunnande och dess betydelse för individ och samhälle”, 1996, s. 383; S. Hansson, Den skapande människan: Om människan och tekniken under 5000 år", 2002, s. 441-478; J. Hult, "Bondeland blir industriland: 1870-1914”, 1989a, s. 269; M. Hård \& A. Jamison, Hubris and hybrids: A cultural history of technology and science, 2005, s. 57.
} 
Likaså bidrog behovet av standardiserade militäruniformer till att textilindustrin utvecklades. Exempelvis var den franska armén den första att använda symaskinen när den uppfanns. Mumford ser därför soldaterna i armén som de första riktiga "konsumenterna". Arméer behöver äta, inhysas och utrustas utan att erbjuda någon "service" tillbaka - förutom skydd i krigstider. Den mekaniserade krigföringen bidrog till varje aspekt av standardiserad massproduktion, skriver Mumford. ${ }^{382}$

I skildringen av den stora jätten i "Kriget och dess släktingar" finns likheter med Mary Shelleys Frankenstein, or, The Modern Prometheus (1818). ${ }^{383}$ Liksom i Shelleys berättelse ifrågasätts människans omdöme eftersom dennes hybris leder till skapandet av ett monster som människan sedan förlorar kontrollen över. "Kriget" i den tekniska sagan beskrivs dessutom som teknikens fulländning, vilket för tankarna till Mumfords beskrivning av den moderna krigsapparaten som en megamaskin. ${ }^{384}$

I "Spökfisken" lyfts det inbördes förhållandet mellan människa och teknik fram. När valen och delfinen frågar "stålfisken" (torpedbåten) varför den harpunerar krigsskepp svarar den att den faktiskt aldrig funderat över saken, men att det måste finnas någon mening med det ändå: "Människan gjorde mig sådan som jag

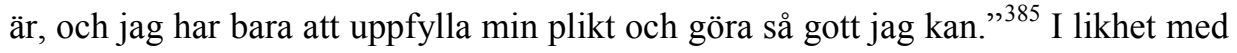
i "Kriget och dess släktingar" är budskapet i "Spökfisken" att det är människan som styr tekniken och inte tvärtom. Tekniken i sig har vare sig makt eller kan beskrivas som "ond". Däremot kan det sätt på vilket människan använder tekniken vara av ondo. Den tekniksyn som förmedlas påminner därmed om Joseph C. Pitts synsätt, det vill säga att eftersom tekniken är ett redskap kan den inte ha någon moral eller innesluta några värderingar. Pitt kritiserar exempelvis de normativa

\footnotetext{
${ }^{382}$ L. Mumford, Technics and civilization, 1934/1963, s. 85-92, 164-165.

${ }^{383}$ M.W. Shelley, Frankenstein, or, The modern Prometheus, Ware: Wordsworh, 1818 /1993; M. Hård \& A. Jamison, Hubris and hybrids: A cultural history of technology and science, s. 60.

${ }^{384}$ L. Mumford, The myth of the machine. Vol. 1, Technics and human development, 1967, s. 188211.

385 O. Witt, ”Spökfisken", Krigets tekniska sagor för stora och små, Stockholm: Hökerberg, 1915h, s. 36.
} 
bedömningar som leder till slutsatser som att tekniken hotar vårt sätt att leva, när det i själva verket är människans tillämpning av den som skapar problem. ${ }^{386}$

Den historiska aspekten är ytterligare något som genomsyrar flera av de tekniska sagorna. I "Jättefåglarna och svalan" beklagar vinden att människan inte värderar det arbete som hennes förfäder utfört:

\begin{abstract}
»Människorna», sade vinden, »människorna vilja gärna frånkänna äldre släkten äran av det arbete dessa uträttat; de undervärdera sina förfäder. Ty tänk, är inte varje uppfinning, som göres, blott högsta stenen, som lägges på en byggnad, som visserligen ej var färdig helt och hållet, men vars grundmur varit länge lagd och vars väggar stått resta $\mathrm{i}$ åratal? Jo, förvisso. Och så är det också med den nya märkliga flygkonsten, som nu, även den, blivit ett modernt vapen i krigets tjänst. [...]». ${ }^{387}$
\end{abstract}

Det budskap som vinden förmedlar är att teknisk utveckling bygger på att ny kunskap läggs till gammal. Lindqvist uttrycker en liknande tekniksyn när han skriver att teknik bygger på att erfarenhet läggs till erfarenhet och att alla försök (såväl lyckade som misslyckade) bidrar till att öka den samlade kunskapen. Ett misslyckande att framställa järn var exempelvis ingen värdelös kunskap, utan kunskapen om varför det gick fel fördes vidare till nästa generation, konstaterar Lindqvist. ${ }^{388}$ Berättelsens illustration föreställande flera tusen år gamla pyramider och tidens nya luftfarkoster, förstärker bilden av att det teknikhistoriska perspektivet är viktigt för förståelsen av tekniken som sådan (se bild 4:3).

\footnotetext{
${ }^{386}$ J.C. Pitt, “'Guns don't kill, people kill'; Values in and/or around technologies”, 2014, s. 89102.

${ }^{387}$ O. Witt, "Jättefåglarna och svalan" i Krigets tekniska sagor för stora och små, Stockholm: Hökerberg, 1915c, s. 107.

${ }^{388}$ S. Lindqvist, "Vad är teknik?", 1987, s. 21.
} 


\section{Tekniklandskapet i Otto Witts tekniska sagor}

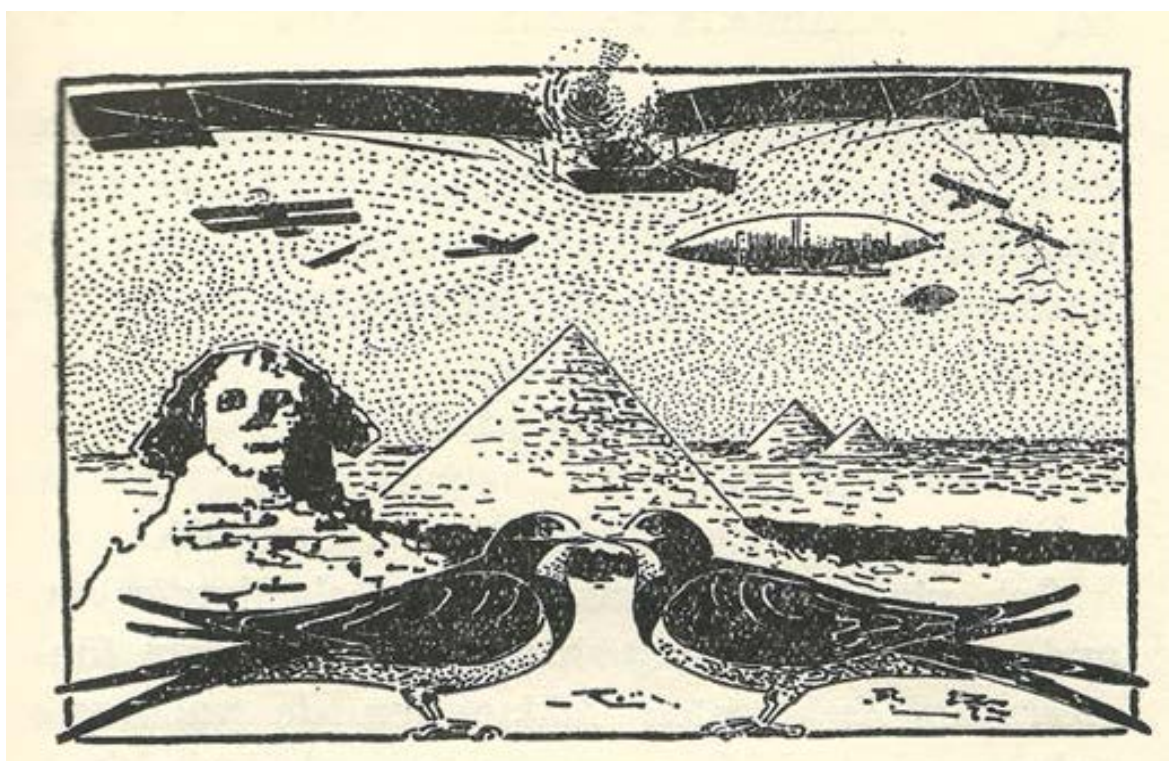

Bild 4.3: Illustration från ”Jättefåglarna och svalan” (Edwin \& Ingeborg Lundborg, 1915)

I sagan om "Tändstickan" berättas historien om människan och elden, från stenålderstid och framåt. Huvudpersonen är den lille vetgirige sexårige pojken Hans som ständigt ställer frågan "varför?" till sin pappa. En dag handlar "varför-frågan" om hur tändstickan fungerar:

»Jo, ser du. Tändstickan är ett stycke trä. På ändan av det lilla trästycket sitter en liten klump av ett ämne, som är lätt antändligt. Den klumpen kallas tändsatsen. Nu vet du att om man gnider två saker hårt mot varandra så blir de varma. När man nu river denna lättantändliga tändsats mot plånet, som är strävt, så blir det varmt utav rivningen. Och när det blir varmt i den lilla klumpen på stickans ända, så tänder den. Och så fort den har tänt sig, så meddelar den sin värme till träet, som då börjar brinna.»» ${ }^{389}$

När tändstickans olika delar meddela sig med varandra, väcks tändstickan till liv, men det är pojkens pappa som berättar om hur den fungerar. I den historiska beskrivningen sätter han människans användning i relation till samhällsutvecklingen

\footnotetext{
389 O. Witt, "Tändstickan" i Tekniska sagor för stora och små, Stockholm: Hökerberg, 1914e, s. 66.
} 
i andra delar av världen: "Och vildarna, det vet du väl, de få ännu i dag sin eld genom att gnida ett par trästycken emot varandra". ${ }^{390}$ Det som framför allt gör intryck på pojken är den spännande historien om "vildarna" och ett par dagar senare leker han "vilde" och försöker göra upp eld genom att gnida ett par byggklossar mot varandra. Pappan skrattar och förklarar för pojken att det inte kommer att fungera. Träet måste vara torrt som fnöske och mycket löst i veden. Pappan förklarar vidare hur man med hjälp av en käpp i hårt trä sedan kan tända upp en eld. Pojken tycker det verkar enkelt, men får då följande svar av sin far: "Ja, de vilda tycka nog det. Men om de kände till våra tändstickor skulle de nog ej säga så."391

Här skildras teknikutveckling som en linjär och evolutionär process. Genom jämförelsen mellan tändstickan och "vildens" teknik att göra upp eld, framhävs den västerländska kulturens tekniska överlägsenhet. En liknande beskrivning finns i sagan om "Kamelen och de tusen hästarna" då kamelens herre shejken Djalumet Sheik träffar en vit europeisk man:

»Detta», sade Djalumet Sheik till den vite mannen och pekade på tidningsnotisen, »detta får min vite broder vara god att förklara för mig. Eder västerländska teknik går framåt med sådana stormsteg, att en stackars österlänning blir rent av yr i huvudet.» ${ }^{392}$

Genom denna positionering av européerna högst upp på civilisationsskalan, förmedlar sagan ett budskap som har likheter med det socialdarwinistiska synsätt som beskrevs i kapitlet om tekniksynen i Nils Holgersson. Dess företrädare (exempelvis Spencer med flera) var av åsikten att det var på européerna det ankom att försvara kulturens framsteg mot "naturens grymhet" samt att "civilisera" andra delar av världen. Bilder föreställande rasande lejon och imperialistiska äventyrare i tropikhjälm med pistol och piska i handen, fungerade som symboler för en försvarskamp för "den goda ordning" som upprättats i Europa. ${ }^{393}$ Kampen skulle spridas "[...] likt telegrafens signaler och järnvägens tämjande manschett över en oregerlig och otacksam värld", skriver Sörlin. ${ }^{394}$ Viktorianerna trodde sig inte ha något att

\footnotetext{
${ }^{390}$ Ibid., s. 67.

${ }^{391}$ Ibid., s. 69.

${ }^{392}$ O. Witt, "Kamelen och de tusen hästarna", 1914c, s. 15.

${ }^{393}$ S. Sörlin, Naturkontraktet: Om naturumgängets idéhistoria, 1991, s. 125-127.

${ }^{394}$ Ibid., s. 127.
} 
lära av "vilden", men däremot ansåg man sig kunna lära "vilden" allt och imperieflaggan hissades över folken på södra halvklotet. Civilisationsidealet var nästan alltid avhängig teknikens och vetenskapens erövring av naturen. Civilisation innebar en slags självständighetsförklaring gentemot naturen. ${ }^{395}$

Utifrån ett genusperspektiv är det enkelt att konstatera att tekniken i de tekniska sagorna är något som hör till de manliga domänerna. Huvudpersonerna, djuren och artefakterna är i huvudsak pojkar eller tillhör det manliga könet. Ett undantag är glödlampan som benämns som "hon". När det gäller representationen av kvinnor är den "vackra och rara" nittonåringen Lisa i "Mistelns spådom” ett exempel. Hon sitter hemma vid julbordet och hoppas på ett frieri från en ung man. Genom mistelkvisten i julljuskronan får hon lära sig om krigsvapnens historiska utveckling - från gudarna i den nordiska mytologins vapen, till moderna mausergevär. Berättelsen slutar med att Lisa somnar och vaknar av en kyss från sin fästman, som meddelar att de kan gifta sig eftersom han lyckats sälja en av sina uppfinningar. Den uppfinning det handlar om är en elektrisk kanon, som kan slunga sina kulor ljudlöst och upp till 5000 meter långt. ${ }^{396}$ Andra exempel på kvinnliga representationer är Fru Spindel i "Det förvånade spindelparet”, en drömgudinna i sagan om "Färglådan", köksan Lisa i "Blyertspennan och spiselsvärtan", mamman i sagan om "Ringen" och hennes döttrar Maja och Doris, fruarna som dricker kaffe i "Brodern från fjärran land" samt några övriga mammor som nämns i förbigående. De få kvinnor och flickor som finns med hyser varken något intresse för, eller har någon kunskap om, teknik utan är birollsinnehavare. Att tekniken i de tekniska sagorna kopplas samman med det manliga könet är inte förvånande eftersom teknikbegreppet vid denna tid knöts till mäns uppfinningar och den industriella och vetenskapliga utvecklingen. Den "kvinnligt kodade" tekniken och de områden där kvinnorna dominerade inrymdes inte och tekniken blev därmed något som hörde männens värld till. ${ }^{397}$ I de tekniska sagorna förstärks detta budskap genom att det ofta är den manliga ingenjören eller uppfinnaren som lyfts fram som hjälte eller föredöme. I slutet av historien om "Tändstickan" säger exempelvis pappan till sin

\footnotetext{
${ }^{395}$ D. Worster, De ekologiska idéernas historia, 1996, s. 131-133.

${ }^{396}$ O. Witt, "Mistelns spådom" i Krigets tekniska sagor för stora och små, Stockholm: Hökerberg, 1915e, s. 46-53.

${ }^{397}$ R. Oldenziel, Making technology masculine: Men, women, and modern machines in America, 1870-1945, Amsterdam: Amsterdam University Press, 1999, s. 19-42.
} 
son: "När du växer upp, lille Hans, så blir du kanske ingenjör." ${ }^{398}$ Ett ytterligare exempel på när ingenjören skildras som en hjälte, dock mer indirekt, finns i "Spökfisken", där torpeden blivit "[...] mäkta styv i matematiken tack vare alla fiffiga ingenjörer" som konstruerat varje detalj i den, vilket refererar till ingenjörer som är män. ${ }^{399}$

I den industriella expansionens spår ökade betoningen på vetenskaplig bildning och teknisk kompetens. Tysklands satsning på forskning inom dessa områden bidrog till att landet blev en stormakt som fungerade som tankeväckande föredöme för andra västländer. USA kom vid sekelskiftet 1900 också alltmer att betraktas som ett industriellt föregångsland. Genom utvecklingen höjdes ingenjörernas status. ${ }^{400}$ Som Boel Berner konstaterar uppstod en dyrkan av teknikens manliga hjältar i många länder i början av 1900-talet. Det restes statyer över uppfinnare och vetenskapsmän och Jules Vernes böcker om tekniska stordåd såldes i miljoner exemplar. Detta bidrog till att alltfler unga män drömde om att bli ingenjörer. ${ }^{401}$

Utvecklingen och utbyggnaden av järnvägarna i början av artonhundratalet krävde hållbara järnvägsbroar. Järn var den naturliga ersättningen av trä som de tidigare broarna var byggda av. De nya järnbroarna var dock oförutsägbara och ett stort antal av dem kollapsade. ${ }^{402}$ I sagan "Den svagaste punkten" blir något så abstrakt som en järnbros "svagaste punkt" levande och ger sig ut i världen för att söka efter sin egen nytta. Järnvägsbron är missnöjd med såväl sig själv som ingenjören samt arbetarna som byggt den och den grubblar över de ord den hört byggnadsingenjören upprepa: "En konstruktion är aldrig starkare, än dess svagaste del." ${ }^{403}$ Orsaken till brons missnöje är att ett tungt lastat tåg fătt den att darra och samtidigt känna något som liknar en människas ryggskott. Ryggskott får här agera

\footnotetext{
${ }^{398}$ O. Witt, "Tändstickan", 1914e, s. 75.

${ }^{399}$ O. Witt, "Spökfisken", 1915h, s. 38.

${ }^{400}$ H. Björck, Teknikens art och teknikernas grad: Föreställningar om teknik, vetenskap och kultur speglade i debatterna kring en teknisk doktorsgrad, 1900-1927”, 1992, s. 26.

${ }^{401}$ B. Berner, Perpetuum mobile? Teknikens utmaningar och historiens gång, Lund: Arkiv, 1999, s. 156-157.

${ }^{402}$ H. Petroski, To engineer is human: The role of failure in successful design, 1. Vintage Books ed., New York: Vintage Books, 1992b, s. 70.

${ }^{403}$ O. Witt, "Den svagaste punkten" i Tekniska sagor för stora och små, Stockholm: Hökerberg, 1914b, s. 93.
} 
metafor för brons svagaste punkt. Det som bron dock inte vet är att det inte finns en endaste maskin i hela världen som inte har en "svag punkt". Den svagaste punkten finns till och med representerad i de gamla gudasagorna genom Akilles respektive Balder. ${ }^{404}$

Järnvägsbron grälar på sin svagaste punkt, men bultar, nitar, stänger och skruvar hånar den också. Den svagaste punkten försöker försvara sig med att det ändå måste finnas någon nytta med den, eftersom den inte enbart kan ha skapats ”[...] till förtret och ingen glädje." ${ }^{405}$ En av de andra brodelarna, den kraftigaste av dem, utmanar den svagaste delen och säger att den får åtta dagar på sig att ge sig ut $\mathrm{i}$ världen för att ta reda på vilken nytta den har. Om den bara lyckas finna en endaste, blir den lovad att fortsättningsvis bli lämnad i fred. Den svagaste punkten besöker underjordens härskare, vattnets, luftens, eldens, djurens och växternas riken, men får inledningsvis höra att den inte är till någon glädje alls. ${ }^{406}$

I berättelsen används liknelser mellan natur och människa och teknik: hos alla tre kan man finna "en svagaste punkt". Flodhästen har sin strax bakom örat och människorna är sega och starka när det gäller många saker, ”[...] men träffar det oss något, direkt riktat mot vår svagaste punkt, följer både sjukdom och död". 407

Den sjunde dagen besöker den svagaste punkten det allra sista riket, människans rike och med henne hela "den modärna tekniken". Där får den höra en ångmaskin och flyger in i ett ångpannerum för att lyssna på ett samtal mellan ångmaskinen och ångpannan. Genom dialogen mellan de båda får den svagaste punkten lära sig hur viktigt det är att människan har kunskap om tekniken. Ångpannan berättar att den varit nära att få "reumatisk feber" på grund av en ny maskinist. Den nye maskinisten är en "ren idiot", förklarar ångpannan, för var morgon tappade han ut det ljumma vattnet och fyllde på nytt som var iskallt, vilket fick som följd att det skar i ångpannans rör.

\footnotetext{
404 Ibid., s. 94.

405 Ibid., s. 95.

${ }^{406}$ Ibid., s. 92-108.

${ }^{407}$ Ibid., s. 93-95.
} 


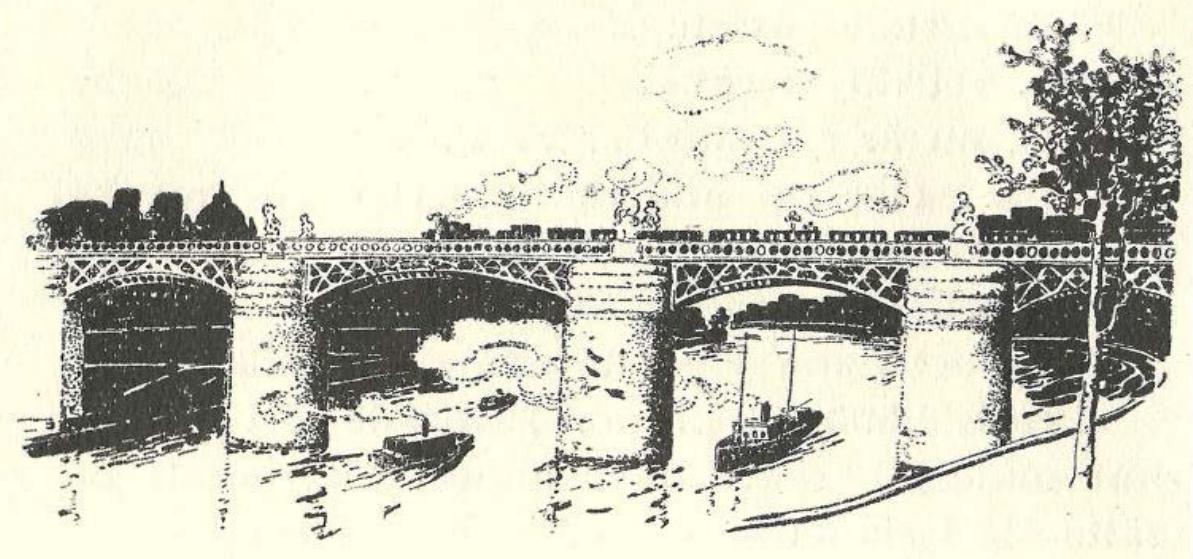

Bild 4.4: Illustration från "Den svagaste punkten" (Edwin \& Ingeborg Lundborg, 1914)

Den svagaste punkten ger sig så småningom till känna och undrar om det kan finnas några "släktingar" i människans rike. Ångpannan berättar att människan faktiskt har nytta av den svagaste punkten när det kommer till "den modärna tekniken". Den svagaste punkten blir naturligtvis glad och önskar höra ett exempel. Ångpannan visar då sin säkerhetsventil där den heta ångan kan strömma ut och den förklarar hur det fungerar. Ångmaskinerna kan vara farliga eftersom de har en svag punkt: de exploderar då hållfastheten inte är anpassad för alltför högt tryck. Därför har de utrustats med en säkerhetsventil.

Den svagaste punkten återvänder hem till bron och kan berätta att alla "modärna säkerhetsanordningar" faktiskt utgörs av de svagaste punkterna. Först blir den utskrattad och får ge de andra brodelarna flera exempel, varav ett är stenkrossen. För att förebygga ett "axelbrott" om en järnbit kommer emellan, har den konstruerats med ett par halvkulor. Vid överansträngning går dessa sönder och därigenom räddas hela maskinen från förstöring, ifall järnstycket skulle fresta på allt för hårt, berättar den svagaste punkten. De övriga brodelarna ger till sist med sig och dess största del konstaterar: 
»Du har vunnit. Hädanefter skall du få vara i fred. Och vad mera är. Du är ju stamfader till en stor och nyttig släkt. Av dina fel har tekniken slutit sig till de fördelar dina anhöriga borde äga.» ${ }^{408}$

Den tekniska utvecklingen skildras i sagan som ett resultat av svaga punkter och misslyckanden. Samtidigt är den svagaste punkten i naturen ofta (men inte alltid) förödande. En möjlig tolkning av berättelsens budskap är att människan har makt över sin teknik medan den svagaste punkten i naturen inte går att kontrollera eller tygla. Däremot är tekniska misslyckanden nödvändiga för teknisk utveckling och framgångsrik design. De brister som uppstår vid byggandet av nya broar bidrar till utveckling av tekniska färdigheter. En sådan syn på teknisk utveckling företräds av bland annat Henry Petroski som skriver:

The collapse of a single bridge made from a relatively new material or design should have been enough to make engineers of that era and their customers, the railroads, reflect on the new technology. ${ }^{409}$

Petroski hävdar vidare att ingen historisk beskrivning av broar är komplett utan ett erkännande av att många ambitiösa konstruktioner misslyckades. Därför kan den tekniska utvecklingen av broar ses som ett positivt resultat från en rad av misslyckanden.

\section{Natursynen i de tekniska sagorna}

I Krigets tekniska sagor är det framför allt djuren som agerar huvudkaraktärer och naturen utnyttjas i stor utsträckning som metaforer för teknik. Det är framför allt djuren i och vid havet som kommer i kontakt med krigets teknik. Människan intar en särställning i förhållande till djuren och djuren framställs som de naivt goda. "Ond" används enbart för att beskriva människan.

Att beskriva den tekniska förmågan att göra upp eld som något som skiljer människan från djuren, går att koppla till den så kallade Prometheusmyten. Prometheus var en titan i den grekiska mytologin och genom att ge människorna elden gjorde han dem överlägsna djuren. Utifrån ett historiskt perspektiv hamnar Prometheusmyten i början av människans erövring av naturen. Kontrollen över

\footnotetext{
${ }^{408}$ Ibid., s. 108.

${ }^{409}$ H. Petroski, To engineer is human: The role of failure in successful design, 1992b, s. 70.
} 
elden påverkade människornas tillredning av födan, den sociala samvaron samt höll rovdjuren på avstånd. ${ }^{410}$ Elden tas även upp i Nils Holgersson men ges ett större utrymme i sagan om "Tändstickan":

Det är allmänt känt, att träd och buskar, djur och allt i naturen fruktar elden som en farlig makt, som en fruktansvärd förhärjare. Det är bara människan, som lyckats besegra elden och göra den till sin nyttiga slav och använda den till allt möjligt. Men fastän människan lyckats göra sig till herre över elden, fruktar människan den och vaktar den noga, att den icke skall slita sig lös och fara fri fram med sin stora och farliga makt. De känna till eldens förfärlighet från skogsbranden, präriebranden och den häftiga blixten. Människorna frukta eldsvådorna men älska elden i den lugna brasan, och de behöva elden i sin tjänst att smälta metaller, att driva ångmaskiner och på tusen sätt utföra arbete. ${ }^{411}$

Elden kan här tolkas som metafor för människans relation till naturen i stort. Människan älskar elden och är i behov av den, samtidigt som den kan vara farlig om den inte hanteras på rätt sätt.

I sagan om "Trollsvanen" berättar en mås för de övriga i måsflocken att han sett en "trollsvan" susa fram på vågorna. Den höll upp huvudet så rakt att det såg ut som om "han" ("trollsvanen") hade fătt ett fiskben i halsen. "Trollsvanens" ögon var fyrkantiga, lyste som fyrar och hade stirrat rakt in i solen. Plötsligt kommer trollsvanen simmande mot fåglarna och de ser att den är alldeles svart. En av måsarna konstaterar föraktfullt att det nog är "[...] ett nytt påhitt av tvåbeningarna med kläder på. En konstgjord valfisk eller sådant". ${ }^{412}$

"Trollsvanens" periskop presenterar sig som undervattensbåtens öga, en sorts skvallerspegel på ett långt rör. Måsen undrar hur människorna i båten kan andas under vattnet. Periskopet skämtar och säger att det beror på att allt sjöfolk andas med gälar, precis som fisken. Då sticker en av båtens matroser upp näsan och konstaterar att det är skönt att få lite frisk sjöluft igen. Den komprimerade luften i reservoarerna är nämligen lite "enformig". Måsen undrar också hur båten kan höja och sänka sig. Den får till svar att det beror på att den har simblåsor precis som fiskarna. Undervattensbåtens tankar har precis samma funktion som fiskens sim-

\footnotetext{
${ }^{410}$ L. Mumford, Technics and civilization, 1934/1963, s. 37.

${ }^{411}$ O. Witt, "Tändstickan”, 1914e, s. 71-72.

${ }^{412}$ O. Witt, "Trollsvanen" i Krigets tekniska sagor för stora och små, Stockholm: Hökerberg, 1915i, s. 138.
} 


\section{Tekniklandskapet i Otto Witts tekniska sagor}

blåsor. ${ }^{413}$ Det är i naturen människan finner inspiration till sitt skapande av ny - ett återkommande budskap i de tekniska sagorna.

Ett ytterligare exempel finns i berättelsen "Pappas snusdosa", i vilken en snusdosa av sköldpaddsskal kommer till liv och blir en sköldpadda. Den berättar för pojken Karl Edvard att: "Människorna, som lärt sig allting annat med djuren som förebilder, lärde sig också efter mig något." ${ }^{414}$ Karl Edvard, som först inte tror på "sköldpaddan", får då veta att människan hämtat inspiration till pansarbåtarna från hur sköldpaddans skyddande skal fungerar. "Jättefåglarna och svalan" tar upp samma tema, då den handlar om hur människan alltid har avundats fågeln som kan flyga, vilket är bakgrunden till flygteknikens utveckling. ${ }^{415}$ Önskan att flyga är en av de äldsta formerna av mänsklig hybris, menar Hård och Jamison och i slutet av 1800-talet var det bara var en fråga om tid innan någon skulle lyckas bevisa att människan visst var ämnad att kunna flyga som en fågel. ${ }^{416}$

Cirka ett decennium innan de tekniska sagorna skrevs (1903) lyckades två amerikanska bröder, Orville och Wilbur Wright, företa den första lyckade flygningen och landningen med en flygmaskin. Åren därefter genomfördes publikdragande flygdemonstrationer i Europas huvudstäder. Den första i Sverige skedde på Gärdet i Stockholm 1909 och då av en fransman. ${ }^{417} 1912$ fattade den svenska riksdagen beslut att bifalla en proposition om att anskaffa en flygmaskin plus medel för att göra övningar med den. Samma år överlämnades en gåva från Svenska Aeronautiska Sällskapet för ett inköp av ännu en flygmaskin. Efter krigsutbrottet 1914 beställdes ytterligare flygplan till armén. De flesta var svensktillverkade. ${ }^{418}$ Men redan 1909 hade det första svenskbyggda flygplanet tillverkats i Landskrona. ${ }^{419}$

\footnotetext{
${ }^{413}$ Ibid., s. 139-141.

${ }^{414}$ O. Witt, "Pappas snusdosa" i Krigets tekniska sagor för stora och små, Stockholm: Hökerberg, 1915f, s. 147.

${ }^{415}$ O. Witt, "Jättefåglarna och svalan", 1915c, s. 107-108.

${ }^{416}$ M. Hård \& A. Jamison, Hubris and hybrids: A cultural history of technology and science, 2005, s. 97.

${ }^{417}$ Tekniska muséet, "Första flygningen", http://www.tekniskamuseet.se/1/462.html (läst 2014-03-10).

${ }^{418}$ J. Hult, "Tekniken mitt ibland oss: 1914-1970", 1989c, s. 306.

${ }^{419}$ J. Hult, "Bondeland blir industriland: 1870-1914", 1989a, s. 244.
} 
Som en följd av flygets utveckling rådde kring sekelskiftet 1900 något som kan beskrivas som flygfeber, vilket bekräftas i Erik Pallins bok Flygande människor från 1909. Pallin finner utvecklingen av flygkonsten som " $[\ldots]$ en av de märkligaste uppfinningar eller upptäckter, som mänskligheten hittills gjort" och han konstaterar att intresset för flygseglingskonsten i Sverige på senare år blivit "synnerligen livligt", särskilt i Stockholm. ${ }^{420}$ I ett kapitel redogör författaren för ett besök hos Wilbur Wright i Le Mans i Frankrike. I sin intervju frågar Pallin Wright om han tror att det snart kommer att göras någon uppfinning som gör att planet kan höja sig direkt från marken, utan skenor eller hjul. Wright svarar bestämt att det tror han inte: "Nej, aldrig. Aeroplanet är ingen fågel. Det höjer sig och svävar endast genom sin fart framåt, och denna fart måste först å ett lutande plan eller på annat sätt bibringas detsamma." ${ }^{421}$ Här gör Wright själv en distinktion mellan fågel och flygplan. Samtidigt kallades han enligt Pallin av fransmännen för 'L'Homme Oiseau" (fågelmannen) och när Wright berättar för Pallin att Förenta staterna är spekulanter på hans flygplansmodell, benämner han flygplanet som "fågeln". ${ }^{422}$

Hård och Jamison menar att bröderna Wright drevs av löftet om lycka och framgång, men de inspirerades även av andra betydelsefulla uppfinningar vid samma tid som det elektriska ljuset, telefonen, rörliga bilder och vagnen som rörde sig utan hästkraft. Genom dessa hade den mänskliga kapaciteten fundamentalt förvandlats och det var en tid då ingenting verkade kunna hålla tillbaka den mänskliga uppfinningsrikedomen. ${ }^{423}$

I Technics and civilization (1934/1963) tar Mumford upp bröderna Wright och hans åsikt är att skälet till att bröderna lyckades där andra hade misslyckats var att de så noga hade observerat naturen:

[T] he final touch, necessary for stable flight, came when two bicycle mechanics, Orville and Wilbur Wright, studied the flight of soaring birds, like the gull and the hawk, and discovered the function of warping the tips of the wings to achieve lateral stability. Further improvements in the design of airplanes have been associated, not

\footnotetext{
${ }^{420}$ E. Pallin, Flygande människor. Populär översikt av luftseglingskonstens utveckling under dess genombrottsår, Stockholm: Bonnier, 1909, s. 1, 7.

${ }^{421}$ Ibid., s. 61.

${ }^{422}$ Ibid., s. 58, 65.

${ }^{423}$ M. Hård \& A. Jamison, Hubris and hybrids: A cultural history of technology and science, 2005, s. 97-98.
} 


\section{Tekniklandskapet i Otto Witts tekniska sagor}

merely with the mechanical perfection of the wings and the motors, but with the study of the flight of other types of bird, like the duck, and the movement of fish in water. $^{424}$

Otto Witt var själv involverad i utvecklingen av flyget och 1913 publicerade han i Smålands Allehanda en längre artikel om flygets historia. ${ }^{425}$ Han konstruerade också en uppfinning som kunde stabilisera flygplan. Detta "geniala patent" ska enligt tidningen Kalmar ha tagits över av ett nybildat aktiebolag. ${ }^{426}$ Olika slags flygfarkoster är därmed ett frekvent inslag i Witts Krigets tekniska sagor. I "Jättefåglarna och svalan" redogörs exempelvis för flygets historia, från 1700-talet och framåt och i samma saga används fåglar som metaforer för flygfarkoster. Berättelsen handlar om en svala som stött på tio av "de väldigaste örnar" men som hade vingar som inte rörde sig. Svalan beskriver dem som "[...] humlor och bin i väl hundrade tusende svärmar". "Fåglarna" är "hemska och elaka" och när de flög över städer och byar släppte de ned ägg med brinnande "ungar" i: "Och när äggen nådde marken, sprang skalet $\mathrm{i}$ tusende bitar med ett väldigt dån, och deras förfärliga eldungar flögo ut och förtärde allt de kommo över." ${ }^{427}$ Svalan har dessutom träffat på "luftdjur" som ser ut som stora cigarrer (luftskepp). ${ }^{428}$ Trots att både aeroplan och luftskepp jämförs med otäcka djur, är sagan samtidigt fylld av noggranna och detaljerade beskrivningar av teknikutvecklingen i luften, där flygtekniken framställs som något fascinerande och spännande:

»Har du sett Watts första ångmaskin avbildad?» undrade den sjungande vinden. »Ja», svarar jag, »visst har jag så.»

\footnotetext{
${ }^{424}$ L. Mumford, Technics and civilization, 1934/1963, s. 251.

${ }^{425}$ O. Witt, ”Apropå Kapten Sundstedts flygningar. Flygkonstens historia”, Smålands Allehanda, 16 maj 1913.

426 "Notis", Kalmar, 13 mars 1912, Kungliga bibliotekets digitaliserade svenska dagstidningar, http://magasin.kb.se/searchinterface/page.jsp?id=kb:169279\&recordNumber=1\&totalRecordNum ber=1 (läst 2012-08-12); "Notis", Kalmar, 3 april 1912. Kungliga bibliotekets digitaliserade svenska dagstidningar, http://magasin.kb.se/searchinterface/page.jsp?id=kb:216899\&recordNumber=2\&totalRecordNum ber=2 (läst 2012-08-12).

${ }^{427}$ O. Witt, "Jättefåglarna och svalan”, 1915c, s. 105.

${ }^{428}$ Ibid.
} 
»Tänk då», fortsätter blåsten tuta, »tänk då vilken väldig skillnad mellan det vidundret och nutidens lätta, kraftiga Gnomemotor i luftseglingens tjänst! Man måste beundra teknikens oerhörda framsteg, det mänskliga snillets snabba gång fram mot väldet över alla naturkrafter. Ty - var den första ångmaskinen ett lejon med en råttas styrka, så är Gnomemaskinen en råtta med ett lejons krafter.»> ${ }^{429}$

Budskapet är att de tekniska framstegen är något att beundra och det finns ingen deterministisk syn på teknikutvecklingen i de tekniska sagorna. Tekniken styr inte människan; det är människan som har makten över såväl teknik som natur. Denna syn på relationen mellan människa, teknik och natur bekräftas i "Kriget och dess släktingar" där Jätten (Kriget) ber pojken att nämna en plats där det råder fred, eftersom han känner att han skulle behöva få en stunds vila. Att "Kriget" just ber pojken om hjälp är för att pojken är människa och därför känner till alla riken: "[D]u är herre över djur-, växt-, och stenriken. Jag är blott en slav hos människan." ${ }^{430}$ Det som jätten säger talar för en antropocentrisk natursyn där människan styr över såväl det levande som det icke levande. Denna natursyn har de tekniska sagorna gemensamt med Nils Holgersson och böckerna företräder på så vis vad Sörlin kallar möjligheternas diskurs, ett synsätt som utgår från att det inte finns några gränser för vad människan kan uträtta på jorden. ${ }^{431}$

De tekniska sagorna förmedlar ett kritiskt förhållningssätt till kriget och dess fasor, men genom parallellerna till naturen framstår människornas krig inte enbart som "ont" utan också som en del av den mänskliga naturen. Liksom vissa episoder i Nils Holgersson skildras företeelser i naturen utifrån ett darwinistiskt perspektiv, det vill säga som en kamp och ett krig där den starkaste segrar. ${ }^{432}$

Tillsammans med jätten besöker Karl Axel i "Kriget och dess släktingar" vad jätten benämner som olika riken på jorden och jätten visar att överallt pågår en kamp på liv och död. I skogen för exempelvis de olika trädslagen ett "vilt utrotningskrig" mot varandra när de starkaste breder ut sig på de klenare arternas be-

\footnotetext{
${ }^{429}$ Ibid., s. 113-114.

${ }^{430}$ O. Witt, "Kriget och dess släktingar", 1915d, s. 9.

${ }^{431}$ S. Sörlin, Naturkontraktet: Om naturumgängets idéhistoria, 1991, s. 87-93.

432 T. Frängsmyr, Framsteg eller förfall: Framtidsbilder och utopier $i$ västerländsk tanketradition, 1990, s. 188; K. Johannisson, "Det sköna i det vilda: En aspekt på naturen som mänsklig resurs", 1984, s. 70-71; D. Worster, De ekologiska idéernas historia, 1996, s. 132-134.
} 


\section{Tekniklandskapet i Otto Witts tekniska sagor}

kostnad. Mellan hav och land förs också ett krig när landet höjer sig och erövrar plats från havet och havet i sin tur gräver grottor i klipphällen. Inte ens Nordpolen eller underjorden undgår krig och kamp. Isbjörnen jagar valrossar och fiskarna jagar varandra, sommarmånaderna slåss med vintern om ljuset. Nere i underjorden förs en kamp mellan vattnet och de eldhärdar, vulkanerna, som finns i jordens inre. När de möts sprängs berget med eld och brak i våldsamma utbrott. Till och med inuti människans kropp förs ett krig mellan baciller och blodkroppar. ${ }^{433}$ I "I den röda tunneln" utnyttjas järnvägstunneln som metafor för en skottskada på en soldat:

Det hemskaste var ingalunda, att den röda tunneln gick fram genom en människas kött, att det där vita var ett ben i samma människokropp eller att borrmaskinen var en gevärskula, ehuru redan detta var hemskt. Det hemskaste var ej heller, att en människa sänt den mot en annan medmänniska, ty skytten hade blott lytt order. Nej, det hemskaste var, att den soldat, som avlossat kulan, gjort sig skyldig till något, som aldrig kan förlåtas, varken i himmelen eller på jorden; han hade förvandlat kulan till en dum-dum-kula. Detta är det största av alla brott kriget för med sig; det är det nesligaste, det råaste och det mest upprörande. ${ }^{434}$

Längre fram i sagan möter kulan en kolerabakterie och den får också uppleva hur "försvaret", de vita blodkropparna, hjälper kroppen att läka och till sist ta död på "kolerabacillen". Beskrivningen av hur människokroppen fungerar som en kamp samt att göra jämförelser mellan människans krig och "kampen" i människokroppen”, går även det att relatera till det darwinistiska och evolutionistiska synsättet. Som socialdarwinist använde exempelvis Spencer liknelser mellan organismer och samhället i sina sociologiska skrifter. Affärsvinster har, enligt Spencer, sin motsvarighet i näringstillförsel och tillväxt i människokroppen och underhuset är samhällets "hjärna" som sänder budskap till sina väljare, "ganglierna", som verkställer besluten. Spencer, som i grunden var ingenjör, benämner också tekniska system som järnvägar och telegraftrådar som "kommunikationernas artärer" och "statens nervsystem". ${ }^{435}$ Kamptemat tas tillika upp i sagan om "Spökfisken". Det

\footnotetext{
${ }^{433}$ O. Witt, "Kriget och dess släktingar", 1915d, s. 9-11.

${ }^{434}$ O. Witt, "I den röda tunneln" i Krigets tekniska sagor för stora och små, 1915g, s. 68-69.

${ }^{435}$ D. Worster, De ekologiska idéernas historia, 1996, s. 168.
} 
som delfinen och valen har svårt att förstå är varför människan förstör sådant som människan själv har skapat:

\begin{abstract}
Människans kamp mot oss djur, det förstår jag. Av mig får man späck och tran, av fiskarna mat och av de fyrfota djuren hudar och kläder - och människans strid mot elementen, mot stormar, kyla och värme, det begriper jag också - men - att först bygga det härliga fartyget och sedan en apparat för att förstöra det med - se det, det övergår alldeles mitt eget förstånd. Ty antingen är jag oerhört inskränkt, som inte begriper det fina i människans handlingssätt, eller också är människan galen. ${ }^{436}$
\end{abstract}

Naturlagen som Charles Darwin introducerar i Om arternas uppkomst (1859) handlar just om kampen för tillvaron. I sin dagbok år 1839 konstaterar han: "It is difficult to believe in the dreadful but quiet war of organic beings going on [in] the peaceful woods \& smiling fields" - det är svårt att förstå att ett tyst och förfärligt krig pågår i fridsamma skogar och bland leende fält. ${ }^{437}$

Något som kan betecknas som motsägelsefullt i de tekniska sagorna är att de trots sin så tydligt uttalade antropocentriska natursyn, samtidigt presenterar något som kan tolkas som en holistisk syn på världen. I "Solens makt" skildras hur allt har sitt ursprung i solen, till och med människans teknik. Kungen i sagan befaller att man ska tända alla ljus som finns. Han beundrar sedan kristallkronorna i slottssalarna, gasblossen på gatorna, det elektriska ljuset från palatsen, fotogenlampor och ljusbitar från de enklare boningarna, automobiler och bicyklar med acetylenlyktor och konstaterar att nu kan inte solen behövas mera. När den gamle trollkarlen Vanha Spa säger att han har fel blir kungen upprörd och bestämmer sig för att undersöka saken. Kungen ger sig av ut i världen och träffar på ett antal av människans tekniska uppfinningar. Det visar sig att trollkarlen har rätt. Stearinljuset talar om att det är solen som drivit fram de plantor och djur som sedan blivit till fettet i stearinljuset, fotogenlampan berättar att det är de djur och växtrester "varav fotogenen danats" som har solen att tacka för sitt forna liv, liksom bensinen och automobilen. Till och med glödlampan kan tacka solen eftersom den dynamo som ger den energi att lysa drivs med vatten och det är solens strålar som gjort att vatt-

\footnotetext{
${ }^{436}$ O. Witt, "Spökfisken", 1915h, s. 33.

${ }^{437}$ C. Darwin, "Notebooks", Notebook E, 114, 12 March 1839, s. 429, http://darwinonline.org.uk/content/frameset?viewtype=text\&itemID=CUL-DAR124.-\&pageseq=1 (läst 2014-04-15).
} 
net blivit till ånga som omvandlas till regn och därefter vattenkraft: "Det är solen, som givit vattnet dess kraft, genom vilken den driver maskinerna, som framkalla elektricitetsströmmar." ${ }^{438}$ Till sist tror sig kungen kunna visa att den gamle trollkarlen har fel. Stjärnorna kan väl ändå inte fått sitt ljus från solen? Trollkarlen svarar: "De äro själva solar, nådig herre."

Solens betydelse var något som vid ungefär samma tid var ett centralt tema för Nobelpristagaren Wilhelm Ostwald (1853-1932). För Ostwald var samhällets energiförsörjning det primära och solen var den viktigaste energikällan. Han menade att alla andra organiska material enbart var derivat av denna yttersta livgivare. Solen hade, enligt Ostwald, inte enbart med energi att göra, utan den hade också en symbolisk roll som förnyare och livgivare - den manliga kraft som skänkte liv åt den kvinnliga jorden. ${ }^{440} \mathrm{I}$ "Kriget och dess släktingar" framträder det holistiska budskapet än tydligare:

Men en långt större varelse än människorna, nationerna, raserna finnes. Det är hela vår jord. Ty vår egen jord är en varelse. Den lever, andas och kläder av och på sig. Den har en själ och ett inre liv. ${ }^{441}$

Det som här kallas för jordens "själ" är den mänskliga kulturen, vilken beskrivs som andlig. Kriget däremot, är jordens "andliga sjukdom".

En holistisk syn på världen går exempelvis att finna hos naturfilosofen Henry David Thoreau (1817-1862), men då utifrån ett biocentriskt perspektiv. Thoreau menar att naturen är en kropp, en organiskt sammanhängande helhet och att den har en ande. I Thoreaus föreställningsvärld finns inte någon död i naturen utan allt lever. Helheten är det primära liksom samspelet mellan naturens olika komponenter - inte komponenterna var för sig. Thoreau var emot skövlingen av naturen och han var övertygad om att alla djur bar en vitalkraft (anima). Människan har därför ingen rätt att tanklöst utnyttja naturen för egen vinning och på andra arters bekostnad, enligt Thoreau. ${ }^{442}$ I en av sina texter från 1851 ger han uttryck för en natursyn

\footnotetext{
${ }^{438}$ O. Witt, "Solens makt" i Tekniska sagor för stora och små, Stockholm: Hökerberg, 1914d, s. 58-59. 
som står i kontrast till en herraväldesattityd, det vill säga den natursyn som de tekniska sagorna (trots sitt holistiska budskap) företräder:

The earth I tread on is not a dead, inert mass. It is a body, has a spirit, is organic, and fluid to the influence of its spirit, and to whatever particle of that spirit is in me. ${ }^{443}$

Budskapet i sagan om "Solens makt" skulle också kunna härledas till Ernst Haeckels (1834-1919) holistiska idéer om att naturen var en sammansatt och balanserad helhet. Andreas Nyblom menar exempelvis att det knappast torde råda någon tvekan om att Witt hade influerats av Haeckel då denne spelade en viktig roll för spridningen av såväl Darwins evolutionsteori, som Haeckels egen version av den, i Norden. ${ }^{444}$ Genom sin så kallade monism menade Haeckel att världen inte gick att dela upp i en andlig - själslig del och en materialistisk, utan allt var av samma stoff. ${ }^{445}$ I "Kriget och dess släktingar" uttrycks, som det tidigare citatet visar, något liknande. Jorden tillskrivs ha en själ och ett inre, andligt liv.

Haeckel avvisade ett antropocentriskt synsätt genom att hävda att djur och människor hade samma moraliska rättigheter eftersom naturen inte går att reducera till ett förråd av resurser för människan. Naturen ska istället agera vägvisare för människorna till ett bättre liv och samhället bör därför organiseras efter naturens principer. ${ }^{46}$ Haeckel jämför det inbördes förhållandet mellan jordens olika organismer med hushållets. I likhet med familjemedlemmarna i ett hushåll, utgör jordens alla organismer en ekonomisk enhet inom vilken medlemmarna lever nära varandra, i ömsesidigt bistånd och konflikter, enligt Haeckel. Genom detta synsätt var det Haeckel som introducerade begreppet ekologi inom naturvetenskapen. ${ }^{447}$

Vid en jämförelse av budskapen i de tekniska sagorna och de idéer som Thoreau respektive Haeckel företräder finns dock en stor skillnad. I de tekniska sagorna placeras människorna $i$ en hierarkiskt högre position jämfört med djuren.

\footnotetext{
${ }^{443}$ The writings of Henry D. Thoreau, "The Journal of Henry David Thoreau", Volume III: Chapter III, vol.9, 1906, http://thoreau.library.ucsb.edu/writings_journals.html (läst 2014-05-05), s. 165.

${ }^{444}$ A. Nyblom, Den tekniska sagan. Samtidsförankring och framtidsvision i fyra svenska science fiction-romaner 1911-1932, 2001, s. 19.

${ }^{445}$ S. Sörlin, Naturkontraktet: Om naturumgängets idéhistoria, 1991, s. 133-134.

${ }^{446}$ Ibid., s. 134-135.

${ }^{447}$ D. Worster, De ekologiska idéernas historia, 1996, s. 148-150.
} 


\section{Tekniklandskapet i Otto Witts tekniska sagor}

Sagorna kan därför inte sägas förmedla ett biocentriskt budskap, det vill säga den natursyn som både Haeckel och Thoreau företrädde.

\section{Framtidssynen i de tekniska sagorna}

Någon explicit framtidssyn i förhållande till de tekniska framstegen, framträder inte i de tekniska sagorna. Däremot kan en pessimistisk syn på utvecklingen skönjas mellan raderna i några av berättelserna i Krigets tekniska sagor. När boken publicerades (1915) pågick första världskriget och utvecklings- och framstegstrons epok hade få̊tt ett abrupt slut. Tekniker och vetenskapsmän använde sina kunskaper i syfte att förstöra och synen på vetenskapen förändrades, vilket också påverkade framstegssynen. ${ }^{448}$

I "Kriget och dess släktingar" får Karl Axel lära sig att där det finns varelser med olika åsikter och intressen, där finns också kriget. Sagan övergår sedan till något som kan liknas vid en domedagsprofetia:

När kulturen börjar luta mot sitt fall - på ett eller annat ställe på jordytan - när familjens bärande styrka föraktas, när hjärtats känslor smädas och endast hjärnan prisas, när religion och Gudsdyrkan dragas i smutsen och hänvisas till att vara barnsligheter - där är jordens själ, den mänskliga kulturen, sjuk. Det är då det stora kriget föddes. Med glödande feberhetta griper det omkring sig i samhällskropparna. ${ }^{449}$

Kriget är en sjukdom som rasar en tid men som sedan kommer att försvinna. När kriget väl är över, kommer det endast vara ett "rent yttre" som har skadats, medan sinnena har "renats" och allt kan återgå till det normala igen: "Kriget är hemskt. Men vilken sjukdom är inte det? Och i synnerhet hos en så väldig organism som jorden, där bacillerna utgöras av sådana jättar som människorna." ${ }^{450}$ I sagan liknas inte kriget enbart vid en sjukdom, utan den metaforiska beskrivningen utvecklas vidare genom att fred kopplas till "frisk" och människa till "bacill". Citatet kan vidare tolkas som att trots att det pågår ett krig, finns hopp om en ljus framtid längre fram. Kriget är en hemsk "sjukdom", som så småningom går över. Samtidigt

\footnotetext{
${ }^{448}$ T. Frängsmyr, Svensk idéhistoria: Bildning och vetenskap under tusen år. D. 2, 1809-2000, 2000, s. 102.

${ }^{449}$ O. Witt, "Kriget och dess släktingar", 1915d, s. 18-19.

${ }^{450}$ Ibid., s. 19.
} 
benämns människor som "baciller", vilket kan te sig en smula tvetydigt. Kan baciller vara något bra? I dag är det vetenskapligt vedertaget att bakterier är nödvändiga, men det är troligtvis inte detta budskap som avses här.

\section{Sammanfattande analys av Otto Witts tekniska sagor}

Det är framför allt fascinationen för den vardagliga tekniken, det vill säga den som människor kommer i kontakt med i sin vardag, som genomsyrar sagorna i Tekniska sagor för stora och små. Budskapet i den andra boken, Krigets tekniska sagor för stora och små, är emellertid mer teknikkritisk och den kritik som framförs handlar om krigets teknik. I denna bok ges dessutom djuren och naturen ett större utrymme jämfört med i den första boken.

I de tekniska sagornas tekniklandskap återfinns Mitchams (1994) alla beskrivningar av teknik: som viljekraft, som kunskap, som aktivitet, liksom tekniken som objekt, men även teknik som system. ${ }^{451}$ Det tekniska arbetets värde är ekvivalent med den tekniska processen (aktivitet). Detta illustreras exempelvis genom att beskriva processen från järnmalm till stålpenna, där järnmalmen utvinns med hjälp av dynamitsprängning och bergborrning, går vidare till smälthyttan och masugnen, genomgår "kemiskt arbete" till stål och till sist blir en stålpenna. ${ }^{452}$ Tekniska kunskaper framhålls som viktiga och budskapet är att det uppstår allvarliga problem om inte människan som ska hantera tekniken har tillräckligt med kunskaper. ${ }^{453} \mathrm{I}$ de tekniska sagorna är tekniken ett resultat av fantasi och kreativitet, det vill säga människans viljekraft. Sin tekniska och kreativa förmåga är något som människan måste få utlopp för. Konsekvenserna kan annars bli ödesdigra, vilket sagan om "De röda soldaterna" skildrar. ${ }^{454}$ Tekniken som delar (komponenter) av ett större

\footnotetext{
${ }^{451}$ T.P. Hughes, "The seamless web: Technology, science, etcetera, etcetera", 1986, s. 281-292; T.P. Hughes, "The evolution of large technological systems", 1987, s. 51-82; T.P. Hughes, "Technological momentum", 1994, s. 101-113; C. Mitcham, Thinking through technology: The path between engineering and philosophy, 1994, s. 160.

${ }^{452}$ O. Witt, "Arbetets värde", 1914a, s. 6-7.

${ }^{453}$ O. Witt, ”Den svagaste punkten”, 1914b, s. 102.

${ }^{454}$ O. Witt, "De röda soldaterna", 1915a, s. 167-172.
} 


\section{Tekniklandskapet i Otto Witts tekniska sagor}

system skildras bland annat genom människans utnyttjande av vattenkraften för att skapa elektricitet. ${ }^{455}$

Metaforer och liknelser från naturen utnyttjas som didaktisk metod. Tekniken kommer dessutom själv ofta till liv, blir en antropomorf, som berättar hur den eller annan teknik fungerar. Däremot är det endast en av böckernas illustrationer som avbildat tekniken som antropomorf (se bild 4:2). I sagorna är det inte enbart artefakterna som skildras som levande och med mänskliga egenskaper, utan även abstrakta tekniska fenomen som "den svagaste punkten". ${ }^{456}$ När tekniken kommer till liv och får mänskliga känslor, knyts människa och teknik samman. Tekniken fungerar som människans förlängda arm och det är människan som styr tekniken och inte tvärtom. De tekniska sagorna saknar på så vis ett teknikdeterministiskt synsätt.

Genom liknelser och metaforer förmedlas dessutom ett budskap om att det råder ett "släktskap" mellan människa, teknik och natur. Metaforerna gestaltar tekniken som en moderniserad form av naturen. Exempelvis skildras flygplan som "örnar" som "surrar som bin". ${ }^{457}$ I båda böckerna, men framför alltid i Krigets tekniska sagor, är det djuren som kommer i kontakt med, och förundras (och förfasas) över, människornas teknik, vilket illustrerar den ofrånkomliga krock som sker mellan naturen och människans teknik. Det som djuren framför allt häpnas över är varför människan skapar något som förstör och dödar hennes egen art. En alternativ tolkning är att djuren i själva verket är människor i djurförklädnad som skildrar tidens människor och deras upplevelse av kontakten med tidens nya teknik, det vill säga att sagorna i själva verket är fabler. Ett visst tekniskt fenomen gestaltas ibland som en hybridisering mellan natur och teknik. Distanstorpeden blir en "stålfisk", flygplanen benämns som "jätteinsekter" och taggtrådsstängslet liknas vid ett törnesnår.

Samtidigt som naturen utnyttjas som metafor för att beskriva tekniken, görs en tydlig åtskillnad dem emellan. Det är vetenskapen och människans förmåga till teknik som särskiljer och placerar människan $i$ en hierarkiskt högre position i förhållande till djuren. Dessutom kan en evolutionistisk syn på utvecklingen anas mellan raderna. Människan har genom sin förmåga att utveckla teknik fått herra-

\footnotetext{
${ }^{455}$ O. Witt, "Kamelen och de tusen hästarna", 1914c, s. 12-21.

${ }^{456}$ O. Witt, "Den svagaste punkten", 1914b, s. 92-108.

${ }^{457}$ O. Witt, "Jättefåglarna och svalan”, 1915c, s. 105.
} 
väldet på jorden. Men med detta följer ett ansvar att se till att tekniken används och utvecklas på ett sätt så att den varken är till skada för henne själv eller för naturen. Därför kan de tekniska sagorna tolkas som att de företräder en svag antropocentrisk natursyn. ${ }^{458}$

Framtidssynen framträder inte så tydligt i de tekniska sagorna. De tekniska landvinningarna hyllas, samtidigt som teknikutvecklingen har en baksida. Återgången till ett liv närmare naturen framställs aldrig som ett alternativ till ett modernare och tekniskt avancerat industrisamhälle. Därför är det närmast framtidsbilden av det tekniskt avancerade och effektiva samhället som de tekniska sagorna tecknar, där tilltron på framsteg är stark. ${ }^{459}$ Samtidigt är budskapet om tekniska framsteg tvetydigt. Vid en jämförelse mellan de båda sagoböckerna är tonen bitvis näst intill uppgiven i Krigets tekniska sagor. Genom djurens ögon skildras människans krig som något fasansfullt. Samtidigt presenterar sig jätten, Kriget, som "teknikens fulländning", vilket kan tolkas som ett uttryck för teknikens och vetenskapens dubbla natur; den har två ansikten precis som den romerska guden Janus, ett positivt och ett negativt. ${ }^{460}$

Sammantaget förmedlar de tekniska sagorna en syn som kan betecknas som ett ambivalent förhållningssätt gentemot teknik. $\AA$ ena sidan företräder de (liksom Nils Holgersson) ett slags antropocentrisk optimism när det handlar om teknisk utveckling. ${ }^{461} \AA$ andra sidan skildras teknikutvecklingens baksidor mer explicit jämfört med i Nils Holgersson.

Elsa Beskows sagosamling Sagobok publicerades samma år som Krigets tekniska sagor och fyra år senare kom hennes sagosamling Muntergök ut (1919). I några av sagornas tekniklandskap ingår den för tiden moderna tekniken liksom ett budskap som kan tolkas som kritik mot såväl teknikutveckling som industrialisering. Däremot är kriget helt frånvarande, trots att båda böckerna kom till under

\footnotetext{
$\overline{458}$ A. Dobson, Green political thought, 2000, s. 51-61.

${ }^{459}$ T. Frängsmyr, Framsteg eller förfall: Framtidsbilder och utopier $i$ västerländsk tanketradition, 1990, s. 234-236.

${ }^{460}$ P. Gyberg, "Teknikens janusansikte" i Världens gång - teknikens utveckling: Om samspelet mellan teknik, människa och samhälle, P. Gyberg \& J. Hallström (red.), Lund: Studentlitteratur, 2009, s. 177-187; T.P. Hughes, Human-built world: How to think about technology and culture, 2004, s. 5.

${ }^{461}$ S. Sörlin, Naturkontraktet: Om naturumgängets idéhistoria, 1991, s. 87-92.
} 
pågående världskrig. Samtidigt lyfter Beskows sagor fram en aspekt på teknik som inte finns med i vare sig Nils Holgersson eller de tekniska sagorna: att teknikutveckling kan leda till en mekanisering av människornas liv. 



\section{KAPITEL 5}

\section{Tekniklandskapet i Elsa Beskows sagor}

\section{Elsa Beskow (1874-1953)}

Elsa Beskow föddes den 11 februari 1874 i Stockholm. Vid fyra års ålder började Beskow i sina mostrars skola, en experimentskola i Ellen Keys anda. När hon blev äldre gick hon över till Whitlockska samskolan i Stockholm där Ellen Key arbetade. Skolan var ett forum för reformpedagogik. ${ }^{462}$ När det gäller Beskows inställning till skolundervisning är det därmed sannolikt att Ellen Key var en person som kom att påverka Elsa Beskows syn på pedagogik. Stina Hammar tolkar exempelvis berättelserna om de tre tanterna (Tant Grön, Tant Brun och Tant Gredelin) som en protest i Ellen Keys anda mot "det fördumningsverk som kallas folkskolan". ${ }^{463}$ Liksom Selma Lagerlöf arbetade Elsa Beskow en tid som lärarinna.

Elsa Beskow förknippas ofta med små söta och idylliska berättelser som Puttes äfventyr i blåbärsskogen (1909), Tant Grön, Tant Brun och Tant Gredelin (1918) och $A B C$-resan (1945). Litteraturvetare och litteraturkritiker hävdar dock att bilden av henne som enbart en "rar sagotant" inte gör henne rättvisa. Hitintills har dock Elsa Beskows barnböcker inte varit föremål för någon omfattande forskning, vilket kan te sig en smula förvånande då hon är en av våra mest kända barnboksförfattare. Eva von Zweigbergk konstaterar exempelvis att näst efter Selma Lagerlöf blev Elsa Beskow den internationellt mest kända svenska författaren under 1900-talets första hälft. ${ }^{464}$ Pia Huss menar att den Beskowska släktens ytterst

\footnotetext{
${ }^{462}$ S. Hammar, Solägget: Fantasi och verklighet i Elsa Beskows konst, Stockholm: Bonnier, 2002, s. 178-179; M. Sjögren, Elsa Beskow och hennes värld, Stockholm: Bonnier fakta, 1983, s. 6-8.

${ }^{463}$ S. Hammar, Solägget: Fantasi och verklighet i Elsa Beskows konst, 2002, s. 18.

${ }^{464}$ E. von Zweigbergk, Barnboken i Sverige 1750-1950, 1965, s. 360.
} 
restriktiva hållning förmodligen har bidragit till att forskningen kring Elsa Beskow och hennes författarskap är så begränsad. ${ }^{465}$ Beskows böcker är översatta till fjorton språk och hon anses vara den som introducerade den svenska bilderboken $\mathrm{i}$ utlandet. ${ }^{466}$

Pär Bergmans Studier kring Tant Grön, Tant Brun och Tant Gredelin från 1971 är en av de fåtal studier som undersöker Elsa Beskows författarskap. Bergman tar dels upp litterära aspekter, dels moraliska värderingar och samhällssyn i böckerna om "tanterna". Stina Hammar har bidragit med två biografier om Elsa Beskow. Den första, Elsa Beskow, en biografi, kom ut redan 1958, fem år efter Beskow död. ${ }^{467}$ Hennes andra och mer omfattande biografi, Solägget: Fantasi och verklighet i Elsa Beskows konst, publicerades 2002. ${ }^{468}$ Även Margareta Sjögren har bidragit med en biografi om författarinnans liv: Elsa Beskow och hennes värld som kom ut $1983 .{ }^{469}$ Dessutom finns en tysk forskare, Angelika Nix, som har analyserat Elsa Beskows bildspråk. ${ }^{470}$ Hammars biografi bygger till stor del på de privata brev som släkten Beskow lät henne få tillgång till. Breven vittnar om att Elsa Beskow var djupt engagerad i tidens frågor. Förutom uppväxten hos en familj med reformivrare och nytänkande pedagoger, hade hon såväl direkta som indirekta kontakter med inflytelserika personer som Ellen Key, Viktor Rydberg, August Strindberg, Fridtjuv Berg och Gurli Linder. En bild som sonen Bo Beskow bekräftar när han skriver att hemmets gäster bestod av "[...] pionjärer för samvetsäktenskap, kvinnans likställighet, socialarbetare, fredskämpar, frihetskämpar, vapenvägrare,

${ }^{465}$ P. Huss, "Elsa Beskow - inte bara en snäll sagotant", Dagens Nyheter, 2 januari, 2006, http://www.dn.se/kultur-noje/filmrecensioner/elsa-beskow-inte-bara-en-snall-sagotant/ (läst 201111-11).

${ }^{466}$ Bonnier Carlsen, "Elsa i världen", http://kampanj.bonniercarlsen.se/beskow/elsa_i_varlden.htm (läst 2011-08-13).

${ }^{467}$ S. Hammar, Elsa Beskow: En biografi, Stockholm: Bonnier, 1958.

${ }^{468}$ S. Hammar, Solägget: Fantasi och verklighet i Elsa Beskows konst, 2002.

${ }^{469}$ M. Sjögren, Elsa Beskow och hennes värld, 1983.

${ }^{470}$ A. Nix, Das Kind des Jahrhunderts im Jahrhundert des Kindes: Zur Entstehung der phantastischen Erzählung in der schwedischen Kinderliteratur, Freiburg im Breisgau, Rombach, 2002. 
engelska kväkare och färgade intellektuella". ${ }^{471}$ Elsa Beskows man Natanael var dessutom en engagerad samtidskritiker och debattör. ${ }^{472}$

I kampen mot den så kallade kolportagelitteraturen utsände Folkbildningsförbundet i december 1909 en skrivelse till 45 personer, däribland Elsa Beskow, Fridtjuv Berg, Per Albin Hansson, Karl-Erik Forsslund, ${ }^{473}$ Verner von Heidenstam, Ellen Key, Selma Lagerlöf, Gurli Linder ${ }^{474}$ och Valfrid Palmgren. ${ }^{475}$ Skrivelsen avslutas med en inbjudan till de 45 personerna att jämte undertecknarna bilda en kommitté och ett arbetsutskott. Resultatet blev "Kommittén för främjandet av god och billig nöjesläsning”. 1912 gav kommitténs arbetsutskott ut en bokförteckning med böcker som ansågs motsvara fordringarna på god och billig nöjeslitteratur. ${ }^{476}$ Jag har inte funnit något som talar om hur Elsa Beskow tog emot denna inbjudan, men den visar att hon, tillsammans med Selma Lagerlöf, räknades till en av de mest inflytelserika författarna vid denna tid. Ellen Key uppskattade Elsa Beskows

${ }^{471}$ B. Beskow, Krokodilens middag, Stockholm: Bonnier, 1969, s. 19.

${ }^{472}$ S. Hammar, Solägget: Fantasi och verklighet i Elsa Beskows konst, 2002, s. 450-452.

${ }^{473}$ För mer information om Karl-Erik Forsslund (1872-1941), se exempelvis B. Sundin, ”Ljus och jord! Natur och kultur på Storgården" i Paradiset och vildmarken: Studier kring synen på naturen och naturresurserna, T. Frängsmyr (red.), Stockholm: Liber Förlag, 1984, s. 321-322. Sundin skriver att Forsslund är en tämligen okänd person i dag, men var i början av 1900-talet en av Sveriges mest omtalade kulturpersonligheter. Han var författare, folkbildare och grundare av Brunnsviks folkhögskola. Han kom att spela en viktig roll även inom naturskydds- respektive hembygdsrörelsen. Sundin kallar Forsslund för "Haeckels store svenske apostel”. Fridtjuv Berg (1815-1916) var en känd svensk politiker och skolman.

${ }^{474}$ Gurli Linder (1865-1947) gav 1902 ut boken Våra barns nöjesläsning (Stockholm: Bonnier) och 1916 Våra barns fria läsning (Stockholm: Norstedt). Hon var barnboksanmälare i Dagens Nyheter mellan 1899 och 1935 samt i Biblioteksbladet. Hennes syn på litteraturen för barn gick i Ellen Keys spår. För vidare läsning se exempelvis E. von Zweigbergk, Barnboken i Sverige 17501950, 1965, s. 306-308; L. Kåreland, Gurli Linders barnbokskritik: Med en inledning om den svenska barnbokskritikens framväxt, 1977.

${ }^{475}$ Valfrid Palmgren (1877-1967) var språkvetare och pedagog och engagerade sig i folkbibliotekens utveckling i Sverige. Efter en resa till Amerika 1907 framlade hon sina förslag hur biblioteksväsendet skulle utvecklas. Hon lyckades bland annat genomdriva att svenska bibliotek ska vara öppna för alla. Se exempelvis N. O. Bruce, Svenska folkskolans historia. D. 4. Det svenska folkundervisningsväsendet 1900-1920, 1940, s. 491.

${ }^{476}$ L. Kåreland, Gurli Linders barnbokskritik: Med en inledning om den svenska barnbokskritikens framväxt, s. 142-143. 
barnböcker och Beskows böcker fanns med i den bilaga till Barnets århundrade där förslag på böcker som borde ingå i de ungas bibliotek fanns listade. ${ }^{477}$

I denna studie har en saga ur sagosamlingen Sagobok (1915), två sagor från Muntergök (1919) samt bilderboken Röda bussen och gröna bilen (1952) valts ut för analys. Urvalet motiveras av att det är de av Beskows sagor som explicit innehåller gestaltningar av teknik samt förmedlar budskap om tekniska företeelser.

\section{Tekniksynen i "Herr Klumpedump från Klumpedonien”}

I Barnets århundrade (1900) tar Ellen Key upp hur skolmannen doktor George Kerschensteiners "epokgörande arbete" påverkat omdaningen av folkskolan. ${ }^{478}$ Kerschensteiner förespråkade en undervisning där kunskaper förvärvades genom att barnen var självverksamma. Handens arbete ledde till kunskaper och arbeten av papp, trä och metall rekommenderades. Trots betoningen av att barnen skulle utföra arbete med sina händer, förbisågs inte läsning av böcker, men detta vetande skulle levandegöras av barnen själva så att de inte mekaniskt bara läste. Det fanns därmed ingen motsättning mellan arbetsskola och bokstudier. ${ }^{479}$ I sagan om "Herr Klumpedump från Klumpedonien" (1915) är det just vad barnen skapar med hjälp av sina händer som lyfts fram som betydelsefullt. Dessa artefakter ställs emot industrisamhällets massproducerade föremål.

Sagan handlar om Sixten, Gösta, Lisa, Sven och Tor som har jullov. De sitter runt det stora salsbordet och är sysselsatta med allehanda tekniska aktiviteter som skildras detaljerat. Sixten mekar med en gammal väckarklocka, Gösta löser rebusar och är så upptagen att han "[...] bestämt inte skulle ha hört, om man smällt ett pistolskott i örat på honom". ${ }^{480}$ Lisa gör pappersdockor och Tor tillverkar en "lustig gubbe" av vaxstänger i olika färger. Utifrån formbara material av olika slag och med hjälp av sina händer åstadkommer barnen hela sagovärldar. Sixten plockar inledningsvis isär en klocka för kunna använda kugghjul och fjädrar till en

\footnotetext{
${ }^{477}$ E. Key, Barnets århundrade: Studie. 2, Stockholm: Bonnier, 1900, s. 245.

${ }^{478}$ Ibid., s. 181.

${ }^{479}$ N. O. Bruce, Svenska folkskolans historia. D. 4. Det svenska folkundervisningsväsendet 19001920, 1940, s. 418-420.

${ }^{480}$ E. Beskow, "Herr Klumpedump från Klumpedonien" i Sagobok, 5. uppl., Stockholm: Wahlström \& Wistrand, 1915/1955, s. 76.
} 
motor på sin undervattensbåt, men han överger aktiviteten för ett mer fritt skapande i vax där inga färdiga delar finns. När sedan Tor vill använda vaxet i Sixtens drake till något annat, lovar Sixten honom ett aeroplan dagen därpå, bara han låter draken vara. Tor går med på Sixtens förslag.

Liksom i de tekniska sagorna kommer tingen i "Herr Klumpedump från Klumpedonien" till liv (antropomorfism). När Tor går och lägger sig på kvällen ställer han vaxgubben bredvid sängen och rätt vad det är kommer vaxgubben till liv. Han presenterar sig som "Herr Klumpedump från Klumpedonien" och utanför huset har han en släde som väntar på Tor. Eftersom Sixtens drake redan är i Klumpedonien har Herr Klumpedump kommit till Tor för att be om hjälp. Tor frågar vaxgubben hur han kunnat bli levande och får då svaret: "På ett mycket enkelt sätt [...], när du knådade mig, knådade du in en bit av din egen själ, och du vet ju, att så snart någonting har en själ, så lever det." ${ }^{481}$ När Tor undrar om även tennsoldaterna i leksaksskåpet nu är levande får han till svar:

\begin{abstract}
"Tennsoldaterna!" sa Herr Klumpedump föraktfullt, ”de är ju gjorda med en maskin, minst hundra åt gången! Hur skulle de kunna vara levande? Såna där maskingjorda saker ha aldrig själ. Titta bara på Svens häst och Lisas docka där borta! Se så dumma och stela de ser ut! Tacka vet jag Brunte, som du knådade nyss. Den är det liv i! Hör du inte hur otåligt han stampar utanför?" ${ }^{482}$
\end{abstract}

I sagan följer Tor med i släden som Lisa klippt till i papper. Väl framme i Klumpedonien, som är en grön ö, upptäcker Tor en massa båtar. Det är dock endast en båt som fungerar som den ska - den som han själv tillverkade i somras. Den seglar så fint och Tor gläds åt att han gjort tacklingen så pass omsorgsfullt och att han tagit snöre istället för tråd till skoten. ${ }^{483}$ De andra båtarna i sjön går det sämre för; de går snett och snurrar runt utan att lyda roder eller åror. Tor tror att det måste bero på att de inte prövats ordentligt innan de sjösattes. Han tänker att han måste tala om det för Stina (barnflickan) nästa gång när hon blir irriterad för att de vill provsegla båtarna hemma i badkaret. Tor konstaterar också att det är ångbåtarna och torpedbåtarna som fungerar sämst. De har alla har något "mankemang med

\footnotetext{
${ }^{481}$ Ibid., s. 78.

482 Ibid., s. 79.

483 "Tackling" respektive "skot" är båttermer. Tackling kallades den så kallade "stående riggen" för förr.
} 
maskineriet". ${ }^{484}$ Det Herr Klumpedump ger uttryck för är ett avståndstagande från det maskingjorda, här symboliserat genom de industritillverkade tennsoldaterna. De är inte bara döda ting - de är alla exakta kopior som saknar originalitet. Det som barnen själva skapat med sina händer är däremot levande, det har en själ. På samma sätt är det med båtarna. Till skillnad från Tors båt har ångbåtar och torpedbåtar problem med "maskineriet". Tors båt har inte bara tillverkats utifrån Tors fantasi och med hjälp av hans händer, den är dessutom ett resultat av ett noggrant och systematiskt arbete. Tennsoldaterna, däremot, är själlösa maskiner och liksom torpedbåtarna saknar de känslor. Att det är soldater och torpedbåtar som framställs som något med allvarliga brister, kan tolkas som ett uttryck för en pacifistisk hållning till krig. Tennsoldaterna är massproducerade i en fabrik och är därmed själlösa, precis som kriget.

Som redan nämnts i avsnittet om Nils Holgersson, växte kritiken mot industrialiseringen mot slutet av 1800-talet. Parallellt med samhällsomdaningen utvecklades en oro för mekaniseringen av människors liv. Bland andra agerade författare och konstnärer som språkrör för denna industrikritik. ${ }^{485}$ I kritiken använde man industristäderna som exempel på kulturens och utvecklingens urartning och ett liv närmare naturen framhölls som ideal. ${ }^{486}$ I William Morris utopiska samhälle existerade ingen imperialism, skriver Frängsmyr. Det som tillverkades var bara sådant som alltigenom var ändamålsenligt. Människorna skulle inte längre tvingas tillverka en massa värdelöst skräp utan få tid att känna glädje i arbetet. Tråkigt arbete skulle utföras av maskiner, medan det mer nöjsamma kunde göras för hand. Konsthantverket och det estetiska kunde därmed inta en viktig plats i människors liv. $^{487}$

Såväl Frängsmyr som Hård och Jamison menar dock att Morris på sätt och vis var en "självmotsägelse". Han var en framgångsrik kapitalistisk affärsman men samtidigt en socialistisk politiker, konstnär och konsthanverkare. Morris tog avstånd från både de pessimistiska och de okritiskt positiva inställningarna till tek-

\footnotetext{
${ }^{484}$ E. Beskow, ”Herr Klumpedump från Klumpedonien”, 1915/1955, s. 81.

${ }^{485}$ J. Hult, "Bondeland blir industriland: 1870-1914", 1989a, s. 260; M. Kylhammar, Maskin och idyll: teknik och pastorala ideal hos Strindberg och Heidenstam, 1987, s. 52-53.

${ }^{486}$ Ibid., s. 10.

${ }^{487}$ T. Frängsmyr, Framsteg eller förfall: Framtidsbilder och utopier $i$ västerländsk tanketradition, 1990, s. 151-154.
} 
niken och det industriella samhället. Som konstnär ville han föra in konst och skönhet i vanliga människors liv. Hans utpräglat ambivalenta inställning till teknik och vetenskap var grundad i hans erfarenhet inom inredningsbranschen. Det han särskilt ställde sig kritisk till var industrialiseringens inverkan på konsten. Han menade att den hade blivit vulgariserad och reducerad till fula produkter med låg kvalitet som såldes på den kommersiella marknaden. Han ville istället kombinera det nya och det gamla, det innovativa och det traditionella, liksom det funktionella och det estetiska. Morris kom därför att spela nyckelrollen i utvecklandet av Arts and Crafts Movement, en rörelse bestående av professionella och kreativa nätverk för industridesigners och inredare över hela världen. Denna rörelse nådde också Skandinavien. ${ }^{488} \mathrm{Ett}$ av rörelsens mål var att motverka det "förtingligande" av människan som man ansåg att industrialismen medförde. ${ }^{489}$

John Ruskins texter var en inspirationskälla för Morris och enligt Bosse Sundin kan man tala om något av en Ruskin-renässans i Sverige vid sekelskiftet 1900 då Ruskins texter översattes till svenska. ${ }^{490}$ Han porträtteras exempelvis i tidskriften Ord och Bild som den som med sin "[...] siareblick har för oss upptäckt den ljusa horisont, som han sett skymta bakom fabriksskorstenarnas rök, och har visat den väg vi hafva att gå för att uppnå framtidslandet". ${ }^{491}$ Det var genom Arts and Crafts Movement som tidens förnyelse av arkitektur och konsthantverk utvecklades och vars synsätt bland annat förmedlades via tidskriften The Studio. ${ }^{492}$ Svensk Läraretidning observerade 1898 den svenska utgåvan av Ruskins Hvad vi skola älska och vårda:

Englands främste konstkritiker, på senare tider äfven bekant genom sina försök att uppträda som socialpolitisk reformator till förmån för arbetareklassen, uttalar i detta arbete sina åsikter om smak, den goda såväl som den dåliga, om konsten, om människans andliga uppfostran och förädling genom sin omgifning: himmel, vatten, berg,

\footnotetext{
${ }^{488}$ Ibid., s. 150-157; M. Hård \& A. Jamison, Hubris and hybrids: A cultural history of technology and science, 2005, s. 145-148.

${ }^{489}$ S. Hammar, Solägget: Fantasi och verklighet i Elsa Beskows konst, 2002, s. 348.

${ }^{490}$ B. Sundin, ’Ljus och jord! Natur och kultur på Storgården”, 1984, s. 346.

${ }^{491}$ F. Carlberg, ”Johan Ruskin”, Ord och Bild, 1898, s. 182, http://runeberg.org/ordochbild/1898/ (läst 2011-10-15).

${ }^{492}$ B. Sundin, ”Ljus och jord! Natur och kultur på Storgården”, 1984, s. 346-347.
} 
stenar, blommor och landskapet i allmänhet. Uppfostrans mål anser förf:n i korthet vara att leda människosjälar till det bästa, och bör detta gälla alla klasser. ${ }^{493}$

Den "dåliga konsten" finns i "Herr Klumpedump från Klumpedonien" exemplifierad genom tennsoldaterna, men det finns ytterligare exempel. I Klumpedonien får Tor syn på några pojkar och flickor som tysta dansar omkring på en äng. Att de varken har någon själ eller kan tala beror på att de är fabrikstillverkade pappersdockor. Kor och får som betar på ängen är gran- och tallkottsfår och de kan råma och bräka "som andra kor och får." ${ }^{494}$ Ting av naturliga material från skogen är levande. Husen i Klumpedonien är "trevliga", eftersom de är tillverkade av sand, papp, byggbitar, lera och stenar. Allesammans passar de "[...] så bra ihop med varandra" ${ }^{495}$ Staden med dess hus är ett resultat av barnens eget skapande i material från naturen, ett hantverk, vilket gör den unik och vacker till skillnad mot det perfekta och exakta.

När "Riddare Tor" i sagan kommer fram till slottet, hälsas han välkommen av kungen. Han följer med kungen till en stor sal. Där han får träffa prinsessan Kunigunda. ${ }^{496}$ Hon har dock inte tid att hälsa eftersom hon inte hunnit " $[. .$.$] prova mer$ än fem nya dräkter i dag" ${ }^{497}$ Prinsessan har så fullt upp med sina materiella ting, att hon väljer bort samvaron med de människor som omger henne. Plötsligt dyker draken upp. Han tar prinsessan och flyger bort till en borg på ett högt berg. Prinsessan är ett offer för tidens materiella överdåd och eftersom hon inte är på sin vakt, blir hon tagen av draken.

Tor funderar snart ut hur han ska döda draken. Han har lagt märke till att när Sixten gjorde draken satte han fast drakens huvud rätt så slarvigt. Om Tor bara kan rikta sitt svärd just på den svaga punkten, kommer han kunna hugga huvudet av

\footnotetext{
493 "Vad vi skola älska och vårda", Svensk Läraretidning, nr. 4, 1898, s. 670, http://runeberg.org/svlartid/1898/0674.html (läst 2011-08-14).

${ }^{494}$ E. Beskow, "Herr Klumpedump från Klumpedonien”, 1915/1955, s. 85.

${ }^{495}$ Ibid., s. 86.

${ }^{496}$ Namnet "Kunigunda" är detsamma som prinsessan i Voltaires satiriska idéroman Candide från 1759. I romanen är Kunigunda Candides stora kärlek som ung som han många år senare söker upp och gifter sig med, trots att hon p.g.a. våldtäkter och prostitution blivit argsint och ful. Av plikt gifter han sig dock med henne och tillsammans lever de resten av sina liv på en gård. Se Voltaire, Candide, Ny utg., Nacka: Klassikerförl. STENIQ, 1759/1997.

${ }^{497}$ E. Beskow, ”Herr Klumpedump från Klumpedonien”, 1915/1955, s. 86.
} 
den. Liksom i Otto Witts saga finns "den svagaste punkten" med i sagan och här utnyttjas den för att ta död på draken.

När prinsessan inte vågar klättra ned för berget där hon hållits fången, inser Tor att han hade behövt det där aeroplanet som Sixten lovat honom. Han frågar därför Herr Klumpedump om det inte finns en trådlös telegraf i Klumpedonien. Det visar sig faktiskt finnas en sådan och Herr Klumpedump telegraferar till Sixten å Tors vägnar. Snart dyker Sixten upp i ett flygplan och pojkarna och prinsessan kan flyga ned till slottet där alla står och hurrar. ${ }^{498}$

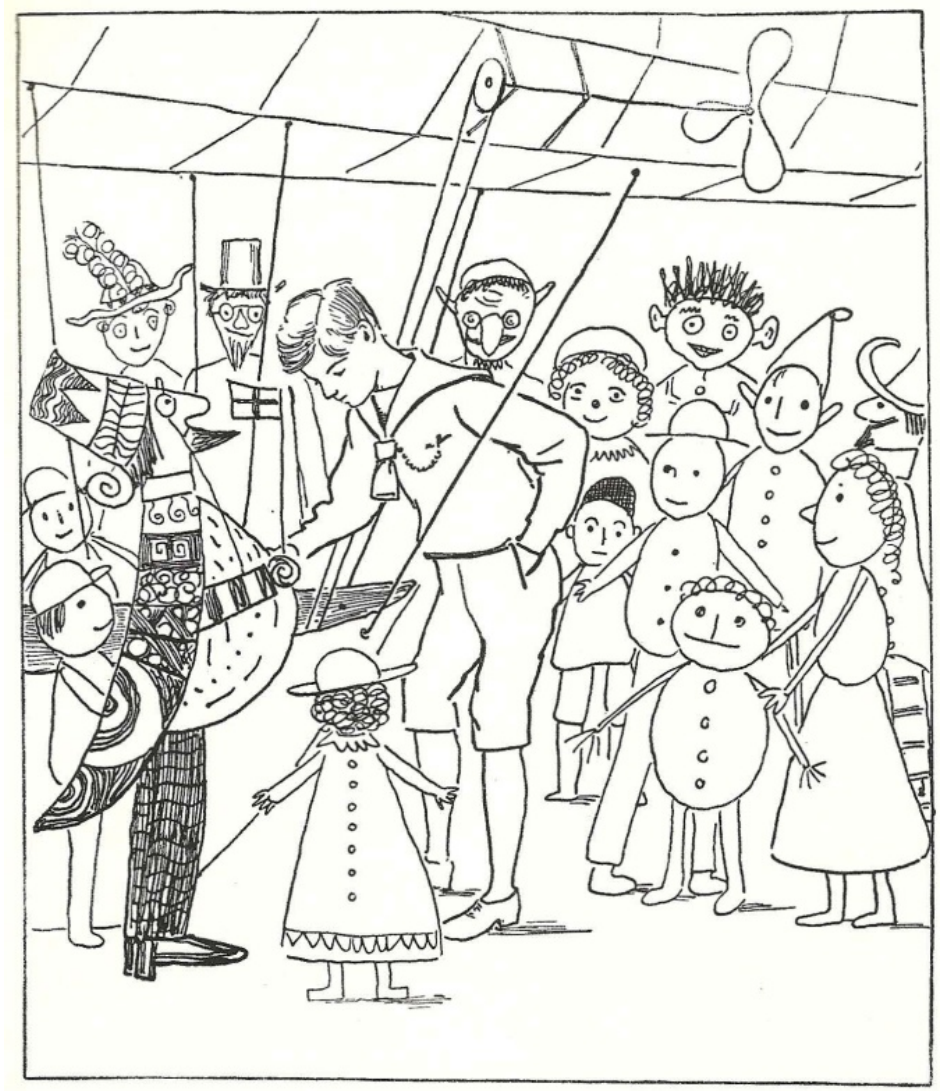

Bild 5.1: Illustration från "Herr Klumpedump från Klumpedonien" (Elsa Beskow, 1915/1955)

${ }^{498}$ Ibid., s. 90-91. 


\section{Tekniklandskapet i Elsa Beskows sagor}

I berättelsens illustration (se bild 5.1) avbildas de hyllande klumpedonierna som tecknade av barn. Vissa saknar näsor, händer eller öron medan andra har olika stora öron. Varje klumpedonier är dock unik och ingen är den andra lik. Alla ler och är glada nu när draken är dräpt och prinsessan räddad.

Hammar menar att draken kan tolkas som en metafor för industrialiseringen. ${ }^{499}$ Industrialismen är en drake som slukar människornas förmåga att skapa själva. Det som talar emot en sådan tolkning är att det samtidigt är den modernare tekniken som är ett resultat av industrialismen (telegraf och flygplan) som gör det möjligt för barnen att rädda prinsessan. På så sätt ger sagan om "Herr Klumpedump från Klumpedonien", i likhet med Nils Holgersson och de tekniska sagorna, uttryck för vad som kan tolkas som en ambivalent syn på tekniken. Å ena sidan är den moderna och industritillverkade tekniken likriktad och "själlös", å andra sidan kan människan utnyttja den för svårlösta problem.

Tor erbjuds prinsessans hand, vilket han avböjer. Han anser sig inte ha så mycket gemensamt med någon som inte gör annat än provar klänningar hela dagarna. Kungen kallar sin dotter för fåfäng och prinsessan gråter och menar att det är just detta som hon är född till, vilket hon inte kan rå för. Tor tröstar henne och säger att det faktiskt är Lisas fel eftersom hon tillverkade så många dräkter till sin klippdocka. Han lovar dock att försöka ordna en prins till henne - en prins som har lika många dräkter som hon själv. Då kan de ägna tiden åt att prova tillsammans. ${ }^{500}$

Sagans budskap kan tolkas som att Lisa och prinsessan företräder det materialistiska tänkandet medan Tor är kritikern av det. När det materiella går före andra värden hämmas kreativiteten och fantasiförmågan. Människan likriktas, hon reifieras (förtingligas) och hennes tid går åt till bevaka tingen istället för att engagera sig i världen utanför. Draken blir på så vis en metafor för materialism. Om människan inte är vaksam, blir hon ett offer för den.

Tor beger sig iväg för att se vart Sixten har tagit vägen. Han finner honom sysselsatt med ett luftskepp:

\footnotetext{
${ }^{499}$ S. Hammar, Solägget: Fantasi och verklighet i Elsa Beskows konst, 2002, s. 356.

${ }^{500}$ E. Beskow, ”Herr Klumpedump från Klumpedonien”, 1915/1955, s. 91.
} 
"Det här var ett livat land", tyckte Sixten, "såna skojiga människor här är, och så många halvfärdiga maskiner och grejor! Ser du, här har jag hittat en riktig Zeppelinare. Den ska vi segla hem på i stället för på mitt aeroplan."

I mitten av 1800-talet genomfördes de första flygningarna med luftskepp och 1909 hade man kommit så långt i teknikutvecklingen att de kunde användas för transport av människor. Utvecklingen leddes av tysken Ferdinand von Zeppelin (18381917). Zeppelinarna kom att användas under första världskriget $i$ en del bombräder, bland annat mot England, men det var framför allt inom den civila luftfarten som luftfarkosten användes. ${ }^{502}$ Erik Pallin skriver att sin största triumf nådde von Zeppelin genom sin färd på hösten 1909 då han flög från Friedrichshafen till Berlin och tillbaka. Denna händelse låg nära i tid till Louis Blériots flygning i sitt egenhändigt konstruerade flygplan från Calais till Dover liksom den första internationella flygveckan i Reims. ${ }^{503}$ Samtidigt skedde vid samma tid olyckor med luftfarkoster. I september 1909 störtade en militärballong i Frankrike och året innan hade Zeppelin varit med om en ödesdiger olycka när luftskeppet efter en flygning exploderade på grund av ett oväder. ${ }^{504}$

I sagan är Tor orolig för att zeppelinarens hopklistring inte ska hålla, men Sixten säger att han redan prövat både motor och propellrar. Sixten har en övertro på tekniken (zeppelinaren) medan Tor ser dess svagheter och därför ifrågasätter den. Men trots att Tor inte litar på luftskeppets flygförmåga, följer han ändå med. Plötsligt hörs en krasch och han känner hur han slår emot något hårt: "'Ser du det, Sixten', ropar han 'det var det jag sa, att det inte skulle hålla." "505 Då vaknar Tor och inser att han drömt alltihop.

Som redan konstaterats innehåller "Herr Klumpedump från Klumpedonien" inte samma explicita kritik mot kriget som Krigets tekniska sagor, trots att båda böckerna kom ut samma år (1915). Militär teknik, här gestaltad av tennsoldater

\footnotetext{
${ }^{501}$ Ibid., s. 92.

${ }^{502}$ S. Hansson, Teknikhistoria: Om tekniskt kunnande och dess betydelse för individ och samhälle, 1996, s. 375-376.

${ }^{503}$ E. Pallin, Flygande människor: Populär översikt av luftseglingskonstens utveckling under dess genombrottsår, 1909, s. 35.

${ }^{504}$ Ibid., s. 42.

${ }^{505}$ E. Beskow, ”Herr Klumpedump från Klumpedonien”, 1915/1955, s. 94.
} 
och torpedbåtar, skildras som att den har "problem", men budskapet stannar där och utvecklas inte vidare. Det är dessutom med hjälp av den militära tekniken (telegrafen) Tor kallar på hjälp, med ett aeroplan han räddar prinsessan och det är i en zeppelinare Tor och Sixten tar sig hem igen. Tor är konsthantverkaren som snidar båtar och gör vaxgubbar. Den nya tekniken skrämmer honom en smula. Kan han verkligen lita på att den fungerar? Genom sitt skapande får han dessutom en inbjudan till att besöka fantasilandet Klumpedonien. Som tekniker mekar Sixten med klockor, planerar att bygga en undervattensbåt och tycker att människorna $\mathrm{i}$ Klumpedonien är "skojiga" eftersom de har så många halvfärdiga maskiner och grejor. Han inbjuds inte till att besöka Klumpedonien och är heller inte den som får till uppgift att dräpa draken. Däremot är det till Sixten och hans teknik som Tor vänder sig till när ingen annan lösning finns.

I "Herr Klumpedump från Klumpedonien" är det svårt att uttolka något budskap om framtiden, men i en annan av Beskows sagor, "Doktor Klokamundus' uppfinning" beskrivs ett framtida samhälle där människornas tilltro till tekniken har gått för långt.

\section{Teknik- och framtidssynen i "Doktor Klokamundus' uppfinning"}

Berättelsen om "Doktor Klokamundus' uppfinning" utspelar sig i det futuristiska landet Kringelkrokien, ett samhälle som ligger långt före "i allting". Uppfinningar som telegraf, telefon, grammofon, flygmaskiner, biografer har de haft i flera hundra år. Landets invånare beskrivs som entusiastiska innovatörer, vilket fått som konsekvens att det mesta görs med maskiners hjälp. I Kringelkrokien hyser människorna hög tilltro till vetenskap och teknik och landets store uppfinnare Doktor Klokamundus är kungens närmaste rådgivare. Beskrivningen av Kringelkrokien för tankarna till utopisten Edward Bellamys (1850-1898) framtidssamhälle. Hans idealstat påminner om en armé, där varje individ som är arbetsför utför en industriell tjänstgöring. Något hushållsarbete existerar inte utan sådana sysslor sköts centralt. All osämja och kriminalitet har avskaffats. Bellamys utopi bygger på rationell och industriell produktion och hans tilltro till de enskilda människornas förmåga är 
svag: Han förespråkar därför en överorganiserad stat. ${ }^{506}$ I likhet med Bellamys utopi, bygger samhället i Kringelkrokien också på rationalitet och tekniska lösningar.

Doktor Klokamundus är änkling och han har en son, Petrus. Petrus är sin fars motsats och "[...] den ostyrigaste gosse man kan tänka sig". Han beskrivs som att han har ett huvud som är "[...] lika fullt av upptåg som hans fars av uppfinningar". ${ }^{507}$ Doktor Klokamundus har aldrig tid med Petrus och han tål inte att sonen fingrar på hans dosor och maskiner.

När Petrus började skolan blev hans lärare alldeles över sig givna över hans olydnad och bångstyrighet. Men när de försökte komma åt att tala med Doktor Klokamundus om hur svår Petrus var, så hade han aldrig tid att höra på. ${ }^{508}$

Någon uppmärksamhet av sin far får inte Petrus förrän den dag då det kommer ett brev från Petrus skola. Enligt brevet kan Petrus inte gå kvar på skolan eftersom han har ett så dåligt inflytande på sina skolkamrater. Brevet gör Doktor Klokamundus upprörd, men istället för att direkt engagera sig för sonen, bestämmer han sig för att lösa problemet med hjälp av ny teknik: han ska uppfinna en uppfostringsmaskin. Planen är att ostyriga barn ska kunna stoppas in i maskinen för att sedan komma ut välartade och fullärda. När kungen får vetskap om maskinen blir han nöjd. Det finns nämligen en hel "liga" med pojkar med liknande problem som Petrus:

”Jag har just i dessa dagar hört så många klagomål över skolungdomens självsvåld, och snart lär det väl inte finnas en enda människa, som vill bli lärare i landet Kringelkrokien." $" 509$

Kungen lovar Doktor Klokamundus att om bara han fullföljer uppfinningen, kan han få hur mycket pengar som helst ur statskassan. Men trots att maskiner övertagit allt tungt arbete i det starkt teknikutvecklade landet Kringelkrokien, finns en

\footnotetext{
${ }^{506}$ T. Frängsmyr, Framsteg eller förfall: Framtidsbilder och utopier $i$ västerländsk tanketradition, 1990, s. 141-150.

${ }^{507}$ E. Beskow, ’Doktor Klokamundus' uppfinning" i Muntergök: Sagobok, Ny utg., Stockholm: Bonnier Carlsen, 1919/1996, s. 56.

${ }^{508}$ Ibid., s. 56.

${ }^{509}$ Ibid., s. 58.
} 


\section{Tekniklandskapet i Elsa Beskows sagor}

baksida: ingen vill lägga ned någon tid eller omsorg på barnen. Sagans vuxna tror att tekniken ska lösa problemet med de ouppfostrade barnen. De inser inte att det $\mathrm{i}$ själva verket är deras egen brist på omsorg om barnen som skapat problemen.

En följd av industrialiseringsprocessen var att båda föräldrarna började arbeta utanför hemmet. Detta fick konsekvenser för barnen, vilket var ett återkommande diskussionsämne i bland annat Svensk Läraretidning:

En ytterligare orsak till den sedliga förvildningen är bristande tillsyn. I många fall måste båda föräldrarna under arbetet för det dagliga brödet lämna sina barn ensamma. Dessa komma att växa upp så att säga på gatan, utan tillsyn och moralisk omvårdnad. ${ }^{510}$

Ett viktigt mål med införandet av en allmän skola i Sverige var att hålla barnen borta från gatan. I jordbrukssamhället hade barnuppfostran till största delen skötts av familjen, men i och med industrialiseringen kom staten att få en allt större roll. Barns uppförande blev en offentlig angelägenhet och inte endast en privatsak för föräldrarna. ${ }^{511}$ Även i sagan om Kringelkrokien tar samhället över fostran av barnen som inte anpassar sig efter samhällets normer och då genom skapandet av uppfostringsmaskinen.

Doktor Klokamundus konstruerar först en försöksmaskin i liten skala. I den stoppar han in fem små kaninungar och efter en månad därinne släpps kaninerna ut. När de stoppades in i maskinen var de i olika färger, men när de hoppar ut är de alla identiskt spräckliga och utför precis samma konster. Kungen tycker att det är fantastiskt med de små väluppfostrade kaninerna och han ser genast maskinens potential:

”Tänk så bra det skulle ta sig ut om alla mina soldater var lika långa, inte en upp och en i minnet som nu, och så mycket rättvisare det skulle bli om alla människor hade ungefär samma utseende istället för att somliga var vackra och andra fula." ${ }^{512}$

\footnotetext{
510 "Ungdomens vanart" i Svensk Läraretidning, nr. 49, 1895, s. 643, http://runeberg.org/svlartid/1895/0646.html (läst 2011-08-08).

${ }^{511}$ B. Sandin, "Barndomens omvandling - från särart till likart" i Barnets bästa - En antologi om barndomens innebörder och välfärden organisation, 2003, s. 231. Se även B. Sandins avhandling Hemmet, gatan, fabriken eller skolan. Folkundervisning och barnuppfostran i svenska städer 1600-1850 , diss., Lunds universitet, Lund: Studentlitteratur, 1986.

${ }^{512}$ E. Beskow, ”Doktor Klokamundus' uppfinning”, 1919/1996, s. 60.
} 
Uppfostringsmaskinen har till uppgift är att förvandla pojkarna till identiska kopior med exakt samma förmågor och kunskaper, vilket kungen tycker är bra. Kungens ideologi är att ett samhälle bara är rättvist om alla är precis likadana. Med teknikens hjälp ska äntligen en sådan rättvisa kunna skapas. Barnen i Kringelkrokien har dock inte den minsta lust att hamna i uppfostringsmaskinen. Kanske för att de ser att kaninungarna har blivit spräckliga allihop? Barnen vill inte alls likriktas och disciplineras på det sätt som de vuxna önskar. Doktor Klokamundus är dock nöjd med de små väluppfostrade kaninerna och sätter igång med bygget av den stora maskinen. Till skillnad från i de tekniska sagorna är den här sagans ingenjörer inga hjältar. De skildras som viljelösa karaktärer som blint lyder vetenskapsmannens order utan att ifrågasätta huruvida maskinen är bra eller ej.

Uppfostringsmaskinen liknar ett skolhus, dock bestående av kaklade smårum. Fönstren sitter så högt upp att barnen vare sig kan se ut eller rymma den vägen. Pojkarna är fast inuti en stor, trist maskin med total avsaknad av estetik och hemtrevnad. Varje rum är försett med en klocka och en hög röst ropar varje timme ut order. Om den som bor i rummet inte lyder, får han plötsligt en iskall dusch över sig. På morgnarna ringer väckarklockan och när den slutat ringa vänds alla bäddarna upp och ned och fälls in i väggen. Därefter skjuts ett badkar upp ur golvet. Frukostmaten kommer in genom en skiva i väggen som svänger tillbaka igen efter en halvtimme. Klockan sju börjar lektionerna. Eleven får sätta sig i en skrivpulpet mitt i rummet och sedan rabblar en grammofon läxan om och om igen tills han kan den. Därefter följer nästa läxa. När det är dags för gymnastik hissas ett rep och en trapets ned genom taket och grammofonen talar om vilka rörelser eleven ska göra. Två gånger i veckan visas skioptikonbilder och biograffilmer som illustrerar hur man bockar sig på rätt sätt och hur man ska hålla kniv och gaffel när man äter. ${ }^{513}$

Fostran av barnen ska ske helt utan mänsklig kontakt - vare sig barnen emellan eller med någon vuxen. Syftet med Doktor Klokamundus' maskin är att producera "belevade" och "fullärda" elever. Tanken är att ett år i uppfostringsmaskinen kommer att leda till att barnen lär sig mer än vad de skulle göra på fem år i en vanlig skola. Det gör att efter några år med uppfostringsmaskinen kommer Kringel-

${ }^{513}$ Ibid., s. 61-62 
krokien vara "världens mest överciviliserade land". ${ }^{514}$ När kungen inser maskinens potential blir han så nöjd att han dunkar Doktor Klokamundus i ryggen.

Något som skiljer sagan från Bellamys utopi är att maskinerna i Kringelkrokien inte enbart tar över vissa av sysslorna, utan snarare allt arbete. Det finns en dammsugningsapparat som suger upp allt damm ur rummet och en "renakläderautomat" där barnen varje lördag, på ett bestämt klockslag, stoppar ner sina smutskläder i ett fack och sedan kommer de ut rena ur en annat. Det finns till och med en hårklippningsautomat som påminner om en tandläkarstol och som klipper håret "[...] lika lätt som om den skalat en potatis". ${ }^{515}$ Genom dessa hushållsapparater finns även hushålltekniken representerad i sagan.

Runt 1910 skapades en diskussion bland el- och kraftverksexperter i Sverige om hur man skulle kunna intressera allmänheten för elektriska apparater i hushållsarbetet. USA var föregångslandet. De viktigaste hushållstekniska nyheterna på den amerikanska marknaden vid denna tid var kokapparater, strykjärn, spisar och dammsugare. Några år in på 1910-talet startades industrier i Sverige som var inriktade på att tillverka elektriska hushållsapparater. Den elektriska produkt som först blev allmän i de svenska hushållen var strykjärnet och av de större produkterna var det dammsugaren. Dammsugaren var en maskin som inte bara kompletterade andra städformer, utan den förbättrade dessutom städningen kvalitativt. De tidiga tvättmaskinerna hade däremot inte samma kvalitetshöjande förmåga utan krävde mycket kringarbete. Detta gjorde att de betraktades med större misstänksamhet jämfört med andra nya hushållsmaskiner. Först mot slutet av 1920-talet kom det exempelvis tvättmaskinsmodeller som kunde värma upp vattnet. ${ }^{516}$ Grammofonen, en för tiden ny maskin som också omnämns i sagan, började massproduceras och säljas i större skala under 1900-talets första årtionden. ${ }^{517}$ På den bild som illustrerar sagan (och som även är sagosamlingens bokomslag) finns grammofonen avbildad i ett av Doktor Klokamundus skåp, det skåp under vilket Petrus gömmer sig (se bild 5.2).

\footnotetext{
${ }^{514}$ Ibid., s. 64.

${ }^{515}$ Ibid., s. 63.

${ }^{516}$ J.-E. Hagberg, Tekniken i kvinnornas händer: Hushållsarbete och hushållsteknik under tjugooch trettiotalen, 1986, s. 40-52.

${ }^{517}$ Ibid., s. 36.
} 


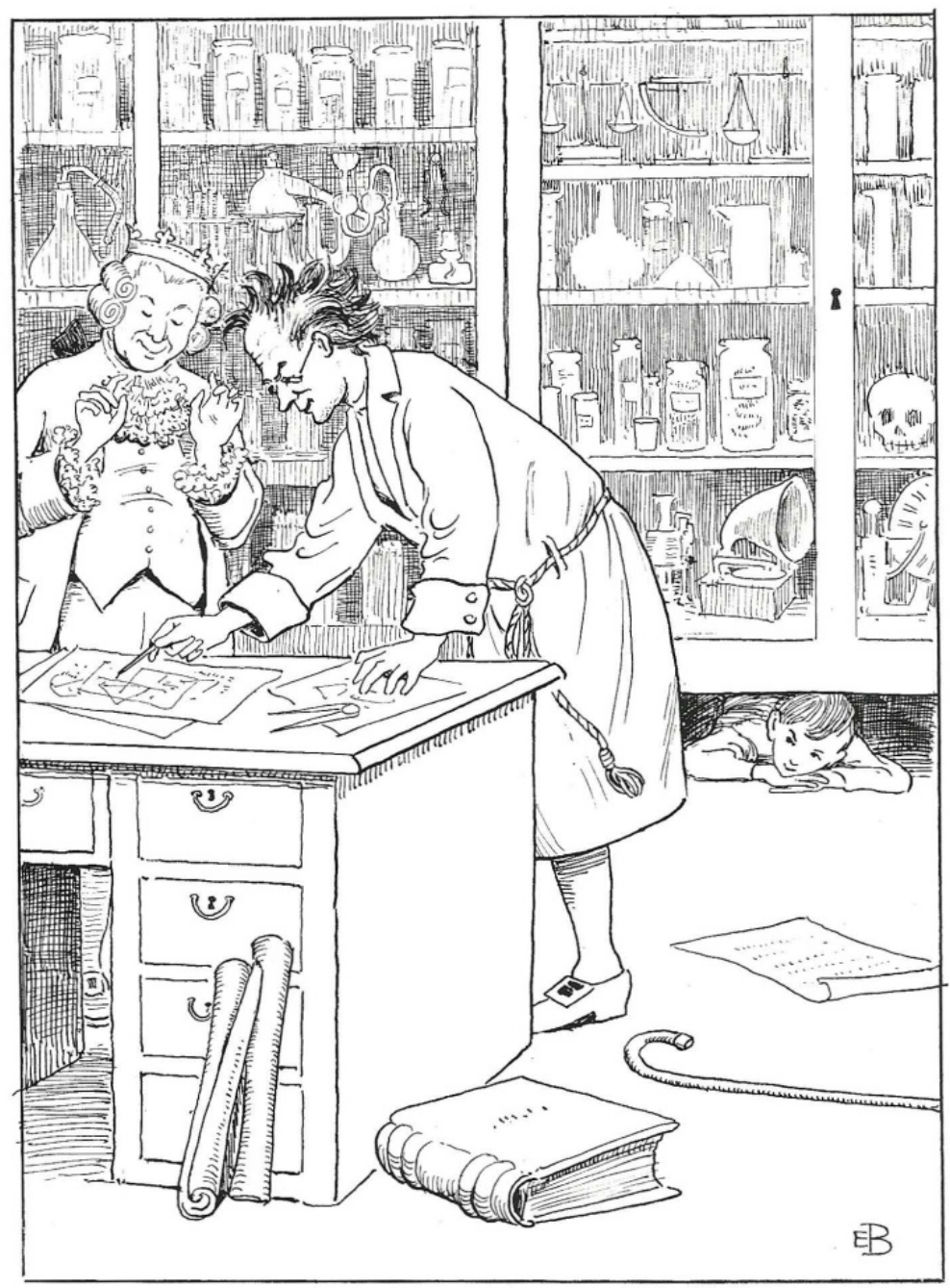

Bild 5.2: Illustration från "Doktor Klokamundus' uppfinning” i Muntergök (Elsa Beskow, 1919/1996)

I berättelsen utnyttjas den för tiden nya tekniken, bland annat grammofonen, som fostrings- och disciplineringsverktyg, med syftet att producera lydiga medborgare. Den sociala gemenskapen är ersatt av teknik. Om någon av pojkarna känner sig ensam och längtar efter någon att prata med kan han få det på en bestämd timme på eftermiddagen och då via en lur på väggen. Kommunikationen sker dock inte med någon levande människa utan med en grammofon. Vid sängdags släcks ljuset 


\section{Tekniklandskapet i Elsa Beskows sagor}

exakt klockan nio, klockan ropar god natt och grammofonen sjunger en kvällspsalm. Inte ens vid måltiderna ges chans till någon form av social samvaro. I köksvåningen sätts färdiglagad mat $\mathrm{i}$ burkar in $\mathrm{i}$ olika fack och varje barn får matransonen för en hel vecka $i$ taget. Maten värms upp automatiskt och serveras vid bestämda klockslag. Kontakten människor emellan är obefintlig och isoleringen total; tekniken alienerar människorna från varandra. Uppfostringsmaskinen kan tolkas som en metafor för såväl kritik av "korvstoppningspedagogik", som kritik av industrialiseringens mekanisering av människors liv. Doktor Klokamundus uppfostringsmaskin har dock en positiv egenskap: barnen kan inte bli sjuka när de vistas i den. En luftsteriliseringsapparat i taket ordnar att till och med "okynnesbacillerna" endast kan leva en kort tid därinne. Den sterila miljön skildras dock långt ifrån som något trevligt - snarare som något trist.

Maskinen blir invigd med tal, hurrarop och musikkår och Doktor Klokamundus låser in pojkarna. Han går därefter in i det innersta maskinrummet och sätter igång hela maskineriet med hjälp av en enda skruvnyckel. Det Doktor Klokamundus och de andra vuxna inte vet är att Petrus i hemlighet har tagit avtryck av låsen och tillverkat nycklar samt planerat för att han och de andra pojkarna ska kunna rymma till en gammal övergiven borgruin på en holme utanför staden. Petrus har i förväg samlat saker som de kan behöva; halmmadrasser, gamla filtar, kokkärl och bränsle.

Pojkarna rymmer från uppfostringsmaskinen så snart de blivit lämnade ensamma. Vid borgruinen kan de bada, fiska och leka indianer och rövare hela dagarna. Matfrågan löser de genom att hämta matburkarna från uppfostringsmaskinen. För att inte väcka de vuxnas misstänksamhet, ställer de varje vecka tillbaka de tomma burkarna.

Och under tiden surrade alla de små hjulen därinne i maskinrummet i uppfostringsmaskinen, och grammofonen upprepade samma läxa ideligen, för det var ju aldrig någon pojke som svarade, och klockan utdelade sina befallningar och den iskalla duschen strilade litet emellan över olydiga gossar som inte fanns, och maten sköts in och ut orörd genom väggen, och sängarna fälldes ner och upp igen. Ja, allt fungerade så utmärkt, det var bara pojkarna som fattades. ${ }^{518}$

\footnotetext{
${ }^{518}$ E. Beskow, ”Doktor Klokamundus' uppfinning”, 1919/1996, s. 66-67.
} 
Vid borgruinen ägnar sig pojkarna åt sådant som att täta väggar och tak, bygga en ordentlig spis samt samla bränsle för regnperioden. I likhet med filosofen JeanJacques Rousseaus (1712-1778) idéer om fostran, är det i det fria livet i naturen som pojkarna utvecklar sina tekniska förmågor. Rousseau menade att kulturmänniskan föds, lever och dör i slaveri. Målet för en sund utveckling för hela mänskligheten måste därför vara att anpassa sig efter naturen. I sitt berömda verk Emile ou de l'education (1762) ska Emile på samma sätt som vilden lära sig av naturen och sina erfarenheter. Utantilläxor är meningslösa och det är endast genom erfarenheter vi förstår sammanhang och inser orsak och verkan, menar Rousseau. Den första bok Emile får läsa är därför Daniel Defoes Robinson Crusoe (1719). Robinson klarar sig genom att använda sitt eget förstånd och med hjälp av sin uppfinningsrikedom och uthållighet lyckas han leva ett primitivt liv och han lär sig dessutom att uppskatta det. $^{519}$ Barnboksdiskussionerna i Sverige vid sekelskiftet 1900 var påverkade av Rousseau och de konstnärliga strömningarna. Det var just de skapande krafterna i människan som betraktades som angelägna. Sådant som fantasi och känsla var därför viktiga ingredienser i barnlitteraturen och Robinson Crusoe betraktades vara en lämplig övergång från sagor och sägner. ${ }^{520}$

I sagan tröttnar dock pojkarna småningom på Robinsonlivet vid borgruinen. När deras kläder efter en tid börjar gå sönder, försöker de laga dem med segelgarn och en rostig syl, men det går inget vidare. Tvål och borstar har de heller inte tillgång till och snart ser de ut som "riktiga vildar": "[...] smutsiga och sotiga och solbrända och tatuerade, som de var, och med långt, tovigt hår". ${ }^{521}$ Nöjet med det fria livet vid borgruinen får sitt definitiva slut när regnperioden kommer, då pojkarna till och med börjar längtar tillbaka till uppfostringsmaskinen. Till sist smyger de sig in köksvägen till maskinen och kastar sig i sina sängar. De sover så tungt att de inte vaknar när väckarklockorna ringer, inte ens när sängarna stjälps upp och ned.

\footnotetext{
${ }^{519}$ J.-J. Rousseau, Emile, Project Gutenberg. E-bok, 2004 (1762), http://www.gutenberg.org/cache/epub/5427/pg5427.html (läst 2013-09-30).

${ }^{520}$ G. Klingberg, Sekelskiftets barnbokssyn och Barnbiblioteket Saga, 1966, s. 17-19. Robinson Crusoe är återkommande även i mer sentida litteratur som rekommenderad läsning för barn. Exempelvis kallas barnen i 9-10-årsåldern för "Robinsonåldern" i G. Bolin, E.v. Zweigbergk, Barn och böcker, Stockholm: Kooperativet förbundets bokförl., 1951, s. 16, 60.

${ }^{521}$ E. Beskow, "Doktor Klokamundus’ uppfinning", 1919/1996, s. 68.
} 


\section{Tekniklandskapet i Elsa Beskows sagor}

När uppfostringsmaskinen så småningom öppnas finner inte barnens föräldrar de välartade gossar som de förväntat sig. Doktor Klokamundus får panik, stoppar maskineriet och drar slutsatsen att maskinen måste ha gått baklänges. Istället för att gå framåt i civilisationen har den gått bakåt och närmat sig "vildarnas ståndpunkt". Han förbjuder därför omedelbart alla uppfostringsmaskiner i Kringelkrokien och konstaterar att: "Tänk, vilken lycka, att man hejdat maskinen så pass tidigt, så de inte hunnit tillbaka till människoätareståndpunkten." ${ }^{, 522}$

Föräldrarna tar med sina pojkar hem, tvättar dem, klipper håret på dem och sätter på dem rena kläder. Pojkarna är "fogliga som lamm" och föräldrarna och lärarna tror att maskinen trots allt gjort nytta. Petrus får till och med lov att gå tillbaka till skolan medan maskinen lagas.

Doktor Klokamundus kommer att ägna resten av sitt liv åt att grubbla över vad som gick fel med uppfostringsmaskinen. Grubblandet är dock förgäves eftersom det inte var något fel på den. Under tiden står uppfostringsmaskinen oanvänd, vilket är till stor skada, tycker människorna i Kringelkrokien:

För om den hade hunnit göra så mycket nytta, fast den backat, tänk vilka storverk den skulle ha uträttat, om den gått rätt!! ${ }^{523}$

I motsats till det Robinsonliv som Rousseau förespråkar, visar sagan att det till sist ändå är ett modernt och bekvämt liv som pojkarna i Kringelkrokien föredrar. Under sin vistelse i det vilda hämtar de maten från uppfostringsmaskinen istället för att helt leva på sådant som går att finna i naturen. Men i likhet med Rousseaus uppfostringsideal lär sig pojkarna mer av sina erfarenheter än av den mekaniska utantillinlärningen som uppfostringsmaskinen erbjuder. Deras positiva utveckling beror på att de fått leva som "civiliserade vildar" och utnyttja sin kreativitet och tekniska förmåga för att överleva, istället för att fostras i en högteknologisk uppfostringsmaskin.

Den "civiliserade vilden" som ideal förekommer även i vuxenlitteraturen kring sekelskiftet 1900. Enligt Kylhammar var denne exempelvis August Strindbergs ideal. Strindberg hyllar Robinson Crusoe i Gamla Stockholm (1882) och menar att anledningen till att den griper, inte minst barnen, är för att den handlar om konflik-

\footnotetext{
${ }^{522}$ Ibid., s. 71.

${ }^{523}$ Ibid.
} 
ten mellan natur och kultur. I boken symboliserar Robinson den "kultiverade naturhjälten”. När han utlämnas till naturen på en öde ö, startar han sitt projekt att kultivera naturen. ${ }^{524}$

I skildringen av det framtida samhället i sagan om Kringelkrokien finns ett budskap som kan tolkas som en explicit varning för konsekvenserna av en alltför hög tro på nya och moderna tekniska lösningar. I vare sig "Herr Klumpedump från Klumpedonien" eller i "Doktor Klokamundus' uppfinning" framställs dock tekniken enbart som av ondo, utan den har två sidor: både en negativ och en positiv. Däremot ges naturen inget betydande utrymme i någon av sagorna. Pojkarna $\mathrm{i}$ "Doktor Klokamundus' uppfinning" lever under en period i det fria, men det är till en övergiven borgruin de rymmer och inte till vildmarken. I en annan av Beskows sagor, "När stora blåbärsberget kom till stan", agerar däremot naturen själv huvudkaraktär och kommer i konflikt med människans urbana värld.

\section{Teknik- och natursynen i "När stora blåbärsberget kom till stan"}

Som redogjorts för i kapitlet om Nils Holgersson kom naturen liksom hembygden att ingå som centrala delar i den svenska nationella diskursen kring sekelskiftet 1900. ${ }^{525}$ Parallellt med nationalromantiken, var vildmarksromantiken i grunden knuten till den norrländska naturen. Genom författare och konstnärer kom den i och med den svenska "Jack London-febern" kring 1910- och 1920-talen, att blomma ut i en egen genre. ${ }^{526}$ Samuel Edquist menar att dessa naturromantiska strömningar var något som karaktäriserade såväl allmogen som arbetarrörelsen.

\footnotetext{
${ }^{524}$ M. Kylhammar, Maskin och idyll: Teknik och pastorala ideal hos Strindberg och Heidenstam, 1985, s. 30.

${ }^{525}$ S. Edquist, "Blå som himlen och gul som solen: Om vänstern och den svenska nationalismen kring sekelskiftet 1900", 1999, s. 78-79; S. Sörlin, Framtidslandet: Debatten om Norrland och naturresurserna under det industriella genombrottet, 1988; S. Sörlin, "Norrlandsfrågan: Idéer och debatt i samband med det industriella genombrottet", 1984, s. 265-319.

${ }^{526}$ K. Johannisson, ”Det sköna i det vilda: En aspekt på naturen som mänsklig resurs”, 1984, s. 73. Jack Londons böcker, bland annat hans mest kända bok Skriet från vildmarken, blev mycket populära i Sverige kring sekelskiftet 1900 och rekommenderades som läsning för unga i såväl tidskrifter som Biblioteksbladet och grundkatalogerna. Se exempelvis "Litteratur", Biblioteksbladet, 1918, s. 192, http://runeberg.org/biblblad/1918/0192.html (läst 2012-09-15); "Det andra nordiska biblioteksmötet i Stockholm", Biblioteksbladet, 1928, s. 217, http://runeberg.org/biblblad/1928/0229.html (läst 2012-09-15).
} 


\section{Tekniklandskapet i Elsa Beskows sagor}

Den socialistiska framtidsutopismen kring 1900 inkluderade en önskan att kombinera en fortsatt industriell och vetenskaplig utveckling med decentralisering och ett liv i samklang med naturen. ${ }^{527}$ Den nationalistiska retoriken om naturen handlade därmed både om estetiska värden och om skogen som leverantör av råvaror för industriell produktion. Naturen representerade historiska band bakåt i tiden men var samtidigt vägen framåt mot en industriell ekonomi. ${ }^{528}$

Om Nils Holgersson kan tolkas som en berättelse i vilken bilden av skogen som resurs lyfts fram, är det naturens värde utifrån ett estetiskt perspektiv som ges uttryck för i "När stora blåbärsberget kom till stan". I Nils Holgersson skildras den vilda naturen som både tråkig och hotfull, medan naturen i sagan om blåbärsberget är levande, vacker och vänlig. I berättelsen skildras de ödesdigra konsekvenserna av ett möte mellan den vilda, orörda naturen och den urbana storstaden.

Sagan handlar om ett "väldigt trevligt", mossbelupet berg, fullt med olika slags bär och vackra blommor. En dag får berget besök av två små flickor som kommit dit för att plocka av bären. Flickan från landet har friska röda kinder, medan flickan från staden är blek och späd. Livet i naturen får här agera sinnebild för det goda livet, medan stadslivet med sin gråa bebyggelse och utestängda sol ger bleka barn:

Den ena flickan, hon med det bleka, smala ansiktet, satt alldeles hänryckt över vad hon såg. Hon var inte ett lantbarn, utan hade bott hela sitt liv i en stor stad, där de grå husen stod tätt packade och stängde för solen. Aldrig förr hade hon vetat, att det fanns något så vackert som detta skogsberg. ${ }^{529}$

Stadsflickan Greta drömmer om att stadens barn ska få chans att njuta av det vackra berget och innan hon beger sig hemåt omfamnar hon berget och ropar: "Kära, kära bergtroll, låt mig få ditt berg med mig till stan!" ${ }^{330}$ I sagan väcks det sovande bergtrollet av flickans bön. I sin ungdom var han ett vilt och grymt troll, men bergets mjuka mossa och "de små vänliga ljungblommorna" hade gjort hans sinne

\footnotetext{
${ }^{527}$ S. Edquist, "Blå som himlen och gul som solen: Om vänstern och den svenska nationalismen kring sekelskiftet 1900", 1999, s. 86.

${ }^{528}$ M. Sjöberg, Barnen, skogen och skolan: Om skolelevers plantering av skog i Sverige ca 18801960, 2011, s. 38.

${ }^{529}$ E. Beskow, "När stora blåbärsberget kom till stan" i Muntergök: Sagobok, Ny utg., Stockholm: Bonnier Carlsen, 1919/1996, s. 112-113.

${ }^{530}$ Ibid., s. 113.
} 
blidare. Han är numera ett gammalt och snällt troll. Naturen har haft en helande effekt på trollets sinnelag och han vill nu göra flickan glad. Med berget på ryggen beger han sig till staden och så försiktigt som möjligt makar han sig på plats bland husen mitt i staden. Naturen är inte något som hänsynslöst reder sig plats, utan något som hänsynsfullt försöker anpassa sig efter staden.

Beskrivningen av hur staden förvandlas till en grön idyll med ett stort berg mitt på torget har likheter med William Morris utopi. I Morris idealsamhälle är alla fabriker borta, skillnaden mellan stad och land har utplånats och stadens centrala delar består av stora parker och skogsområden. ${ }^{531}$ I sagan om blåbärsberget är det den vilda och orörda naturen som flyttar in mitt i staden och sagans illustration visar hur berget beger sig i riktning mot staden på två mänskliga ben. Genom bergtrollet besjälas naturen och antar mänsklig gestalt, den blir en antropomorf.

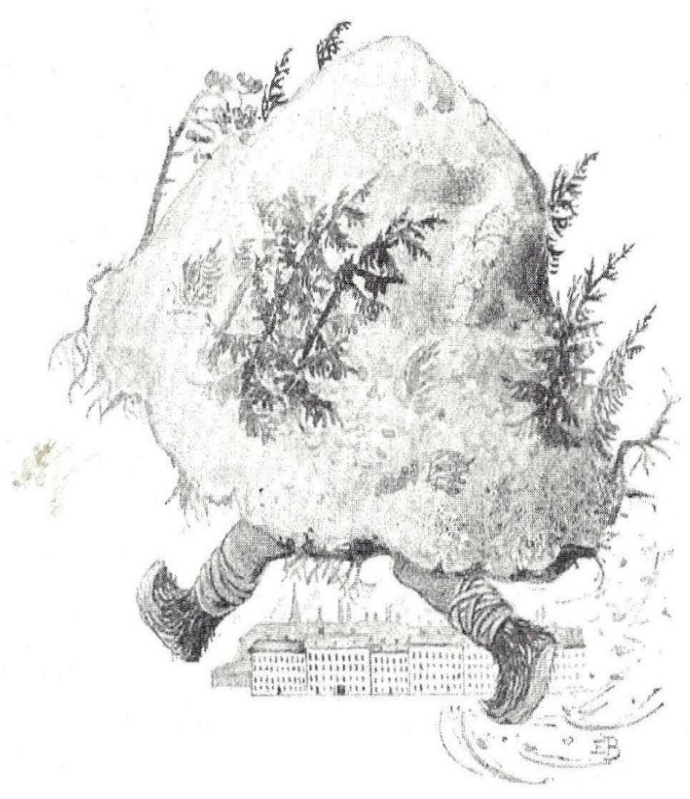

Bild 5.3: Illustration från ”När stora blåbärsberget kom till stan” (Elsa Beskow, 1919/1996)

\footnotetext{
${ }^{531}$ R. Ambjörnsson, Fantasin till makten! Utopiska idéer i västerlandet under fem hundra år, 2004, s. 168; T. Frängsmyr, Framsteg eller förfall: Framtidsbilder och utopier $i$ västerländsk tanketradition, 1990, s. 64.
} 


\section{Tekniklandskapet i Elsa Beskows sagor}

Stadsbarnen förhåller sig till en början avvaktande, men bären lyser så frestande att de till sist vågar sig upp på berget. De kommer sedan att tillbringa all sin lediga tid där. Om någon av dem håller på att skada berget, behöver Greta bara ropa till trollet som då ruskar lite på sig, och då blir barnen snälla igen. Naturen är både helande och fostrande och barnen lär sig respektera den genom att vistas där. Idyllen med berget i staden är fullständig tills myndigheterna börjar fundera på hur de skulle kunna använda det där "förargliga" berget, eftersom de inte tycker att det vilda skogsberget hör hemma mitt $i$ en stad. Kejsaren engagerar sig i projektet och vill att det ska förevisas för honom. ${ }^{532}$ Den dagen som Kejsaren ska komma på besök stängs berget för barnen. Slutsatsen efter hans besök är att mossan och riset måste bort och ersättas av fina klippta gräsmattor med stängsel omkring. Vägar ska anläggas och trappsteg huggas ut i berget och högst upp ska det byggas ett utkikstorn och en restaurang. För att få igen allt vad detta kommer att kosta, ska man sätta upp en hög mur och de som önskar komma in måste betala. Med hjälp av sina redskap (teknik) planerar människorna i staden att tukta berget (naturen). ${ }^{533}$

I sagan om blåbärsberget görs ett försök att få de överciviliserade stadsmänniskorna att leva ett liv närmare naturen, men det urartar. Stadsmänniskorna förstår inte att värdesätta den vilda. Urbanisering och industrialisering har lett till en alienering från naturen och människorna vill omforma och tukta naturen utifrån sina egna behov. En alternativ tolkning av berättelsen är att naturen (berget) är en metafor för barnet som först måste "tuktas" och formas för att passa in i de vuxnas (myndigheters och kejsares) värld. Flickan Greta har tidigare besökt berget i dess naturliga hemvist i skogen och upplevt det där. Hon är därför den av stadens alla barn som kan uppskatta berget mest:

\footnotetext{
Särskilt intresserad var hon av en blåsippsfamilj, som stod under den stora granen på södra sluttningen av berget. Den bestod av väl en tio små blåsippsbarn, de minsta ännu så väl insvepta i sina silvergrå pälsar, men de större redan otåliga att få titta ut $[\ldots] .{ }^{534}$
}

Naturen antar mänsklig gestalt genom beskrivningen av en familj med barn. Några stadsbarn blir nyfikna och kommer rusande och innan Greta hinner hejda dem har

\footnotetext{
${ }^{532}$ E. Beskow, ”När stora blåbärsberget kom till stan”, 1919/1996, s. 116.

${ }^{533}$ Ibid., s. 117-118.

${ }^{534}$ Ibid., s. 119.
} 
de ryckt upp alla blåsipporna - stora som små. Samma historia upprepas dag efter dag utan att Greta lyckas hejda dem. Bergtrollet sover och hör inte hennes rop på hjälp:

Och allt morskare blev de okynniga barnen. De for fram som vildar, bröt av grenar och ryckte upp blomsterstånd och gjorde allt ofog, som föll dem in. ${ }^{535}$

När sommaren kommer blir situationen på berget än värre då allt fler människor kommer för att besöka det med sina matsäckskorgar:

Det hade så muntert och trevligt där, och allt hade varit bra, om de bara hade tagit sina äggskal och buteljer och smörgåspapper med sig hem i stället för att lämna det kvar på berget. Stackars Greta försökte städa, så gott hon kunde, på sitt älskade berg, men det var nästan ett hopplöst göra, för alltjämt kom där nytt skräp - det var en svår tid för Greta. ${ }^{536}$

Att stadsmänniskorna saknar respekt för naturen och dess skönhet är tydligt och Greta betraktar det som sker med sorg och förtvivlan. Skövlingen av berget fortsätter och bergtrollet vaknar inte förrän han hör ett skott. Det är en pojke med gevär som är ute i skogen och skjuter småfåglar. När trollet inser vad som har hänt sparkar han till i berget under pojken. Pojken, som ramlar och tappar bössan, får en stor bula, men: ”Det var just rätt åt honom!" ${ }^{537}$ När bergtrollet sedan upptäcker vad människorna har gjort med blommorna och att hans mossa är full med skräp, blir han ledsen och säger till Greta att de ska ge sig av därifrån:

Innan han gav sig av, snurrade han dock runt några tag, så papper och äggskal rykte

- och sedan bar det i väg med långa steg tillbaka till hans skog. ${ }^{538}$

Kvar står stadsmänniskorna på ett öde och tomt torg, fullt med buteljskärvor, äggskal och flottigt smörgåspapper. Försöket att skapa en pastoral idyll mitt i staden har misslyckats och världen är återigen delad, med naturen och människan var för sig.

\footnotetext{
${ }^{535}$ Ibid., s. 120.

${ }^{536}$ Ibid.

${ }^{537}$ Ibid.

${ }^{538}$ Ibid., s. 121.
} 


\section{Tekniklandskapet i Elsa Beskows sagor}

En annan uppdelning, men då mellan stad och landsbygd, skildras i sagan "Den gröna bilen”. I sagan om blåbärsberget är det naturen som är huvudkaraktär, men i sagan om bilen är det tekniken som är protagonist. Röda bussen och gröna bilen. Bilderbok till Johan från farmor gavs ut 1952. Bilderboken skildrar krocken mellan landsbygd och stad, den sistnämnda materialiserad genom en bil. Utifrån Rhedins indelning av bilderböcker, kan "Den gröna bilen" beskrivas som en genuin bilderbok, eftersom text och bild är beroende av varandra för att berättelsen ska kunna läsas och tolkas. ${ }^{539}$

\section{Teknik- och natursynen i "Den gröna bilen"}

I slutet av Elsa Beskows författarliv höjdes röster bland barnbokskritikerna som efterlyste någon som kunde skriva om de vardagsting som omgav tidens barn. ${ }^{540}$ Barnbokskritikern Gurli Linder kom med tiden att anse att moderna sagoförfattare skulle nå bättre resultat om de hämtade sina motiv från sin samtid. Som ett exempel ger hon Elsa Beskows saga om en trafikbuss, en saga som Linder anser vara en av Beskows bästa. ${ }^{541}$ I en annan av Beskows senare sagor kommer ett sopnedkast till liv. ${ }^{542}$ Sjögren delar dock inte Linders åsikt och menar att resultatet inte är lika inspirerande som Beskows tidigare böcker. "Röda bussen och gröna bilen" och ”Den sönderslagna mjölkflaskan" är exempel på "skomakarrealism", anser Sjögren och konstaterar vidare att den sistnämnda slutar med att ett sopnedkast "[...] äger ett snusförnuft som man annars lyckligt saknar i hennes produktion". 543 Ett annat exempel på hur Elsa Beskows böcker följer teknikutvecklingen finns i småskolans Vill du läsa? I läseboken skulle sagan "Lisas framtidsplaner" från 1907 vara med, men den behövde då moderniseras. I den nya versionen blir barnen bjudna på en biltur och Beskow lär ha uttryckt att: "Barnen tycker nog, att det blir lika roligt att åka i bil som att åka i hölass." 544

\footnotetext{
${ }^{539}$ U. Rhedin, Bilderboken: På väg mot en teori, 2001, s. 94.

${ }^{540}$ M. Sjögren, Elsa Beskow och hennes värld, 1983, s. 60.

${ }^{541}$ L. Kåreland, Gurli Linders barnbokskritik: Med en inledning om den svenska barnbokskritikens framväxt, 1977, s. 186.

${ }^{542}$ E. Beskow, "Den sönderslagna mjölkflaskan" i Den lilla vävaren, Stockholm: Bonnier, 1954.

${ }^{543}$ M. Sjögren, Elsa Beskow och hennes värld, 1983, s. 60.

${ }^{544}$ S. Hammar, Solägget: Fantasi och verklighet i Elsa Beskows konst, 2002, s. 347.
} 
Massbilismens genombrott i Sverige skedde under 1950-talet och tiden och fram till mitten av 1960-talet ses ibland som "bilismens guldålder". ${ }^{545}$ Bilinnehavet $\mathrm{i}$ Sverige sköt i höjden och enbart under första hälften av 1950-talet steg antalet inregistrerade personbilar från 194000 till 536 000. Detta innebar en ökning från en bil per 36 invånare till en bil per 13 invånare och Sverige uppnådde därmed Europas högsta biltäthet. ${ }^{56} 1956$ skrev den dåvarande kommunikationsministern Sven Andersson skriften Har vi råd med bilen? i vilken han konstaterar att:

Bilägare finns nu i alla samhällsklasser och vi är på väg att rasera de skrankor som ännu finns kvar. Frågan är om inte bilismens utveckling är det mest påtagliga i vår tids demokratisering. ${ }^{547}$

När allt fler människor började använda bilen till och från arbetet kunde också arbetsplatserna förläggas längre bort från hemmet. Människor var inte längre beroende av kollektiva transporter i samma utsträckning. Bilen användes dock fortfarande i huvudsak för semesterresor eller söndagsutflykter tillsammans med familjen och på så vis överfördes bilsamhällets kultur på barnen. Olle Hagman menar att under 1950-talet utvecklades bilen till att bli en slags förlängning av vardagsrummet där familjen kunde samlas och resa ut i världen. Varje familjemedlem hade sin bestämda plats i såväl bilen som i den sociala ordningen. ${ }^{548}$

Under 1950-talet hade de som ifrågasatte utvecklingen mot ett bilsamhälle svårt att få sina röster hörda. En flesta av de problem som togs upp för diskussion var av teknisk karaktär och lösningen på dessa ansågs vara fler bilar, vägar, gator och parkeringsplatser. ${ }^{549}$ Bilismens snabba utveckling i Sverige ledde till omfattande förändringar i den fysiska samhällsstrukturen. Hagman konstaterar att förmodligen har ingen annan mänsklig teknik någonsin medfört större ingrepp i

\footnotetext{
${ }^{545}$ O. Hagman, Bilen, naturen och det moderna: Om natursynens omvandlingar $i$ det svenska bilsamhället, diss., Göteborgs universitet, Göteborg, 1999, s. 35.

${ }^{546}$ P. Lundin, Bilsamhället: Ideologi, expertis och regelskapande i efterkrigstidens Sverige", diss., Kungliga Tekniska högskolan, Stockholm, 2008, s. 7-21. Se även E. Lindgren, Samhällsförändring på väg: Perspektiv på den svenska bilismens utveckling mellan 1950 och 2007, diss., Umeå universitet, Umeå, 2010.

${ }^{547}$ S. Andersson, Har vi råd med bilen? Stockholm: Tiden, 1956, s. 3.

${ }^{548}$ O. Hagman, Bilen, naturen och det moderna: Om natursynens omvandlingar $i$ det svenska bilsamhället, 1999, s. 35, 57.

${ }^{549}$ Ibid., s. 32, 35.
} 
naturen än den massbilism som utvecklades under 1900 -talet. ${ }^{550}$ Trots att det rådde en optimistisk syn på bilismen och att den för sin samtid framstod som en naturkraft som var omöjlig att hejda, väckte dess konsekvenser med tiden debatt. Trängsel och trafikolyckor var inte nya inslag, men i massbilismens spår ökade dessa problem dramatiskt. ${ }^{551}$ Problemen speglades genom intensiva och upprörda debatter om trafiksäkerhet på dagstidningarnas ledar- och kultursidor under 1950- och 1960-talen. ${ }^{552}$

Sagan om "Den gröna bilen" från 1952 kan vid en första genomläsning tolkas som att den främst vill varna för alkoholens konsekvenser, men utifrån ett teknikdidaktiskt perspektiv finns samtidigt i text och bild sådant som kan tolkas som ett budskap om teknik. I berättelsen är tekniken (bilen) en antropomorf med en stark egen vilja. Den är till och med så "mänsklig" att den kan dricka sig onykter på bensin.

\author{
Det var en bil \\ som blev alldeles tokig, \\ för den hade druckit \\ för mycket bensin. \\ Den gav sig iväg \\ när chauffören var i boden \\ och rusade ensam \\ på vägen ut. ${ }^{553}$
}

Dess vingliga färd får människor och djur att fly åt sidorna för att undvika att bli påkörda och när den passerar en gammal gumma med en äggkorg, blir gumman så rädd att hon ramlar omkull. Inte ens polisen får hejd på dess vilda färd. Tekniken skildras som autonom: den tar egna initiativ och är därmed en fara för människor-

\footnotetext{
${ }^{550}$ Ibid., s. 113.

${ }^{551}$ P. Lundin, Bilsamhället: Ideologi, expertis och regelskapande i efterkrigstidens Sverige, 2008, s. 17-21.

${ }^{552}$ J. Anshelm, Rekordårens tbc: Debatten om trafiksäkerhet $i$ Sverige 1945-1965, Tema Teknik och social förändring, Linköpings universitet, Linköping, 2005.

${ }^{553}$ E. Beskow, "Den gröna bilen" i Röda bussen och gröna bilen: Bilderbok till Johan från farmor, Stockholm: Bonnier, 1952, opag.
} 


\section{Tekniklandskapet i Elsa Beskows sagor}

na som kommer i kontakt med den. På så vis skiljer sig här den tekniska antropomorfen i "Den gröna bilen" från antropomorferna i Witts tekniska sagor, då dessa inte är lika explicit deterministiska utan snarare har till uppgift att skapa en känsla av samhörighet och förståelse mellan människa och teknik.

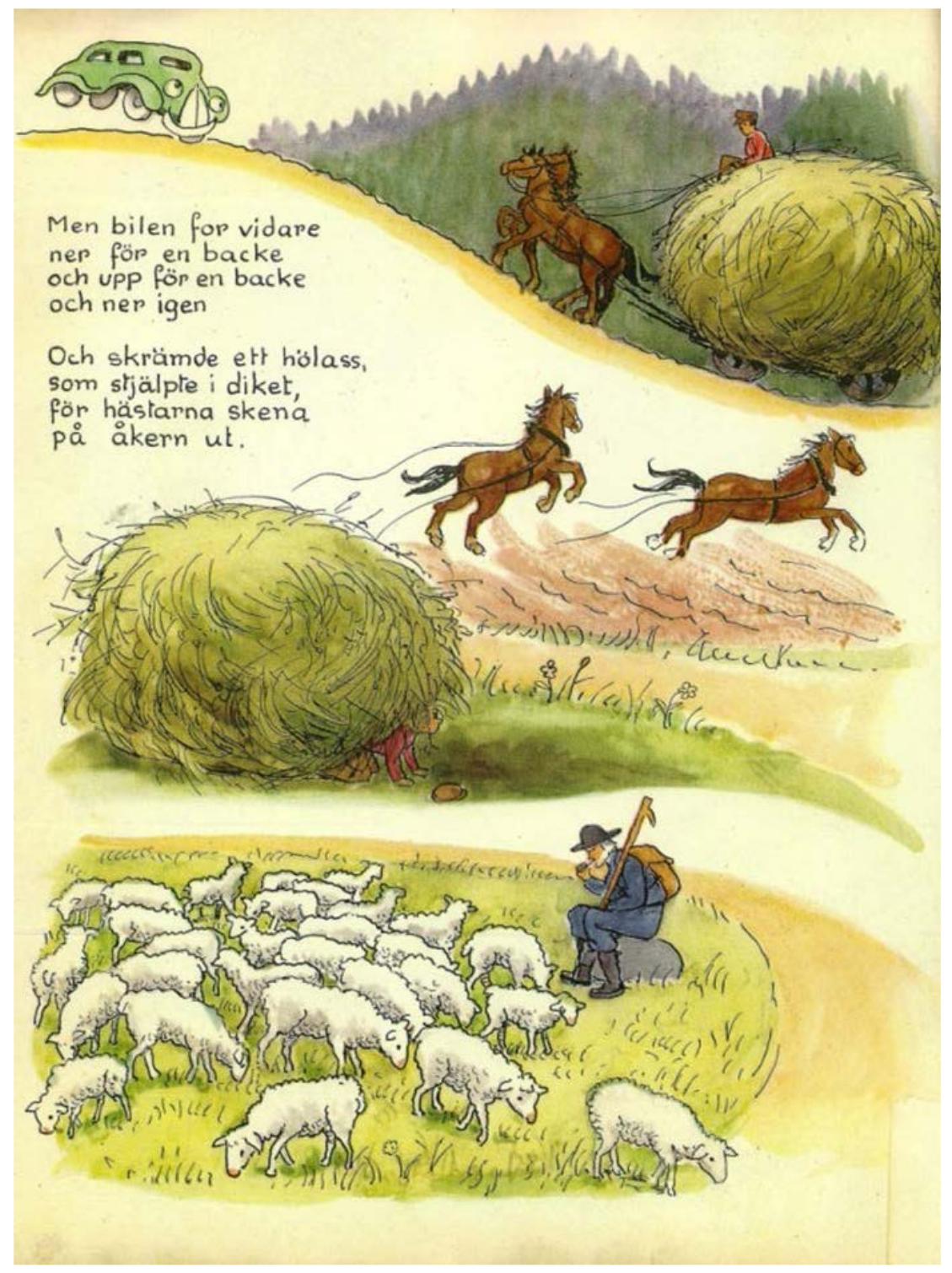

Bild 5.4: Illustration från ”Den gröna bilen” (Elsa Beskow, 1952) 
När den gröna bilen kommer ut på landet skiftar illustrationerna från dovt grön till klara färger. Bilen skrämmer ett hölass som välter och hästarna skenar iväg ut på åkern. En herde sitter och röker pipa, omgiven av sina får, men fårskocken blir skrämd av bilen och springer iväg (se bild 5.4). Fåraherden springer efter och försöker hejda dem. Därefter möter bilen en flock med kor som vägrar flytta på sig:

\author{
Och de ville inte \\ gå undan för bilen, \\ de stod där och blängde \\ och bölade: "muuuu!"554
}

Den "stackars bilen" blir då så rädd att den snurrar runt. På sidan som följer far bilen ner i en å och fiskarna i vattnet flyr åt alla håll, liksom fåglarna på himlen. "På stunden" blir bilen "alldeles klok" och den står i vattnet, fryser och längtar hem. Till sist bogseras den leriga bilen upp med hjälp av polis och vuxna och barn hjälps åt att göra den ren. Därefter får två hästar dra hem den till garaget:

\author{
Och hästarna gnäggade \\ Åt stackars bilen, \\ De skratta' och sa: \\ "Det var rätt åt dej"555
}

I sagan är mötet mellan gammalt och nytt dramatiskt. Den nya tekniken (bilen) är svår att kontrollera och den skrämmer både människor och djur i sin vilda framfart. När bilen till sist hamnar i ån, är det ett slags naturens seger över tekniken. Likaså är det den äldre pålitliga jordbrukstekniken (bonden med hästarna) som till sist får bogsera hem den slokörade bilen. Berättelsen kan tolkas som en metaforisk varning för vad som sker när människan förlorar kontrollen över sin teknik. Den blir då opålitlig och kan ta sina egna oförutsägbara vägar. Pålitligare är dock den äldre, väl beprövade tekniken som i sagan visar sin överlägsenhet. Den sista bilden, när bilen står utanför garaget med den glade chauffören vid ratten, visar att när tekniken är under kontroll så är den glänsande fin.

\footnotetext{
${ }^{554}$ Ibid., opag.

${ }^{555}$ Ibid., opag.
} 
Budskapet i berättelsen har likheter med Elluls tanke om att den moderna tekniken följer sina egna lagar och därmed kan beskrivas som autonom. ${ }^{556}$ Langdon Winner, som avfärdar denna tanke, menar istället att synsättet att tekniken lever sitt eget liv snarare är en reaktion på den snabba tekniska utvecklingen. Den autonoma synen på tekniken är istället, enligt Winner, ett uttryck för "jag förstår inte vad som sker omkring mig" ${ }^{557}$ En sådan tolkning av sagan om "Den gröna bilen” är möjlig, men budskapet kan också tolkas som en varning för teknikens oförutsägbara konsekvenser, alternativt en uppmaning till försiktighet i trafiken.

I Sverige stod skolbarnen tidigt i fokus för ökad trafiksäkerhet. Skolmaterial togs fram och man utbildade lärarna i ämnet. Senare kom också de trafikundervisande poliserna in skolan. Trafikundervisning i skolan prövades redan 1938 och under 1950-talet kom den in i ett nytt skede. Tillsammans med Skolöverstyrelsen producerade Nationalföreningen för trafiksäkerhetens främjande, NTF, världens första lärarhandledning för trafikundervisning 1952. Undervisningen skedde bland annat utifrån populära skolplanscher. ${ }^{558}$

I "Den gröna bilen" sker ett möte mellan det urbana samhället (bilen) och naturen/landsbygden. Hagman skriver att det moderna och industriella samhället ledde till en uppdelning av naturen; å ena sidan som ett produktionslandskap - ett landskap som formats om av människan som offras för välståndet, å andra sidan ett rekreationslandskap. Enligt Hagman kan bilen och vägarna ses som förbindelselänkar mellan de båda sidorna. Vägen har exempelvis en dubbelroll och tillhör båda sidorna - både den natur som "offrats" och den som avsatts för rekreation. Bilen är det redskap med vilket människan förflyttar sig mellan produktions- och rekreationssfären. På så vis, menar Hagman, uttrycker bilen och det tekniska system som den ingår $\mathrm{i}$, hur naturen får underordna sig människan på ett konkret sätt. Liksom järnvägen är det moderna vägbyggandets mål raka, breda och jämna vägar och genom tekniker som att schakta undan, fylla ut och bygga broar och

\footnotetext{
${ }^{556}$ J. Ellul, The technological society, 1964, s. 14.

${ }^{557}$ L. Winner, Autonomous technology: Technics-out-of-control as a theme in political thought, 1977, s. 28.

${ }^{558}$ NTF, "Hundra år med trafiksäkerhet", http://www.ntf.se/omoss/pdf/ntf\%20historia.pdf (läst 2013-11-23)
} 
tunnlar kan hindren i naturen överbryggas. ${ }^{559}$ Utifrån ett sådant perspektiv kan bilen i sagan om "Den gröna bilen" tolkas som en överbryggare mellan natur och urbanitet.

Berättelsen företräder inte en biocentrisk natursyn, då det är människans teknik som står i berättelsens fokus. Däremot kan den tekniska framstegstron tolkas som svag, då den äldre tekniken skildras som både bättre och mer pålitlig än den nyare.

\section{Sammanfattande analys av Elsa Beskows sagor}

Tekniklandskapen i de sagor av Elsa Beskow som här har blivit föremål för analys innehåller alla fyra budskap om teknik. I sagan om "Herr Klumpedump från Klumpedonien" lyfts barnens eget skapande fram som betydelsefullt. I samstämmighet med pedagoger som Key och Kerschensteiner finns ett budskap om att barnet bör vara självverksamt samt att handens arbete leder till kunskaper. Att barnen i sagan modellerar, tecknar och konstruerar i material som papp, trä och lera har likheter med Kerschensteiners pedagogiska idéer. ${ }^{560}$

"Herr Klumpedump från Klumpedonien" förmedlar budskapet att de maskinellt och fabrikstillverkade tingen saknar både liv och själ. Dessutom förtingligar (reifierar) industrialiseringen människan och reducerar henne till att bli en likriktad del av det industriella samhällets maskineri. Det fabrikstillverkade står i kontrast till den mer hantverksinriktade teknik som människan skapar utifrån sin fantasi och med hjälp av sina händer. I sagan tillmäts barnens eget skapande stor betydelse, medan de fabrikstillverkade leksakerna betraktas som mer eller mindre skräp. I ett samhälle där det masstillverkade hyllas, går det unika och levande förlorat. I sagan finns en varning för att människan kan bli ett offer för den materiella världen om förmågan att se bortom tingen går förlorad. Människan blir en platt, tråkig karaktär i en konstgjord värld, där tingen tillmäts större betydelse än människorna. Hyllandet av hantverket, liksom kritiken av det industritillverkade i sagan, har likheter med den kritik av industrisamhället som Arts and Crafts Movement stod för och som företräddes av bland andra William Morris. Inom rörelsen betraktades

\footnotetext{
${ }^{559}$ O. Hagman, Bilen, naturen och det moderna: Om natursynens omvandlingar $i$ det svenska bilsamhället, 1999, s. 94-95.

${ }^{560}$ N. O. Bruce, Svenska folkskolans historia. D. 4. Det svenska folkundervisningsväsendet 19001920, 1940, s. 418-420.
} 
hantverket som en förening av tanke och känsla samt kropp och själ och arbetet är betydelsefullt. ${ }^{561}$ I "Herr Klumpedump från Klumpedonien" är arbetet inte bara viktigt utan också roligt och utvecklande. När "draken", det materialistiska tänkandet, väl är dräpt kan människorna återta herraväldet över utvecklingen. Budskapet om teknik är, emellertid, något tvetydigt eftersom berättelsen samtidigt skildrar tekniken som något som är både roligt och något som människan kan använda sig av för att lösa svåra problem.

I berättelsen om "Doktor Klokamundus' uppfinning" skildras ett futuristiskt samhälle som påminner om utopisten Edward Bellamys maskindominerade utopi, där allt arbete ska skötas med hjälp av maskiner. ${ }^{562}$ I Kringelkrokien har tilltron till tekniken och vetenskapen gått så långt att teknik används för att lösa det mesta och den fungerar som ett maktmedel och redskap för att likrikta människor. Här, liksom i "Herr Klumpedump från Klumpedonien", leder teknikutvecklingen till att människorna förtingligas. Till och med den mänskliga samvaron anses kunna ersättas av teknik. Som en följd av den alienering teknikutvecklingen lett till, ges barnen allt mindre uppmärksamhet, vilket får konsekvenser för deras uppförande. Men istället för att se de bakomliggande orsakerna tror de vuxna att tekniken, en högteknologisk uppfostringsmaskin, ska lösa problemet. Sagan kan dock inte sägas ge uttryck för ett teknikdeterministiskt synsätt eftersom barnen väljer att gå sin egen väg och tekniken lyckas heller inte lösa problemen. Det finns alternativ till storskaliga tekniska lösningar och människorna i berättelsen har ett val. Att sagan får ett lyckligt slut beror på att barnen flyr från uppfostringsmaskinen och får leva Robinson Crusoe-liv under en tid. Med hjälp av sin fantasi och kreativitet utvecklar de sina tekniska färdigheter, samtidigt som erfarenheterna bidrar till deras fostran. Precis som i sagan om "Herr Klumpedump från Klumpedonien", liksom i Nils

\footnotetext{
${ }^{561}$ R. Ambjörnsson, Fantasin till makten! Utopiska idéer $i$ västerlandet under fem hundra år, 2004, s. 175-192; T. Frängsmyr, Framsteg eller förfall: Framtidsbilder och utopier $i$ västerländsk tanketradition, 1990, s. 154-160; B. Sundin, "Ljus och jord! Natur och kultur på Storgården", 1984, s. 346-347.

${ }^{562}$ T. Frängsmyr, Framsteg eller förfall: Framtidsbilder och utopier $i$ västerländsk tanketradition, 1990, s. 141-150.
} 
Holgersson, finns här ett budskap i Rousseausk anda om att det är genom erfarenheter man lär sig bäst. ${ }^{563}$

I "När stora blåbärsberget kom till stan" skildras mötet mellan naturen och en modern och urbaniserad värld. När stadsflickan Greta hänförs av hur vackert berget är, är det den naturliga, vilda och orörda naturen som hyllas - inte den "tuktade" och "tämjda" som i Lagerlöfs berättelse om Nils Holgersson. Naturen är besjälad, antar mänsklig gestalt och genom bergtrollet förvandlas den till en antropomorf. I sagan görs ett försök att integrera naturen i staden, men det misslyckas när människorna försöker exploatera berget. Genom den vildmarksromantiserade gestaltningen av den besjälade naturen förmedlas en något svagare antropocentrisk natursyn i berättelsen jämfört med Nils Holgersson. Sagan om blåbärsberget slutar inte i någon idyll. Stadsmänniskornas girighet och oförmåga att uppskatta bergets skönhet leder till att bergtrollet får nog och flyr därifrån. Naturen slår tillbaka och lämnar de förvånade människorna kvar i sitt eget skräp. Någon explicit kritik mot tekniken i sig finns inte i berättelsen, men däremot en varning för vad som sker när människan förlorar respekten för naturen och försöker utnyttja den utifrån egna, egoistiska behov.

I sagan "Den gröna bilen" kan bilen i berättelsen tolkas som en metafor för ett dramatiskt möte mellan ett äldre jordbrukssamhälle och industrisamhället. Men bilen fungerar också som en länk som knyter samman stad och landsbygd när människorna med hjälp av bilen smidigt kan förflytta sig mellan dessa båda världar. Det finns samtidigt en varning för vad som kan ske om människan förlorar herraväldet över den nyare tekniken: den kan då bli autonom och löpa amok. Trots det förkastas inte den, även om det är den äldre tekniken som i slutänden visar sig vara den mest pålitliga.

Sammanfattningsvis finns i de sagor av Elsa Beskow som här valts ut för analys ett budskap som kan tolkas som en implicit kritik av den industriella och tekniska utvecklingen av samhället. I skildringen av sagornas tekniklandskap framställs samtidigt tekniken som rolig, spännande och som något som kan lösa människans problem. Ingen av berättelserna kan sägas ta helt avstånd från teknisk utveckling utan har snarare en tekniksyn som har likheter med Kranzbergs beskrivning av tekniken som vare sig "god", "ond" eller "neutral". Tekniken är kontext-

\footnotetext{
${ }^{563}$ G. Klingberg, Svensk barn- och ungdomslitteratur 1591-1839: En pedagogikhistorisk och bibliografisk översikt, 1964, s. 193-194; L. Kåreland, Barnboken i samhället, 2013, s. 19.
} 
beroende och en teknik som utvecklas i ett gott syfte för några, kan få oanade och negativa konsekvenser för andra. ${ }^{564}$ I likhet med Nils Holgersson och de tekniska sagorna företräder Beskows sagor sammantaget framtidssynen om det effektiva samhället snarare än en önskan om tillbakagång till ett samhälle helt i samklang med naturen. ${ }^{565}$ Den av de fyra sagorna som tydligast företräder en viss syn på naturen är "När stora blåbärsberget kom till stan". Det är dock ingen biocentrisk sådan som framträder eftersom budskapet att människan är en bland alla andra arter, och därmed en del av naturen, saknas. Sagan kan snarare tolkas som att människa och natur bör leva sida vid sida samt att människan bör ta mer hänsyn till naturen. Därmed överensstämmer natursynen närmast med vad Dobson benämner som en svag antropocentrism. ${ }^{566}$

Karl-Aage Schwartzkopfs böcker om familjen Tuff-Tuff är ungefär samtida med "Den gröna bilen", men till skillnad mot Beskows saga skildras tekniken i böckernas tekniklandskap om tågfamiljen som något oproblematiskt och naturen fungerar endast som en kuliss i berättelserna.

\footnotetext{
${ }^{564}$ M. Kranzberg, “Technology and history: 'Kranzberg's Laws”, 1986, s. 544-560.

${ }^{565}$ T. Frängsmyr, Framsteg eller förfall: Framtidsbilder och utopier $i$ västerländsk tanketradition, 1990, s. 134-135.
}

${ }^{566}$ A. Dobson, Green political thought, 2000, s. 51-61. 



\section{KAPITEL 6}

\section{Tekniklandskapet i Karl-Aage Schwartzkopfs barnböcker}

\section{Karl-Aage Schwartzkopf (1920-2009)}

Författaren, journalisten och fjällflygaren Karl-Aage Schwartzkopf föddes i Lund 1920 och växte upp i Osby. ${ }^{567}$ Under andra världskriget var Schwartzkopf gränspolis i Lapplandsfjällen. ${ }^{568}$ I en intervju i tidskriften Fjället 2003 berättar han att han på 1940-talet också arbetade som fjällförare åt Svenska Turistföreningen. Arbetet handlade främst om att bära utrustning åt vetenskapsmän som besökte området samt att sköta båttransporter. Med tiden kom Schwartzkopf att bli redaktör för Fjällklubbens tidskrift Till Fjälls i vilken han skrev ett tiotal artiklar. Han bidrog därutöver med artiklar till tidningen Levande livet vars fokus var "det äventyrliga i tillvaron."569 Schwartzkopfs första barnbok, Familjen Tuff-Tuff kom ut 1949. Förutom 43 barnböcker bidrog han med ett 25-tal sagor i sagosamlingarna Bland tomtar och troll (från 1952 och framåt) och ungefär 200 tv- och radiopjäser. ${ }^{570}$ De följande decennierna utkom Schwartzkopf med en ny bok så gott som årligen. Många av dem har getts ut i senare upplagor och även översatts. ${ }^{571}$ Han skrev dessutom manuset till 1968 års julkalender för radio och tv, Klart spår till

\footnotetext{
${ }^{567}$ E. Selin, ’Intervju med Karl-Aage Schwartzkopf”, Fjället. Svenska fjällklubben, nr. 1, 2003, http://www.fjallklubben.se/fjallet/artiklar/1-03art2.htm (läst 2013-02-10).

${ }^{568}$ G. Bolin m.fl., Barn och böcker: En orientering, Stockholm: Rabén \& Sjögren, 1972, s. 215.

${ }^{569}$ E. Selin, "Intervju med Karl-Aage Schwartzkopf", 2003.

570 S. C. Swahn, "Karl-Aage Schwartzkopf" i De läses än: Från Bertil Almqvist till Anna Lisa Wärnlöf. Porträtt av tolv svenska barnboksförfattare, C. Brattström (red.), Lund: Bibliotekstjänst, 1987, s. 131-144.

${ }^{571}$ E. Selin, ’Intervju med K.-A. Schwartzkopf", 2003.
} 
Tomteboda som samma år gavs ut i bokform. ${ }^{572}$ Schwartzkopf hyste ett stort intresse för tåg- och järnvägshistoria och tåg och järnvägar är återkommande teman i hans barnböcker. Han författade också böcker som handlar om fjällflygning och kunde i dem få användning för sina kunskaper om flyget. Förutom skönlitterära barnböcker har han skrivit faktaböcker om järnvägen, exempelvis När järnvägen kom till Stockholm (1960).

Nina Lekander konstaterar att "den sorgligt bortglömde" Karl-Aage Schwartzkopf tillhörde samma generation författare som Thomas Funck, Gösta Knutsson, Astrid Lindgren, Tove Jansson, Lennart Hellsing och Nils-Olof Franzén. ${ }^{573}$ Att han är så pass bortglömd kan tyckas förvånande med tanke på hans enorma produktion samt att han tilldelades ett antal litterära stipendier, som Kungastipendiet (1952), Litteraturfrämjandets stipendium (1967), Sveriges författarfonds konstnärsbidrag (1971, 1972), Sveriges författarfonds arbetsstipendium (1973-1977), Nordiskt stipendium (Norge, 1975) samt innehade garanterad författarpenning mellan åren 1978 och 1982. Enligt författarfondens statistik tillhörde Karl-Aage Schwartzskop de författare som hade över 50000 boklån under 1960- och 70-talen och han var därmed en av de hundra mest utlånade författarna. ${ }^{574}$ I statistiken för 1979-1981 har dock Schwartzkopf försvunnit, vilket talar för att hans popularitet sjönk med åren. I den senare utlåningsstatistiken finns dock endast författare med över 100000 lån på folk- och skolbibliotek upptagna. Det indikerar att bokutlåningen ökade stort runt 1980 (författare nr 106 hade 1981 över 101000 boklån).

Humor är det som framför allt kännetecknar Schwartzkopfs barnböcker. Margareta Strömstedt skriver att när det är som bäst i hans böcker så utvecklas Schwatzkopfs berättelser till "[...] en vilt blommande festlig absurdism". ${ }^{575}$ I ett författarporträtt av Schwartzkopf konstaterar Sven Christian Swahn att författaren

\footnotetext{
${ }^{572}$ Sveriges Radio, ”1968 års julkalender. Klart spår till Tomteboda, http://sverigesradio.se/sida/artikel.aspx?programid=4155\&artikel=4668695 (läst 2012-11-28).

${ }^{573}$ N. Lekander, ”Bollen är stroppad”, Expressen kultur, 31 december 2010, http://www.expressen.se/kultur/bollen-ar-stroppad/ (läst 2012-11-10).

${ }^{574}$ Sveriges författarfond, Utlåningsstatistik, 1961-1977, Stockholm, 1978. Elsa Beskow låg under dessa år som nummer två, efter Astrid Lindgren som toppade statistiken med i genomsnitt ungefär en miljon boklån per år. Selma Lagerlöfs böcker låg också högt upp i utlåningsstatistiken fram till början av 1970-talet (plats 11-30).

${ }^{575}$ M. Strömstedt, "Från nonsens till crazy" i Läsning för barn: Orientering i dagens barnlitteratur, M. Strömstedt \& G. Ambjörnsson (red.), Stockholm: Bonnier fakta, 1983, s. 114.
} 


\section{Tekniklandskapet i Karl-Aage Schwartzkopfs barnböcker}

var uppenbart tjusad av järnvägarna som slingrade sig kring småländska sjöar och berg och han tyckte inte om när järnvägslinjerna försvann. Intresset för tåg var något som Schwartzkopf delade med många unga läsare och Swahns slutsats är att anledningen till att berättelser om tåg är så omtyckta är att barn ofta har ett personligt förhållande till både bilar och tåg. ${ }^{576}$

De berättelser av Schwartzkopf som här valts ut för analys är två av böckerna om tågfamiljen Tuff-Tuff samt de två böckerna om höghuset Talleborg. Urvalet motiveras av att i skildringen av berättelsernas tekniklandskap lyfts olika dimensioner av teknik fram. Berättelserna kan också tolkas som att de har ett budskap om tekniken och dess relation till natur och framtid.

\section{Handlingen i böckerna om familjen Tuff-Tuff}

Familjen Tuff-Tuff sändes först som serie på radion (1949) och blev sedan populära barnböcker. Böckerna trycktes i flera upplagor och gavs ut i serieform genom den danske tecknaren Gil Johansen. I Sverige publicerades serien först i Sagoserien och därefter i Pellefant. Under 1970-talet publicerades serien i Tyskland i serietidningen Bildermärchen under titeln "Familie Tuff-Tuff". ${ }^{577}$ Böckerna handlar om tågfamiljen Tuff-Tuff som består av pappa Loket, lilla koltendern Sotsvart, hans syster Finka och mamma Tuff-Tuff. Mamma Tuff-Tuff är en "värdig personvagn" med både andra och tredje klass. Familjen lever i trakterna av Krylbo och familjemedlemmarna, som är frisinnade och äventyrslystna, trotsar gärna auktoriteternas påbud. Stinsen på Krylbo station skäller och gnatar på familjen och hotar med att nästa gång han ertappar dem med att "hoppa av skenorna" för att äta blåbär, så kommer han att avskeda dem och skicka dem till skrotning. När det utbryter kaos vid "lokomotivkonserten" på Krylbo station får familjen Tuff-Tuff skulden och stinsen tvingar in dem i lokomotivfängelset. Familjen lyckas dock rymma och beger sig av på en resa över världen. Under sin flykt besöker familjen Tuff-Tuff först tivolit i Köpenhamn, fortsätter genom Tyskland, Schweiz och Balkan innan de

\footnotetext{
${ }^{576}$ S. C. Swahn, "Karl-Aage Schwartzkopf" i De läses än: Från Bertil Almqvist till Anna Lisa Wärnlöf. Porträtt av tolv svenska barnboksförfattare, 1987, s. 132.

577 ’Järnvägen 150 år. Tåget genom kulturhistorien”, Dagens Nyheter, 2 mars 2006, http://www.dn.se/kultur-noje/taget-genom-kulturhistorien/ (läst 2010-10-05); "Familjen TuffTuff', http://seriewikin.serieframjandet.se/index.php/Familjen_Tuff-Tuff (läst 2010-01-05).
} 
hoppar över Bosporen och färdas vidare genom Mindre Asien mot Afrika. Resans sista anhalt innan återfärden är Nordpolen dit de tar sig genom en tunnel som en märklig varelse, Mulle Tunnelgrävare, gräver åt dem.

Krigsslutet 1945 brukar inom svensk litteraturforskning tillskrivas den moderna svenska barnbokens genombrott. Nyorienteringen av barnlitteraturen efter krigsslutet handlade bland annat om att författarna började skildra världen utifrån ett barnperspektiv. Barnlitteraturen solidariserar sig med barnet och står på dess sida gentemot vuxenvärlden. ${ }^{578}$ Till de främsta förnyarna av den svenska barnlitteraturen vid denna tid räknas Astrid Lindgren, Lennart Hellsing och den finlandssvenska Tove Jansson. ${ }^{579}$ Tågfamiljens ständigt trotsande och ifrågasättande av auktoriteter (stinsen) kan tolkas som en metafor för relationen mellan barn och vuxen. Något annat som tågfamiljen har gemensamt med bland annat Lindgrens, Hellsings och Janssons böcker är att de ger sig av på äventyr till exotiska miljöer. I böckernas illustrationer är tågfamiljen antropomorfer där även kön framgår (se bild $6.1)$.

\footnotetext{
${ }^{578}$ L. Kåreland, "40-tals-modernismen och barnboken - vad har de gemensamt?" i Konsten att berätta för barn, Centrum för barnkulturforskning, Stockholms universitet, Stockholm, 1996, s. 121-133; L. Kåreland, Modernismen i barnkammaren: Barnlitteraturens 40-tal, Stockholm: Rabén \& Sjögren, 1999, s. 314; L. Kåreland, ”Barnlitteraturens utveckling i Sverige”, 2008.

${ }^{579}$ Ibid.; B. Westin, Children's literature in Sweden, 1996, s. 32.
} 


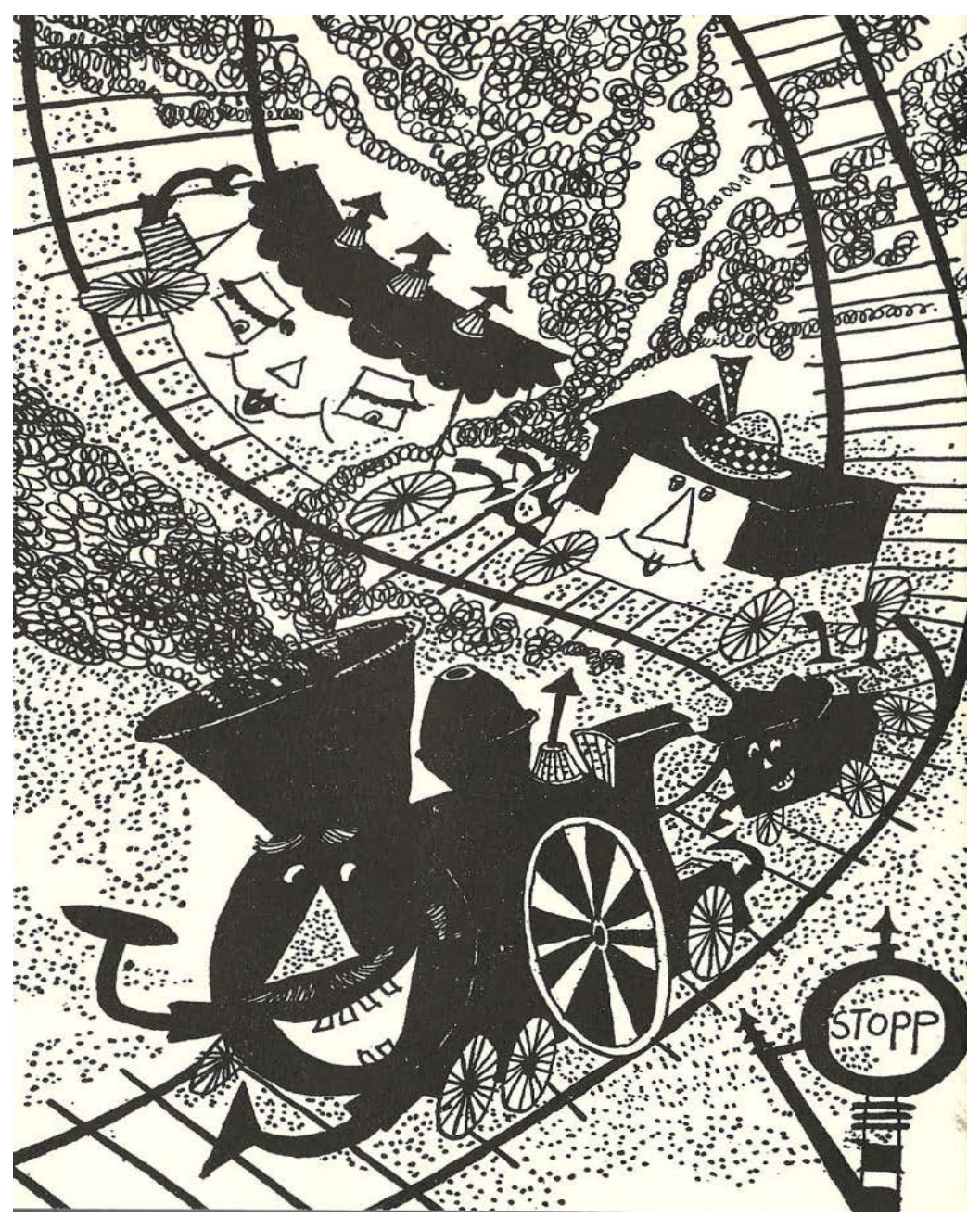

Bild 6.1: Illustration från Familjen Tuff-Tuff(Kerstin Hedeby, 1949/1966)

Bok nummer två om tågfamiljen, Hemma hos familjen Tuff-Tuff, publicerades 1950 och kom ut i ytterligare en upplaga 1966. Förutom att familjen deltar i Vasaloppet är handlingen huvudsakligen förlagd till stationen i Krylbo. Inledningsvis får familjen tillökning i form av en liten rälsbuss. Läsarna får sedan följa förberedelserna av dopet, hur Sotsvart söker till Visselgymnasiet och påbörjar sina studier där samt när tågen i Krylbo anordnar ett välgörenhetsarrangemang. Tågen i Australien har drabbats av torka och därför arrangeras en lokomotivcirkus med 
målet att samla in pengar till tiotusen flaskor sockerdricka som sedan ska skickas för att undsätta de uttorkade tågen.

Det som skiljer uppföljaren om tågfamiljen från den första är att den är en kapitelbok där de olika episoderna går att läsa som separata äventyr. I Hemma hos familjen Tuff-Tuff är tekniken framför allt närvarande genom de frekventa tekniska begreppen som finns invävda i dialogerna. Samma slags teknik finns både i människornas och i tågens värld. Det är hur de tekniska artefakterna används som skiljer människa och tåg åt.

\section{Tekniksynen i böckerna om familjen Tuff-Tuff}

Som tidigare nämnts i kapitlet om tekniklandskapet i Nils Holgersson har tåg fătt agera såväl positiv som negativ metafor för hur den moderna tekniken bröt sig genom landskapet vid industrialiseringens genombrott. Järnvägen hade en viktig roll i byggandet av den moderna nationalstaten vid slutet av 1800-talet och den kom att fungera som symbol för framåtskridande, människans triumf över naturen samt erövring av naturen. ${ }^{580}$ Utbyggnaden av kommunikationsnätet ledde till en dramatisk förändring av geografin och en integrering av ekonomi och kultur, såväl på nationell nivå som internationellt. Järnvägen, liksom andra kommunikationsmedel, öppnade och skapade nya territorier och omformade natur och kulturlandskap. ${ }^{581}$

Den svenska järnvägshistorien går tillbaka till 1850-talet. Redan 1856 hade järnvägssträckorna Malmö-Lund, Göteborg-Jonsered och Örebro-Ervalla-Nora öppnats för trafik. I en historisk bok om järnvägen som Schwartzkopf skrev tillsammans med Kurt Högman, konstateras att vid denna tid fick stockholmarna nöja

\footnotetext{
${ }^{580}$ M. Hård \& A. Jamison, Hubris and hybrids: A cultural history of technology and science, 2005, s. 143; E. G. Ingersoll, Representations of science and technology in British literature since 1880, 1992, s. 2; L. Marx, The machine in the garden: Technology and the pastoral ideal in America, 1964; D. E. Nye, American technological sublime, 1994, s. 59; M. L. Smith, "Recourse of empire: Landscapes of progress in technological America", 1994, s. 37-52; B. Sundin, Den kupade handen: Historien om människan och tekniken, 2., utök. uppl., Stockholm: Carlsson, 2006, s. 187.

${ }^{581}$ M. Hård \& A. Jamison, Hubris and hybrids: A cultural history of technology and science, 2005, s. 174-175; W. Schivelbusch, The railway journey: The industrialization of time and space in the $19^{\text {th }}$ century, Berkley, Calif.: University of California Press, 1986; B. Sundin, Den kupade handen: Historien om människan och tekniken, 2006, s. 185-186.
} 


\section{Tekniklandskapet i Karl-Aage Schwartzkopfs barnböcker}

sig med att läsa om det nya kommunikationsmedlet i tidningarna: "[O]m frustande ånghästar, blanka räler, ${ }^{582}$ tunnlar, broar och viadukter". ${ }^{583}$ Samma år, 1856, bildades också Statens järnvägar. ${ }^{584}$ Järnvägsfrågan kom att bli en av de viktigaste politiska frågorna under 1850-talet. De beslut som riksdagen fattade då blev avgörande för det svenska järnvägssystemets utveckling. Än i dag har stambanorna i stort sett samma sträckning som när de byggdes. Det som ur ett internationellt perspektiv gör den svenska järnvägshistorien tämligen unik var statens direkta engagerande i järnvägsbyggande. Sverige var ett glest bebyggt land med långa avstånd. För att huvudjärnvägarna skulle byggas på ett sådant sätt att det samhällsekonomiskt skulle gynna hela Sverige, ansåg man att järnvägarna måste byggas i statlig regi. Risken fanns annars att järnvägssträckningarna skulle begränsas till sådana som var vinstmässigt intressanta för vissa aktörer. Därför kom staten att svara för merparten av järnvägsbyggandet fram till 1870. Därefter skedde en större del av utbyggnaden i enskild regi. De regionala järnvägarna betraktades som hörande till den enskilda sfären och byggandet av "bibanor" överläts till privata bolag. Genom behovet av samtrafik, fortsatte dock staten att ha stort inflytande. ${ }^{585}$

I och med järnvägen fick tid och avstånd nya dimensioner när man kunde färdas långa sträckor på mycket kortare tid. Utvecklingen av järnvägen banade väg för masstransporter. Gångavstånd satte inte längre gränserna för den urbana tillväxten och takten i stadsutvecklingen ökade snabbt. ${ }^{586}$ I Sverige var spårvägen ett annat viktigt kommunikationsmedel. Allteftersom elektrifieringen fortskred, kom de elektriska spårvagnarna att ersätta de som drogs med hästar. Det dröjde till efter

\footnotetext{
582 "Räl" kallas de skenor som spårfordon rullar på.

${ }^{583}$ K. Högman \& K.-A. Schwartzkopf, När järnvägen kom till Stockholm: Ett hundraårsminne, Stockholm: Järnvägsstyrelsen, 1960, s. 5.

${ }^{584}$ Statens Järnvägar, ”Svensk järnvägshistoria”, http://www.statensjarnvagar.se/info.asp/id/1515 (läst 2013-03-12).

585 J. Hult, "Bondeland blir industriland: 1870-1914", 1989a, s. 239-240; A. Kaijser, I fädrens spår: Den svenska infrastrukturens historiska utveckling och framtida utmaningar, Stockholm: Carlsson, 1994; A. Kaijser, "Den hjälpande handen: staten och infrastrukturen" i Då förändras Sverige: 25 experter beskriver drivkrafter bakom utvecklingen, E. Giertz (red.), Lund: Studentlitteratur, 2008, s. 65-70.

${ }^{586}$ L. Mumford, The city in history: Its origins, its transformations, and its prospects, New York: Harcourt Brace Jovanovich, 1961, s. 429.
} 


\section{Tekniklandskapet i Karl-Aage Schwartzkopfs barnböcker}

andra världskriget innan spårvägstrafikens betydelse kom att minska när bussar och ökad privatbilism tog över. ${ }^{587}$

Att just tåg utnyttjas som antropomorf $\mathrm{i}$ en barnbok går därmed att relatera till att järnvägen är en del av ett infrastruktursystem som har haft stor betydelse för samhällsutvecklingen och därmed har ett symboliskt värde. Som system är järnvägen allmänt tillgängligt och något som många människor utnyttjar och har en relation till. Att tåg agerar huvudaktör i barnböcker är därför inte unikt. Redan 1875 skrev den här tidigare omnämnde Richard Gustafsson (1840-1918) en saga, Lokomotivet, där ett lok vid namn Tor är levande, har känslor och kan tala. ${ }^{58}$ Vidare har bland annat Graham Greene skrivit en barnbok om ett tåg, The Little Train (1946), som senare kom ut på svenska (1974). ${ }^{589}$

I böckerna om familjen Tuff-Tuff är det den lilla järnvägsstationen Krylbo och dess tåg och vagnar som är i händelsernas centrum. Verklighetens Krylbo station öppnades 1873 och blev i början av 1900-talet en av Sveriges viktigaste järnvägsknutar. Avesta Krylbo är än i dag en station, men fungerar dock främst som en resandestation för resenärer till och från Avesta. Schwartzkopfs adventskalender Klart spår till Tomteboda utspelar sig på järnvägsstationen Tomteboda, det vill säga även den en i verkligheten existerande järnvägsstation.

I familjen Tuff-Tuff-böckerna är det framför allt samverkan mellan de olika komponenterna inom det större tekniska järnvägssystemet som är i fokus samt vilken inbördes inverkan dessa har på varandra. Tågfamiljen, en viktig del av systemet, bryter sig ur och går sin egen väg, vilket får konsekvenser för passagerarna från Krylbo. De blir väntandes kvar på Krylbo station.

Det tekniklandskap som berättelserna om familjen Tuff-Tuff utspelar sig i innehåller många tåg- och järnvägsrelaterade begrepp. I inledningen i den första boken presenteras familjen som består av lok samt olika slags järnvägsvagnar. Likaså redogörs för signalsystemet och vad de olika signalerna på "lokomotivspråk" betyder. Förutom alla exempel på lok och vagnar (godsvagn, växellok, koltender, snälltåg med flera) förekommer begrepp som stins, ångpanna, perrong,

\footnotetext{
${ }^{587}$ J. Hult, "Tekniken mitt ibland oss: 1914-1970”, 1989c, s. 295-296. För vidare läsning se exempelvis T. Ekman, Spår i vägen: Teknikval, politik och spårvägstrafik i Stockholm 1920-2002, diss., Kungliga Tekniska högskolan, Stockholm, 2003.

${ }^{588}$ E. von Zweigbergk, Barnboken i Sverige 1750-1950, 1965, s. 210.

${ }^{589}$ G. Greene, Det lilla tåget, Malmö: Bergh, 1974.
} 
tidtabell, semafor, vändskiva och skenor. Några närmare förklaringar av dessa ges inte utan de vävs in i ett sammanhang. De tekniska begreppen förekommer också i dialogerna, som när Sotsvart konstaterar att "[...] de där långhalsade girafferna klarar man ju av med en buffert". 590

I böckerna är det endast lok och tågvagnar, inga andra tekniska artefakter, som är antropomorfer med mänskliga känslor och attribut. I Familjen Tuff-Tuff fryser familjen när de kommer till Nordpolen och får därför bråttom att ta fram sina "magvärmare", "skorstensskydd", "hjulkalsonger", "takluvor" och "buffertvantar". ${ }^{591}$ Familjen deltar också i mänskliga aktiviteter som konserter, luciatåg, simtävlingar, spelar bandymatch och åker skridskor. Också djuren agerar och tänker som människor.

I Hemma hos familjen Tuff-Tuff antar medlemmarna i tågfamiljen än mer mänsklig gestalt. Berättelsen kan tolkas som en fabel med budskapet att "tåg är också människor". I det inledande kapitlet föder mamma Tuff-Tuff ett litet "barn" i form av en rälsbuss. Själva födseln sker i reparationsverkstaden med Samarita Sjukvagn som barnmorska. Rulle Tankvagn får rulla in med varmvatten till "förlossningssalen". Alla stationens tåg och vagnar står förväntansfulla och väntar utanför. När sedan den lilla nyfödda rälsbussen visas upp beskrivs det som "något alldeles extra nyfött" och Finka och Sotsvart får komma fram för att titta på sin lillebror. Den lille rälsbussen "suger på buffertarna" och vill dricka mjölk. När han druckit sina femhundra liter, somnar han med buffertarna instuckna i den lilla röda dörren. ${ }^{592}$ Pappa Tuff-Tuff uppvaktar sin fru med en liten bukett med järnvägsskenor. Av stinsen får hon en semafor och Ville Växellok har med sig en egen "buffrigt tillverkad vindrutetorkare" som ska hjälpa den lille att torka tårarna ur rutorna. Onkel Tiff-Tiff dyker också upp och har med sig en present i form av en nappflaska i skinande plåt som är fylld med "den allra läckraste bensin". Mormor Tuff-Tuff har till och med gjort i ordning "blöjskydd" av ett gammalt perrongtak:

\footnotetext{
${ }^{590}$ K.-A. Schwartzkopf, Familjen Tuff-Tuff, 3 uppl., Stockholm: Geber, 1949/1966, s. 53. Buffert är en fjäderanordning som tar upp och dämpar tryckkrafterna mellan två järnvägsvagnar.

${ }^{591}$ Ibid., s. 128.

${ }^{592}$ K.-A. Schwartzkopf, Hemma hos familjen Tuff-Tuff, 2. uppl., Stockholm: Geber, 1950/1966, s. 12.
} 
- Måtte han bara inte förkyla sig och få hosta i den lilla motorn, sa hon ängsligt, för mormödrar är nu en gång mormödrar, antingen de är restaurangvagnar eller människor! ${ }^{593}$

Tågen använder kläder. Onkel Tiff-Tiff har både plåtkalsonger och järnvästar på sig och pappa Tuff-Tuff klär sig i skrotpyjamas och plåtfrack. Tågen kan likaså drabbas av sjukdomar som åderförkalkning, "pannsten" och "plåtreumatism".

Huvudkaraktärerna tillhör den äldre tekniken. Pappa Tuff-Tuff är exempelvis ett ånglok. De första ångloken i Sverige användes vid stambanebyggena i mitten av 1800-talet och var inköpta från England. Ett svenskt lok hade dock byggts åren 1847 och 1848, den så kallade "Förstlingen", vilken användes till en gruvjärnväg i Norberg. Kunskaperna som krävdes för att tillverka ånglok hade växt fram i arbetet med de första ångfartygen och det var grunden till att Motala Verkstad redan från början av 1860-talet kunde leverera ånglok. Den största tillverkaren blev senare Trollhättans Mekaniska Verkstad som hade levererat över 500 lok vid seklets slut. $^{594}$

Cirka 50 år innan böckerna om tågfamiljen skrevs (1895) invigdes Sveriges första elektrifierade järnväg. De elektriska loken klarade dubbelt så stor last, gick dubbelt så fort i uppförsbackar, klarade hårt klimat samt hade lägre driftkostnader. Detta ledde till en elektrifiering av järnvägsnätet i stor skala. Genom den kraftiga satsningen på eldrift kom Sverige att bli ledande på området. Järnvägsnätet och elkraftsnätet, två stora tekniska system, hade nu kopplats samman. Elektrifieringen gjorde dessutom Sverige mindre beroende av kolimport. Statens järnvägars sista ångdrivna lok togs ur tjänst 1972. Ett stort antal ånglok behölls som beredskapslok men de kom aldrig till användning. ${ }^{595}$ Samtidigt kom störningar i elförsörjningen att bli ett latent hot mot järnvägsdriften och i takt med att de gamla ångloken skrotades, började en medvetenhet om de stora tekniska systemens sårbarhet växa fram. $^{596}$

\footnotetext{
${ }^{593}$ Ibid., s. 14.

${ }^{594}$ J. Hult, ”Järn, ånga och ingeniörer: 1815-1870", 1989b, s. 201-202.

${ }^{595}$ Statens Järnvägar, "Svensk järnvägshistoria”, http://www.statensjarnvagar.se/info.asp/id/1515 (läst 2013-03-12).

${ }^{596}$ J. Hult, ”Tekniken mitt ibland oss: 1914-1970”, 1989c, s. 294.
} 


\section{Tekniklandskapet i Karl-Aage Schwartzkopfs barnböcker}

Den nya tekniken representeras i Familjen Tuff-Tuff av bland andra det elektriska detektivloket Skumpo från Schweiz. Skumpo intar sin "elektricitetsmiddag" när lokomotivpolisen ringer för att be om hjälp i jakten på den efterlysta tågfamiljen. Han blir då så arg att han sätter "elektriciteten i halsen" och hostar "flera meter" med långa gnistor $i$ telefonen. När han blir erbjuden en stor påse elektricitet $\mathrm{i}$ belöning antar han dock genast uppdraget.

I Hemma hos familjen Tuff-Tuff skildras spänningen mellan den äldre och nyare tekniken genom en världsmästerskapsmatch i tungviktsboxning mellan pappa Tuff-Tuff och det elektriska loket Bluff-Bluff, lokomotivvärldsmästaren från Chicago. Med stort självförtroende ger sig pappa Tuff-Tuff in i matchen och får in en träff på sin motståndare. Bluff-Bluff visar sig dock vara både den starkare och mest tekniskt avancerade av dem båda och pappa Tuff-Tuffs träffar är "som myggviskningar" i jämförelse med dem som Bluff-Bluff delar ut. Men när BluffBluff ska få den stora lagerkransen av nysmidd räls stiger mamma Tuff-Tuff fram och utmanar det elektriska loket. Mamma Tuff-Tuff ger sig inte förrän Bluff-Bluff rullar ut mellan repen och lämnar Krylbo. I hastigheten tappar han sina boxningshandskar och ur varje faller en hästsko. Alla inser då att boxningsmästaren var en riktig bluff jämfört med det genuina ångloket. Det är pappan i familjen som är loket och som därmed är familjens ledare, men det är mamma Tuff-Tuff som här är den starkare och får Bluff-Bluff på fall.

Förutom en maharadja i Indien, utgör människorna snarast ett hot mot tågfamiljen. Stinsen är en auktoritär förtryckare och tågkannibalerna i Afrika i Familjen Tuff-Tuff är hänsynslösa tågätare. När tågfamiljen kommer till Afrika omringas de och förs till kannibalbyn mitt i urskogen, men det är först när de kommer fram till byn som de inser vems fångar de är: "Hyddorna var nämligen byggda som små järnvägsstationer, och överallt låg det avgnagda lokomotivskorstenar och söndertuggade hjul på marken!" ${ }^{597}$ Tågkannibalerna svälter hellre än att äta något annat än tåg och så snart det sker en tågolycka i Afrika är de där och äter upp rubb och stubb. Lyckligtvis är tågkannibalerna (i likhet med stinsen) lättlurade och kan överlistas av tågfamiljen.

I beskrivningen av tågkannibalerna finns ett antal tekniska begrepp invävda. Kannibalerna sätter sig i en stor cirkel runt familjen och deras hovmästare delar ut

${ }^{597}$ K.-A. Schwartzkopf, Familjen Tuff-Tuff, 1949/1966, s. 71. 
matsedlarna som består av gamla tidtabeller. Tidtabellen fungerar som religiös text och när tågkannibalhövdingen kommer ut ur en av hyddorna reser sig alla och börjar läsa ur tabellen i korus. Kannibalernas hövding går sedan fram till en slipsten och slipar sina tänder, innan han tar sin tåggaffel och går fram till familjen. Hovmästaren delar ut stänkskärmar som tågkannibalerna fäster i sina mungipor. Middagen inleds med ett "smörgåsbord" bestående av en gammal blå spårvagn som skramlar in på festplatsen. Hövdingen går fram till en stor semafor. Han ändrar den från "stopp" till "ät" och inom mindre än en halv minut är spårvagnen uppäten "till minsta skruv". En kannibal har svalt en hel klinkapparat, vilket får som konsekvens att för varje steg han tar klinkar det i magen på honom. Kannibalerna borstar tänderna med riktigt vassa brynstenar och hövdingen tar på sig sin bästa haklapp med riktiga skenor på för att kunna gnaga på en hel vagn utan att behöva ta sönder den.

Berättelsen kan läsas som att tågfamiljen representerar en tekniskt överlägsen kultur, medan tågkannibalerna fortfarande befinner sig på ett primitivare utvecklingsstadium där det grundläggande behovet att finna föda är det primära. Därför saknar tågkannibalerna insikter om teknikens fördelar. Samtidigt är den afrikanska kontinenten något som pappa Tuff-Tuff har längtat till ända sedan han var litet leksakslokomotiv, eftersom alla människor där går omkring "kolsvarta som lokomotiv". Afrika företräder något exotiskt och spännande, men det är djuren som styr Afrika, inte människorna. Det koloniserande budskapet förstärks genom att tågfamiljens resa genom Afrika skildrar hur järnvägen stärker människans ställning som herre över naturen. Tåget drivs rätlinjigt fram med hjälp av en kraft som vägrar anpassa sig efter naturens beskaffenhet. ${ }^{598}$

Tekniken finns också representerad i böckerna genom alla de liknelser som löper som en röd tråd genom berättelserna. Liknelser görs mellan människa och teknik, mellan en teknik och en annan, naturen liknas vid teknik samt det omvända. Det är framför allt tekniken som utnyttjas för att beskriva människor och djur. Exempelvis har kannibalerna tänder som liknar plåtsaxar, naglar som ser ut som järnfilar och magar stora som masugnar. I ett annat kapitel finner familjen en stor

\footnotetext{
${ }^{598}$ Se exempelvis K. Johannisson, ”Det sköna i det vilda: En aspekt på naturen som mänsklig resurs", 1984, s. 70; W. Schivelbusch, The railway journey: The industrialization of time and space in the 19th century, 1986.
} 
giraff som liknar en jättelik byggnadsställning och skyskrapa. ${ }^{599}$ Exempel på olika slags förekommande liknelser i böckerna är:

Teknik liknas vid människa:

Filmstjärneloket Stinky Puff från Hollywood, som hade världens tjusigaste ångpanna och djupa, blå lyktor och en ångvissla som påminde om Jussi Björling. ${ }^{600}$

Bluff-Bluff hade vunnit och stod kvar i ringen med buffertarna i kors och försökte likna Napoleon. ${ }^{601}$

- Halledudanedå, sa mamma Tuff-Tuff och lät som en sagotant $\mathrm{i}$ rösten. ${ }^{602}$

Människa liknas vid teknik:

Hövdingen själv hade hunnit med mest av alla, och hans mage putade ut som en kupol. [...] När han slog sig på magen, lät det nästan som en plåtslagarverkstad där inne. ${ }^{603}$

I munnen hade [stinsen] en cigarr som han bolmade på och på huvudet sin höga hatt, som precis liknade en skorsten. ${ }^{604}$

Stinsen skrek som hundra tågvisslor, men kunde inte komma loss. ${ }^{605}$

\footnotetext{
${ }^{599}$ K.-A. Schwartzkopf, Familjen Tuff-Tuff, 1949/1966, s. 55, 57.

${ }^{600}$ K.-A. Schwartzkopf, Hemma hos familjen Tuff-Tuff, 1950/1966, s. 13.

${ }^{601}$ Ibid., s. 90.

${ }^{602}$ K.-A. Schwartzkopf, Familjen Tuff-Tuff, 1949/1966, s. 78.

${ }^{603}$ Ibid., s. 73.

${ }^{604}$ K.-A. Schwartzkopf, Hemma hos familjen Tuff-Tuff, 1950/1966, s. 50.

${ }^{605}$ Ibid., s. 58.
} 
Teknik liknas vid annan teknik:

Teknik liknas vid naturen:

Naturen liknas vid teknik:
Pappa Tuff-Tuff funderade så ångpannan blev bucklig som en tvättbräda. ${ }^{606}$

Spelmansloket visslade igång en hambo och pappa Tuff-Tuff började hoppa runt på alla åtta hjulen som en stenkross. ${ }^{607}$

Mamma Tuff-Tuffs buffertar smattrade mot hans plåt som två borrmaskiner. ${ }^{608}$

[Detektivloket] skumpade direkt ut på skenorna med nosen ända nere vid rälsen precis som en jakthund. ${ }^{609}$

[Snälltågen] var ilskna som bin. ${ }^{610}$

Tutman var pigg som en mygga och kröp hem för egen maskin. ${ }^{611}$

[Ormen] hade ett huvud som precis liknade ett hänglås. ${ }^{612}$

Till slut skrek [Överste Lokomotivpoliselefanten] på hjälp, och ljudet, som gick ge-

\footnotetext{
${ }^{606}$ K.-A. Schwartzkopf, Familjen Tuff-Tuff, 1949/1966, s. 27.

${ }^{607}$ K.-A. Schwartzkopf, Hemma hos familjen Tuff-Tuff, 1950/1966, s. 22.

${ }^{608}$ Ibid., s. 92.

${ }^{609}$ K.-A. Schwartzkopf, Familjen Tuff-Tuff, 1949/1966, s. 27.

${ }^{610}$ K.-A. Schwartzkopf, Hemma hos familjen Tuff-Tuff, 1950/1966, s. 9.

${ }^{611}$ Ibid., s. 120.

${ }^{612}$ K.-A. Schwartzkopf, Familjen Tuff-Tuff, 1949/1966, s. 35.
} 
nom snabeln kom ut genom andra örat, och det lät som en grammofon. ${ }^{613}$

Äggen sprack och började rinna nedåt halsen i långa forsar, så till slut såg giraffen ut som en spettekaka. ${ }^{614}$

Ett ytterligare exempel på en liknelse är en flygande elefant som beskrivs som att den har sina öron utspända som segel. Ett flygplan av modellen DC-6 används också som metafor för den flygande elefanten:

- Den där hade bråttom, skrek pappa Tuff-Tuff och var väldigt ledsen att inte han hade lika stora öron.

- Det kanske är Saharas nya DC 6:a, föreslog Sotsvart. Men det var ingen som skrattade åt hans kvickhet, för varken mamma eller pappa Tuff-Tuff eller Finka visste vad en DC 6:a var för nånting. Och så måste Sotsvart förklara att DC 6:a var ett jättestort passagerarflygplan, men de hade alla glömt bort elefanten och tyckte inte att en DC 6:a var något roligt alls. ${ }^{615}$

När Familjen Tuff-Tuff publicerades 1949 var DC-6:an en ny flygplansmodell, ett fyrmotorigt propellerplan som tillverkades av Douglas mellan åren 1946 och 1959. Ursprungligen skapades planet som ett militärt transportplan men redan 1946 började amerikanska flygbolag beställa flygplansmodellen för att kunna starta turistflyg över Nordatlanten. ${ }^{616}$ Två år senare, den 9 maj 1948, anlände den första av de Douglas DC-6:or som Scandinavian Airlines System, SAS, beställt till Bromma flygplats. ${ }^{617}$ DC-6:an kom att betyda mycket för det civila trafikflygets genombrott och utveckling efter andra världskriget. Det var tack vare denna flygplanstyp som en stor del av världens ledande flygbolag på allvar kunde börja satsa på interkontinentala flyglinjer där resenärerna erbjöds dåtidens mest optimala komfort. I Sveri-

\footnotetext{
${ }^{613}$ Ibid., s. 40.

${ }^{614}$ Ibid., s. 54-55.

${ }^{615}$ Ibid., s. 49.

${ }^{616}$ The Company Boeing, "History. DC-6/C-118. A liftmaster transport", http://www.boeing.com/boeing/history/mdc/dc-6.page (läst 2013-07-01).

${ }^{617}$ Kontaktgruppen för flyghistorisk forskning, ”Douglas DC-6/DC-6B”, Göteborg, 1982, s. 17.
} 
ge blev den SAS-flottans nya flaggskepp. Från 1952 fick den dock träda tillbaka som långdistansmaskin när dess uppdaterade efterföljare, DC-6B, togs i tjänst. ${ }^{618}$ DC-6:an avfärdas dock i Familjen Tuff-Tuff som "inget roligt alls".

I Indien kommer tågfamiljen i kontakt med en varelse som är en blandning mellan teknik och djur, vilket sker när de träffar Maharadjan av Brahmaputra. Maharadjan har ett problem. Hans uppfinningsrike farfar har skapat ett djur, Mulle Tunnelgrävare, som är en blandning mellan mullvad, flodhäst, dammsugare, grävmaskin och vägskrapa. Med hjälp av Mulle har det grävts en tunnel mellan Indien och Amerika. Problemet är att när maharadjan skickade ett invigningståg med guld till Amerika, kom det aldrig fram. Det gjorde inte något av de tjugo tåg han skickade senare heller. Mulle är nämligen så glad i att gräva att han gjort tusentals tunnlar i jorden och tågen kör därför vilse. Familjen Tuff-Tuff får i uppdrag av maharadjan att spåra upp de försvunna tågen samt be Mulle att sluta gräva. Djupt inne i ett tunnelsystem finner de honom:

Han liknade en mullvad, sedd genom ett mycket stort förstoringsglas. Utom framtassarna, som var jättelika grävskopor, och baktassarna, som var ännu större vägskrapor. Han hade nosen mellan framskoporna. Var gång han snarkade, sög han in grus genom näsborrarna, som liknade en dammsugare. Grusen sprutade sedan direkt ut genom öronen. ${ }^{619}$

Mulle består av både biologisk vävnad och syntetiska delar (se bild 6.2). Då han är en total sammansmältning av djur och maskin påminner han om en cyborg, vilken enligt Donna Haraways beskrivning är en " $[\ldots]$ hybrid of machine and organism, a creature of social reality as well as a creature of fiction". ${ }^{620}$ För Haraway är cyborgen en metafor för den tekno-organiska hybrid som människan blivit genom den tekniska utvecklingen.

Begreppet "cyborg" har sitt ursprung i cybernetiken och den amerikanske matematikern Norbert Wieners definition av begreppet från 1948: "The entire field

\footnotetext{
${ }^{618}$ Ibid., s. 4-8.

${ }^{619}$ K.-A. Schwartzkopf, Familjen Tuff-Tuff, 1949/1966, s. 122.

${ }^{620}$ D. J. Haraway, "A cyborg manifesto: Science, technology, and socialist-feminism in the late twentieth century", 1991, s. 149.
} 


\section{Tekniklandskapet i Karl-Aage Schwartzkopfs barnböcker}

of control and communication theory, whether in the machine or in the animal., ${ }^{, 621}$ Med utgångspunkt $\mathrm{i}$ Wieners definition introducerade sedan Manfred Clynes och Nathan Kline termen "cyborg" i en artikel 1960 som en förkortning av "cybernetisk organism", det vill säga ett självreglerande människa/djur-maskin-system som skulle vara anpassningsbart i nya miljöer. Clynes och Kline var aktiva under kalla krigets rymdkapplöpning och målet med deras forskning var att förändra astronauternas kroppar så att de blev mer anpassade till den svåra miljön i yttre rymden, ett alternativ till att skapa en jordliknande miljö för rymdresor. Clynes och Kline menade att om astronauternas kroppar kunde regleras genom ett samarbete mellan teknik och den organiska kroppen, skulle behovet av utomstående tekniska apparater minska. Genom artificiella förbättringar skulle den mänskliga kroppen bli självreglerande även i krävande miljöer som exempelvis rymden. ${ }^{622}$ Redan innan cyborgbegreppet myntades av vetenskapen förekom cyborger i litteraturen och Mary Shelleys monster i Frankenstein (1818) är exempel på en tidig sådan. ${ }^{623}$

\footnotetext{
${ }^{621} \mathrm{~N}$. Wiener, Cybernetics or control and communication in the animal and the machine, Cambridge, Mass.: MIT Press, 1965, s. 19.

${ }^{622}$ M.E. Clynes \& N.S. Kline, “Cyborg and space”, Astronautics, September 1960, http://web.mit.edu/digitalapollo/Documents/Chapter1/cyborgs.pdf (läst 20140315); M.E. Clynes \& N. S. Kline, "Cyborgs and space" i The cyborg handbook, C.H. Gray (red.), New York: Routledge, 1995, s. 29-33; R. Kline, "Where are the cyborgs in cybernetics?", Social Studies of Science, vol. 39(3), 2009, s. 331-362.

Den första varelse som Clynes och Kline kallade cyborg var en vit laboratorieråtta i vilken de inplanterade en osmotisk pump som regelbundet injicerade kemiska substanser i syfte att höja råttans motståndskraft mot infektioner. Musen och den implanterade pumpen bildar tillsammans en "cybernetically extended organism", en organism förlängd genom cybernetisk teknik, vilket Clynes och Kline definierar som en "cyborg" (Se "Cyborg and space", 1960;1995).

${ }^{623}$ M. Hård \& A. Jamison, Hubris and hybrids: A cultural history of technology and science, 2005, s. 160-161; M.W. Shelley, Frankenstein, or, The modern Prometheus, 1818/1993.
} 


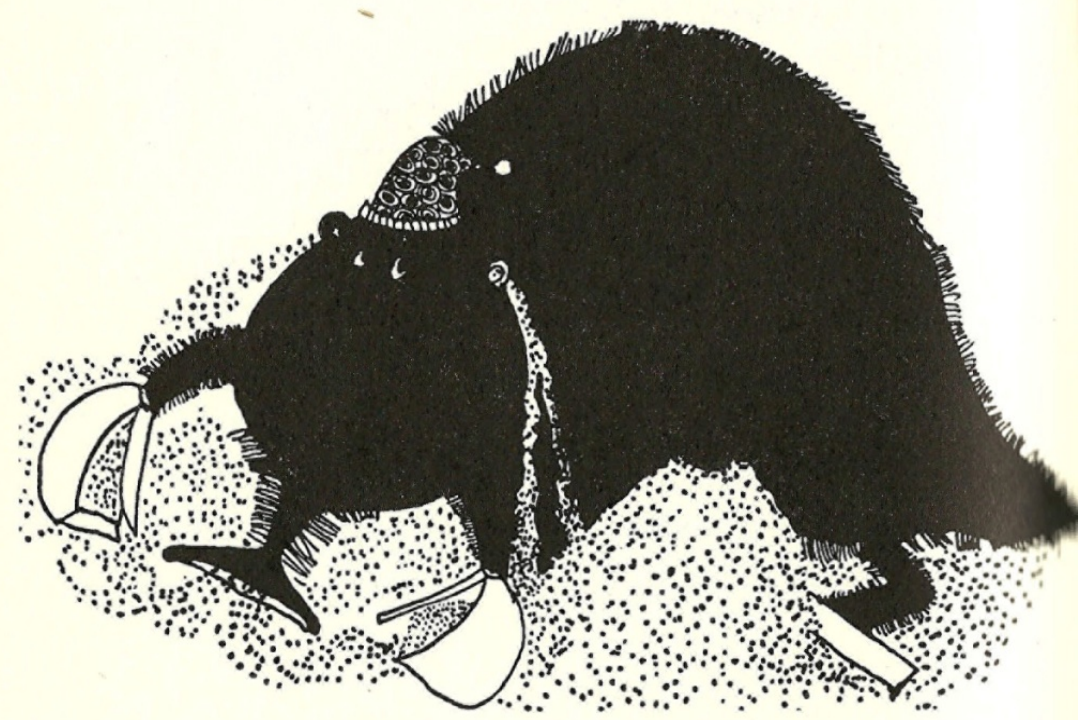

Bild 6.2: Illustration från Familjen Tuff-Tuff (Kerstin Hedeby, 1949/1966)

Mulle Tunnelgrävare är i berättelsen en "levande tunnelmaskin" och liksom Frankensteins monster är han en skapelse som dess uppfinnare tappar kontrollen över. Lyckas ingen hejda Mulle finns en stor risk att han underminerar hela jorden med sitt grävande.

Mitcham menar att Wieners definition förutsätter en fundamental identitet mellan djur och människa. Mot bakgrund av denna reduktion av djur och maskin till ett mönster av bestämda beteenden, verkar det vara en tolkningsfråga huruvida man betraktar maskiner som förlängningar av djur (inklusive människa) eller djur som komplexa maskiner, skriver Mitcham. ${ }^{624}$ Utifrån Mitchams beskrivning av cyborgen är Mulle närmast att betrakta som en maskinell förlängning av ett djur. Episoden om Mulle Tunnelgrävare kan dessutom läsas som en implicit varning för vilka ödesdigra konsekvenser det kan få om människan förlorar kontrollen över sina tekniska skapelser.

${ }^{624}$ C. Mitcham, Thinking through technology: The path between engineering and philosophy, 1994, s. 206. 


\section{Natursynen i böckerna om familjen Tuff-Tuff}

I böckerna om familjen Tuff-Tuff skildras den svenska naturen som något man rymmer till och plockar blåbär i medan urskogen i Afrika är hemlighetsfull och farlig samt något som måste erövras med hjälp av tekniken. Tågfamiljens resa över jorden kan tolkas som en geografilektion, samtidigt som djur- och naturbeskrivningarna bitvis är absurdistiska. Något budskap om huruvida naturen i sig har något värde är svårt att identifiera. Det som naturen erbjuder är framför allt rekreation och äventyr. Den kan också fungera som ett tekniskt hjälpmedel. När familjen Tuff-Tuff blir infångade av Krokodildetektiven använder han inte rep eller kedjor för att binda familjen, utan en lång orm. Ett annat exempel är hur den indiske maharadjan använder "en extra spetsnäbbig hackspett" som tandpetare för att hacka fram de diamanter som fastnat $\mathrm{i}$ hans guldtänder. Likaså fungerar nyhetsrapporteringen i Saharaöknen enbart med hjälp av djur. Ökentidningens redaktion består av strutsar som skriver ner nyheterna direkt på Saharas sandkullar så att vem som helst ska kunna gå fram och läsa, även tågfamiljen. Den allvarligaste nyheten är att ett krig utbrutit mellan giraffernas nordarmé och den sammanslagna sebrakavalleristyrkan. Girafferna har överfallit de sovande sebrorna och tillfogat dem stora förluster. Tidningen uppmanar alla varelser med hjärta i kroppen att skynda till sebrornas undsättning. Själv har tidningen sänt fem av sina bästa "bombfällare" (strutsar) för att fälla strutsägg i huvudet på girafferna. Den krigsteknik som djuren använder sig av är hämtad från naturen trots att själva kriget i sig påminner ett mänskligt krig. Precis som i Witts saga om "De röda soldaterna" utnyttjas djurens värld för att beskriva ett krig, men skildringen i Familjen Tuff-Tuff påminner mer om en fabel.

\section{Framtidssynen i böckerna om familjen Tuff-Tuff}

Någon framtidssyn framträder inte så tydligt i böckerna om familjen Tuff-Tuff och framför allt finns inget budskap som kan tolkas som teknisk framstegstro, eftersom det framför allt är den äldre tekniken som hyllas, medan den nyare framställs som sämre. Samtidigt finns inget budskap som kan tolkas som att det är ett liv närmare naturen som förespråkas, utan snarare ett samhälle där tekniken intar en central och viktig roll. Om naturen endast får agera kuliss i böckerna om familjen TuffTuff, så ges den desto större utrymme i några andra av Schwartzkopfs böcker; de två böckerna om höghuset Talleborg. I det utopiska samhälle som gestaltas i hög- 
husböckerna, är det i första hand ett liv i harmoni med djur och natur som eftersträvas.

\section{Handlingen i böckerna om höghuset Talleborg}

Den första boken om höghuset, Höghuset vid myren, publicerades 1965 och dess uppföljare, Höghuset vandrar norrut, kom ut fyra år senare. Bibliotekstjänsts recensenters omdömen var positiva. Den ena skriver att de är en trevlig blandning av "fantasterier" och realistiska vardagsdetaljer. Den andra menar att författaren "sätter höghuset Talleborg och läsarnas fantasi i rörelse på ett sätt, som säkert kommer att roa de yngre." 625

Böckerna handlar om människorna $i$ ett höghus som en dag blir avskurna från omvärlden. Mellan höghuset och staden finns en djup flodfåra och över den en lång bro, via vilken en karavan med bilar varje morgon åker in till staden för att sedan återvända "med trötta mammor och pappor" varje kväll. Likaså går en skolbuss fram och tillbaka till staden med barnen: "Somliga inte riktigt samma, för de hade lärt sig en massa saker under dagen. Men somliga var precis samma." ${ }^{626}$ En dag slår blixten ned och bron rasar. Ovädret får som konsekvens att telefon- och elektricitetsledningar går av och banden mellan höghuset och den stora staden där så många arbetade, men så få tyckte om, klipps av. Konsekvensen blir att människorna i höghuset börjar omvärdera den teknik som ingår i deras tekniklandskap. De närmaste dagarna efter blixtnedslaget tycker alla i höghuset att det är underbart: inga telefoner ringer, inga bilar behöver tas ut ur garaget och inga "otäcka" elektriska lampor lyser i ögonen. Istället plockar människorna fram julgransljus och äter maten ur de konservburkar som man har haft i flera år. Man glömmer bort att det finns sådant som kylskåp, tv, radio, bandspelare, rakapparater och elgitarrer och människorna upplever det som att det är en "stilla julafton" varje kväll. Till en början räknar höghusmänniskorna med att någon ska komma till deras undsättning och att bron kommer att repareras. Men eftersom det redan finns så många människor i staden, glömmer man bort att det finns ett ensamt höghus vid en myr. Höghusets invånare lär sig leva av vad skogen ger, de stiftar egna lagar

\footnotetext{
${ }^{625}$ Bibliotekstjänst, Sambindningskatalog 691-070, december 1969.

${ }^{626}$ K.-A. Schwartzkopf, Höghuset vid myren, Stockholm: Bonnier, 1965, s. 7-8.
} 
och märker snart att de trivs mycket bättre med ett liv i harmoni med naturen jämfört med det tidigare stressande, urbana livet. En av invånarna, byrådirektören i Skolöverstyrelsen, Justus Jansson, börjar dock efter en tid tvivla och beger sig därför iväg till staden för att underrätta myndigheterna. Väl i staden hamnar han i fängelse för sitt beteende och sina konstiga kläder. Några av barnen i höghuset ger sig av till staden och lyckas rädda honom, men då är polisen på väg till det bortglömda huset. Familjerna i Talleborg hinner dock fly in i skogen innan polisernas helikoptrar dyker upp.

I den andra boken, Höghuset vandrar norrut, bestämmer sig människorna för att rulla iväg sitt höghus på stockar. Målet är att flytta det till Norrland och till Paradisets dal vid Kebnekajses fot och på så vis slippa det industrialiserade samhället som har berövat dem kontakten med naturen. Där hörs inga bilar och "[...] luften är klar som en nyslipad diamant". ${ }^{627}$ Man vill fly "den stereotypa civilisationen" som berövat dem kontakten med naturen. ${ }^{628}$ Förflyttningen norrut sker under ledning av en ingenjör som en gång i unga år har flyttat en hel stad i Australien. Genom att placera huset på stockar drar man det efter sig med hjälp av linor. Företaget är ett samarbete där alla, oavsett ålder, har en viktig funktion. Barnen är de som beger sig till skogen och sågar till stockarna som huset ska rullas på. Bokens budskap är att förflyttningen av huset är historiskt eftersom man visar omvärlden att ett hus inte behöver vara bundet av att tillbringa hela sitt "liv" från uppbyggnad till rivning på ett och samma ställe. Förflyttningen blir därmed en vändpunkt för fjättrade hyresmänniskor och man tänker att kanske miljoner andra senare kommer att följa i deras spår och på så vis ska hela samhällsstrukturen på sikt förändras. ${ }^{629}$ Paradisets dal är inte någon reell plats på någon karta utan fungerar som en motbild till det alienerande livet i storstaden. Berättelsen kan på så vis ses som en företrädare för den utopiska genren. Liksom övrig utopisk litteratur handlar höghusböckerna om ett icke-existerande och imaginärt samhälle, men som framställs som verkligt. Då många av utopierna dessutom har sitt ursprung i bibelns värld, kan

\footnotetext{
${ }^{627}$ K.-A. Schwartzkopf, Höghuset vandrar norrut, Stockholm: Bonnier, 1969, s. 67.

${ }^{628}$ Ibid., s. 29-30.

${ }^{629}$ Ibid., s. 30.
} 


\section{Tekniklandskapet i Karl-Aage Schwartzkopfs barnböcker}

namnet på dalen tolkas som att det anspelar på det bibliska paradiset. ${ }^{630}$ Föreställningen om den alienerade människan har höghusböckerna gemensamt med 1960talets motkultur. Inom denna fanns ett antagande att människan i det moderna samhället inte bara levde under ekonomiskt och socialt förtryck - som en effekt av förtrycket blev hon också främmande för sina egna innersta behov. Därför var en vision inom motrörelsen att realisera människan och frigöra henne. ${ }^{631}$

\section{Tekniksynen i böckerna om höghuset Talleborg}

Frängsmyr skriver att utifrån ett retrospektivt perspektiv framstår skillnaden mellan 1950-talet och 1960-talet tydligt. 1950-talet kan beskrivas som "oskuldens årtionde", då välfärdsstaten och framsteget aldrig riktigt ifrågasattes. Under 1960talet, däremot, förändrades det kulturella klimatet radikalt. Sverige framstod inte längre som ideallandet. ${ }^{632}$ Kjell Östberg skriver att trots att 1960-talet, och då särskilt 1968, väcker starka känslor, kan i själva verket "1968" beskrivas som en process som tog sin början i slutet av 1950-talet och pågick långt in på 1970-talet. ${ }^{633}$ Urbaniseringen var något som präglade dessa decennier. Enligt SCB:s statistik var andelen boende inom tätorterna 45,2 procent 1920. 1965 hade den siffran stigit till 77,4 procent. ${ }^{634}$ Bostadspolitiken var en av de viktigaste framstegsmotorerna i utvecklingen av den svenska välfärden. Efter andra världskrigets slut och med diktaturer i färskt minne, oroade sig forskare för att stadens brist på primärkontakter skulle forma massmänniskor som lätt kunde förledas av en diktator. Torgny Segerstedt, Sveriges första professor i sociologi, argumenterade exempelvis för att primärkontakterna var grunden för skapandet av demokratiska människor. Att ha tillgång till primärgrupp(er) var en förutsättning för att kunna delta i demokratiska

\footnotetext{
${ }^{630}$ R. Ambjörnsson, Fantasin till makten! Utopiska idéer $i$ västerlandet under fem hundra år, 2004, s. 23, 28.

${ }^{631}$ L. Lennerhed, ”Det är rätt att göra uppror!” i Europas idéhistoria. 1900-talet. Framstegets arvtagare, N. Runeby (red.), Stockholm: Natur och Kultur, 1998, s. 194-222.

${ }^{632}$ T. Frängsmyr, Svensk idéhistoria: bildning och vetenskap under tusen år. D. 2, 1809-2000, 2000, s. 322.

${ }^{633}$ K. Östberg, 1968 - När allting var i rörelse: Sextiotalsradikaliseringen och de sociala rörelserna, Stockholm: Prisma, 2002, s. 99.

${ }^{634}$ H. Ylander, "Urbanisering och tätortsutveckling i Sverige", 2008.
} 
processer. ${ }^{635}$ Lösningen var ett grannskapsideal, ett avgränsat bostadsområde med gemensamhetsanläggningar och skola där familjen och de goda grannkontakterna kunde bevaras. ${ }^{636}$ Tanken med det avgränsade grannskapet handlade inte enbart om demokratiska mål utan inkluderade också omtanken om människornas psykiska hälsa. Genom grannskapsidealet skulle stadslivets instrumentella förhållningssätt och avskärmande från omgivningen undvikas. ${ }^{637}$ Dessa målsättningar var något som exempelvis kom till uttryck i 1945 års bostadssociala utredning. ${ }^{638}$

Skildringen av människorna i höghuset Talleborg kan ses i ljuset av den samhällsplaneringsideologi som låg bakom skapandet av de svenska förorterna och budskapet i böckerna kan tolkas som en reaktion mot storskaliga bostadsprojekt. En av de främsta inspirationskällorna för de svenska samhällsplanerarna inför efterkrigstidens stadsbyggnation var Lewis Mumford. ${ }^{639}$ Hans bok The culture of the cities utkom på svenska 1942 under titeln Stadskultur. I boken är han inte emot städer i sig, men anser att storstäderna borde omvandlas till mindre regionala centrum, där hänsyn tas till både individ och hela den sociala miljön. Inom dessa miljöer kan invånarna bilda en medborgerlig helhet genom att kombinera arbete, bostäder och service. ${ }^{640}$ I artikeln "What is a city?" (1937) skriver Mumford att "[...] social facts are primary, and the physical organization of a city, its industries and its markets, its lines of communications and traffic, must be subservient to its

\footnotetext{
${ }^{635}$ S. Urban, "Grannskapet som planeringsenhet" i Samhällsbyggande och integration: Frågor om assimilation, mångfald och boende, G. Graninger och C. Knuthammar (red.), Linköping: Linköpings universitet. Linköping University Interdisciplinary Studies, 2009, s. 69. När det gäller "primärgrupper" var det den amerikanske sociologen Charles H. Cooley som redan år 1900 började använda begreppet i sina föreläsningar och i sin Social Organization (1909) behandlar han sin teori om begreppet, se exempelvis F. R. Clow, “Cooley's doctrine of primary groups", American Journal of Sociology, vol. 25(3), 1919, s. 326-347.
}

${ }^{636}$ U. Åhrén, Ett planmässigt samhällsbyggande: Särtryck ur bostadssociala utredningen (SOU 1945:63), Omtr., Stockholm: Kungliga Tekniska högskolan, 1981.

${ }^{637}$ S. Urban, "Grannskapet som planeringsenhet", 2009, s. 70-71.

${ }^{638}$ U. Åhrén, Ett planmässigt samhällsbyggande: Särtryck ur bostadssociala utredningen (SOU 1945:63).

${ }^{639}$ A. Sundberg, Jakten på det goda livet: Förortslinjen - från utopi till verklighet, diss., Kungliga Tekniska högskolan, Stockholm, 1992, s. 72-73.

${ }^{640}$ L. Mumford, Stadskultur, Stockholm: Kooperativa förbundet, 1942, s. 476. 


\section{Tekniklandskapet i Karl-Aage Schwartzkopfs barnböcker}

social needs" ${ }^{641}$ Något annat som böckerna om Talleborg har gemensamt med Mumford är kritiken av städernas utarmning av den naturliga miljön. Mumford förespråkar ett mer ekologiskt helhetstänkande i regionplaneringen. Regionplanering, menar han, handlar både om att skydda den vilda naturen, ge trädgårdarna ökad utbredning och införa en målmedveten vård av landskapet. ${ }^{642}$

Den svenska samhällsplaneringen under 1960-talet kom till sist ändå i huvudsak inriktas mot att lösa tekniska problem och inte mänskliga sociala behov. Även om det fanns sociala visioner, sågs de nu som orealistiska att genomföra. Det sociala engagemanget skiftade till teknisk rationalitet som exempelvis innebar en trafik- och bostadsplanering utifrån ett ekonomiskt perspektiv. De nya förorterna som började byggas mot slutet av 1960-talet hade kvar grannskapstanken men då mer som en praktisk byggnadslösning; gårdsformationen skapade ett lagom avstånd när de industritillverkade husdelarna skulle lyftas fram av lyftkranen. ${ }^{643}$

Det faktum att industrin gick på högvarv, samtidigt som tjänstesektorn växte, fick som konsekvens att allt fler människor flyttade in till storstäderna, samtidigt som det pågick en stark arbetskraftinvandring. För att lösa problemet tillsattes 1959 en utredning, den så kallade Bostadsbyggnadsutredningen. Utredningens slutbetänkande (SOU 1965:32) gav riksdagen underlag att 1965 besluta att en miljon lägenheter skulle uppföras under tio år - en tidsperiod som kom att rubriceras som miljonprogrammets epok. ${ }^{644} \mathrm{I}$ själva verket var riksdagsbeslutet enbart ett klartecken för projektet som redan hade rullat igång. Sveriges första fullskaliga höghusförort Vällingby invigdes redan 1953. Den blev en internationell begivenhet och inledningen till en höghusvåg över hela landet. Höghuset var en manifestation som visade att man låg i framkant i utvecklingen. ${ }^{645}$

\footnotetext{
${ }^{641}$ L. Mumford, "What is a city?" i The city reader, R. T. LeGates \& F. Stout (red.), New York: Routledge, 1937/1996, s. 93.

${ }^{642}$ L. Mumford, Stadskultur, 1942, s. 336.

${ }^{643}$ S. Urban, "Grannskapet som planeringsenhet", 2009, s. 71-72.

${ }^{644}$ Bostadsbyggnadsutredningen, Höjd bostadsstandard [Elektronisk resurs]: Betänkande, Stockholm, 1965, http://urn.kb.se/resolve?urn=urn:nbn:se:kb:sou-617108 (läst 2014-01-25); J. Rådberg, "Mellan humanism och futurism: 1900-talets stadsbyggande" i Den välsignade tillväxten: Tankelinjer kring ett århundrade av kapitalism, teknik, kultur och vetenskap, P. Elmlund \& $\mathrm{K}$. Glans (red.), Stockholm: Natur och Kultur, 1998, s. 226-230.
}

${ }^{645}$ Ibid., s. 227. 
Precis som miljonprogrammets hus är höghuset vid myren ett nybyggt hyreshus beläget en bit från ett storstadscentrum. I berättelsen tar flickan Lena tydligt avstånd från staden och hon ser den som "elak" och att den "idisslar" människor tills de förvandlas till "odjur". Ett annat av barnen, Nick, protesterar dock och menar att staden är nog mer som människor i allmänhet: "elak ibland, snäll ibland". ${ }^{646}$

De 52 familjerna i huset ser från början sin situation enbart som temporär, men med tiden inser de fördelarna med att slippa åka in till staden. Livet hos familjerna i höghuset övergår från modernt och urbant liv till ett liv nära naturen som påminner om en Robinson Crusoe-tillvaro. Man till och med döper sitt hus till Talleborg: höghuset är den borg i vilken människorna förskansar sig för att skydda sig mot stadslivet. Skildringen av flykten från det moderna livet i en stad med starkt förorenad miljö för tankarna till Harry Martinsons epos Aniara (1956), även om höghusmänniskorna inte flyr så långt som ut i rymden. ${ }^{647}$ Flykten är en revolt mot den samhälleliga ordningen och höghusmänniskorna drivs av en vilja att kasta det gamla över ända för att skapa något nytt.

Den civilisationskritik som utvecklades under 1960- och 1970-talen handlade om ifrågasättande av materiell tillväxt, konsumism, miljöförstöring och om städernas tilltagande stress och miljöproblem. ${ }^{648}$ I böckerna om höghuset (liksom i sagorna "Herr Klumpedump från Klumpedonien" och "Doktor Klokamundus' uppfinning”) skildras hur tekniken påverkar samhällsutvecklingen och leder till en alienering människor emellan. I böckerna om höghuset handlar kritiken dessutom om den alienering som uppstått mellan människa och natur.

Innan ovädret har de 52 familjerna i höghuset inte haft någon närmare kontakt med varandra, men nu blir alla som en enda stor familj som hjälps åt med att samla mat. Var och en har sin särskilda uppgift och husets samtliga 49 barn lär sig fiska i sjöar och bäckar. Alla män får långa skägg och alla kvinnor och barn så långt hår att de kan knyta det runt halsen istället för halsdukar.

De fyra lärare som bor $\mathrm{i}$ huset håller den första tiden skola för husets barn, men när det blir vinter inser lärarna att skolböckerna är mycket mer användbara som bränsle än som läromedel. Istället övergår man till en undervisning som

\footnotetext{
${ }^{646}$ K.-A. Schwartzkopf, Höghuset vid myren, 1965, s. 73.

${ }^{647}$ H. Martinson, Aniara: En revy om människan i tid och rum, Stockholm: Bonnier, 1956.

${ }^{648}$ S. Sörlin, Naturkontraktet: Om naturumgängets idéhistoria, 1991, s. 232.
} 


\section{Tekniklandskapet i Karl-Aage Schwartzkopfs barnböcker}

bygger på att lärarna berättar fritt ur hjärtat för barnen. Barnen lär sig då mer på en enda lektion än vad det tidigare tagit flera månader att lära sig. När ingen radio eller tv längre fungerar, övergår dessutom människorna i huset till att arrangera sagostunder som underhållning.

Sagostunderna kan ses som en reaktion mot den medieexpansionen som skedde genom introduktionen av televisionen 1956 i Sverige. Introduktionen genomfördes efter ett par års försöksverksamhet med sändningar från Kungliga Tekniska högskolan (KTH) i Stockholm och Chalmers tekniska högskola i Göteborg. Genom VM i fotboll 1958 fick televisionen sitt stora genombrott i Sverige och i och med satellitsändningarna under 1960-talet blev televisionen ett globalt täckande medium med stor slagkraft. Kriget i Vietnam kom att utspelas inför ögonen på miljoner tittare och tv blev ett medium som skapade politisk opinion. ${ }^{649}$ Näst efter USA var Sverige 1966 det land som hade flest tv-apparater per invånare och mellan åren 1956 och 1965 såldes två miljoner tv-apparater i Sverige. ${ }^{650}$ Såväl människors vardag som kulturen i stort påverkades av tv:ns intåg. Fram till 1969 fanns bara en tv-kanal, vilket gjorde att det existerade en slags enhetskultur. Hela svenska folket blev deltagare i en enda och likriktad "studiecirkel" av tv-program, skriver Hägg. ${ }^{651}$ Men tv-mediet väckte också starka känslor. I diskussionen framträdde något som kan liknas vid moralpanik samtidigt som det fanns en stor entusiasm inför mediets folkbildande och konstnärliga möjligheter. ${ }^{652} \mathrm{I}$ böckerna om Talleborg finns inget positivt budskap om televisionen och dess folkbildande potential. Den fungerar snarare som en symbol för en modern teknik som fătt människorna att fjärma sig från såväl varandra som naturen. Även det möte som varje vecka hålls för alla höghusets invånare fungerar som ett bildningstillfälle, där alla beslut sker i demokratisk ordning. På mötena tar man bland annat beslut om

\footnotetext{
${ }^{649}$ J. Hult, "Tekniken mitt ibland oss: 1914-1970", 1989c, s. 325.

${ }^{650}$ A. Frenander, Debattens vågor: Om politisk-ideologiska frågor i efterkrigstidens svenska kulturdebatt, diss., Göteborgs universitet, Göteborg, 1999, s. 19.

${ }^{651}$ G. Hägg, Välfärdsåren: Svensk historia 1945-1986, Stockholm: Wahlström \& Widstrand, 2005, s. 149.

${ }^{652}$ L. Kåreland, Inga gåbortsföremål: Lekfull litteratur och vidgad kulturdebatt i 1960- och 70talens Sverige, Göteborg: Makadam, 2009, s. 21. När det gäller diskussionen om televisionen som medie- och kulturellt fenomen, se exempelvis Pierre Bourdieus bok Om televisionen: Följd av journalistikens herravälde, Stockholm: B. Östlings bokförl. Symposion, 1998.
} 


\section{Tekniklandskapet i Karl-Aage Schwartzkopfs barnböcker}

hur matanskaffningen ska gå till och en återkommande punkt på dagordningen är att alla i höghuset måste visa respekt för djuren och naturen. Mötena avslutas med en gemensam sagostund. Veckomöten går att likna vid en studiecirkel där deltagarna tillsammans resonerar sig fram till beslut. Studiecirkeln var något som folkbildare under 1960-talet lyfte fram som ett ideal. ${ }^{653}$

Böckernas tekniklandskap innehåller många tekniska objekt varav de flesta kan kategoriseras som vardags- och hushållsteknik, exempelvis telefon, sopnedkast, tv, oljeeldningsaggregat, kylskåp och bilar. Mat får familjerna genom att jaga, fiska och samla örter och växter i skogen. Man bygger också en bakugn av flata stenar som man sedan bakar barkbröd i. Den matlagnings- och jaktteknik som höghusfamiljerna begagnar sig av är en återgång till forna tiders teknik. Man använder pil och båge, fiskar, samlar rötter och örter och vid ett tillfälle i berättelsen kommer tekniken att kasta lasso väl till pass.

All modernare teknik förkastas inte utan får istället nya funktioner. Ett exempel är husets sopnedkast. Eftersom familjerna i huset inte längre producerar några sopor används det istället som högtalare när man vill meddela alla $i$ huset något, eller läsa en godnattsaga för alla på en gång: "Och istället för att ta emot skräp, strömmade det nu vacker och rolig underhållning ur de gapande hålen. De flesta tyckte det var trevligare på det viset." ${ }^{654}$ Att det inte finns några sopor tyder på ett hållbart samhälle där allt återvinns och ingenting slängs. När sopnedkastet får ett nytt användningsområde, bidrar det också till att föra människorna närmare varandra. Stadslivet, däremot, skapar känslomässiga avstånd mellan människorna:

Som de flesta stadsmänniskor såg de ingenting. Deras blickar var vända inåt och de tänkte bara på sina egna bekymmer - vad de skulle äta till lunch och om deras pengar skulle räcka till veckans slut eller bara till torsdan. ${ }^{655}$

Människorna i höghuset glömmer med tiden bort de bilar som de tidigare varit så beroende av. Det är enbart när de vill känna "[...] den exotiska doften av något förgånget” som de tittar in i garaget. Ett av barnen, Nick, konstaterar när han känner lukten i garaget att han inte direkt tycker illa om doften: "Tänka sej - att vi en

\footnotetext{
${ }^{653}$ T. Frängsmyr, Svensk idéhistoria: Bildning och vetenskap under tusen år. D. 2, 1809-2000, 2000, s. 322.

${ }^{654}$ K.-A. Schwartzkopf, Höghuset vid myren, 1965, s. 74.

${ }^{655}$ Ibid., s. 53.
} 


\section{Tekniklandskapet i Karl-Aage Schwartzkopfs barnböcker}

gång hade den i näsborrarna nästan jämt. Vi är uppfödda med den - så luktade vi nog själva en gång." ${ }^{656}$ Lena berättar att hon brukar gå ned i källaren för att bli "botad" om hon någon gång känner längtan tillbaka till staden. Det är billukten som gör att Lena aldrig vill återvända till staden. Hon anser det är en "elak lukt" och att människor blir stygga av den:

- Den är stygg, det är den visst det, sa Nick drömmande. Stygg och intressant. En gång, om kanske tusen år, kommer fornforskarna, arkeologerna, som gräver efter oss, att hitta oss på lukten. Bensinlukten. Bilåldern, kommer nog den här tiden att döpas till. Människor kommer mer och mer bli fastvuxna i sina bilar, deras ben blir gaspedaler och armarna en förlängning av ratten. Och blodproven kommer att innehålla sjuttiofem procent bensin och resten olja. ${ }^{657}$

Det Nick ger uttryck för är att det finns en risk att människan blir så beroende av sin teknik att hon smälter samman med den, vilket kan tolkas som en varning för att människa genom sitt beroende av bilen kan förvandlas till en cyborg. ${ }^{658}$

Hagman beskriver bilen som en förstärkare av människokroppens funktioner. Bilen kan, enligt Hagman, liknas vid extra långa och starka ben som ger oss utsträckt rörelseförmåga både när det gäller räckvidd och hastighet. Bilen fungerar också som "extra armar" eftersom den hjälper oss att bära med oss packning, barn och vänner på resan. Genom förstärkningen av de mänskliga kroppsfunktionerna, gör bilen människan överlägsen. Med hjälp av bilen kan människan överbrygga såväl fysiska som sociala avstånd. Därutöver fungerar den som en sorts kostym eller rustning som skyddar mot väder, vind och mot kollisioner. Den kan därutöver, konstaterar Hagman, betraktas som ett personligt uttrycksmedel då den sänder ut information om förarens position och ställning i samhället. ${ }^{659}$

Bilen är en artefakt som förändrade många människors vardag och levnadsmönster under 1900-talet. Mumford skriver exempelvis angående bilens intåg som transportmedel i slutet av 1800-talet: "With the new automobile, power and

\footnotetext{
${ }^{656}$ Ibid., s. 46.

${ }^{657}$ Ibid., s. 56-57.

${ }^{658}$ D. J. Haraway, "A cyborg manifesto: Science, technology, and socialist-feminism in the late twentieth century", 1991, s. 149.

${ }^{659}$ O. Hagman, Bilen, naturen och det moderna: Om natursynens omvandlingar $i$ det svenska bilsamhället, 1999, s. 35.
} 
movement were no longer chained to the railroad line: a single vehicle could travel as fast as a train of cars: again the smaller unit was as efficient as the larger one." 660

Tengström är av åsikten att det enda tekniska föremål som spelat en jämförelsevis så stor roll för människors beteende och liv är möjligtvis datorn och tv:n. Men trots dess stora inverkan på människors liv, har det skrivits väldigt lite om bilens och bilanvändningens kulturhistoria i Sverige. ${ }^{661}$ Som redan nämnts i analysen av Den gröna bilen ökade bilägandet snabbt under dessa årtionden. En barnfamilj med bil var under de första åren av 1950-talet mycket ovanligt, medan snarare det omvända rådde redan i slutet av 1960-talet, det vill säga att det var ovanligt med barnfamiljer utan bil. ${ }^{662}$

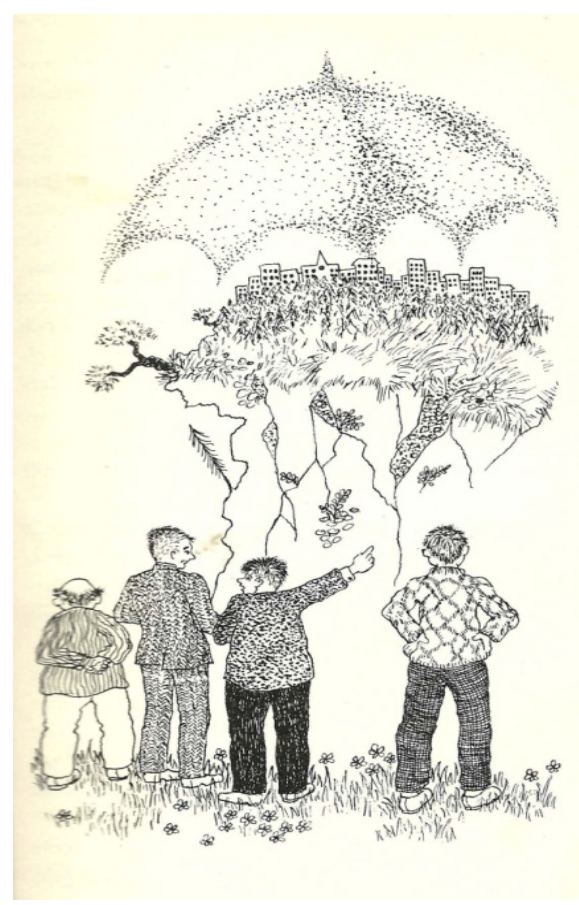

Bild 6.3: Illustration från Höghuset vid myren (Lisbeth Holmberg, 1965)

\footnotetext{
${ }^{660}$ L. Mumford, Technics and civilization, 1934/1963, s. 236.

${ }^{661}$ E. Tengström, Bilen \& människan i svensk prosa och poesi, 2009, s. 13.

${ }^{662}$ Ibid., s. 30.
} 


\section{Tekniklandskapet i Karl-Aage Schwartzkopfs barnböcker}

Avgaser som en konsekvens av bilismen är en negativ aspekt som tas upp i höghusböckerna. Vyn av staden från den rasade bron beskrivs som att rök och avgaser "[...] hängde som en blå paraply över huset" och de tätt hoptryckta husen "[...] såg elaka ut med sina miljontals kisande fönster". Likaså är ljudet från staden inte "[...] det milda suset från träden utan ett elakt, hårt brus - som en farlig visa utan melodi och utan något slut" ${ }^{663}$ Bokens illustration skildrar hur bilavgaserna lägger sig som ett stort, hotfullt paraply över hela staden (se bild 6.3).

Historiskt sett har en ambivalent inställning till bilismen dominerat, skriver Hagman. Allt sedan 1800-talet har det funnits ett ifrågasättande av bilen då den betraktats som både problemlösare och problemskapare. Den övervägande positiva attityden under 1950- och 1960-talen kan därför betraktats som en relativt kortvarig parentes, skriver Hagman. ${ }^{664}$ Miljöfrågornas inträde i samhällsdebatten under 1960-talet medförde en förändrad syn på naturen och som om en följd av detta kom även inställningen till bilen att genomgå en förändring. Bilen sågs nu inte längre enbart som ett redskap för att omvandla natur till välstånd för människan, utan samtidigt som ett hot mot såväl människa som natur. ${ }^{665}$ Under 1960-talet blev diskussionerna om bilismens konsekvenser för miljön alltmer intensiva och frågan om bilavgaserna kom att påverka utvecklingen av hela miljödebatten. Avgaser och buller i tätorten ansågs vara de största miljöproblemen. ${ }^{666}$ Diskussionerna kring luftföroreningarnas hälsoeffekter startade i USA. Redan i mitten av 1950-talet visste man att dessa stod för cirka 60 procent av alla luftföroreningar. ${ }^{667}$ Genom "The Clean Air Act" (1963) lade grunden för en nationell standard för bilarnas utsläpp av kolmonoxid och kolväten i USA och två år senare, 1965, kom den första federala lagen som reglerade luftföroreningar, den så kallade "Motor Vehicle Air

\footnotetext{
${ }^{663}$ K.-A. Schwartzkopf, Höghuset vid myren, 1965, s. 11, 15.

${ }^{664}$ O. Hagman, Bilen, naturen och det moderna: Om natursynens omvandlingar $i$ det svenska bilsamhället, 1999, s. 9.

${ }^{665}$ Ibid., s. 101.

${ }^{666}$ NTF, "Hundra år med trafiksäkerhet", http://www.ntf.se/omoss/pdf/ntf\%20historia.pdf (läst 2013-11-23).

${ }^{667}$ O. Hagman, Bilen, naturen och det moderna: Om natursynens omvandlingar $i$ det svenska bilsamhället, 1999, s. 109.
} 


\section{Tekniklandskapet i Karl-Aage Schwartzkopfs barnböcker}

Pollution Act”. ${ }^{668}$ Det amerikanska initiativet ledde till diskussioner i övriga världen och 1967 antog den svenska riksdagen en lag för att begränsa bilavgaserna. ${ }^{669}$

I berättelsen om höghuset vänds på det historiska perspektivet genom att "bilåldern" skildras som en förgången tid, medan framtiden är ett samhälle byggt på närheten till naturen och utan avancerad teknik som bilar. Liksom sopnedkastet får bilarna i Talleborgs garage en ny funktion när de förvandlas från transportfordon till bostäder för allehanda djur: "Nu hade frost och fukt och vindar och råttor och rävar och grävlingar och sorkar och hela den övriga underjordiska djurvärlden förvandlat de stolta åken till en anonym massa skrot. ${ }^{\text {} 670}$ Beskrivningen kan tolkas som en metafor för hur naturen erövrar herraväldet över människan och hennes teknik. I likhet med berättelsen om tågfamiljen är det den äldre tekniken som är "god", medan den nyare står för problem.

När människorna i Talleborg oroar sig för vad Justus Janssons avhopp (se det tidigare avsnittet om handlingen i böckerna om höghuset Talleborg) ska få för konsekvenser, börjar man diskutera att man kanske behöver vapen för att skydda sig. Först finner de tanken skrämmande. Krig är ju det sista de vill ha. Slutsatsen är dock att det är oundvikligt eftersom det handlar om självförsvar och att skrämma bort fienden. Man bestämmer sig för att bygga om huvudröret i oljeeldningspannan till en kanon. Krut kan en pensionerad militär bidra med, liksom en stridstrumpet som han fått i avskedsgåva från det militära. Kanonen tillverkas med hjälp av "kunniga karlar": en plåtslagare, en finmekaniker och en lärare i historia med äldre vapen som specialintresse. Alla $i$ höghuset hjälps åt att samla ihop allt möjligt skrot som kan användas som projektiler. När polisen till sist dyker upp möts de av en kanonsalva:

Det kändes som hela Talleborg hoppade jämfota. Hela himlen var för en kort stund förmörkad av skrot. Sedan regnade det gökur och symaskinsdelar och tandborstar

\footnotetext{
${ }^{668}$ M. Melosi, "The automobile and the environment in American history. Automobil in American life and society", University of Michigan-Dearborn, http://www.autolife.umd.umich.edu/Environment/E_Overview/E_Overview1.htm (läst 2013-12-14).

${ }^{669}$ O. Hagman, Bilen, naturen och det moderna: Om natursynens omvandlingar $i$ det svenska bilsamhället, 1999, s. 110.

${ }^{670}$ K.-A. Schwartzkopf, Höghuset vid myren, 1965, s. 45.
} 
och munspel och strumphållare och pianotangenter och allt möjligt annat över poliskedjan. ${ }^{671}$

Kanonen går dock sönder i samband med skjutningen. Poliserna retirerar men människorna i höghuset förstår att de snart kommer att återvända och då med förstärkning. Eftersom ingen till något pris vill tillbaka till livet i staden, beslutar man sig för att ge sig av. Justus Jansson uppmanar alla att ta med sig någon personlig minnessak. Någon mat behöver de inte ta med eftersom föda kan hämtas direkt ur skogen. Några av höghusets människor hämtar sådant som fotografier och tar med sig som minne, men de flesta beger sig av utan att ta med sig något alls. Människorna i höghuset har nu frigjort sig från sina materiella ting och kan återvända till ett liv nära naturen.

\section{Natursynen i böckerna om höghuset Talleborg}

I höghusböckerna tas relationen mellan människa och natur upp utifrån ett demokratiskt perspektiv. Om en förändring i rätt riktning ska genomföras måste detta ske utifrån ett demokratiskt agerande såväl människor emellan som mellan människa och natur. Familjerna lever tillsammans i ett kollektiv där var och en har en uppgift utifrån sina kunskaper och förmågor. En gång i veckan hålls rådslag. Barnen är också med och de har precis lika mycket att säga till om som de vuxna. De vuxna har en talesman och barnen en egen. Mötena hålls i pingpongrummet $\mathrm{i}$ källaren, där man slängt ut oljeeldningsaggregatet. För vad ska man ha ett sådant till när man inte har någon olja? På mötena tas allehanda spörsmål upp och många av dessa handlar om att lösa de intressekonflikter som ibland uppstår mellan människa och natur. Vem ska exempelvis ta över grävlingfamiljen som Fru Svensson tröttnat på eftersom de bråkade så väldigt att hon inte kan sova om nätterna?

Den optimistiska syn på utvecklingen som hade präglat 1950-talet, började i mitten av 1960-talet få konkurrens av ett nytt tänkande om människan, naturen, samhället och utvecklingen. Människans ansvarstagande för miljön hade sin grund i kritiken mot idén om ständig ekonomisk utveckling, men denna kom att följas av ytterligare argument. ${ }^{672}$ Nedsmutsning och hälsoproblem på grund av lokal miljö-

\footnotetext{
${ }^{671}$ K.-A. Schwartzkopf, Höghuset vid myren, 1965, s. 130.

${ }^{672}$ E. Friman, "Tillväxtens gränser" i Då förändras Sverige: 25 experter beskriver drivkrafter bakom utvecklingen, E. Giertz (red.), Lund: Studentlitteratur, 2008, s. 221.
} 


\section{Tekniklandskapet i Karl-Aage Schwartzkopfs barnböcker}

förstöring har uppmärksammats i alla tider, men under 1960-talet skedde ett första steg mot att miljöproblemen globaliserades. I boken Silent spring (1962) visade den amerikanska författaren Rachel Carson vilka ödesdigra konsekvenser de farliga kemikalierna inom jordbruket och konsumtionsindustrin fick för människor och djur. Uppdagandet av dessa nya miljöproblem ledde till en förändring av många människors syn på naturen. ${ }^{673}$ Carsons bok blev mer än något annat väckarklockan till en miljödebatt bland den stora allmänheten. ${ }^{674}$

När det gäller startpunkten för den svenska moderna miljödebatten menar Lars J. Lundgren att den sammanfaller med 1960-talets kvicksilverdebatt, liksom debatten kring övriga bekämpningsmedel, vilka sedan kom att bana väg för åtgärder mot andra miljögifter och hot mot miljön. Företeelser som oljeutsläpp, algblomning, igenväxning av förorenade sjöar, avgaser från trafiken, skogsbrukets effekter på landskapsbilden och älvarnas reglering, som tidigare sällan kopplats samman, började nu uppfattas som varianter av samma tema: miljöproblem. ${ }^{675}$ Rolf Edberg och hans bok Spillran av ett moln (1966) liksom Hans Palmstierna med Plundring, svält, förgiftning (1967) är exempel på svenska miljökritiker som genom att föra upp miljögifterna på den politiska agendan bidrog till att det svenska ekologiska krismedvetandet vaknade till liv. Enligt Jonas Anshelm betraktade Edberg och Palmstierna miljöproblemen utifrån två olika synsätt. Edberg var civilisationskritisk utifrån ett biocentriskt perspektiv, medan Palmstiernas synsätt var naturvetenskapligt, reformistiskt och antropocentriskt. ${ }^{676}$ Naturskyddsföreningen hade redan på 1910-talet tagit upp industrisamhällets förhållningssätt till naturen, men nu menade Edberg att människan med sin moderna teknik var på väg att förstöra livsbetingelserna för såväl sig själv som för allt annat levande. Endast en återgång till ett

\footnotetext{
${ }^{673}$ B. Skovdahl, Förlorad kontroll: Den ifrågasatta framstegstanken, 2010, s. 155.

${ }^{674}$ R. Carson, Silent spring, Boston, 1962; G. Eriksson \& T. Frängsmyr, Idéhistoriens huvudlinjer, 4. rev. uppl., Stockholm: Wahlström \& Widstrand, 2004, s. 227.

${ }^{675}$ C. Bernes \& L. J. Lundgren, Bruk och missbruk av naturens resurser: En svensk miljöhistoria, 2009 , s. 87.

${ }^{676}$ J. Anshelm, Socialdemokraterna och miljöfrågan: En studie av framstegstankens paradoxer, Stockholm: B. Österlings bokförlag Symposion, 1995, s. 14; R. Edberg, Spillran av ett moln: Anteckningar i färdaboken, 2. uppl., Stockholm: Norstedt, 1966; H. Palmstierna \& L. Palmstierna, Plundring, svält, förgiftning, Stockholm: Rabén \& Sjögren, 1967.
} 


\section{Tekniklandskapet i Karl-Aage Schwartzkopfs barnböcker}

samhälle med naturenligt kretslopp skulle kunna stoppa den förestående undergången. ${ }^{677}$

1960-talet var därmed ett decennium där en djupare medvetenhet om naturen skapades. Människans relation till naturen framträdde som problem som krävde snabba lösningar och en politisk strävan efter helhetssyn på naturen utifrån ett ekologiskt perspektiv växte fram. ${ }^{678}$ Miljörörelsens "väckelse" gick dock inte så snabbt och det var först på 1970-talet som den ruraliseringsvåg som brukar kallas "gröna vågen" kom igång på allvar. ${ }^{679}$ Under 1960- och 1970-talen började också realistiska vardagsskildringar ta plats i barnboksutbudet. Även böcker som vände sig till yngre barn, tog nu upp ämnen som politik, miljöfrågor och sociala problem. $^{680}$

I Höghuset vid myren skildras skolans undervisning som att den står i konflikt med ett liv nära naturen. Människorna i höghuset har upptäckt att den enda utbildning de egentligen behöver är kunskaperna om hur man lever i harmoni med naturen, vilket också är förutsättningarna för ett lyckligt och tillfredsställande liv. I Rousseaus anda lär de sig genom sina erfarenheter i naturen och i samarbete med andra och talleborgarna är lika uppfinningsrika som pojkarna som rymmer från uppfostringsmaskinen i "Doktor Klokamundus' uppfinning". Liksom Robinson Crusoe lever de ett primitivt men tillfredsställande liv avskilt från civilisationen. ${ }^{681}$ Människorna i böckerna om Talleborg kan därmed ses som föregångare till 1970-

\footnotetext{
${ }^{677}$ E. Friman, ”Tillväxtens gränser", 2008, s. 282.

${ }^{678}$ Ibid., s. 281-285.

${ }^{679}$ T. Frängsmyr, Svensk idéhistoria: Bildning och vetenskap under tusen år. D. 2, 1809-2000, 2000, s. 322.

${ }^{680}$ L. Kjersén Edman, I ungdomsrevoltens tid: Svensk ungdomsbok och dess mottagande åren kring 1968, diss., Umeå universitet, Umeå, 1990; L. Kåreland, "Barnlitteraturens utveckling i Sverige", 2008; L. Kåreland, Inga gåbortsföremål: Lekfull litteratur och vidgad kulturdebatt $i$ 1960- och 70-talens Sverige, 2009, s. 63-69.

${ }^{681}$ T. Frängsmyr, Framsteg eller förfall: Framtidsbilder och utopier $i$ västerländsk tanketradition, 1990, s. 97-103; G. Klingberg, Svensk barn- och ungdomslitteratur 1591-1839: En pedagogikhistorisk och bibliografisk översikt, 1964, s. 193-194; L. Kåreland, Barnboken i samhället, 2013, s. 19.
} 


\section{Tekniklandskapet i Karl-Aage Schwartzkopfs barnböcker}

talets så kallade grönavågare. ${ }^{62}$ Redan i den första bokens inledningsord finns ett budskap om att ett liv närmare naturen är något som människan borde sträva mot:

Huset var mycket högt.

Det låg mitt inne i skogen, vid kanten av en myr. Han som hade byggt huset älskade naturen. Han ville vakna på mornarna och höra fåglar sjunga. Han ville somna på kvällarna och höra grodorna kväka i myrkanten. Det fanns många som förut bodde i den stora staden som tyckte som han och därför blev huset väldigt högt - hela 13 våningar. ${ }^{683}$

När människorna i höghuset blivit avskurna från den urbana världen, går de successivt över från att använda modern teknik till att ta hjälp av naturen för att lösa vardagens bestyr. Almanackor och klockor går sönder, men människorna har insett att det är oviktigt och man övergår till att avläsa tiden med hjälp av solen. De dagar det är mulet använder man sig av en ugglefamilj som bodde i en spricka $i$ husväggen. Ugglehannen vaknade nämligen alltid klockan tre och tittade ut.

Med tiden börjar naturen ta över huset. I väggarna på det stora huset slår frön rot och det växer snart fram tallar och björkar ur sprickorna. Ingen bryr sig om att ta bort dem, eftersom de skyddar huset som en päls om vintern. Dessutom susar vinden så bra i dem att människorna ibland slipper höra ”[...] det onda bruset från staden". ${ }^{684}$ Skogens alla djur, som man tidigare bara kunnat skymta på avstånd i skogen, flyttar närmare och vissa av dem till och med in i huset tillsammans med människorna.

Betydelsen av att ta hänsyn till djur och natur genomsyrar båda böckerna om höghuset och liksom i Nils Holgersson och de tekniska sagorna finns här en uttalad kritik mot jakt på djur. Döda djur får människorna i Talleborg endast göra för att skaffa sig föda, men då inga däggdjur utan endast djur som fiskar, grodor, sniglar och myror. Jakten på dessa djur måste genomföras med stor hänsyn mot djur och natur. Doktor Bask får sig exempelvis en ordentlig åthutning efter att ha råkat ta fel på en groda och en hare. Han blir efter ett rådslag fråntagen sin pilbåge och pilar som straff. Doktor Bask hade dock direkt efter skjutningen av haren ångrat sitt

\footnotetext{
${ }^{682}$ T. Frängsmyr, Svensk idéhistoria: Bildning och vetenskap under tusen år. D. 2, 1809-2000, 2000, s. 322.

${ }^{683}$ K.-A. Schwartzkopf, Höghuset vid myren, 1965, s. 7.

${ }^{684}$ Ibid., s. 18.
} 


\section{Tekniklandskapet i Karl-Aage Schwartzkopfs barnböcker}

tilltag och hade försökt återuppliva den med konstgjord andning och hjärtmassage, dock förgäves. Här finns en konflikt. $\AA$ ena sidan behöver människorna i höghuset mat, å andra sidan blir konsekvensen att oskyldiga djur får sätta livet till. Det man kommer fram till är att ingen jakt får bedrivas på närmare håll än tjugo stenkast från huset. Ett ytterligare exempel på hur en konflikt mellan människa och natur löses är att man inför förbud mot att ta grodrom, trots att många i huset tycker att det är en delikatess. Risken finns annars att grodorna utrotas, vilket betyder en rätt mindre på matsedeln. Likaså beslutas att endast "de ännu ej färdigvuxna" ska mjölka älgkorna i skogen, eftersom de har mjukare händer. Den kritiska hållningen till jakt har höghusberättelsen gemensamt med flera utopiska samhällsskildringar, då nästan alla de tidiga utopisterna ansåg att jakt står för råhet och barbari. ${ }^{65}$

Omtanken om djuren, en fågel i ett fågelbo, är också orsaken till varför talleborgarna under sin vandring mot Norrland tar en omväg som tar en halv dag extra:

Doktor Bask blev lite besk och tyckte att det var onödigt. Men då tog det eld i Tant Mathilda och hon höll en lång föreläsning för honom. En fågel var precis lika viktig som en doktor, sa hon, och kanske till och med viktigare, för den kunde både sjunga och lägga ägg och ingetdera var henne veterligt doktor Bask något vidare på. Något slokörad måste han dra sig tillbaka och hela resten av dan gick han och grubblade och sög på stetoskopet och tyckte att livet var hårt som inte hade gjort honom till en fågel i stället för till doktor. ${ }^{686}$

En liten fågel är här lika viktig som en människa. Djur och människors värde går inte att sätta mot varandra och det finns ingen hierarkisk rangordning dem emellan, vilket vittnar om en biocentrisk natursyn. Rolf Edberg ger uttryck för en liknande natursyn när han i Spillran av ett moln (1966) konstaterar att människan inte har velat inse att jorden inte tillhör oss utan att det är vi som tillhör jorden. Att människan har trott sig kunna behärska naturen är en villfarelse och "[...] på varje sida av naturens bok står ett cave hominem - varning för människan”. Människan har arbetat mot naturen, ej med, vilket kan få ödesdigra konsekvenser, skriver Edberg. ${ }^{687}$

\footnotetext{
${ }^{685}$ R. Ambjörnsson, Fantasin till makten! Utopiska idéer $i$ västerlandet under fem hundra år, 2004, s. 32.

${ }^{686}$ K.-A. Schwartzkopf, Höghuset vandrar norrut, 1969, s. 41.

${ }^{687}$ R. Edberg, Spillran av ett moln: Anteckningar i färdaboken, 1966, s. 165.
} 


\section{Tekniklandskapet i Karl-Aage Schwartzkopfs barnböcker}

När Justus Jansson upptäcker hur djuren på en cirkus behandlas blir han upprörd. Cirkusdirektören använder dressyrpiskor mot tigrarna som uppgivet kryper runt $\mathrm{i}$ en cirkel kring honom. Justus menar att det är "nedrigt" att slå djur, medan cirkusdirektören hävdar att man måste det - annars blir man uppäten. Cirkusdirektören blir dock övertalad att sluta använda piskor. Vid föreställningen senare på kvällen vägrar tigrarna att hoppa upp på de pallar som placerats ut i manegen. När cirkusdirektören smäller med piskan ropar Justus Jansson till honom och påminner honom om att han lovat att aldrig mer slå ett djur. Tigrarna känner inte igen cirkusdirektören utan piska, men tycker inte att han "ser ett dugg kul ut" och vänder ut från manegen:

Hela Talleborg applåderade och snart applåderade publiken också. Men den förstod inte riktigt det fina i vad som hade hänt. Den hade kommit dit för att se människans seger över djuren. Det som hade hänt var precis tvärtom. ${ }^{688}$

Talleborgarna får cirkusdirektören och cirkuspubliken att inse att djuren har ett egenvärde och att djur inte ska behöva anpassa sig och lyda människan.

Den syn på naturen som berättelsen förmedlar, i kombination med höghusets demokratiska styrelseskick där alla har lika mycket att säga till om, gör att det samhälle som människorna i höghuset skapar skulle kunna beskrivas som en ekosocialistisk utopi. Ekosocialismen är en ideologi som länkar samman socialism och ekologi och enligt ekosocialismen är kapitalismen omöjlig att förena med ett ekologiskt tänkande. ${ }^{689}$ Den natursyn som förmedlas i böckerna om människorna i höghuset kan sammantaget tolkas som biocentrisk, då budskapet är att allt levande har ett egenvärde och människan intar inte en hierarkiskt högre position på jorden jämfört med andra arter. ${ }^{690}$

\footnotetext{
${ }^{688}$ K.-A. Schwartzkopf, Höghuset vandrar norrut, 1969, s. 92.

${ }^{689}$ D. Pepper, Eco-socialism: From deep ecology to social justice, London: Routledge, 1993;

D. Wall, The rise of the green left: Inside the worldwide ecosocialist movement, London: Pluto, 2010, s. 1-2.

${ }^{690}$ E. Erlandson-Hammargren, Från alpromantik till hembygdsromantik: Natursynen $i$ Sverige från 1885 till 1915, speglad i Svenska turistföreningens årsskrifter och Nils Holgerssons underbara resa genom Sverige, 2006, s. 19; S. Sörlin, Naturkontraktet: Om naturumgängets idéhistoria, 1991, s. 157-159.
} 


\section{Framtidssynen i böckerna om höghuset Talleborg}

I böckerna om Talleborg framställs Norrlands natur som en antites till staden. Stadslivet skildras som onaturligt och ohälsosamt och böckernas budskap har likheter med Edbergs tankar om det moderna samhället i Spillran av ett moln (1966). Liksom i Edbergs bok finns ett budskap om att det är en skenvärld man lever i när välstånd mäts i antal bilar, tv-apparater, telefoner och cementproduktion. Sanningen, menar Edberg, är att civilisationen baseras på en självätande ekonomi där människan kommit $\mathrm{i}$ obalans med naturen och på så vis "[...] blivit det enda väsen $\mathrm{i}$ skapelsen, som vegeterar på att förstöra sin egen miljö". Tekniken beskriver han som ett "utflöde av människohjärnan" som utnyttjas för att spoliera människans egen existensbas. ${ }^{691}$

Talleborgarnas längtan till den orörda norrländska naturen har också gemensamma beröringspunkter med 1960-talets uppvärderande av naturen i sig. Ett liv i naturen ter sig mer äkta och ursprungligt och står i kontrast till ett urbant förkonstlat liv. Att flytta ut på landet framstår därför som ett alternativ och en mer positiv livsstil. ${ }^{692}$

Talleborgarnas äventyr slutar med att cirkusen och dess människor och djur följer med till Norrland. Själva beskrivningen av hur färden dit går till är tekniskt noggrant beskriven. Talleborg dras av fem cirkuselefanter och Tant Mathilda och de andra talleborgarna sköter stockbytena: "[S]å fort en stock kom fri bakom huset, lyftes den genast fram." ${ }^{693}$ Att man lyckas undvika att bli upptäckt av polishelikoptern beror på att man först kamouflerat huset med cirkustältet och sedan täckt tältet med mossa och grangrenar. Från luften ser därför huset ut som en bergknalle. Det samhälle som man planerar att bygga upp vid Kebnekajses fot skiljer sig från det som de har lämnat bakom sig. Man ska inte ha någon vanlig skola utan all undervisning ska ske ute i friheten. Inte heller ska man ha några skatter utan alla kommer att dela lika. Naturen ska vara helt fri från nedskräpning och cirkusens hyenor ska få fara runt som "levande dammsugare". Väl på plats vid Paradisets dal vid Kebnekajses fot, lever sedan människorna lyckliga. Boken avslutas med en uppmaning till läsarna:

\footnotetext{
${ }^{691}$ R. Edberg, Spillran av ett moln: Anteckningar i färdaboken, 1966, s. 136.

${ }^{692}$ L. Lennerhed, ”Det är rätt att göra uppror!”, 1998, s. 194-222.

${ }^{693}$ K.-A. Schwartzkopf, Höghuset vandrar norrut, 1969, s. 109.
} 
Här lämnar vi Talleborg och Paradisets dal. Jag vet att många nu kommer att fråga, hur man kommer dit. Ni vill att jag ska peka ut på kartan, var den ligger. Jag kan bara svara, att Paradisets dal inte finns utsatt på någon karta. Men den finns hos alla som har det rätta sinnelaget, som tror på den.

Sök gärna. Men fråga inte efter den. Ni måste hitta den helt av er själva. Ni kanske inte alls behöver fara ända upp till Kebnekajse. Ni kanske har den inom er. Lycka till! $!^{694}$

Bokens slutord bekräftar budskapet $\mathrm{i}$ att framtiden är ett utopiskt idealsamhälle som står i kontrast till det stressiga livet i staden.

\section{Sammanfattande analys av Karl-Aage Schwartzkopfs barnböcker}

Efter andra världskrigets pessimism kom ett ekonomiskt uppsving och en stark tro på framtiden växte fram och Kimberley Reynolds konstaterar att det inom litteraturen vid denna tid uppstod ett slags " $[. .$.$] modernists' excitement about machines,$ new technology, and the future of culture" ${ }^{695}$ I böckerna om tågfamiljen som skrevs kring 1950 framställs tekniken också som något oproblematisk. Det är snarare människorna som skapar problem för tekniken än tvärtom. Höghusböckerna, som publicerades i slutet av 1960-talet, förmedlar däremot en mer kritisk syn på samhällsutvecklingen och teknikens inverkan på människa och natur. Det finns dock vissa likheter berättelserna emellan. I båda berättelserna framställs den äldre tekniken som överlägsen den nyare. Något annat som berättelserna har gemensamt är att det är tekniska system som ges en central roll. I böckerna om familjen TuffTuff är det delar (komponenter) av en större helhet (järnvägssystemet) som är huvudaktörer och läsarna får stifta bekantskap med ett antal tekniska begrepp som har med tåg och järnväg att göra. I böckerna om Talleborg kan höghuset ses som ett tekniskt system där människorna ingår som viktiga delkomponenter. Det tekniska systemet höghuset kan i sig inte uträtta något utan är beroende av att varje delkomponent fungerar eller utför sitt uppdrag.

Eftersom det tekniska och sociala hänger ihop, är det många gånger inte möjligt att strikt separera tekniska system från socio-tekniska system. Ett socio-

\footnotetext{
${ }^{694}$ Ibid., s. 118-119.

${ }^{695}$ K. Reynolds, Radical children's literature: Future visions and aesthetic transformations in juvenile fiction, New York: Palgrave Macmillan, 2007, s. 28.
} 


\section{Tekniklandskapet i Karl-Aage Schwartzkopfs barnböcker}

tekniskt system kan definieras som att det består av både sociala aktörer och tekniska artefakter. ${ }^{696}$ I böckerna om familjen Tuff-Tuff ingår konduktören och människorna som reser med tågen som viktiga komponenter och i Talleborg är interaktionen människorna emellan liksom mellan människorna och tekniken viktiga för att livet $\mathrm{i}$ höghuset ska fungera.

En stor skillnad mellan berättelsernas tekniksyn är att $\mathrm{i}$ böckerna om familjen Tuff-Tuff är det tekniska systemet autonomt, medan det är människorna som styr systemet i böckerna om höghuset. I böckerna om familjen Tuff-Tuff är tekniken i hög grad förmänskligad och gestaltas som en antropomorf. De tekniska artefakterna har mänskliga känslor och behov och beter sig som människor. Tågen föder "barn”, går i skolan, roar sig på restaurang, åker Vasalopp, deltar i boxningsmatcher, idkar välgörenhet med mera. Människorna, däremot, uppträder snarare som teknikens fiender som ständigt försöker begränsa tågens handlingsutrymme eller bestraffa dem för att de inte lyder order. Hotet mot tågfamiljens existens är människans strävan att vilja vidareutveckla sin teknik och det finns därför en överhängande risk att människan förr eller senare överger sina äldre "trotjänare". Tågfamiljen lyckas dock alltid överlista människorna, till och med tågkannibaler som äter tåg.

En sammansmältning (hybrid) av biologisk vävnad och teknik (maskin), en cyborg, finns med i berättelsen i form av Mulle Tunnelgrävare. ${ }^{697}$ Liksom i Shelleys berättelse om Doktor Frankenstein tappar människorna kontrollen över sin skapelse med ödesdigra konsekvenser som följd. ${ }^{698}$ Tågfamiljen är själva exempel på teknik som människorna (konduktören) förlorat kontrollen över. De bryter sig ut ur det tekniska system de är en del av, när de ständigt är på rymmen från tågstationen i Krylbo.

\footnotetext{
${ }^{696}$ J. Hallström, ”Systemteori och teknik. En introduktion till stora tekniska system", 2009, s. 99; L. Ingelstam, "Varför är tekniska system intressanta?" i Världens gång - teknikens utveckling: Om samspelet mellan teknik, människa och samhälle, P. Gyberg \& J. Hallström (red.), Lund: Studentlitteratur, 2009, s. 81-97; L. Ingelstam, System: Att tänka över samhälle och teknik, 2012, s. 214-256.

${ }^{697}$ D. J. Haraway, "A cyborg manifesto: Science, technology, and socialist-feminism in the late twentieth century", 1991, s. 149.

${ }^{698}$ M. W. Shelley, Frankenstein, or, The modern Prometheus, 1818/1993.
} 


\section{Tekniklandskapet i Karl-Aage Schwartzkopfs barnböcker}

Det är bilden av det effektiva samhället där människan använder tekniken för att både kolonisera naturen och människor i andra delar av världen som förmedlas $i$ böckerna om familjen Tuff-Tuff. ${ }^{699}$ Samtidigt kan framstegstron tolkas som något svag, då det finns ett tydligt budskap om att den äldre tekniken är bättre och mer pålitlig än den nyare. Genom att attribuera tågfamiljen mänskliga känslor samt väva in tekniska uttryck i dialog och beskrivningar, framställs den äldre tekniken som sympatisk och pålitlig. Ny teknik är däremot oberäknelig och går till och med att muta. Berättelsen företräder på så vis både konservatism och utvecklingskritik.

Mählqvist konstaterar att den barn- och ungdomslitteratur som han undersökt mellan åren 1850 och 1950 nästan helt saknar politiska inslag som torgför en bestämd uppfattning. ${ }^{700}$ Något tydligt ideologiskt budskap har inte heller böckerna om tågfamiljen jämfört med böckerna om Talleborg. Däremot är tekniken i hög grad närvarande. Tekniken står i centrum medan människor och natur får agera birollsinnehavare och kuliss. Naturen är något som tågfamiljen då och då rymmer till för att plocka blåbär eller utforska på andra kontinenter, men det förmedlas inget budskap om dess egenvärde. Djuren företräder inte naturen utan är snarare människor i djurskepnad, vilket episodvis gör berättelsen till en fabel. Berättelsen förmedlas ur den antropomorfa teknikens perspektiv. Den innehar herraväldet över naturen och den erövrar naturen. På så vis företräder böckerna en antropocentrisk natursyn. ${ }^{701}$ Böckerna om höghuset Talleborg är däremot en utopisk berättelse om hur familjerna $\mathrm{i}$ ett förortshus övergår från ett urbant storstadsliv till att leva ett Robinson Crusoe-liv. Böckerna är samhällskritiska, men det är med humor som kritiken framförs. Det samhälle som höghusets familjer skapar är en direkt demokrati, där barnen har lika stort inflytande som de vuxna. Ibland till och med större. Ett övergripande budskap handlar om att det urbana livet i staden leder till alienering människor emellan samt mellan människa och natur. Därför är ett liv i harmo-

\footnotetext{
${ }^{699}$ T. Frängsmyr, Framsteg eller förfall: Framtidsbilder och utopier $i$ västerländsk tanketradition, 1990, s. 134-135.

${ }^{700}$ S. Mählqvist, Böcker för svenska barn 1870-1950: En kvantitativ analys av barn- och ungdomslitteratur i Sverige, diss., Uppsala universitet, Stockholm: Gidlund, 1977, s. 158-160.

${ }^{701}$ E. Erlandson-Hammargren, Från alpromantik till hembygdsromantik: Natursynen i Sverige från 1885 till 1915, speglad i Svenska turistföreningens årsskrifter och Nils Holgerssons underbara resa genom Sverige, 2006, s. 19; S. Sörlin, Naturkontraktet: Om naturumgängets idéhistoria, 1991, s. 157-159.
} 
ni och i symbios med naturen människans rätta element. Livet i staden framställs däremot som stressigt och anonymt och kan dessutom enbart erbjuda en smutsig och bullrig miljö. Natursynen är övervägande biocentrisk och i det fiktiva samhället Talleborg finns ett kompanjonskap mellan människa och natur. ${ }^{702}$ Den tillvaro som talleborgarna skapar bygger också på ett slags grannskapsideal där gemensamma aktiviter och samarbete är viktigt. Höghusmänniskornas nya liv beskrivs som en julafton varje dag, vilket kan betraktas som en metafor för pånyttfödelse och starten på ett nytt liv. Genom sin utopiska skildring av Paradisets dal i Norrland, företräder berättelsen framtidssynen om det goda livet. ${ }^{703}$ En förutsättning för en ljus framtid är att människan ger upp sin materiella strävan. Däremot är inte framsteg ekvivalent med tekniska landvinningar, utan framsteg handlar här istället om ett ekologiskt hållbart samhälle. Det finns ett val; på sin väg mot utopin måste människan alltid välja att inte skada naturen. Det kräver en del extra arbete och tid, men är den enda framkomliga vägen. Djuren ges också ett stort utrymme i böckerna. De är människans följeslagare och medhjälpare, men inte människor i djurskepnad.

Då kritiken mot "bilåldern" löper som en röd tråd genom berättelsen kan bilen tolkas som en symbol eller metafor för det industriella och högteknologiska samhället. Bilen (tekniken) är inte bara något som har en negativ inverkan på miljön. Det finns också en stor risk att människan blir så beroende av den att den inte längre enbart är en förstärkning eller förlängning av hennes egna fysiska begränsningar. Hon blir ett med den, en cyborg, i vilken blodet har ersatts av bensin och olja och extremiteterna blir en förlängning av dess olika delar. ${ }^{704}$

Vetenskapen, här personifierad genom doktor Bask med sitt stetoskop, är av mindre betydelse. Människorna bör istället lära av naturen och använda sin fantasi och uppfinningsförmåga för att överleva. Den moderna teknik de tidigare varit beroende av fungerar inte längre, utan de får använda en uråldrig, men väl fungerande sådan. Den befintliga moderna tekniken tilldelas istället en ny funktion: sopnedkastet blir en högtalare och bilarna blir till bostäder för djur. Tekniken

\footnotetext{
${ }^{702}$ Ibid.

${ }^{703}$ T. Frängsmyr, Framsteg eller förfall: Framtidsbilder och utopier $i$ västerländsk tanketradition, 1990, s. 227-236.

${ }^{704}$ D. J. Haraway, "A cyborg manifesto: Science, technology, and socialist-feminism in the late twentieth century", 1991, s. 149.
} 


\section{Tekniklandskapet i Karl-Aage Schwartzkopfs barnböcker}

ersätts också av skogens djur. Det visar att den moderna tekniken i mångt och mycket anses som onödig. Beskrivningen av hur naturen (växter och djur) snabbt tar över höghuset visar också att den teknik människan skapat lätt vittrar sönder, medan naturen är det som i längden består.

Sammantaget kan böckerna om Talleborg tolkas som att de har ett implicit politiskt budskap inkluderat i den tekniksyn de förmedlar. Berättelsen kan ses som en uppmaning till den moderna människan att våga ta kommandot över sitt liv liksom teknikens inverkan på människa och samhälle. Att man klipper av de gamla elektricitets- och telefonledningarna för att kunna dra iväg med huset ut i vildmarken, är en symbolisk handling: människorna klipper banden till en icke hållbar utveckling.

En bokserie som både förmedlar en syn på teknikutvecklingen i kombination med ett mer tydligt politiskt budskap jämfört med böckerna om höghuset är Sven Wernströms Den underbara resan. En läsebok om Sverige. Berättelsen publicerades i tre volymer mellan åren 1985 och 1987 och kan beskrivas som en parafras på Lagerlöfs läsebok om Nils Holgersson. Den underbara resans budskap handlar om en kritik av den riktning i vilken samhället är på väg och i detta ingår ett ifrågasättande av den vetenskapliga världens företrädare och deras "sanningar". 



\section{KAPITEL 7}

\section{Tekniklandskapet i Sven Wernströms barnbok Den underbara resan}

\section{Sven Wernström (1925-)}

Sven Wernström är född 1925 och han växte upp i ett arbetarhem i Stockholm. Redan som nittonåring började han skriva ungdomsböcker och hans första bok kom ut 1945 . $^{705}$ Wernström började sin yrkeskarriär som typograf på bland annat Aftonbladet och han arbetade inom yrket fram till 1964. Under den tiden skrev han flera böcker per år, många på uppdrag av B. Wahlströms förlag. Efter 1962 slutade Wernström skriva ren underhållningslitteratur, då han genom sina böcker istället ville lära barn och ungdomar hur världen och samhället fungerade. ${ }^{706}$ Wernström var särskilt aktiv i samhällsdebatten under 1960- och 1970-talen, främst i frågor som rörde skolan och han har skrivit romaner, pjäser och debattartiklar i ämnet. Förutom skolan var Wernström engagerad i debatten om barn- och ungdomsbokens roll liksom författarens funktion i samhället. ${ }^{707}$ Han har skrivit barn- och ungdomsböcker inom många olika genrer, som exempelvis kriminalromaner, science fiction, robinsonader, samtidsskildrande fiktion, historiska skildringar och sagoböcker. Av dessa är ett sjuttiotal böcker utgivna i hans eget namn och ett femtontal under pseudonym. Enligt Jerry Määttä är Wernström, vid sidan av sina omfattande insatser inom olika genrer, en av de mest produktiva och lästa svenska författarna inom science fiction. Med böcker som Rymdgänget (1956), Rymd-

\footnotetext{
${ }^{705}$ M. Nilson \& B. Sjöstrand, Max Lundgren och Sven Wernström: Två författarbiografier, Examensarbete, Bibliotekshögskolan, Borås, 1974, s. 16.

${ }^{706}$ Ibid.

${ }^{707}$ Ibid., s. 17.
} 
gänget och mannen i trädet (1957), Mannen i lådan (1958), Resa på en okänd planet (1967), Rymdskeppets gåta (1968), Destination Mars (1969), Den galna planeten (2001) och Tusen år efteråt (2012) anser Määttä att det bara är ett fåtal svenska författare som kan mäta sig med honom. Att genren är central i hans författarskap vittnar också en av hans memoarer, Ett författarliv: Roman (2009) om. Den är skriven som en tillbakablick från år 2025 där den 100-årige Wernström ser tillbaka på sitt liv. ${ }^{708}$

Wernström finns upptagen i Sveriges författarfonds förteckningar. De visar att hans barn- och ungdomsböcker var flitigt utlånade på folk- och skolbibliotek. Mellan åren 1961 och 1981 låg utlåningen på hans böcker mellan 62000 och 232000 lån och år 1976 låg han på plats 33. Wernström har erhållit flera utmärkelser, bland annat Nils Holgersson-plaketten (1974), Expressens Heffaklump (1978), Ture Nerman-priset (1989), samt LO:s kulturpris (2004).

När kulturdebatten under 1960- och 1970-talen breddades kom den även att influera barnlitteraturen. Barnboksdebatten blev vassare och det var snarare barnbokens ideologi än dess estetik som kom i rampljuset, menar Kåreland. Den så kallade "politiska barnboken" slog igenom kring 1970. Med Wernström i spetsen såg författarna till dessa barnböcker som sin främsta uppgift att informera om aktuella politiska och sociala förhållanden i syfte att skapa medvetenhet och solidaritet hos sina unga läsare, skriver Kåreland. ${ }^{709}$ Björn Sundmark beskriver Sven Wernströms författarskap som ett "vi fixar allt", då det inrymmer ett så stort antal olika slags barn- och ungdomsböcker. "Vi:et" kan också, enligt Sundmark, stå för att Wernström så genomgående lyfter fram gruppen som viktig. Trots att hans böcker genomsyras av samhällskritik, är den samtidigt konstruktiv och i hans böcker finns en i det närmaste en utopisk tro på unga människors möjligheter att påverka och förbättra sina och andras livsvillkor, skriver Sundmark. ${ }^{710}$ Maria

\footnotetext{
${ }^{708}$ J. Määttä, "Från flygkamrater till rymdrevolutionärer: Om Sven Wernströms tidigaste science fiction", Barnboken/Journal of Children's Literature Research, vol. 35, 2012, s. 2-3. http://barnboken.net/index.php/clr/article/view/132 (läst 2013-02-02).

${ }^{709}$ L. Kåreland, Inga gåbortsföremål: Lekfull litteratur och vidgad kulturdebatt i 1960- och 70talens Sverige, 2009, s. 33.

${ }^{710}$ B. Sundmark, "Sven Wernström", Barnboken - tidskrift för barnlitteraturforskning/Journal of Children's Literature Studies, vol. 35, 2012, s. 1-2. http://dx.doi.org/10.3402/clr.v35i0.19991 (läst 2013-01-20).
} 
Andersson instämmer med Sundmark och konstaterar att i likhet med ett antal av 1970-talets svenska barn- och ungdomsboksförfattare karaktäriseras Wernströms böcker av en socialistisk grundsyn och en didaktisk ambition att avslöja samtidens samhälleliga orättvisor. ${ }^{711}$

\section{Handlingen i Den underbara resan}

De tre delarna av Den underbara resan kom ut mellan åren 1985 och 1987 och liksom Nils Holgersson är bokens avsnitt indelade efter Sveriges olika landskap. Huvudpersonen är den 12-årige Nicke Svensson från Norrköping som blir uttagen att spela huvudrollen i en tv-version av Lagerlöfs bok om Nils Holgersson. Tillsammans med filmteamet ger han sig ut i transportbil och helikopter för att filma Nils färd genom Sverige. Det tekniklandskap Nicke rör sig genom skiljer sig från det som Nils upplevde i boken cirka 80 år tidigare. I Wernströms bok ställs Lagerlöfs beskrivningar av landet mot det som Nicke upplever under sin resa. Precis som Nils Holgerssons underbara resa genom Sverige är Den underbara resan en skildring av en ung pojkes bildningsresa, men de är av olika slag. I boken om Nils genomgår huvudpersonen en utveckling från "ouppfostrad" och egocentrisk pojke, till att bli en välartad samhällsmedborgare som inser sin nations framtida möjligheter. Nickes bildningsresa handlar om att utvecklas från oengagerad till en politiskt medveten ungdom som fått upp ögonen för sociala orättvisor och miljöförstöring. Målet med Nils resa är att han ska integreras och anpassa sig till tidens rådande samhällsnormer. Nickes bildningsresa, däremot, handlar snarare om att utvecklas till en handlingskraftig medborgare som vågar ifrågasätta rådande samhällsstrukturer och som dessutom engagerar sig för att förändra dem.

Nicke, som tidigare aldrig läst böcker, lär sig att uppskatta litteraturen genom de böcker som hans lärarinna ger honom i uppgift att läsa. Förutom boken om Nils Holgersson läser Nicke böcker som beskriver landets historia och som lyfter fram samhälleliga orättvisor utifrån ett historiskt perspektiv. Under resan börjar han dessutom fundera på vad han vill arbeta med som vuxen. De olika yrken han stöter på har både för- och nackdelar, vilket gör att hans drömyrke ständigt växlar.

\footnotetext{
${ }^{711}$ M. Andersson, 'Sverige i rövarhänder: berättelsen om nationen i Sven Wernströms 'Den underbara resan"” i Barnboken/Journal of Children's Literature Research, vol. 35, 2012, s. 2. http://barnboken.net/index.php/clr/article/view/135 (läst 2013-02-02).
} 
I berättelsen är det den teknik som människor på ett eller annat sätt kommer i kontakt med i sin vardag som väcker Nickes intresse. Denna fascination är något han delar med sin föregångare Nils. Böckerna genomsyras av en kritik och oro för de konsekvenser tekniken har för samhällsutvecklingen, framförallt ur miljöhänsyn. Grundhållningen i Den underbara resan gör att den diskuterar tekniken utifrån ett mer explicit politiskt perspektiv jämfört med böckerna om Talleborg. ${ }^{72}$ Den underbara resan innehåller exempelvis tydligt uttalad kritik mot ekonomiska klyftor, politiska ledare, företagsledare samt inflytande från USA.

\section{Tekniksynen i Den underbara resan}

I Den underbara resans tekniklandskap har det som förutspåddes i Nils Holgersson realiserats och det är industrinationen Sverige som skildras. Efter djupdykningen för svensk industri i slutet av 1970-talet, påbörjades en återhämtning under 1984. Investeringar i form av nya maskiner, forskning och utveckling ökade. Inom industrin genomfördes nya arbets- och organisationsformer och företag som Asea, Volvo och Saab införde längre rotationsperioder och bredare arbetsinnehåll. Förändringarna var grundade i ny produktionsteknik som gjorde det möjligt att producera i kortare serier och med ett mer decentraliserat ansvar för både planering och produktion. ${ }^{713}$ Den nya produktionsprocessen och dess konsekvenser skildras i Den underbara resan. Annan teknik som ges ett något större utrymme i berättelsens skildring av tekniklandskapet är energisystem, skogsbruksteknik, jordbruksteknik samt kommunikationer. Däremot ges inte rymdtekniken något större utrymme i berättelsen, trots Nickes besök vid raketbasen Esrange i Kiruna. Nicke finner den inte alls intressant utan som "ganska trist", då den består av vanliga kontor, ett rödvitt sändartorn av metall samt en raketramp. ${ }^{714}$

I Nils Holgersson kan järnvägen ses som en metafor för den industriella utvecklingen i stort och den är i berättelsen dessutom det tekniska system som knyter

\footnotetext{
${ }^{712}$ Schwartzkopf skrev senare Revolutionen i Soldalen (1972) som har ett mer uttalat politiskt budskap jämfört med böckerna om höghuset Talleborg.

${ }^{713}$ M. Benner, "Välfärdskapitalismens era" i Den välsignade tillväxten: Tankelinjer kring ett århundrade av kapitalism, teknik, kultur och vetenskap, P. Elmlund \& K. Glans (red.), Stockholm: Natur och Kultur, 1998, s. 129-143.

${ }^{714}$ S. Wernström, Den underbara resan: En läsebok om Sverige. D. 2, 1986, Stockholm: Gidlund, s. 56.
} 
samman nationen. ${ }^{715}$ I Den underbara resan har järnvägen en liknande funktion, då den kan tolkas som en symbol för såväl teknikutvecklingen som helhet som svensk industri. Vid filminspelningen i Västmanland besöker Nicke Asea tillsammans med en flicka, Johanna. Hennes pappa är elektronikoperatör och tillverkar strömriktare till ellok, de elektriska lokens "hjärta". Johanna beundrar sin pappa och planerar att utbilda sig till ingenjör. Hon förklarar för Nicke hur elloken fungerar och informerar honom om att "vi" är bäst i världen på den här tekniken:

Det är en grej, stor som en folkvagnsbuss, som omvandlar nätets växelström till den likström som driver tåget. [...] Ett elektriskt lok tar ner sextontusen volt från ledningen och skickar ut en fruktansvärd strömstyrka till sina fyra motorer. Så långt är allt bra, men sen uppstår problemen. För det första måste loket vara tungt så att inte hjulen slirar, för de har ju en väldigt liten yta som ligger an mot rälsen. För det andra måste alla fyra motorerna arbeta exakt likadant. För det tredje - och svåraste - måste motorerna ha samma dragkraft när tåget går fort som när det går långsamt. I ett lok finns ju ingen växellåda, utan man måste reglera både dragkraft och hastighet med elströmmen. ${ }^{716}$

I Johannas beskrivning ingår många tekniska begrepp. Den är så ingående och komplex att texten bitvis övergår från skönlitterär till faktatext och den har därmed likheter med Witts tekniska sagor.

I Den underbara resan, liksom i Familjen Tuff-Tuff, konkurrerar Sverige med USA i teknisk utveckling. I Familjen Tuff-Tuff skildras detta utifrån en boxningsmatch mellan ett ånglok och ett modernt amerikanskt elektriskt lok. I Den underbara resan berättar Johanna om en annan slags tävling: att det svenska företaget Asea skickat ett ellok till USA för att tävla med ett amerikanskt diesellok. Tävlingen går ut på att loken kopplas ihop och sedan får de dra åt varsitt håll. Precis som i boken om tågfamiljen går det svenska loket som segrare ur kampen. Johanna berättar för Nicke att det amerikanska loket "fick åka baklänges och hade inte en chans" och på så vis lyfter hon fram Sverige som ett föregångsland på teknikområdet. ${ }^{717}$ Den stolthet över den svenska tekniken som Johanna ger uttryck för

\footnotetext{
${ }^{715}$ S. Lagerlöf, Nils Holgerssons underbara resa genom Sverige. Bd 2, 1908, s. 546.

${ }^{716}$ S. Wernström, Den underbara resan: En läsebok om Sverige. D. 1, 1985, Stockholm: Gidlund, s. 260.

${ }^{717}$ Ibid.
} 
påminner om när Nils uttrycker sin fascination över vad "snillrika män" kan åstadkomma. $^{718}$

När Nicke får se Asea:s största robot, får han än en gång bekräftat att Sverige ligger i framkant på teknikområdet. Liksom i Nils Holgersson och böckerna om familjen Tuff-Tuff finns därmed även i denna berättelse ett budskap som kopplar samman teknik och en stolthet över nationen Sverige: "Nicke kände hur han stod där och kände sig stolt över svenska robotar. Svensk teknik. Svenskt kunnande. Svensk precision. Som om det vore hans egna grejer." ${ }^{\text {719 }}$ Det inbördes förhållandet mellan robot och människa i fabriken klargörs också vid Asea-besöket:

Den påminde honom om något. Kraftiga rörelser - och så stopp - och så samma rörelser igen. Den påminde honom om ett instängt djur, en isbjörn på Skansen, som gick några steg åt ena hållet och stannade och slängde med huvudet, och så gick några steg åt andra hållet och gjorde samma sak. Men robotar var ju döda. De rörde sig och såg levande ut, men de följde bara ägarens inprogrammerade order. ${ }^{720}$

Att den moderna tekniska produktionsprocessen har fått som konsekvens att individens inflytande över arbete och teknik har minskat är ett återkommande tema $\mathrm{i}$ Den underbara resan. Däremot har fabriksägaren makt över arbetsprocess och teknik och därmed även över arbetaren. Utifrån det perspektivet skildras inte tekniken som autonom.

I robotverkstaden får Nicke se en robot som arbetar timme efter timme, dag och natt, med blind lydnad och envishet och med en precision på en halv millimeter. En liknelse mellan människa och maskin görs när roboten skildras som att den har en "arm" och ett ställe där "handen borde sitta". ${ }^{721}$ Det som skiljer dem åt är att roboten inte har några av de mänskliga behoven. Eftersom en maskin inte blir trött kan den utföra ett arbete utan avbrott och dessutom med en precision som är svår för en människa att uppnå. Fabriksbesöken får Nicke att inse att det finns ytterligare ett perspektiv på industrins effektiviseringar:

- Och göra folk arbetslösa! sa Berit

\footnotetext{
${ }^{718}$ S. Lagerlöf, Nils Holgerssons underbara resa genom Sverige. Bd 1, 1908, s. 115-116

${ }^{719}$ S. Wernström, Den underbara resan: En läsebok om Sverige. D. 1, 1985, s. 264.

${ }^{720}$ Ibid., s. 265.

${ }^{721}$ Ibid., s. 263.
} 
- Eller befria folk från farliga och ansträngande jobb, sa Rolle. Det beror på hur man ser det. ${ }^{722}$

Berits och Rolles dialog illustrerar olika hållningar till effektiviseringarnas inverkan på människans arbete. Maskinen gör att människan slipper att utsättas för tunga, enformiga och arbetsmiljömässigt smutsiga arbeten, men samtidigt behövs färre människor som arbetar. Berit menar att roboten rationaliserar bort människan från tillverkningsprocessen. Hon förlorar sin funktion samtidigt som roboten tar över tunga eller monotona arbetsmoment. Är robotens uppgift att underlätta för människan, eller har den ett annat syfte? Å ena sidan finns här ett budskap som överensstämmer med Kranzbergs tekniksyn: att tekniken är vare sig ond, god eller neutral eftersom dess konsekvenser är svåra att förutsäga. ${ }^{723} \AA$ andra sidan beskrivs teknikens konsekvenser utifrån ett politiskt perspektiv där tekniken används som redskap för kontroll.

Ett ytterligare exempel på en teknisk process som Nicke får se på nära håll är tillverkningen av lastbilshytter vid Scaniafabriken:

Till fabriken kom plåt i stora rullar. De gick in i ett klippverk och klipptes i bitar, som sedan pressades till golv, tak, ryggar och frampartier till lastbilshytter. Det största pressarna sköttes av fyra arbetare - två la in och två tog ut. Men alla fyra måste samtidigt trycka på åtta knappar för att pressverktyget skulle gå ner [...] Hytter svetsas ihop. Det finns mer än fyratusen svetspunkter i en hytt. De flesta görs med robotar som också är svenska och kommer från ASEA i Västerås. Robotarna såg farliga ut. De svängde sina näbbar som hungriga gamar med kraft och beslutsamhet och svetsade punkt till punkt. [...] Själva hopsättningen gjordes i alla fall för hand. Nio svetsare arbetade snabbt och jäktat. Svetslågorna fräste som tomtebloss mot det blåvita stålet. $^{724}$

I likhet med i Nils Holgersson används här liknelser från naturen för att förklara det tekniska förloppet. Genom att använda ord som "näbbar", "hungriga gamar" och "tomtebloss" skapas visuella bilder av hur tekniken fungerar. Men liknelserna gör samtidigt att robotarna inte framställs som något som underlättar arbetet. De är snarare monster som arbetarna måste kämpa med att försöka bemästra. Robotars

\footnotetext{
722 Ibid.

${ }^{723}$ M. Kranzberg, “Technology and History: 'Kranzberg's Laws””, 1986, s. 544-560.

${ }^{724}$ S. Wernström, Den underbara resan: En läsebok om Sverige. D. 1, 1985, s. 121-122.
} 
funktion och förhållande till människan klargörs genom Nickes fundering längre fram i berättelsen:

"Var det bra eller dåligt med robotar? Bra för vem? Roboten var blind i sin lydnad.

Den arbetade åt den som köpte den. Ägaren bestämde vem den skulle vara bra för." 725

Tekniken (roboten) kopplas här till makt. Arbetarna i den tekniska processen är dessutom underordnade fabriksägaren samt är reducerade till komponenter i ett större tekniskt system.

Samma år som Den underbara resan publicerades, kom Georg Henrik von Wrights bok Vetenskapen och förnuftet ut (1987). Boken väckte debatt bland politiker och i svensk massmedia. ${ }^{726}$ Till vissa delar kan Wernströms berättelse tolkas utifrån von Wrights kritik, exempelvis att den tekniska och industriella utvecklingen skapar maktstrukturer. Von Wright menar att den rationalitet som tidigare förhärskade genom religiösa och sociala fördomar, i det industriella samhället ersatts av en instrumentell eller tekniskt målinriktad rationalitet. Genom sitt krav på ökad effektivitet, "strömlinjeformar" den våra liv, skriver von Wright. Konsekvensen är nya former av förtryck med avsaknad av hänsyn till individen och där makten ligger i "statsapparaten". 727

Som redan nämnts i inledningen av detta kapitel är Den underbara resan inte enbart en resa genom det moderna tekniklandskapet utan också en bildningsresa för Nicke under vilken han blir politiskt medveten. Sin klarsyn gällande politisk åskådning når Nicke genom att just betrakta teknikens inverkan på individ och samhälle. Ett sådant tillfälle är när han får se en torgteater med ett tydligt budskap. I teatern "De mäktiga" ingår karaktärerna "Volvo-chefen", "Tidningskungen", "Sossepampen" samt en som heter Mats som plockas upp från publiken:

- Jag vill sälja fler bilar.

Mats gapade av låtsad förvåning.

\footnotetext{
${ }^{725}$ Ibid., s. 264-265.

${ }^{726}$ S. Sörlin, Naturkontraktet: Om naturumgängets idéhistoria, 1991, s. 33.

${ }^{727}$ G. H. von Wright, Vetenskapen och förnuftet: Ett försök till orientering, Ny utg., 1987/ 2010, s. $17-18$.
} 
- Nä vad ser jag... är det du! Inte hade jag räknat med att träffa en sån mäktig man i den här miljön. Vad sa du?

- Jag vill sälja fler bilar.

- Du är faktiskt den mäktigaste människan i hela landet. Alla andra har någon över sej, tillåmed statsministern för han har riksdan över sej. Men du har ingen över dej. Om jag hade sån makt, då skulle jag ge jobb åt alla människor och dagis åt alla barn och jag vet inte allt. Vad vill du göra? Vad ligger dig varmt om hjärtat?

- Jag vill sälja mer bilar. ${ }^{728}$

Sensmoralen i teaterföreställningen kan tolkas som att när ekonomiska intressen styr ett samhälle, är sådant som demokrati, miljö eller rättvisefrågor av underordnad betydelse. Tekniken, bilen, får här fungera som en metafor för kapitalismen.

Langdon Winner tar upp den politiska aspekten på tekniken och skriver att även om tanken att tekniken är politisk kan provocera, kan maskiner och tekniska system inte enbart bedömas utifrån deras effektivitet, produktivitet och positiva respektive negativa inverkan på miljön. De behöver också bedömas utifrån hur de förkroppsligar makt och auktoritet. Winner finner det naivt att tro att tekniken endast är ett resultat av en intern dynamik, opåverkad av yttre influenser, eftersom den i själva verket är skapad utifrån sociala och ekonomiska krafter. Därför har tekniken många gånger politiska konsekvenser, såväl avsiktliga som oavsiktliga, menar Winner. ${ }^{729}$ Utifrån Winners resonemang får exempelvis robotarna i Den underbara resan sociala följder när de gör människor arbetslösa, vilket i sin tur leder till att politiska frågor kommer i fokus. De val samhället gör avseende teknik får konsekvenser för hur människor kommer att arbeta, kommunicera, resa, konsumera och så vidare. Detta går också att koppla till Latour som ser tekniken och samhället som helt beroende av varandra och att de därför är omöjliga att separera eller se som två olika delar. ${ }^{730}$ Detta synsätt delas även av Svante Beckman som konstaterar att "vad som är höna" och "vad som är ägg" egentligen är av underordnad betydelse jämfört med iakttagelsen att en viss teknik också har en inneboende politisk egenskap eftersom den införlivar en fördelning av makt. Beckmans slut-

\footnotetext{
${ }^{728}$ S. Wernström, Den underbara resan: En läsebok om Sverige. D. 3, 1987, Stockholm: Gidlund, s. 337.

${ }^{729} \mathrm{~L}$. Winner, The whale and the reactor: A search of limits in an age of high technology, 1989, s. 19-23.

${ }^{730}$ B. Latour, Reassembling the social: An introduction to actor-network-theory, 2005.
} 
sats är att den grundläggande svårigheten $\mathrm{i}$ analysen av relationen mellan teknik och makt är just att de båda har alldeles för mycket med varandra att göra. ${ }^{731}$

Att den tekniska utvecklingen leder till att det skapas nya maktstrukturer $\mathrm{i}$ samhället illustreras också utifrån ett historiskt perspektiv i Den underbara resan. I avsnittet om Öland träffar Nicke flickan Gunnel som arbetar på hotell. Genom Gunnels släkthistoria ges en övergripande beskrivning av Ölands historia från vikingatid till 1980-tal. Från att hennes förfäder hade levt ett relativt fritt liv som bönder och jägare, började "rikemännen röva i hemlandet" och övriga i samhället blev alltmer kuvade: "Gunnel såg med sorg hur hennes far lärde sig lyda. Hans söner ville behålla sin frihet och flyttade till Amerika. De som blev kvar gick till industrin., 732

Gunnels budskap är att den äldre hantverksinriktade tekniken genom historien fătt ge vika för den industriella och samtidigt auktoritära tekniken. Detta är ett återkommande budskap i berättelsen och återkommer bland annat $\mathrm{i}$ avsnittet om Småland.

När Nicke besöker ett glasbruk får han se en tillverkningsprocess som står i kontrast till en automatiserad industriell process: "Det var ett fint lagarbete. Stämningen i lokalen kändes skön och trivsam. Inga chefer, inga datorer, inga stämpelklockor, inte ens en klocka på väggen." ${ }^{, 733}$ På samma sätt inser Nicke när han träffar en snickare att snickare är något han kan tänka sig att bli, eftersom "reparera kåkar" är "[...] åtminstone ett jobb som de aldrig skulle kunna sätta en robot på”. ${ }^{734}$ Nicke fascineras av samma skäl av husvagnstillverkningen vid fabriken i Västerbotten. Där finns ett tv-team som intervjuar Nicke:

- Vad ska du jobba med när du blir stor? Har du bestämt dej för att bli skådespelare?

- Nej! vrålade Nicke.

- Du låter väldigt bestämd?

- Jag ska jobba på en verkstad, en sån här!

- Jaså? sa tjejen. En sån här verkstad? Varför det?

- För att den är liten!

\footnotetext{
${ }^{731}$ S. Beckman, "Inledning: Teknik, makt och vanmakt" i Teknokrati, arbete, makt, S. Beckman (red.), Stockholm: Carlsson, 1990, s. 14.

${ }^{732}$ S. Wernström, Den underbara resan: En läsebok om Sverige. D. 1, 1985, s. 79.

${ }^{733}$ Ibid., s. 133.

${ }^{734}$ Ibid., s. 251.
} 


\section{Tekniklandskapet i Sven Wernströms barnbok ...}

- För att den är liten? sa tjejen. Nu förstår jag inte?

- Man ser vad man gör! skrek Nicke. Från början till slut. Man ser vad det blir va!

Det var något som han kom på just då. Om man jobbade på en stor fabrik gjorde man bara sin lilla del och fick aldrig se den färdiga grejen. Här såg man hela husvagnen växa fram, tills den stod där blänkande och färdig med möbeltyg och lyxkök och toalett och alltihop. ${ }^{735}$

Ovanstående är ytterligare ett exempel på hur berättelsen skildrar hur den moderna produktionstekniken leder till att människan reduceras till en delkomponent $i$ ett större, oöverskådligt tekniskt system. Arbetet inom den högeffektiva produktionen står i motsatsförhållande till ett arbete där människan kan överblicka alla olika moment. Här finns därmed likheter med budskapet i Beskows saga "Herr Klumpedump från Klumpedonien" där hantverkets överordnade värde lyfts fram. ${ }^{736}$

Utifrån Mumfords indelning i auktoritär respektive demokratisk teknik, kan tekniken i verkstaden som tillverkar husvagnar som betraktas mer demokratisk jämfört med industritekniken med sina robotar. Inom den större industrin är det snarare det tekniska systemet som är i centrum, inte individen. Robotarna och deras ägare kan därmed tolkas som företrädare för den auktoritära tekniken. ${ }^{737}$

Trots att den modernare tekniken i Den underbara resan skildras som en maktfaktor med negativ inverkan på människors liv, är budskapet inte entydigt kritiskt då den samtidigt framställs som något fascinerande och som väcker Nickes beundran:

Allt var fint på Hiab Foco.

I varje fall var allting mycket vackert. Silverblanka hydraulcylindrar, nymålade kranarmar och fundament, rader av splitternya gripklor för timmerlastning. Och en stor låda full med runda bussningar som glänste som riktigt guld. ${ }^{738}$

Den "vackra tekniken" samt stoltheten över den svenska industrin blir här något av en motsägelse i förhållande till den kritik mot den auktoritära tekniken som böckerna samtidigt förmedlar.

\footnotetext{
${ }^{735}$ S. Wernström, Den underbara resan: En läsebok om Sverige. D. 2, 1986, s. 240.

${ }^{736}$ E. Beskow, "Herr Klumpedump från Klumpedonien”, 1915/1955, s. 79.

${ }^{737}$ L. Mumford, "Authoritarian and democratic technics", 1963, s. 1-8.

${ }^{738}$ S. Wernström, Den underbara resan: En läsebok om Sverige. D. 1, 1985, s. 132.
} 
En annan aspekt som går att tolka utifrån ett maktperspektiv och som Den underbara resan dessutom har gemensamt med Witts tekniska sagor, är att de tekniskt kunniga intar en särställning i berättelsen. Ingenjören agerar även i denna berättelse teknikexpert som didaktiskt kan förklara begrepp och redogöra för tekniska processer. Ingenjören är någon som både "hittar på” och löser problem.

Vid ett besök vid Hiab Foco i Hudiksvall möter en ingenjör upp vid grindarna och informerar Nicke om att de tillverkar fordonsmonterade hydrauliska lyftkranar. Nicke tycker om de tekniska orden och han lyssnar intresserat när ingenjören berättar om fabriken:

- Vad är hydraulisk? sa Nicke.

- Va? sa ingenjörn. Ha, bra fråga! [...] Ja ... ä ... hur ska man säga. Kan du lyfta en bil?

- Inte jag inte, sa Nicke.

- Jodå, det kan du visst. Om du släpper ur luften ur en bilring så orkar du pumpa upp den med en vanlig handpump. Då har du lyft bilen en bit.

- Ja då ja, sa Nicke.

- Och det har du gjort med en luftpump, den kallas pneumatisk. Nu byter vi ut den mot en vätskepump, den kallas hydraulisk. Med den pumpar vi in olja i en kolv som kan höja en arm med en krok i ändan - då har du en lyftkran. [...] Och vitsen är att du pumpar in genom ett mycket litet hål, så att du bara behöver lite kraft. Om hålet är en hundradel av kolvens diameter, då får du ut hundra gånger större lyftkraft än du pumpar in. Begriper du?

- Ja, sa Nicke. Det vill säga ... nä.

- Fundera på det! sa ingenjörn. ${ }^{739}$

Ingenjörens förklaring är didaktisk, men Nicke behöver tid för att assimilera de nya kunskaperna och låta dem sjunka in.

Rolf Torstendahls åsikt är att när man talar om ingenjörers makt så kommer man nästan omedelbart in på begreppet teknokrati. Teknokrati brukar i allmänhet innebära att den kunskap som ligger till grund för den är en makt som är oberoende av mänskligt handlande. Det kan handla om att ingenjörers ställning och inflytande är en konsekvens av utövande av specialistkunskaper. Men också att deras ställning och makt i samhället kan ses som ett anspråk på att få mer inflytande över

\footnotetext{
${ }^{739}$ S. Wernström, Den underbara resan: En läsebok om Sverige. D. 2, 1986, s. 130.
} 
samhällets organisation. ${ }^{740}$ I Den underbara resan är det i första hand den första beskrivningen som ges uttrycks för, det vill säga att det är de tekniska specialistkunskaperna som ger ingenjören inflytande och makt. Däremot skildras forskaren och vetenskapsmannen, precis som i "Doktor Klokamundus' uppfinning", som någon som inte går att lita på och som drivs av helt andra syften än ingenjören. Denna insikt når Nicke när han besöker Hälsingland.

Genom en by i Hälsingland går två kraftledningar "[...] med tunga kablar mellan höga metallstolpar i raka hyggen genom skogen" ${ }^{741}$ En av byborna berättar att hon fått en hjärntumör. Likaså har det fötts ett barn med cp-skada och många missbildade djur och växter. När Nicke frågar om det beror på kraftledningarna, svarar bybon att det beror på vem man frågar. Experterna, sådana som "[...] ska tala om för vanligt folk hur det är", ändrar sig hela tiden. ${ }^{742}$ Bybon menar att det beror på att de är köpta av dem som tjänar pengar på energin och människorna som drabbas är i underläge. Experterna å sin sida hävdar att dagens människor är omgivna av elektricitet från tv-apparater, kaffekokare, elspisar, element " [...] och det ena är inte farligare än det andra" ${ }^{743}$ Det som inte går att bevisa vetenskapligt, är inte sant. Denna tolkning förstärks av att en forskare kommer till byns bibliotek för att besvara bybornas frågor och dämpa deras oro:

Mickans mamma vände sig till Forskaren och sa:

- Du har skrivit i din rapport att lågfrekventa magnetiska fält påverkar omsättningen av kalcium i hjärnan. Och att störningarna i kalciumflödet får biologiska följder för både människor och djur [...] Det har du skrivit. Men sen kommer du till oss och säger att vi inte behöver vara ängsliga för kraftledningarna. Vilket är det som gäller nudå? ${ }^{744}$

Nicke försöker titta in i forskaren, Professorns, ögon men det är omöjligt då hans blick hela tiden flackar hit och dit. Professorn är en person som slits mellan olika

\footnotetext{
${ }^{740}$ R. Torstendahl, "Ingenjörernas makt" i Teknokrati, arbete, makt, S. Beckman (red.), Stockholm: Carlsson, 1990, s. 224-225.

${ }^{741}$ S. Wernström, Den underbara resan: En läsebok om Sverige. D. 2, 1986, s. 146.

${ }^{742}$ Ibid., s. 148.

${ }^{743}$ Ibid., s. 150.

${ }^{744}$ Ibid., s. 152.
} 
lojaliteter - sin forskning och de som ger forskningsanslag. Nicke, som tidigare haft en "barnatro" på forskare och vetenskapsmän, börjar vackla i sin tilltro:

Män och kvinnor i vita rockar gör experiment och forskar och skriver böcker om Hur Det Är. Av det blir de doktorer och professorer. Specialister, som Mickan kallat dem. Men specialister har sin lön någonstans ifrån. De har någons uppdrag att forska. Och de som betalar lönen vill ha något för pengarna. ${ }^{745}$

Liksom i "Doktor Klokamundus' uppfinning" finns här en stark skepticism mot forskarvärlden. I Beskows saga går vetenskapsmannen i första hand kungens ärenden. I Den underbara resan handlar kritiken om vilka ödesdigra konsekvenser det får när ekonomiska intressen får styra forskningen. Nickes synsätt har vissa likheter med von Wright när han kritiserar utvecklingen inom den vetenskapliga världen. Han konstaterar att vetenskapen går obegränsat framåt, men att det inte enbart sker på vetenskapsmännens egna villkor. I allt större utsträckning är forskarna istället styrda av samhället och statsmakten, vilket kan leda till en likriktning av forskningen, menar von Wright, då forskarna söker sig till "[...] de mest intensivast odlade tegarna". ${ }^{746}$ På samma sätt är forskaren i Den underbara resan styrd av sina uppdragsgivare och kan därför inte tala om "sanningen" för byborna.

En annan kritisk aspekt på forskarvärlden som lyfts fram i berättelsen är klyftan mellan den vetenskapliga världen och övriga samhället som det vetenskapliga språket skapar. Det skapas ett avstånd när människorna utanför forskarvärlden inte förstår vad forskarna talar om. Däremot framställs i berättelsen det tekniska språket som mer förståeligt eftersom det är konkret. Nicke snappar upp de tekniska begreppen och funderar över deras betydelse:

Så fanns det svetsrobotar, såna hade Nicke sett förut. De rörde sig längsmed arbetsstycket och svetsade sin jämna fog medan svetstråden matades fram från sin rulle. Men under tiden måste arbetsstycket sitta fast i någonting, det måste fixeras så att det satt stadigt $i$ en slags bädd, en fixtur.

Fixeras i en fixtur.

\footnotetext{
${ }^{745}$ Ibid., s. 153.

${ }^{746}$ G. H. von Wright, Vetenskapen och förnuftet: Ett försök till orientering, 1987/2010, s. 101, 127.
} 
Det lät så självklart när man hörde det, men det var ju omöjligt att gissa sig till såna ord i förväg. Vilken massa ord det måste finnas, när det fanns så många yrken med olika fackuttryck!

Nicke kom på en djup tanke:

Man har ord i huvudet som man inte vet om! Hur skulle man annars kunna förstå ett ord första gången man hör det? Skärare, arbetsstycke, fixtur, det var nya ord men han förstod dem genast. Liksom sjukjournal, det kändes också nytt, men han hade genast förstått det när Mickan sagt det.

Inte föddes man väl med språk i huvudet? Var kom alla ord ifrån? ${ }^{747}$

Här knyts kunskaper i tekniken till språket. För att Nicke ska förstå det tekniska förloppet, behöver han sätta ord på det. Denna aspekt är något som Sven-Eric Liedman tar upp när han skriver att en av de vetenskapliga förklaringarna till människans evolutionära utveckling är just det talade och skrivna språket i kombination med människans förmåga till teknik (tillverka redskap). En annan är vår förmåga att planera framåt och föreställa oss saker. ${ }^{748}$ Den sistnämnda förmågan tar lärarinnan Stina upp när hon förklarar för Nicke vad som driver på teknikutvecklingen. Hon menar att förklaringen ligger i att mänskligheten "[...] alltid är på väg framåt". ${ }^{749}$ Stinas framåtsyftande perspektiv på teknik kan också tolkas som ett uttryck för Mitchams beskrivning av teknik som viljekraft eller viljeyttring (volition), att tekniken är ett resultat av sådant som människans strävan att överleva och att tillfredsställa grundläggande behov att kontrollera, liksom strävan efter frihet eller vilja att effektivisera. ${ }^{750}$

Arbetet är en annan särpräglad mänsklig egenskap som går att koppla till viljekraft eller viljeyttring. Lärarinnan Stina säger till Nicke att alla barn måste få se hur arbete fungerar. Nicke undrar varför och han får svaret: "För att det är arbetet som gör oss till människor! Vi är de enda varelser i naturen som arbetar, alltså medvetet, planmässigt." ${ }^{751}$ Detta särskiljande mellan människa och djur påminner

\footnotetext{
${ }^{747}$ S. Wernström, Den underbara resan: En läsebok om Sverige. D. 2, 1986, s. 131.

${ }^{748}$ S. Liedman, Ett oändligt äventyr: Om människans kunskaper, Stockholm: Bonnier, 2001, s. $149-156$

${ }^{749}$ S. Wernström, Den underbara resan: En läsebok om Sverige. D. 2, 1986, s. 164.

${ }^{750}$ C. Mitcham, Thinking through technology: The path between engineering and philosophy, 1994, s. 247-248.

${ }^{751}$ S. Wernström, Den underbara resan: En läsebok om Sverige. D. 3, 1987, s. 56.
} 
om budskapet i Nils Holgersson liksom i de tekniska sagorna. Men i Nils Holgersson är det människans förmåga att skapa teknik som lyfts fram som unikt för människan, medan det i de tekniska sagorna är både människans tekniska förmåga och vetenskapen som gjort människan till herre över jorden.

För att illustrera teknikutvecklingen ber Stina Nicke och Lotta att föreställa sig att de befinner sig i ett land fullt av skog, två stora floder och många mindre vattendrag. Vad behöver de om de ska bygga ett hus? Ungdomarna kommer fram till att om de går ut i skogen och sågar ned träd och lägger dem på varandra så blir det timmerväggar. Läraren undrar då om det inte blir bättre väggar om de tar bort grenarna först. Stina svarar att utvecklingen i så fall måste ha gått så långt att det finns sågar och yxor. Nicke och Lotta får därefter i uppgift att fundera på hur de ska frakta timret till byggplatsen och hur de ska orka lyfta de tunga timmerstockarna. Lärarinnan använder rollspel som didaktisk metod och hon utmanar deras kreativitet och förmåga att tänka ut tekniska lösningar:

\begin{abstract}
- [...] Det var jobbigt att fälla träden med handsåg. Det blir ännu jobbigare att såga längsmed hela stocken. Gång efter gång, planka efter planka. [...] Nu upptäcker ni att plank går att sälja till folk i andra trakter. Det gäller att såga mycket plank. Man kan sätta hjul i forsarna och bygga vattendrivna sågverk. [...] Och plank vräks i älvarna och flottas till kusten. [...] Och vad finns det vid kusten? ${ }^{752}$
\end{abstract}

Här skildras teknikutvecklingen som något positivt. Samtidigt finns avsnitt i boken som ger uttryck för en spänning mellan ny och gammal teknik. Ett sådant exempel är när Nicke besöker Skövde och får veta att man där är så modern att många miljoner lagts ned på datorer och man har infört dataundervisning "till och med" på lågstadiet. Här finns ett budskap som kan tolkas som ett ifrågasättande av datorerna och den nya informationsteknikens inverkan på människan, såväl fysiskt som intellektuellt:

Om barnen fått böcker för 15 miljoner kunde de ha blivit klokare och fătt tankar och fantasi och språk och kultur och berättarglädje och kunskaper i huvet. $\mathrm{Nu}$ har de fått datorer. När journalister frågade vad de tyckte om det, sa barnen:

- Det är jättekul att trycka på knapparna ...

${ }^{752}$ S. Wernström, Den underbara resan: En läsebok om Sverige. D. 2, 1986, s. 164. 
[...] Små barn är starkare än stora. Kanske skulle de kunna göra uppror innan strålningen från dataskärmarna hunnit göra dem alltför korkade. ${ }^{753}$

Informationssamhället som begrepp började användas under 1980-talet och det var under detta årtionde som persondatorerna gjorde sitt intåg i hemmen. Den första pc:n kom ut på marknaden i augusti $1981 .{ }^{754}$ År 1983 fann Time Magazine persondatorn vara "Machine of the year", men sitt stora genomslag fick persondatorerna på 1990-talet i och med internets allt större spridning. ${ }^{755}$ Tom Forester beskriver i sin bok High-Tech Society: The story of the information technology revolution från 1987 hur informationstekniken dramatiskt kommer att transformera samhället. Han inleder med att konstatera att världens nationer är indragna i en teknologisk revolution vilket kommer att skapa dramatiska förändringar för människans liv, arbete och till och med tankesätt. Det är de ekonomiska, teknologiska och politiska trenderna som är drivkrafterna bakom denna high-tech-revolution, menar Forester, och när dessa tre kommer samman under 1980-talet resulterar det i " [...] an explosion of technological and social innovation on a scale not seen for many decades, perhaps not since the Industrial Revolution two hundred years ago" ${ }^{756}$ Forester hävdar vidare att eftersom minneslagring blivit så pass billigt, har datorerna intagit samhällets "blodflöde". ${ }^{757}$ Den underbara resan förmedlar inte en sådan entydigt positiv syn på datoriseringen i samhället. Å ena sidan underlättar den människans arbete men å andra sidan skildras den som både skadlig och "fördummande".

Luftföroreningarna är en annan negativ konsekvens av teknikutvecklingen. Värst "giftspridare" är bilar och bussar och i samstämmighet med Schwartzkopfs böcker om Talleborg tas bilavgasernas negativa inverkan på människa och miljö upp i berättelsen:

Stockholm har landets smutsigaste luft. I hela länet spreds varje år 40000 ton svaveldioxid, 50000 ton kväveoxider, 350000 ton kolmonoxid och 75000 ton organiska ämnen som paraffiner, aromater och klorerade kolväten i luften. [ ...] Stockholm

\footnotetext{
${ }^{753}$ S. Wernström, Den underbara resan: En läsebok om Sverige. D. 3, 1987, s. 300.

${ }^{754}$ S. Hansson, Den skapande människan: Om människan och tekniken under 5000 år, s. 498.

${ }^{755}$ T.P. Hughes, Human-built world: How to think about technology and culture, 2004, s. 100.

${ }^{756}$ T. Forester, High-tech society: The story of the information technology revolution, Oxford: Basil Blackwell, 1987, s. 1.

${ }^{757}$ Ibid.
} 
hade en gång haft rena, fina, elektriska spårvagnar, men de togs bort 1967 samtidigt som högertrafiken infördes i landet. Sedan 1950 fanns det tunnelbana. Därmed var gatorna öppna för vem som helst som ville åka omkring och spruta giftig gas på folk. ${ }^{758}$

Det är barnen som drabbas värst eftersom bilarnas avgasrör sitter så lågt. Hade avgasrören däremot suttit på bilarnas tak hade gaserna hamnat $i$ ansiktet på de vuxna och "[...] då skulle det nog ha blivit ett förskräckligt liv". ${ }^{759}$ Trots bilens negativa inverkan beskrivs alla fordon i berättelsen till både färg och märke (Volvo, Toyota, Sierra Laser, Nissan Micra med flera). Nicke får exempelvis se en vit Range Rover som "[...] borde kunna göra ett par hundra knutar". ${ }^{760}$ En så "snygg" bil har Nicke inte sett på länge och han får lust att köra den. Budskapet är att bilen är en teknisk artefakt som uttrycker något om den som innehar den, en statussymbol.

Tekniken i Den underbara resan finns därutöver representerad i form av energisystem som vatten-, vind- och kärnkraft. På grund av den expanderande industrin och hushållens allt större behov, skedde en stor ökning av elkonsumtionen i Sverige efter andra världskrigets slut. Statsmakterna mötte upp med en kraftfull satsning på utbyggnaden av vattenkraften i Norrland. Enbart statliga Vattenfall byggde mellan åren 1945 och 1960 ett femtontal större anläggningar. ${ }^{761}$ Det starkt ökade behovet av elkraft ledde också till en snabb teknikutveckling inom kraftverksbyggandet och man fann metoder för att överföra elenergi och sedan distribuera den över hela landet med små kraftförluster. ${ }^{762}$ Resultatet av utvecklingen blev att år 1970 hade varje svensk tillgång till mer än 30 gånger så mycket eleffekt jämfört med 1914. Utbyggnaden av älvarna mötte till en början litet motstånd och problemen som uppstod initialt handlade framför allt om försämrat fiske, svårigheter med timmerflottning och minskade odlingsarealer. En särskild vattendomstol inrättades

\footnotetext{
${ }^{758}$ S. Wernström, Den underbara resan: En läsebok om Sverige. D. 2, 1986, s. 38.

${ }^{759}$ Ibid., s. 39.

${ }^{760}$ Ibid., s. 123.

${ }^{761}$ J. Anshelm, Vattenkraft och naturskydd: En analys av opinionen mot vattenkraftutbyggnaden $i$ Sverige 1950-1990, Linköpings universitet, Tema Teknik och social förändring, Linköping, 1992, s. 13 .

${ }^{762}$ Statens Vattenfallsverk, Vattenfall under 75 år: (1909-1984), Vällingby: Statens Vattenfallsverk, 1984.
} 
1918 för att lösa sådana tvister. ${ }^{763}$ Vattenkraftutbyggnaden sågs som något eftersträvansvärt av de allra flesta och miljöeffekterna betraktades som oundvikliga. Utbyggnaden började ifrågasättas under 1950-talet men det dröjde in på 1970-talet innan den på allvar bromsades upp av argument som tog hänsyn till miljön. ${ }^{764}$

När Nicke kommer till Uppland vid Älvkarleby kan inte teamet filma eftersom vattenflödet hejdas av ett kraftverk som inte fanns på Lagerlöfs tid:

Vattenfallen hade tämjts av höga dammbyggnader. Ovanför turbinstationen fanns en stor fyrkantig bassäng med stillastående vattenyta. Men vid sidan av kraftverket glimmade naturens egna forsar i ett fantastiskt stenlandskap med nakna klippor och runda hällar. ${ }^{765}$

Vid vattnet finns kraftstationen som "såg precis så ren och fin ut som den var.",766 Vattenkraften räknas som en ren energikälla, trots det faktum att dammarna har förändrat landskapet:

För vatten är ju egentligen solkraft. Solen drar ånga ur sjöar och hav. Ångan blir till moln som ger regn. Och regnet ger forsande vatten som ger elström. Och vattnet rinner tillbaka till havet för att på nytt bli moln och regn och elström. ${ }^{767}$

Redogörelsen för hur solen är grunden till vattenkraften påminner om Witts saga om "Solens makt". ${ }^{768} \mathrm{I}$ båda berättelserna skildras hur solen skapar vattnets kretslopp, vilket skapar forsande vatten som i sin tur kan driva turbiner som alstrar elektricitet. Kritiken mot utbyggnaden av älvarna i Den underbara resan handlar inte enbart om vilken påverkan den har på naturen, utan också om att de pengar som vattenkraften genererar inte kommer människorna som bor i vattenkraftens närhet till del. Genom att staten och kraftbolagen tar ut flera miljarder kronor i vinst, rinner dessa iväg någon annanstans. ${ }^{769}$ Här, liksom i avsnitten om industri-

\footnotetext{
${ }^{763}$ J. Hult, ”Tekniken mitt ibland oss: 1914-1970”, 1989c, s. 290-291.

${ }^{764} \mathrm{C}$. Bernes \& L. J. Lundgren, Bruk och missbruk av naturens resurser: En svensk miljöhistoria, 2009, s. 137.

${ }^{765}$ S. Wernström, Den underbara resan: En läsebok om Sverige. D. 1, 1985, s. 343-344.

${ }^{766}$ Ibid., s. 344.

${ }^{767}$ Ibid.

${ }^{768}$ O. Witt, "Solens makt", 1914d, s. 58-59.

${ }^{769}$ S. Wernström, Den underbara resan: En läsebok om Sverige. D. 3, 1987, s. 139.
} 
robotarna, kopplas tekniken till politik och makt samt den enskilda människans begränsade inflytande på tekniken när det handlar om stora tekniska system. Arne Kaijser menar att energisystemets utveckling $i$ hög grad är en fråga om makt och då särskilt de ledningsbundna energisystemen eftersom det skapar ett starkt beroende mellan leverantör och abonnenter. ${ }^{770}$

Under 1950-talet blev det inom kraftindustrin en allmän uppfattning att vattenkraften i det långa loppet inte skulle räcka till och man ansåg att den behövde kompletteras. Det uppstod dock två olika uppfattningar om hur denna utbyggnad skulle gå till. Elverken i de större och medelstora städerna förespråkade att detta skulle ske genom kraftvärmeverk, medan de stora kraftproducenterna och Asea (de ledande aktörerna inom elsystemet), istället satsade på att bygga ut kärnkraften. Tillsammans med halvstatliga AB Atomenergi inledde de under 1950-talet ett omfattande utvecklingsarbete på kärnkraftsområdet. ${ }^{771}$ Bakgrunden till satsningen på kärnkraft handlade om hoten om nya elransoneringar, framtida sinande oljekällor, minskad kolproduktion samt att man förutspådde en dramatisk efterfrågan på energi i framtiden. Att lösningen var atomkraft ifrågasattes knappast av någon. ${ }^{772}$

Atomåldern var en benämning på den nya epoken under 1940- och 1950-talen, uppkallad efter den vetenskapliga kunskapen om atomkärnan och möjligheten att tillgodogöra sig dess inbundna energi. ${ }^{773}$ Det teknologiska framskridandet uppfattades som ett tecken på civilisering och kärnkraften blev en symbol för civilisationen. ${ }^{774}$ Under 1950-talet förmedlade vetenskapsmän, ingenjörer, politiker och journalister samma utvecklingsoptimistiska bild av den nya tekniken: atomkraften. Det var inte enbart elförsörjningen som atomkraften skulle kunna vara lösningen på, utan det fanns idéer om att den atomdrivna maskinen i framtiden skulle kunna

\footnotetext{
${ }^{770}$ A. Kaijser, "Ledningen och makten" i Teknokrati, arbete, makt, S. Beckman (red.), Stockholm: Carlsson, 1990, s. 151-153. Med ledningsbundna system avser Kaijser exempelvis el, gas, fjärrvärme, vilka leds via ett särskilt ledningsnät och som skapats endast för detta ändamål. Exempel på icke-ledningsbundna system är oljeprodukter, kol, koks och biobränslen, där transportnätet till användarna även används för andra ändamål, se ”Ledningen och makten”, s. 153.

${ }^{771}$ Ibid., s. 162-163.

772 J. Anshelm, Mellan frälsning och domedag: Om kärnkraftens politiska idéhistoria i Sverige 1945-1999, Eslöv: B. Östlings bokförl. Symposion, 2000, s. 27, 32, 41.

773 "Atomåldern”, Nationalencyklopedin, http://www.ne.se/atom\%C3\%A5ldern (läst 2013-08-13).

${ }^{774}$ J. Anshelm, Mellan frälsning och domedag: Om kärnkraftens politiska idéhistoria i Sverige 1945-1999, 2000, s. 14.
} 
ersätta kol- och oljeeldade maskiner. Bilar, båtar, tåg och flygplan förutsågs kunna drivas med hjälp av egna reaktorer. Tanken var att kärnkraften även kunde lösa naturskyddsfrågorna, eftersom älvarna som ännu inte exploaterats då skulle kunna fortsätta att vara orörda. ${ }^{775}$ Nicke får i berättelsen se Forsmarks kärnkraftverk från helikoptern:

Havsytan låg småkrusig och solglittrande i Lövstabukten och Öregrundsgrepen. På havssidan bredde Gräsö ut sig. På fastlandet reste sig teknikens senaste vidunder ur den flacka stranden.

- Forsmarks kärnkraftverk! sa Peo. Ta en sväng så jag får se det uppifrån!

- Det är nog inte tillåtet, sa Janne Frid. Bäst vi sticker så fort vi kan.

Det ofantliga kraftverkets byggnader var vita och syntes bra från luften. Första och andra blocken låg bredvid varandra och liknade kyrkor med reaktorhusen som höga torn framför turbinhusens lägre huskroppar. Tredje blocket var större och låg lite avsides.

Man kunde förstå att landets regering var stolt över att ha fătt det här byggt - ett verk för 2850 megawatt! Jämfört med till exempel Älvkarlebys 70 megawatt. Och svenskt var det också. Med reaktortankar från Uddcomb i Karlskrona, turbiner från STAL i Finspång och generatorer från ASEA i Västerås. ${ }^{776}$

Här är ännu ett exempel på hur Sverige, i Den underbara resan, framställs som ett föregångsland på teknikområdet. Ovanstående avsnitt följs av en miljöbeskrivning där omgivningen skildras som "skön" och där solblänk "[...] flimrade i vattnet mellan skogsbevuxna öar med gult gräs och steniga stränder [...]" och där ligger Öregrund "[...] med rött klocktorn och vackra villor på steniga backar", ${ }^{777}$ På samma sätt som i Nils Holgersson vävs tekniken in som en del av landskapsbilden men till skillnad mot Lagerlöfs berättelse övergår Den underbara resan i en varning, vilken här handlar om kärnkraftens negativa konsekvenser. Nicke möter några militärer som berättar att de övar inför en eventuell härdsmälta. En av soldaterna berättar att om världens säkraste kärnkraftverk ändå skulle "paja" ska man hålla en näsduk för munnen, gå inomhus och lyssna på radion. Nicke informeras om att

\footnotetext{
${ }^{775}$ Ibid., s. 30; C. Bernes \& L. J. Lundgren, Bruk och missbruk av naturens resurser: En svensk miljöhistoria, 2009, s. 140-141.

${ }^{776}$ S. Wernström, Den underbara resan: En läsebok om Sverige. D. 1, 1985, s. 345.

${ }^{777}$ Ibid., s. 346.
} 
man då ska äta jodtabletter för att skydda sköldkörteln så att den inte tar upp radioaktivt jod som kan ge cancer. ${ }^{778}$

Den tilltro till atomkraftens möjligheter som rådde under 1950-talet kom så småningom att minska och kritiken och skepticismen växte över tid. Anshelm konstaterar att i Sverige förändrades synen på kärnkraft när det högaktiva kärnavfallets slutförvaring i Sverige blev föremål för intensiva debatter och konflikter under 1970-talet. De ställningstaganden och argument som olika aktörer tidigare fört fram förändrades. Det som vid en viss tidpunkt framstod som sanning, kunde vid en annan plötsligt förlora sin sanningshalt. ${ }^{779}$

Under andra hälften av 1970-talet genomsyrades kärnkraftsdiskursen av en stigande grad av insikt om de stora tekniska systemens komplexitet, i synnerhet kärnkraften med dess kärnavfall. Under 1970-talet hade debatten kring kärnkraftens vara eller icke vara ökat och 1976 blev kärnkraften en huvudfråga. ${ }^{780}$ Bernes och Lundgren menar att socialdemokraternas positiva hållning till energikällan bidrog till att de förlorade regeringsmakten för första gången på över fyrtio år. ${ }^{781}$ Den borgliga koalitionsregering som nu tillträdde var inte heller den överens om kärnkraftens framtid och regeringen sprack. Inte heller experterna var ense om hur avfallsfrågan skulle lösas. ${ }^{782}$

${ }^{778}$ Ibid., s. 347.

${ }^{779}$ J. Anshelm, "Kärnavfallets hantering - ett föränderligt problem" i Världens gång - teknikens utveckling: Om samspelet mellan teknik, människa och samhälle, P. Gyberg \& J. Hallström (red.), Lund: Studentlitteratur, 2009, s. 161.

${ }^{780}$ J. Anshelm, Mellan frälsning och domedag: Om kärnkraftens politiska idéhistoria i Sverige 1945-1999, 2000, s. 190-201; J. Anshelm, "Kärnavfallets hantering - ett föränderligt problem, 2009, s. 164-166; C. Bernes, \& L. J. Lundgren, Bruk och missbruk av naturens resurser: En svensk miljöhistoria, 2009, s. 145.

${ }^{781}$ Ibid. Det finns dock sådant som talar emot att kärnkraftsfrågan var så avgörande för valutgången 1976. Sifo konstaterar exempelvis i sin analys av valet 1976 att även om kärnkraftsfrågan dominerade debatten under valrörelsens sista veckor, var det endast två procent av väljarna som $\mathrm{i}$ augusti samma år svarade att de på grund av kärnkraften bytt parti. Fyra procent funderade på att byta. Detta, skriver Sifo, antyder att kärnkraften hade en mindre inverkan på väljarnas ställningstagande på valdagen än vad politiker och massmedia förmodade. För vidare läsning se Sifo, Svenska institutet för opinionsundersökningar AB, Indikator 1976:5, "Det svenska valet 1976. Den lidande borgerlighetens seger i massmedias valrörelse i koncessionsstaten", Stockholm, 1976.

782 J. Anshelm, Mellan frälsning och domedag: Om kärnkraftens politiska idéhistoria i Sverige 1945-1999, 2000, s. 190-201; J. Anshelm, "Kärnavfallets hantering - ett föränderligt problem, 
Reaktorhaveriet i Harrisburg 1979 kom att ha en inverkan på utvecklingen av debatten, då en majoritet av kärnkraftsexperterna tidigare påstått att risken för en sådan olycka i det närmaste var obefintlig. Detta ledde till en folkomröstning i mars 1980, där linje 2 fick flest röster, det vill säga att kärnkraften skulle vara avvecklad 2010. Men utslaget innebar samtidigt att innan avvecklingen genomfördes, skulle en kraftig utbyggnad ske. ${ }^{783}$ Anshelm konstaterar att den ambivalens inför kärnkraften som präglat såväl hantering som opinionsbildning under andra hälften av 1970-talet materialiserades i folkomröstningens resultat. ${ }^{784}$ I folkomröstningen fick svenska folket för första gången ta ställning till en rent teknisk fråga, skriver Hult, och menar att detta gjorde det tydligt att de sociala aspekterna på kärnkraftsfrågan inte gick att isolera från de tekniska. "Teknikdebatten blev samtidigt en samhällsdebatt." ${ }^{785}$ Nicke får insyn i debatten genom ett demonstrationståg mot kärnkraft. På torget står en ung läkare och håller tal:

- Kärnkraften är den största fara som någonsin hotat mänskligheten. En svensk reaktor drivs av fyrtiotusen bränslestavar med uran. Åttatusen av dom måste bytas varje år. Då innehåller de en massa farligt material, däribland plutonium. Det har sitt namn efter Pluto, härskaren i helvetet. Det behövs bara att man andas in ett miljondels gram för att man ska dö - men döden kommer inte förrän efter femton eller tjugo år. Under den tiden har varje svensk reaktor lämnat ifrån sej hundrafemtiotusen bränslestavar som ingen vet var man ska göra av. ${ }^{786}$

Nicke får dessutom veta att man har tänkt att avfallet ska gömmas femhundra meter ner i urberget för att "glömmas bort", detta trots att plutonium inte är något man bara kan "gömma och glömma". Avfallet har en halveringstid på tjugofyratusen fyrahundra år och behöver tio halveringar för att bli ofarligt.

2009, s. 164-166; C. Bernes \& L. J. Lundgren, Bruk och missbruk av naturens resurser: En svensk miljöhistoria, 2009, s. 145.

${ }^{783}$ J. Anshelm, Mellan frälsning och domedag: Om kärnkraftens politiska idéhistoria i Sverige 1945-1999, 2000, s. 247-347; C. Bernes \& L. J. Lundgren, Bruk och missbruk av naturens resurser: En svensk miljöhistoria, 2009, s. 145-148.

${ }^{784}$ J. Anshelm, Mellan frälsning och domedag: Om kärnkraftens politiska idéhistoria i Sverige 1945-1999, 2000, s. 299.

${ }^{785}$ J. Hult, "Tekniken mitt ibland oss: 1914-1970", 1989c, s. 333.

${ }^{786}$ S. Wernström, Den underbara resan: En läsebok om Sverige. D. 1, 1985, s. 348. 
- [...] Det plutonium som framställs i dag kommer alltså att vara farligt i en halv miljon år - tio gånger så länge det har funnits människor på jorden! ${ }^{787}$

När Nicke hör vad den unga läkaren säger, önskar han att hans lärarinna Stina hade varit där och hört talet. Eftersom kärnkraften är en sådan "allvarlig sak" är det något som man borde prata om i skolan, tänker Nicke. ${ }^{788}$ Budskapet att skolan och de vuxna har ett ansvar för att göra eleverna medvetna om samhälleliga frågor förstärks när en annan lärare tar över mikrofonen:

- Hittills har ingen lärobok sagt ett ont ord om kärnkraften. För den skull får inte vi lärare vara lika fega. Vi har ansvar för våra barn och det måste vi ta.

- Hallå där! ropade en äldre man bland åhörarna och satte upp ett finger i luften. De som skriver läroböcker har väl också ett ansvar för barnen!

- Nejnej, sa läraren med de tjocka glasögonen. Dom har bara ansvar för att läromedelsföretagen går med vinst. Men vi lärare har skyldigheter mot barnen. Ett samhälle som tar ut obegränsat med energi under tjugofem år och sen lämnar dödligt avfall efter sej för tusentals år framåt, det är ett omoraliskt samhälle och det måste vi tala om för barnen. ${ }^{789}$

Synsättet att samhället har ett ansvar även för kommande generationer är något som också återfinns i FN:s definition av "hållbar utveckling" i rapporten Vår gemensamma framtid, den så kallade Brundtlandrapporten 1987. ${ }^{790}$

I Den underbara resan tillhör Kåre från filmteamet motståndarna till kärnkraften. Kärnkraften är känslig för sabotage och måste övervakas av militär och polis. Konsekvensen, menar Kåre, är en ökad misstänksamhet människor emellan, eftersom man inte kan veta vem som är sabotör:

- Men vi behöver väl elströmmen? sa Nicke.

\footnotetext{
${ }^{787}$ Ibid., s. 348.

${ }^{788}$ Ibid.

${ }^{789}$ Ibid., s. 349-350.

${ }^{790}$ World Commission on Environment and Development, Our common future, [United Nations Environment Programme], [Nairobi], Vår gemensamma framtid: [rapport från] Världskommissionen för miljö och utveckling under ordförandeskap av Gro Harlem Brundtland, Stockholm: Prisma, 1988, s. 57. För en mer utförlig redogörelse, se vidare kapitlet om tekniksyn i Sven Nordqvists böcker om Pettson och Findus.
} 


\section{Tekniklandskapet i Sven Wernströms barnbok ...}

- Nä vadå till? För att tillverka luktisar och engångsglas och plast och skräp och Husmodern och porrtidningar och stridsflygplan? Sånt kan vi vara utan. Och sånt måste vi vara utan när du blir stor och vi bara har avfallet kvar av kärnkraften. ${ }^{791}$

Det Kåre uttrycker kan tolkas som kritik mot konsumtionssamhället där den mesta av elenergin går till att tillverka "onödiga" ting som människan egentligen inte behöver. ${ }^{792}$ Nicke tycker att det Kåre säger låter sant.

I och med folkomröstningen försvann kärnkraftsfrågan för en tid från den politiska agendan liksom från tidningarnas förstasidor, men den skulle snart återkomma. ${ }^{793}$ I den tredje delen av Den underbara resan (1987) tas olyckan i Tjernobyl 1986 upp som en bekräftelse på kärnkraftens opålitlighet. ${ }^{794}$ Det var på morgonen den 28 april som mätinstrumenten i Forsmark slog larm om förhöjda strålningsnivåer. På kvällen samma dag medgav Sovjetunionen att en explosion hade ägt rum tre dagar tidigare $\mathrm{i}$ en av reaktorerna i Tjernobyl i Ukraina. Reaktorhärdens innehåll fördes med vindarna över hundra mil åt nordväst. ${ }^{795}$ Om konsekvenserna av olyckan får Nicke höra när han är i Lappland och träffar samer och får prova renkött:

- Åhnej! sa Janne Frid. Det här är prima ren, det sa de när jag köpte. Slaktad före Tjernobyl-olyckan, så det är inga beckereller heller.

Tjernobyl var ett sovjetiskt kärnkraftverk som pajat några månader tidigare och som det talades mycket om det året. Radioaktivt stoft hade spritts med vindarna över stora

\footnotetext{
${ }^{791}$ S. Wernström, Den underbara resan: En läsebok om Sverige. D. 1, 1985, s. 354.

${ }^{792}$ Begreppet "konsumism" myntades under 1970-talet och i boken Consuming life (2007) klargör Zygmunt Bauman för vad som kännetecknar ett "konsumtionssamhälle". Det karaktäristiska för konsumtionssamhället är, enligt Bauman, att medborgarna i första hand förväntas agera konsumenter istället för producenter, vilket var fallet i industrialiseringens föregående fas, "produktionssamhället”. Se Z. Bauman, Consuming life, Cambridge: Polity, 2007.

793 J. Anshelm, Mellan frälsning och domedag: Om kärnkraftens politiska idéhistoria i Sverige 1945-1999, 2000, s. 347; C. Bernes \& L. J. Lundgren, Bruk och missbruk av naturens resurser: En svensk miljöhistoria, 2009, s. 146.

${ }^{794}$ S. Wernström, Den underbara resan: En läsebok om Sverige. D. 3, 1987, s. 33-34.

795 J. Anshelm, Mellan frälsning och domedag: Om kärnkraftens politiska idéhistoria i Sverige 1945-1999, 2000, s. 341-342; C. Bernes \& L. J. Lundgren, Bruk och missbruk av naturens resurser: En svensk miljöhistoria, 2009, s. 148.
} 
delar av Europa och även över Sverige. Men till norra Norrbotten hade det inte nått, påstod experterna, så häruppe var det ingen risk för radioaktiva ämnen i maten. ${ }^{796}$

Här lämnas till läsaren att tolka budskapet om huruvida det renkött Nicke och filmteamet äter är ofarligt eller ej. Kärnkraftens baksidor återkommer i skildringen av Nickes besök i Västergötland. Då handlar det om kritik mot uranbrytningen vid Billingen, med hänvisning till att den sker utifrån ekonomiska vinstintressen och utan hänsyn till miljön. Nicke funderar över varför man satsat på något så farligt som kärnkraft när det finns alternativ:

Stina talade om Stora Mellösa, där det funnits vindkraftverk för elektricitet redan 1910. Varför hade inte den tekniken utvecklats? Vinden fanns ju överallt. Vindkraften var ofarlig, den måste ju verkligen vara framtidens energikälla! Men vinden var gratis. Det gick inte att tjäna stora pengar på den. Därför hade vindkraften gömts undan av dem som tänkte mera på pengar än vad människorna behövde. ${ }^{797}$

Genom att lyfta fram hur ekonomiska intressen går före konsekvenserna för miljön, förs än en gång den politiska dimensionen av teknikutvecklingen fram.

Von Wright tar upp den vetenskapliga aspekten på energifrågan när han diskuterar riskerna med en planmässig satsning på forskning i en viss riktning. När forskningen styrs av ekonomiska intressen leder det till minskad flexibilitet och begränsat utrymme för nytänkande, menar han. Denna styrning med kortsiktigt vinstinriktade mål begränsar exempelvis utrymmet för forskning på energiområdet, skriver von Wright, och ställer den något ironiska frågan: "Varför satsa på 'alternativa' energiformer, då risken för misslyckande är stor och avkastningen på kort sikt är ringa?",798

Budskapet om teknik i Den underbara resan kan sammantaget beskrivas som tvetydigt. Å ena sidan skildras tekniken som en nationell framgångsfaktor, å andra sidan skapar den strukturer där den som har makt över tekniken också har makt över andra människor. I vissa avsnitt beskrivs tekniken som något fascinerande och estetiskt tilltalande, beskrivningar som sedan övergår i kritik av bland annat

\footnotetext{
${ }^{796}$ S. Wernström, Den underbara resan: En läsebok om Sverige. D. 3, 1987, s. 33.

${ }^{797}$ S. Wernström, Den underbara resan: En läsebok om Sverige. D. 1, 1985, s. 219.

${ }^{798}$ G. H. von Wright, Vetenskapen och förnuftet: Ett försök till orientering, 1987/2010, s. 128.
} 
dess negativa sociala och miljömässiga konsekvenser. Liksom i Nils Holgersson ges dessutom naturen ett stort utrymme i berättelsen.

\section{Natursynen i Den underbara resan}

Den underbara resan är en realistisk skildring utan vare sig sagoväsen eller talande djur. Däremot ges naturen utrymme att med egen röst beskriva utvecklingen. I Småland träffar Nicke Göran som är ute i skogen och undersöker miljöskador på granar:

- Du kan prata med djuren du Nils Holgersson, sa Göran. Synd att du inte kan prata med träden också. Vet du vad en gran tänker när den sätter såhär många kottar?

- Granar tänker väl inte! sa Nicke.

- Jodu! sa Göran. Det gäller bara att kunna läsa tankarna. Den här granen tänker: Hjälp, jag är förgiftad, nu går det åt helvete! Nu är det bäst jag sätter så många frön jag nånsin kan innan jag dör ...!

- Det ser man ju! sa Lotta häpen.

Plötsligt tyckte Nicke också att han begrep. Det måste vara tungt att sätta så många kottar, det kunde inte vara naturligt. Det var inte gjort i glädje utan i förtvivlan. Granen visste att den skulle dö. Och den gjorde allt för att skogen skulle leva vidare.

- Träden vet ju inte som vi, sa Stina snusförnuftigt. Men på något sätt vet de ändå. ${ }^{799}$

Trädet beskrivs som att det har en vetskap om att det ska dö men samtidigt görs en tydlig skillnad mellan trädets och en människas medvetande.

När Nicke går på en stig i Lappland börjar han filosofera över människans inverkan på naturen. Han känner sig som en jätte, en förstörare, eftersom han i varje steg han tar trampar ihjäl små varelser som lever på marken. Det är hemskt men oundvikligt. Att finnas som människa är att trampa på sin omgivning. Nicke funderar återigen över om naturen har ett vetande:

Naturen måste också veta en massa. Den spindel som kunde hänga upp ett löv i en tråd över stigen måste väl kunna en hel del naturlagar. Och en björk! En björk som först skapat lövet och sen burit det en hel sommar och till sist färgat det brandgult

${ }^{799}$ S. Wernström, Den underbara resan: En läsebok om Sverige. D. 1, 1985, s. 142-143. 
och släppt det ifrån sig, en björk måste väl veta mer än någon vetenskapsman kunde veta? ${ }^{800}$

Nicke slutsats är att om man är en liten fjällbjörk måste man ha kunskaper i kemi, fysik och matematik, om färg och form och om "vackert och ovackert". Man måste vara klok och sparsam. Björken behöver dessa kunskaper för att få fotosyntesen att fungera, trädets egen "lilla kemiska fabrik". ${ }^{801}$ Genom sina grubblerier kommer Nicke slutligen fram till vad som skiljer träd från människor:

Om man var en liten björk på en svensk fjällsluttning skulle man alltså veta ganska mycket. Men en sak skulle man inte veta: Man skulle inte veta att man visste! En björk kan aldrig veta att den vet.

För någon skillnad måste det ju vara mellan björkar och människor. ${ }^{802}$

Denna åtskillnad mellan människan och andra levande varelser går att koppla till (och som redan nämnts) lärarinnan Stinas förklaring till människans tekniska utveckling: att människan "[...] alltid är på väg framåt". ${ }^{803}$ Det vill säga dels vad Mitcham benämner som människans vilja (volition) eller strävan att utveckla teknik, ${ }^{804}$ dels den mänskliga förmågan att kunna föreställa sig saker samt fundera över det egna varandet.

I likhet med i Nils Holgersson är naturen i Den underbara resan något som människan omformar och exploaterar utifrån sina egna intressen och behov, och något som Nils och Nicke har gemensamt är deras kritiska hållning till kalhuggning av skogar. Som redogjorts för i kapitlet om Nils Holgersson, konstaterar Nils när han passerar ett kalhygge att det är en "ful och fattig" plats och när han flyger över sågverket tänker han att nog all Medelpads skog snart kommer att vara uppsågad. ${ }^{805}$ Nickes färd över avverkad skog, skildras som en färd "[...] genom ett

\footnotetext{
${ }^{800}$ S. Wernström, Den underbara resan: En läsebok om Sverige. D. 3, 1987, s. 101.

${ }^{801}$ Ibid., s. 102.

${ }^{802}$ Ibid., s. 103.

${ }^{803}$ S. Wernström, Den underbara resan: En läsebok om Sverige. D. 2, 1986, s. 164.

${ }^{804}$ C. Mitcham, Thinking through technology: The path between engineering and philosophy, 1994, s. 247-266.

${ }^{805}$ S. Lagerlöf, Nils Holgerssons underbara resa genom Sverige. Bd 2, 1986, s. 453-454.
} 
skogigt landskap med otäcka kalhyggen", ${ }^{806}$ När filmteamet senare anländer till Getåravinen utanför Norrköping för att spela in ett avsnitt, upptäcker de att skogen avverkats:

Getåravinen hade till helt nyligen varit det vildaste stället i hela Östergötland med hundraårig granskog och med klippor och skrevor som ännu såg ut att vara tillhåll för rövare som i gamla tider. ... Men nu var ravinen kalhuggen!

Alla stod förstummade och stirrade på förödelsen.

Det finns inget värre miljöbrott än ett kalhygge. Här hade det legat ett stycke svensk natur när den är som vackrast och bäst. Nu låg marken kal och ful och våldtagen och ropade till himlen i torr och tyst förtvivlan. ${ }^{807}$

Genom beskrivningen av hur naturen upplever en "tyst förtvivlan" och att kalhuggning jämställs med våldtäkt, skildras naturen även här som att den har mänskliga känslor. Att människan utnyttjar skogen, och därmed naturen, för ekonomiska och bekvämliga intressen är ett återkommande tema i Den underbara resan. I Västerbotten träffar Nicke en gammal man i en stuga i skogen. Han kämpar mot avverkningen av en flera hundra år gammal skog:

- Skogen består av stora granar och hänglav, sa gubben. Den är renbetesmark på hösten. Den är hem för älg och lo. Och den skyddar oss för stormarna från fjället. Om de tar skogen blir vi helt oskyddade, det begriper alla naturvårdare i hela Sveriges land. Så mycket förstörelse för några futtiga tvåhundratusen kronor! Mera ger inte den här skogen. ${ }^{808}$

När mannen inser att avverkningen redan påbörjats under natten, börjar han gråta. Nicke och helikopterföraren Kåre bestämmer sig för att tillsammans med den gamle mannen bege sig i helikoptern till platsen där avverkningen pågår. Hygget beskrivs som ett "slagfält efter strid". ${ }^{809}$ Mannen som sköter processorn visar sig dock också vara kritisk till utvecklingen:

- Jag vill inte försvara nånting, jag skulle också föredra gallring i stället för kalhuggning häruppe. Men det är inte jag som bestämmer. Vi är ju maktlösa allihop. [...] Jag

\footnotetext{
${ }^{806}$ S. Wernström, Den underbara resan: En läsebok om Sverige. D. 1, 1985, s. 146.

${ }^{807}$ Ibid., s. 158.

${ }^{808}$ S. Wernström, Den underbara resan: En läsebok om Sverige. D. 2, 1986, s. 247.

${ }^{809}$ Ibid., s. 249.
} 
har fru och tre barn i Lycksele, och lån på kåken. Jag måste ta ett jobb när jag får ett. Jag har alltid jobbat i skogen, jag har sett skogsbruket förändras. ${ }^{810}$

Den mekaniserade och rationella avverkningen av skogen är något oundvikligt på grund av att utvecklingen och skogsnäringen övergått till att vara en auktoritär teknik som skogsarbetaren har ett mycket litet inflytande över. Både människor och natur blir "offer" för den:

Maskinen baxade sig långsamt fram över stenblock och skrevor, tung och smidig som en urtidsödla. När den kom i läge stelnade den till - och sträckte ut sin fångstarm av stål mot nästa utvalda träd, kall och känslolös som en krigsmaskin. Jag gör bara mitt jobb, tycktes den morra. Jag lyder bara order. Order från vem? ${ }^{811}$

"Urtidsödla" och "krigsmaskin" används som liknelser för skogsmaskinen - båda står för blodtörstighet och känslokyla. Ett liknande exempel är att gruvföretagets Bolidens maktinflytande liknas vid en bläckfisk som sträcker sina armar över hela Sverige och som hänsynslöst utnyttjar människor och natur för ekonomisk vinning. ${ }^{812}$

Det finns en spänning mellan naturen och teknikutvecklingen. I skogen hämtade människans förfäder det de behövde för att överleva: mat och trä för att kunna bygga sig ett boende. Med tiden har dock synen på skogen förändrats. Att den betraktas som en viktig råvarukälla har inte längre huvudsakligen sin grund i att tillfredsställa människans grundläggande behov, utan snarare i människans girighet:

Bakom det tysta loket stod vagn efter vagn med trettio kubikmeter skog på varje. Skog som kanske stått och susat uppe i Jämtland i går. Skog som varit ett levande hem för massor av levande varelser. Skog som stått och gett syre till luften och tillhört alla och varit öppen för vem som helst att kliva omkring i. Nu på väg att bli trä och papper och skickas utomlands.

Varför?

För att några mystiska ägare ska få pengar. Och vi andra några kalhuggna berg $\mathrm{i}$ Jämtland. ${ }^{813}$

\footnotetext{
${ }^{810}$ Ibid., s. 251.

${ }^{811}$ Ibid., s. 253.

${ }^{812}$ Ibid., s. 69, 84-85.

${ }^{813}$ Ibid., s. 182.
} 
Om människan har rätt att döda djur är annan en fråga som Nicke återkommer till i sina funderingar. Stina har berättat för honom att det egentligen är stenålderslivet som är människans naturliga sätt att leva; det är den slags tillvaro hon levt i under nittionio procent av sin tillvaro på jorden. Människan är dessutom anpassad till att leva i en liten grupp som jagar och fiskar med hjälp av enkla redskap. En viktig instinkt hos de tidiga människorna var att inte döda varandra - de hade annars utrotat varandra. Nickes slutsats är att det är naturligt för människan att döda djur men inte människor. Själv upplever han dock det omvända. Med intresse har han under sin resa tittat på jaktplan och stridsvagnar, sådant som är avsett att döda människor. Han har dessutom många gånger lekt att han dödat människor. Att döda människor känns "bekant", vilket det inte gör när det kommer till att sticka en kniv i nacken på en nyfångad torsk. ${ }^{814}$ Vid första försöket klarar han inte av att avliva en fisk. Lite senare i berättelsen får han en ny chans:

Torsken låg med ryggsidan mot Nicke. Den tittade på honom och gapade och kippade efter andan. Nicke fick tvinga sig att tänka att torsken inte kunde tänka över sitt liv och sin död.

Det knastrade i nacken på torsken när Nicke stötte till - och så var torsken förvandlad från liv till mat.

Så enkelt var det.

Men varför i helvete verkade det vara så svårt om det var så enkelt? Nicke ville vara normal. Han ville att det som varit normalt för människan i hundratusentals år skulle vara normalt för honom också. Att döda djur men inte människor, det var det normala. Inte tvärtom. ${ }^{815}$

Nicke utsätts för ett moraliskt dilemma när han ska avliva fisken, men hans slutsats är att människan har rätt att döda djur för sin egen överlevnad. Människans behov går före djurens. Här skiljer sig budskapet från Nils Holgersson, de tekniska sagorna och böckerna om höghuset Talleborg, då dessa berättelser mer explicit tar avstånd från jakt och dödande av djur. Detta skulle kunna kopplas till det politiska budskapet i Den underbara resan och att den socialistiska ideologi som har sin grund marxismen, snarare är antropocentriskt än biocentriskt inriktad. ${ }^{816}$

\footnotetext{
${ }^{814}$ S. Wernström, Den underbara resan: En läsebok om Sverige. D. 3, 1987, s. 268.

${ }^{815}$ Ibid., s. 274.

${ }^{816}$ D. Pepper, Eco-socialism: From deep ecology to social justice, 1993, s. ix.
} 


\section{Framtidssynen i Den underbara resan}

Den underbara resan är ingen utopisk berättelse som Schwartzkopfs böcker om höghuset Talleborg och inte heller förmedlar den en lika tydlig framtidssyn som Nils Holgersson. Däremot finns en explicit varning för den riktning den tekniska utvecklingen går i och även ett budskap som till vissa delar påminner om de socialistiska utopisternas tankar om idealsamhället. Hos dem, liksom i Den underbara resan, finns kritik mot det kapitalistiska och materialistiska samhället, en önskan om en mer jämlik ekonomisk fördelning och en arbetssituation som stimulerar kreativitet och intelligens. Med andra ord ett samhälle som står i kontrast till den mekanisering av människans arbete som industrialiseringen medför. ${ }^{817}$

Under filminspelningen i Västerbotten får Nicke lyssna till "den stora författarinnan" och "vår tids Selma Lagerlöf", Sara Lidman, när hon håller tal. ${ }^{818}$ Lidman protesterar mot misshushållningen med såväl Sveriges befolkning som natur. Författarinnan talar om naturens "klokhet" och att det finns ett "vett" som naturens varelser äger tillsammans, men som människan förlorat kunskapen om. Som exempel ger hon att falken vet flera månader i förväg att det ska bli god tillgång på sork så att den kan lägga dubbelt så många ägg. Och myrorna vet i september vilket väder det ska bli i januari så att de kan vinterbona sin stack. Författarinnan kallar det "samvetande, en samkunskap". ${ }^{819}$ Men nu protesterar naturen mot människans okunskap. Valarna går upp på land och begår självmord för att slippa att sakta kvävas i nedsmutsade hav. Det finns en risk att de vilda djuren kommer att dö ut på grund av förgiftning men även de tama djuren går samma öde till mötes på grund av "koncentrationslägren" de tvingas bo i (ladugårdarna). Författarinnan slår fast att det är sådan kunskap som barnen i Norrland behöver få för att kunna göra något åt utvecklingen. ${ }^{820}$ Här, liksom i Nils Holgersson, står därmed hoppet till barnen och de unga när det gäller att vända utvecklingen åt rätt håll.

\footnotetext{
${ }^{817}$ R. Ambjörnsson, Fantasin till makten! Utopiska idéer $i$ västerlandet under fem hundra år, 2004, s. 186-187; T. Frängsmyr, Framsteg eller förfall: Framtidsbilder och utopier $i$ västerländsk tanketradition, 1990, s. 128-164.

${ }^{818}$ S. Wernström, Den underbara resan: En läsebok om Sverige. D. 2, 1986, s. 276.

${ }^{819}$ Ibid., s. 277.

${ }^{820}$ Ibid., s. $276-278$.
} 
Trots de mörka beskrivningarna av vilka miljökonsekvenser människans utveckling av tekniken har, är Den underbara resan ingen dystopisk skildring. Istället kan budskapet tolkas som ett upprop till samling för att vända utvecklingen. Berättelsen företräder såväl en positiv framtidssyn som positiv framstegstro. Tekniken är inte enbart något som har en negativ inverkan på människa och miljö, den löser också problem. Det är därmed vad Frängsmyr benämner som det effektiva samhället som är framtiden. ${ }^{821}$

\section{Sammanfattande analys av Den underbara resan}

I Nils Holgerssons underbara resa kan skildringarna av tekniken tolkas som att de har som syfte att väcka en kärlek till fosterlandet och på så vis skapa en nationell enighet människor emellan. Den underbara resan har även den ett budskap som kan tolkas som en uppmaning till nationell samling, men utifrån ett annat perspektiv: att ena ungdomen att göra uppror mot sociala orättvisor och miljöförstöring och det är utifrån ett politiskt maktperspektiv som tekniken skildras i berättelsen. Beskrivningarna av tekniklandskapen i Nils Holgersson respektive Den underbara resan skiljer sig åt. Det landskap Nils upplever är initialskedet av skapandet av industrinationen Sverige och det är framför allt jordbruks- och bruksbygdens teknik han kommer i kontakt med. Nickes tekniklandskap består istället av verkstäder, varv, livsmedelsindustrier, gjuterier, bilfabriker, sockerindustrier, svavelsyrefabriker, petroleumindustrier, cementfabriker, stenhuggerier, konservfabriker, telefonfabriker, kärnkraftverk och vattenkraftverk. Berättelsen präglas av noggranna beskrivningar av hur tekniken fungerar och hur olika tekniska processer går till. Bilen är en viktig artefakt och beskrivs i detalj. I likhet med berättelsen om Nils Holgersson får tåget eller järnvägen stå som symbol för Sverige som föregångsland på teknikens område.

I Den underbara resan lyfts de negativa konsekvenserna av tekniken fram explicit och det är inte enbart utifrån miljöhänsyn. Mekaniseringen av människors arbeten leder till stress och psykisk ohälsa. Problemet har sin grund i att människans drivkraft att utveckla teknik har övergått från att handla om att lösa problem, till att styras av girighet och maktbegär. I likhet med hur Anders Ewerman beskri-

\footnotetext{
${ }^{821}$ T. Frängsmyr, Framsteg eller förfall: Framtidsbilder och utopier $i$ västerländsk tanketradition, 1990, s. 134-135.
} 
ver utvecklingen, har människan reducerats till en "[...] kugge i det mekanistiska systemet". Människan i det industrialiserade samhället identifieras utifrån "vad hon gör" och inte "vem hon är", skriver Ewerman. ${ }^{822}$

En av förklaringarna till teknikens negativa inverkan är att teknikutvecklingen har gått för fort och att människan därför förlorat kontrollen över den. Detta belyses i Den underbara resan genom att tekniken sätts i relation till hela mänsklighetens historia och hur snabbt samhället har förändrats under de senaste århundradena. Detta kan tolkas utifrån Elluls syn på den tekniska utvecklingen: att den moderna teknikutvecklingen går så snabbt att den inte hinner integrera äldre traditioner. Konsekvensen är att tekniken följer sina egna lagar och att människan inte längre kan kontrollera den; att tekniken utvecklats till att bli autonom. ${ }^{823} \mathrm{I}$ berättelsen om Nicke råder därmed en spänning mellan den äldre och den nya tekniken, vilket bland annat exemplifieras genom kritiken mot det nya informationssamhället där datorer ersätter böcker i skolan. En liknande spänning återfinns i Nils Holgersson, Den gröna bilen, Familjen Tuff-Tuff och böckerna om Talleborg.

I likhet med sagan om "Herr Klumpedump från Klumpedonien" tillskrivs hantverkstekniken ett högre värde än industriprocessen. Hantverket är en aktivitet som är överskådlig, medan det mekaniserade och högspecialiserade industritekniska systemet kan beskrivas som en "svart låda" ("black box"), det vill säga att avsaknaden av överskådlighet leder till att tekniken eller systemet endast går att betrakta utifrån "input" och "output". Man kan se hur det uppför sig och utvecklas men det är svårt att skaffa sig en förståelse och kunskap om varför det uppför sig på ett visst sätt. ${ }^{82}$ Utifrån Mumfords indelning av tekniken som demokratisk respektive auktoritär, kan hantverkstekniken räknas till kategorin demokratisk teknik, medan den industriella företräder den auktoritära tekniken. ${ }^{825}$

Något som Den underbara resan har gemensamt med Witts tekniska sagor är att ingenjören lyfts fram som den didaktiske problemlösaren samt som en aktör

\footnotetext{
${ }^{822}$ A. Ewerman, "Den informationssociala revolutionen. Historiens cykler och vår tids epokskifte" i Handla! Om förändring, välfärd, arbete, lärande, konsumtion, arkitektur, design, kultur, framtid, G. H. von Wright (red.), Stockholm: Nerenius \& Santérus, 1997, s. 102.

${ }^{823}$ J. Ellul, The technological society, 1964, s. 14; J. Ellul, "The autonomy of technology”, 2010, s. $67-75$.

${ }^{824}$ L. Ingelstam, System: Att tänka över samhälle och teknik, 2012, s. 57.

${ }^{825}$ L. Mumford, “Authoritarian and democratic technics”, 1963, s. 1-8.
} 
som intar en viktig maktposition i samhället. Det är ingenjören som genom sin uppfinningsrikedom skapar ny teknik, samtidigt som han eller hon har förmågan att finna lösningar på de problem som tekniken eventuellt skapar. Utifrån ett genusperspektiv är det dessutom intressant att uppmärksamma att en flicka agerar teknikexpert $\mathrm{i}$ ett avsnitt $\mathrm{i}$ boken. Hon ger dessutom uttryck för att hennes högsta önskan är att utbilda sig till ingenjör. "Johanna" (flickan på Asea) är den enda teknikexperten av kvinnligt kön som finns med i de böcker som ingår i studien.

Forskaren och vetenskapsmannen styrs, till skillnad från ingenjören, antingen av egocentriska intressen eller sitter i knäet på marknadskrafter. En möjlig tolkning är att ingenjören företräder den demokratiska tekniken, medan forskaren representerar den auktoritära eftersom han eller hon inte vet vilka konsekvenser de vetenskapliga landvinningarna får i förlängningen. ${ }^{826}$

Liksom i Nils Holgersson, Witts tekniska sagor och böckerna om familjen Tuff-Tuff används metaforer och liknelser från naturen för att beskriva tekniken. Industrirobotarna liknas vid djur som isbjörn och gamar och skogsmaskinen blir en urtidsödla. Det som skiljer liknelserna i Den underbara resan från övriga barnböcker som ingår i studien är att de till övervägande del används för att lyfta fram teknikens negativa sidor. Samtidigt använder Nicke liknelsen "kemisk fabrik" för att beskriva björkens fotosyntes, vilket gör att han här snuddar vid Descartes mekanistiska syn på naturen, naturen som maskin. ${ }^{827}$

Den underbara resan är en realistisk berättelse och den inrymmer ingen antropomorfism. Däremot beskrivs teknikens negativa inverkan på naturen utifrån bland annat ett träds och en fisks perspektiv och naturen framställs som besjälad. Trots att det finns ett budskap om att människan inte har rätt att begå våld mot naturen för att tillfredsställa sina egna behov kan berättelsen, till skillnad från Schwartzkopfs höghusböcker, inte sägas ge uttryck för en biocentrisk natursyn. Det är framför allt de negativa effekterna för människan om lyfts fram. Det är därför snarare en svag antropocentrisk natursyn som berättelsen ger uttryck för. ${ }^{828}$ Denna tolk-

\footnotetext{
${ }^{826}$ Ibid.

${ }^{827}$ P. J. Bowler, The earth encompassed: A history of the environmental sciences, 2000, s. 93; S. Sörlin, Naturkontraktet: Om naturumgängets idéhistoria, 1991, s. 72-77; D. Worster, De ekologiska idéernas historia, 1996, s. 61-63; G. H. von Wright, Vetenskapen och förnuftet: Ett försök till orientering, 1987/2010, s. 62.

${ }^{828}$ A. Dobson, Green political thought, 2000, s. 51-61.
} 
ning förstärks när huvudpersonen funderar över huruvida människan har rätt att döda djur för att få föda eller ej. Trots kluvenheten är berättelsens budskap att så länge djuret inte utsätts för onödigt lidande, är jakt och fiske något som ingår i människans naturliga behov. Däremot har hon inte rätt att frånta djuren deras naturliga miljö, hålla dem i fångenskap. Det sistnämnda synsättet påminner om Nils Holgersson i vilken Nils befriar både örnen Gorgo och räven Smirre. Budskapet att de vilda djuren hör hemma i sitt naturliga habitat återfinns också i böckerna om Talleborg. En skillnad mellan Nils och Nickes upplevelser är att Nils upplever den vilda naturen som "tråkig", medan den av människan kultiverade naturen ses som vacker. Nicke, däremot, uppskattar den vilda, orörda naturen och han vill inte tillbaka till staden. Nicke är den urbana människan som längtar tillbaka till ursprunget men som samtidigt uppskattar och fascineras av den moderna tekniken; hans känslor är ambivalenta.

När det gäller framtidssynen finns ett budskap om att tillståndet i nationen är alarmerande. De som har makten att påverka utvecklingen lever endast i nuet och tänker inte på kommande generationer. Det finns sålunda en tydlig gräns mellan vuxna och barn, där de vuxna i första hand är ute efter att kortsiktigt tillfredsställa sina egna önskningar och behov istället för att tänka på de unga och deras framtid. För att en bättre framtid ska kunna skapas behöver barn och unga få veta hur allvarligt tillståndet är. Utvecklingen kan vändas och det är barnen och de unga som hoppet står till. Skolan är viktig i denna utveckling, men den behöver förändras. De kunskaper som skolan förmedlar måste därför vara sådana som eleverna upplever att de har nytta av.

Den underbara resan kan sammanfattas med att den förmedlar en ambivalent syn på tekniken och dess relation till människa och natur. Teknikutvecklingen kan ha en negativ inverkan på individ och natur och den bidrar till att maktstrukturer skapas, men den är samtidigt spännande och fascinerande, uppfyller människans behov samt löser problem inför framtiden. Nicke sammanfattar vad han har lärt sig under sin resa med orden: "Sverige är vackert och rikt men det ligger i rövarhänder." 829

Vid ungefär samma tid som Wernströms tre delar av Den underbara resan publicerades, kom Sven Nordqvists första böcker om Pettson och Findus ut. Till

\footnotetext{
${ }^{829}$ S. Wernström, Den underbara resan: En läsebok om Sverige. D. 3, 1987, s. 373.
} 
innehåll och form är Wernströms och Nordqvists böcker mycket olika, även om bägge författarnas böcker har ett teknikdidaktiskt innehåll. Den underbara resan är en realistisk och samtidskritisk berättelse, medan böckerna om Pettson och hans katt utspelar sig i ett tekniklandskap där tiden tycks stå stilla. Till skillnad från Den underbara resan har berättelserna om Pettson och Findus dessutom flera genredrag från sagorna. Pettson kan tala med sin katt och sina höns och dessutom spelar ett slags fantasiväsen, "mucklorna", en viktig roll i böckerna. I det följande kapitlet avhandlas tekniken i Sven Nordqvists böcker. 



\section{KAPITEL 8}

\section{Tekniklandskapet i Sven Nordqvists böcker om Pettson och Findus}

\section{Sven Nordqvist (1946-)}

Sven Nordqvist är författare, tecknare, grafiker och arkitekt. Han föddes i Helsingborg 1946 och studerade vid Lunds Tekniska Högskola. Efter att ha varit verksam som arkitekt ett år övergick han till att arbeta som lärare på arkitekthögskolan i Lund. Sedan 1970-talet har han utöver sitt författarskap verkat som tecknare. ${ }^{830}$ 1981 vann Nordqvist en bilderbokstävling på bokförlaget Opal med boken Agaton Öman och alfabetet och senare kom Minus och stora världen, med siffror i lekfulla kombinationer. Det stora genombrottet kom med nästa bok, den första boken om Pettson och Findus (Pannkakstårtan), som publicerades 1984. Nordqvist skriver att eftersom både han och läsarna trivdes med de båda figurerna Pettson och Findus, kom det så småningom att bli ett antal böcker om dem. ${ }^{831}$ Med bilderboken Var är min syster? erhöll Nordqvist Augustpriset i kategorin "Årets svenska barnoch ungdomsbok 2007". ${ }^{832}$ Förutom sina egna barnböcker har Nordqvist illustrerat många andra författares böcker som de om Mamma Mu och Kråkan. Han har också provat på att göra tecknad film. Nordqvist beskriver sitt författarskap som att han i första hand inte skriver för att berätta en historia för någon annan, "utan sna-

\footnotetext{
${ }^{830}$ Bokförlaget Opal, "Sven Nordqvist", http://www.opal.se/index.php?p=up\&id=Sven@Nordqvist\#.U4mlXfl_um4 (läst 2014-05-10); Bokförlaget Opal, "Pettson och Findus", http://www.pettsonochfindus.se/index.php?p=hem\&lang=sv (läst 2014-05-09).

${ }^{831}$ Ibid.; Rabén \& Sjögren, "Sven Nordqvist", http://www.rabensjogren.se/Alfabetiskt/N/SvenNordqvist/ (läst 2014-05-10).

${ }^{832}$ Bokförlaget Opal, "Sven Nordqvist"; Rabén \& Sjögren, "Sven Nordqvist".
} 
rare för att själv få återvända till den fria värld som en saga kan berätta om.” Han ser fantasin som viktig i barnböcker, eftersom den bjuder in barnen i en värld som skiljer sig från vardagen." ${ }^{\prime 833}$

Böckerna om Pettson och Findus är översatta till över fyrtio språk och Laura A. Wideburg förklarar i tidskriften World Literature Today (2005) deras popularitet med att: "The star of the series, the cat Findus, has a winning way that charms without syrup. ${ }^{, 834}$ Findus sätt att ivrigt undersöka världen omkring sig, påminner om en femårings nyfikenhet. Dessutom, skriver Wideburg, återspeglas Findus personlighet inte bara i texten utan i de uttrycksfulla bilderna. Pettson i sin tur är otroligt uppfinningsrik och alltid redo att skapa, oavsett om det handlar om att skrämma räven eller skicka Findus till månen. Wideburg beskriver Pettsons värld som en skildring av den svenska visionen av världen. Den lilla röda stugan är en symbol för den frid som svenskarna hoppas finna när de åker till sina sommarstugor, nära en sjö, mitt i skogen. ${ }^{835}$

Enligt Sveriges författarfonds statistik har Nordqvist varit en av de tio mest utlånade författarna från 1990-talets början fram till och med 2013, med mellan ungefär 540000 och 890000 utlån. ${ }^{836}$ Trots Pettsonböckernas popularitet såväl i Sverige som utomlands finns få studier gjorda om böckerna. Förutom ovan nämnda artikel av Wideburg finns en artikel i en litteraturvetenskaplig tidskrift samt en akademisk artikel där analyser av böckerna om Pettson och Findus ingår. ${ }^{837}$ Därutöver har ett par uppsatser publicerats. ${ }^{838}$ Ingen av de befintliga studierna analyserar dock tekniken i böckerna. Däremot undersöker Larisa Savenkova i sin uppsats na-

\footnotetext{
${ }^{833}$ Ibid.

${ }^{834}$ L. A. Wideburg, "Pettson and Findus charm children and adults alike", World Literature Today, vol. 79(3-4), 2005, s. 71-72.

${ }^{835}$ Ibid.

${ }^{836}$ Sveriges författarfond, Utlåningsstatistik, 1993-2013, Stockholm, 2014.

${ }^{837}$ C. Andersson \& C. Lindgren, "Text, image and cultural designers. Reflections on translation and the acceptance of Pettson in France", Moderna språk, vol. 102(2), 2008, s. 24-34; C. Axell m.fl., "Images of technology and sustainable development in Swedish children's literature", Australasian Journal of Technology Education, vol. 1(1), 2014, s. 1-9.

${ }^{838}$ E. Granath, Pettson \& Findus mucklor. En narratologisk studie av text och bild $i$ Sven Nordqvists Pettsonböcker, C-uppsats, Södertörns högskola, Huddinge, 2007; L. Savenkova, Barnlitteratur för lärande för hållbar utveckling. En ekokritisk textanalys av barnboksserien om Pettson och Findus, uppsats för yrkesexamina på avancerad nivå, Uppsala universitet, Uppsala, 2011.
} 
tursynen i böckerna. Hennes slutsats är att trots att böckerna till övervägande del förmedlar en antropocentrisk natursyn, kan böckerna ändå fungera som utgångspunkter för diskussioner om hållbar utveckling i skolans undervisning. ${ }^{839}$

\section{Handlingen i böckerna om Pettson och Findus}

Böckerna handlar om en äldre man, Pettson. Han lever på landet på en liten gård tillsammans med sin katt Findus och några höns. Pettson är en tystlåten man som trivs bra med Findus som enda sällskap. Pettson och katten pratar med varandra och Findus har mänskliga egenskaper, går på bakbenen och bär kläder. I böckerna dyker grannarna upp då och då. Närmaste grannen är Gustavsson som har kor och en hund. Gustavssons fru Elsa och sonen Axel tittar ibland in till Pettson och Findus. Beda Andersson är en annan granne och det var hon som gav Findus till Pettson, då hon tyckte att Pettson behövde sällskap.

Enligt hemsidan "Pettson och Findus" som bokförlagen Opal och Rabén \& Sjögren står för, bodde Pettson som liten med sin mamma, pappa och fem syskon på en gård där det fanns kor, grisar, getter, höns och två hästar. Som ung hade han en fästmö under några år, men hon träffade en dansk schlagersångare och flyttade till Australien tillsammans med honom. Sedan dess lever Pettson ensam på gården med sina djur. ${ }^{840}$

Pettson spenderar sina dagar med att se till att Findus och hönorna har det bra, vara i snickarboden och uppfinna saker eller att pyssla i sitt trädgårdsland där han odlar sina egna grönsaker. Ibland går Pettson och katten till sjön för att fiska eller bada. Pettson och Findus tillbringar mycket tid tillsammans i kökssoffan, där de lyssnar på radion medan Pettson löser korsord och dricker kaffe.

Det tekniklandskap som böckerna om Pettson och Findus utspelar sig i är tidsmässigt svåridentifierat eftersom berättelserna kan läsas som att de utspelar sig bortom tid och rum. ${ }^{841}$ Att böckernas handling kan äga rum i en icke identifierbar

\footnotetext{
${ }^{839}$ Ibid., s. 29-30.

${ }^{840}$ Bokförlaget Opal, "Pettson och Findus".

${ }^{841}$ I filmen Kattonauten (2000) finns rymdhunden Laika med, liksom kung Gustav VI Adolf vilket ger en indikation om att Pettson och Findus skulle kunna utspela sig i slutet på 1950-talet. Eftersom sådana referenser helt saknas $i$ böckerna, har jag valt att bortse från filmernas tidsreferenser.
} 
tid beror på att de handlar om en ensam äldre man och en katt samt innehåller teknik som inte entydigt och bestämt fixerar berättelsen i en viss tid.

I denna studie har samtliga utgivna Pettsonböcker gåtts igenom eftersom så gott som alla innehåller olika former av teknik samt att tekniken spelar en viktig roll i dem. Detta kapitel bygger i huvudsak på analyserna av två av böckerna: Rävjakten (1986) och Tomtemaskinen (1994). Urvalet motiveras dels av att Tomtemaskinen är den enda berättelsen som både är en bilderbok och längre kapitelbok (129 sidor), dels att dessa båda böcker innehållsligt kan tolkas som något mer explicit teknikdidaktiska än de övriga.

Med hänvisning till denna studies syfte är bilderna i böckerna om Pettson och Findus särskilt viktiga eftersom det huvudsakligen är där som tekniken finns gestaltad, liksom i förklaringarna till hur tekniken fungerar. Böckerna är utifrån Rhedins kategorisering av bilderböcker ett slags mellanting mellan expanderande och genuina texter. ${ }^{842}$ Texten i Pettsonböckerna fungerar i sig men utan de detaljrika bilderna blir berättelserna tämligen platta. Bilderna i Pettsonböckerna är inte enbart illustrationer av vad texten säger, utan innehåller ofta till och med mer information än texten. ${ }^{843}$ Genom illustrationerna berättas dessutom ofta en parallell berättelse till primärhistorien, vilket öppnar för alternativa tolkningar. Rhedin menar att bilderna i en bilderbok skulle kunna liknas vid en scen där bilderna iscensätter den tillhörande texten. ${ }^{844}$ Det är således till stor del illustrationerna som iscensätter det teknikdidaktiska perspektivet i Pettsonböckerna.

\section{Tekniksynen i böckerna om Pettson och Findus}

I mitten av 1980-talet ökade intresset för miljö- och naturvårdsfrågor i den svenska offentliga debatten. Detta kulminerade runt valet 1988, ett val som kom att gå till historien som "miljövalet". Opinionsundersökningarna visade att en allt större andel av befolkningen ansåg att miljön var den viktigaste politiska frågan och på kort

\footnotetext{
${ }^{842}$ U. Rhedin, Bilderboken: På väg mot en teori, 2001, s. 88-105.

${ }^{843}$ M. Nikolajeva, Bilderbokens pusselbitar, 2000, s. 27.

${ }^{844}$ U. Rhedin, Bilderboken: På väg mot en teori, 2001, s. 76.
} 
tid fördubblades antalet inslag i televisionen som tog upp dessa frågor. Likaså mångdubblades artiklar i tidningar och tidskrifter som behandlade miljöfrågor. ${ }^{845}$

"Hållbar utveckling" blev ett allmänt och vedertaget begrepp under 1980-talet.

En av dem som först använde sig av begreppet var den amerikanske miljövetaren Lester R. Brown. I boken Building a sustainble society (1981) slår han bland annat fast att den snabbt växande världsbefolkningen gör att det måste utvecklas ett nytt tänkande kring energiförsörjning, transportsystem, jordbruk, skogar, hav och fiske. Annars kommer naturens resurser att bli allvarligt överansträngda. Browns bok innehåller också den minnesvärda metaforen: "[W]e have not inherited the earth from our fathers, we are borrowing it from our children". ${ }^{846}$ Det var dock inte förrän i FN:s rapport Vår gemensamma framtid, den så kallade Brundtlandrapporten 1987, som "hållbar utveckling" för första gången kom att användas mer officiellt. Brundtlandkommissionen gjorde följande definition av begreppet: "En hållbar utveckling är en utveckling som tillgodoser dagens behov utan att äventyra kommande generationers möjligheter att tillgodose sina behov." 847

Att miljöfrågorna fick stor genomslagskraft i samhällsdebatten speglades i läroböckerna i de naturorienterade ämnena från 1980-talet och framåt. ${ }^{848}$ Utbildningsprogrammen i radio och tv var andra kanaler som förmedlade budskap om miljöfrågornas betydelse till yngre barn. Efter att Brundtlandrapporten publicerats sändes utbildningsprogram som visade negativa miljökonsekvenser på global nivå, men informationen förmedlades i kombination med budskapet att om människan bara lärde sig att utnyttja jordens resurser på rätt sätt, fanns hoppfulla tecken inför framtiden. ${ }^{849}$

\footnotetext{
${ }^{845}$ J. Anshelm, Socialdemokraterna och miljöfrågan: En studie av framstegstankens paradoxer, s. 108; J. Anshelm, Det vilda, det vackra och det ekologiskt hållbara: Om opinionsbildningen $i$ Svenska Naturskyddsföreningens tidskrift Sveriges Natur 1943-2002, Umeå universitet, Umeå, 2004, s. 106.

${ }^{846}$ L.R. Brown, Building a sustainable society, New York: W.W. Norton, 1981, s. 359.

${ }^{847}$ World Commission on Environment and Development, Our common future, [United Nations Environment Programme], [Nairobi], Vår gemensamma framtid: [rapport från] Världskommissionen för miljö och utveckling under ordförandeskap av Gro Harlem Brundtland, 1988, s. 57.

${ }^{848}$ M. Hultén, Naturens kanon: Formering och förändring av innehållet i folkskolans och grundskolans naturvetenskap 1842-2007, diss., Stockholms universitet, Stockholm, 2008, s. 213-214.

${ }^{849}$ B. Linnér, Att lära för överlevnad: Utbildningsprogrammen och miljöfrågorna 1962-2002, Lund: Arkiv, 2005, s. 129-139. Se även K. Sandell \& S. Sörlin, ”Naturen som ungdomsfostrare" i
} 
Wernströms Den underbara resan skrevs i mitten av 1980-talet men kan ändå räknas till den mer samhälls- och probleminriktade genren av barnböcker som slog igenom under 1970-talet. Däremot tillhör böckerna om Pettson och Findus snarare den sentida barnlitteratur som bidrar till att Elsa Beskows sagotradition lever vidare. Kåreland förklarar deras popularitet med att 1970-talets kraftigt samhällstillvända och reportagebetonade litteratur lämnade efter sig en slags trötthet, vilket ledde till att intresset för realistiska skildringar minskade. Istället fick sagorna tillsammans med fantasy-genren en ny renässans under 1980-talet. ${ }^{850}$

Tekniklandskapet som böckerna om Pettson och Findus utspelar sig i är förlagt till landsbygden i en idyll nära naturen. Det finns ingen explicit uttalad kritik mot teknikens inverkan på samhällsutvecklingen men böckerna skulle kunna tolkas som en implicit sådan eftersom det industrialiserade samhället är helt frånvarande. I motsats till Den underbara resan finns exempelvis inga bilar som kommunikationsmedel med. Den enda bil som nämns är den som en dam i en lådaffär använder när hon kör hem en trälåda till Pettson. Den är inte ens avbildad. Däremot finns en liten lastbil som tillhör mucklorna med i När Findus var liten och försvann (2001). ${ }^{851}$

Mucklorna är små varelser som bara Findus kan se och prata med. De påminner om djur men också om vättarna inom den svenska folktron. Precis som vättarna är mucklorna små, i ungefär samma storlek som råttor och de bor under husgolvet på Pettsons gård. Eftersom såväl mucklor som vättar kan dyka upp överallt måste man vara försiktig så man inte skadar dem. Enligt folktron är vättar några man ska hålla sig väl med och de tar också saker som pengar och ringar som gårdsfolket tappar. ${ }^{852}$ Mucklorna lever i en parallell värld till Pettsons, där de både har sin egen teknik och utnyttjar Pettsons artefakter, vilka då ofta används på ett alternativt sätt. När något försvinner på gården är det ofta mucklorna som ligger bakom.

Friluftshistoria: från "härdande friluftslif" till ekoturism och miljöpedagogik: teman i det svenska friluftslivets historia, K. Sandell \& S. Sörlin (red.), Stockholm: Carlsson, 2000.

${ }^{850}$ L. Kåreland, Barnlitteraturens utveckling i Sverige, 2008, s. 7-9.

${ }^{851}$ S. Nordqvist, När Findus var liten och försvann, Stockholm: Opal, 2001, opag.

${ }^{852}$ E. Schön, Älvor, vättar och andra väsen: En bok om gammal folktro, Stockholm: Rabén \& Sjögren, 1986. 


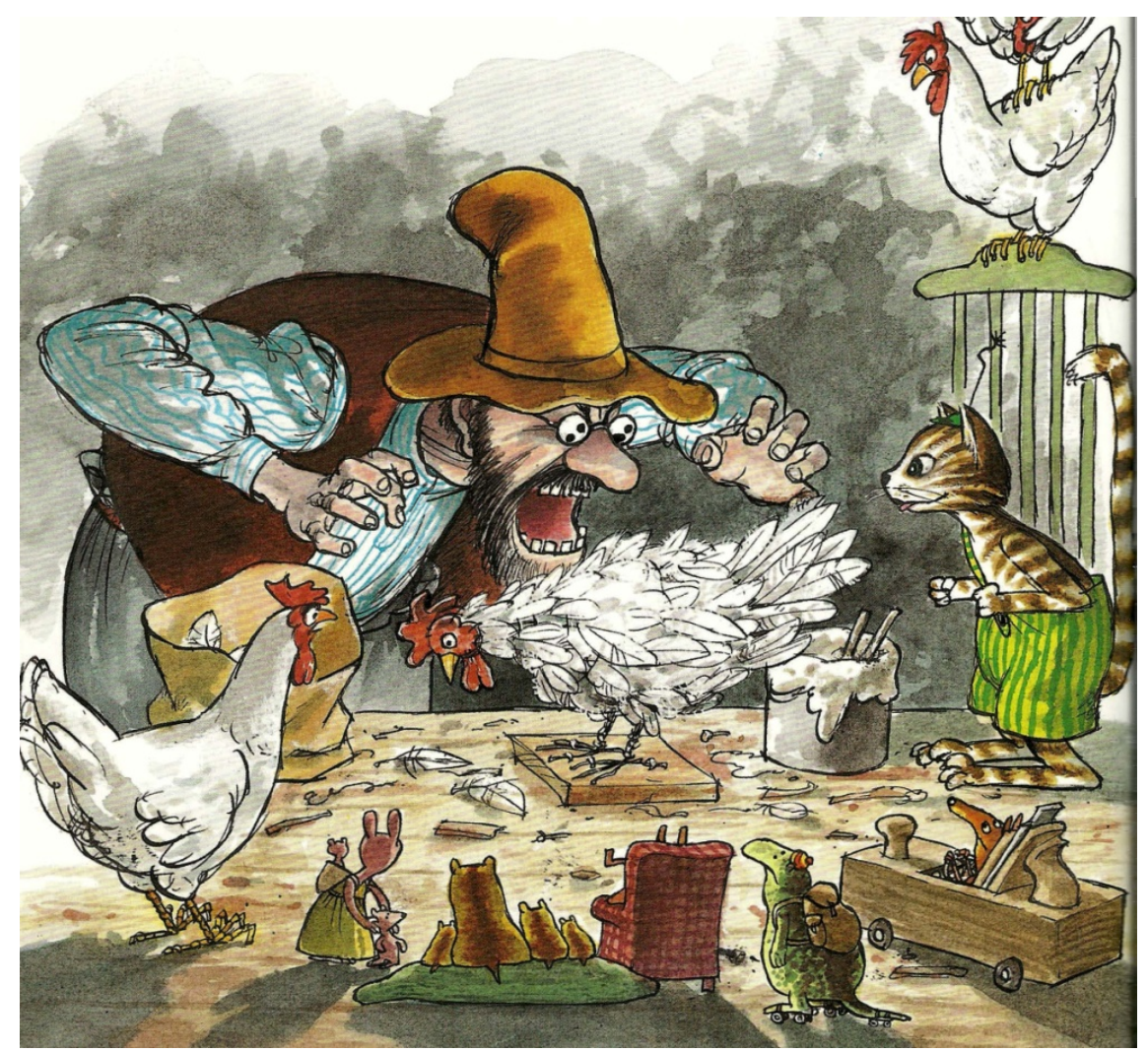

Bild 8.1: Illustration från Rävjakten (Sven Nordqvist, 1986)

Sommartid går Pettson till fots eller åker cykel och på vintern tar han sin sparkstötting. Findus åker skidor och kälke. Sparkstötting, skidor och kälke är alla exempel på artefakter som har en lång historia och som fortfarande används och är utifrån den bemärkelsen inte tidsbundna.

Kevin Kelly lyfter fram den något ovanliga aspekten att med några få undantag så är det väldigt lite av den teknik som en gång etablerats som sedan försvinner. Hans slutsats bygger bland annat på en genomgång av de närmare 600 sidorna i Montgomery Ward Catalog för året 1894 till 1895. Han fann att en majoritet av alla de ting som såldes där, går att köpa än i dag. Själva designen eller stilen kan ha förändrats, skriver Kelly, men den underliggande tekniska funktionen 
är densamma. En del av den teknik som har blivit alltmer ovanlig i den moderna och urbana världen, lever dessutom fortfarande kvar i utvecklingsländerna. ${ }^{853}$ Fortfarande används primitiva handredskap i våra trädgårdar, helt enkelt för att de fungerar. "As long as the backyard tomatoes taste better than farmed ones, the primeval hoe will survive", konstaterar Kelly. ${ }^{854}$

Pettson och Findus tekniska skapande går även att läsa utifrån Berners beskrivning av hur teknisk kunskap överförs mellan individer och generationer. Teknisk förändring har sedan urminnes tider skett på grundval av människors praktiska erfarenheter, skriver Berner. Genom modifiering av den äldre praktiken skedde sedan en långsam utveckling, ofta grundad på snilleblixtar, slump eller "trial-anderror"-försök. Via lärlingsskap eller genom deltagande i sysslorna på gården eller verkstaden fördes sedan kunskaperna vidare. ${ }^{855}$ I böckerna om Pettson och Findus är det Pettsons praktiska erfarenhet som ligger till grund för hans uppfinningar och katten lär sig genom delaktighet.

David Edgerton tar upp en liknande aspekt som Kelly och Berner men från en annan utgångspunkt. Edgerton ifrågasätter den vanliga beskrivningen av teknikutvecklingen som en historisk tidslinje som består av årtal där vissa specifika uppfinningar och innovationer presenteras som nya revolutionerande skapelser. Edgerton menar att i själva verket handlar "det nya" många gånger snarare om att redan befintlig kunskap och teknik överförs till ett nytt användningsområde. Mycket av den teknik som kommer till vid en viss tidpunkt får dessutom inte sitt viktigaste inflytande förrän långt senare. Därför, hävdar Edgerton, borde ett skifte i fokus ske när man talar om teknikens natur, inverkan och utveckling över tid - ett fokus som istället utgår från "the technology-in-use". ${ }^{856}$ Trots att teknik utvecklas och att utveckling är något som anses tillhöra dess själva essens, har den teknik vi omger oss med många gånger gamla rötter, ett perspektiv som böckerna om Pettson kan sägas lyfta fram.

\footnotetext{
${ }^{853}$ K. Kelly, What technology wants, New York: Viking, 2010, s. 52-54.

${ }^{854}$ Ibid., s. 54.

${ }^{855}$ B. Berner, Perpetuum mobile? Teknikens utmaningar och historiens gång, 1999, s. 49.

${ }^{856}$ D. Edgerton, The shock of the old: Technology and global history since 1900, 2006, s. xi.
} 
I boken Rävjakten dyker grannen Gustavsson upp med geväret på axeln och sin jakthund i koppel. Han undrar om Pettson har haft påhälsning av räven. Själv har han blivit av med en höna och tänker skjuta räven så snart han ser honom. Han uppmanar Pettson att göra detsamma. Pettson har dock ingen lust att skjuta någon räv, utan bestämmer sig för att uppfinna något som skrämmer räven så att den aldrig mer tar några hönor. Han börjar därefter "tänka och grubbla och fundera" på den nya uppfinningen. ${ }^{857}$ När Pettson tänkt klart går han och Findus till snickarboden: "I snickarboden fanns allt som behövdes för att skrämma en räv." 858

Mitcham beskriver den tekniska aktiviteten utifrån en process i fyra steg: 1) Att i abstrakta termer tänka ut det man ska skapa (conceiving), 2) Att i konkreta termer föreställa sig det man ska skapa (imagining), 3) Tillverka/konstruera det man tänkt och därmed "tänka genom händerna" (fabricating), 4) Testa och observera det man konstruerat (testing). ${ }^{859}$ Ett femte steg skulle kunna vara modifiering och ett sjätte tillämpning eller användande av det som konstruerats.

När Pettson påbörjar arbetet tänker han först ut den uppfinning han ska bygga. I nästa steg gör han sig konkreta föreställningar utifrån vilka olika delar som behöver ingå för att den ska fungera. Till sist konstruerar han den:

Pettson letade fram en liten vit ballong och en rulle ståltråd i skomakarlådan. Sen började han stöka i en gammal väska som stod i hyllan [...] Han trädde ballongen på en tratt och hällde i så mycket peppar som fick plats. Sedan blåste han upp ballongen så den nästan exploderade. ${ }^{860}$

I realiteten är dock designprocessen sällan så linjär som i skildringen av Pettsons konstruerande av rävskrämmaren. De olika stegen kan dels ske i en annan ordning, dels har sådant som misslyckaden en inverkan på processen. Likaså kan olika utomstående aktörers önskningar och behov påverka hur designprocessen utvecklar sig. ${ }^{861}$ Pettson, däremot, följer här den linjära ordningen.

\footnotetext{
${ }^{857}$ S. Nordqvist, Rävjakten, Bromma: Opal, 1986, opag.

${ }^{858}$ Ibid.

${ }^{859}$ C. Mitcham, Thinking through technology: The path between engineering and philosophy, 1994, s. 220.

${ }^{860}$ S. Nordqvist, Rävjakten, 1986, opag.

${ }^{861}$ J. Hallström \& P. Gyberg, "Technology in the rear-view mirror: How to better incorporate the history of technology into technology education", International Journal of Technology \& Design
} 


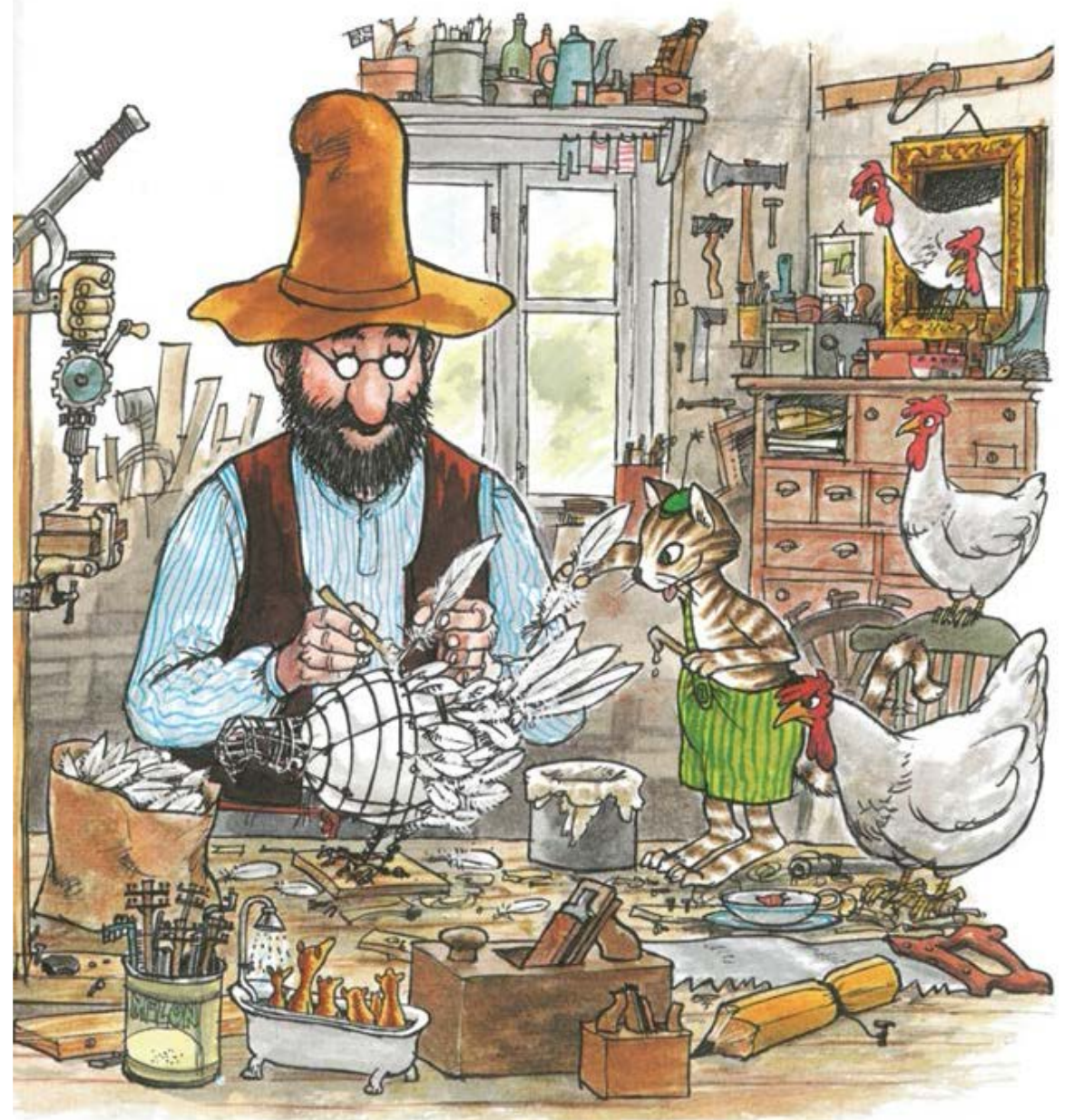

Bild 8.2: Illustration från Rävjakten (Sven Nordqvist, 1986)

Education, vol. 21(1), 2011, s. 3-17; M. Hård \& A. Jamison, Hubris and hybrids: A cultural history of technology and science, 2005, s. 6; D. Ihde, "The designer fallacy and technological imagination" i Defining technological literacy: Towards an epistemological framework, J. R. Dakers (red.), New York: Palgrave Macmillan, 2006, s. 129; D.A. Norman, The design of everyday things, New York: Basic Books, 2002; H. Petroski, The evolution of useful things, New York: Knopf, 1992a; H. Petroski, To engineer is human: The role of failure in successful design, 1992b. 
Genom skildringen av förloppet i text och bild förmedlas budskapet att teknik är resultatet av en kreativ process där Pettson är en "gör-det-självare" som utgår från sådant han redan har till hands och som ursprungligen haft en annan funktion. Förutom att detta går att tolka utifrån ett hållbarhetsperspektiv, tecknas samtidigt bilden av Pettson som överensstämmer med bricoleuren. Termen bricoleur introducerades av antropologen Claude Lévi-Strauss i The savage mind (1962). Bricoleuren är en slags motsats till ingenjören, skriver Lévi-Strauss. Bricoleuren är skicklig på att utföra ett stort antal olika uppgifter men till skillnad från ingenjören eller vetenskapsmannen använder han/hon en enklare uppsättning verktyg och är därför inte underordnad tillgången på råvaror och verktyg. Bricoleuren utgår istället från vad som finns till hands, både när det gäller uppsättningen av verktyg och material. ${ }^{862}$

Bo Dahlboms definition av bricolage är "mekande" eller "grejande", vilket han menar är en filosofi såväl för konstruktionen av, som för interaktionen med, artefakter. Grejandet är vårt förhållningssätt till artefakterna när vi inte enbart är passiva konsumenter utan aktiva sådana. Grejande är dessutom något helt annat än användning, skriver Dahlbom, eftersom vi i aktiviteten drar nytta av våra tidigare erfarenheter och inte enbart passivt anpassar oss till den användning konstruktören tänkt sig. ${ }^{863}$

Sven-Eric Liedman beskriver bricoleuren som en tusenkonstnär som kan mångahanda saker men som inte är specialist på någonting. Ur en begränsad repertoar söker bricoleuren ständigt efter nya knep att utvinna osedda möjligheter. ${ }^{864}$ Det är just som "tusenkonstnär" som Pettson löser sina problem genom att återanvända de saker han har i sin snickarbod och sin trädgård. Pettsons tekniska artefakter delar många gånger sina komponenter med annan teknik. En stor del av teknisk utveckling sker också, som Brian Arthur konstaterar, när komponenterna förbättras inom andra användningsområden som ligger utanför de ursprungliga ${ }^{865}$ Mucklorna, som finns med på många av illustrationerna i böckerna om Pettson och

\footnotetext{
${ }^{862}$ C. Lévi-Strauss, The savage mind, London: The University of Chicago Press, 1962/1973, s. 17.

${ }^{863}$ B. Dahlbom, ’En vetenskap om artefakter", VEST: Tidskrift för vetenskapsstudier, vol. 6(4), 1993, s. 53-75.

${ }^{864}$ S.-E. Liedman, Ett oändligt äventyr: Om människans kunskaper, 2001, s. 163.

${ }^{865}$ W.B. Arthur, The nature of technology: What it is and how it evolves, London: Allen Lane, 2009, s. 188.
} 
Findus, är även de ett slags bricoleurer som skapar sina egna tekniska lösningar genom att utnyttja den befintliga tekniken på alternativt sätt. ${ }^{866}$

Pettsons utvecklande av rävskrämmaren går stegvis vidare och blir alltmer avancerad. För att verkligen vara säker på att räven ska bli rädd, kopplar Pettson med hjälp av stubintråden ihop smällare och bengaliska eldar. Tanken är att när räven biter i ballonghönan så den exploderar, är det en signal till Pettson som då tänder stubinen. Findus tycker dock inte att det räcker för att skrämma räven utan menar att de behöver skrämma honom med ett spöke också:

- MMM, du med dina spökerier! grymtade gubben. Jag tycker nog att det räcker med det här. Men samtidigt började han fundera på hur man skulle kunna ordna med ett bra spökeri. Och ju mer han funderade desto roligare blev det. Så snart stod han där ute på gårdsplanen igen och mumlade för sig själv och tittade upp i luften åt höger och åt vänster. Sen sa han:

- Nu ska vi bygga en linbana [...] Sen letade han upp ett spöklakan och ett hjul som satt fast på en järnstång. Han gick ut och spände upp linan mellan taket på stora huset och trädet på andra sidan gården. Sen hängde han hjulet på linan.

- Kom här, Findus, så får du åka linbana, sa han. ${ }^{867}$

Här förmedlas ytterligare en syn på tekniken: att den inte enbart är något som existerar som enskild artefakt, utan är något som går att vidareutveckla så att den blir en del av ett tekniskt system. Ett tekniskt system består av någon form av komponenter och samband dem emellan. Tillsammans bildar komponenterna stora, mellanstora eller små helheter, vilka i sin tur bildar större vävar av system som i olika hög grad interagerar med varandra. ${ }^{868}$

\footnotetext{
${ }^{866}$ B. Dahlbom, "En vetenskap om artefakter", 1993, s. 53-75; C. Lévi-Strauss, The savage mind, 1962/1973, s. 17; S.-E. Liedman, Ett oündligt äventyr: Om människans kunskaper, 2001, s. 163.

${ }^{867}$ S. Nordqvist, Rävjakten, 1986, opag.

${ }^{868}$ T.P. Hughes, "The seamless web: Technology, science, etcetera, etcetera”, 1986, s. 281-292; T. P. Hughes, "The evolution of large technological systems", 1987, s. 51-82; L. Ingelstam, "Varför är tekniska system intressanta?”, 2009, s. 81-97; L. Ingelstam, System: Att tänka över samhälle och teknik, 2012, s. 21-24.
} 


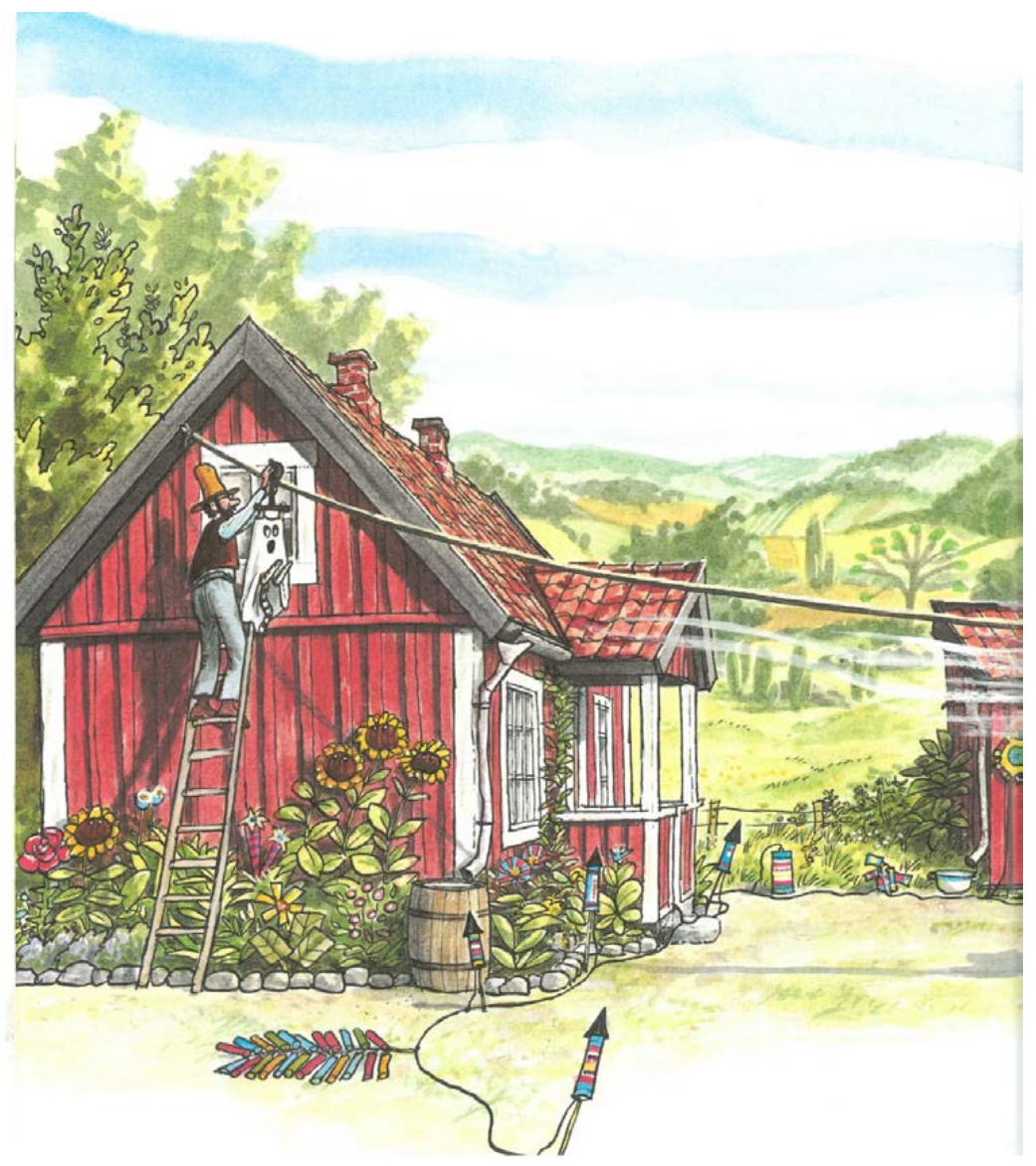

Bild 8.3: Illustration från Rävjakten (Sven Nordqvist, 1986)

I Pettsons och Findus anordning blir hönan en delkomponent $\mathrm{i}$ ett system där stubintråden, fyrverkerierna, de bengaliska eldarna och linbanan med "spöket" ingår som övriga delar. Eftersom Pettson och Findus själva är delkomponenter i systemet (Pettson ska tända stubintråden och Findus agera spöke), kan uppfinningen beskrivas som ett socio-tekniskt system. ${ }^{869}$ Utan deras aktiva deltagande fungerar

${ }^{869}$ J. Hallström, "Systemteori och teknik. En introduktion till stora tekniska system", s. 99; L. Ingelstam, "Varför är tekniska system intressanta?", 2009, s. 81-97; L. Ingelstam, System: Att tänka över samhälle och teknik, 2012, s. 214-256. 
inte uppfinningen. Illustrationerna skildrar detaljrikt hur uppfinningen successivt växer fram, från att Pettson funderar ut konstruktionen, till att den till sist testas. ${ }^{870}$

När Pettson och Findus gått och lagt sig tänker de för säkerhets skull igenom hela förloppet med uppfinningen en gång till:

Mitt i natten, när de sover som bäst, ska räven komma. Han ska springa fram och bita i ballonghönan så den exploderar. Då ska de vakna. Pettson ska tända stubinen och Findus ska springa upp på vinden. När det smäller som värst ute på gården ska Findus hoppa upp i linbanan och åka iväg och skrika: "DU SKA INTE STJÄLA HÖNS!" Och då ska räven försvinna och aldrig mer komma tillbaka. ${ }^{871}$

Här finns därmed ytterligare en aspekt av den tekniska utvecklingsprocessen: att säkerställa att något oförutsett inte ska hända när uppfinningen sedan används.

Temat att skapa något för att skydda mot att främmande djur inkräktar på Pettsons gård finns även med i böckerna Kackel i grönsakslandet (1990) och Findus flyttar ut (2012). I Kackel i grönsakslandet är det ett nysatt potatisland som behöver skyddas och Pettson och Findus får konstruera ett antal tekniska lösningar för att hålla främmande djur som höns, grisar, kor och rävar borta från gården ${ }^{872} \mathrm{I}$ Findus flyttar ut bygger Pettson och Findus ett larm till Findus hus med hjälp av snubbeltrådar, pinglande klockor och skramlande lyktor. Larmet är tänkt att både väcka Pettson och skrämma bort räven om den dyker upp. ${ }^{873}$

I berättelsen om Tomtemaskinen är uppfinningsprocessen mer utdragen jämfört med i Rävjakten, Kackel i grönsakslandet och Findus flyttar ut. Pettson stöter på en hel del problem innan uppfinningen till sist är klar, vilket komplicerar designprocessen. Berättelsen inleds med att Findus har hört barnen prata om att tomten brukar komma till dem på julafton med julklappar och nu vill Findus också få tomtebesök. Pettson inser att Findus kommer att bli förtvivlad och att julen är förstörd om tomten inte kommer. Problemet är att han inte vill be grannarna om hjälp eftersom Findus kommer att genomskåda att det inte är den riktiga tomten. Därför bestämmer sig Pettson för att bygga en tomtemaskin:

\footnotetext{
${ }^{870}$ C. Mitcham, Thinking through technology: The path between engineering and philosophy, 1994, s. 220.

${ }^{871}$ S. Nordqvist, Rävjakten, 1986, opag.

${ }^{872}$ S. Nordqvist, Kackel i grönsakslandet, Bromma: Opal, 1990, opag.

${ }^{873}$ S. Nordqvist, Findus flyttar ut, Stockholm: Opal, 2012, opag.
} 
- Nej, jag måste... göra en tomte på något sätt, tänkte han. Men... jag kan ju inte bara ställa en tomtedocka utanför dörren, den måste ju röra sig också, så att den ser verklig ut. Jag måste bygga en docka som kan röra sig, knacka på dörren och lämna paket och gå därifrån. Och helst säga god jul också. Hur ska jag kunna göra det? Det kan jag inte. Det går inte.

Han tog ett nytt tag med skyffeln, men så stannade han upp igen.

- ... Eller så gör det det? funderade han. Maskiner rör sig ju. Och en sprattelgubbe rör sig bara man drar i en tråd. Det kanske inte... är alldeles... omöjligt... ${ }^{874}$

Önskan att inte vilja göra Findus besviken ger Pettson drivkraft att bestämma sig för att utveckla en maskin, vilket kan tolkas som ett uttryck för tekniken som viljekraft (volition). ${ }^{875}$ Pettson överväger ett antal olika alternativa tekniska lösningar men finner hela tiden svagheter i dem:

- Hur ska detta gå till? tänkte han bekymrat. Hur ska jag kunna bygga en tomte som knackar på dörren och sen kommer in i hallen, går fram till finrummet och säger "Finns det nån snäll katt här?" och sen lämnar ett paket och går ut igen utan att Findus ser att det bara är en maskin? Det går inte. Det är för mycket. Jag får tala om för honom att det inte finns någon tomte. För detta klarar jag inte av. Nu bestämmer jag mig för att sluta fundera på det här. Det är för svårt. [...]

Men efter bara en liten stund syntes det att det började tänka inne i huvet på honom i alla fall, och snart var han där igen och funderade och konstruerade och försökte komma på hur han skulle göra om han nu trots allt skulle bygga en tomtemaskin, fast han hade bestämt sig för att det inte gick. ${ }^{876}$

Genom att uttrycka att den planerade tekniska uppfinningen "bara är en maskin", klargörs relationen mellan människa och maskin; maskinen kan inte ersätta människan. Den är ett redskap, ett fysiskt föremål, som människan utnyttjar för att tillfredsställa sina önskningar och behov. ${ }^{877}$

Eugene S. Ferguson gör en skillnad mellan hur en ingenjör och en hantverkare utvecklar teknik och genomför en teknisk aktivitet. Båda utgår från en idé men när en ingenjör designar en ny maskin eller någon annan teknisk artefakt, börjar han

\footnotetext{
${ }^{874}$ S. Nordqvist, Tomtemaskinen, Stockholm: Opal, 1994, s. 17-18.

875 C. Mitcham, Thinking through technology: The path between engineering and philosophy, 1994, s. 247-248.

${ }^{876}$ S. Nordqvist, Tomtemaskinen, 1994, s. 24.

${ }^{877}$ S. Lindqvist, "Vad är teknik?", 1987, s. 11.
} 
eller hon med att omvandla sin idé till ritningar. Detta utmynnar sedan i tentativa sådana och en analys av dessa för att se om maskinen eller artefakten har tillräcklig prestanda. Nästa steg kretsar kring de färdiga ritningarna och den som ska bygga maskinen, det vill säga en konstruktion. En hantverkare däremot, menar Ferguson, behöver inte göra en ritning. Oftast har hantverkaren den i huvudet. Om material, redskap och färdighet finns kan han eller hon omvandla materialet till det önskade tinget. ${ }^{878}$ I Tomtemaskinen arbetar Pettson först med ritningar, det vill säga i enlighet med en ingenjörs planering av ett projekt, men detta övergår sedan i en mer hantverksbetonad process:

Hela kvällen före hade han funderat på hur maskinen skulle fungera. Han hade ritat och räknat och det låg fullt med lappar på köksbordet. [...] Det är ganska svårt att bygga en tomtemaskin. Pettson kunde inte tänka ut allt på en gång. Vi får ta en bit i taget, tänkte han. Ett kugghjul behövde han i alla fall, och en kuggstång, så det skulle han börja med att bygga. Det är inte många gånger i livet man har en oemotståndlig lust att bygga ett kugghjul, men nu hade Pettson det. Han skyndade sig ut i snickarboden. ${ }^{879}$

Tekniska begrepp som "kugghjul" och "kuggstång" förklaras inte närmare i texten utan förklaringarna ges i de detaljerade bilderna; det är text och bild som tillsammans för fram berättelsen. ${ }^{800}$ Pettson stöter dock på problem och vet inte hur han ska gå vidare för att utveckla sin tomtemaskin:

Han grubblade på hur han skulle få stången att först gå fram och sedan stå still och sen gå tillbaka igen, fast hjulen går runt hela tiden. Det var ett svårt problem att lösa. Det borde han kanske ha tänkt ut först. ${ }^{881}$

Lösningen kommer från oväntat håll. Några mucklor skjuter iväg en boll mot Pettsons uppfinning. När Findus kastar sig efter bollen, välter han både sin och Pettsons maskin. Pettsons kugghjul faller till marken och tre kuggar går av. Illustrationen av skeendet förklarar hur ett kugghjul ser ut och hur det är konstruerat (se bild 8.4).

\footnotetext{
${ }^{878}$ E.S. Ferguson, Engineering and the mind's eye, Cambridge, Mass.: MIT Press, 1993, s. 2-3.

${ }^{879}$ S. Nordqvist, Tomtemaskinen, 1994, s. 35.

${ }^{880}$ U. Rhedin, Bilderboken: På väg mot en teori, 2001, s.103.

${ }^{881}$ S. Nordqvist, Tomtemaskinen, 1994, s. 37.
} 


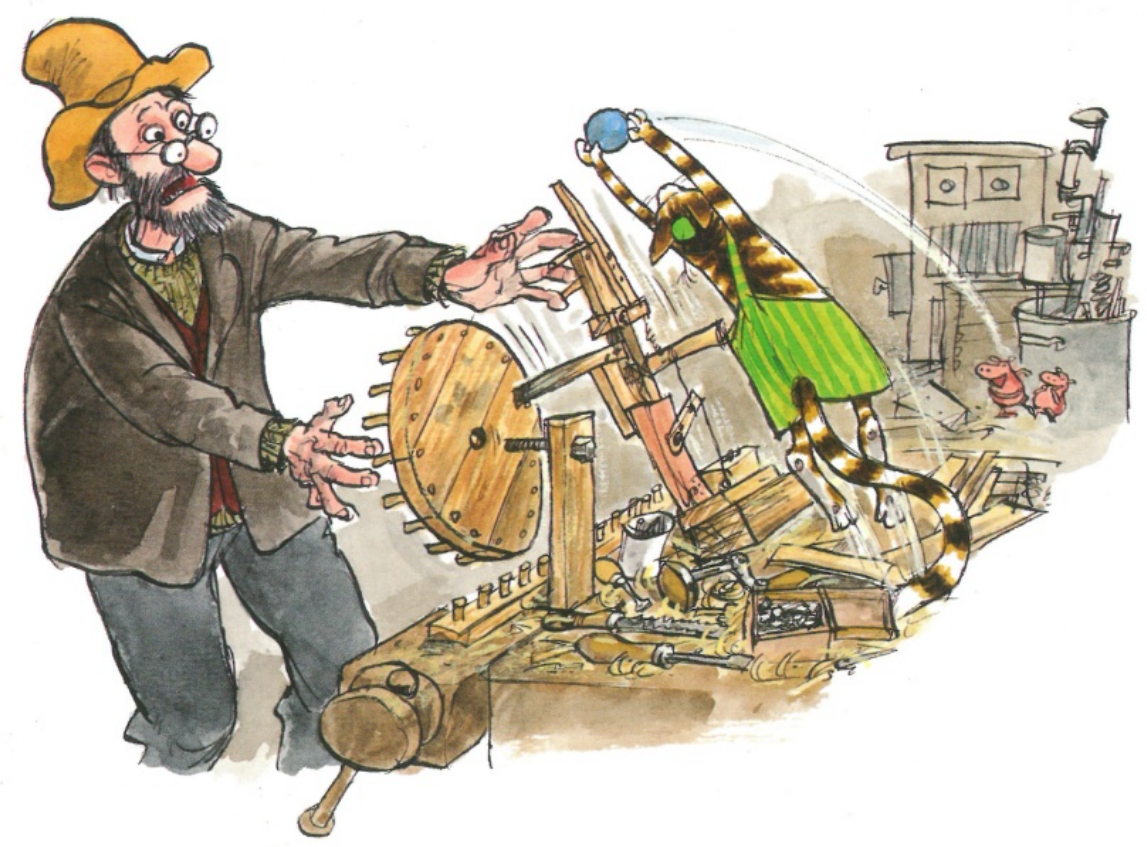

Bild 8.4: Illustration från Tomtemaskinen (Sven Nordqvist, 1994)

Först blir Pettson upprörd men sedan upptäcker han något:

- Jo, men på ett kugghjul måste alla kuggarna vara med, annars stannar kuggstången där... där...

Pettson hejdade sig och ett leende lyste fram genom skägget.

- Annars stannar kuggstången där! Just det! Jag tar bort några kuggar helt enkelt, så var den saken klar! Tack för hjälpen, Findus. ${ }^{882}$

Att Pettson kommer på en lösning beror på att mucklorna orsakar en olycka med kugghjulet. Mucklorna är dock inte de enda övernaturliga sagofigurerna som hjälper till och löser Pettsons problem. En mystisk brevbärare dyker exempelvis upp med en olja, en "mirakelolja", som "[...] smörjer allt: Skördetröskor, nagelbitare,

${ }^{882}$ Ibid., s. 38. 
vedinkastare, tomtemaskiner och mekaniska tumvantar". ${ }^{883}$ Med hjälp av oljan glider kuggarna tyst och fint $\mathrm{i}$ varandra och luckan öppnas så att tomten kan åka fram och sedan tillbaka in i lådan igen. Pettson är dock förbryllad över hur oljan i den lilla flaskan kan göra sådana underverk med hans maskin. Samtidigt vill han inte grubbla för mycket utan istället glädjas över att det fungerar så bra.

I Tomtemaskinen försvinner några skruvar och muttrar som Pettson behöver till sin maskin. Findus berättar att han vet vem som tagit dem. Det är en muckla som bor under köksgolvet. Findus berättar att mucklan anser att skruvarna är hennes nu. Pettson blir upprörd och tycker att hon är en tjuv, men varnas av Findus. Man får inte skrika till mucklor, de kan bli ledsna. Findus lyckas dock förhandla med "Sara Tustra", som mucklan heter, så att Pettson får tillbaka några av sina skruvar och muttrar igen. ${ }^{84}$

Längre fram i berättelsen dyker en underlig försäljare upp hemma hos Pettson. Eftersom försäljaren har med sig en mekanisk tomte, bidrar han (liksom mucklorna och brevbäraren) till att lösa ett tekniskt problem som Pettson har. Försäljaren försvinner, precis som brevbäraren, på ett oförklarligt sätt. Brevbäraren dyker emellertid återigen upp när Pettson och Findus gått vilse i skogen och genom att följa efter honom hittar de hem igen. Pettson stöter därutöver på en skogvaktare som bor i en arbetarvagn mitt ute i skogen. Skogvaktaren kan spela fiol på ett sätt som Pettson aldrig hört någon spela förut. Det är så vackert att Pettson sitter som "förtrollad".

Pettson konstaterar att det var ett "mirakel" som skedde när brevbäraren dök upp. Det är så det kallas när något händer som ingen kan förstå och Pettson tänker att brevbäraren varit som en "skyddsängel" som vakat över dem. ${ }^{885}$ Muckorna, brevbäraren, försäljaren och skogvaktaren kan tolkas som övernaturliga väsen som hjälper Pettson och Findus när de får problem. De kan också tolkas som metaforer för "slumpen" som bidrar till lösningar på tekniska problem, eftersom dessa inslag leder Pettson framåt i hans utvecklande av maskinen.

Till skillnad från i boken om Rävjakten är konstruktionsprocessen av tomtemaskinen långt ifrån linjär, vilket gör att den ligger närmare en verklig design-

\footnotetext{
${ }^{883}$ Ibid., s. 70 .

${ }^{884}$ Ibid., s. 86.

${ }^{885}$ Ibid., s. 113.
} 
process. Exempelvis råkar Pettson ut för en rad missöden som gör att han flera gånger får tänka om, något som bland annat Henry Petroski lyfter fram som faktorer som har en inverkan på teknisk utveckling. Han menar att misslyckande i, och missnöje med, design har varit en drivande kraft bakom tekniska uppfinningar. ${ }^{886}$ Lärdomen från misslyckandet är också, som Petroski skriver, att svagheterna i konstruktionen lokaliseras så att de kan åtgärdas. ${ }^{87}$ Don Ihde och Donald Norman företräder en liknande tekniksyn som Petroski och de ger båda exempel på hur en teknisk design ofta följer en slingrig väg genom ett antal försök, misstag och misslyckanden innan den får sin slutliga utformning. ${ }^{888}$

Pettson gör ett inköp av en trälåda till tomtemaskinen men i övrigt utgår han från sådant som redan finns i hans snickeriverkstad på gården. Precis som William Morris beskrivning av den ideala tekniken, har Pettsons uppfinningar en estetisk dimension. ${ }^{889}$ Exempelvis är trä det material som dominerar i hans uppfinningar, vilket passar in i miljön på gården. Vid ett besök i en lådaffär försöker en affärsinnehavare övertala honom att köpa en låda i plast:

- Det här, min bäste herre, är äkta PLASTIK! Ett helt nytt material. Från Amerika.

Eller Usa, som vi säger nuförtiden. Den här lådan kan stå ute året om, i alla väder, utan att kakorna blir förstörda. Kräver ingen som helst underhållning. ${ }^{890}$

Här uppstår en konflikt eller konkurrens mellan det traditionella materialvalet (trä) och ett modernare material (plast). Pettson är dock inte intresserad av en låda i det nya materialet, utan bestämmer sig för en stor låda i trä.

Pettsons teknik kan räknas till vad Mumford benämner som den demokratiska tekniken eftersom han kan överblicka alla moment i utvecklingsprocessen när han skapar sina uppfinningar. En sådan tolkning kan också motiveras med att den demokratiska tekniken hör samman med den småskaliga produktionsmetoden, att den huvudsakligen bygger på människors skicklighet samt utvecklas utifrån ett

\footnotetext{
${ }^{886}$ H. Petroski, The evolution of useful things, 1992a, s. 7-8.

${ }^{887}$ H. Petroski, To engineer is human: The role of failure in successful design, 1992b, s. 97.

${ }^{888}$ D. Ihde, "The designer fallacy and technological imagination”, 2006, s. 121-131; D. A. Norman, The design of everyday things, 2002.

${ }^{889}$ M. Kylhammar, "Teknikdebattens grammatik” i I teknikens backspegel: Antologi i teknikhistoria, B. Sundin (red.), Stockholm: Carlsson, 1987, s. 399.

${ }^{890}$ S. Nordqvist, Tomtemaskinen, 1994, s. 30.
} 
begränsat utnyttjande av naturens resurser. ${ }^{891}$ Pettsons teknik uppfyller alla dessa kriterier. Men för att han ska kunna vidareutveckla sitt projekt behöver han därutöver kunskap om mekanik, vilken han finner i en bok som handlar om Christopher Polhem och hans mekaniska alfabete. ${ }^{892}$ Pettson förklarar för Findus:

- Det är en bok om mekanik, sa han och lyfte undan katten. Alltså, hur man bygger maskiner. Jag kommer ihåg att här står lite om en gubbe som hette Polhem, som var duktig på sådant. Han gjorde ett mekaniskt alfabet ... [...] Han kom på en massa olika sätt att få maskiner att röra sig, fortsatte Pettson. Till exempel om man har ett hjul i ena änden som snurrar runt, så kan det få en stång att röra sig fram och tillbaka i andra änden. Eller om man har en pinne som rör sig fram och tillbaka på det här sättet, så kan den få en annan pinne att röra sig på det här hållet. Han visade med armarna. ${ }^{893}$

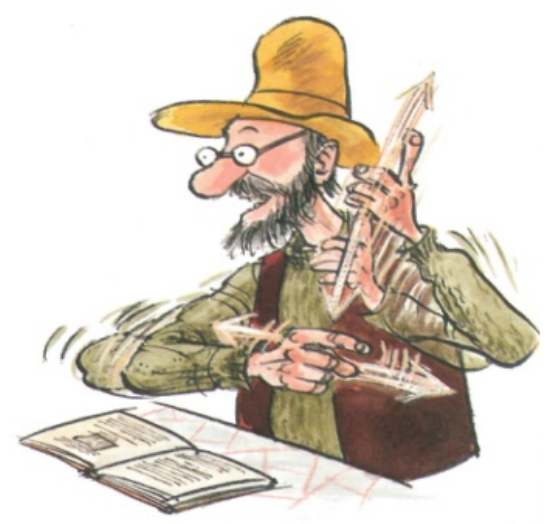

Bild 8.5: Illustration från Tomtemaskinen (Sven Nordqvist, 1994)

\footnotetext{
${ }^{891}$ L. Mumford, "Authoritarian and democratic technics", 1963, s. 1-8.

${ }^{892}$ M.H. Lindgren, Christopher Polhems testamente. Berättelsen om ingenjören och pedagogen som ville förändra Sverige, Stockholm: Nielsen \& Norén Förlag, 2011, s. 11-13. Michael H. Lindgren beskriver Christopher Polhem (1661-1751) som "uppfinnare, innovatör, entreprenör, industriman, gruvingenjör, arkitekt, byggmästare, teknikspridare, tekniklärare och teknikpedagog". Det var inom dessa teknikområden som Polhem gjorde sina mest revolutionerande insatser, menar Lindgren. Polhem var en problemlösare och en mästare på att snabbt kombinera kraft, rörelser och material till en ny fungerande maskin. Han ville gärna lära ut hur man skulle lyckas med teknik och för att förstå hur mekaniken fungerar och samverkar skapade han mekanikens eget alfabete.
}

${ }^{893}$ S. Nordqvist, Tomtemaskinen, 1994, s. 41. 
Findus inspireras ofta av Pettson till att själv uppfinna saker. Hans tekniska skapelseprocess skiljer sig dock från Pettsons, då den är av mer spontan natur. Vid ett tillfälle i Tomtemaskinen utgår Findus från små brädbitar, järnbitar, spikar och ståltråd för att konstruera en egen uppfinning. Vad den ska användas till får däremot ge sig "när den väl är färdig", tänker Findus. ${ }^{894}$ Findus tänkande kring sitt tekniska skapande kan tolkas som att det inte överensstämmer med Lindqvists beskrivning av tekniken som att den inkluderar handlingar som har ett syfte. Pettson, däremot, drivs mer tydligt av ett specifikt syfte när han förändrar den materiella världen med hjälp av sin teknik. ${ }^{895}$

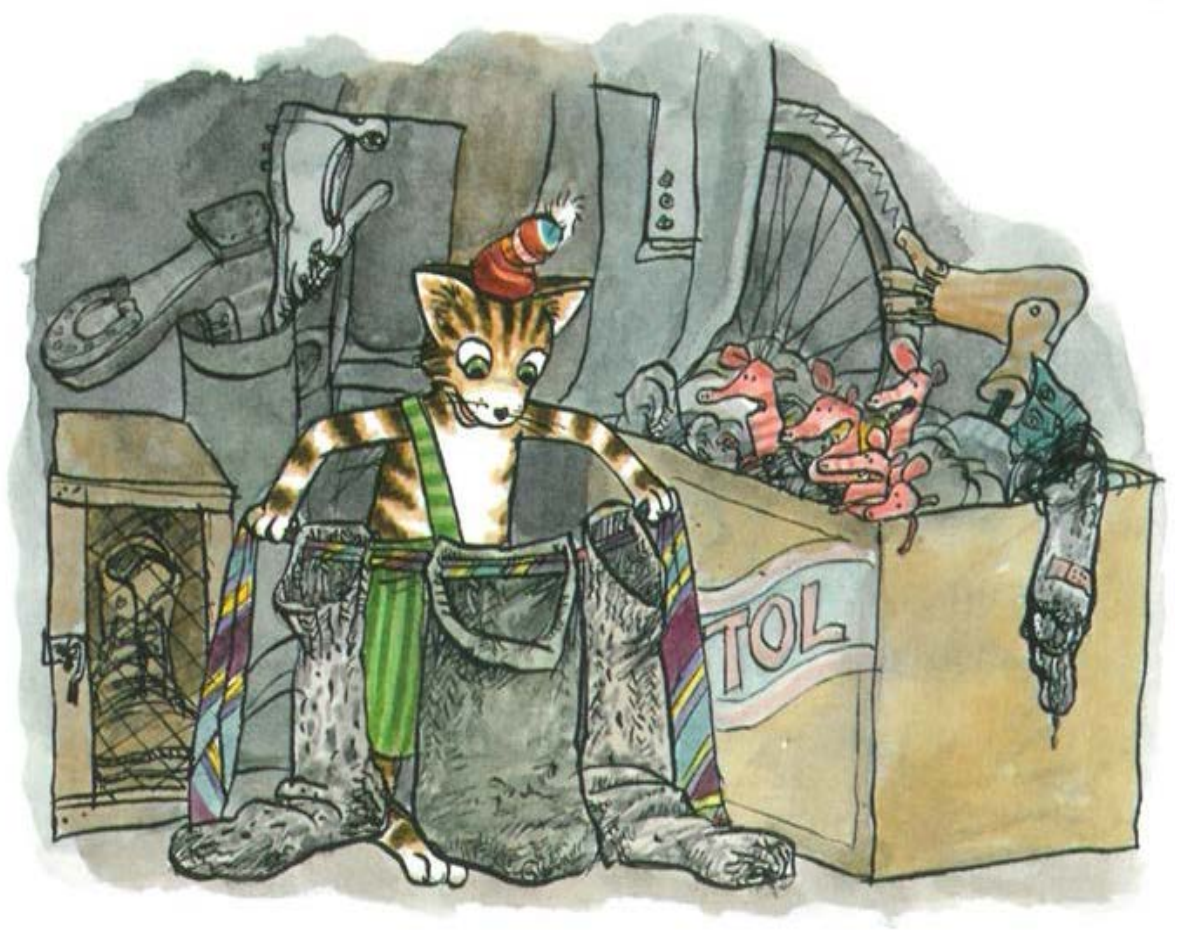

Bild 8.6: Illustration från Tomtemaskinen (Sven Nordqvist, 1994)

\footnotetext{
${ }^{894}$ Ibid., s. 36.

${ }^{895}$ S. Lindqvist, ”Vad är teknik?", 1987, s. 33.
} 
Lite senare i berättelsen uppfinner dock Findus något utifrån ett syfte, det vill säga att han skapar något som han anser att Pettson behöver. I sovrumsgarderoben finns en låda med raggsockor, mössor och "lite av varje". Genom att trä ena änden av en slips genom maskorna på några sockor och en mössa tillverkar han ett verktygsbälte till Pettsons tumstockar, eftersom Pettsons tumstockar försvinner hela tiden. ${ }^{896} \mathrm{I}$ båda ovanstående exempel agerar också Findus i samstämmighet med en bricoleur. Istället för att köpa en present till Pettson skapar han något nytt utifrån de redan befintliga ting han finner på vinden (se bild 8.6).

I Tomtemaskinen drömmer Pettson att Polhem dyker upp i skepnad av en skräckinjagande tomte. Det är en mardröm där Pettson inte kan bestämma sig för vilken modell av det mekaniska alfabetet som han vill ha.
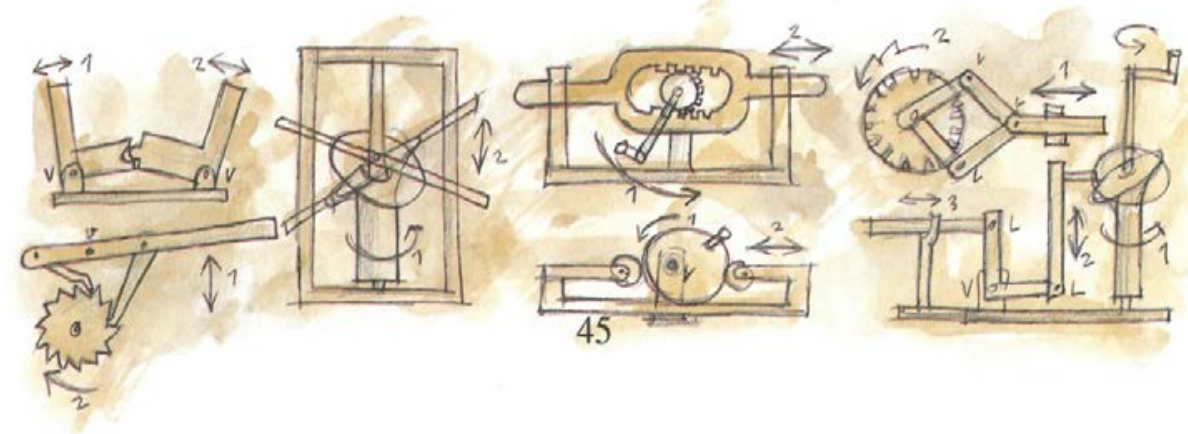

Bild 8.7: Illustration från Tomtemaskinen (Sven Nordqvist, 1994)

I texten förklaras inte Polhems mekaniska alfabete närmare men när Pettson vaknar finner han skisser av några av alfabetets mekaniska modeller i sin anteckningsbok. Han känner igen tre av dem från sin egen bok men minst tio andra "bokstäver" finns nu avskissade i anteckningsboken. Modellerna innehåller pilar och siffror som visar hur mekaniken fungerar (se bild 8.7).

Pettson skissar vidare på sin maskin och genom att studera teckningarna av Polhems alfabete vet han till sist hur han ska göra för att få tomten att komma ut ur

${ }^{896}$ S. Nordqvist, Tomtemaskinen, 1994, s. 118-119. 
lådan, stå still en stund och sedan återvända in i den igen. Som bricoleur utforskar Pettson hur andra artefakter han har i sitt hem skulle kunna användas till tomtemaskinen.

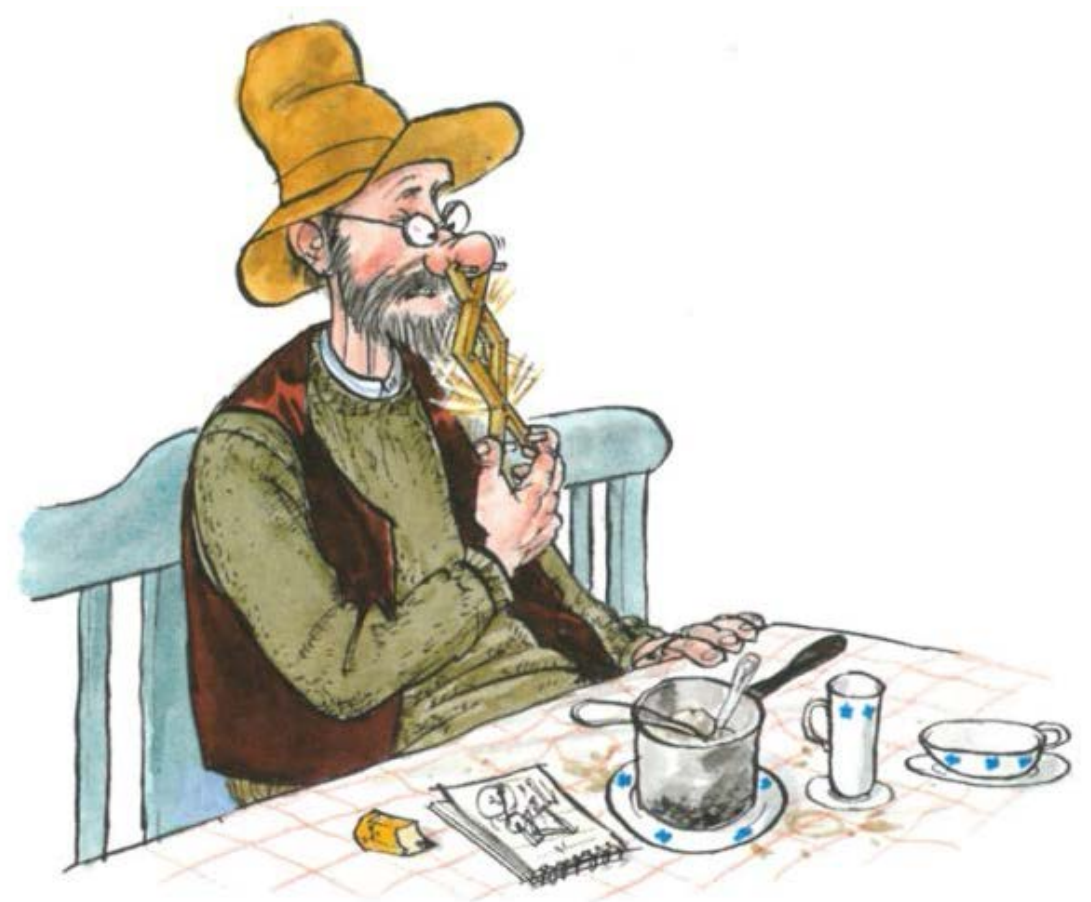

Bild 8.8: Illustration från Tomtemaskinen (Nordqvist, 1994)

Med hjälp av ett värmeskydd till kastruller undersöker han hur han skulle kunna utnyttja rörelse och kraftöverföring i sin tomtemaskin. Mekanismen i värmeskyddet förklaras som: "När han klämde ihop det på ena hållet så åkte det ut på det

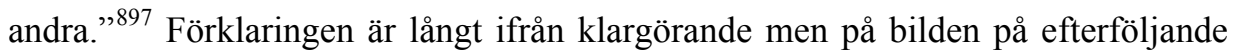
siduppslag leker några mucklor med värmeskyddet och där illustreras mekanismen. Värmeskyddet är på var sida utrustat med två piggar vilket gör att när man trycker ihop den ledade konstruktionen, klämmer piggarna åt om kastrullen. Det gör att värmeskyddet sitter kvar när man lyfter på kastrullen.

${ }^{897}$ S. Nordqvist, Tomtemaskinen, 1994, s. 55. 


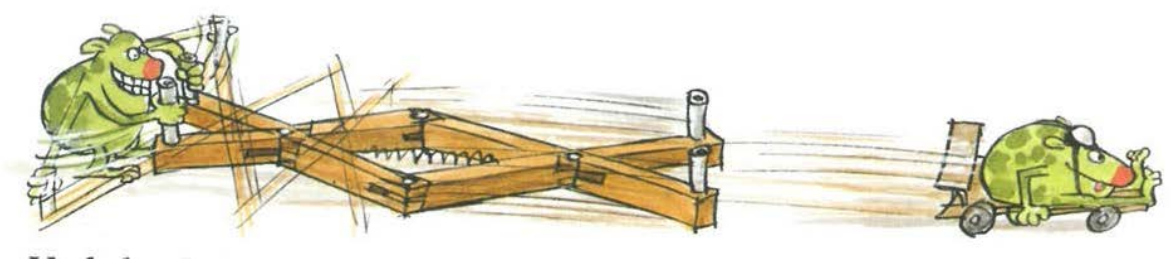

Bild 8.9: Illustration från Tomtemaskinen (Sven Nordqvist, 1994)

Hur tomtemaskinen i realiteten fungerar finns inte heller tydligt beskrivet $\mathrm{i}$ texten, men däremot kan läsaren lista ut funktionen genom att studera de detaljrika bilderna. Där syns kugghjulen, luckan, småtomtarna som kan "prata", luckorna i lådan samt Pettsons tomte. Tomtemaskinen är, liksom rävskrämmaren, ett tekniskt system. Den består av ett antal komponenter som samverkar och som får den att fungera och ingen av delkomponenterna kan ensam utnyttjas för att få samma funktion. ${ }^{898}$ Pettsons tomtemaskin är dock en artefakt som vare sig rationaliserar eller effektiviserar något. ${ }^{899}$ Den är snarare en teknik som utför något som i själva verket skulle kunna lösas på ett enklare sätt. Pettson hade kunnat klä ut sig till jultomte, bett en granne vara tomte eller skapat en maskin som var mindre komplicerad. Pettsons uppfinning påminner därför om vad som kallas en "Rube Goldbergmaskin", vilket även Pettsons och Findus rävskrämmare gör.

\footnotetext{
${ }^{898}$ T.P. Hughes, "The seamless web: Technology, science, etcetera, etcetera”, 1986, s. 281-292; T. P. Hughes, "The evolution of large technological systems", 1987, s. 51-82; L. Ingelstam, "Varför är tekniska system intressanta?”, 2009, s. 81-97; L. Ingelstam, System: Att tänka över samhälle och teknik, 2012, s. 21-24.
}

${ }^{899}$ S. Lindqvist, "Vad är teknik?", 1987, s. 11. 


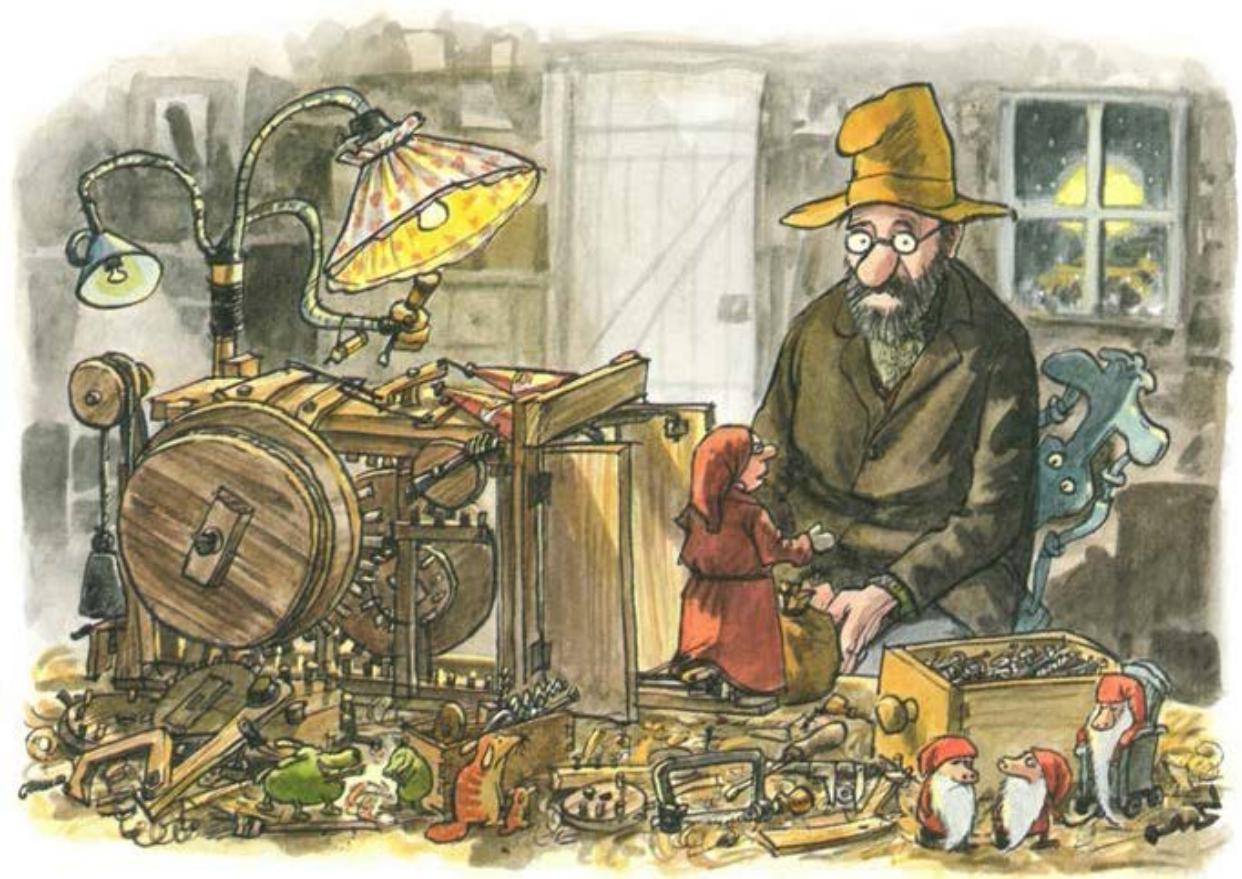

Bild 8.10: Illustration från Tomtemaskinen (Sven Nordqvist, 1994)

Sådana maskiner är uppkallade efter serietecknaren Rube Goldberg (1883-1970) vars tekniska skapelser Merriam-Webster Online Dictionary (2014) definierar som: "Doing something simple in a very complicated way that is not necessary." 900 De flesta Rube Goldberg-uppfinningarna är komplicerade tekniska lösningar som består av flera på varandra följande moment med ett antal ingående komponenter. ${ }^{901}$ Vanligt förekommande komponenter är kugghjul, propellrar, vattenskovlar, kedjedrev, vattenskruvar, vattenhjul, bollar, djur med mera. Goldbergs bilder före-

\footnotetext{
900 "Rube Goldberg", Merriam-Webster Online Dictionary, http://www.merriamwebster.com/dictionary/rube\%20goldberg (läst 2014-06-01).

901 S. Acharya \& A. Sirinterlikci, "Introducing engineering design through an intelligent Rube Goldberg implementation", Journal of Technology Studies, vol. 36(2), 2010, s. 63-72. Rube Goldberg är inte den enda tecknare som blivit känd genom sina komplicerade maskiner. Exempel på andra tecknare som skapat liknande innovationer är den brittiske serietecknaren William Heath Robinson (1872-1944) och den danske serietecknaren Robert Storm Petersen (1882-1949). Den sistnämndes skapelser brukar benämnas som Storm P.-maskiner.
} 
ställer exempelvis komplicerade väckarklockor, anordningar för att sätta på och stänga av ljuset, säkerhetsanordningar för att gå på isiga trottoarer, maskiner som sätter på frimärken på kuvert, garagedörröppnare och komplicerade pennvässare. ${ }^{902}$ Rube Goldberg-maskiner utnyttjas som motivatorer inom vissa ingenjörsutbildningar i USA. Projekten som ingenjörsstudenterna ska genomföra måste bland annat uppfylla följande kriterier:

- Att maskinen slutför sina uppgifter utan någon eller med minimal mänsklig inblandning.

- Att maskinens olika moment syns tydligt.

- Att maskinen drivs så lite som möjligt av elektriska motorer eller använder minimalt med elkraft. ${ }^{903}$

Pettsons tomtemaskin uppfyller alla tre kriterierna, liksom rävskrämmaren även om den sistnämnda kräver att Pettson och Findus också handlar.

I Tomtemaskinen får Findus en idé och bestämmer sig för att uppfinna en automatisk kaffepanna. Denna gång följer Findus arbete med uppfinningen ett mer linjärt förlopp som har likheter med Mitchams beskrivning av den tekniska processen. Han funderar först ut vad han ska uppfinna. När han får syn på kaffepannan får han sin idé. I det första steget i processen när han tänker sig vad han ska skapa, vandrar han runt "[...] och härmar hur Pettson brukar se ut när han tänker”. ${ }^{904}$ Findus övergår därefter till att mer konkret tänka och föreställa sig det han ska skapa:

- Mmmm, sa Findus och tittade tankfullt upp i taket och kliade sig på hakan. Där fanns en krok som lampan hängde i. Han undersökte hur mycket han måste tippa kaffekannan innan kaffet började rinna ur pipen. Han vickade på en stol så att bakbenet lyfte från golvet.

- Just det..., funderade han. Han stannade mitt i ett långt kliv och tänkte djupt, sen spratt han till så att flugan började flyga i rena förskräckelsen.

\footnotetext{
${ }^{902}$ Rube Goldberg, "Rube Goldberg's Gallery”, http://www.rubegoldberg.com/gallery\# (läst 2014-06-01).

${ }^{903}$ S. Acharya \& A. Sirinterlikci, "Introducing engineering design through an intelligent Rube Goldberg implementation", 2010, s. 63-72.

${ }^{904}$ S. Nordqvist, Tomtemaskinen, 1994, s. 48.
} 
$-\mathrm{Nu}$ vet jag! $!^{905}$

När Findus sedan börjar konstruera det han tänkt, inleder han med att knyta fast ett snöre från kaffepannan upp till lampan ovanför köksbordet. Kaffepannan står i en stekpanna, från den går ett snöre via lampkroken, gardinstången och sedan ned i köksstolen. Snöret kortas så att stolens bakben hänger lite ovanför golvet. Findus testar och observerar det han konstruerat. ${ }^{906}$ När han trycker ner stolen hälls kaffet upp i kaffekoppen på bordet. Han inser då att det finns ett problem: om Pettson sitter kvar på stolen så fortsätter det att rinna kaffe ur kannan trots att koppen är full. Problemet löser han genom att hämta en värmeflaska som han tömmer på vatten:

Han försökte blåsa in luft i den i stället, men det gick inte. Då hämtade han en ballong och en liten kork i syskrinet. Han pillade in ballongen i gummiflaskan, blåste upp ballongen och täppte till den med korken. Han la värmeflaskan på golvet och trampade på den. Om han tryckte tillräckligt hårt åkte korken ut med ett pruttande. Precis som Findus hade tänkt. Han blåste upp värmeflaskan igen på samma sätt och la den under stolsbenen. En bräda behövde han också att lägga ovanpå värmeflaskan. Skärbrädan räckte precis. Nu var det klart! Han såg mycket nöjd ut. ${ }^{907}$

Findus testar till sist sin uppfinning på en tant från missionsförsamlingen som kommer förbi. När tanten sätter sig på stolen åker korken ur ballongen med ett ljudligt pruttande. Tanten hoppar förskräckt upp och kannan tippar tillbaka och slutar rinna. Findus är nöjd - hans uppfinning fungerar precis som han tänkt. Findus uppfinnande följer därmed, precis som Pettsons rävskrämmare, en relativt linjär ordning utifrån Mitchams beskrivningar av designprocessen. ${ }^{908}$ Findus uppfinning är samtidigt en Rube Goldberg-maskin; den utför något på ett mer komplicerat sätt än vad som är nödvändigt, de ingående momenten är tydligt synliga och den tekniska anordningen fungerar helt utan motor eller elkraft. Likaså agerar

\footnotetext{
905 Ibid.

906 C. Mitcham, Thinking through technology: The path between engineering and philosophy, 1994, s. 220.

${ }^{907}$ S. Nordqvist, Tomtemaskinen, 1994, s. 49.

908 C. Mitcham, Thinking through technology: The path between engineering and philosophy, 1994, s. 220.
} 
Findus här ett slags bricoleur eftersom han använder befintliga ting för att skapa något nytt.

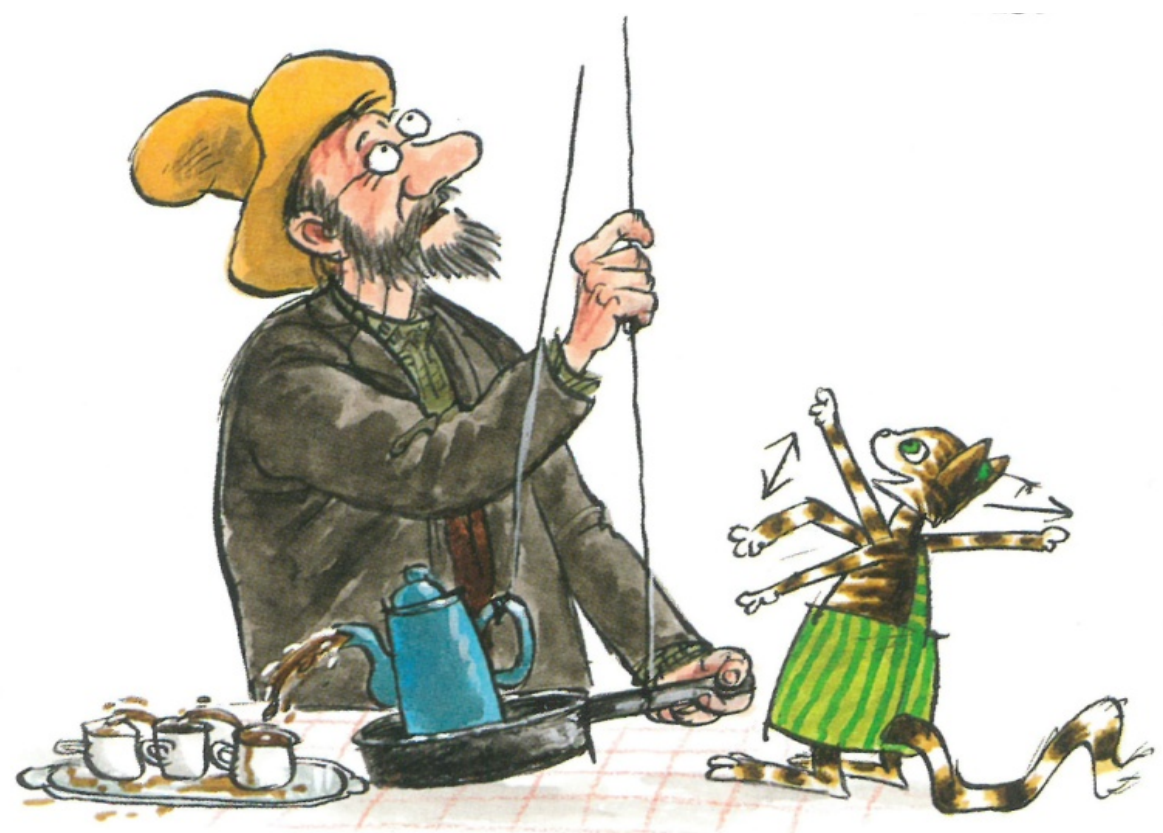

Bild 8.11: Illustration från Tomtemaskinen (Sven Nordqvist, 1994)

Tomtemaskinen är en uppfinning som har ett tydligt problem som den ska lösa. På så sätt skiljer den sig mot många andra tekniska lösningar i böckerna, vilka i själva verket löser sådant som $i$ teknisk mening knappast är att betrakta som problem. Till exempel kan ett redskap eller en artefakt utnyttjas av Pettson och Findus (och även mucklorna) på ett annat sätt än vad den i grunden är avsedd för. Dessa lösningar framträder framför allt i bilderna. I Tomtemaskinen är exempelvis brödet på köksbordet fastsatt i skärbrädet med en tving och istället för en brödkniv skivas brödet med en handsticksåg. ${ }^{909}$ Den fastsatta brödlimpan löser i och för sig "problemet"

${ }^{909}$ S. Nordqvist, Tomtemaskinen, 1994, s. 90. 
att brödet åker över skärbrädan när man skär brödskivor, men den teknik som utnyttjas (en tving) ges en något ovanlig funktion: att hålla fast ett bröd. Andra liknande exempel i boken är en hatt som fungerar som lampskärm (s. 46), en liten trähyvel används som osthyvel (s. 74) och en borrsväng har fått en ny funktion som mugghållare (s. 83).

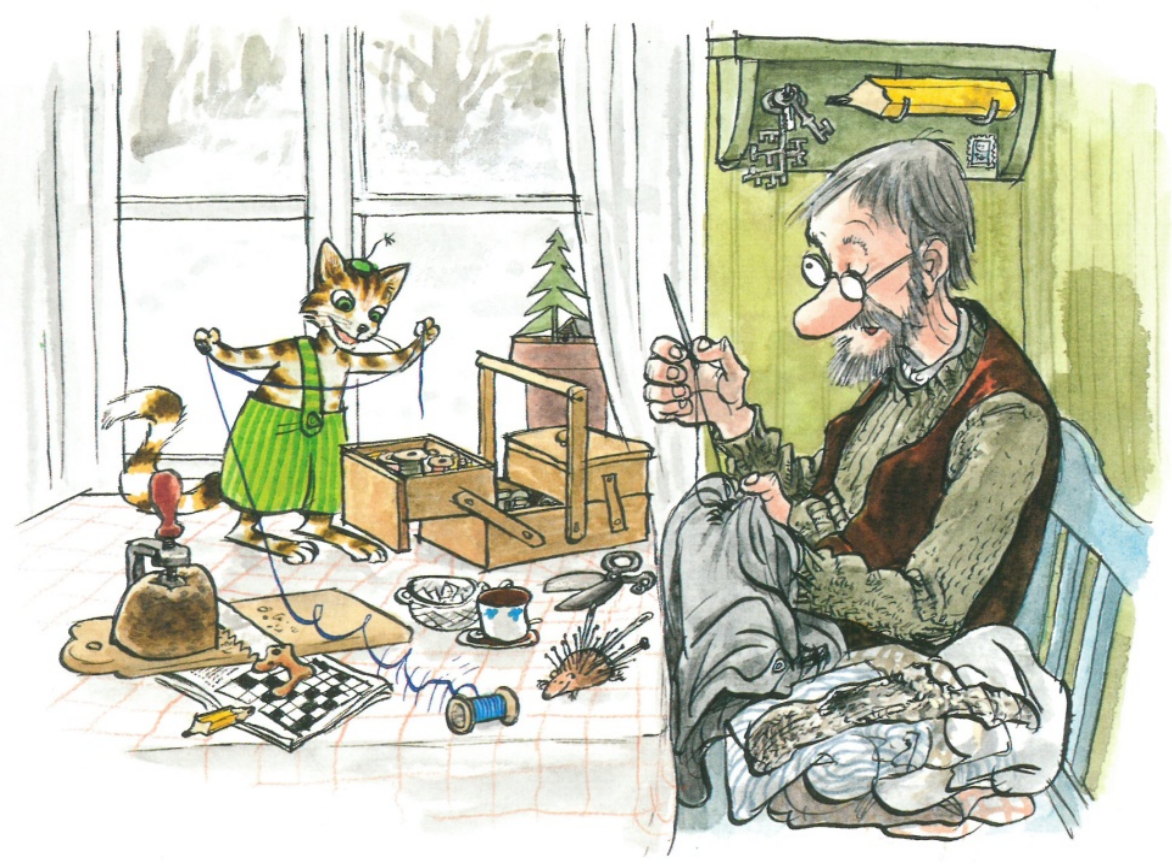

Bild 8.12: Illustration från Tomtemaskinen (Sven Nordqvist, 1994)

Pettsons tekniska lösningar är dessutom många gånger mer att betrakta som uttryck för innovationsglädje och uppfinningslusta än som lösningar på problem. I Tomtemaskinen finns bland annat följande exempel på sådana: i grytskåpet finns en liten kastrull på hjul (s. 21), i hallen står en kombinerad spade och sopborste (s. 23) och på snickarbänken ligger en hammare som är ledad och utrustad med en liten motor i ena änden (s. 72). Den sistnämnda kan dock samtidigt ses som att den underlättar snickeriarbetet, eftersom den inte kräver lika mycket muskelkraft som en vanlig hammare. Liknande tekniska lösningar finns även i de övriga böckerna om Pettson och Findus: 
- Pennhållare på hjul.

- Ett timglas är ombyggt till en väckarklocka.

- En hovtång fungerar som sockertång.

- Nattduksbord på skidor.

- Slangklämma runt skorstensrör.

- Gröten rörs om med en spade.

- En hängränna avslutas med en tratt och en kran.

- Underlägget till kaffekannan har hjul och ett snöre att dra i så att man kan flytta den.

- På kaffekannans pip sitter dels en liten kran, dels en påträdd gummislang som är tillsluten med hjälp av en klädnypa.

- Vetelängden ligger på ett skärbräde i form av en vagn med hjul och sockerbitarna ligger i en följevagn.

- En hatthållare, skapad genom att en pinne satts fast på stolen med hjälp av en tving.

- En brevlåda på sänggaveln fungerar som strumplåda. ${ }^{910}$

Ovanstående innovationer består inte av flera ingående moment men kan ändå definieras som kombinerade bricoleur- och Rube Goldberg-uppfinningar; de är alla okonventionella lösningar skapade av det som finns att tillgå på Pettsons gård. I böckerna om Pettson och Findus går det därmed inte att identifiera och beskriva artefakterna enbart utifrån en synbar eller uppenbar funktion. Don Ihde använder begreppet "the designer fallacy" när han ifrågasätter huruvida en designer verkligen kan få in en artefakts syfte och användningsområden i själva designen. Tekniken är inbäddad i olika kulturella kontexter, skriver Ihde, vilket påverkar design och användningsområden. Samma slags teknik kan passa in olika väl i specifika kontexter och som artefakter tycks tekniken innehålla multipla användningsområden eller utvecklingsbanor. ${ }^{911}$ Som exemplen i Pettsonböckerna visar är det

${ }^{910}$ S. Nordqvist, Pannkakstårtan, Bromma: Opal, 1984; S. Nordqvist, Pettson tältar, Bromma: Opal, 1992; S. Nordqvist, När Findus var liten och försvann, 2001; S. Nordqvist, Findus flyttar ut, 2012.

${ }^{911}$ D. Ihde, “The designer fallacy and technological imagination”, 2006, s. 121-131. 
kontexten som styr teknikens användningsområden eller så är det Pettson som användare av tekniken som bestämmer dess funktion.

Daniel C. Dennett är inne på samma linje som Ihde och ger bland annat exemplet att äldre strykjärn i dag används som bokstöd och dörrstopp. Dennetts slutsats är att uppfinnaren inte är den slutgiltige domaren som avgör vad en artefakt är eller vad den ska användas till, det är användaren som avgör. ${ }^{912}$

Genom budskapet att det är användaren eller kontexten som avgör vad en teknisk artefakt är, och inte den ursprungliga intentionen, kan Pettsonböckerna sägas företräda en tekniksyn i enlighet med Kranzberg: tekniken i sig är inte är ond, god eller neutral men den är däremot kontextberoende. ${ }^{913}$ Delvis stämmer tekniksynen i böckerna också överens med J.C. Pitts tekniksyn, det vill säga att tekniken bör betraktas som ett neutralt redskap vars funktion bestäms av hur människorna använder den. Eftersom Pettson använder och skapar sin teknik utifrån goda intentioner så är också hans teknik god. ${ }^{914}$

Åke Ingerman diskuterar relationen mellan teknik och användare och hans åsikt är att det är viktigt att användaren reflekterar kring tillgång, konsekvenser och syften när han/hon använder föremål i sin vardag. Användaren har sällan kunskap om tillverkningsprocessen, skriver Ingerman, vilket gör det svårt att överblicka konsekvenserna av växelspelet mellan användare och teknik. ${ }^{915}$ I Pettsonböckerna finns den överblick, från tillverkning till tillämpning, som Ingerman tar upp och på så vis företräder Pettsons uppfinningar inte bara Mumfords demokratiska teknik, utan fungerar också som alternativ till det moderna konsumtionssamhällets teknik. Pettsons uppfinningar har aldrig något kommersiellt syfte utan har endast till uppgift att lösa ett för stunden uppkommet problem. De kan därmed tolkas som att de företräder en tekniksyn som tar avstånd från konsumism. Därutöver har Pettson och Findus teknik gemensamma beröringspunkter med von Wrights beskrivning av "det goda livet". Von Wright skiljer mellan önskningar och behov

\footnotetext{
912 D. C. Dennett, "The interpretation of texts, people and other artifacts", Philosophy and Phenomenological Research, vol. 50, 1990, s. 186.

${ }^{913}$ M. Kranzberg, “Technology and history: ‘Kranzberg's Laws”, 1986, s. 544-560.

914 J.C. Pitt, “'Guns don’t kill, people kill'; Values in and/or around technologies”, 2014, s. 89102.

915 Å. Ingerman, "Kunskaper, engagemang och handling" i På spaning efter teknisk bildning, Å. Ingerman, K. Wagner \& A.-S. Axelsson (red.), Stockholm: Liber Förlag, 2009, s. 39-41.
} 
som båda täcks av termen "intresse". Hans slutsats är att en människa lever både irrationellt och oförnuftigt om hon tillfredsställer önskningar som i själva verket skadar hennes välbefinnande på sikt. Förnuftig är däremot den som lever så att önskningarna i stort sett överensstämmer med vad han eller hon behöver, menar von Wright. ${ }^{916}$ Pettsons uppfinningar motsvarar såväl hans önskningar som behov och de skadar aldrig hans välbefinnande vare sig på kort eller lång sikt.

Då Pettsons uppfinningar många gånger är att betrakta som ett uttryck för kreativt skapande snarare än problemlösning, går det även att tolka dem utifrån ett konstnärligt perspektiv. Som Liedman framhåller, har teknik och konst det gemensamt att båda är skapade av människan och med hjälp av mänsklig konstfärdighet. Konsten har sin bas i tekniken: författaren har sin penna, skulptören sin mejsel, målaren sin pensel och musikern sitt instrument. I och med den nya teknikens inträde har teknik och konst alltmer kommit att flyta samman, liksom gränsen mellan konstnär och tekniker, menar Liedman. Han ser kreativitet som något gemensamt för konstnären och teknikern. Den moderne teknikern når framgång genom sin fantasi och okonventionella lösningar. Den kreative konstnären gör en originell helhet av de delar han eller hon har till hands. På så sätt, skriver Liedman, handlar det i båda fallen om att använda sin kreativitet med de redskap som finns att tillgå. ${ }^{917}$ Detta överensstämmer delvis med Pettsons tekniska skapande. Vissa av Pettsons tekniska skapelser kan i första hand tolkas som konstnärliga uttryck, och i andra hand som teknik som löser ett problem. Pettson är både tekniker och konstnär.

Berättelsen om tomtemaskinen slutar med att det dyker upp en tomte på julafton hos Pettson och Findus. Tomten ser ut som den mekaniska tomte som Pettson byggt, men rör sig som om den vore levande. När han pratar säger han inte heller det som de små tomtarna Pettson köpte av försäljaren säger. Pettson finner till och med spår i snön efter tomten men när han tittar i skåpet där han gömt sin tomtemaskin, finner han tomtedockan med stelt ansikte, hängande armar och hela

\footnotetext{
${ }^{916}$ G. H. von Wright, Vetenskapen och förnuftet: Ett försök till orientering, 1987/2010, s. 140141.

${ }^{917}$ S.-E. Liedman, I skuggan av framtiden: modernitetens idéhistoria, 1999, s. 395-401.
} 
dockan ser "lika död ut" som den är. ${ }^{918}$ Pettsons tekniska uppfinningar är kreativa skapelser men de kan inte ersätta det levande, som exempelvis en "riktig" tomte.

\section{Natursynen i böckerna om Pettson och Findus}

Huvudsakligen utspelar sig böckerna om Pettson och Findus på Pettsons gård men ibland gör Pettson och katten utflykter till skogen. Den vilda naturen är något man besöker och därmed görs en uppdelning mellan naturen och människornas värld. Vid en första anblick av landskapet som omger Pettsons gård, tycks den stämma väl överens med vad texten skildrar. Den första boken om Pettson och hans katt, Pannkakstårtan (1984), inleds med orden:

Det var en gång en gubbe som hette Pettson. Han hade en katt som hette Findus. De bodde i ett litet rött hus med snickarbod och hönshus och vedbod och utedass och trädgård. Runtom fanns åkrar och ängar och lite längre bort låg skogen. ${ }^{919}$

Vid en närmare studie av bilderna finns dock detaljer som berättar mer än texten. På den första bilden i boken finns exempelvis ett gigantiskt stenblock på en stenkulle. Det som hindrar stenblocket från att tippa är en smal pinne. På kullen växer tre jättesvampar, stora som träd, och i bergssluttningen står en känga som är högre än träden. I Rävjakten finns ett träd vars trädstam i själva verket är en blockflöjt, randiga svampar, en korg med två blå fåglar som hänger i ett träd, det sitter en liten grön brevlåda uppe i äppelträdet och på marken vandrar ett vedträ iväg på fyra ben. Ofta är det mucklornas värld som illustreras, det vill säga sådant som Findus, men inte Pettson, kan se. Genom dessa surrealistiska detaljer skapas en bild av naturen som något hemlighetsfullt som inrymmer mycket som människorna inte kan se eller uppfatta. I Tomtemaskinen skildras skogen som något skrämmande:

Pettson satte Findus i ryggsäcken och gick iväg i samma riktning som de kom. Men han hittade inte stigen som han hade trott. Han stannade och tänkte efter hur han hade gått förut. Det kändes som om de skulle åt vänster så han försökte med det. Men snart stannade han igen för där låg stora stenblock som han aldrig hade sett förut. Han följde sina spår tillbaka men snart hade han tappat bort dem. [...] Pettson gick vidare på måfå, men stannade snart igen när han inte kände igen sig. Han kände

\footnotetext{
${ }^{918}$ S. Nordqvist, Tomtemaskinen, 1994, s. 128.

${ }^{919}$ S. Nordqvist, Pannkakstårtan, 1984, opag.
} 
hur han började gripas av panik. Han försökte lugna Findus, men katten blev bara ännu räddare och var nära att börja gråta. ${ }^{920}$

Deras räddning är den lille brevbäraren. När de följer efter honom hittar de tillbaka. Findus uppmanar Pettson att inte gå in i skogen igen och Pettson tänker efteråt på hur otäckt det var när han gick vilse. Tänk om de hade frusit ihjäl! I kombination med de surrealistiska detaljerna förstärks föreställningen om en uppdelning mellan naturen och den av människan skapade världen.

Jakt återfinns som tema i en majoritet av de analyserade berättelserna och även i Rävjakten finns ett tydligt budskap om att man inte ska jaga eller döda djur. Däremot brukar Pettson och Findus ägna sig åt att fiska. ${ }^{921}$ Grannen Gustavsson, som är jägare, är avbildad med ett argt ansiktsuttryck. Hans hund ser lika arg ut och den morrar på några mucklor som gömt sig under en vedklamp. När Gustavsson gått säger Pettson till Findus att det är lika bra att låsa in hönsen. Findus tycker att Pettson ska låsa in Gustavsson istället eftersom han inte litar på "gubbar med gevär". ${ }^{922}$

I likhet med berättelsen om Nils Holgersson görs i böckerna om Pettson och Findus en uppdelning mellan skogens vilda djur och de domesticerade djuren genom att de framställs på olika sätt. Katten och hönorna kan tala, de är antropomorfer, medan vilda djur som räv och grävling beter sig som djur. De vilda djuren besöker Pettson på hans gård ibland men det är sällan Pettson och Findus besöker de vilda djuren i skogen. Räven är dessutom ett hot mot Pettsons husdjur hönorna. Men trots att det är människans behov som står i centrum, har djuren rätt att leva och de förtjänar såväl människans respekt som hänsyn.

Sammantaget kan man se Pettsonböckerna som förespråkare för ett gott och småskaligt liv närmare naturen. Utifrån perspektivet hållbar utveckling odlar Pettson sina egna grönsaker, har egna ägg och mjölkkannan på köksbordet vittnar om att han hämtar sin mjölk hos grannen som har kor.

\footnotetext{
${ }^{920}$ S. Nordqvist, Tomtemaskinen, 1994, s. 111.

${ }^{921}$ S. Nordqvist, Pettson tältar, 1992, opag.

${ }^{922}$ S. Nordqvist, Rävjakten, 1986, opag.
} 


\section{Framtidssynen i böckerna om Pettson och Findus}

I skildringen av Pettson och Findus tekniklandskap finns inga indikationer på att tiden går framåt. Såsom böckernas miljö gestaltar sig, har den alltid sett ut och kommer alltid så göra. De tekniska uppfinningar som Pettson skapar bidrar inte till en utveckling, utan är snarare att betrakta som breddningar av teknikens befintliga användningsområden, vilket gör dem både miljövänliga och energisnåla. Utifrån det perspektivet skulle berättelsen kunna tolkas som att den ändå företräder en viss syn på framtiden: en utveckling mot ett i längden mer hållbart samhälle. Pettsons utvecklande av teknik är inte framåtsyftande utan löser ett problem för stunden. Här finns därmed en viss samsyn med det utopiska framtidssamhället i Schwartzkopfs böcker om höghuset Talleborg som också kan tolkas som att de förespråkar ett hållbart liv som inte bygger på konsumism. Den framtidssyn som förmedlas via Pettsonböckerna skildrar därmed inte en utveckling mot det effektiva samhället. Kontexten kan snarare tolkas som en utopisk beskrivning av ett samhälle som bygger på småskalighet. Till skillnad från böckerna om Talleborg föredrar Pettson ensamheten före gemenskapen med grannarna.

En alternativ tolkning är att böckerna skildrar en pastoral idyll samt nostalgisk längtan tillbaka till det samhälle som fanns innan industrialiseringen slog igenom. ${ }^{923}$ Utifrån en sådan tolkning är Pettsons och hans katts värld hållbar men samtidigt statisk. Trots att böckerna kan ses som en historisk beskrivning av (förslagsvis) 1950-talet, kvarstår budskapet till läsaren: det finns alternativa och mer hållbara sätt att leva på jämfört med ett konsumtions- och tillväxtsamhälle. ${ }^{924}$

\section{Sammanfattande analys av böckerna om Pettson och Findus}

Böckerna om Pettson och Findus kan ses som representanter för sagogenren som fick en renässans i slutet av 1900-talet. ${ }^{925}$ Sammantaget kan böckerna å ena sidan läsas som att de företräder en nostalgisk tillbakablick med ett inneboende budskap om att "det var bättre förr". $\AA$ andra sidan kan de ses som skildringar av ett teknik-

\footnotetext{
${ }^{923}$ M. Kylhammar, Maskin och idyll: Teknik och pastorala ideal hos Strindberg och Heidenstam, 1985, s. 14.

${ }^{924}$ C. Axell m.fl., "Images of Technology and sustainable development in Swedish children's literature", 2014, s. 5-7.

${ }^{925}$ L. Kåreland, "Barnlitteraturens utveckling i Sverige", 2008, s. 7-9.
} 
landskap som företräder ett alternativt och hållbart sätt att leva, vilket står i kontrast till det moderna konsumtionssamhället. ${ }^{926}$ Den sistnämnda tolkningen motiveras av att de första böckerna i serien publicerades i mitten av 1980-talet då bland annat miljöfrågor och hållbar utveckling stod i fokus i samhällsdebatten. ${ }^{927}$ Så trots att Wernströms Den underbara resan och böckerna om Pettson och Findus är så olika till sin karaktär, kan miljödiskussionen sägas vara närvarande fast på olika sätt. Till skillnad från i Den underbara resan undviker Pettsonböckerna exempelvis att lyfta fram negativa bilder av vad tekniken får för konsekvenser och de erbjuder istället alternativ. Precis som människorna i böckerna om höghuset finner Pettson och Findus ständigt nya användningsområden för den redan befintliga tekniken. Den återanvänds och den teknik de använder tär inte på naturens resurser eller kräver energi för att fungera. Pettson och Findus är båda bricoleurer som skapar sina uppfinningar utifrån vad som finns på gården; det är sällan något nytt behöver köpas. ${ }^{928}$ Pettson lagar sina kläder istället för att köpa nya, odlar sina egna grönsaker samt är självförsörjande på ägg. Övrigt han behöver får han av sina grannar. Småskalighet är därmed något som kännetecknar Pettsons liv på gården.

Som Mumford och Frängsmyr påpekar, är nästan alla 1800-talsutopisters idealsamhällen förlagda till städer. ${ }^{929}$ Det är emellertid vare sig böckerna om människorna i höghuset Talleborg eller Pettson och Findus. Dessa böckers utopier är istället förlagda till vildmarken respektive landsbygden och i böckerna om Pettson och Findus är städer och industrier helt frånvarande. Böckerna utspelar sig huvudsakligen på Pettsons gård, där han och katten ständigt hittar på nya kluriga uppfinningar. Genom uppfinningarna är det hantverkets teknik som är idealet.

\footnotetext{
${ }^{926}$ C. Axell m.fl., "Images of technology and sustainable development in Swedish children's literature", 2014, s. 5-7.

${ }^{927}$ J. Anshelm, Socialdemokraterna och miljöfrågan: En studie av framstegstankens paradoxer, 1995, s. 108; J. Anshelm, Det vilda, det vackra och det ekologiskt hållbara: Om opinionsbildningen i Svenska Naturskyddsföreningens tidskrift Sveriges Natur 1943-2002, 2004, s. 106; C. Bernes \& L. J. Lundgren, Bruk och missbruk av naturens resurser: En svensk miljöhistoria, 2009, s. 276-278; S. Sörlin, Naturkontraktet: Om naturumgängets idéhistoria, 1991, s. 227-245.

${ }^{928}$ B. Dahlbom, "En vetenskap om artefakter", 1993, s. 53-75; C. Lévi-Strauss, The savage mind, 1962/1973, s. 17; S.-E. Liedman, Ett oündligt äventyr: Om människans kunskaper, 2001, s. 163.

${ }^{929}$ T. Frängsmyr, Framsteg eller förfall: Framtidsbilder och utopier $i$ västerländsk tanketradition, 1990, s. 128-164; L. Mumford, "Utopia, the city and the machine", Daedalus, vol. 94(2), 1965, s. 271-292.
} 
Utifrån ett sådant perspektiv kan William Morris utopi sägas leva vidare i böckerna om Pettson och Findus. I Morris utopi, liksom Pettsonböckerna, har industrilandskapet försvunnit och förutom att städerna är gröna, har människor i stor utsträckning bosatt sig på landsbygden. ${ }^{930}$

Det som gör böckerna om Pettson och hans katt unika jämfört med övriga barnböcker som ingår i denna studie, är att de gestaltar tekniken som att den inte är tidsbunden: den "föds", men "dör" inte, trots att den samtidigt är i ständig utveckling. En stor del av de tekniska artefakter som Pettson använder sig av har funnits länge och fyller fortfarande sin funktion. Dessutom skapar han teknik genom att utnyttja sina praktiska kunskaper, kunskaper som han för vidare till Findus. ${ }^{931}$

I böckerna står tekniken för kreativitet och uppfinningslusta. Samtidigt som tekniken löser problem behöver den dock inte vara "nyttig" och den behöver heller inte underlätta eller leda till att ett arbete utförs på ett enklare eller mer effektivt sätt. ${ }^{932}$ Vissa av Pettsons och Findus uppfinningar är snarast att beskrivas som konstnärliga "Rube Goldberg-maskiner" som utför något på ett mer komplicerat sätt än nödvändigt. ${ }^{933}$ Förutom dessa "krångliga" maskiner, ger Pettson ständigt sina artefakter nya funktioner eller utnyttjar dem i en annan kontext än den ursprungligen tänkta. Det är Pettson som användare som bestämmer artefaktens funktion och inte den ursprunglige konstruktören av föremålet. ${ }^{934}$ På så vis förmedlas en bild av tekniken som något som den fantasifulle kan utnyttja flexibelt eftersom dess användningsområden är oändliga.

Något annat som skiljer böckerna om Pettson och Findus från de övriga barnböckerna i studien, är att de innehåller övernaturliga inslag, bland annat i form av "mucklor". De övernaturliga inslagen bidrar till att lösa de tekniska problem som

\footnotetext{
${ }^{930}$ R. Ambjörnsson, Fantasin till makten! Utopiska idéer $i$ västerlandet under fem hundra år, 2004, s. 172; T. Frängsmyr, Framsteg eller förfall: Framtidsbilder och utopier $i$ västerländsk tanketradition, 1990, s. 150-160.

931 B. Berner, Perpetuum mobile? Teknikens utmaningar och historiens gång, 1999, s. 49; K. Kelly, What technology wants, 2010, s. 52-54; D. Edgerton, The shock of the old: Technology and global history since 1900, 2006.

932 Jämför S. Lindqvist, ”Vad är teknik?”, 1987, s. 32-33.

${ }^{933}$ S. Acharya \& A. Sirinterlikci, "Introducing engineering design through an intelligent Rube Goldberg implementation”, 2010, s. 63-72.

${ }^{934}$ D. C. Dennett, "The interpretation of texts, people and other artifacts", 1990, s. 186; D. Ihde, "The designer fallacy and technological imagination", 2006, s. 121-131.
} 
uppstår. En möjlig tolkning är att lösningen på ett tekniskt problem kan komma från oväntat håll. Mucklorna kan dessutom sägas representera "slumpen", det vill säga de misstag eller positiva och slumpmässiga upptäckter som ofta ligger bakom att teknik utvecklas. ${ }^{935}$

Vad gäller natursynen i Pettsonböckerna finns en uppdelning mellan naturen och människornas värld. Bilden förstärks av att skogen skildras som något främmande och skrämmande som man kan gå vilse i. Samtidigt finns ett explicit budskap om att människan ska respektera djur och natur. Böckerna om Pettson och Findus kan därför sägas företräda vad Dobson benämner som en svag antropocentrism, eftersom de inte förmedlar en helt instrumentell syn på naturen. ${ }^{936}$

Något tydligt budskap om framtiden går inte att finna i böckerna, då Pettsons värld kan ses som en utopi, en pastoral idyll där tiden står stilla. Samtidigt kan Pettsons sätt att leva tolkas som ett framtidsideal att sträva mot: ett hållbart och småskaligt samhälle med ett minimalt utnyttjande av naturens resurser.

Tekniksynen i böckerna om Pettson och Findus kan sammanfattas med vad Pettson svarar när Findus undrar om inte Pettson har skräp så det räcker: "Man vet aldrig när man behöver saker och ting. Det är bäst att spara på allt [...]". 937

${ }^{935}$ B. Berner, Perpetuum mobile? Teknikens utmaningar och historiens gång, 1999, s. 49; D. Ihde, "The designer fallacy and technological imagination", 2006, s. 121-131; D. A. Norman, The design of everyday things, 2002; H. Petroski, The evolution of useful things, 1992a, s. 7-8; H. Petroski, To engineer is human: The role of failure in successful design, $1992 \mathrm{~b}$.

${ }^{936}$ A. Dobson, Green political thought, 2000, s. 46-61.

${ }^{937}$ S. Nordqvist, Tomtemaskinen, 1994, s. 103. 


\section{KAPITEL 9}

\section{Sammanfattande analys och slutdiskussion}

En central utgångspunkt för denna avhandling har varit min övertygelse om att skönlitterära barnböcker kan ses som bärare av värderingar och förhållningssätt till teknik och att de därför är intressanta att undersöka utifrån ett teknikdidaktiskt perspektiv. En viss syn på teknik är dessutom ofta intimt sammanknippad med en specifik syn på naturen respektive framtiden. ${ }^{938}$ Syftet har därmed varit att utifrån ett didaktiskt perspektiv undersöka budskap om teknik i ett urval svenska skönlitterära barnböcker samt undersöka hur berättelsernas tekniksyner förhåller sig till deras natur- respektive framtidssyn. I analyserna har jag utgått från den övergripande frågeställningen:

Vilka olika slags tekniksyner kommer till uttryck i skönlitterära barnböcker med ett teknikdidaktiskt innehåll och hur förhåller sig tekniksynerna till natur- respektive framtidssyn?

I studien har jag identifierat vad för teknik som finns med i barnböckerna, hur den gestaltas och varför. Utifrån varför-frågan har jag tolkat vilka syner på teknik och teknisk utveckling som förmedlas samt hur dessa förhåller sig till berättelsernas natur- respektive framtidssyn. I teknik-, natur- och framtidssyn ingår ett ställningstagande till människans roll i växelverkan mellan människa, natur och framtid.

\footnotetext{
${ }^{938}$ N. Applebaum, "The myth of the innocent child: Interplay between nature, humanity and technology in contemporary children's science fiction", 2006, s. 1-17; N. Applebaum, Representations of technology in science fiction for young people, 2010; T. Frängsmyr, Framsteg eller förfall: Framtidsbilder och utopier i västerländsk tanketradition, 1990, s. 235.
} 
Då jag betraktar det historiska perspektivet som en naturlig och viktig del i tänkandet kring teknik, består det empiriska materialet av barnböcker från 1900talets början och fram till 2000-talets inledning. Att det just är det senaste seklets litteratur som blivit föremål för analys motiveras av att det var under denna tid som Sverige gick från att vara jordbruksland till att bli en modern industrination och att tekniklandskapet därmed kom att radikalt förändras. Tekniklandskap är det begrepp jag har använt för att med vetenskapliga glasögon undersöka förekomsten av tekniska artefakter liksom sambanden dem emellan i barnböckerna. ${ }^{939}$ Avhandlingen kan därför beskrivas som en vandring genom ett urval av svenska barnböckers tekniklandskap, skrivna vid olika tidpunkter under det senaste århundradet.

Ett större antal barnböcker (130 stycken) genomgick en noggrannare undersökning i studiens initialskede och avhandlingen kom till sist att grunda sig på sex svenska författares skönlitterära barnböcker: Selma Lagerlöf, Otto Witt, Elsa Beskow, Karl-Aage Schwartzkopf, Sven Wernström och Sven Nordqvist. Det övergripande kriteriet för att valet föll på dessa författare var att deras barnböcker återkommande har vad jag tolkar som ett uttalat och utvecklat teknikdidaktiskt innehåll, de är skrivna vid olika tidpunkter från 1900-talets början och fram till inledningen av 2000-talet samt vänder sig till barn mellan sex och tolv år. Med "teknikdidaktiskt innehåll" åsyftar jag inte enbart att de innehåller skildringar av teknik, utan att de också har ett innehåll som inkluderar frågeställningar och problematiker som i dag är betydelsefulla och relevanta inom teknikens didaktik. Det handlar exempelvis om reflektioner om tekniken som sådan samt dess för- och nackdelar. ${ }^{940}$

Med inspiration från Ricoeurs idé om en misstankens hermeneutik har jag genom närläsning av texterna sökt efter såväl explicita som implicita budskap om

\footnotetext{
939 J.-E. Hagberg, Livet genom tekniklandskapet: Livslopp, åldrande och vardagsteknikens förändring, 2008, s. 19-20; J.-E. Hagberg, "Att lära i teknikens rum och landskap. En metadidaktisk betraktelse", 2009, s. 45-46.

${ }^{940}$ V. Bjurulf, Teknikdidaktik, 2011, s. 209; J. R. Dakers, "Towards a philosophy for technology education”, 2006b, s. 145-158; J.-E. Hagberg \& M. Hultén, Skolans undervisning och elevers lärande i teknik: svensk forskning i internationell kontext, 2005, s. 12-19.
} 
teknik i berättelserna samt identifierat olika alternativa tolkningar. ${ }^{941}$ Analyser och tolkningar av det empiriska materialet (barnböckerna) har först skett i kronologisk ordning samt i relation till den historiska kontext berättelserna tillkommit i. Jag har även sökt efter gemensamma budskap om teknik berättelserna emellan.

I analysprocessens nästa steg har jag gått under ytan och i berättelserna sökt efter "dolda budskap" om teknik. Här har jag riktat en "misstanke" mot det som verkar uppenbart för att på så vis nå en förståelse som går bortom förklaringar utifrån såväl historisk kontext som det explicit uttalade i texterna. ${ }^{942}$ Avslutningsvis har jag i en jämförande analys avkronologiserat texterna, det vill säga fört samman det textinnehåll som berättelserna har gemensamt. ${ }^{943}$ Detta utmynnade i ett antal teman. ${ }^{944}$

Mina analyser och tolkningar visar sammantaget att barnböckernas skildringar av tekniken är mångfacetterade och under den hundraårsperiod som det empiriska materialet härrör från, beskrivs tekniken på en mängd olika sätt. Då tekniken är en del av vår kultur och mänskliga strävan, kan den betraktas som bärare av betydelser, värderingar och normer. ${ }^{945}$ Det är därför svårt att göra en strikt åtskillnad mellan beskrivningen av tekniken som sådan i berättelserna och den tekniksyn de förmedlar. I denna sammanfattande analys har jag av strukturella skäl ändå valt att göra denna uppdelning. I den första delen, Teknikens representationer, sammanfattar jag vad för slags teknik som finns med i barnböckerna. I den andra delen, Teknikens olika gestaltningar, beskriver jag hur teknik i sin konkretaste form

${ }^{941}$ B. S. Brummett, Techniques of close reading, 2010, s. 25; S. Claesson m.fl., "Ricoeurs kritiska hermeneutik vid empiriska studier", 2011, s. 18-35; P. Ricoeur, "Hermeneutik och ideologikritik", 1993b, s.144-156.

${ }^{942}$ S. Claesson m.fl., "Ricoeurs kritiska hermeneutik vid empiriska studier", 2011, s. 18-20; B. Gustavsson,"Bildning i vår tid”, Högskoleverket, s. 6, www.hsv.se/bildning (läst 2014-09-20); B. Kristensson Uggla, Kommunikation på bristningsgränsen: en studie i Paul Ricoeurs projekt, 1994, s. 251-284; P. Ricoeur, "The model of the text: Meaningful action considered as a text", 1973, s. 91-117; P. Ricoeur, "Förklara och förstå. Text - handling - historia”, 1993a, s. 77-78.

${ }^{943}$ P. Ricoeur, "Vad är en text?", 1993c, s. 50-52.

${ }^{944}$ L. Marx, The pilot and the passenger: Essays on literature, technology, and culture in the United States, 1988, s. 114.

945 J. R. Dakers, "Towards a philosophy for technology education”, 2006b, s. 145-158; J. Habermas, "Teknik och vetenskap som ideologi”, 1984, s. 63-103; L. Winner, "Do artifacts have politics?", Daedalus, vol. 1, 1980, s. 121-136; L. Winner, The whale and the reactor: A search of limits in an age of high technology, 1989. 
gestaltas i barnböckerna, det vill säga hur tekniken som sådan presenteras. I den tredje delen, Tekniksyn i relation till natur och framtid, redovisas de olika teknik-, natur- och framtidssyner som jag funnit i barnböckerna. Min jämförande analys ledde till att en fjärde analyskategori utkristalliserades: Tekniksyn i förhållande till kontext. Här avses inte de reella kulturella eller historiska kontexter som texterna tillkommit $i$, utan de kontexter som framträder utifrån analyserna av texternas tekniklandskap.

\section{Teknikens representationer}

Som vägledning i identifieringen av tekniken i texterna har jag använt mig av Mitchams fyrdelade beskrivning av teknik som objekt (object), aktivitet (activity), kunskap (knowledge) och viljekraft (volition) i kombination med Hughes beskrivning av tekniska system. ${ }^{946}$ Undersökningen av texternas tekniklandskap visar att alla dessa fem aspekter av teknik finns väl representerade i de i studien ingående barnböckerna.

I Otto Witts tekniska sagor är det ofta tingen som är huvudaktörer, exempelvis pennor, klockor, glödlampor och ubåtar och i Karl-Aage Schwartzkopfs böcker om familjen Tuff-Tuff, liksom i Sven Nordqvists böcker om Pettson och Findus är det såväl tekniken som objekt, som system, som är i fokus. I de tekniska sagorna finns den teknik som återfinns i hemmet representerad, liksom i böckerna om Pettson och Findus samt Schwartzkopfs böcker om höghuset Talleborg. Elsa Beskows sagor lyfter fram tekniken som objekt utifrån ett hantverksperspektiv, vilket Sven Wernströms Den underbara resan och böckerna om Pettson och Findus också gör. Förutom att tåg lyfts fram som betydelsefull teknik (i Nils Holgersson, böckerna om familjen Tuff-Tuff och Den underbara resan), ges även bilen som tekniskt objekt stort utrymme i en av Elsa Beskows sagor samt delvis i Den underbara resan. Då jag medvetet valt att inte inkludera science fiction-litteratur i studien, är rymdtekniken så gott som frånvarande som representation, trots att flera av

\footnotetext{
946 T.P. Hughes, “The seamless web: Technology, science, etcetera, etcetera”, 1986, s. 281-292; T.P. Hughes, "The evolution of large technological systems", 1987, s. 51-82; T. P. Hughes, "Technological momentum", 1994, s. 101-113; C. Mitcham, Thinking through technology: The path between engineering and philosophy, 1994, s. 160.
} 
berättelserna härrör från den tid som rymdkapplöpningen fick sitt startskott i och med Sovjetunionens uppskjutning av satelliten Sputnik 1 hösten $1957 .{ }^{947}$

Representationen av teknik som objekt i de undersökta barnböckerna kan kategoriseras på följande sätt:

- Hemmets teknik

- Industriell och maskinell teknik

- Verkstadsteknik

- Jordbruksteknik

- Skogsbruksteknik

- Kommunikationsteknik

- Hantverksteknik

- Krigsteknik

- Energiteknik

- Jaktteknik

- Kluriga uppfinningar och lösningar

När det gäller tekniken som kunskap, viljekraft och aktivitet är dessa aspekters inbördes förhållande, samt relation till tekniken som objekt, tydligt skildrat i Nils Holgersson, de tekniska sagorna, Beskows båda sagor "Herr Klumpedump från Klumpedonien" och "Doktor Klokamundus' uppfinning", Den underbara resan samt böckerna om Pettson och Findus. Berättelsernas beskrivningar av den tekniska processen visar att teknisk kunskap är en förutsättning för att en framgångsrik teknisk aktivitet överhuvudtaget ska kunna äga rum. Vilja att skapa eller använda teknik framställs i flera av berättelserna som en unik mänsklig egenskap som skiljer oss från djuren. Denna aspekt tas bland annat upp i Nils Holgersson, de tekniska sagorna och Den underbara resan.

Tekniken som system finns relativt noggrant beskriven i några av böckerna om Pettson och Findus. Dessutom visar flera av de övriga berättelserna hur små stör-

${ }^{947}$ J. Määttä, Raketsommar: Science fiction i Sverige 1950-1968, 2006, s. 13. 
ningar kan få stora konsekvenser för systemet som helhet. ${ }^{948}$ Systemen som finns representerade i berättelserna är av olika storlek. I Nils Holgersson, de tekniska sagorna, böckerna om familjen Tuff-Tuff och Den underbara resan ingår större sådana, som eldistributionssystem och transportsystem. ${ }^{949}$ Eftersom flera av de större systemen i böckerna dessutom består av både artefakter och sociala aktörer, kan de beskrivas som socio-tekniska system. ${ }^{950}$ Övriga exempel är industritekniska system som tillverkningen av halvledare till elektriska lok, en uppfostringsmaskin med många olika komponenter samt kluriga uppfinningar som en "rävskrämmare" och en "tomtemaskin".

Teknikens närvaro i böckerna kan sägas ha två övergripande funktioner: att väcka intresse för teknik utifrån beskrivningar av hur den fungerar och att varna för teknikens negativa konsekvenser. Nils Holgersson, de tekniska sagorna, "Herr Klumpedump från Klumpedonien", Den underbara resan samt böckerna om Pettson och Findus har det gemensamt att de innehåller mer eller mindre noggranna tekniska beskrivningar. Dessa genomsyras av en fascination för tekniken som sådan. I "Doktor Klokamundus' uppfinning" har den tekniska beskrivningen av hur uppfostringsmaskinen fungerar ett motsatt syfte. Berättelsen vill här istället varna för konsekvenserna av en överdriven tro på vilka problem tekniken kan lösa. En varning för teknikens konsekvenser om människan använder den på fel sätt, finns också i Krigets tekniska sagor, "Herr Klumpedump från Klumpedonien", böckerna om höghuset samt Den underbara resan.

\section{Teknikens gestaltningar}

Hur tekniken gestaltas i barnböckerna kan delas in i sex övergripande teman: som metafor eller liknelse, som antropomorf, som autonom, som resultat av kreativ

\footnotetext{
${ }^{948}$ T.P. Hughes, "The seamless web: Technology, science, etcetera, etcetera", 1986, s. 281-292; L. Ingelstam, "Varför är tekniska system intressanta?", 2009, s. 81-97; L. Ingelstam, System: Att tänka över samhälle och teknik", 2012; A. Kaijser, "Snärjda i systemen?", 2002, s. 87-102.

949 J. Hallström, "Systemteori och teknik. En introduktion till stora tekniska system", 2009, s. 99117; T.P. Hughes, "The seamless web: Technology, science, etcetera, etcetera", 1986, s. 281-292; T.P. Hughes, "The evolution of large technological systems", 1987, s. 51-82.

${ }^{950}$ J. Hallström, "Systemteori och teknik. En introduktion till stora tekniska system”, 2009, s.99; L. Ingelstam, "Varför är tekniska system intressanta?", 2009, s. 81-97; L. Ingelstam, System: Att tänka över samhälle och teknik, 2012, s. 214-256.
} 
drivkraft, som männens teknik samt som icke tidsbunden. Antropomorfen är nära besläktad med metaforen, men eftersom mina tolkningar visar att deras funktion i berättelserna delvis är olika, har jag här valt att se dem som två olika teman.

\section{Tekniken gestaltad som metafor eller liknelse}

Utifrån ett teknikdidaktiskt perspektiv är de förekommande metaforerna och liknelserna av två slag: explicita respektive implicita. De explicita (konkreta) metaforerna och liknelserna är hämtade från naturen eller människans värld och har som huvudfunktion att skapa en bild av hur en viss teknik ser ut eller fungerar. I Nils Holgersson, de tekniska sagorna och Den underbara resan får djur agera såväl metaforer som liknelser för teknik. I böckerna om familjen Tuff-Tuff finns liknelser mellan människa och teknik samt mellan teknik och natur och vice versa. Teknik liknas också vid annan och jämförelsevis mer bekant teknik. I Nils Holgersson benämns sågverk som "timmerkvarnar" och gruvorna som "åkrar" och genom att det bekanta knyts till det obekanta skapas en förståelse för den nya tekniken. Genom metaforiska beskrivningar målas tekniken dessutom in i landskapet som en naturlig del och blir på så sätt inte något som stör den ursprungliga pastorala landskapsbilden. ${ }^{951}$ Metaforer och liknelser används därutöver i teknikkritiskt syfte. I Den underbara resan blir industriroboten ett "instängt" djur, skogsmaskinen blir en "urtidsödla" och gruvföretaget skildras som en "bläckfisk". Här, liksom i Krigets tekniska sagor, skapas en hotfull bild av tekniken.

När det andra slaget av metaforer används, de implicita (abstrakta), företräder metaforen något större, exempelvis ett fenomen, ett skeende eller samhällsutvecklingen i stort. Dessa är inte tydligt uttryckta i texterna utan kan ses som dolda eller gömda budskap. ${ }^{952}$ Bergtrollet i "När stora blåbärsberget kom till stan" kan exempelvis ses som symbol eller metafor för naturen och som för dess talan $i$ krocken mellan naturen och människans urbana värld. I Den gröna bilen, böckerna om Talleborg och Den underbara resan finns kritiken mot "bilåldern". Bilen blir här metafor för det industriella och högteknologiska samhället och dess baksidor. Förutom att tekniken (bilen) har en negativ inverkan på miljön, är den också svår

\footnotetext{
${ }^{951}$ D. E. Nye, American technological sublime, 1994, s. 59; M. L. Smith, "Recourse of empire: Landscapes of progress in technological America”, 1994, s. 37-52.

${ }^{952}$ P. Ricoeur, "The model of the text: Meaningful action considered as a text", 1973, s. 91-117.
} 
att kontrollera och det finns en uppenbar risk att människan förlorar kontrollen över den. Trots att bilen här får agera symbol för kritik, är det ett ambivalent förhållande till tekniken som kommer till uttryck, eftersom bilen samtidigt framställs som en statussymbol. I alla tre berättelserna där bilen som teknik intar en central roll, kan den betraktas som en överbryggare mellan natur och det urbana samhället. Den är det redskap med vilket människan förflyttar sig mellan dessa båda världar. En annan implicit metafor är tåget och järnvägen som inom konst och litteratur fătt fungera som en symbol för såväl kraft och framtid, som kritik mot industrialiseringen. ${ }^{953}$ I böckerna om Nils Holgersson och familjen Tuff-Tuff kan tåg därutöver tolkas som en implicit metafor för kolonialism. I båda berättelserna skildras hur järnvägen intar vildmarken och i familjen Tuff-Tuff även främmande kontinenter. Dessa skildras som något "vilt och otuktat", något som behöver civiliseras. I Afrika finns till och med kannibaler som äter tåg. Förekomsten av tåg i barnböckerna går därmed att relatera till både deras teknikhistoriskt symboliska värde och till det faktum att järnvägen är en del av ett infrastruktursystem som har haft stor betydelse för, och inverkan på, samhällsutvecklingen.

Järnet är en annan förekommande implicit metafor i berättelserna. I Nils Holgersson och Witts saga "Arbetets värde" kan järnet ses som en metafor för både industrialiseringen och den mänskliga evolutionen. I Nils Holgersson är det människans tekniska förmåga att utnyttja järnet som ger makt över naturen, ligger till grund för industrialiseringen och separerar människan från djuren. I sagan "Arbetets värde" skildras hur järnet genom människans tekniska arbete omvandlas till användbart stål. Att tillmäta järn ett sådant högt värde har berättelserna gemensamt med vissa utopiska samhällsskildringar. I den tidiga utopisten Thomas Mores Utopia (1516) anses järn ha ett högre värde än guld, eftersom det är mer användbart. Järnet gick att använda på en mängd olika sätt och hade en påtaglig funktion. Behovet av guld var däremot inte naturligt, enligt More, och behandlades därför

\footnotetext{
${ }^{953}$ E. G. Ingersoll, Representations of science and technology in British literature since 1880, 1992, s. 2; D. E. Nye, American technological sublime, 1994, s. 59; M. L. Smith, "Recourse of empire: Landscapes of progress in technological America", 1994, s. 37-52; M. R. Smith, "Technological determinism in American culture" i Does technology drive history? The dilemma of technological determinism, M. R. Smith \& L. Marx (red.), 1994, s. 1-35.
} 
som ett sämre material. Sådant som pottor tillverkades därför i guld och fångarnas kedjor var smidda av guld i hans utopiska stat. ${ }^{954}$

Ytterligare ett exempel på en implicit metafor är när första världskrigets fasor skildras genom en beskrivning av livet i en rödmyrestack i Witts saga om "De röda soldaterna". I två andra av Witts sagor, "Den röda tunneln" och "Kriget och dess släktingar", görs däremot explicita jämförelser (liknelser) mellan kriget och en sjukdom. Den mänskliga kroppens reaktion mot virus liknas här vid kriget och dess teknik.

Genom utnyttjandet av metaforer och liknelser skapas ett släktskap mellan människa - teknik - natur. På så vis förmedlas ett budskap om att det inte är tekniken i sig som skapar problem eller är "ond", utan det är hur vi människor använder oss av den. ${ }^{955}$ Likaså kan metaforer och liknelser anses ha en bildande funktion eftersom de skapar en förståelse av omvärlden. ${ }^{956}$ I berättelserna handlar det om nya tekniska företeelser. Över lag framställer de explicita metaforerna tekniken mer neutralt jämfört med de implicita. De implicita företräder ofta civilisationskritik eller finns i ett sammanhang som uttrycker ambivalens gentemot tekniken och teknikens konsekvenser i samhällsutvecklingen.

\section{Tekniken gestaltad som antropomorf}

Att låta djur och ting få mänskliga egenskaper och attribut som exempelvis känslor, antropomorfism, är vanligt i folksagor och barnberättelser. I Witts tekniska sagor, "Herr Klumpedump från Klumpedonien", böckerna om familjen Tuff-Tuff och sagan om "Den gröna bilen” är det vardagliga ting som är levande. En möjlig tolkning av antropomorfernas funktion i berättelserna är att de hjälper läsaren att känna sig hemma i en teknifierad värld där människa och teknik samexisterar. När tekniken blir så avancerad att det är svårt att förstå hur den fungerar, skapar vi en antropomorf med stora likheter med oss själva. På så vis överbryggas den tekniska komplexitet som annars kan skapa en barriär mellan människa och teknik. Berättelsernas antropomorfer bidrar till att upprätta en känslomässig relation

\footnotetext{
${ }^{954}$ R. Ambjörnsson, Fantasin till makten! Utopiska idéer i västerlandet under fem hundra år, 2004, s. 36.

${ }^{955}$ J.C. Pitt, “'Guns don’t kill, people kill'; Values in and/or around technologies”, 2014, s. 89102.

${ }^{956}$ G. Lakoff \& M. Johnson, Metaphors we live by, 2003, s. 3.
} 
mellan människa och maskin. ${ }^{957}$ Denna intention stärks genom budskapet att både barn och tåg/bilar kan vara olydiga och busiga ibland. I berättelserna har antropomorferna samtidigt (liksom metaforer och liknelser) en bildande funktion. De tekniska objekten berättar hur de fungerar och berättelserna innehåller många tekniska begrepp. Gestaltningen av den levande tekniken i Krigets tekniska sagor liksom den i "Den gröna bilen" inrymmer dessutom en varning för konsekvenserna om människan använder tekniken i destruktivt syfte eller förlorar kontrollen över den.

\section{Tekniken gestaltad som autonom}

Den autonoma tekniken finns gestaltad i sagan om "Den gröna bilen" och i böckerna om familjen Tuff-Tuff. Förutom att bil och tåg är antropomorfer, skildras tekniken som att den har utvecklats till att bli självbestämmande och agerar utom människans kontroll. ${ }^{958}$ En antropomorf med känslor och vilja kan därmed också symbolisera autonomi och determinism. Eftersom människan förlorat kontrollen över den kan den både rymma och löpa amok. Budskapet i de båda berättelserna skiljer sig dock åt. I berättelsen om tågfamiljen framstår teknikens autonomi som något oproblematiskt och kan till och med tolkas som en uppmaning att våga ifrågasätta auktoriteter. I sagan om den gröna bilen finns istället ett implicit varningsbudskap om hur illa det kan gå om människan förlorar herraväldet över sin teknik. Det de båda berättelserna har gemensamt är att de förmedlar ett budskap om att den äldre tekniken är mer pålitlig (ånglok och häst och vagn) än den nyare (elektriska tåg och bilar).

Jätten i "Kriget och dess släktingar" kan ses som en metafor för den okontrollerbara krigsmaskin tekniken utvecklas till när människan förlorat kontrollen över den. Samtidigt anser sig jätten vara människans "slav", vilket talar emot det autonoma synsättet. Då han dessutom samtidigt presenterar sig som "teknikens

\footnotetext{
${ }^{957}$ H. J. Schwarcz, "Machine animism in modern children's literature", 1967, s. 80; A. Waytz, "Making meaning by seeing human" i The psychology of meaning, K. D. Markman, T. Proulx \& M. J. Lindberg (red.), Washington DC: American Psychological Association, 2013, s. 135-146; A. Waytz, "The mind in the machine: Anthropomorphism increases trust in an autonomous vechicle”, Journal of Experimental Social Psychology, vol. 52(3), 2014, s. 113-117.

${ }^{958}$ J. Ellul, The technological society, 1964, s. 14; J. Ellul, "The autonomy of technology”, 2010, s. 67-75; L. Winner, Autonomous technology: Technics-out-of-control as a theme in political thought, 1977.
} 
fulländning i vår tid", lyfter sagan snarare fram teknikens dubbla natur - att den har såväl positiva som negativa sidor. ${ }^{959}$ Cyborgen "Mulle" som finns med i berättelsen om familjen Tuff-Tuff är ett annat exempel på teknikens autonomi. Mulle är en mänsklig skapelse, en sammansmältning av djur och maskin och ett resultat av mänsklig teknisk utveckling. ${ }^{960}$ Genom utvecklandet av cyborgen kan människan överskrida sina biologiska begränsningar. Liksom Doktor Frankenstein, förlorar dock skaparen av Mulle kontrollen över sin skapelse. ${ }^{961}$ Cyborgen finns representerad även i böckerna om höghuset och här beskrivs människans relation till bilen som ett hot. Budskapet är att människans beroende av bilen i förlängningen kommer att leda till en fusion med fordonet: extremiteterna växer samman med gaspedaler och rattar och blodet ersätts av bensin. ${ }^{962}$

\section{Tekniken som kreativ viljekraft}

I flera av berättelserna skildras tekniken som ett resultat av en kreativ aktivitet som bygger på den mänskliga viljan, det vill säga korresponderar med Mitchams beskrivningar av teknik som viljekraft, kunskap, aktivitet och objekt. ${ }^{963}$ Exempel på när alla dimensionerna finns med är när björnen visar Nils Holgersson järnverket, när Pettson skapar sin tomtemaskin samt när människorna i höghuset Talleborg bygger sin kanon. Aktiviteten i de två sistnämnda berättelserna går att bryta ned till en process i fyra steg: att man tänker ut det man ska skapa, föreställer sig det, konstruerar och till sist testar uppfinningen. ${ }^{964}$ En liknande beskrivning finns i sagan om "Herr Klumpedump från Klumpedonien". Teknikutvecklingen är en kreativ process som löser ett problem eller uppfyller en mänsklig önskan. ${ }^{965}$

\footnotetext{
${ }^{959}$ P. Gyberg, "Teknikens janusansikte", 2009, s. 177-187; T.P. Hughes, Human-built world: How to think about technology and culture, 2004, s. 5.

${ }^{960}$ D. J. Haraway, "A cyborg manifesto: Science, technology, and socialist-feminism in the late twentieth century", 1991, s. 149; N. Wiener, Cybernetics or control and communication in the animal and the machine, 1965, s. 19.

${ }^{961}$ M. W. Shelley, Frankenstein, or, The modern Prometheus, 1818/1993.

${ }^{962}$ K.-A. Schwartzkopf, Höghuset vid myren, 1965, s. 56-57.

${ }^{963}$ C. Mitcham, Thinking through technology: The path between engineering and philosophy, 1994, s. 160.

${ }^{964}$ Ibid., s. 220.

${ }^{965}$ S. Lindqvist, "Vad är teknik?", 1987, s. 29-33.
} 
I såväl böckerna om Talleborg som böckerna om Pettson och Findus agerar protagonisterna bricoleurer i sitt skapande och användande av teknik. ${ }^{966}$ Pettson och Findus använder de saker som finns att tillgå i snickarboden, på vinden eller i trädgården. Talleborgarna tillverkar en kanon med hjälp av de tekniska artefakter som i och med avskärmningen från den urbana världen förlorat sin funktion. Vare sig Pettson eller talleborgarna slänger något utan skapar teknik genom att återanvända redan existerande sådan. Sixten i "Herr Klumpedump från Klumpedonien" är även han en bricoleur när han plockar sönder en gammal väckarklocka och använder kugghjulen och fjädrarna för att bygga en motor till sin undervattensbåt. Förutom att berättelserna om talleborgarna och Pettson och Findus skildrar bricoleurens utvecklande av teknik, har de också det gemensamt att de ger den befintliga tekniken andra användningsområden än de ursprungligen tänkta. I böckerna om Talleborg blir sopnedkastet en funktionell högtalare och bilarna blir bostäder för vilda djur. I böckerna om Pettson och Findus används en sticksåg för att skära upp bröd och en borrsväng fungerar som mugghållare. Det är användaren alternativt kontexten som styr artefaktens funktion och användningsområden och inte den användning och de behov som artefakten ursprungligen skapades för. ${ }^{967}$ Genom teknikern som bricoleur samt Pettsons och Findus breddade användningsområden av tekniken, lyfts användarperspektivet på teknik fram. Budskapet är att det är användaren som är den slutgiltige domaren av teknikens funktion och inte den ursprunglige konstruktören eller designern. ${ }^{968}$

Det som skiljer Pettsonböckernas teknik från övriga berättelser i studien är att den inte alltid skapas för att effektivisera eller lösa ett problem. Många gånger används den på ett alternativt sätt eller löser något som knappast går att betrakta som ett genuint problem. Exempel på sådana lösningar är kastruller på hjul och kaffefat med "teskedshållare". Tekniken är här snarare att betrakta som ett konstnärligt uttryck. Teknikens mål och uppgift i "Herr Klumpedump från Klumpe-

\footnotetext{
${ }^{966}$ B. Dahlbom, "En vetenskap om artefakter", 1993, s. 53-75; S.-E. Liedman, Ett oändligt äventyr: Om människans kunskaper, 2001, s. 163; C. Lévi-Strauss, The savage mind, 1962/1973, s. 17. ${ }^{967}$ D. Ihde, "The designer fallacy and technological imagination", 2006, s. 121-131; Å. Ingerman m.fl.,"Till läsaren" i På spaning efter teknisk bildning, A. Ingerrman, K. Wagner \& A.-S. Axelsson (red.), 2009, s. 7-9; D. C. Dennett, "The interpretation of texts, people and other artifacts", 1990, s. 186.

968 Ibid.
} 
donien" kan tolkas på ett liknande sätt. Det barnen skapar fritt med sina händer i formbara material är värdefullt, har en själ och kommer till liv i sagan, vilket står i kontrast till de själlösa, industritillverkade leksakerna. Syftet med barnens skapelser, liksom Pettsons och Findus uppfinningar, är inte att de ska vara perfekta utan unika, vilket har likheter med utopisten William Morris syn på hantverkets betydelse. Morris menade att tråkigt arbete kunde utföras med maskiner, medan konsthantverket gör att man finner nöje i arbetet och kan lägga större vikt vid det estetiska. ${ }^{969}$ Barnen i "Herr Klumpedump från Klumpedonien” är, liksom Pettson, både tekniker och konstnärer. ${ }^{970}$

\section{Männens teknik}

Tingen (artefakterna) associeras många gånger med manligt respektive kvinnligt kön. ${ }^{971}$ Detta bekräftas i denna studie då de genomgångna barnböckerna presenterar tekniken som något som framför allt tillhör den manliga sfären. Endast ett ting, en glödlampa i en av de tekniska sagorna, benämns som "hon" och det är enbart i Den underbara resan som en flicka är teknikexpert och förklarar hur avancerad teknik fungerar. ${ }^{972}$ Sett utifrån Mitchams beskrivningar av teknik skulle dock den kvinnligt kodade tekniken ha kunnat ges ett större utrymme (tekniken som kunskap, vilja, aktivitet och objekt). ${ }^{973}$ Huvudskälet till att studiens empiriska material domineras av manligt kodad teknik går att härleda till att förutom att urvalet av barnböcker skulle innehålla olika representationer av teknik, skulle de samtidigt förmedla ett budskap om teknik och/eller dess inverkan på natur och framtid. De barnböcker som genomgick en genomläsning och som innehöll vad som kan kate-

\footnotetext{
${ }^{969}$ R. Ambjörnsson, Fantasin till makten! Utopiska idéer $i$ västerlandet under fem hundra år, 2004, s. 188; T. Frängsmyr, Framsteg eller förfall: Framtidsbilder och utopier $i$ västerländsk tanketradition, 1990, s. 154.

${ }^{970}$ S.-E. Liedman, I skuggan av framtiden: Modernitetens idéhistoria, 1999, s. 395-401.

971 B. Berner, "Teknikens kön” i Världens gång - teknikens utveckling: Om samspelet mellan teknik, människa och samhälle, P. Gyberg \& J. Hallström (red.), Lund: Studentlitteratur, 2009, s. 282-283.

${ }^{972}$ S. Wernström, Den underbara resan: En läsebok om Sverige. D. 1, 1985, s. 260; O. Witt, "Arbetets värde", $1914 \mathrm{a}$, s. 8 .

973 C. Mitcham, Thinking through technology: The path between engineering and philosophy, 1994, s. 160
} 
goriseras som kvinnligt kodad teknik, uppfyllde inte detta kriterium. När representationer av detta slag fanns närvarande i berättelserna, fungerade de oftast endast som ett slags "rekvisita" eller "kuliss" i berättelsens bakgrund. Artefakter med en viss kvinnlig kodning som synål, sax och grytor nämns i och för sig i Nils Holgersson och "Doktor Klokamundus' uppfinning" och i böckerna om familjen TuffTuff finns dammsugaren med. Dessa omnämnanden sker dock endast i förbigående. Med ett urval grundat endast på omnämnande av teknik hade det varit svårt att nå avhandlingens syfte. Samtidigt bekräftar studien att inom de områden där kvinnor traditionellt sett dominerat, inryms sällan det som definierats som teknik. ${ }^{974}$ Fabriker, kommunikationer, vapen och stora tekniska system är sådant som förknippas med, och vanligen styrs av, män. Likaså är det historiskt sett männen som har haft makten över hur tekniken ska utformas. En tänkbar förklaring till varför det framför allt är männens teknik som skildras i böckerna är att flera av barnböckerna härrör från en tid då manliga vetenskapsmän och uppfinnare hyllades som hjältar (sekelskiftet 1900 och decennierna därefter). ${ }^{975}$ Denna förklaring håller dock inte då de uppfinningsrika, manliga hjältarna är lika frekvent förekommande i barnböckerna som är skrivna ett sekel senare. Schablonbilden av "mekaren" och ingenjören är fortfarande att denne är en man. ${ }^{976} \mathrm{I}$ den litterära framställningen av den prototypiske uppfinnaren är denne så gott som alltid en man - från de vetenskapligt avancerade hjältarna hos Jules Verne till Uppfinnar-Jocke, Skalman, Professor Kalkyl eller andra kluriga figurer i barnlitteraturen. ${ }^{977}$ Sett till tidigare forskning bekräftar denna studie därmed att $\mathrm{i}$ barnlitteraturen är det manliga ingenjörer och uppfinnare som har fătt, och fortfarande får, agera hjältar och förebilder på teknikens område. ${ }^{978}$ Detta budskap framträder tydligast $\mathrm{i}$ Witts tekniska sagor.

\footnotetext{
974 B. Berner,"Teknikens kön”, 2009, s. 279-293; R. Oldenziel, Making technology masculine: Men, women, and modern machines in America, 1870-1945, 1999.

${ }^{975}$ B. Berner, Perpetuum mobile? Teknikens utmaningar och historiens gång, 1999, s. 156-157.

${ }^{976}$ B. Berner, "Teknikens kön”, 2009, s. 279-293; U. Mellström, "Män i teknikens värld" i Världens gång - teknikens utveckling: Om samspelet mellan teknik, människa och samhälle, P. Gyberg \& J. Hallström (red.), Lund: Studentlitteratur, 2009, s. 295-310.

${ }^{977}$ B. Berner, ”Teknikens kön”, 2009, s. 281.

${ }^{978}$ E. S. Hintz, "Heroes of the laboratory and the workshop: Inventions and technology in books for children, 1850-1950", 2008, s. 197-211; J. McCannon, "Technological and scientific utopias in Soviet children's literature, 1921-1932”, 2001, s. 153-169.
} 
I Nils Holgersson hyllas "snillrika män" och Doktor Klokamundus är en man. Dessutom är mekarna i "Herr Klumpedump från Klumpedonien" pojkar och Pettson och Findus fungerar som manliga, kreativa förebilder och inspiratörer till skapande av teknik.

\section{Den icke tidsbundna tekniken}

När man talar om teknisk utveckling hamnar fokus ofta på vissa specifika uppfinningar som anses extra betydelsefulla för mänskligheten. Detta trots att många uppfinningar har en kort livslängd och därmed en liten inverkan på människors vardagliga liv. ${ }^{979}$ Teknikhistorien blir då ett slags "Whig-tolkning", där den tekniska utvecklingen skildras som ett enda långt "segertåg" av alltmer avancerade tekniska uppfinningar. ${ }^{980}$ Bitvis presenteras teknikutvecklingen på så sätt i Nils Holgersson, "Doktor Klokamundus' uppfinning" och Den underbara resan. I böckerna om Pettson och Findus är det däremot en motsatt aspekt av tekniken som lyfts fram: teknikens icke tidsbundna dimension. Det tekniklandskap inom vilket berättelserna om Pettson och hans katt utspelar sig, ingår sådant som sparkstöttingar, kälkar, skidor, köksgeråd, radioapparater, trädgårdsredskap och verktyg som alla har en relativt lång historia, men som fortfarande används. Det är teknik som knappast förändrats över tid. ${ }^{981}$ Till skillnad från de övriga berättelserna i studien, är det kring dessa ting som böckerna om Pettson och Findus kretsar. Trots att böckerna till stor del handlar om Pettsons uppfinningar, är dessa så gott som alltid konstruerade av komponenter som Pettson redan har. Den befintliga tekniken utnyttjas på ett nytt sätt. Teknisk förändring eller utveckling handlar många gånger om, vilket böckerna om Pettson visar, att teknik överförs från ett område till ett annat. ${ }^{982}$ Genom att lyfta fram den icke tidsbundna dimensionen, synliggörs teknik

\footnotetext{
${ }^{979}$ D. Edgerton, The shock of the old: Technology and global history since 1900”, 2006, s. ix.

980 "Whig”-tolkning är ett begrepp som härrör från historikern Herbert Butterfields benämning av en skildring av historien som en process av utveckling och som sätts i samband med en oproblematisk idé om utveckling och "civilisering", en stadig marsch framåt. Se H. Butterfield, The Whig interpretation of history, London: W.W. Norton, 1931/1965.

${ }^{981}$ D. Edgerton, The shock of the old: Technology and global history since 1900, 2006; K. Kelly, What technology want, 2010, s. 52-54; H. Petroski, The evolution of useful things, 1992a.

982 B. Berner, Perpetuum mobile? Teknikens utmaningar och historiens gång, 1999, s. 49; D. Edgerton, The shock of the old: Technology and global history since 1900, 2006, s. 209.
} 
som historiskt sett har varit, och fortfarande är, viktig i människors liv. Ny teknik skapas samtidigt som den äldre sällan slutar användas. Det finns undantag, men ofta lever den äldre tekniken kvar, sida vid sida med den nyare som växer fram. ${ }^{983}$ I de tekniska sagornas tekniklandskap ingår visserligen vad som kan betecknas som "vardagsteknik", men samtidigt är den evolutionistiska synen på teknikutvecklingen i hög grad närvarande.

\section{Tekniksyn i förhållande till natur- och framtidssyn}

Det inbördes förhållandet mellan teknik - natur - framtidssyn framträder inte alltid så tydligt i berättelserna. Är det en viss tekniksyn som ligger till grund för en viss natur- respektive framtidssyn? Är det natursynen som skapar en viss syn på teknik och framtid? Eller är det en viss framtidssyn som leder till en specifik syn på teknik respektive natur? Vilken utgångspunkt som dominerar kan dessutom variera inom samma berättelse. Min konklusion är dock att i Tekniska sagor för stora och små, Krigets tekniska sagor, "Herr Klumpedump från Klumpedonien", "Den gröna bilen", böckerna om familjen Tuff-Tuff samt böckerna om Pettson och Findus är det tekniken som står i centrum. Därmed är det berättelsernas olika tekniksyner som är utgångspunkten för de budskap om naturen respektive framtiden som förmedlas. I Nils Holgerssons underbara resa, "Doktor Klokamundus' uppfinning" och Den underbara resan är det snarare framtidssynen som ligger till grund för den syn på teknik och natur som kommer till uttryck. I två av berättelserna, "När stora blåbärsberget kom till stan" samt böckerna om höghuset Talleborg, är det natursynen som ligger till grund för teknik- respektive framtidssynen. Att det är framtidssynen som är utgångspunkten i Nils Holgersson skulle kunna förklaras med att boken skrevs som en lärobok vars syfte var att väcka folkskolebarnens framtidstro. ${ }^{984}$ De tekniska sagorna, som också de skrevs i början av 1900-talet,

${ }^{983}$ B. Berner, Perpetuum mobile? Teknikens utmaningar och historiens gång, 1999, s. 49; K. Kelly, What technology wants, 2010, s. 52-54; D. Edgerton, The shock of the old: Technology and global history since 1900, 2006.

${ }^{984}$ G. Ahlström, Den underbara resan: En bok om S. Lagerlöfs Nils Holgersson, 1942; V. Edström \& S. X. Erixson, Uppdrag läsebok: Nils Holgersson, 1996; C. Nordlund, "Naturen och det nationella i det tidiga 1900-talets Sverigelitteratur", 2002, s. 74-100; E. von Zweigbergk, Barnboken i Sverige 1750-1950, 1965, s. 310. 
genomsyras av ett liknande budskap samtidigt som det är tekniksynen som dominerar.

När det gäller berättelsernas tekniksyner har jag identifierat fyra teman eller kategorier. Vissa av barnböckerna har inslag av en kombination av flera av dessa, alternativt att tekniksynen växlar i olika delar av berättelserna:

- Den tjänande tekniken: en syn där tekniken ses som ett kraftfullt redskap som hjälper människan att uppfylla sina önskningar och drömmar.

- Den deterministiska eller instrumentella: en syn där människan är på väg eller redan har förlorat herraväldet över tekniken och teknikutvecklingen.

- Den nostalgiska: en syn där den äldre tekniken är bättre än den modernare eller att den äldre tekniken anses ha ett högre värde.

- Den konsumtionskritiska: en syn som företräder ett mer hållbart tekniksamhälle där tingen återanvänds och teknik inte skapas i syfte att ge ekonomisk vinning.

I böckerna om Pettson och Findus är tekniken ett redskap som tjänar Pettson och hans katt så att de kan uppfylla sina önskningar. Den är människans lojale och jämlike kompanjon. Eftersom det är hur människan väljer att använda den som avgör vad den används till är den dessutom värdeneutral. ${ }^{985}$ Nils Holgersson, liksom sagorna i Tekniska sagor för stora och små, kan även tolkas som att de företräder denna tekniksyn. Med hjälp av tekniken kan människan lösa problem och uppfylla sina önskningar. Böckerna om familjen Tuff-Tuff kan delvis räknas till denna kategori eftersom människa och teknik existerar sida vid sida i tågfamiljens värld. Tekniken hjälper människan och människan bistår tekniken när så behövs. I Nils Holgersson, Tekniska sagor för stora och små och i vissa avsnitt av Den underbara resan framställs den tekniska utvecklingen som något grundläggande för landets omdaning till framgångsrik industrination. På så vis tjänar tekniken människans intressen.

Den deterministiska eller instrumentella synen på teknik finns närvarande i den civilisationskritik som återfinns i "Herr Klumpedump från Klumpedonien”,

${ }^{985}$ J.C. Pitt, “'Guns don't kill, people kill'; Values in and/or around technologies”, 2014, s. 89102. 
"Doktor Klokamundus' uppfinning", "Den gröna bilen" samt böckerna om höghuset Talleborg. Kritiken handlar framför allt om teknikens negativa inverkan på natur och samhälle, att människan utvecklar teknik utan att inse dess konsekvenser samt en oro för att industrialiseringen kan leda till en likriktning och mekanisering av människors liv. Tekniken främmandegör människor från varandra och från naturen och reducerar dem till att bli en del eller objekt (reifierar) $i$ den industriella processen. Tekniken skildras här snarare som auktoritär än som demokratisk. ${ }^{986} \mathrm{I}$ Krigets tekniska sagor är budskapet civilisationskritiskt, men samtidigt klargörs förhållandet mellan människa och teknik: den är människans "slav". ${ }^{987}$ Den autonoma tågfamiljen Tuff-Tuff kan också betraktas som ett uttryck för en deterministisk tekniksyn där tekniken lever sitt eget liv oberoende av människans inverkan. I Nils Holgersson och Den underbara resan finns också en varning för teknikens inverkan på natur och människa närvarande, men båda berättelserna företräder samtidigt en optimistisk framstegstro när det gäller den tekniska utvecklingen.

Den hantverksinriktade liksom den äldre tekniken, den nostalgiska tekniken, tillmäts i böckerna genomgående ett högre värde i jämförelse med den industriella och nyare tekniken. Detta kan kopplas till att den äldre tekniken betraktas som mer demokratisk, eftersom den skapas och utnyttjas i ett sammanhang där det finns en närmare kontakt mellan människa och teknikkonstruktion. I motsats till hantverkstekniken framträder den industriella tekniken som något som saknar estetik. Den är dessutom auktoritär och därför en potentiellt destruktiv maktfaktor. ${ }^{988}$ Teknik som hantverk ställs mot massproduktion: till skillnad från det som människan skapar med sina händer har massproducerade ting ingen själ. "Herr Klumpedump från Klumpedonien" kan tolkas som företrädare för denna tekniksyn (den nostalgiska tekniken ställs mot den auktoritära) men hantverkets värde lyfts likväl fram i Nils Holgersson och Den underbara resan, då böckerna innehåller nostalgiska tillbakablickar på tiden innan industrialiseringen slog igenom. I böckerna om familjen Tuff-Tuff framställs den äldre tekniken dessutom som varande överlägsen den modernare genom att ångloken gestaltas som mer pålitliga och sympatiska jämfört

\footnotetext{
${ }^{986}$ L. Mumford, “Authoritarian and democratic technics”, 1963, s. 1-8

${ }^{987}$ Angående tekniksynen att det är människan som styr tekniken och inte tvärtom, se exempelvis L. Mumford, Technics and civilization, 1934/1963, s. 6; L. Winner, Autonomous technology: Technics-out-of-control as a theme in political thought, 1977.

${ }^{988}$ L. Mumford, “Authoritarian and democratic technics", 1963, s. 1-8.
} 
med de moderna elektriska loken. Delvis stämmer beskrivningen av den nostalgiska in på böckerna om Pettson och Findus då den teknik som finns representerad i böckerna endast är sådan som funnits under lång tid.

Konsumtions- och tillväxtkritiken är tydlig i böckerna om Talleborg och Den underbara resan, men frånvarande i Nils Holgersson och de tekniska sagorna från 1900-talets början. Böckerna om Pettson och Findus kan också de läsas som en reaktion mot konsumtions- och tillväxtsamhället, då böckerna visar hur man kan leva på ett mer hållbart sätt. Samtidigt som teknikutvecklingen kan tolkas som hotfull, är budskapet inte apokalyptiskt i någon av de undersökta barnböckerna. Mellan raderna anas budskapet att väcka de unga läsarnas medvetenhet om situationen och på så vis få en förändring till stånd. Situationen är alarmerande, men människorna kan gå samman och påverka framtiden. Ansvaret vilar framför allt på de unga, framtiden ligger i deras händer. ${ }^{989}$ Studiens genomgång av barnlitteraturen visar att detta tema går att finna redan i barnböcker från det tidiga 1900-talets berättelser för barn. Ett exempel är avsnittet i Nils Holgersson där barnen planterar skog.

Den slags teknikkritik som återfinns i några av berättelserna överensstämmer till stora delar med den debattposition som Kylhammar kallar civilisationskritik. Denna grundar sig på föreställningen att en del av den samtida tekniken är oupplösligt förbunden med negativa konsekvenser för naturen men även för människans liv, arbete och tänkande. En sådan kritisk hållning har likheter med William Morris tekniksyn och kan därmed inte tolkas som teknikpessimistisk. Däremot hyser dess företrädare endast förtroende för den hantverksbetonade tekniken, det vill säga den som med nöje kan utföras för hand. Det monotona och "tråkiga" arbetet anses däremot kunna överlämnas till maskiner. ${ }^{990}$

Utifrån Frängsmyrs framtidssyner om det effektiva samhället respektive det goda livet är det tydligt att framtidssynen om det effektiva samhället dominerar,

\footnotetext{
${ }^{989}$ N. Applebaum, "The myth of the innocent child: Interplay between nature, humanity and technology in contemporary children's science fiction, 2006, s. 1-17; N. Applebaum, Representations of technology in science fiction for young people, 2010; M. Sjöberg, Barnen, skogen och skolan: Om skolelevers plantering av skog i Sverige ca 1880-1960, 2011.

${ }^{990}$ M. Kylhammar, ”Teknikdebattens grammatik”, 1987, s. 380-401.
} 
men utopin om det goda livet finns också representerad i ett par av berättelserna. ${ }^{991}$ Däremot skiljer sig min studies resultat från Frängsmyrs på en väsentlig punkt. Frängsmyrs slutsats är att trots att den framtidssyn som bygger på en tro på teknisk utveckling kan tyckas stå i motsatsförhållande till en utopi som bygger på en anpassning till naturen, inrymmer även den utopiska tanken en förhoppning om ett framtida effektivt samhälle. ${ }^{992}$ Denna studies analyser och tolkningar visar istället att i de utopiska berättelserna (böckerna om höghuset Talleborg respektive böckerna om Pettson och Findus), har tekniken inget framåtsyftande mål alls. Tekniken löser i dessa berättelser ett för stunden uppkommet problem, alternativt löser något på ett mer komplicerat sätt än nödvändigt: det är den kreativa processen i det tekniska skapandet som är det viktiga. De utopiska berättelsernas teknik behöver därmed inte ha som mål att vare sig effektivisera eller göra något enklare att utföra. Till skillnad mot den tidigare forskning som visar att skönlitterära barnböcker inom science fiction-genren många gånger skildrar dystopier, är det ingen av berättelserna i studien som förmedlar en dystopisk syn på framtiden. ${ }^{993}$

Den natursyn som majoriteten av barnböckerna företräder kan beskrivas som antropocentrisk eller svagt antropocentrisk, där den sistnämnda är en natursyn som sätter människans behov i centrum men som ändå inte har en helt instrumentell syn på naturen. ${ }^{994} \mathrm{I}$ "När stora blåbärsberget kom till stan" finns ett budskap om att människan behöver naturen, såväl själsligt som kroppsligt, men eftersom urbaniseringen lett till en förlorad förståelse för naturen, är en åtskillnad dem emellan nödvändig - för naturens skull. Berättelsen om höghuset är den enda som företräder en natursyn som kan tolkas som biocentrisk. ${ }^{995}$ Ett liv i harmoni med naturen förespråkas, vilket också är vägen mot utopin. Människan skildras som en del av natu-

\footnotetext{
991 T. Frängsmyr, Framsteg eller förfall: Framtidsbilder och utopier $i$ västerländsk tanketradition, 1990, s. 227-236.

${ }^{992}$ Ibid., s. 235.

${ }^{993}$ N. Applebaum, "The myth of the innocent child: Interplay between nature, humanity and technology in contemporary children's science fiction", 2006, s. 1-17; N. Applebaum, Representations of technology in science fiction for young people, 2010.

${ }^{994}$ A. Dobson, Green political thought, 2000, s. 51-61.

995 E. Erlandson-Hammargren, Från alpromantik till hembygdsromantik: natursynen i Sverige från 1885 till 1915, speglad i Svenska turistföreningens årsskrifter och Nils Holgerssons underbara resa genom Sverige, 2006, s. 19; S. Sörlin, Naturkontraktet: Om naturumgängets idéhistoria, 1991, s. 157-159.
} 
ren och ett liv $i$ naturen är hennes rätta element och det råder ett jämbördigt kompanjonskap mellan människa och natur.

\section{Tekniksyn i förhållande till kontext}

Utifrån tolkningarna av texterna och identifiering av återkommande teman $\mathrm{i}$ berättelserna, kan de olika syner på teknik som förmedlas i barnböckernas tekniklandskap tolkas utifrån fyra olika kontexter:

- Tekno-centrisk

- Tekno-utopisk

- Pastoral idyll

- Biocentrisk utopi

I den tekno-centriska kontexten ser människorna tekniken som ett redskap för att få kontroll eller ekonomiska fördelar utan att ta hänsyn till andra människors behov eller till naturen. Hit hör också den tekniksyn där människan har blivit så beroende av sin teknik att den utvecklats till ett hot mot kreativiteten. Natursynen är antropocentrisk och framsteg går före naturhänsyn. Kungen och uppfinnaren $\mathrm{i}$ sagan om "Doktor Klokamundus' uppfinning” återspeglar denna tekniksyn liksom flera av berättelserna i Krigets tekniska sagor.

Nils Holgersson, Tekniska sagor för stora och små, böckerna om familjen Tuff-Tuff liksom Den underbara resan är exempel på berättelser som företräder en tekno-utopisk syn på teknik. Tekniken ses här som en positiv kraft som kan lösa mänskliga problem och utveckla samhället i rätt riktning. Trots att denna tekniksyn samtidigt företräder en antropocentrisk syn på naturen, finns ett budskap om att den tekniska samhällsutvecklingen måste ske i harmoni med naturen och med hänsyn till kommande generationer.

I den pastorala idyllen är tekniken en naturlig del av livet på landsbygden. Den teknik som finns representerad är den som sedan generationer varit en del av landsbygdslivet. I den pastorala idyllen ingår en svag antropocentrisk natursyn, där kontakten med naturen sker med respekt. Naturen har ett värde, men människans behov sätts i första hand. Böckerna om Pettson och Findus utspelar sig i en sådan kontext, där tiden tycks stå stilla. "Den gröna bilen" kan också räknas till den pastorala idyllen liksom "Herr Klumpedump från Klumpedonien”. Den sistnämnda med motiveringen att den utspelar sig i en sagovärld långt från det industrialisera- 
de samhället. I "När stora blåbärsberget kom till stan" finns ett hopp om att skapa en pastoral idyll genom att låta naturen flytta in till staden, även om försöket misslyckas. $^{996}$

Böckerna om höghuset Talleborg kan placeras in i den fjärde kontexten, den biocentriska utopin. Tekniken i den biocentriska utopin är utvecklad i harmoni och samklang med naturen. Människorna lever ett Robinson Crusoe-liv där de skapar teknik utifrån vad de har att tillgå. Tekniken har inte som mål att effektivisera, utan att lösa problem. Naturen har ett egenvärde oberoende människans syften. Människan är inte överordnad naturen utan en del av den. ${ }^{997}$

Barnlitteraturen beskrivs ofta som att den har en pedagogisk och didaktisk funktion eftersom budskap och värderingar ofta är mer explicit uttryckta i berättelser skrivna för barn jämfört med i vuxenlitteraturen. ${ }^{998}$ I berättelserna som ingår i studien finns ett explicit budskap när det handlar om naturen. Exempelvis förmedlar böckerna normen att människan inte får skada eller döda djur. Däremot är budskapet om teknik och den tekniska samhällsutvecklingen många gånger tvetydigt, vilket kan betraktas som svårförenligt med en "traditionell" didaktisk ambition. Så gott som alla berättelserna som ingår i studien genomsyras snarare av vad som kan betecknas som en ambivalent syn på tekniken och dess konsekvenser. Å ena sidan skildras tekniken som något fascinerande, spännande och betydelsefullt för samhällsutvecklingen. Å andra sidan lyfts dess skadliga och hindrande inverkan på individ, samhälle och natur fram. I berättelserna finns därutöver en dualitet inbyggd genom skildringen av att tekniken kan skapa frihet på individnivå, men att den på samhällsnivå försvagar vänskapsbanden människor emellan.

\footnotetext{
${ }^{996}$ M. Kylhammar, Maskin och idyll: Teknik och pastorala ideal hos Strindberg och Heidenstam, 1985, s. 13-14.

${ }^{997}$ Se exempelvis: S. J. Rowe, "Ecocentrism: The responsive chord", 1994; M. Stenmark, Miljöetik och miljövård: Miljöfrågornas värderingsmässiga dimension, 2000; S. Sörlin, Naturkontraktet: Om naturumgängets idéhistoria, 1991, s. 123-152.

${ }^{998}$ G. Klingberg, Barn- och ungdomslitteraturen, Stockholm: Natur och Kultur, 1970, s. 84; M. Nikolajeva, Barnbokens byggklossar, 2004, s. 17; K. Reynolds, "Introduction" i Children's literature studies: A research handbook, 2011, s. 1-2.
} 


\section{Avslutande reflektioner}

Min sammantagna slutsats är att skönlitterära barnböcker mycket väl kan fungera som utgångspunkter för kreativa diskussioner och samtal om teknikens natur samt dess inverkan på människa, samhälle, natur och miljö i såväl nutid som dåtid. I den senaste läroplanen för grundskolan (Lgr11) är berättelser, sagor och myter något som ingår i det centrala innehållet i så gott som alla skolämnen i årskurs 1 till 3, respektive årskurs 4 till 6. Enligt kursplanen i skolämnet slöjd ska berättelser exempelvis användas som inspirationskällor och förebilder för elevernas egna idéer och skapande. Ett kunskapskrav i årskurs 3 för ämnena biologi, fysik och kemi är att eleven ska kunna samtala om skönlitteratur som handlar om naturen och människan. ${ }^{999}$ Det finns ingen explicit skrivning i läroplanen om att barnlitteratur och sagor ska vara en del av undervisningen i teknik. Däremot går följande att läsa avseende teknikundervisningens syfte:

Genom undervisningen ska eleverna ges möjlighet att utveckla förståelse för att teknisk verksamhet har betydelse för, och påverkar, människan, samhället och miljön. Vidare ska undervisningen ge eleverna förutsättningar att utveckla tilltro till sin förmåga att bedöma tekniska lösningar och relatera dessa till frågor som rör estetik, etik, könsroller, ekonomi och hållbar utveckling.

Undervisningen ska bidra till att elever utvecklar kunskaper om teknikens historiska utveckling för att de på så sätt bättre ska förstå dagens komplicerade tekniska företeelser och sammanhang och hur tekniken påverkat och påverkar samhällsutvecklingen. $[\ldots]^{1000}$

För många människor är tekniken dock starkt förknippad med artefakter, det vill säga föremål som är tillverkade av människan. Ett sådant fokus finns även i teknikundervisningen. Claes Klasander använder uttrycket "artefakternas skugga" för att för att illustrera hur undervisningen tenderar att hamna på objekt istället för att tekniken sätts in i ett större sammanhang. ${ }^{1001}$ Denna bild av teknikundervisningen

\footnotetext{
${ }^{999}$ Skolverket, Läroplan för grundskolan, förskoleklassen och fritidshemmet, 2011, s. 20-279. ${ }^{1000}$ Ibid., s. 269.

1001 C. Klasander, Talet om tekniska system: Förväntningar, traditioner och skolverkligheter, diss., Linköpings universitet, Linköping, 2010, s. 177.
} 
bekräftas av Skolinspektionens senaste granskning av grundskolans teknikundervisning:

På många skolor i granskningen begränsas elevernas möjligheter att kontinuerligt utveckla de förmågor som beskrivs i kursplanen för teknikämnet. Detta är särskilt framträdande när det gäller förmågorna som innebär att eleverna ska reflektera över tekniken i ett samhälleligt och historiskt sammanhang. ${ }^{1002}$

Min konklusion är att barnlitteraturens mångskiftande tekniklandskap kan bidra till att både vidga och fördjupa det teknikdidaktiska perspektivet. Det ambivalenta budskapet i böckerna gör att teknikens mångskiftande natur och komplexitet lyfts fram samt problematiseras på ett sätt som exempelvis skolans läroböcker sällan gör. Barnlitteraturens tekniklandskap skulle därmed kunna bidra till att göra tekniken i sig, dess "väsen", mer begriplig och synlig för eleverna samt bredda perspektiven och därmed fungera som ett didaktiskt redskap för att uppfylla teknikämnets övergripande syfte.

${ }^{1002}$ Skolinspektionen, Skolinspektionens rapport 2014:04, Teknik - gör det osynliga synligt. Om kvaliteten i grundskolans teknikundervisning, 2014, s. 27, http://www.skolinspektionen.se/Documents/Kvalitetsgranskning/teknik/kvalgr-teknikslutrapport.pdf (läst 2014-06-01). 


\title{
English Summary
}

\section{Technology landscapes in children's literature A didactic journey from Nils Holgersson to Pettson and Findus}

\begin{abstract}
The eagle flapped his wings again, and went over to Aln Island, which lies opposite Sundsvall. The boy was greatly surprised to see all the sawmills that decked the shores. On Aln Island they stood, one next another, and on the mainland opposite were mill upon mill, lumber yard upon lumber yard. He counted forty, at least, but believed there were many more. «How wonderful it all looks from up here!« he marvelled. «So much life and activity I have not seen in any place save this on the whole trip. It is a great country that we have! Wherever I go, there is always something new for people to live upon. ${ }^{1003}$
\end{abstract}

$\mathrm{I}$ 1906, the children's book character Nils Holgersson flew over Sweden, and Swedish schoolchildren followed his adventures through Selma Lagerlöf's book The Wonderful Adventures of Nils. It was a Sweden in a state of change. The country was transforming from an agrarian to an industrial nation, and this industrialisation was dependent on the exploitation of iron ore, forests and hydroelectric power. Throughout his journey, Nils sees all sorts of technological innovations such as blast furnaces, lumber mills, steam engines, mowers and warships. These innovations arouse wonder in Nils about what "ingenious men" can achieve. Eighty years later, in Sven Wernström's book The Wonderful Journey (1985-87), a boy undertakes a journey in Nils Holgersson's footsteps. In this story, Lagerlöfs book was being turned into a TV-series and the twelve-year-old Nicke Svensson from Norrköping was chosen for the lead role. Together with the film crew, he

${ }^{1003}$ S. Lagerlöf, Nils Holgerssons underbara resa genom Sverige, Bd 2, 1908, p. 528. 
travels by car and by helicopter to recreate Nils' adventures throughout Sweden. Meanwhile, Nicke also reads Lagerlöf's book during the filming and realizes that the Sweden he i experiencing is quite different from the one that Nils experienced on the back of his goose. Nicke's technology landscape is full of state-of-the-art technology such as cars, space rockets, industrial machinery, forest machines, tractors, nuclear power plants, chemical industries and hydroelectric power stations. Nicke realizes that technology also has a dark side and has turned into a threat for both humans and nature. The book's message is that Sweden is in a critical condition, since the development of society only serves economic interests, without regard to individuals and the environment. ${ }^{1004}$

The Wonderful Adventures of Nils and Sven Wernström's reinterpretation are examples of children's books where technology appears in fiction. Both stories describe developments in society at two different time points in the 1900s. The fictional world in which the books' protagonists live could be seen as a technology landscape that changes character over time and space. ${ }^{1005}$ Despite the changes in the systems and artefacts in the two technology landscapes, however, there are also similarities. The stories prompt a dialogue about the effects of technology to individuals, society and nature, and incite reflection about what future direction society will take. Both books also show that debates about technological development and moral responsibility, are not only being discussed in academic books, government reports and philosophical texts, but also in fiction. ${ }^{1006}$ Fiction makes it possible for us to make self-identifications such that we can place ourselves into the described situation while simultaneously being able to imagine other alternative realities than that depicted. ${ }^{1007}$ Since fiction often concretely illustrates how individuals experience social phenomena, it is also able to reflect human beings' complex and contradictory nature better than other genres. ${ }^{1008}$

\footnotetext{
1004 S. Wernström, Den underbara resan: En läsebok om Sverige, D1-3, Stockholm: Gidlund, 1985-87.

1005 J.-E. Hagberg, Livet genom tekniklandskapet: Livslopp, åldrande och vardagsteknikens förändring, 2008; J.-E. Hagberg, "Att lära i teknikens rum och landskap. En metadidaktisk betraktelse", 2009, p. 41-75.

${ }^{1006}$ J. Anshelm, Förnuftets brytpunkt: Om teknikkritiken i P. C. Jersilds författarskap, 1990, p. 21. ${ }^{1007}$ Ibid., p. 17.

${ }^{1008}$ E. Tengström, Bilen \& människan i svensk prosa och poesi, 2009, p. 14-17.
} 
In light of this, an important starting point for this dissertation is my conviction that the technology landscapes in children's literature can be understood as transmitters of values and attitudes about technology, and that this therefore makes them an interesting subject matter for technology education. Technology education deals not only with knowledge in and about technology, but also with how this knowledge intertwines with different social, cultural and historical contexts. ${ }^{1009}$ In this study, it is the discourse about technology that I link to children's fiction and its didactic function. From a societal perspective, children's literature - just as any other art form - has different functions. Besides being a medium for mastering language, children's literature also serves to socially orient children in time and space in order for them to develop desirable values with respect to society. ${ }^{1010}$ If we consider social orientation as one of the functions of children's fiction, then it follows that technological aspects have a natural place in these stories, since technology is something that permeates much of human activity.

\section{Aim and overarching research questions}

With this study, I want to show how the perspectives within technology education could be used to analyse and interpret children's fiction. I hope that the study can contribute to an educational-inspired discussion of technology and children's literature, which also includes a historical perspective.

One's approach and standpoint with respect to technology (view of technology) is often intimately interwoven with certain perspectives about nature (view of nature) as well as specific futures perspective (view of the future). ${ }^{1011}$ Using the views of technology in the children's books as starting points, I examine if there are similarities or differences between the narratives. The reason for my approach is that views of technology should preferably be studied in relation to other socie-

\footnotetext{
${ }^{1009}$ J. Hagberg \& M. Hultén, Skolans undervisning och elevers lärande i teknik: Svensk forskning i internationell kontext, 2005, p. 19; S. Selander, "Didaktik - undervisning och lärande", 2010, p. 197-215.

${ }^{1010}$ L. Hellsing, Tankar om barnlitteraturen, Ny utg., 1963/1999, p. 25-27.

${ }^{1011}$ N. Applebaum, "The myth of the innocent child: Interplay between nature, humanity and technology in contemporary children's science fiction”, 2006, p. 1-17; N. Applebaum, Representations of technology in science fiction for young people, 2010; T. Frängsmyr, Framsteg eller förfall: Framtidsbilder och utopier $i$ västerländsk tanketradition, 1990, p. 234-243.
} 
tal dimensions, rather than as isolated phenomena. ${ }^{1012}$ Accordingly, discourse and debates about technology deal not only with technology itself but are often coupled with views about nature, culture, the current times and a future outlook. ${ }^{1013}$

The aim of this study is to examine, from a didactic perspective, the messages conveyed about technology (view of technology) in a selection of Swedish children's books which contain elements of technology, and to explore how these views of technology relate to views of nature and views of future. The study's overarching research questions are:

What are the views of technology conveyed in children's fiction which contain aspects of technology, and how do these views relate to nature and futures perspectives?

In the analysis, I identified what types of technology were depicted and how it was depicted in the chosen children's books. Besides representations of actual technological items, I also considered linguistic symbols such as metaphors and analogies pertaining to technology. I explore the whys through interpreting what the stories convey about the aims and purposes of technology and their assumptions about technology's effects to humankind, society and nature.

As a whole, the study can be said to have three analytical perspectives, namely: the identification of technologies represented in children's books; the identification and interpretation of the views of technology transmitted in the stories, in relation to nature and futures perspectives; and the identification of shared and divergent themes in the different stories. To conclude, I used a comparative analysis to synthesize what the texts had in common about technology, and these resulted in different themes. ${ }^{1014}$

\footnotetext{
${ }^{1012}$ S. Sörlin, Naturkontraktet: Om naturumgängets idéhistoria, 1991, p. 26-27, 36.

${ }^{1013}$ M. Kylhammar, Maskin och idyll: Teknik och pastorala ideal hos Strindberg och Heidenstam, 1985, p. 11-12.

${ }^{1014}$ L. Marx, The pilot and the passenger: Essays on literature, technology, and culture in the United States, 1988, p. 114; P. Ricoeur, "Vad är en text?", 1993c, p. 50-52.
} 


\section{Theoretical and methodological starting points}

I consider the historical perspective as a natural and important dimension that affects attitudes to technology. History is valuable for our ability to analyse the present and envision the future. ${ }^{1015}$ As a concept, technology is related to a time perspective in that it is associated with other concepts such as invention, development and change. ${ }^{1016}$ A historical perspective can further our understanding about technology and human beings' changing relationship to it. By uncovering themes that help us understand our present time, a historical perspective can also benefit us in making well-reasoned decisions in the future regarding technology. ${ }^{1017}$ Since fiction depicts technology from the perspective of the experiences and thoughts of its human characters, it is also possible to study the messages about technology in the texts.

In my view, the last century is an especially interesting period to study within technology education. During this time, Sweden underwent a radical transformation from an agrarian society to a modern industrial one, changing with it the technology landscape. The analysed material thus consists of Swedish children's literature written at different time points from the start of the $20^{\text {th }}$ century. Some of these books are still the most frequently borrowed books in Swedish libraries. Initially, a large number of children's books (ca. 130 books) were examined for the study, and ultimately, children's books written by six Swedish authors were chosen. These authors are: Selma Lagerlöf (1858-1940), Otto Witt (1875-1923), Elsa Beskow (1874-1953), Karl-Aage Schwartzkopf (1920-2009), Sven Wernström (1925-) and Sven Nordqvist (1946-). I consider these books to contain elements of technology education since they not only contain depictions of technology, but also depict issues and problems considered relevant today in the field of technology education. Examples of these issues include reflections about the na-

\footnotetext{
${ }^{1015}$ D. Edgerton, The shock of the old: Technology and global history since 1900, 2006, s. xvi. ${ }^{1016}$ Ibid., p. ix-xviii, 28-51.

${ }^{1017}$ J. Hallström, ”Teknikhistoria öppnar upp vidare perspektiv på tekniken”, 2013, p. 62-65.
} 
ture of technology, discussions about its advantages and disadvantages, or the way technology is described in a social and historical context. ${ }^{1018}$

Technology landscape is a concept used when examining various environments through observing the different technological artefacts at hand and the relations between them. In other words, it is a kind of empirical "reality" that includes values and attitudes about technology. ${ }^{1019}$ This dissertation could thus be described as a journey through the technology landscapes of some of the Swedish children's books from the start of the 1900s to the early 2000s. For my theoretical and methodological starting points, I found inspiration from a number of different research areas, mainly Technology education, History of technology, Philosophy of technology, Literature and History of Ideas.

Technology is an elusive concept in society, but at best, technology deals with ways of changing our world and solving problems with the help of man-made objects, methods, activities and processes. To apprehend the central aspects of technology, I use Carl Mitcham's fourfold description of technology (volition, knowledge, activity, object), combined with Thomas P. Hughes' systems perspective. ${ }^{1020}$ These perspectives encapsulate the dimensions of technology central in my analysis of the chosen children's books. To describe the views of nature and futures conveyed in the children's books, I use the notions of anthropocentric and biocentric views of nature, and views of the future as the effective society or a utopian idea of the good life. ${ }^{1021}$

${ }^{1018}$ V. Bjurulf, Teknikdidaktik, 2011, p. 209; John R. Dakers, “Towards a philosophy for Technology Education”, 2006b, p. 145-158; J.-E. Hagberg \& M. Hultén, Skolans undervisning och elevers lärande i teknik: Svensk forskning i internationell kontext, 2005, p. 12-19.

1019 J. Hagberg, Livet genom tekniklandskapet: Livslopp, åldrande och vardagsteknikens förändring, 2008, p. 19-20; J. Hagberg, "Att lära i teknikens rum och landskap. En metadidaktisk betraktelse", 2009, p. 45-46.

${ }^{1020}$ T. P. Hughes, "The seamless web: Technology, science, etcetera, etcetera", 1986, p. 281-292; T. P. Hughes, "The evolution of large technological systems", 1987, p. 51-82; P. Hughes, "Technological momentum", 1994, p. 101-113; C. Mitcham, Thinking through technology: The path between engineering and philosophy, 1994, p. 160.

${ }^{1021}$ E. Erlandson-Hammargren, Från alpromantik till hembygdsromantik: Natursynen i Sverige från 1885 till 1915, speglad i Svenska turistföreningens årsskrifter och Nils Holgerssons underbara resa genom Sverige, 2006, p. 19; T. Frängsmyr, Framsteg eller förfall: Framtidsbilder och utopier $i$ västerländsk tanketradition, 1990, p. 227-236; S. Sörlin, Naturkontraktet: Om naturumgängets idéhistoria, 1991, p. 157-159. 
To interpret the messages conveyed in the children's books, I found it useful to employ Paul Ricoeur's hermeneutics of suspicion, which means that I not only analysed self-evident messages about technology in these books, but also considered the ones that may be obscured or hidden. ${ }^{1022}$ As for messages about technology, I consider these to be intimately related to (implicit or explicit) arguments within the narratives for or against a technological "phenomena" or technological developments in society. I read the material very closely in what could be described as "the mindful, disciplined reading of an object with a view to deeper understanding of its meanings." "1023 As I used the hermeneutic method, the starting point for all my interpretations was the written text. Although I acknowledge that historical and cultural contexts are important in forming my own understanding of the text, I do not necessarily regard the texts as windows to the values and thoughts of its time. Instead, my focus is to examine, understand and interpret the text at hand.

\section{Representations of technology and technology as system}

The results of my analysis show that in general, the studied children's books present technology in diverse ways. Various facets of technology appear throughout the hundred-year period from which the empirical material originates.

A close examination of the books' technology landscapes shows that both Mitcham's aspects of technology as well as Hughes' systems perspective are present. ${ }^{1024}$ With regards to technology as volition, knowledge and activity, these aspects' relation to one another and their relationship to technology as object is clearly depicted in The Wonderful Adventures of Nils (1906-07), Witt's technical stories (Technical stories for young and for old, 1914; Technical Stories of the War, 1915), Beskow’s fairy tales “Mr Klumpedump from Klumpedonien” (1915)

\footnotetext{
${ }^{1022}$ P. Ricoeur, "The hermeneutical function of distanciation", 1981, p. 131-144; P. Ricœur, "The model of the text: Meaningful action considered as a text”, 1973, p. 91-117.

${ }^{1023}$ B. Brummett, Techniques of close reading, 2010, p. 25.

1024 T.P. Hughes, “The seamless web: Technology, science, etcetera, etcetera”, 1986, s. 281-292; T.P. Hughes, "The evolution of large technological systems", 1987, s. 51-82; T. P. Hughes, "Technological momentum", 1994, s. 101-113; C. Mitcham, Thinking through technology: The path between engineering and philosophy, 1994, s. 160.
} 
and “Doctor Klokamundus' Invention" (1919), Wernström's The Wonderful Journey (1985-87) and the Nordqvist's series about Pettson and his cat Findus (1984; $1986 ; 1988 ; 1990 ; 1992 ; 1994 ; 2001 ; 2012)$. The descriptions of the technological process in these stories show how knowledge about technology is a premise for pursuing technology as an activity. The volition or willingness to use techno-logy is depicted in several of the books as a unique activity that sets humans apart from other animals. This aspect is taken up in, for instance, The Wonderful Adventures of Nils, Witt's technical stories and The Wonderful Journey.

Technology as system is depicted in relative detail in some of the books in the Pettson and Findus series. The other stories also show how small malfunctions could lead to greater consequences for the system as a whole. ${ }^{1025}$ The systems depicted in the stories vary in size. Larger systems, such as transport systems and electricity distribution systems, are depicted in The Wonderful Adventures of Nils, the technical stories, the books about a train family, The Choo-Choo Family (The Choo-Choo Family, 1949; At home with the Family Choo-Choo, 1950), and The Wonderful Journey. ${ }^{1026}$ Because many of these large systems described in the books also involve artefacts and social actors, they can also be seen as sociotechnical systems. ${ }^{1027}$ Other examples of technological systems in the books are the industrial production of semiconductors for electric trains, and systems consisting of different components such as a Santa Clause machine, a fostering machine and a creative invention that will scare away a fox.

It seems that the presence of technology in the books has two overarching functions: to arouse interest for technology, through descriptions about how they work, and to warn about technology's negative consequences. The Wonderful Adventure of Nils, Witt's technical stories, "Mr Klumpedump from Klumpedonien", The Wonderful Journey and the Pettson and Findus series are all similar in

\footnotetext{
${ }^{1025}$ T.P. Hughes, "The seamless web: Technology, science, etcetera, etcetera”, 1986, p. 281-292; L. Ingelstam, "Varför är tekniska system intressanta?", 2009, p. 81-97; L. Ingelstam, System: Att tänka över samhälle och teknik", 2012; A. Kaijser, "Snärjda i systemen?", 2002, p. 87-102.

${ }^{1026}$ J. Hallström, "Systemteori och teknik. En introduktion till stora tekniska system", 2009, p. 99117; T.P. Hughes, "The seamless web: Technology, science, etcetera, etcetera", 1986, p. 281-292; T.P. Hughes, "The evolution of large technological systems", 1987, p. 51-82.

${ }^{1027}$ J. Hallström, "Systemteori och teknik. En introduktion till stora tekniska system", 2009, p. 99; L. Ingelstam, "Varför är tekniska system intressanta?", 2009, p. 81-97; L. Ingelstam, System: Att tänka över samhälle och teknik, 2012, p. 214-256.
} 
that they have more or less detailed descriptions of how technology works. These stories are also characterized by a fascination for technology. In "Doctor Klokamundus' Invention", the opposite is true. In describing how the fostering machine works, the story instead warns the reader against misplaced optimism that technology can solve all problems. Another warning for the bad effects of technology, when used in erroneous ways, can also be found in Technical Stories of the War, "Mr Klumpedump from Klumpedonien", the books about the high-rise building "Talleborg" (The High-rise by the Mire, 1965; The High-rise goes North, 1969) and The Wonderful Journey.

How technology appeared in the chosen children's books could be categorized into six different themes: technology as metaphor or analogy; technology as anthropomorphic; technology as autonomous; technology as a result of a creative driving force; masculine technology; and technology as enduring.

\section{Depictions of technology}

\section{Technology as metaphor or analogy}

Metaphors and analogies in the analysed children's books were of two types: explicit (concrete) or implicit (abstract). Explicit metaphors develop from the natural world or the world of human beings and are used to elicit pictures of certain technologies and how they are used. When abstract metaphors are used, these stand in for something greater, for instance a phenomenon, event or social process. Abstract metaphors are never explicit in the text and more appropriately described as hidden or obscured messages. ${ }^{1028}$ Through the use of metaphors and analogies, associations of kinship are created between human being - technology - nature. Because of this, the message conveyed is not of technology as inherently "evil". Rather, the focus is on how human beings use technology. Metaphors can also have an educational function since they can create understanding for one's surroundings. ${ }^{1029}$ In the stories, these could be about new technological phenomena. In The Wonderful Adventures of Nils saw mills are described as "lumber camps" and mines are described as "fields". Understanding for new technology can be

\footnotetext{
${ }^{1028}$ P. Ricoeur, "The model of the text: Meaningful action considered as a text", 1973, p. 91-117.

${ }^{1029}$ G. Lakoff, M. Johnson, Metaphors we live by, 2003, p. 3.
} 
formed by linking the unfamiliar to the familiar. Further, in the metaphorical images found in the book, the technological aspects in the landscape are described as natural parts of the primordial pastoral landscape. ${ }^{1030}$ Examples of metaphors and analogies critical to technology could be found in, among others, The Wonderful Journey, where industrial machines are described as "caged animals" and the forest machine is called a threatening "prehistoric lizard".

One example of an implicit metaphor in the stories involves trains and railways in the critique of industrialization, since the railway has come to symbolize command and future prospects. ${ }^{1031}$ In the books about Nils Holgersson and the Choo-Choo family, the train could be interpreted a symbol for colonialism. Both books describe how railways occupy the wilderness or even other continents that are "wild and untamed" and need to be civilized. In one of the books about the Choo-Choo family, Africa is even portrayed as inhabited by train-eating cannibals. The presence of trains in the children's books could be related both to the symbols within the history of technology and to the fact that railways have been an important piece of infrastructure for the development of society.

As with the train, the automobile is also used as an implicit metaphor for a critique against modernity, industrialism and a high-tech society. Besides the fact that automobiles have negative effects on the environment, a risk is expressed that human beings may lose control over it. However, the message is not black-and-white. Cars also act as a bridge between the urban society and nature; it is a tool humans use to transport themselves from one world to the other. In general, explicit metaphors are more neutral in tone than the implicit ones. Critique of society is often embedded in implicit metaphors, and they also express certain ambivalence about technology and technological development.

\footnotetext{
${ }^{1030}$ D.E. Nye, American technological sublime, 1994, p. 59; M. L. Smith, "Recourse of Empire: Landscapes of progress in technological America", 1994, p. 37-52.

${ }^{1031}$ E. G. Ingersoll, Representations of science and technology in British literature since 1880, 1992, p. 2; D. E. Nye, American technological sublime, 1994, p. 59; M. L. Smith, "Recourse of empire: Landscapes of progress in technological America", 1994, p. 37-52; M. R. Smith, "Technological determinism in American culture", 1994, p. 1-35.
} 


\section{Technology as anthropomorphic}

Anthropomorphism - ascribing human traits and attributes, such as feelings, to animals or things - is quite common in folk tales and children's literature. In Witt's technical stories, Schwartzkopf's books about the Choo-Choo Family and Beskow's two fairy tales "Mr Klumpedump from Klumpedonien" and "The Green Car" (1953), everyday gadgets come alive. One suggested reason for this is that the use of anthropomorphism helps the reader feel at ease with technology as a part of the human world. If a technology is so complicated that it is hard to understand or grasp, a possibility would be to depict it as something that is alive. This is one way of bridging the barrier between oneself and the complex technology. Anthropomorphism also contributes to building an emotional bond between human and machine. ${ }^{1032}$ This intention is reinforced through, for instance, showing how both children and vehicles (trains and cars) could both be sometimes disobedient and mischievous.

\section{Technology as autonomous}

Autonomous technology could be found in several of the stories, for instance in "The Green Car" and the books about the Choo-Choo Family. On the one hand, trains and cars may be ascribed human traits and behaviours, but on the other hand, technology could also be portrayed as autonomous and self-determining. ${ }^{1033}$ These stories describe cars, trains and cyborgs that have developed free and act beyond human control. The cyborg "Mulle The Tunnel Digger" in Schwartzkopf's stories about the Choo-Choo Family is one example of autonomous technology. Mulle is a human creation, a hybrid between biological matter and machine, but nevertheless a result of human beings' technological activities. ${ }^{1034}$ Through the develop-

\footnotetext{
${ }^{1032}$ H. J. Schwarcz, "Machine animism in modern children's literature", 1967, p. 80; A. Waytz, "Making meaning by seeing human", 2013, p. 135-146; A. Waytz, "The mind in the machine: Anthropomorphism increases trust in an autonomous vehicle", 2014, p. 113-117.

${ }^{1033}$ J. Ellul, The technological society, 1964, p. 14; J. Ellul, "The autonomy of technology”, 2010, p. 67-75; L. Winner, Autonomous technology: Technics-out-of-control as a theme in political thought, 1977.

${ }^{1034}$ D. J. Haraway, "A cyborg manifesto: Science, technology, and socialist-feminism in the late twentieth century", 1991, p. 149; N. Wiener, Cybernetics or control and communication in the animal and the machine, 1965, p. 19.
} 
ment of the cyborg, human beings can surpass their own natural limits. As in Mary Shelley's Frankenstein, however, Mulle's creator loses control of his own invention. ${ }^{1035}$ If no one is able to stop Mulle, the world would be at risk from his constant digging. A parallel thread in both "The Green Car" and the story about "Mulle The Tunnel Digger", is that they depict older types of technology (such as steam engines and horse-driven carriages) as more reliable than newer ones (such as electric trains and cars).

Implicitly, this way of describing technology as autonomous serves as a warning about what might possibly happen when humans lose domination over their own technological inventions. Scwartzkopf's books about the high-rise building “Talleborg”, are cautionary tales about human beings' dependence on automobiles. The message carried forth is that human dependence on cars will subsequently lead to being one with the car: extremities will fuse together with the gas pedal and steering wheel, and human blood will turn to petrol. ${ }^{1036}$ Humans will meld together with machines, becoming cyborgs.

\section{Technology as creative driving force}

In many of the stories, technology is expressed as results of creative activity and is premised on human beings' own desire and need to create. Examples of this way of describing technology are in the form of personified bricolages. ${ }^{1037}$ Bricolage is a way of making use of and recycling old technology, or finding new ways to use existing technology. For instance, neither Pettson nor the people in the high-rise throw anything away, but turn existing items into gadgets. Sixten (a boy) in "Mr Klumpedump from Klumpedonien" also makes a bricolage by tearing apart an old alarm clock and using its parts to build a motor for his underwater boat. The stories about Pettson and the talleborgs are similar since they depict how the bricoleurs use technology in other ways than for which it was meant. In The High-rise by the Mire a rubbish chute turns into a speaker. In the books about Pettson and Findus, they use an electric jigsaw as a breadknife, and a brace and bit as a mug holder.

\footnotetext{
${ }^{1035}$ M. W. Shelley, Frankenstein, or, The modern Prometheus, 1818/1993.

${ }^{1036}$ K. Schwartzkopf, Höghuset vid myren, 1965, p. 56-57.

${ }^{1037}$ B. Dahlbom, "En vetenskap om artefakter", 1993, p. 53-75; S. Liedman, Ett oündligt äventyr: Om människans kunskaper, 2001, p. 163; C. Lévi-Strauss, The savage mind, 1962/1973, p. 17.
} 
The message of the stories is that it is the user or the context that determines the function of an artefact, and not necessarily the function for which the artefact was invented. ${ }^{1038}$ By portraying Pettson and Findus as bricoleurs, the range of use for technology becomes greater. What sets the Pettson and Findus books apart from the others, however, is that not all inventions there are made in order to make things more effective or to solve problems. Many of their bricolages are only good for doing things in an alternative way or for "solving" things that could hardly be called problems. Examples of these are pots on wheels and tea cups with "teaspoon holders". In these examples, technology could instead be interpreted as a form of creative expression. The goal of technology in "Mr Klumpedump from Klumpedonien" could be regarded in a similar way. There, children make toys with malleable material. In contrast to the lifeless factory-made toys, these toys are valuable for the children, have a soul and come to life in the stories. The aim of the children's creations is not to produce something perfect, but something unique. ${ }^{1039}$ Pettson and Findus, as well as the children in "Mr Klumpedump from Klumpedonien" are thus both inventors and artists. ${ }^{1040}$

\section{Masculine technology}

Technology is very often associated with boys and men. Both historically and at the present time, there are seldom accounts of technology in those spheres of life in which women have dominated. ${ }^{1041}$ For this thesis, the primary reason for why masculine-coded technology dominates the empirical material is that the books have been chosen for their representativeness in terms of different types of technology as well as for having a message about nature and the future. As for the feminine-coded books that were preliminarily examined, these did not fulfil the

${ }^{1038}$ D. Ihde, "The designer fallacy and technological imagination", 2006, p. 121-131; A. Ingerman, K. Wagner \& A.-S. Axelsson, "Till läsaren” i På spaning efter teknisk bildning, 2009, p. 79; D. C. Dennett, "The interpretation of texts, people and other artifacts", 1990, p. 186.

${ }^{1039}$ R. Ambjörnsson, Fantasin till makten! Utopiska idéer i västerlandet under fem hundra år, 2004, p. 188; T. Frängsmyr, Framsteg eller förfall: Framtidsbilder och utopier $i$ västerländsk tanketradition, 1990, p. 154.

${ }^{1040}$ S.-E. Liedman, I skuggan av framtiden: Modernitetens idéhistoria, 1999, p. 395-401.

${ }^{1041}$ B. Berner, "Teknikens kön”, 2009, p. 279-293; R. Oldenziel, Making technology masculine: Men, women, and modern machines in America, 1870-1945, 1999. 
mentioned criteria. The diversity of technological items in these books served a very minor role as "props" or "background", and it would have been hard to make an analysis on these grounds. At the same time, this thesis also confirms that technology is seldom discussed in spheres of life where women dominate. ${ }^{1042}$ Factories, transportation networks, weapons and other large technological systems are often associated with, and controlled by men. Historically, it is also men that had held influence on the design of technology. One possible reason for why masculine technology dominates in the empirical material is that they have been written at a time when male inventors and scientists were held in high regard as heroes (early 1900s). ${ }^{1043}$ However, this explanation is not satisfactory, since children's books written almost a century later still mainly feature inventive male heroes. The stereotype for a handy-man or an engineer is still a man. ${ }^{1044}$ In literary imageries of the prototypical inventor, this character is also practically always a man - from the technologically advanced heroes in Jules Verne's books, to Gyro Gearloose, Professor Calculus and other ingenious figures in children's literature. ${ }^{1045}$ This stereotype is also present in those stories that were examined. Engineers as well as the living bricoleurs were, with one exception, all men. In relation to previous research, this study confirms the fact that male engineers and inventors have been, and still are, acting as heroes and role models in children's literature. ${ }^{1046}$

\section{Technology as enduring}

In descriptions of social progress, there are often accounts of key inventions that are thought to have been extra influential for human society. This is beside the fact that most other inventions have a short life span and have little effect on our daily

\footnotetext{
1042 Ibid.

${ }^{1043}$ B. Berner, Perpetuum mobile? Teknikens utmaningar och historiens gång, 1999, p. 156-157.

${ }^{1044}$ B. Berner, ”Teknikens kön”, 2009, p. 279-293; U. Mellström, ”Män i teknikens värld”, 2009, p. 295-310.

${ }^{1045}$ B. Berner, "Teknikens kön”, 2009, p. 281.

${ }^{1046}$ E. S. Hintz, "Heroes of the laboratory and the workshop: Inventions and technology in books for children, 1850-1950", 2008, p. 197-211; J. McCannon, "Technological and scientific utopias in Soviet children's literature, 1921-1932”, 2001, p. 153-169.
} 
life. $^{1047}$ In the books about Pettson and Findus (Nordqvist, 1984; 1986; 1988; $1992 ; 1994 ; 2001$; 2012) however, another aspect of technology appears, namely its enduring dimension. The technology landscape in these books do not contain any modern or state-of-the-art technology, but rather items such as kicksleds, sledges, skis, radio sets, kitchen items, gardening tools and other tools that have a long history but are still in daily use. These are things that have hardly changed through time. Through underlining technology's enduring dimension, there is an appreciation for the technologies that have - historically and through the present time - have been an important part of people's lives. New technologies emerge and other technologies disappear, but there are also technologies that continue to be used over time. They continue to exist, side by side with the new emerging technology. ${ }^{1048}$

\section{Views of technology and its relationship to the views of nature and the future}

With regard to different views of technology and its outcomes for society, there are in general two sets of attitudes. On the one hand, there is a view that technology exists independent of other social forces. On the other hand, there is also a view of technology as a product of human beings' social and cultural world, and consequently, that human beings control technology and not the other way around. ${ }^{1049}$ The different views of technology identified in this study could be divided into four different themes or dimensions:

- View of technology as servant: a view where technology is seen as a powerful tool serving to help humans achieve their dreams and aspirations.

\footnotetext{
${ }^{1047}$ D. Edgerton, The shock of the old: Technology and global history since 1900, 2006, p. ix. ${ }^{1048}$ Ibid; K. Kelly, What technology wants, 2010, p. 52-54; H. Petroski, The evolution of useful things, 1992.

1049 J. Ellul, The technological society, 1964, p. 14; J. Ellul, "The autonomy of technology”, 2010, p. 67-75; L. Mumford, Technics and civilization, 1934/1963, p. 6; L. Winner, Autonomous technology: Technics-out-of-control as a theme in political thought, 1977.
} 


\section{English Summary}

- The deterministic or instrumental view of technology: a view maintaining that human beings have already lost their domination over technology and technological advancement.

- The nostalgic view of technology: a view that holds that early technology is better than modern technology, and that old technology has higher value.

- The anti-consumeristic view of technology: a view that campaigns for a sustainable technology society where objects are reused and technology is not made for economic profit.

In the books included in this study, technology for crafts as well as early technologies is given a higher value compared with industrial and state-of-the-art technology. This is related to the idea that early technologies are in some way more democratic, since they are used in contexts where human beings have a closer relationship with the technical construction. In contrast to technology for crafts, industrial technology appears to lack aesthetics, is autocratic (authoritarian) and is therefore a potential destructive power. ${ }^{1050}$ Crafts and trade are contrasted with industrial mass production. Whereas crafts are produced by human hands, mass produced objects have no "soul". The critique of technology is grounded in the belief that new technologies are inevitably accompanied by negative consequences for nature as well as for human lives, human activity and the human mind. There is however a belief in technology, but only those technologies related to crafts and trade, which are hand-made. Monotonous and "boring" jobs can nevertheless be handed down to machines. ${ }^{1051}$

The view of nature adopted in the majority of the children's books could be described as anthropocentric or weak anthropocentric. The latter is a view of nature premised on the centrality of human beings' needs but does not have a merely instrumental view of nature. ${ }^{1052}$ Schwartzkopf's books about the high-rise building were the only ones in the material that could be interpreted as having a biocentric

\footnotetext{
${ }^{1050}$ L. Mumford, “Authoritarian and democratic technics”, 1963, p. 1-8.

${ }^{1051}$ M. Kylhammar,”Teknikdebattens grammatik”, 1987, p. 399.

${ }^{1052}$ A. Dobson, Green political thought, 2000, p. 51-61.
} 
view of nature. ${ }^{1053}$ This critique of civilization advocates a life of harmony with nature, as a path to utopia. Human beings are pictured here as a part of nature: the human person's right place is within the natural world and humans and nature are seen equals.

Using Tore Frängsmyr's views of the future, the effective society and the good life, it is clear that the effective society dominates the material, although a couple of books also depict the good life. ${ }^{1054}$ However, my study diverges from Frängmyr's on one important point. Frängsmyr posits that although belief in the power of technology seems contradictory to the utopia of the good life that respects natures' own way, the utopian idea actually also contains a hope for an effective society. ${ }^{1055}$ The results of this study, however, show that the analysed books representing the idea of a good life (the books about the high-rise Talleborg and the books about Pettson och Findus) did not have any orientation towards future goals. In these books, technology solves workaday problems, or even shows alternative solutions that may not necessarily be the easiest. The creative process is what is in focus. In these utopian stories of technology, it is not the goal to be more effective or to solve problems in an easier way. Contrasting with previous studies that posit that children's fiction, specifically science fiction, as picturing dystopias, none of the examined books have a dystopic view of the future. ${ }^{1056}$

\section{Views of technology in relation to contexts}

Analysis of the texts and recurring themes in the stories' technological landscapes also lead to another possibility for interpreting views of technology, this time from the perspective of the contexts in which they belong:

\footnotetext{
${ }^{1053}$ E. Erlandson-Hammargren, Från alpromantik till hembygdsromantik: Natursynen $i$ Sverige från 1885 till 1915, speglad i Svenska turistföreningens årsskrifter och Nils Holgerssons underbara resa genom Sverige, 2006, p. 19; S. Sörlin, Naturkontraktet: Om naturumgängets idéhistoria, 1991, p. 157-159.

1054 T. Frängsmyr, Framsteg eller förfall: Framtidsbilder och utopier $i$ västerländsk tanketradition, 1990, p. 227-236.

${ }^{1055}$ Ibid., p. 235.

${ }^{1056}$ N. Applebaum, "The myth of the innocent child: Interplay between nature, humanity and technology in contemporary children's science fiction”, 2006, p. 1-17; N. Applebaum, Representations of technology in science fiction for young people, 2010.
} 
- Techno-centric

- Techno-utopic

- Pastoral-idyllic

- Biocentric utopia

In the techno-centric context, human beings use technology as a means to gain power or economic resources, without regard for other people or for nature. Also included in this context is the view of man as so dependent on technology in such a way that technology becomes a threat to human creativity. The view of nature here is anthropocentric and progress goes before respect for nature.

In a techno-utopic context, technology is seen as a positive force which can help human beings solve problems and bring society in the right direction. Although this view of technology advocates an anthropocentric view of nature, it also advocates that technological progress should be in harmony with nature and consider future generations.

In the pastoral-idyllic view, technology is a part of countryside life. The technology described is or have been part of country life for generations. The pastoralidyllic view has a weak anthropocentric view of nature, since it advocates respect for nature through all our contact with it. Nature has a value, but human beings' needs still come first.

Technology in the biocentric utopia is developed in harmony and concurrence with nature. Human beings live in a Robinson Crusoe-world where they build technologies with what they find. Here, the goal of technology is not for effectivization but to solve problems. Nature has an inherent value independent of human goals and human beings are not superior to nature, but a part of it. ${ }^{1057}$

Children's literature is often described to have a pedagogical and didactic function because messages and values are often more explicitly expressed in literature for children, compared to books for adults. ${ }^{1058}$ In the books analysed for this

\footnotetext{
${ }^{1057}$ See for example: S. J. Rowe, "Ecocentrism: The responsive chord", 1994; M. Stenmark, Miljöetik och miljövård: Miljöfrågornas värderingsmässiga dimension, 2000; S. Sörlin, Naturkontraktet: Om naturumgängets idéhistoria, 1990, p. 123-152.

1058 G. Klingberg, Barn- och ungdomslitteraturen, 1970, p. 84; M. Nikolajeva, Barnbokens byggklossar, 2004, p. 17; K. Reynolds, "Introduction" in Children's literature studies: A research handbook, 2011, p. 1-2.
} 
study, there are explicit messages about nature. For instance, there could be an explicit directive that one should not harm or kill animals. Messages about technology and technological progress, on the other hand, are often ambiguous. This ambiguity seems to be in contradiction with a "traditional" didactic ambition. Practically all of the stories analysed for this study are characterized by an ambivalent view of technology and its consequences. On the one hand, technology is seen as something fascinating, exciting and meaningful for society. On the other hand, aspects of technology that hamper or harm human beings, society and nature, are also lifted. The stories also seem to have a built-in duality, since they describe how technology can both create individual freedom, but weaken human bonds.

\section{Concluding reflections}

The main conclusion of this thesis is that children's fiction can serve as creative jumping boards for discussing the nature of technology, technology and gender, and technology's effects on individuals, society, nature and environment in past and present time. In the Swedish Curriculum for Compulsory School (Lgr11), children's stories, fairy tales and myths take a central place in many of the subjects from grades 1 to 6 . The syllabus for Crafts, for example, encourages the use of stories as sources of inspiration for the children's own creative work. A learning goal in Grade 3 Biology, Physics and Chemistry is that students should be able to discuss books about nature and human beings. ${ }^{1059}$ For some reason, there is no mention in the Curriculum that children's literature should be used in technology education. Nevertheless, the aim of technology education is stipulated:

Through teaching, pupils should be given the opportunity to develop their understanding of the importance of technology and its impact on people, society and the environment. In addition, teaching should give pupils the preconditions to develop confidence in their own ability to assess technical solutions and relate these to questions concerning aesthetics, ethics, gender roles, the economy and sustainable development.

Teaching should help pupils to develop their knowledge about the historical development of technology so that they are in a better position to understand complicated

\footnotetext{
${ }^{1059}$ Skolverket, Curriculum for the compulsory school, preschool class and the recreation centre, 2011, p. 20-279.
} 
technological phenomena and contexts of today, and how technology has impacted and impacts the development of society. $[\ldots]^{1060}$

For many people however, technology remains strongly associated with various artefacts alone, or in other words, man-made items. One can also see this trend in technology education. Claes Klasander uses the term "the shadow of the artefact" to describe the tendency of education to focus on the technological object, rather than its context. ${ }^{1061}$ This view has also been confirmed by the Swedish Schools Inspectorate in its latest evaluation of technology education in Compulsory School:

Many of the schools under evaluation provided limited possibilities for pupils to develop the skills described in the syllabus for technology education. This is especially so with regards to developing reflection about technology and setting technology in a social and historical context. ${ }^{1062}$

The conclusion of this thesis after a careful analysis of a number of chosen books is that the technology landscapes in children's literature could contribute to broadening and expanding technology education. The ambivalent messages in the books reveal technology's multifaceted nature and its complexity. The messages in children's literature could also make it possible to problematize technology in ways that textbooks seldom can. The technology landscapes in children's literature could contribute to making technology and the nature of technology more comprehensible and visible for the pupils. They could also help to broaden their perspectives, thereby functioning as a didactic tool in fulfilling the aims of technology education.

\footnotetext{
${ }^{1060}$ Ibid., p. 254.

1061 C. Klasander, Talet om tekniska system: Förväntningar, traditioner och skolverkligheter, 2010, p. 177.

${ }^{1062}$ Skolinspektionen, Skolinspektionens rapport 2014:04, Teknik - gör det osynliga synligt. Om kvaliteten i grundskolans teknikundervisning, 2014, p. 27.

http://www.skolinspektionen.se/Documents/Kvalitetsgranskning/teknik/kvalgr-teknikslutrapport.pdf (läst 2014-06-01).
} 


\section{Källor och litteratur}

\section{Personlig kommunikation}

Assergård, Gunvor, redaktör Bibliotekstjänst. Mailkontakt 2012-03-26.

Ernerot, Fredrik, ordförande i Skolbibliotek Väst. Mailkontakt 2010-01-22.

Kåreland, Lena, professor, Uppsala universitet. Mailkontakt 2009-11-23.

Lammassaari, Johan, Sveriges författarfond. Mailkontakt 2010-01-22.

Westin, Boel, professor, Stockholms universitet. Mailkontakt 2010-08-18.

\section{Offentligt tryck}

Bostadsbyggnadsutredningen, Höjd bostadsstandard [Elektronisk resurs]: Betänkande, Stockholm, 1965, http://urn.kb.se/resolve?urn=urn:nbn:se:kb:sou617108 (läst 2014-01-25).

Motion 2008/09:Ub236, Litterär kanon, http://www.riksdagen.se/sv/DokumentLagar/Forslag/Motioner/Litterar-khanon_GW02Ub236/?text=true (läst 2013-12-13).

SFS 2010:860 Lag om ändring i bibliotekslagen (1996:1596), http://www.lagboken.se/dokument/andrings-sfs/638660/sfs-2010_860-lag-omandring-i-bibliotekslagen-1996_1596?id=59924 (läst 2012-03-14).

Skolinspektionen, Skolinspektionens rapport 2014:04, Teknik-gör det osynliga synligt. Om kvaliteten i grundskolans teknikundervisning, 2014, http://www.skolinspektionen.se/Documents/Kvalitetsgranskning/teknik/kvalg r-teknik-slutrapport.pdf (läst 2014-06-01).

Skolverket, Läroplan för grundskolan, förskoleklassen och fritidshemmet, Stockholm: Fritzes, 2011.

Warnqvist, Åsa, "Dragonball, LasseMaja och Twilight: Utgivningen av barn- och ungdomslitteratur i Sverige 2001-2010" i Läsarnas marknad, marknadens läsare: En forskningsantologi utarbetad för Litteraturutredningen (SOU 2012:10), s. 329-361, http://www.riksdagen.se/sv/DokumentLagar/Utredningar/Statens-offentliga-utredningar/Lasarnas-marknadmarknadens-1_H0B310d4/?html=true (läst 2013-12-12). 


\section{Otryckta referenser}

Witt, Otto. Privat brev till Verner von Heidenstam, daterat 16 januari 1916, Övralidsarkivet (E005/1984:5) Brevskrivarregistret, Linköpings stiftsbibliotek, Linköping.

\section{Uppslagsverk}

"Atomåldern", Nationalencyklopedin, http://www.ne.se/atom\%C3\%A5ldern (läst 2013-08-13).

"Bildningsroman", Nationalencyklopedin, http://www.ne.se/bildningsroman (läst 2014-05-05).

"Rube Goldberg", Merriam-Webster Online Dictionary, http://www.merriamwebster.com/dictionary/rube\%20goldberg (läst 2014-06-01).

"Teknik", Nordisk familjebok. Uggleupplagan, 1919 http://www.runeberg.org (läst 2011-09-26).

"Teknik", Nordisk familjebok, 1891, http://www.runeberg.org (läst 2011-09-26).

"Teknologi", Nordisk familjebok. Uggleupplagan, 1919, http://www.runeberg.org (läst 2011-09-26).

"Teknologi", Nordisk familjebok, 1891, http://www.runeberg.org (läst 2011-09-26).

\section{Internetsidor}

Bibliotekstjänst, Btj, "Historik", http://corp.btj.se/?id=961 (läst 2011-09-20).

Bokförlaget Opal, "Pettson och Findus", http://www.pettsonochfindus.se/index.php? $\mathrm{p}=$ hem\&lang $=\mathrm{sv}$ (läst 2014-05-09).

Bokförlaget Opal, "Sven Nordqvist", http://www.opal.se/index.php?p=up\&id=Sven@Nordqvist\#.U4mlXfl_um4 (läst 2014-05-10).

Bonnier Carlsen, "Elsa i världen”, http://kampanj.bonniercarlsen.se/beskow/elsa_i_varlden.htm (läst 2011-08-13).

$N T F$, Historia, "Hundra år med trafiksäkerhet", http://www.ntf.se/omoss/pdf/ntf\%20historia.pdf. (läst 2013-11-23) 
Rabén \& Sjögren, "Sven Nordqvist", http://www.rabensjogren.se/Alfabetiskt/N/Sven-Nordqvist (läst 2014-05-10).

Rube Goldberg, "Rube Goldberg's Gallery", http://www.rubegoldberg.com/gallery\# (läst 2014-06-01).

Seriefrämjandet, "Familjen Tuff-Tuff", http://seriewikin.serieframjandet.se/index.php/Familjen_Tuff-Tuff (läst 2010-01-05).

Statens järnvägar, "Svensk järnvägshistoria", http://www.statensjarnvagar.se/info.asp/id/1515 (läst 2013-03-12).

Sveriges Radio, "1968 års julkalender. Klart spår till Tomteboda", http://sverigesradio.se/sida/artikel.aspx?programid=4155\&artikel=4668695 (läst 2012-11-28).

Tekniska muséet, "Första flygningen", http://www.tekniskamuseet.se/1/462.html (läst 2014-03-10).

Tekniska muséet, "Jubileumsflygningen på Stockholms flygfestival", http://www.tekniskamuseet.se/1/1808.html (läst 2014-03-10).

The Boeing Company, "History. DC-6/C-118. A liftmaster transport", http://www.boeing.com/boeing/history/mdc/dc-6.page (läst 2013-07-01).

The writings of Henry D. Thoreau, "The Journal of Henry David Thoreau”, Volume III, Chapter III, vol. 9, 1906, http://thoreau.library.ucsb.edu/writings_journals.html (läst 2014-05-05).

\section{Tryckta och internetbaserade referenser}

A. L. O. E., En synåls historia: Berättelse för barn och ungdom, 4. uppl., Stockholm: Evangeliska fosterlands-stiftelsen, 1904.

Acharya, Sushil \& Sirinterlikci, Arif, "Introducing engineering design through an intelligent Rube Goldberg implementation", Journal of Technology Studies, vol. 36(2), 2010, s. 63-72.

Ahlström, Gunnar, Den underbara resan: En bok om Selma Lagerlöfs Nils Holgersson, Lund: Gleerup, 1942.

Alvesson, Mats \& Sköldberg, Kaj, Tolkning och reflektion: Vetenskapsfilosofi och kvalitativ metod, 2. [uppdaterade] uppl., Lund: Studentlitteratur, 2008.

Ambjörnsson, Ronny, Fantasin till makten! Utopiska idéer $i$ västerlandet under fem hundra år, Stockholm: Ordfront, 2004. 
Andersen, Hans Christian, "Flaskehalsen" i Nye eventyr og historier, I:1 Bd 3, Arkiv for Dansk Litteratur, 1845, http://adl.dk//adl_pub/vaerker/cv/e_vaerk/e_vaerk.xsql?ff_id=22\&id=9151\&hi $\mathrm{st}=\mathrm{fmF} \&$ nnoc $=$ adl_pub (läst 2013-09-09).

Andersen, Hans Christian, "Stoppenaalen" i Nye eventyr. 2 saml., Kjøbenhavn: Reitzel, 1845.

Andersson, Carina \& Lindgren, Charlotte, "Text, image and cultural designers. Reflections on translation and the acceptance of Pettson in France", Moderna Språk, vol. 102(2), 2008, s. 24-34.

Andersson, Dan, Folkbibliotek, makt och disciplinering: En genealogisk studie av folkbiblioteksområdet under den organiserade moderniteten, diss., Stockholms universitet, Stockholm, 2009.

Andersson, Maria, "Borta bra, men hemma bäst? Elsa Beskows och Astrid Lindgrens idyller" i Barnlitteraturanalyser, Maria Andersson \& Elina Druker, (red.), Lund: Studentlitteratur, 2008.

Andersson, Maria, "Sverige i rövarhänder: Berättelsen om nationen i Sven Wernströms Den underbara resan", Barnboken/Journal of Children's Literature Research, vol. 35, 2012, s. 1-14, http://barnboken.net/index.php/clr/article/view/135 (läst 2013-02-02).

Andersson, Sten, Har vi råd med bilen? Stockholm: Tiden, 1956.

Anshelm, Jonas, Förnuftets brytpunkt: Om teknikkritiken i P. C. Jersilds författarskap, diss., Linköpings universitet, Stockholm: Bonnier, 1990.

Anshelm, Jonas, Vattenkraft och naturskydd: En analys av opinionen mot vattenkraftutbyggnaden i Sverige 1950-1990, Tema Teknik och social förändring, Linköpings universitet, 1992.

Anshelm, Jonas, Socialdemokraterna och miljöfrågan: En studie av framstegstankens paradoxer, Stockholm: B. Östlings bokförl. Symposion, 1995.

Anshelm, Jonas, Mellan frälsning och domedag: Om kärnkraftens politiska idéhistoria i Sverige 1945-1999, Eslöv: B. Östlings bokförl. Symposion, 2000.

Anshelm, Jonas, Det vilda, det vackra och det ekologiskt hållbara: Om opinionsbildningen i Svenska Naturskyddsföreningens tidskrift Sveriges Natur 19432002, Umeå universitet, Umeå, 2004.

Anshelm, Jonas, Rekordårens tbc: Debatten om trafiksäkerhet i Sverige 19451965, Tema Teknik och social förändring, Linköpings universitet, Linköping, 2005. 
Anshelm, Jonas, "Kärnavfallets hantering - ett föränderligt problem" i Världens gång - teknikens utveckling: Om samspelet mellan teknik, människa och samhälle, Per Gyberg \& Jonas Hallström (red.), Lund: Studentlitteratur, 2009.

Applebaum, Noga, "The myth of the innocent child: Interplay between nature, humanity and technology in contemporary children's science fiction", The Journal of Children's Literature Studies, vol. 3(2), 2006, s. 1-17.

Applebaum, Noga, Representations of technology in science fiction for young people, New York: Routledge, 2010.

Arnling, Rune, 'De moderna pionjärerna", Ikoner, vision och tradition, nr. 2, 2006, s. 6-9, http://www.btj.se/ikoner/arkiv/2006/pdf/06_2.pdf.

(läst 2010-03-17).

Arthur, W. Brian, The nature of technology: What it is and how it evolves, London: Allen Lane, 2009.

Arvidsson, Håkan, "Dåtiden - tur och retur", Historisk Tidskrift, Stockholm, vol. 122(3), 2002, s. 409-425.

Ashley, Michael, Out of this world: Science fiction, but not as you know it, London: British Library, 2011.

Axell, Cecilia, "Otto Witts tekniska sagor: Tekniksyn i det tidiga 1900-talets barnlitteratur" i Teknik som kunskapsinnehåll i svensk skola 1842-2010, Jonas Hallström, Magnus Hultén \& Daniel Lövheim (red.), Möklinta: Gidlund, 2013.

Axell, Cecilia \& Hallström, Jonas, "Representations of technology in the 'Technical stories' for children of Otto Witt, early $20^{\text {th }}$ century Swedish technology educator", International Journal of Technology and Design Education, vol. 23(4), 2013, s. 817-834.

Axell, Cecilia, Hallström, Jonas \& Hagberg, Jan-Erik, "Images of technology and sustainable development in Swedish children's literature", Australasian Journal of Technology Education, vol. 1(1), 2014, s. 1-9.

Bacon, Francis, "De Augmentis", Works, vol. 4. Citerad i C. Merchant, The death of nature. Women, ecology and the scientific revolution, San Francisco, CA: Harper \& Row, 1989.

Bauman, Zygmunt, Consuming life, Cambridge: Polity, 2007.

Beckman, Svante, 'Inledning: Teknik, makt och vanmakt" i Teknokrati, arbete, makt, Svante Beckman (red.), Stockholm: Carlsson, 1990.

Benner, Mats, "Välfärdskapitalismens era" i Den välsignade tillväxten: Tankelinjer kring ett århundrade av kapitalism, teknik, kultur och vetenskap, Peter Elmlund \& Kay Glans (red.), Stockholm: Natur och Kultur, 1998. 
Berg, Kurt, 'Livingstone och Stanley. Synen på Afrikas natur" i Paradiset och vildmarken: Studier kring synen på naturen och naturresurserna, Tore Frängsmyr (red.), Stockholm: Liber Förlag, Stockholm, 1984.

Berner, Boel, "Professional or wage worker? Engineers and economic transformation in Sweden" i Engineering labour: Technical workers in comparative perspective, Peter Meiksins \& Chris Smith (red.), London \& New York: Verso, 1996.

Berner, Boel, Perpetuum mobile? Teknikens utmaningar och historiens gång, Lund: Arkiv, 1999.

Berner, Boel, "Teknikens kön" i Världens gång - teknikens utveckling: Om samspelet mellan teknik, människa och samhälle, Per Gyberg \& Jonas Hallström (red.), Lund: Studentlitteratur, 2009.

Bernes, Claes \& Lundgren, Lars J., Bruk och missbruk av naturens resurser: En svensk miljöhistoria, Stockholm: Naturvårdsverket, 2009.

Beskow, Bo, Krokodilens middag, Stockholm: Bonnier, 1969.

Beskow, Elsa, "Herr Klumpedump från Klumpedonien” i Sagobok, 5. uppl., Stockholm: Wahlström \& Widstrand, 1915/1955.

Beskow, Elsa, "Doktor Klokamundus' uppfinning” i Muntergök: Sagobok, Ny utg., Stockholm: Bonnier Carlsen, 1919/1996.

Beskow, Elsa, "När stora blåbärsberget kom till stan" i Muntergök: Sagobok, Ny utg., Stockholm: Bonnier Carlsen, 1919/1996.

Beskow, Elsa, "Den gröna bilen” i Röda bussen och gröna bilen: Bilderbok till Johan från farmor, Stockholm: Bonnier, 1952.

Beskow, Elsa, "Den sönderslagna mjölkflaskan" i Den lilla vävaren, Stockholm: Bonnier, 1954.

Björck, Henrik, Teknikens art och teknikernas grad: Föreställningar om teknik, vetenskap och kultur speglade i debatterna kring en teknisk doktorsgrad, 1900-1927, diss., Kungliga Tekniska högskolan, Stockholm, 1992.

Bjurulf, Veronica, Teknikdidaktik, Stockholm: Norstedt, 2011.

Bolin, Greta \& Zweigbergk, Eva von, Barn och böcker, Stockholm: Kooperativa förbundets bokförl., 1951.

Bolin, Greta, Zweigbergk, Eva von \& Ørvig, Mary, Barn och böcker: En orientering, Stockholm: Rabén \& Sjögren, 1972.

Bourdieu, Pierre, Om televisionen: Följd av journalistikens herravälde, Stockholm: B. Östlings bokförl. Symposion, 1998. 
Bowler, Peter J., The earth encompassed: A history of the environmental sciences, Ny utg., New York: Norton, 2000.

Brown, Lester R., Building a sustainable society, New York: W. W. Norton, 1981.

Bruce, Nils Olof, Svenska folkskolans historia. D. 4. Det svenska folkundervisningsväsendet 1900-1920, utg., Stockholm, 1940.

Brummett, Barry, Techniques of close reading, Los Angeles: SAGE, 2010.

Burman, Anders \& Sundgren, Per, "Inledning. Kampen om bildningen" i Bildning: Texter från Esaias Tegnér till Sven-Eric Liedman, Anders Burman \& Per Sundgren (red.), Göteborg: Daidalos, 2010.

Butterfield, Herbert, The Whig interpretation of history, London: W.W. Norton \& Company, 1931/1965.

Butts, Dennis, "Barbara Hofland: The moral tale and the Industrial Revolution" i Children's literature and social change: Some case studies from Barbara Hofland to Philip Pullman, Cambridge: Lutterworth Press, 2010.

Butts, Dennis, "Introduction" i Children's literature and social change: Some case studies from Barbara Hofland to Philip Pullman, Cambridge: Lutterworth Press, 2010.

Butts, Dennis, "Imperialists of the air: Flying stories 1900-1950" i Children's literature and social change: Some case studies from Barbara Hofland to Philip Pullman, Cambridge: Lutterworth Press, 2010.

Carson, Rachel, Silent spring, 10. pr., Boston, 1962.

Claesson, Silwa, Hallström, Henrik, Kardemark, Wilhelm \& Risenfors, Signhild, "Ricoeurs kritiska hermeneutik vid empiriska studier", Pedagogisk forskning $i$ Sverige, vol. 16(1), 2011, s. 18-35.

Clow, Frederick R., "Cooley's doctrine of primary groups", American Journal of Sociology, vol. 25(3), 1919, s. 326-347.

Clynes, Manfred E. \& Kline, Nathan S., "Cyborg and space”, Astronautics, September 1960, http://web.mit.edu/digitalapollo/Documents/Chapter1 /cyborgs.pdf (läst 20140315).

Clynes, Manfred E. \& Kline, Nathan S., "Cyborgs and space" i The cyborg handbook, C.H. Gray (red.), New York: Routledge, 1995.

Dahlbom, Bo, "En vetenskap om artefakter", VEST: Tidskrift för vetenskapsstudier, 6(4), 1993, s. 53-75. 
Dakers, John R., "Introduction" i Defining technological literacy: Towards an epistemological framework, J. R. Dakers (red.), New York: Palgrave Macmillan, 2006a.

Dakers, John R., "Towards a philosophy for technology education" i Defining technological literacy: Towards an epistemological framework, John R. Dakers (red.), New York: Palgrave Macmillan, 2006b.

Darwin, Charles, "Notebooks", Notebook E, 114, 12 March 1839, http://darwinonline.org.uk/content/frameset?viewtype=text\&itemID $=$ CUL-DAR124.\&pageseq $=($ läst 2014-04-15).

Dennett, Daniel C., "The interpretation of texts, people and other artifacts", Philosophy and Phenomenological Research, vol. 50, 1990, s. 177-194.

Dobson, Andrew, Green political thought, 3. uppl., London: Routledge, 2000.

Dusek, Val, Philosophy of technology. An introduction, Malden, Mass.: Blackwell, 2006.

Edberg, Rolf, Spillran av ett moln: Anteckningar i färdaboken, 2. uppl., Stockholm: Norstedt, 1966.

Edgerton, David, The shock of the old: Technology and global history since 1900, London: Profile Books, 2006.

Edling, Nils, Det fosterländska hemmet: Egnahemspolitik, småbruk och hemideologi kring sekelskiftet 1900, diss., Stockholms universitet, Stockholm: Carlsson, 1996.

Edquist, Samuel, "Blå som himlen och gul som solen: Om vänstern och den svenska nationalismen kring sekelskiftet 1900" i I nationens intresse, Lars Petterson (red.), Historiska institutionen, Uppsala universitet, Uppsala, 1999.

Edström, Vivi \& Erixson, Sven X-et, Uppdrag läsebok: Nils Holgersson, Stockholm: Rabén \& Sjögren, 1996.

Ekholm, Mats, "Den hållbaraste läroplanen - 1919 års undervisningsplan för rikets folkskolor", Vägval i skolans historia: Tidskrift från Föreningen för svensk utbildningshistoria, vol. 6(3-4), 2006, s. 3-5.

Ekman, Tomas, Spår $i$ vägen: Teknikval, politik och spårvägstrafik $i$ Stockholm 1920-2002, diss., Kungliga Tekniska högskolan, Stockholm, 2003.

Elenius, Lars, "Selma Lagerlöf och Norrland: Nationella idealbilder i Nils Holgerssons underbara resa" i Sekelskiftets utmaningar: Essäer om välfärd, utbildning och nationell identitet vid sekelskiftet 1900, Ann-Katrin Hatje (red.), Stockholm: Carlsson, 2002.

Elleström, Lars, Lyrikanalys: En introduktion, Lund: Studentlitteratur, 1999. 
Ellul, Jacques, The technological society, New York: Vintage Books, 1964.

Ellul, Jacques, "The autonomy of technology" i Technology and values: Essential readings, Craig Hanks (red.), Malden, MA: Wiley-Blackwell, 2010.

Engdahl, Boel, "Hungern efter entydighet. Om Ricoeurs både-och och samhällsvetenskapens andra" i Text och existens. Hermeneutik möter samhällsvetenskapen, Staffan Selander \& Per-Johan Ödman (red.), Göteborg: Daidalos, 2005.

Eriksson, Gunnar \& Frängsmyr, Tore, Idéhistoriens huvudlinjer, 4. rev. uppl., Stockholm: Wahlström \& Widstrand, 2004.

Erlandson-Hammargren, Erik, Från alpromantik till hembygdsromantik: Natursynen $i$ Sverige från 1885 till 1915, speglad i svenska turistföreningens årsskrifter och Nils Holgerssons underbara resa genom Sverige, diss., Lunds universitet, Hedemora: Gidlund, 2006.

Ewerman, Anders, "Den informationssociala revolutionen. Historiens cykler och vår tids epokskifte" i Handla! Om förändring, välfärd, arbete, lärande, konsumtion, arkitektur, design, kultur, framtid, Georg von Wright (red.), Stockholm: Nerenius \& Santérus, 1997.

Ferguson, Eugene S., Engineering and the mind's eye, Cambridge, Mass.: MIT Press, 1993.

Forester, Tom, High-tech society: The story of the information technology revolution, Oxford: Basil Blackwell, 1987.

Franssen, Maarten, Lokhorst, Gert-Jan \& van de Poel, Ibo, "Philosophy of technology" i The Stanford encyclopedia of philosophy, [Elektronisk resurs], Edward N. Zalta (red.), Metaphysics Research Lab, Center for the Study of Language and Information, Stanford California: Stanford University, 1995, http://plato.stanford.edu/2013 (läst 2014-02-15).

Frenander, Anders, Debattens vågor: Om politisk-ideologiska frågor i efterkrigstidens svenska kulturdebatt, diss., Göteborgs universitet, Göteborg, 1999.

Friman, Eva, "Tillväxtens gränser" i Då förändras Sverige: 25 experter beskriver drivkrafter bakom utvecklingen, Eric Giertz (red.), Lund: Studentlitteratur, 2008.

From, Jörgen \& Holmgren, Carina, "Hermeneutik och pedagogik", Nordisk Pedagogik, vol. 20(3), 2000, s. 219-229.

Frängsmyr, Tore, Framsteg eller förfall: Framtidsbilder och utopier $i$ västerländsk tanketradition, 2. uppl., Stockholm: Allmänna förl., 1990.

Frängsmyr, Tore, Svensk idéhistoria: Bildning och vetenskap under tusen år. D. 2, 1809-2000, Stockholm: Natur och Kultur, 2000. 
Furuland, Lars, Lindberger, Örjan \& Örvig, Mary, Barnlitteratur i Sverige: Läsning för barn och barnboksprogram, Stockholm: Wahlström \& Widstrand, 1970.

Furuland, Lars, "Ljus över landet. Elektrifieringen och litteraturen" i Ljus över landet och andra litteratursociologiska uppsatser, Hedemora: Gidlund, 1991.

Galef, David, “Crossing over: Authors who write both children's and adults' fiction”, Children's Literature Association Quarterly, vol. 20(1), 1995, s. 29-35.

Garnert, Jan, Anden i lampan: Etnologiska perspektiv på ljus och mörker, diss., Stockholms universitet, Stockholm: Carlsson, 1993.

Ginner, Thomas, Den bildade arbetaren: Debatten om teknik, samhälle och bildning inom arbetarnas bildningsförbund 1945-1970, diss., Linköpings universitet, Linköping, 1988.

Godhe, Michael, Morgondagens experter: Tekniken, ungdomen och framsteget $i$ populärvetenskap och science fiction i Sverige under det långa 1950-talet, diss., Linköpings universitet, Stockholm: Carlsson, 2003.

Granath, Emma, Pettson \& Findus mucklor. En narratologisk studie av text och bild i Sven Nordqvists Pettsonböcker, C-uppsats, Södertörns högskola, Huddinge, 2007.

Greene, Graham, Det lilla tåget, Malmö: Bergh, 1974.

Gren, Leif, "Historiska tillbakablickar" i Samhällsförändringar och vården av natur och kultur: En debattskrift om natur-och kulturmiljövårdens utveckling under 100 år, [elektronisk resurs], Leif Gren (red.), Riksantikvarieämbetet, Stockholm, 2010, http://www.raa.se/publicerat/9789172095717.pdf (läst 2011-01-08).

Grenby, Matthew. O., "Basic children's literature research skills" i Children's literature studies: A research handbook, Kimberley Reynolds \& Matthew O. Grenby, (red.), Basingstoke: Palgrave Macmillan, 2011.

Gustavsson, Bengt, "Kunskapandets mångfald - från enhet till fragment" i Kunskapande metoder inom samhällsvetenskapen, Bengt Gustavsson (red.), Lund: Studentlitteratur, 2004, s. 13-14.

Gustavsson, Bernt, ’Bildning i vår tid”, Högskoleverket, www.hsv.se/bildning (läst 2014-09-20).

Gyberg, Per, "Teknikens janusansikte" i Världens gång - teknikens utveckling: Om samspelet mellan teknik, människa och samhälle, Per Gyberg \& Jonas Hallström (red.), Lund: Studentlitteratur, 2009. 
Gyberg, Per \& Hallström, Jonas, "Inledning" i Världens gång - teknikens utveckling: Om samspelet mellan teknik, människa och samhälle, Per Gyberg \& Jonas Hallström (red.), Lund: Studentlitteratur, 2009.

Habermas, Jürgen, "Teknik och vetenskap som ideologi” i Den rationella övertygelsen: En antologi om legitimitet, kris och politik, Stockholm: Akademilitteratur, 1984.

Hagberg, Jan-Erik, Tekniken i kvinnornas händer: Hushållsarbete och hushållsteknik under tjugo- och trettiotalen, diss., Linköpings universitet, Malmö: Liber Förlag, 1986.

Hagberg, Jan-Erik, Livet genom tekniklandskapet: Livslopp, åldrande och vardagsteknikens förändring, Institutet för forskning om äldre och åldrande, Linköpings universitet, Norrköping, 2008.

Hagberg, Jan-Erik, "Att lära i teknikens rum och landskap: En metadidaktisk betraktelse" i Världens gång - teknikens utveckling: Om samspelet mellan teknik, människa och samhälle, Per Gyberg \& Jonas Hallström (red.), Lund: Studentlitteratur, 2009.

Hagberg, Jan-Erik \& Hultén, Magnus, Skolans undervisning och elevers lärande $i$ teknik: Svensk forskning i internationell kontext, Stockholm: Vetenskapsrådet, 2005.

Hagman, Olle. Bilen, naturen och det moderna: Om natursynens omvandlingar $i$ det svenska bilsamhället, diss., Göteborgs universitet, Göteborg, 1999.

Hallberg, Kristin, "Litteraturvetenskapen och bilderboksforskningen", Tidskrift för litteraturvetenskap, vol. 3-4, 1982, s. 163-168.

Hallberg, Kristin, 'Kom an, Alfons Åberg! En studie av Gunilla Bergströms bilderbokssvit" i Barnlitteraturanalyser, Maria Andersson \& Elina Druker (red.), Lund: Studentlitteratur, 2008.

Hallström, Jonas. Constructing a pipe-bound city: A history of water supply, sewerage, and excreta removal in Norrköping and Linköping, Sweden, 18601910, diss., Linköpings universitet, Linköping, 2002.

Hallström, Jonas, “Technology, social space and environmental justice in Swedish cities: Water distribution to suburban Norrköping and Linköping, 1860-90", Urban History, vol. 32(3), 2005, s. 413-433.

Hallström, Jonas, "Systemteori och teknik. En introduktion till stora tekniska system" i Världens gång - teknikens utveckling: Om samspelet mellan teknik, människa och samhälle, Per Gyberg \& Jonas Hallström (red.), Lund: Studentlitteratur, 2009. 
Hallström, Jonas, "Teknikhistoria öppnar upp vidare perspektiv på tekniken" i Ginners teknikdidaktiska handbok: Några teser om teknik, skola och samhälle, Jonas Hallström \& Claes Klasander (red.), Linköping: Linköping University Press, 2013.

Hallström, Jonas \& Gyberg, Per, "Technology in the rear-view mirror: How to better incorporate the history of technology into technology education", International Journal of Technology \& Design Education, vol. 21(1), 2011, s. 3-17.

Hallström, Jonas, Hultén, Magnus \& Lövheim, Daniel, "Inledning" i Teknik som kunskapsinnehåll i svensk skola 1842-2010, Jonas Hallström, Magnus Hultén \& Daniel Lövheim (red.), Möklinta: Gidlund, 2013.

Hammar, Stina, Elsa Beskow: En biografi, Stockholm: Bonnier, 1958.

Hammar, Stina, Solägget: Fantasi och verklighet i Elsa Beskows konst, Stockholm: Bonnier, 2002.

Hammarström, Gunhild, "Att studera värden och värdeförändringar: Ett konkret exempel från en tregenerationsundersökning" i I tider av uppbrott, Jonas Anshelm (red.), Stockholm: B. Östlings bokförl. Symposion, 1995.

Hansson, Staffan, Teknikhistoria: Om tekniskt kunnande och dess betydelse för individ och samhälle, Lund: Studentlitteratur, 1996.

Hansson, Staffan, Den skapande människan: Om människan och tekniken under 5000 år, Lund: Studentlitteratur, 2002.

Haraldsson, Désirée. Skydda vår natur! Svenska Naturskyddsföreningens framväxt och tidiga utveckling, diss., Lunds universitet, Lund, 1987.

Haraway, Donna Jeanne, “A cyborg manifesto: Science, technology, and socialistfeminism in the late twentieth century" i Simians, cyborgs and women: The reinvention of nature, London: Free Associations Books, 1991.

Hellsing, Lennart, Tankar om barnlitteraturen, Ny utg., Stockholm: Rabén \& Sjögren, 1963/1999.

Herschbach, Dennis, "From industrial arts to technology education: The search for direction”, Journal of Technology Studies, vol. 23(1), 1997, s. 24-32.

Hellström, Martin, Förpackningens förvandlingar: Konsumtion och karneval $i$ barnboken, diss., Linköpings universitet, Stockholm: Carlsson, 2011.

Hintz, Eric S., "Heroes of the laboratory and the workshop: Inventions and technology in books for children, 1850-1950" i Enterprising youth: Social values and acculturation in nineteenth-century American children's literature, Monika M. Elbert (red.), New York: Routledge, 2008. 
Hjorth, Ingemar, "Natursyn i förändring: Från natur med själ till ekosystem” i Vetenskapens ansikten, Hans Albin Larson (red.), Jönköping: Jönköping University Press, 1997.

Hughes, Thomas Parke, "The seamless web: Technology, science, etcetera, etcetera", Social Studies of Science, vol. 16(2), 1986, s. 281-292.

Hughes, Thomas Parke, "The evolution of large technological systems" i The social construction of technological systems: New directions in the sociology and history of technology, W. E. Bijker, T. P. Hughes \& T.J. Pinch (red.), Cambridge Mass.: MIT Press, 1987.

Hughes, Thomas Parke, "Technological momentum” i Does technology drive history? The dilemma of technological determinism, Merritt Roe Smith \& Leo Marx (red.), Cambridge, Mass.: MIT Press, 1994.

Hughes, Thomas Parke, Human-built world: How to think about technology and culture, Chicago: University of Chicago Press, 2004.

Hult, Jan, "Bondeland blir industriland: 1870-1914" i Svensk teknikhistoria, Jan Hult (red.), Hedemora: Gidlund, 1989a.

Hult, Jan, ”Järn, ånga och ingeniörer: 1815-1870" i Svensk teknikhistoria, Jan Hult (red.). 1989, Hedemora: Gidlund, 1989b.

Hult, Jan, "Tekniken mitt ibland oss: 1914-1970" i Svensk teknikhistoria, Jan Hult (red.), Hedemora: Gidlund, 1989c.

Hultén, Magnus. Naturens kanon: Formering och förändring av innehållet i folkskolans och grundskolans naturvetenskap 1842-2007, diss., Stockholms universitet, Stockholm, 2008.

Hård, Mikael \& Jamison, Andrew, Hubris and hybrids: A cultural history of technology and science, New York: Routledge, 2005.

Hägg, Göran, "Det nygamla riket: Det industriella genombrottets avspegling i svenskt kulturliv" i Den välsignade tillväxten: Tankelinjer kring ett århundrade av kapitalism, teknik, kultur och vetenskap, Peter Elmlund \& Kay Glans (red.), Stockholm: Natur och Kultur, 1998.

Hägg, Göran, Välfärdsåren: Svensk historia 1945-1986, Stockholm: Wahlström \& Widstrand, 2005.

Högman, Kurt \& Schwartzkopf, Karl-Aage, När järnvägen kom till Stockholm: Ett hundraårsminne, Stockholm: Järnvägsstyrelsen, 1960.

Ihde, Don, "The designer fallacy and technological imagination" i Defining technological literacy: Towards an epistemological framework, John R. Dakers (red.), New York: Palgrave Macmillan, 2006. 
Ingelstam, Lars, Teknikpolitik: En bok om tekniken, människan och socialismen, Stockholm: Tiden, 1978.

Ingelstam, Lars, "Varför är tekniska system intressanta?" i Världens gång - teknikens utveckling: Om samspelet mellan teknik, människa och samhälle, Per Gyberg \& Jonas Hallström (red.), Lund: Studentlitteratur, 2009.

Ingelstam, Lars, System: Att tänka över samhälle och teknik, 2. uppl., Eskilstuna: Statens energimyndighet, 2012.

Ingerman, Åke, "Kunskaper, engagemang och handling" i På spaning efter teknisk bildning, Åke Ingerman, Karin Wagner \& Ann-Sofie Axelsson (red.), Stockholm: Liber Förlag, 2009.

Ingerman, Åke, Wagner, Karin \& Axelsson, Ann-Sofie, "Till läsaren” i På spaning efter teknisk bildning, Åke Ingerman, Karin Wagner \& Ann-Sofie Axelsson (red.), Stockholm: Liber Förlag, 2009.

Ingersoll, Earl G., Representations of science and technology in British literature since 1880, New York: P. Lang, 1992.

Johannisson, Karin, ’Det sköna i det vilda: En aspekt på naturen som mänsklig resurs" i Paradiset och vildmarken: Studier kring synen på naturen och naturresurserna, Tore Frängsmyr (red.), Stockholm: Liber Förlag, 1984.

Johansson, Alf W. (red.), Vad är Sverige? Röster om svensk nationell identitet, Stockholm: Prizma, 2001.

Kaijser, Arne, "Ledningen och makten" i Teknokrati, arbete, makt, Svante Beckman (red.), Stockholm: Carlsson, 1990.

Kaijser, Arne, I fädrens spår: Den svenska infrastrukturens historiska utveckling och framtida utmaningar, Stockholm: Carlsson, 1994.

Kaijser, Arne, "Snärjda i systemen?" i Spänningsfält: Tekniken - politiken - framtiden, Lennart Sturesson (red.), Stockholm: Carlsson, 2002.

Kaijser, Arne, "Den hjälpande handen: Staten och infrastrukturen" i Då förändras Sverige: 25 experter beskriver drivkrafter bakom utvecklingen, Eric Giertz (red.), Lund: Studentlitteratur, 2008.

Kelly, Kevin, What technology wants, New York: Viking, 2010.

Kelly, R. Gordon, Mother was a lady: Self and society in selected American children's periodicals, 1865-1890, Westport, Conn., 1974.

Kemp, Peter \& Kristensson, Bengt, "Inledning" i Från text till handling: En antologi om hermeneutik, 4. uppl., Stockholm: B. Östlings bokförl. Symposion, 1993.

Key, Ellen, Barnets århundrade: Studie. 2, Stockholm: Bonnier, 1900. 
Kjersén Edman, Lena. I ungdomsrevoltens tid: Svensk ungdomsbok och dess mottagande åren kring 1968, diss., Umeå universitet, Umeå, 1990.

Klasander, Claes, Talet om tekniska system: Förväntningar, traditioner och skolverkligheter, diss., Linköpings universitet, Linköping, 2010.

Kline, Ronald, "Where are the cyborgs in cybernetics?", Social Studies of Science, vol. 39(3), 2009, s. 331-362.

Klingberg, Göte. Svensk barn- och ungdomslitteratur 1591-1839: En pedagogikhistorisk och bibliografisk översikt, diss., Uppsala universitet, Stockholm: Natur och Kultur, 1964.

Klingberg, Göte, Sekelskiftets barnbokssyn och Barnbiblioteket Saga, Stockholm, 1966.

Klingberg, Göte, Barn- och ungdomslitteraturen, Stockholm: Natur och Kultur, 1970 .

Kranzberg, Melvin, "Technology and history: 'Kranzberg's Laws", Technology and Culture, vol. 27(3), 1986, s. 544-560.

Kristensson Uggla, Bengt, Kommunikation på bristningsgränsen: En studie i Paul Ricoeurs projekt, diss. Lunds universitet, Stockholm; B. Östlings bokförl. Symposion, 1994.

Kylhammar, Martin. Maskin och idyll: Teknik och pastorala ideal hos Strindberg och Heidenstam, diss., Linköpings universitet, Malmö: Liber Förlag, 1985.

Kylhammar, Martin, "Teknikdebattens grammatik" i I teknikens backspegel: Antologi i teknikhistoria, Bosse Sundin (red.), Stockholm: Carlsson, 1987.

Kåreland, Lena. Gurli Linders barnbokskritik: Med en inledning om den svenska barnbokskritikens framväxt, diss., Stockholms universitet, Stockholm: Bonnier, 1977.

Kåreland, Lena, "40-tals-modernismen och barnboken - vad har de gemensamt?" i Konsten att berätta för barn, Centrum för barnkulturforskning, Stockholms universitet, Stockholm, 1996.

Kåreland, Lena, Modernismen i barnkammaren: Barnlitteraturens 40-tal, Stockholm: Rabén \& Sjögren, 1999.

Kåreland, Lena, 'Barnlitteraturens utveckling i Sverige”, Litteraturbanken, 2008, http://litteraturbanken.se/\#!/presentationer/specialomraden/BarnlitteraturensUt vecklingISverige.html (läst 2010-10-10).

Kåreland, Lena, Inga gåbortsföremål: Lekfull litteratur och vidgad kulturdebatt $i$ 1960- och 70-talens Sverige, Göteborg: Makadam, 2009.

Kåreland, Lena, Barnboken i samhället, Lund: Studentlitteratur, 2013. 
Lagerlöf, Selma, Nils Holgerssons underbara resa genom Sverige. Bd 1, Stockholm: Bonnier, 1908.

Lagerlöf, Selma, Nils Holgerssons underbara resa genom Sverige. Bd 2, Stockholm: Bonnier, 1908.

Lagerlöf, Selma, Brev i urval / 1, 1871-1902, Lund, 1967.

Lagerroth, Erland, Landskap och natur i Gösta Berlings saga och Nils Holgersson, Stockholm: Bonnier, 1958.

Lakoff, George \& Johnson, Mark, Philosophy in the flesh: The embodied mind and its challenge to western thought, New York: Basic Books, 1999.

Lakoff, George \& Johnson, Mark, Metaphors we live by, Chicago: Univ. of Chicago Press, 2003.

Latour, Bruno, Reassembling the social: An introduction to actor-network-theory, Oxford: Oxford University Press, 2005.

Lawrence, David Herbert, Studies in classic American literature, London: Heineman, 1924/1971.

Layton, David, "A school subject in the making? The search for fundamentals" i Innovations in science and technology education, vol. 5, David Layton (red.), UNESCO, Paris, 1994.

Lennerhed, Lena, "Det är rätt att göra uppror!"” i Europas idéhistoria. 1900-talet. Framstegets arvtagare, Nils Runeby (red.), Stockholm: Natur och Kultur, 1998.

Lévi-Strauss, Claude, The savage mind, London: The University of Chicago Press, $1962 / 1973$.

Liedman, Sven-Eric, I skuggan av framtiden: Modernitetens idéhistoria, Stockholm: Bonnier, 1999.

Liedman, Sven-Eric, Ett oändligt äventyr: Om människans kunskaper, Stockholm: Bonnier, 2001.

Linder, Gurli, Våra barns fria läsning, Stockholm: Norstedt, 1916.

Lindgren, Eva, Samhällsförändring på väg: Perspektiv på den svenska bilismens utveckling mellan 1950 och 2007, diss., Umeå universitet, Umeå, 2010.

Lindgren, Michael H., Christopher Polhems testamente. Berättelsen om ingenjören och pedagogen som ville förändra Sverige, Stockholm: Nielsen \& Norén Förlag, 2011.

Lindqvist, Svante, "Vad är teknik?" i I teknikens backspegel: Antologi i teknikhistoria, Bosse Sundin (red.), Stockholm: Carlsson, 1987. 
Lindqvist, Svante, "Change in the technological landscape: The temporal dimension in the growth and decline of large technological systems" i Economics of technology, Ove Granstrand (red.), Amsterdam: Elsevier, 1994.

Linnér, Björn-Ola, Att lära för överlevnad: Utbildningsprogrammen och miljöfrågorna 1962-2002, Lund: Arkiv, 2005.

Lundgren, Anders, "Geologin och jordens tillgångar. Vetenskap och attityder vid 1800-talets slut" i Paradiset och vildmarken: Studier kring synen på naturen och naturresurserna, Tore Frängsmyr (red.), Stockholm: Liber Förlag, 1984.

Lundgren, Lars J., Staten och naturen: Naturskyddspolitik i Sverige 1869-1935. D. 1, 1869-1919, Brottby: Kassandra, 2009.

Lundin, Per, Bilsamhället: Ideologi, expertis och regelskapande i efterkrigstidens Sverige, diss., Kungliga Tekniska högskolan, Stockholm, 2008.

Magnusson, Lars, "Det nya riket: Industrialismens genombrott i Sverige" i Den välsignade tillväxten: Tankelinjer kring ett århundrade av kapitalism, teknik, kultur och vetenskap, Peter Elmlund \& Kay Glans (red.), Stockholm: Natur och Kultur, 1998.

Martinson, Harry, Aniara: En revy om människan i tid och rum, Stockholm: Bonnier, 1956.

Marx, Leo, The machine in the garden: Technology and the pastoral ideal in America, New York: Oxford Univ. Press, 1964.

Marx, Leo, The pilot and the passenger: Essays on literature, technology, and culture in the United States, New York: Oxford Univ. Press, 1988.

Marx, Leo, "The idea of 'technology' and postmodern pessimism" i Does technology drive history? The dilemma of technological determinism, Merritt Roe Smith \& Leo Marx (red.), Cambridge, Mass.: MIT Press, 1994.

McCannon, John, "Technological and scientific utopias in Soviet children's literature, 1921-1932”, Journal of Popular Culture, vol. 34(4), 2001, s. 153-169.

Mellström, Ulf, "Män i teknikens värld" i Världens gång - teknikens utveckling: Om samspelet mellan teknik, människa och samhälle, Per Gyberg \& Jonas Hallström (red.), Lund: Studentlitteratur, 2009.

Melosi, Martin, "The automobile and the environment in American history. Automobil in American life and society", University of Michigan-Dearborn, http://www.autolife.umd.umich.edu/Environment/E_Overview/E_Overview1. htm (läst 2014-12-14).

Merchant, Carolyn, The death of nature. Women, ecology and the scientific revolution, Ny utg., San Francisco: Harper \& Row, 1989. 
Merchant, Carolyn, Radical ecology: The search for a livable world, New York: Routledge, 1992.

Mitcham, Carl, Thinking through technology: The path between engineering and philosophy, Chicago: Univ. of Chicago Press, 1994.

Morell, Mats, "Jordbruket och industriomvandlingen" i Då förändras Sverige: 25 experter beskriver drivkrafter bakom utvecklingen, E. Giertz (red.), Lund: Studentlitteratur, 2008.

Mumford, Lewis, Technics and civilization, 1. Harbinger books ed., New York: Harcourt, Brace \& World, 1934/1963.

Mumford, Lewis, "What is a city?" i The city reader, Richard T. LeGates \& Frederic Stout (red.), New York: Routledge, 1937/2011.

Mumford, Lewis, Stadskultur, Stockholm: Kooperativa förbundet, 1942.

Mumford, Lewis, The city in history: Its origins, its transformations, and its prospects, New York: Harcourt Brace Jovanovich, 1961.

Mumford, Lewis, "Authoritarian and democratic technics", Technology and Culture, vol. 5(1), 1963, s. 1-8.

Mumford, Lewis, "Utopia, the city and the machine", Daedalus, vol. 94(2), 1965, s. 271-292.

Mumford, Lewis, The myth of the machine. Vol. 1. Technics and human development, New York: Harcourt Brace Jovanovich, 1967.

Mählqvist, Stefan, Böcker för svenska barn 1870-1950: En kvantitativ analys av barn- och ungdomslitteratur i Sverige, diss., Uppsala universitet, Stockholm: Gidlund, 1977.

Mählqvist, Stefan, Biggles i Sverige: En litteratursociologisk studie av W. E. Johns Bigglesböcker, Stockholm: Gidlund, 1983.

Määttä, Jerry. Raketsommar: Science fiction i Sverige 1950-1968, diss., Uppsala universitet, Lund: Ellerström, 2006.

Määttä, Jerry, "Från flygkamrater till rymdrevolutionärer: Om Sven Wernströms tidigaste science fiction", Barnboken. Journal of Children's Literature Research, vol. 35, 2012, s. 1-26, http://barnboken.net/index.php/clr/article/view/132 (läst 2013-02-02).

Nikolajeva, Maria, Bilderbokens pusselbitar, Lund: Studentlitteratur, 2000.

Nikolajeva, Maria, Barnbokens byggklossar, Lund: Studentlitteratur, 2004.

Nilson, Margareta \& Sjöstrand, Birgitta, Max Lundgren och Sven Wernström: Två författarbiografier, Examensarbete, Bibliotekshögskolan, Borås, 1974. 
Nilsson, Göran B., "Historia som humaniora" i Den lycklige humanisten: Tio offensiva essäer, Stockholm: Carlsson, 1990.

Nix, Angelika, Das Kind des Jahrhunderts im Jahrhundert des Kindes: Zur Entstehung der phantastischen Erzählung in der schwedischen Kinderliteratur, Freiburg im Breisgau, Rombach, 2002.

Nordlund, Christer, "Naturen och det nationella i det tidiga 1900-talets Sverigelitteratur" i Sekelskiftets utmaningar: Essäer om välfärd, utbildning och nationell identitet vid sekelskiftet 1900, Ann-Katrin Hatje, (red.), Stockholm: Carlsson, 2002.

Nordqvist, Sven, Pannkakstårtan, Bromma: Opal, 1984.

Nordqvist, Sven, Rävjakten, Bromma: Opal, 1986.

Nordqvist, Sven, Pettson får julbesök, Bromma: Opal, 1988.

Nordqvist, Sven, Kackel i grönsakslandet, Bromma: Opal, 1990.

Nordqvist, Sven, Pettson tältar, Bromma: Opal, 1992.

Nordqvist, Sven, Tomtemaskinen, Stockholm: Opal, 1994.

Nordqvist, Sven, När Findus var liten och försvann, Stockholm: Opal, 2001.

Nordqvist, Sven, Findus flyttar ut, Stockholm: Opal, 2012.

Norman, Donald A., The design of everyday things, New York: Basic Books, 2002.

Norström, Per, Technology education and non-scientific technological knowledge, Lic.-avh., Architecture and the Built Environment, Kungliga Tekniska högskolan, Stockholm, 2011.

Nyblom, Andreas, Den tekniska sagan. Samtidsförankring och framtidsvision $i$ fyra svenska science fiction-romaner 1911-1932, Magisteruppsats, Uppsala universitet, Uppsala, 2001.

Nyblom, Andreas, "Giv åt släktet gosselynne, hoppfull håg och fantasi: Populärförfattaren Otto Witt ville med sina vetenskapliga romaner bereda plats åt fantasin i samtiden", Tvärsnitt, vol. 24(3), 2002a, s. 14-25.

Nyblom, Andreas, "Svart på Witt. En svensk Jules Verne i glömska", Dast Magazine, nr. 3, 2002b, http://www.dast.nu/artikel/svart-pa-witt-en-svensk-julesverne-i-glomska (läst 2010-04-05).

Nye, David E., American technological sublime, Cambridge Mass.: MIT Press, 1994.

Oldenziel, Ruth, Making technology masculine: Men, women, and modern machines in America, 1870-1945, Amsterdam: Amsterdam Univ. Press, 1999. 
Oldenziel, Ruth, "Introduction: Signifying semantics for a history of technology", Technology and Culture, vol. 47(3), 2006, s. 477-485.

Pallin, Erik, Flygande människor. Populär översikt av luftseglingskonstens utveckling under dess genombrottsår, Stockholm: Bonnier, 1909.

Palmstierna, Hans \& Palmstierna, Lena, Plundring, svält, förgiftning, Stockholm: Rabén \& Sjögren, 1967.

Pandora, Katherine, “The children's republic of science in the Antebellum literature of Samuel Griswold Goodrich and Jacob Abbot" i National identity: The role of science and technology, Carol E. Harrison \& Ann Johnson (red.), Chicago: University of Chicago Press, 2009.

Pepper, David, Eco-socialism: From deep ecology to social justice, London: Routledge, 1993.

Petroski, Henry, The evolution of useful things, New York: Knopf, 1992a.

Petroski, Henry, To engineer is human: The role of failure in successful design, 1. Vintage Books ed., New York: Vintage Books, 1992b.

Pitt, Joseph C., “'Guns don't kill, people kill'; Values in and/or around technologies" i The moral status of technical artefacts, [Elektronisk resurs], Peter. Kroes \& Peter-Paul Verbeek (red.), Dortrecht: Springer, 2014.

Reynolds, Kimberley, Radical children's literature: Future visions and aesthetic transformations in juvenile fiction, New York: Palgrave Macmillan, 2007.

Reynolds, Kimberley, “Introduction" i Children's literature studies: A research handbook, Kimberley Reynolds \& Matthew O. Grenby, (red.), Basingstoke: Palgrave Macmillan, 2011.

Rhedin, Ulla, Bilderboken: På väg mot en teori, 2. rev. uppl., Stockholm: Alfabeta, 2001.

Ricoeur, Paul, "The model of the text: Meaningful action considered as a text", New Literary History, vol. 5(1), 1973, s. 91-117.

Ricoeur, Paul, "The hermeneutical function of distanciation" i Hermeneutic and the human science: Essays on language, action and interpretation, John B. Thompson (red.), Cambridge: Cambridge University Press, 1981.

Ricoeur, "Förklara och förstå. Text - handling - historia" i Från Text till handling: En antologi om hermeneutik, 4. uppl., Stockholm: B. Östlings bokförl. Symposion, 1993a.

Ricoeur, "Hermeneutik och ideologikritik", i Från Text till handling: En antologi om hermeneutik, 4. uppl., Stockholm: B. Östlings bokförl. Symposion, 1993b. 
Ricoeur, Paul, "Vad är en text?" i Från Text till handling: En antologi om hermeneutik, 4. uppl., Stockholm: B. Östlings bokförl. Symposion, 1993c.

Ross Johnston, Rosemary, "Reader response" i Children's literature studies: A research handbook, Kimberley Reynolds \& Matthew O. Grenby (red.), Basingstoke: Palgrave Macmillan, 2011.

Rousseau, Jean-Jacques, Émile, Project Gutenberg. E-bok, 2004 (1762), http://www.gutenberg.org/cache/epub/5427/pg5427.html (läst 2013-09-30).

Rowe, Stan J., "Ecocentrism: The responsive chord", The Trumpeter, vol. 11(2), 1994, http://trumpeter.athabascau.ca/index.php/trumpet/article/view/330/508 (läst 2013-11-12).

Rådberg, Johan, "Mellan humanism och futurism: 1900-talets stadsbyggande" i Den välsignade tillväxten: Tankelinjer kring ett århundrade av kapitalism, teknik, kultur och vetenskap, Peter Elmlund \& Kay Glans (red), Stockholm: Natur och Kultur, 1998.

Sandell, Klas \& Sörlin, Sverker, "Naturen som ungdomsfostrare" i Friluftshistoria: från "härdande friluftslif" till ekoturism och miljöpedagogik: teman i det svenska friluftslivets historia, Klas Sandell \& Sverker Sörlin (red.), Stockholm: Carlsson, 2000.

Sandin, Bengt, Hemmet, gatan, fabriken eller skolan. Folkundervisning och barnuppfostran i svenska städer 1600-1850, diss., Lunds universitet, Lund: Studentlitteratur, 1986.

Sandin, Bengt, "Barndomens omvandling - från särart till likart" i Barnets bästa En antologi om barndomens innebörder och välfärden organisation, B. Sandin \& G. Halldén (red.), Eslöv: B. Östlings bokförl. Symposion, 2003.

Savenkova, Larisa, Barnlitteratur för lärande för hållbar utveckling. En ekokritisk textanalys av barnboksserien om Pettson och Findus, Uppsats för yrkesexamina på avancerad nivå, Uppsala universitet, 2011.

Schatzberg, Eric, "Technik comes to America. Changing meaning of technology before 1930", Technology and Culture, vol. 47(3), 2006, s. 486-512.

Schivelbusch, Wolfgang, The railway journey: The industrialization of time and space in the $19^{\text {th }}$ century, Berkley Calif.: University of California Press, 1986.

Schmidl, Helen, Från vildmark till grön ängel: Receptionsanalyser av läsning $i$ åttonde klass, diss., Uppsala universitet, Göteborg: Makadam, 2008.

Schwarcz, H. Joseph, "Machine animism in modern children's literature”, The Library Quarterly, vol. 37(1), 1967, s. 78-95.

Schwartzkopf, Karl-Aage, Familjen Tuff-Tuff, 3 uppl., Stockholm: Geber, 1949/1966. 
Schwartzkopf, Karl-Aage, Hemma hos familjen Tuff-Tuff, 2. uppl., Stockholm: Geber, 1950/1966.

Schwartzkopf, Karl-Aage, Höghuset vid myren, Stockholm: Bonnier, 1965.

Schwartzkopf, Karl-Aage, Höghuset vandrar norrut, Stockholm: Bonnier, 1969.

Schön, Ebbe, Älvor, vättar och andra väsen: En bok om gammal folktro, Stockholm: Rabén \& Sjögren, 1986.

Selander, Staffan \& Ödman, Per-Johan, "Inledning" i Text och existens. Hermeneutik möter samhällsvetenskapen, Staffan Selander \& Per-Johan Ödman (red.), Göteborg: Daidalos, 2005.

Selander, Staffan, "Didaktik - undervisning och lärande" i Lärande, skola, bildning: [Grundbok för lärare], Ulf P. Lundgren, Roger Säljö \& Caroline Liberg (red.), Stockholm: Natur och Kultur, 2010.

Shelley, Mary Wollstonecraft, Frankenstein, or, the modern Prometheus, Ware: Wordsworth, 1818/1993.

Sjöberg, Mats, Barnen, skogen och skolan: Om skolelevers plantering av skog $i$ Sverige ca 1880-1960, Kungl. Skogs- och lantbruksakademien, Stockholm, 2011.

Sjögren, Margareta, Elsa Beskow och hennes värld, Stockholm: Bonnier fakta, 1983.

Skovdahl, Bernt, Förlorad kontroll: Den ifrågasatta framstegstanken, Stockholm: Dialogos, 2010.

Smith, Merritt Roe, "Technological determinism in American culture" i Does technology drive history? The dilemma of technological determinism, Merritt Roe Smith \& Leo Marx (red.), Cambridge, Mass.: MIT Press, 1994.

Smith, Michael L., "Recourse of empire: Landscapes of progress in technological America" i Does technology drive history? The dilemma of technological determinism, Merritt Roe Smith \& Leo Marx (red.), Cambridge, Mass.: MIT Press, 1994.

Statens Vattenfallsverk, Vattenfall under 75 år: (1909-1984), Vällingby: Statens Vattenfallsverk, 1984.

Stenmark, Mikael, Miljöetik och miljövård: Miljöfrågornas värderingsmässiga dimension, Lund: Studentlitteratur, 2000.

Stolare, Martin, Kultur och natur: Moderniseringskritiska rörelser i Sverige 19001920, diss. Göteborgs universitet, Göteborg, 2003.

Strahl, Christer, Nationalism \& socialism. Fosterlandet $i$ den politiska idédebatten 1890-1914, diss. Lunds universitet, Lund: Liber Förlag/Gleerup, 1983. 
Strömstedt, Margareta, "Från nonsens till crazy" i Läsning för barn: Orientering $i$ dagens barnlitteratur, Margareta Strömstedt \& Gunila Ambjörnsson (red.), Stockholm: Bonnier fakta, 1983.

Sundbärg, Gustav, Tankar om utvandringsfrågan, Stockholm: P.A. Nordstedts Förlag \& Söner, 1913.

Sundberg, Agneta, Jakten på det goda livet: Förortslinjen - från utopi till verklighet, diss., Kungliga Tekniska högskolan, Stockholm, 1992.

Sundin, Bosse, Ingenjörsvetenskapens tidevarv: Ingenjörsvetenskapsakademin, pappersmassekontoret, Metallografiska Institutet och den teknologiska forskningen i början av 1900-talet, diss., Umeå universitet, Umeå, 1981.

Sundin, Bosse, "Ljus och jord! Natur och kultur på storgården” i Paradiset och vildmarken: Studier kring synen på naturen och naturresurserna, Tore Frängsmyr (red.), Stockholm: Liber Förlag, 1984.

Sundin, Bosse, Den kupade handen: Historien om människan och tekniken, 2., utök. uppl., Stockholm: Carlsson, 2006.

Sundkvist, Maria, De vanartade barnen: Mötet mellan barn, föräldrar och Norrköpings barnavårdsnämnd 1903-1925, diss., Linköpings universitet, Uppsala: Hjelm, 1994.

Sundmark, Björn, "Citizenship and children's identity in The wonderful adventures of Nils and scouting for boys", Children's Literature in Education, vol. 40(2), 2009, s. 109-119.

Sundmark, Björn, "Sven Wernström", Barnboken - tidskrift för barnlitteraturforskning/Journal of Children's Literature Studies, vol. 35, 2012, s. 1-2. http://dx.doi.org/10.3402/clr.v35i0.19991 (läst 2013-01-20).

Swahn, Sven Christer, "Karl-Aage Schwartzkopf" i De läses än. Från Bertil Almqvist till Anna Lisa Wärnlöf: Porträtt av tolv svenska barnboksförfattare, Charlotte Brattström (red.), Lund: Bibliotekstjänst, 1987.

Sörlin, Sverker, "Norrlandsfrågan: Idéer och debatt i samband med det industriella genombrottet" i Paradiset och vildmarken: Studier kring synen på naturen och naturresurserna, Tore Frängsmyr (red.), Stockholm: Liber Förlag, 1984.

Sörlin, Sverker, Framtidslandet: Debatten om Norrland och naturresurserna under det industriella genombrottet, diss., Umeå universitet, Stockholm: Carlsson, 1988.

Sörlin, Sverker, Naturkontraktet: Om naturumgängets idéhistoria, Stockholm: Carlsson, 1991. 
Sörlin, Sverker, "Natursyner" i Humanekologi, Kurt Viking Abrahamsson, JanErik Hällgren, Tage Sundström \& Sverker Sörlin (red.), Stockholm: Carlsson, 1999.

Tengström, Emin, Bilen \& människan i svensk prosa och poesi, Stockholm: Stockholmia, 2009.

Thacker, Deborah Cogan \& Webb, Jean, Introducing children's literature: From romanticism to postmodernism, London: Routledge, London, 2002.

Thunman, Noriko, "Selma Lagerlöf i Japan" i Selma Lagerlöf seen from abroad: Ett symposium i Vitterhetsakademien den 11 och 12 september 1997, Stockholm: Kungl. Vitterhets-, historie- och antikvitetsakademien, 1998.

Tigerstedt, Eugène Napoleon, Svensk litteraturhistoria, Stockholm: Natur och Kultur, 1960.

Torstendahl, Rolf, 'Ingenjörernas makt" i Teknokrati, arbete, makt, Svante Beckman (red.), Stockholm: Carlsson, 1990.

Townsend, John Rowe, A sense of story: Essays on contemporary writers for children, London: Longman, 1971.

Urban, Susanne, "Grannskapet som planeringsenhet" i Samhällsbyggande och integration: Frågor om assimilation, mångfald och boende, Göran Graninger \& Christer Knuthammar (red.), Linköpings University Interdisciplinary Studies, Linköping, 2009.

Wall, Derek, The rise of the green left: Inside the worldwide ecosocialist movement, London: Pluto, 2010.

Waytz, Adam, "The mind in the machine: Anthropomorphism increases trust in an autonomous vehicle", Journal of Experimental Social Psychology, vol. 52(3), 2014, s. 113-117.

Waytz, Adam, "Making meaning by seeing human" i The psychology of meaning, Keith D. Markman, Travis Proulx \& Matthew J. Lindberg (red.), Washington DC: American Psychological Association, 2013.

Wernström, Sven, Den underbara resan: En läsebok om Sverige. D. 1, Stockholm: Gidlund, 1985.

Wernström, Sven, Den underbara resan: En läsebok om Sverige. D. 2, Stockholm: Gidlund, 1986.

Wernström, Sven, Den underbara resan: En läsebok om Sverige. D. 3, Stockholm: Gidlund, 1987.

Westin, Boel, Children's literature in Sweden, 2., rev. ed., Svenska institutet, Stockholm, 1996. 
Westin, Boel, "Karlsson som technobody", Tidskrift för litteraturvetenskap, vol. 32(4), 2003a, s. 128-142.

Westin, Boel, "Världens bästa Karlsson: Barnlitteratur och teknologi", Nordisk tidskrift för vetenskap, konst och industri, vol. 79(4), 2003b, s. 293-300.

Wideburg, L. A., "Pettson and Findus charm children and adults alike", World Literature Today, vol. 79(3-4), 2005, s. 71-72.

Wiener, Norbert, Cybernetics or control and communication in the animal and the machine, Cambridge, Mass.: M.I.T. Press, 1965.

Vinge, Louise, "Selma Lagerlöf", Litteraturbanken.se, http://litteraturbanken.se/\#!/forfattare/LagerlofS/presentation (läst 2010-09-10).

Winner, Langdon, Autonomous technology: Technics-out-of-control as a theme in political thought, Cambridge, Mass.: MIT Press, 1977.

Winner, Langdon, “Do artifacts have politics?”, Daedalus, vol. 1, 1980.

Winner, Langdon, The whale and the reactor: A search of limits in an age of high technology, 5. uppl., Chicago: The University of Chicago Press, 1989.

Witt, Otto, "Arbetets värde" i Tekniska sagor för stora och små, Stockholm: Hökerberg, 1914a.

Witt, Otto, "Den svagaste punkten" i Tekniska sagor för stora och små, Stockholm: Hökerberg, 1914b.

Witt, Otto, "Kamelen och de tusen hästarna" i Tekniska sagor för stora och små, Stockholm: Hökerberg, 1914c.

Witt, Otto, "Solens makt" i Tekniska sagor för stora och små, Stockholm: Hökerberg, 1914d.

Witt, Otto, "Tändstickan" i Tekniska sagor för stora och små, Stockholm: Hökerberg, 1914e.

Witt, Otto, "De röda soldaterna" i Krigets tekniska sagor för stora och små, Stockholm: Hökerberg, 1915a.

Witt, Otto, "Det förvånade spindelparet" i Krigets tekniska sagor för stora och små, Stockholm: Hökerberg, $1915 \mathrm{~b}$.

Witt, Otto, "Jättefåglarna och svalan" i Krigets tekniska sagor för stora och små, Stockholm: Hökerberg, 1915c.

Witt, Otto, "Kriget och dess släktingar" i Krigets tekniska sagor för stora och små, Stockholm: Hökerberg, 1915d. 
Witt, Otto, "Mistelns spådom" i Krigets tekniska sagor för stora och små, Stockholm: Hökerberg, 1915e.

Witt, Otto, "Pappas snusdosa" i Krigets tekniska sagor för stora och små, Stockholm: Hökerberg, $1915 \mathrm{f}$.

Witt, Otto, "I den röda tunneln" i Krigets tekniska sagor för stora och små, Stockholm: Hökerberg, 1915g.

Witt, Otto, "Spökfisken" i Krigets tekniska sagor för stora och små, Stockholm: Hökerberg, $1915 \mathrm{~h}$.

Witt, Otto, "Trollsvanen” i Krigets tekniska sagor för stora och små, Stockholm: Hökerberg, 1915 i.

Voltaire, Candide, Ny utg., Nacka: Klassikerförl. STENIQ, 1759/1997.

Worster, Donald, De ekologiska idéernas historia, Stockholm: SNS (Studieförb. Näringsliv och samhälle), 1996.

Vries, Marc de, Teaching about technology: An introduction to the philosophy of technology for non-philosophers, Dordrecht: Springer, 2005.

Vries, Marc de, “Technological knowledge and artifacts: An analytical view" i Defining technological literacy: Towards an epistemological framework, John R. Dakers (red.), New York: Palgrave Macmillan, 2006.

Wright, Georg Henrik von, "Den stora tanken om framsteget. Om framstegstänkande, tvivel och humanism" i Handla! Om förändring, välfärd, arbete, lärande, konsumtion, arkitektur, design, kultur, framtid, Georg Henrik von Wright (red.), Stockholm: Nerenius \& Santérus, 1997.

Wright, Georg Henrik von, Vetenskapen och förnuftet: Ett försök till orientering, Ny utg., Stockholm: Bonnier, 1987/2010.

Ylander, Hans, "Urbanisering och tätortsutveckling i Sverige”, Örebro: SCB (Statistiska Centralbyrån), 2008, http://www.scb.se/statistik/MI/MI0803/2000I02/MI03SA9301_06.pdf (läst 0505, 2013).

Zipes, Jack David, Saga och samhälle: Den klassiska genren för barn och civilisationsprocessen, Bromma: Mannerheim \& Mannerheim, 1984.

Zweigbergk, Eva von, Barnboken i Sverige 1750-1950, Stockholm: Rabén \& Sjögren, 1965.

Åberg, Alf, Vår svenska historia, Stockholm: Natur och Kultur, 1993.

Åhrén, Ett planmässigt samhällsbyggande: Särtryck ur bostadssociala utredningen (SOU 1945:63), Omtr., Stockholm: Kungliga Tekniska högskolan, 1981. 
Ödman, Per-Johan, Tolkning, förståelse, vetande: Hermeneutik i teori och praktik, Stockholm: ePan/Nordstedt, $1979 / 2001$.

Ödman, Per-Johan, "Hermeneutik och forskningspraktik" i Kunskapande metoder inom samhällsvetenskapen, B. Gustavsson (red.), 3. rev. uppl., 2004, Lund: Studentlitteratur.

Ödman, Per-Johan, ”Den hermeneutiska cirkelns gränser. Till validitetsfrågan inom hermeneutiken" i Text och existens. Hermeneutik möter samhällsvetenskap, Staffan Selander \& Per-Johan Ödman (red.), Göteborg: Daidalos, 2005.

Östberg, Kjell, 1968 - När allting var i rörelse: Sextiotalsradikaliseringen och de sociala rörelserna, Stockholm: Prisma, 2002.

\section{Övriga tryckta källor}

Agenda 21: Programme of action for sustainable development: Rio declaration on environment and development; Statement of forest principles: the final text of agreements negotiated by governments at the United Nations Conference on Environment and Development (UNCED), 3-14 June 1992, Rio de Janeiro, Brazil, United Nations Department of Public Information, New York, 1993.

Bibliotekstjänst, Sambindningskataloger, 1950-1986.

Katalog över böcker som folk- och skolbibliotek samt riksförbund, som bedriva skolbiblioteksverksamhet kunna erhålla i statsbidrag: På uppdrag av Kungl. Ecklesiastikdepartementet. Grundkatalog 1, 1915-16, Stockholm: Haeggströms Boktryckeri, 1915-1922.

Katalog över böcker som folk- och skolbibliotek samt riksförbund, som bedriva skolbiblioteksverksamhet kunna erhålla i statsbidrag: På uppdrag av Kungl. Ecklesiastikdepartementet. Grundkatalog 2, 1924-31, Stockholm: Haeggströms Boktryckeri, 1924-1931.

Katalog över böcker som folk- och skolbibliotek samt riksförbund, som bedriva skolbiblioteksverksamhet kunna erhålla i statsbidrag: På uppdrag av Kungl. Ecklesiastikdepartementet, Grundkatalog 2 med Tillägg, 1932-1964, Stockholm: Haeggströms Boktryckeri, 1932-1964.

Kontaktgruppen för flyghistorisk forskning, "Douglas DC-6/DC-6B", Göteborg, 1982.

Sifo, Svenska institutet för opinionsundersökningar AB, Indikator 1976:5, "Det svenska valet 1976. Den lidande borgerlighetens seger i massmedias valrörelse i koncessionsstaten", Stockholm, 1976.

Sveriges författarfond, Utlåningsstatistik, 1961-1977, Stockholm, 1978. 
Sveriges författarfond, Utlåningsstatistik, 1961-1986, Stockholm, 1987.

Sveriges författarfond, Utlåningsstatistik, 1993-2013, Stockholm, 2014.

World Commission on Environment and Development, Our common future, [United Nations Environment Programme], [Nairobi], Vår gemensamma framtid: [rapport från] Världskommissionen för miljö och utveckling under ordförandeskap av Gro Harlem Brundtland, Stockholm: Prisma, 1988.

\section{Övriga artiklar}

Carlberg, Frigga, ”John Ruskin”, Ord och Bild, årgång 7, 1898. http://runeberg.org/ordochbild/1898/ (läst 2011-10-15).

"Det andra nordiska biblioteksmötet i Stockholm", Biblioteksbladet, 1928, http://runeberg.org/biblblad/1928/0229.html (läst 2012-09-15).

”Dödsfall”, Dalpilen, 16 oktober 1923. Kungliga bibliotekets digitaliserade svenska dagstidningar,

http://magasin.kb.se/searchinterface/page.jsp?id=kb:132303\&recordNumber= 1\&totalRecordNumber=3 (läst 2012-08-12).

Huss, Pia, "Elsa Beskow - inte bara en snäll sagotant", Dagens Nyheter, 2 januari, 2006, http:/www.dn.se/kultur-noje/filmrecensioner/elsa-beskow-inte-bara-ensnall-sagotant/ (läst 2011-11-11).

"Järnvägen 150 år. Tåget genom kulturhistorien", Dagens Nyheter, 2 mars 2006, http:/www.dn.se/kultur-noje/taget-genom-kulturhistorien/ (läst 2010-10-05).

Lekander, Nina, 'Bollen är stroppad”, Expressen Kultur, 12 december 2010, http://www.expressen.se/kultur/bollen-ar-stroppad/ (läst 2012-11-10).

"Litteratur", Biblioteksbladet, 1918, http://runeberg.org/biblblad/1918/0192.htm (läst 2012-09-15).

"Notis", Kalmar, 13 mars 1912. Kungliga bibliotekets digitaliserade svenska dagstidningar, http://magasin.kb.se/searchinterface/page.jsp?id=kb:169279\&recordNumber $=1 \&$ totalRecordNumber=1 (läst 2012-08-12).

"Notis", Kalmar, 3 april 1912. Kungliga bibliotekets digitaliserade svenska dagstidningar, http://magasin.kb.se/searchinterface/page.jsp?id=kb:216899\&record Number $=2 \&$ totalRecordNumber=2 (läst 2012-08-12).

"Orsakerna till 'sedlig förvildning' hos ungdomen", Svensk Lärartidning nr. 14, 4 april 1900, http://runeberg.org/svlartid/1900/0227.html (läst 2010-02-14). 
"Otto Witts elektriska bevattning. En nyhet som lofvar stort för trädgården", Svenska Dagbladet, 17 juni 1917.

"Otto Witt vill ge oss socker gratis genom att utnyttja naturens egen sockerfabrikation”, Karlshamns Allehanda, 7 augusti 1917.

Regfors, Karl. "Hjälpmedel vid valet av böcker för barn och ungdom", Biblioteksbladet, vol. 17, 1932, http://runeberg.org/biblblad/1932/0190.html (läst 2010-0514).

Selin, Eva, "Intervju med Karl-Aage Schwartzkopf", Fjället, svenska fjällklubben nr. 1, 2003, http://www.fjallklubben.se/fjallet/artiklar/1-03art2.htm (läst 2013-02-10).

"Ungdomens vanart", Svensk Läraretidning, nr. 49, 1895, http://runeberg.org/svlartid/1895/0646.html (läst 2011-08-08).

"Vad vi skola älska och vårda", Svensk Läraretidning, nr. 42, 1898, http://runeberg.org/svlartid/1898/0674.html (läst 2011-08-14).

Witt, Otto, "Apropå Kapten Sundstedts flygningar. Flygkonstens historia”, Smålands Allehanda, 16 maj 1913.

Witt, Otto, "Redaktören presenterar sig själv", Hugin, Presentationsnummer, 1 januari 1916.

Witt, Otto, "Vad den 'tekniska sagan' är och dess korta historia", Hugin, Presentationsnummer, 1 januari, 1916. 


\section{Bildförteckning}

Bild 4.1: Illustration från "Kamelen och de tusen hästarna" (Edwin \& Ingeborg Lindborg, 1914).

Bild 4.2: Illustration från "Arbetet och dess värde" (Edwin \& Ingeborg Lundborg, 1914).

Bild 4.3: Illustration från "Jättefåglarna och svalan" (Edwin \& Ingeborg Lundborg, 1915).

Bild 4.4: Illustration från "Den svagaste punkten" (Edwin \& Ingeborg Lundborg, 1914).

Bild 5.1: Illustration från "Herr Klumpedump från Klumpedonien” i Sagobok (Elsa Beskow, 1915/1955).

Bild 5.2: $\quad$ Illustration från ’Doktor Klokamundus' uppfinning” i Muntergök (Elsa Beskow, 1919/1996).

Bild 5.3: Illustration från "När stora blåbärsberget kom till stan" i Muntergök (Elsa Beskow, 1919/1996).

Bild 5.4: Illustration från "Den gröna bilen" i Röda bussen och gröna bilen (Elsa Beskow, 1952).

Bild 6.1: $\quad$ Illustration från Familjen Tuff-Tuff (Kerstin Hedeby, 1949/1966).

Bild 6.2: $\quad$ Illustration från Familjen Tuff-Tuff(Kerstin Hedeby, 1949/1966).

Bild 6.3: Illustration från Höghuset vid myren (Lisbeth Holmberg, 1965).

Bild 8.1 Illustration från Rävjakten (Sven Nordqvist, 1986).

Bild 8.2 Illustration från Rävjakten (Sven Nordqvist, 1986).

Bild 8.3: $\quad$ Illustration från Rävjakten (Sven Nordqvist, 1986).

Bild 8.4: $\quad$ Illustration från Tomtemaskinen (Sven Nordqvist, 1994).

Bild 8.5: $\quad$ Illustration från Tomtemaskinen (Sven Nordqvist, 1994).

Bild 8.6: $\quad$ Illustration från Tomtemaskinen (Sven Nordqvist, 1994).

Bild 8.7: $\quad$ Illustration från Tomtemaskinen (Sven Nordqvist, 1994).

Bild 8.8: $\quad$ Illustration från Tomtemaskinen (Nordqvist, 1994).

Bild 8.9: $\quad$ Illustration från Tomtemaskinen (Sven Nordqvist, 1994).

Bild 8.10: $\quad$ Illustration från Tomtemaskinen (Sven Nordqvist, 1994). 
Källor och litteratur

Bild 8.11: Illustration från Tomtemaskinen (Sven Nordqvist, 1994).

Bild 8.12: Illustration från Tomtemaskinen (Sven Nordqvist, 1994) 

Studies in Science and Technology Education

ISSN 1652-5051

\section{FontD}

1. Margareta Enghag (2004): MINIPROJECTS AND CONTEXT RICH

PROBLEMS - Case studies with qualitative analysis of motivation, learner ownership and competence in small group work in physics. (Licentiate thesis)

Linköping University

2. Carl-Johan Rundgren (2006): Meaning-Making in Molecular Life Science Education - upper secondary school students' interpretation of visualizations of proteins. (Licentiate thesis) Linköping University

3. Michal Drechsler (2005): Textbooks', teachers', and students' understanding of models used to explain acid-base reactions. ISSN: 1403-8099, ISBN: 91-8533540-1. (thesis) Karlstad University

4. Margareta Enghag (2007): Two dimensions of Student Ownership of Learning during Small-Group Work with Miniprojects and context rich Problems in Physics. ISSN: 1651-4238, ISBN: 91-85485-31-4. (Doctoral Dissertation) Mälardalen University

5. Maria Åström (2007): Integrated and Subject-specific. An empirical exploration of Science education in Swedish compulsory schools. (Licentiate thesis) Linköping university

6. Ola Magntorn (2007): Reading Nature: developing ecological literacy through teaching. (Doctoral Dissertation) Linköping University

7. Maria Andreé (2007): Den levda läroplanen. En studie av naturorienterande undervisningspraktiker i grundskolan. ISSN: 1400-478X, HLS Förlag: ISBN 97891-7656-632-9 (Doctoral Dissertation, LHS)

8. Mattias Lundin (2007): Students' participation in the realization of school science activities.(Doctoral Dissertation) Linköping University

9. Michal Drechsler (2007): Models in chemistry education. A study of teaching and learning acids and bases in Swedish upper secondary schools ISBN 978-91-7063112-2 (Doctoral Dissertation) Karlstad University

10. Proceedings from FontD Vadstena-meeting, April 2006.

11. Eva Blomdahl (2007): Teknik i skolan. En studie av teknikundervisning för yngre skolbarn. ISSN: 1400-478X, HLS Förlag: ISBN 978-91-7656-635-0 (Doctoral Dissertation, LHS)

12. Iann Lundegård (2007): På väg mot pluralism. Elever i situerade samtal kring hållbar utveckling. ISSN:1400-478X, HLS Förlag: ISBN 978-91-7656-642-8 (Doctoral Dissertation, LHS)

13. Lena Hansson (2007): "Enligt fysiken eller enligt mig själv?" - Gymnasieelever, fysiken och grundantaganden om världen. (Doctoral Dissertation) Linköping University. 
Studies in Science and Technology Education

ISSN 1652-5051

\section{fontD}

14. Christel Persson (2008): Sfärernas symfoni i förändring? Lärande i miljö för hållbar utveckling med naturvetenskaplig utgångspunkt. En longitudinell studie i grundskolans tidigare årskurser. (Doctoral Dissertation) Linköping University

15. Eva Davidsson (2008): Different Images of Science - a study of how science is constituted in exhibitions. ISBN: 978-91-977100-1-5 (Doctoral Dissertation) Malmö University

16. Magnus Hultén (2008): Naturens kanon. Formering och förändring av innehållet i folkskolans och grundskolans naturvetenskap 1842-2007. ISBN: 978-91-7155612-7 (Doctoral Dissertation) Stockholm University

17. Lars-Erik Björklund (2008): Från Novis till Expert: Förtrogenhetskunskap i kognitiv och didaktisk belysning. (Doctoral Dissertation) Linköping University.

18. Anders Jönsson (2008): Educative assessment for/of teacher competency. A study of assessment and learning in the "Interactive examination" for student teachers. ISBN: 978-91-977100-3-9 (Doctoral Dissertation) Malmö University

19. Pernilla Nilsson (2008): Learning to teach and teaching to learn - primary science student teachers' complex journey from learners to teachers. (Doctoral Dissertation) Linköping University

20. Carl-Johan Rundgren (2008): VISUAL THINKING, VISUAL SPEECH - a Semiotic Perspective on Meaning-Making in Molecular Life Science. (Doctoral Dissertation) Linköping University

21. Per Sund (2008): Att urskilja selektiva traditioner i miljöundervisningens socialisationsinnehåll - implikationer för undervisning för hållbar utveckling. ISBN: 978-91-85485-88-8 (Doctoral Dissertation) Mälardalen University

22. Susanne Engström (2008): Fysiken spelar roll! I undervisning om hållbara energisystem - fokus på gymnasiekursen Fysik A. ISBN: 978-91-85485-96-3 (Licentiate thesis) Mälardalen University

23. Britt Jakobsson (2008): Learning science through aesthetic experience in elementary school science. Aesthetic judgement, metaphor and art. ISBN: 978-91-7155654-7. (Doctoral Dissertation) Stockholm University

24. Gunilla Gunnarsson (2008): Den laborativa klassrumsverksamhetens interaktioner - En studie om vilket meningsskapande år 7-elever kan erbjudas i möten med den laborativa verksamhetens instruktioner, artefakter och språk inom elementär ellära, samt om lärares didaktiska handlingsmönster i dessa möten. (Doctoral Dissertation) Linköping University

25. Pernilla Granklint Enochson (2008): Elevernas föreställningar om kroppens organ och kroppens hälsa utifrån ett skolsammanhang. (Licentiate thesis) Linköping University

26. Maria Åström (2008): Defining Integrated Science Education and putting it to test (Doctoral Dissertation) Linköping University

27. Niklas Gericke (2009): Science versus School-science. Multiple models in genetics - The depiction of gene function in upper secondary textbooks and its influence on students' understanding. ISBN 978-91-7063-205-1 (Doctoral Dissertation) Karlstad University 
Studies in Science and Technology Education

ISSN 1652-5051

\section{FontD}

28. Per Högström (2009): Laborativt arbete i grundskolans senare år - lärares mål och hur de implementeras. ISBN 978-91-7264-755-8 (Doctoral Dissertation) Umeå University

29. Annette Johnsson (2009): Dialogues on the Net. Power structures in asynchronous discussions in the context of a web based teacher training course. ISBN 978-91977100-9-1 (Doctoral Dissertation) Malmö University

30. Elisabet M. Nilsson (2010): Simulated "real" worlds: Actions mediated through computer game play in science education. ISBN 978-91-86295-02-8 (Doctoral Dissertation) Malmö University

31. Lise-Lotte Österlund (2010): Redox models in chemistry: A depiction of the conceptions held by upper secondary school students of redox reactions. ISBN 97891-7459-053-1 (Doctoral Dissertation) Umeå University

32. Claes Klasander (2010): Talet om tekniska system - förväntningar, traditioner och skolverkligheter. ISBN 978-91-7393-332-2 (Doctoral Dissertation) Linköping University

33. Maria Svensson (2011): Att urskilja tekniska system - didaktiska dimensioner i grundskolan. ISBN 978-91-7393-250-9 (Doctoral Dissertation) Linköping University

34. Nina Christenson (2011): Knowledge, Value and Personal experience - Upper secondary students' use of supporting reasons when arguing socioscientific issues. ISBN 978-91-7063-340-9 (Licentiate thesis) Karlstad University

35. Tor Nilsson (2011): Kemistudenters föreställningar om entalpi och relaterade begrepp. ISBN 978-91-7485-002-4 (Doctoral Dissertation) Mälardalen University

36. Kristina Andersson (2011): Lärare för förändring - att synliggöra och utmana föreställningar om naturvetenskap och genus. ISBN 978-91-7393-222-6 (Doctoral Dissertation) Linköping University

37. Peter Frejd (2011): Mathematical modelling in upper secondary school in Sweden An exploratory study. ISBN: 978-91-7393-223-3 (Licentiate thesis) Linköping University

38. Daniel Dufåker (2011): Spectroscopy studies of few particle effects in pyramidal quantum dots. ISBN 978-91-7393-179-3 (Licentiate thesis) Linköping University

39. Auli Arvola Orlander (2011): Med kroppen som insats: Diskursiva spänningsfält i biologiundervisningen på högstadiet. ISBN 978-91-7447-258-5 (Doctoral Dissertation) Stockholm University

40. Karin Stolpe (2011): Att uppmärksamma det väsentliga. Lärares ämnesdidaktiska förmågor ur ett interaktionskognitivt perspektiv. ISBN 978-91-7393-169-4 (Doctoral Dissertation) Linköping University

41. Anna-Karin Westman (2011) Samtal om begreppskartor - en väg till ökad förståelse. ISBN 978-91-86694-43-2 (Licentiate thesis) Mid Sweden University

42. Susanne Engström (2011) Att vördsamt värdesätta eller tryggt trotsa. Gymnasiefysiken, undervisningstraditioner och fysiklärares olika strategier för energiundervisning. ISBN 978-91-7485-011-6 (Doctoral Dissertation) Mälardalen University 
Studies in Science and Technology Education

ISSN 1652-5051

\section{fonkt}

43. Lena Adolfsson (2011) Attityder till naturvetenskap. Förändringar av flickors och pojkars attityder till biologi, fysik och kemi 1995 till 2007. ISBN 978-91-7459-

233-7 (Licentiate thesis) Umeå University

44. Anna Lundberg (2011) Proportionalitetsbegreppet i den svenska gymnasiematematiken - en studie om läromedel och nationella prov. ISBN 978-91-7393132-8 (Licentiate thesis) Linköping University

45. Sanela Mehanovic (2011) The potential and challenges of the use of dynamic software in upper secondary Mathematics. Students' and teachers' work with integrals in GeoGebra based environments. ISBN 978-91-7393-127-4 (Licentiate thesis) Linköping University

46. Semir Becevic (2011) Klassrumsbedömning i matematik på gymnasieskolans nivå. ISBN 978-91-7393-091-8 (Licentiate thesis) Linköping University

47. Veronica Flodin (2011) Epistemisk drift - genbegreppets variationer i några av forskningens och undervisningens texter i biologi. ISBN 978-91-9795-161-6 (Licentiate thesis) Stockholm University

48. Carola Borg (2011) Utbildning för hållbar utveckling ur ett lärarperspektiv Ämnesbundna skillnader i gymnasieskolan. ISBN 978-91-7063-377-5 (Licentiate thesis) Karlstad University

49. Mats Lundström (2011) Decision-making in health issues: Teenagers' use of science and other discourses. ISBN 978-91-86295-15-8 (Doctoral Dissertation) Malmö University

50. Magnus Oscarsson (2012) Viktigt, men inget för mig. Ungdomars identitetsbygge och attityd till naturvetenskap. ISBN: 978-91-7519-988-7 (Doctoral Dissertation) Linköping University

51. Pernilla Granklint Enochson (2012) Om organisation och funktion av människokroppens organsystem - analys av elevsvar från Sverige och Sydafrika. ISBN 978-91-7519-960-3 (Doctoral Dissertation) Linköping University

52. Mari Stadig Degerman (2012) Att hantera cellmetabolismens komplexitet - Meningsskapande genom visualisering och metaforer. ISBN 978-01-7519-954-2 (Doctoral Dissertation) Linköping University

53. Anna-Lena Göransson (2012) The Alzheimer A $\beta$ peptide: Identification of Properties Distinctive for Toxic Prefibrillar Species. ISBN 978-91-7519-930-6 (Licentiate thesis) Linköping University

54. Madelen Bodin (2012) Computational problem solving in university physics education - Students' beliefs, knowledge, and motivation. ISBN 978-91-7459-398-3 (Doctoral Dissertation) Umeå University

55. Lena Aretorn (2012) Mathematics in the Swedish Upper Secondary School Electricity Program: A study of teacher knowledge. ISBN 978-91-7459-429-4 (Licentiate thesis) Umeå University

56. Anders Jidesjö (2012) En problematisering av ungdomars intresse för naturvetenskap och teknik i skola och samhälle - Innehåll, medierna och utbildningens funktion. ISBN 978-91-7519-873-6 (Doctoral Dissertation) Linköping University 
Studies in Science and Technology Education

ISSN 1652-5051

\section{FontD}

57. Thomas Lundblad (2012) Simulerad verklighet i gymnasieskolans fysik: en designstudie om en augmented reality simulering med socio-naturvetenskapligt innehåll. ISBN 978-91-7519-854-5 (Licentiate thesis) Linköping University

58. Annie-Maj Johansson (2012) Undersökande arbetssätt i NO-undervisningen i grundskolans tidigare årskurser. ISBN 978-91-7447-552-4 (Doctoral Dissertation) Stockholm University

59. Anna Jobér (2012) Social Class in Science Class. ISBN 978-91-86295-31-8 (Doctoral Dissertation) Malmö University

60. Jesper Haglund (2012) Analogical reasoning in science education - connections to semantics and scientific modeling in thermodynamics. ISBN 978-91-7519-773-9 (Doctoral Dissertation) Linköping University

61. Fredrik Jeppsson (2012) Adopting a cognitive semantic approach to understand thermodynamics within science education. ISBN 978-91-7519-765-4 (Doctoral Dissertation) Linköping University

62. Maria Petersson (2012) Lärares beskrivningar av evolution som undervisningsinnehåll i biologi på gymnasiet.ISBN 978-91-7063-453-6 (Doctoral Dissertation) Karlstad University

63. Henrik Carlsson (2012) Undervisningsform, klassrumsnormer och matematiska förmågor. En studie av ett lokalt undervisningsförsök för elever med intresse och fallenhet för matematik. ISBN 978-91-86983-89-5 (Licentiate thesis) Linnaeus University)

64. Anna Bergqvist (2012) Models of Chemical Bonding. Representations Used in School Textbooks and by Teachers and their Relation to Students' Understanding. ISBN 978-91-7063-463-5 (Licentiate thesis) Karlstad University

65. Nina Kilbrink (2013) Lära för framtiden: Transfer i teknisk yrkesutbildning. ISBN 978-91-7063-478-9 (Doctoral Dissertation) Karlstad University

66. Caroline Larsson (2013) Experiencing Molecular Processes. The Role of Representations for Students' Conceptual Understanding. ISBN 978-91-7519-607-7 (Doctoral Dissertation) Linköping University

67. Anna-Karin Carstensen (2013) Connect Modelling Learning to Facilitate Linking Models and the Real World through Labwork in Electric Circuit Courses for Engineering Students ISBN 978-91-7519-562-9 (Doctoral Dissertation) Linköping University

68. Konferensproceeding: 10-year Anniversary Meeting with the Scientific Committee

69. Marie Bergholm (2014) Gymnasieelevers kommunikativa strategier i matematikklassrummet. En fallstudie av ett smågruppsarbete om derivata ISBN 978-917519-306-9 (Licentiate thesis) Linköping University

70. Ingrid Lundh (2014) Undervisa Naturvetenskap genom Inquiry - En studie av två högstadielärare. ISBN 978-91-7519-285-7 (Licentiate thesis) Linköping University

71. Nils Boman (2014) Personality traits in fish - implications for invasion biology ISBN:978-91-7601-097-6 (Licentiate thesis) Umeå University 
Studies in Science and Technology Education

ISSN 1652-5051

FontD

72. Torodd Lunde (2014) När läroplan och tradition möts - lärarfortbildning och syften med undersökande aktiviteter inom den laborativa NO-undervisningen i grundskolans senare del. ISBN: 978-91-7063-577-9 (Licentiate thesis) Karlstad University

73. Martin Eriksson (2014) Att ta ställning - gymnasieelevers argumentation och beslutsfattande om sociovetenskapliga dilemman. ISBN 978-91-7063-588-5 (Licentiate thesis), Karlstad University

74. Annalena Holm (2014) Mathematics Communication within the Frame of Supplemental Instruction. Identifying Learning Conditions. ISBN 978-91-7623-112-8 (Licentiate thesis) Lund University

75. Daniel Olsson (2014) Young people's ‘Sustainability Consciousness' - Effects of ESD implementation in Swedish schools. ISBN 978-91-7063-594-6. (Licentiate thesis) Karlstad University

76. Marlene Sjöberg (2014) Möjligheter i kollegiala samtal om NO-undervisning och bedömning. https://gupea.ub.gu.se/handle/2077/24063 (Licentiate thesis) Gothenburg University.

77. Teresa Berglund (2014) Student 'Sustainability Consciousness' and DecisionMaking on Sustainability Dilemmas. Investigating effects of implementing education for sustainable development in Swedish upper secondary schools. ISBN 97891-7063-599-1 (Licentiate thesis) Karlstad University

78. Elisabet Mellroth (2014) High achiever! Always a high achiever? A comparison of student achievements on mathematical tests with different aims and goals. ISBN 978-91-7063-607-3 (Licentiate thesis) Karlstad University

79. Jenny Green (2014) Elevers användande av formativ återkoppling i matematik. ISBN 978-91-7519-164-5 (Licentiate thesis) Linköping University

80. Klara Kerekes (2014) Matematikundervisning om växande geometriska mönsteren variationsteoretisk studie om hur lärare behandlar ett matematiskt innehållI. ISBN: 978-91-7519-135-5 (Licentiate thesis) Linköping University

81. Cecilia Axell (2015) Barnlitteraturens tekniklandskap. En didaktisk vandring från Nils Holgersson till Pettson och Findus. ISBN 978-91-7519-227-7 (Doctoral Dissertation) Linköping University. 


\title{
Skrifter utgivna av Svenska barnboksinstitutet
}

\author{
Skrifter utgivna av Svenska barnboksinstitutet \\ Studies published by the Swedish Institute for Children's Books \\ ISSN 0347-5387 \\ Tidigare titlar, se www.sbi.kb.se
}

115. Gunnarsson, Annika: synligt/osynligt: receptionen av det visuella i bilderböckerna om Alfons Aberg. Göteborg \& Stockholm: Makadam, 2012. - visible/invisible: the reception of the visual in the books about Alfie Atkins. Diss. Stockholm.

116. Paulin, Lotta: Den didaktiska fiktionen: konstruktion av förebilder ur ett barn-och ungdomslitterärt perspektiv 1400-1750. Stockholm: Acta Universitatis Stockholmiensis, 2012. - The didactic fiction: the construction of role models from the perspective of literature for children and young adults 1400-1750. Diss. Stockholm.

117. Till en evakuerad igelkott: festskrift till Maria Nikolajeva. Red. Maria Lassén Seger \& Mia Österlund. Göteborg \& Stockholm: Makadam, 2012. - Celebrating a displaced hedgehog: a Festschrift for Maria Nikolajeva.

118. Bengtsson, Lars: Bildbibliografi över Astrid Lindgrens skrifter 1921-2010. Lidingö: Salikon förlag, 2012. - A bibliography of pictures in the works of Astrid Lindgren 1921-2010.

119. Barnlitteraturens värden och värderingar. Red. Sara Kärrholm \& Paul Tenngart. Lund: Studentlitteratur, 2012. - Values and valuations in children's literature.

120. Pålsson, Yvonne: I skinnstrumpas spår. Svenska barn- och ungdomsböcker om indianer, 1860- 2008. Umeå: Institutionen för kultur- och medievetenskaper, Umeå universitet. Diss. Umeå, 2013.

121. Lindskog, Gerda Helena, Norrbarn. Norrland i 1900-talets svenskspråkiga barnoch ungdomslitteratur. Umeå: h:ström - Text \& Kultur, 2013.

122. En fanfar för bilderboken! Red. Lena Eriksson, Ulla Rhedin \& Oscar K. Stockholm: Alfabeta/Nordiska akvarellmuseet, 2013.

123. Flicktion. Perspektiv på flickan i fiktionen. Red. Bodil Formark, Eva Söderberg \& Mia Österlund. Malmö: Universus Academic Press, 2013.

124. Druker, Elina: Eva Billow: bilderbokskonstnär och författare. Göteborg \& Stockholm: Makadam, 2014.

125. Emanuelsson, Lars \& Ekman, Oskar, Gustaf Tenggren - en biografi. Stockholm: Kartago, 2014

126. Andersen, Jens, Denna dagen, ett liv. En biografi över Astrid Lindgren. Stockholm: Norstedts, 2014

127. Kommande.

128. Axell, Cecilia, Barnlitteraturens tekniklandskap. En didaktisk vandring från Nils Holgersson till Pettson och Findus, Linköpings universitet. Diss. Linköping, 2015. 